SUPPLEMENTS TO

VIGILIAE CHRISTIANAE

\title{
The Earliest History \\ of the Christian \\ Gathering
}

Origin, Development and Content of the Christian Gathering in the First to Third Centuries

VALERIY A. ALIKIN

BRILL 

The Earliest History of the Christian Gathering 


\title{
Supplements \\ to \\ Vigiliae Christianae
}

\author{
Texts and Studies of \\ Early Christian Life and Language
}

\author{
Editors \\ J. den Boeft - B. D. Ehrman - J. van Oort - \\ D.T. Runia - C. Scholten - J.C.M. van Winden
}

VOLUME 102 


\title{
The Earliest History of the Christian Gathering
}

\author{
Origin, Development and Content \\ of the Christian Gathering in the
} First to Third Centuries

by

Valeriy A. Alikin

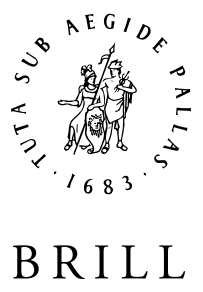


B R I L L This is an open access title distributed under the terms of the CC-BY-NC License, which permits any non-commercial use, distribution, and reproduction in any medium, provided the original author(s) and source are credited.

An electronic version of this book is freely available, thanks to the support of libraries working with Knowledge Unlatched. More information about the initiative can be found at www.knowledgeunlatched.org.

Detailed Library of Congress Cataloging-in-Publication data are available on the Internet at http://catalog.loc.gov

Library of Congress Cataloging-in-Publication Data

Alikin, Valeriy A.

The earliest history of the Christian gathering : origin, development, and content of the Christian gathering in the first to third centuries / by Valeriy A. Alikin.

p. cm. - (Supplements to Vigiliae Christianae ; v. 102)

Revision of the author's thesis-Leiden University, 2009.

Includes bibliographical references (p. ) and index.

ISBN 978-90-04-18309-4 (hardback : alk. paper) 1. Religious gatherings-

Christianity-History. 2. Lord's Supper-History-Early church, ca. 30-600.

3. Church history-Primitive and early church, ca. 30-600. 4. Religious gatheringsRome-Comparative studies. 5. Sacred meals-Rome-Comparative studies.

6. Rome-Religious life and customs. I. Title. II. Series.

BV6.A44 2010

264.3609015-dc22

2010000073

ISSN $0920-623 x$

ISBN 9789004183094

Copyright 2010 by Koninklijke Brill nv, Leiden, The Netherlands.

This work is published by Koninklijke Brill Nv. Koninklijke Brill NV incorporates the imprints Brill, Brill Hes \& De Graaf, Brill Nijhoff, Brill Rodopi and Hotei Publishing.

Koninklijke Brill NV reserves the right to protect the publication against unauthorized use and to authorize dissemination by means of offprints, legitimate photocopies, microform editions, reprints, translations, and secondary information sources, such as abstracting and indexing services including databases. Requests for commercial re-use, use of parts of the publication, and/or translations must be addressed to Koninklijke Brill Nv.

This book is printed on acid-free paper and produced in a sustainable manner. 


\section{CONTENTS}

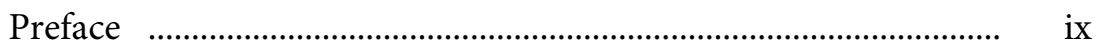

Abbreviations ……......................................................................... xi

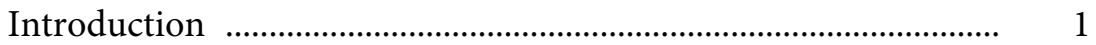

1. A new approach to the study of the early Christian gathering ........................................................................ 2

2. A brief survey of previous research ……………………........ 9

3. The present study ………………………………………......... 14

Chapter One The Origin of the Weekly Gathering in the Early Church …………................................................................... 17

Introduction ............................................................................... 17

1. The early Christian gatherings in the context of Graeco-Roman culture

a. Gatherings of voluntary associations ……………............ 17

b. Gatherings of pagan cult associations ………………....... 23

c. Gatherings of Jewish associations ………………….......... 27

d. Gatherings of Christian communities ……….................. 30

2. Time and place of the gatherings of the early Church ....... 40

a. The Sunday as the day for Christian community gatherings ........................................................................ 40

b. The meeting places of the early Christians ...................... 49

3. Content and order of the community gatherings in the early Church

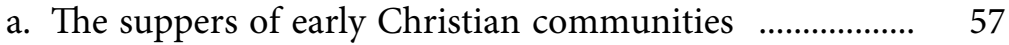

b. Christian symposia ......................................................... 62

c. The order of the Christian gathering …………................ 65

4. The leaders of the gatherings in the early Church .............. 69

Conclusions ............................................................................. 76

Chapter Two The Gatherings of Christians in the Morning $\quad . . . . \quad 79$

Introduction …............................................................................ 79

1. The origin of the Christian gathering in the morning ....... 79

2. The morning gatherings in the second and third centuries ...... 91

Conclusions …...................................................................... 101 
Chapter Three The Lord's Supper in the Early Church $\ldots . . . . . . . . .103$

Introduction ............................................................................... 103

1. The earliest history of the Lord's Supper ………………..... 103

a. The shape and function of the Lord's Supper ................ 103

b. The Lord's Supper and the Eucharist in Paul and the Didache ............................................................................. 108

2. The Last Supper of Jesus and the Lord's Supper ................ 114

a. The origin and function of the Last Supper tradition $\ldots . .114$

b. The Lord's Supper in the Gospel tradition .................... 128

3. The Eucharist in the second and third centuries ................ 132

a. The Eucharist in the second century ……………............ 132

b. The Eucharist in the third century ………………........... 142

Conclusions .......................................................................... 146

Chapter Four The Reading of Scripture in the Gathering of the Early Church ………....................................................... 147

Introduction ......................................................................... 147

1. The origin of Scripture reading in the Christian gathering ............................................................................ 147

a. Public reading at the Graeco-Roman banquet f............. 147

b. Reading of Scripture in Jewish communal gatherings ..................................................................... 150

c. Public reading in Christian communities ....................... 155

2. Development of the public reading of Scripture in the Christian communities

a. Public reading of Scripture in the early Church in the first century

b. Public reading of Scripture in the second century $\ldots . . . . \quad 168$

c. Public reading of Scripture in the third century ........... 175

3. The office of reader ……..................................................... 178

Conclusions …....................................................................... 181

Chapter Five Preaching in the Gathering of the Early

Church

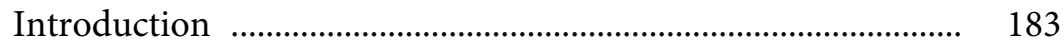

1. The origin of preaching in the Christian gathering ........... 183

2. The development of preaching in the gatherings of the early Church 
a. Preaching in the Christian gathering in the first century

b. Preaching in the Christian gathering in the second century

c. Preaching in the Christian gathering in the third century

3. Preachers in the gatherings of the early Church ................ 205

Conclusions

Chapter Six Singing and Prayer in the Gathering of

the Early Church

Introduction

1. Singing in the gathering of the early Church

a. The origin and locus of singing in the gathering of the early Church

b. Singing and music in the Christian gathering during the first three centuries

2. Prayer in the gathering of the early Church

a. The origin of prayer in the gatherings of the early Church

b. The evolution of the eucharistic prayers during the first three centuries

c. Non-Eucharistic prayers in the Christian gatherings during the first three centuries

Chapter Seven Other Ritual Actions in the Gatherings of the Early Church

Introduction

1. The holy kiss

2. The laying on of hands and ordination 260

3. Ritual footwashing and oil anointing

4. Collections, almsgiving and offerings 268

5. Healing and exorcism

6. Liturgical acclamations and doxologies

Conclusions 
Appendices ..................................................................................... 291

1. The earliest history of the Christian gathering ................... 293

2. The order of the proceedings in the Christian gathering

3. The frequency of the Christian gatherings and their distribution over the morning and the evening during the first three centuries 296

4. An Ancient Religious Community Meeting at Sunrise ....... 298

5. Plans of two third-century Christian gathering places ........ 299

Bibliography ……...................................................................... 301

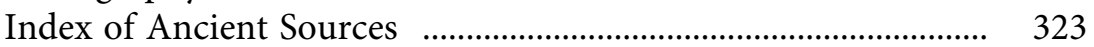

Subject Index ........................................................................... 341 


\section{PREFACE}

The present study is a revision of my $\mathrm{PhD}$ thesis which was accepted and defended at Leiden University in May 2009.

I would like to thank my supervisor, Dr. Henk Jan de Jonge, Professor of New Testament Exegesis and Early Christian Literature at Leiden University, for his willingness to spend his precious time on this project and giving me excellent supervision during the three years that I worked on my dissertation. He proved to be an ideal mentor, exceeding my expectations in every way.

I am also thankful to the Institute for Religious Studies at Leiden University and its staff for providing an agreeable working place and assisting me in all practical matters that arose during the preparation of my dissertation.

The editors in chief of the Supplements to Vigiliae Christianae have studied the manuscript with care, offering some invaluable suggestions.

Helen Vince was kind enough to correct the English of this book; for any mistakes that remain I myself am responsible. 



\section{ABBREVIATIONS}

\section{Primary Sources}

a. Old and New Testament

$\begin{array}{llll}\text { Acts } & \text { Acts of the Apostles } & \text { Lk. } & \text { Luke } \\ \text { 1 Chron. } & \text { 1 Chronicles } & \text { Mk. } & \text { Mark } \\ \text { Col. } & \text { Colossians } & \text { Mt. } & \text { Matthew } \\ \text { 1 Cor. } & \text { 1 Corinthians } & \text { Neh. } & \text { Nehemiah } \\ \text { 2 Cor. } & \text { 2 Corinthians } & 1 \text { Pet. } & \text { 1 Peter } \\ \text { Deut. } & \text { Deuteronomy } & 2 \text { Pet. } & 2 \text { Peter } \\ \text { Eph. } & \text { Ephesians } & \text { Phil. } & \text { Philippians } \\ \text { Gal. } & \text { Galatians } & \text { Phlm. } & \text { Philemon } \\ \text { Gen. } & \text { Genesis } & \text { Rev. } & \text { Revelation } \\ \text { Heb. } & \text { Hebrews } & \text { Rom. } & \text { Romans } \\ \text { Jas. } & \text { James } & 1 \text { Thess. } & 1 \text { Thessalonians } \\ \text { Jn. } & \text { John } & 2 \text { Thess. } & \text { 2 Thessalonians } \\ \text { 1 Jn. } & \text { 1 John } & 1 \text { Tim. } & 1 \text { Timothy } \\ \text { 2 Jn. } & \text { 2 John } & 2 \text { Tim. } & \text { 2 Timothy } \\ \text { Lam. } & \text { Lamentations } & \text { Tit. } & \text { Titus }\end{array}$

b. Apocrypha and Pseudepigrapha

Ass. Mos. Assumptio Mosis

2 Bar. 2 (Syriac Apocalypse) of Baruch

Jos. Asen. Joseph and Aseneth

Jub. Jubilees

2 Macc. 2 Maccabees
3 Macc. 3 Maccabees

Od. Sol. Odes of Solomon Sib. Or. Sibylline Oracles

Sir. Sirach

Test. Job Testament of Job

Tob. Tobit

\section{c. Further Jewish Literature}

Dead Sea Scrolls

1QapGen Genesis Apocryphon 4Q251 Halakhah

1QS Rule of the Community 4Q266 Damascus Document

1QSa Rule of the Congregation 
Josephus (Jos.)

$\begin{array}{llll}\text { Ant. } & \text { Antiquitates Judaicae } & \text { BJ } & \text { De bello judaico } \\ \text { Ap. } & \text { Contra Apionem } & \text { Vit. } & \text { Vita }\end{array}$

Mishnah

Ber. Berakhot Sanh. Sanhedrin

Meg. Megillah Taan. Ta'anit

Philo

Contempl. De vita contemplativa

Flacc. In Flaccum

Hyp. Hypothetica

Legat. $\quad$ Legatio ad Gaium

Mos. Vita Mosis

Opif. $\quad$ De opificio mundi

Quod omn. prob. Quod omnis probus liber sit

Som. De somniis

Spec. De specialibus legibus

Virt. De virtutibus

d. Greek and Roman Literature

Apul., Met. Apuleius, Metamorphoses

Athen., Deipn. Athenaeus, Deipnosophistai

Aul. Gel., NA Aulus Gellius, Noctes Atticae

Cass. Dio Cassius Dio

Cic., Fam. Cicero, Epistulae ad Familiares

Cic., Verr. Cicero, Actio in Verrem

Dio Chrys. Dio Chrysostom

Diog. Laert. Diogenes Laertius

Epict. Epictetus

Juv., Sat. Juvenal, Satirae

Luc., Asin. Lucian, Asinus

Luc., Dances Lucian, On Dances

Luc., Menip. $\quad$ Lucian, Menippus

Luc., Peregr. $\quad$ Lucian, De morte Peregrini

Luc., Symp. Lucian, Symposium

Luc., Ver. hist. Lucian, Verae historiae

Mart.

Martial

Nep., Att. Nepos, Atticus 
Pausan., Descr. Graec. Pausanias, Description of Greece

Petr., Satyr.

Petronius, Satyricon

Philostr., Vita Apol.

Philostratus, Vita Apollonii

Plin., Ep.

Pliny (the Younger), Epistulae

Plut., Quaest. conv. Plutarch, Quaestiones conviviales

Plut., Sept. sap. conv. Plutarch, Septem sapientium convivium

Suet., De vit. caes.

Suetonius, De vita caesarum

Xen., Symp.

Xenophon, Symposium

e. Early Christian Literature

Acta Andr.

Acts of Andrew

Acta Ioan.

Acts of John

Acta Pauli

Acts of Paul

Acta Petri

Acts of Peter

Acta Thom.

Athenag., Plea

Acts of Thomas

Athenagoras, Plea on Behalf of the Christians

Barn.

Can. apost.

Epistle of Barnabas

Canones apostolorum

Clem. Al., Ex. Theod. Clement of Alexandria, Excerpta ex Theodoto

Clem. Al., Paed.

Clement of Alexandria, Paedagogus

Clem. Al., Protr.

Clement of Alexandria, Protrepticus

Clem. Al., Q.d.s.

Clement of Alexandria, Quis dives salvetur

Clem. Al., Str.

1 Clem.

Clement of Alexandria, Stromateis

2 Clem.

1 Clement

2 Clement

Comm., Instr.

Commodianus, Instructiones

Const. ap.

Constitutiones apostolicae

Cypr., Ep.

Cyprian, Epistulae

Cypr., Op. eleem.

Cyprian, De opere et eleemosynis

Cypr., Or. Dom.

Cyprian, De oratione Dominica

Cypr., Unit. eccl.

Did.

Cyprian, De unitate ecclesiae

Didache

Did. ap.

Didascalia apostolorum

Ep. ap.

Epistula apostolorum

Epiph., Panar.

Epiphanius, Panarion

Euseb., $H E$

Eusebius, Historia ecclesiastica

Euseb., Praep. ev.

Gos. Jud.

Eusebius, Praeparatio evangelica

Gos. Peter

Gospel of Judas

Gospel of Peter 
Gos. Phil.

Gos. Thom.

Herm., Mand.

Herm., Sim.

Herm., Vis.

Hippol., Refut.

Ign., Eph.

Ign., Magn.

Ign., Phild.

Ign., Pol.

Ign., Rom.

Ign., Smyr.

Ign., Trall.

Iren., Haer.

Itin. Eg.

Just., 1 Apol.

Just., 2 Apol.

Just., Dial.

Lact., Mort. pers.

M. Iust.

M. Perp.

M. Pion.

M. Polyc.

Min. Fel., Oct.

Or., C. Cels.

Or., Comm. Rom.

Or., Hom. Cant.

Or., Hom. Ex.

Or., Hom. Gen.

Or., Hom. Isa.

Or., Hom. Jer.

Or., Hom. Jos.

Or., Hom. Jud.

Or., Hom. Lev.

Or., Hom. Luc.

Or., Hom. Num.

Or., Orat.

Poly., Phil.

Ps.-Clem., Ep. Jac.

Ps.-Clem., Hom.

Tert., Ad ux.
Gospel of Philip

Gospel of Thomas

Pastor Hermae, Mandates

Pastor Hermae, Similitudes

Pastor Hermae, Visions

Hippolytus, Refutatio omnium haeresium

Ignatius, To the Ephesians

Ignatius, To the Magnesians

Ignatius, To the Philadelphians

Ignatius, To Polycarp

Ignatius, To the Romans

Ignatius, To the Smyrneans

Ignatius, To the Trallians

Irenaeus, Adversus haereses

Egeria, Itinerarium

Justin Martyr, First Apologia

Justin Martyr, Second Apologia

Justin Martyr, Dialogus cum Tryphone Judaeo

Lactantius, De mortibus persecutorum

Martyrium Iustini et septem sodalium

Martyrium Perpetuae et Felicitatis

Martyrium Pionii

Martyrium Polycarpi

Minucius Felix, Octavius

Origen, Contra Celsum

Origen, Commentarii in Epistulam ad Romanos

Origen, Homiliae in Cantica

Origen, Homiliae in Exodum

Origen, Homiliae in Genesim

Origen, Homiliae in Isaiam

Origen, Homiliae in Jeremiam

Origen, Homiliae in Josuam

Origen, Homiliae in Judices

Origen, Homiliae in Leviticum

Origen, Homiliae in Lucam

Origen, Homiliae in Numeros

Origen, De Oratione

Polycarp, To the Philippians

Pseudo-Clement, Epistula ad Jacobum

Pseudo-Clement, Homiliae

Tertullian, Ad uxorem 
Tert., Adv. Jud. Tertullian, Adversus Judaeos

Tert., An. Tertullian, De anima

Tert., Apol. Tertullian, Apologeticus or -ticum

Tert., Bapt. Tertullian, De baptismo

Tert., Carn. Chr. Tertullian, De carne Christi

Tert., Cast. Tertullian, De exhortatione castitatis

Tert., Cor. Tertullian, De corona militis

Tert., Fug. Tertullian, De fuga in persecutione

Tert., Idol. Tertullian, De idololatria

Tert., Ieiun. Tertullian, De ieiunio

Tert., Marc. $\quad$ Tertullian, Adversus Marcionem

Tert., Mon. Tertullian, De monogamia

Tert., Nat. $\quad$ Tertullian, Ad nationes

Tert., Or. $\quad$ Tertullian, De oratione

Tert., Praescr. Tertullian, De praescriptione haereticorum

Tert., Res. Tertullian, De resurrectione carnis

Tert., Scap. Tertullian, Ad Scapulam

Tert., Spect. Tertullian, De spectaculis

Tert., Val. Tertullian, Adversus Valentinianos

Tert., Vir. vel. Tertullian, De virginibus velandis

Theophil., Autol. Theophilus, Ad Autolycum

Trad. ap. Traditio apostolica

\section{f. Inscriptions and Papyri}

CPJ

$I G$

Corpus Papyrorum Judaicarum

IGUR

Inscriptiones Graecae

ILS

Inscriptiones Graecae Urbis Romae

PLond Inscriptiones Latinae Selectae

POxy. Papyrus Londinensis

Oxyrhynchus Papyri

\section{REFERENCE WORKS}

ABD Freedman, D.N. (ed.), The Anchor Bible Dictionary, 6 vols. New York: Doubleday, 1992.

Bauer Bauer, W., A Greek-English Lexicon of the New Testament and Other Early Christian Literature (revised by F.W. Gringrich and F.W. Danker). 2nd ed. Chicago and London: University of Chicago Press, 1979. 
EEC Ferguson, Everett (ed.), Encyclopedia of Early Christianity, 2 vols. 2nd ed. New York: Garland, 1997.

LSJ Liddell, H.G., R. Scott, H.S. Jones, R. McKenzie, A GreekEnglish Lexicon, Oxford: Clarendon Press, 1940, with a Supplement, 1996.

OCD Hornblower, S. and A. Spawforth (eds.), The Oxford Classical Dictionary. 3rd ed. Oxford: Oxford University Press, 1996.

ODCC Cross, F.L. and E.A. Livingstone (eds.), Oxford Dictionary of the Christian Church. 3rd ed. Oxford [etc.]: Oxford University Press, 1997.

OTP Charlesworth, James H. (ed.), The Old Testament Pseudepigrapha, 2 vols. New York et al.: Doubleday, 1983-1985.

PG Migne, J.P. (ed.), Patrologia Graeca, 162 vols. Paris, 18571866.

PGL Lampe, G.W.H. (ed.), A Patristic Greek Lexicon. Oxford: Clarendon Press, 1961.

SEG Supplementum Epigraphicum Graecum

ThDNT Kittel, G. (ed.), Theological Dictionary of the New Testament, 10 vols. (tra. G.W. Bromiley). Grand Rapids: Eerdmans, 1964-1976.

3. Bibliographical Abbreviations

ACW Ancient Christian Writers

AJT American Journal of Theology

ANF Ante-Nicene Fathers

ANRW Aufstieg und Niedergang der römischen Welt

ATR Anglican Theological Review

BBR Bulletin for Biblical Research

CJ Classical Journal

CQ Classical Quarterly

EvQ Evangelical Quarterly

ExpT Expository Times

GRBS Greek, Roman and Byzantine Studies

GTJ Grace Theological Journal

HTR Harvard Theological Review

JAC Jahrbuch für Antike und Christentum

JBL Journal of Biblical Literature 
JECS Journal of Early Christian Studies

JJS Journal of Jewish Studies

JRA Journal of Roman Archaeology

JRS Journal of Roman Studies

JSNT Journal for the Study of the New Testament

JSNT SS Journal for the Study of the New Testament Supplement Series

JTS Journal of Theological Studies

LCL Loeb Classical Library

NovT Novum Testamentum

NTS New Testament Studies

QL Questions Liturgiques

SBL Society of Biblical Literature

SC Sources Chrétiennes

SP Studia Patristica

StLit Studia Liturgica

TL Tijdschrift voor Liturgie

VC Vigiliae Christianae

ZNW Zeitschrift für die neutestamentliche Wissenschaft

\section{General Abbreviations}

$\begin{array}{llll}\text { BCE } & \text { Before the Common Era } & \text { f. } & \text { following } \\ \text { ca. } & \text { circa } & i b . & \text { ibidem } \\ \text { CE } & \text { Common Era } & \text { id. } & \text { idem } \\ \text { cf. } & \text { confer (compare) } & \text { i.e. } & \text { id est (that is to say) } \\ \text { ch. } & \text { chapter } & \mathrm{n}(\mathrm{s}) . & \text { number(s) } \\ \text { ead. } & \text { eadem } & \mathrm{p}(\mathrm{p}) . & \text { page(s) } \\ \text { ed(s). } & \text { editor(s) } & \text { repr. } & \text { reprinted } \\ \text { e.g. } & \text { exempli gratia (for example) } & \text { s.v. } & \text { sub voce } \\ \text { esp. } & \text { especially } & \text { tra. } & \text { translated by } \\ \text { et al. } & \text { et alii or } \text { et alibi } & \mathrm{vol}(\mathrm{s}) . & \text { volume(s) } \\ \text { etc. } & \text { et cetera (and so on) } & \mathrm{v}(\mathrm{v}) . & \text { verse(s) }\end{array}$





\section{INTRODUCTION}

The periodical gathering of the Christian Church has a long and complex history. This present study endeavours to give a reconstruction of the earliest stages of this history. As a social and religious phenomenon, the early Christian gathering did not arise in a cultural vacuum. The Graeco-Roman world was saturated with cults and religious groups, movements, traditions, all with their own meetings and ceremonies. This vibrant and variegated religious environment was the context in which the early Christian gathering took shape. Any attempt to trace the history of the early Christian meeting has to take this historical setting into account. The origins and early development of the Christian gathering should be seen within the context of the social and religious culture of the Graeco-Roman world, of which Christians and Jews formed part. In particular, since the central event of the Christian gathering during the formative period was a meal, the beginnings of the gathering should be considered in the context of the traditions held by various groups in the matter of communal dining.

As a rule, whenever early Christians met as a community, they shared a meal. In this, they did not differ from other groups and associations in the world surrounding them. Practically all clubs, associations and societies in the Graeco-Roman world held periodical gatherings in which a common meal or banquet formed a crucial, if not the main constituent. Such group meals tended to take place according to a traditional, more or less established pattern and conform to certain customs and rules which were virtually the same for all association meals.

In the Graeco-Roman world, the banquet, the formal evening meal, was an important social institution. Formal meals in the Mediterranean culture of the Hellenistic and Roman periods adopted a set, by and large fixed, form. The customs observed at meals could differ in details according to region and group, however, the evidence suggests that formal meals like group suppers and banquets strongly resembled each other in terms of their content and in the main were understood and interpreted in much the same way across a broad spectrum of Graeco-Roman society. 
This study is an attempt to collect, arrange and interpret the scattered information concerning the Christian gathering during the first centuries of its existence and to use this information for a reconstruction of the history of that gathering in the period mentioned. Various Christian, Jewish and pagan sources that attempt to clarify the origin, development and content of the Christian gathering on Sunday and other days of the week, will be discussed. With few exceptions, the period from which non-Christian documents will be used will be limited to the first two and a half centuries CE. This is the period in which the Christian gathering developed from its first beginnings to an established practice. Furthermore, our source material will include Christian writings from the early fifties of the first century until Cyprian $(† 258 \mathrm{CE})$, who is the last major source of information on the Christian gathering before the Peace of the Church in the beginning of the fourth century.

The aim of this study is essentially twofold. First, its objective is to trace the origins of the early Christian gathering within the context of the Mediterranean culture during the first century CE. In particular, an examination will be made of the relationship between the early Christian gathering and the assemblies of various associations, including meals taken. Secondly, this study intends to investigate the content of the Christian gathering during the second and third centuries and to describe how it developed during this period.

\section{A NEW APPROACH TO THE STUdy OF THE EARLY CHRISTIAN GATHERING}

The origins of the Christian gathering have been the object of intensive research ever since the rise of critical biblical scholarship in the eighteenth century. ${ }^{1}$ Recently, research on this topic has still been intensified. Numerous monographs and scholarly articles that have appeared

${ }^{1}$ For a survey of research on the Eucharist from the late 18th century to the 20th centuries, see Hans-Josef Klauck, Herrenmahl und hellenistischer Kult (Münster: Aschendorff, 1982), 8-28, and for a discussion of research on the origins of the Eucharist in the 20th and the beginning of the 21st century, see Gerard Rouwhorst, "Christlicher Gottesdienst und der Gottesdienst Israels. Forschungsgeschichte, historische Interaktionen, Theologie," in Gottesdienst der Kirche. Handbuch der Liturgiewissenschaft, Part 2, vol. 2, Gottesdienst im Leben der Christen. Christliche und jüdische Liturgie, eds. M. Klöckener, A.A. Häußling, R. Messner (Regensburg: Pustet, 2008), 493-572. 
over the last two decades are evidence of a renewed interest in the problem of the origin of the Christian gathering. Scholars, both in the field of New Testament studies and liturgiology, are ceaselessly searching for more satisfactory answers to this ever-intriguing question.

During the past ten years, the study of the periodical gatherings of the early Christians has undergone a substantial shift. A predominantly literary approach gave way to a more sociological approach. ${ }^{2}$ For a long time, research into the origins and early development of the Christian assembly had mainly been the literary-critical and traditio-historical study of texts concerning the Lord's Supper or Eucharist. Since the nineties of the twentieth century, research on the early Christian gathering enlarged its scope to take into consideration the form and dynamics of Hellenistic group suppers as well as the material culture relating to meals in antiquity.

The change began with the publication of Gemeinschaftsmahl und Mahlgemeinschaft by Matthias Klinghardt $(1996)^{3}$ and was continued in studies by Henk Jan de Jonge (2001, 2006, 2007) $)^{4}$ and Dennis Smith (2003). ${ }^{5}$ Several authors, who formerly used to pursue the study of the Eucharist as a mainly textual and literary discipline, such as Paul Bradshaw $(2002,2004)^{6}$ and Gerard Rouwhorst $(2006,2007,2008){ }^{7}$

2 This more sociological approach to early Christianity was initiated from about 1975 by such scholars as Wayne Meeks, The First Urban Christians (New Haven and London: Yale University Press, 1983) and Gerd Theissen, Soziologie der Jesusbewegung (München: Kaiser, 1977); Studien zur Soziologie des Urchristentums (Tübingen: Mohr (Siebeck) 1979).

${ }_{3}$ M. Klinghardt, Gemeinschaftsmahl und Mahlgemeinschaft. Soziologie und Liturgie frühchristlicher Mahlfeiern (Tübingen/Basel: Francke, 1996).

${ }^{4}$ H.J. de Jonge, "The Early History of the Lord's Supper," in Religious Identity and the Invention of Tradition, eds. J.W. van Henten and A. Houtepen (Assen: Van Gorcum, 2001), 209-237; Zondag en sabbat. Over het ontstaan van de christelijke zondag (Leiden: Universiteit Leiden, 2006); Avondmaal en symposium. Oorsprong en eerste ontwikkeling van de vroegchristelijke samenkomst (Leiden: Universiteit Leiden, 2007).

${ }^{5}$ Dennis Smith, From Symposium to Eucharist: The Banquet in the Early Christian World (Minneapolis: Fortress Press, 2003). In 2002, Dennis Smith and Matthias Klinghardt began an ongoing seminar within the Society of Biblical Literature to explore the Graeco-Roman meals as a pivotal factor in the formation of early Christian groups and their meal practices.

${ }^{6}$ Paul Bradshaw, The Search for the Origins of Christian Worship, 2nd ed. (Oxford: Oxford University Press, 2002); Eucharistic Origins (Oxford: Oxford University Press, 2004).

7 Gerard Rouwhorst, "In blijdschap en in een geest van eenvoud," Eredienstvaardig 5 (October 2006), 4-7; "The Roots of the Early Christian Eucharist: Jewish Blessings or Hellenistic Symposia?" in Jewish and Christian Liturgy and Worship. New Insights into Its History and Interaction, eds. Albert Gerhards and Clemens Leonhard (Leiden: 
now gradually tend to accept, at least to a certain extent, a more sociological approach.

The essence of this new approach can be formulated as follows: the local early Christian community, as a socio-cultural phenomenon, functioned as a voluntary religious association just like many other associations in the Graeco-Roman world of the first century CE. There is firm evidence from the first two centuries CE to support this view. ${ }^{8}$ The main activity of both the Graeco-Roman associations and Christian communities was a communal banquet that comprised a supper and a contiguous symposium. Numerous passages in works by Christian authors show that until the middle of the third century Christian communities, too, had a communal meal and convivial gathering on Sunday evening as their main assembly. ${ }^{9}$ The origins of the Christian gathering should be studied, therefore, in the context of the banquet practices of religious associations in the Graeco-Roman world in general.

As a result of the new approach to the early Christian gathering, the question of the origins of the Christian assembly assumed a different orientation. For a long time it had been customary to trace back the origins of the Christian ceremony to a combination of Jewish customs: the synagogue meeting on the Sabbath and one or other of the various types of Jewish ritual meals. This policy was based on a view of the Mediterranean world in the Graeco-Roman period which divided that world into two rival or opposite cultures: Hellenistic and Jewish. Since the first Christians were of Jewish origin, the beginnings of the Christians' gathering and their group meal were readily traced back to certain Jewish customs and traditions. Since the view has gained

Brill, 2007), 295-308; "Christlicher Gottesdienst und der Gottesdienst Israels. Forschungsgeschichte, historische Interaktionen, Theologie," 493-572.

${ }^{8}$ In 55 CE, for instance, Paul compares the local Christian community meal with the pagan religious association meal in Corinth (1 Cor. 10:16-21). In $112 \mathrm{CE}$, Pliny in his correspondence with the Roman Emperor Trajan (Plin., Ep. 10.96) equates Christian communities with associations. In the second century CE, Lucian refers to the leaders of Christian communities as thiasarchai, that is, leaders of cult associations (Luc., Peregr. 11). About 200 CE, Tertullian compares the Christian community meal with the meal consumed by various pagan religious associations, such as the collegia Saliorum and the Dionysus and Sarapis cults (Tert., Apol. 39).

91 Cor. 11:17-14:40; Did. 9-10; 14; Just., 1 Apol. 67; Iren., Haer. 1.13; Clem. Al., Str. 6.113; Athenag., Plea 3; 31; Theophil., Autol. 3.4; Acta Petri 13; Min. Fel., Oct. 8.4; 9.6; 31.1, 5; Tert., Apol. 7; 39; Nat. 1.2; 1.7; Trad. ap. 25-29; Or., C. Cels. 1.1; 8.32; Cypr., Ep. 63. 
ground that the Jewish and Christian groups themselves, in various degrees, were part of Hellenistic culture as a whole, the dichotomy between "Hellenistic" and "Jewish" has become increasingly untenable. This tendency could only be reinforced by the more sociological approach to the early Christian gathering, which directed its attention to social forms rather than to ritual texts and formulas. Accordingly, many scholars now question ${ }^{10}$ or completely abandon ${ }^{11}$ the method of trying to find the origins of Christian liturgical practices only in Jewish traditions.

Yet, whilst holding on to a questionable premise and a contestable view of Graeco-Roman culture, some scholars still try to find the roots of the Christian liturgical gathering in Jewish rituals, as well as, more recently, in the rituals of the Jewish temple. ${ }^{12}$

Other recent authors on the subject do reject the old approach but continue to insist that in a number of ways the Christian groups of the first century were quite different both from cult associations in the Graeco-Roman world and other kinds of voluntary associations, such as craft guilds. According to Wayne Meeks, for instance, Christians developed new social forms of their own. The Church combined features of a household, cult, club and philosophical school, without being altogether like any of them. ${ }^{13}$ However, researchers now increasingly accept and further explore the view that the periodical gathering of the Hellenistic association is the model which best explains the Christian gathering. The main manifestation of virtually all religious voluntary associations was a periodical gathering that had a bipartite structure: a supper and a drinking party afterwards. This is the background

${ }^{10}$ E.g., Maxwell Johnson, "The Apostolic Tradition," in The Oxford History of Christian Worship, eds. G. Wainwright and Karen Westerfield Tucker (New York: Oxford University Press, 2006), 23-55, esp. 44-48.

${ }^{11}$ E.g., Alistair Stewart-Sykes, "The Domestic Origin of the Liturgy of the Word," SP 40 (2006), 115-120, esp. 118.

12 Reinhold Messner, "Der Gottesdienst in der vornizänischen Kirche," in Die Geschichte des Christentums, Band 1. Die Zeit des Anfangs (bis 250), ed. Luce Pietri (Freiburg, Basel, Wien: Herder, 2003), 340-441, esp. 350-354; Ben Witherington, Making a Meal of It (Waco: Baylor University Press, 2007); Margaret Barker, Temple Themes in Christian Worship (Edinburgh: T \& T Clark, 2008), 1-44, 167-220; Alfons Fürst, Die Liturgie der alten Kirche (Münster: Aschendorff, 2008), 12-13.

${ }_{13}$ Wayne Meeks, "Social and Ecclesial Life of the Earliest Christians," in The Cambridge History of Christianity, vol. I, Origins to Constantine, eds. Frances M. Young and Margaret M. Mitchell (Cambridge: Cambridge University Press, 2006), 151-152. 
against which, according to a growing number of researchers, the early Christian gathering must be considered.

As a refinement of the new direction in research on the beginnings of the Christian assembly, Paul Bradshaw has challenged the idea that the format of a supper followed by a drinking party was the sole model on which the Christian gathering was based. Bradshaw argues that meals in the Graeco-Roman world could also have another structure. He points to information about meals in the Qumran scrolls and the Mishnah as well as to the account of a meal of the Roman Emperor Tiberius recorded by Pliny the Elder. According to Bradshaw, this evidence shows that in the first century CE, the prevailing pattern (supper-symposium) occurred in different variants, for instance, one in which the wine was offered, or the blessing over the wine pronounced, before the meal. ${ }^{14}$ However, Bradshaw's argumentation rather seems to confirm that banquets in the Graeco-Roman world were generally modeled on the bipartite format of a supper with a symposium. That this format occurred in practice with some variation is only to be expected and need not be denied.

The paradigm shift mentioned above demands a new inquiry into the origins of the Christian gathering. This investigation should take into account all available evidence that sheds light on how the earliest Christians conducted their communal meals as well as seeking to establish afresh which traditions Christians adopted to shape their gatherings.

Although the Christian gathering had a twofold structure, most attention in recent research has been given to the first part of the gathering, that is, the supper, otherwise known as the Eucharist. This is already clear from the titles and content of several recent publications: "The Early History of the Lord's Supper;" From Symposium to Eucharist; Das Abendmahl; Eucharistic Origins; Paul and the Lord's Supper. ${ }^{15}$ Less attention, however, has been given to the second part of the Christian gathering, which corresponds to the symposium of the Graeco-Roman banquet. It is true that before the paradigm shift of the

\footnotetext{
${ }^{14}$ Paul Bradshaw, Eucharistic Origins, 43-44.

${ }^{15}$ H.J. de Jonge, "The Early History of the Lord's Supper," 209-237; Dennis Smith, From Symposium to Eucharist; Jens Schröter, Das Abendmahl. Frühchristliche Deutungen und Impulse für die Gegenwart (Stuttgart: Verlag Katholisches Bibelwerk, 2006); Paul Bradshaw, Eucharistic Origins. These authors discuss only briefly the other elements of the Christian gathering that took place before or after the communal meal.
} 
nineties in the twentieth century, much work was done on what was called "the service of the Word," held in the morning. ${ }^{16}$ Such "services of the Word" were supposed to have comprised reading, preaching and prayer but not a Eucharist. ${ }^{17}$ The problem is that prior to the third century, there is no evidence for services where praying, reading and preaching took place without a Eucharist. ${ }^{18}$

Invariably, scholars who studied the origins of individual components within the Christian gatherings, such as reading, preaching and prayer, traced them back to certain activities that took place in the synagogue on the Sabbath. ${ }^{19}$ However, on the Christian side these components were part and parcel of the same gathering to which the eating and singing belonged as well. From the discussion of Christian meetings for worship in Paul (1 Cor. 11-14), Justin Martyr (1 Apol. 67) and Tertullian (Apol. 39), it is clear that praying, reading and preaching were parts of one and the same "package," that is, the gathering consisting of both deipnon and symposion. If all components mentioned (eating, singing, reading, preaching and prayer) are seen to be all integrant parts of one ritual event, it becomes very difficult to see the synagogue on the Sabbath as the cradle of the Christian Sunday evening service. The origins of the various components of the noneucharistic part found in the Christian gathering, such as reading, preaching, singing and praying, clearly deserve to be studied anew.

Studying the early Christian gathering in the wider context of banqueting practices in the Graeco-Roman world, seems to recommend itself for several reasons. Firstly, it draws on the broadest possible variety of relevant Hellenistic sources: pagan, Jewish and Christian. Secondly, it may shed light on the form as well as the social dimensions of

16 See, e.g., Jörg Salzmann, Lehren und Ermahnen: Zur Geschichte des christlichen Wortgottesdienstes in den ersten drei Jahrhunderten (Tubingen: Mohr (Paul Siebeck), 1994).

17 This view is advocated by a recent author. See, e.g., Alfons Fürst, Die Liturgie der alten Kirche, 24.

18 G. Rouwhorst, "The Reading of Scripture in Early Christian Liturgy," in What Athens has to do with Jerusalem. Essays on Classical, Jewish, and Early Christian Art and Archaeology in Honour of Gideon Foerster, ed. Leonard Rutgers (Leuven: Peeters, 2002), 324.

19 E.g., Harry Gamble, Books and Readers in the Early Church. A History of Early Christian Texts (New Haven and London: Yale University Press, 1995); Hughes Old, The Reading and Preaching of the Scriptures in the Worship of the Christian Church, vol. 1, The Biblical Period (Grand Rapids and Cambridge: Eerdmans, 1998); G. Rouwhorst, "The Reading of Scripture in Early Christian Liturgy," 305-331. 
the early Christian meals, often neglected by earlier scholars; in their search for Jewish antecedents, they concentrated one-sidedly on the prayer texts and theological interpretations accompanying the meals. Thirdly, it makes one aware of the extent to which the Christians' meetings and meals resembled those of other groups in the world surrounding them. Finally, the study of Graeco-Roman community meals may provide useful information about customs observed at the eucharistic meal as well as those observed during the gathering that took place after the meal.

The approach advocated here remains attentive to possible specifically Jewish traditions that early Christians may have adopted in giving shape to their gatherings and meals. It cannot be denied, for instance, that the weekly cycle of the early Christian gathering is in some way connected with that of the observance of the Sabbath. Nor can one ignore the close affinity of certain early Christian prayers with Jewish meal berakhot: the prominence of thanksgivings and blessings at Christian eucharistic meals can hardly be explained satisfactorily without taking into account prayer traditions transmitted at ceremonial Jewish meals. ${ }^{20}$

In addition, one should have an eye for the innovation that traditions underwent once Christians adopted and used them. From the earliest moment the followers of Jesus developed their own understanding and interpretation of their ritual practices, which served to shape and reinforce the movement's identity, life and belief and to help distinguish it from other groups. ${ }^{21}$ Accordingly, the Christian gathering had its specific Christian features. The food and drink consumed at Christian suppers, for example, were often said to represent Christ, whereas taking the meal was sometimes regarded as a rite accomplished in remembrance of Jesus. ${ }^{22}$ The Christian character of the meal also led to its being designated by typically Christian appellations, such as "the Lord's Supper." Since the meal was used as an occasion for thanksgiving to God, it was, from the beginning of the second century onwards, commonly called the thanksgiving, eucharistia, or Eucharist. ${ }^{23}$

${ }^{20}$ G. Rouwhorst, "The Roots of the Early Christian Eucharist: Jewish Blessings or Hellenistic Symposia?", 302.

${ }^{21}$ Meeks, "Social and Ecclesial Life of the Earliest Christians," 160; G. Rouwhorst, "The Roots of the Early Christian Eucharist: Jewish Blessings or Hellenistic Symposia?", 305.

221 Cor. 11:24-25.

${ }^{23}$ Ign., Eph. 13.1; Did. 9.1, 5; Just., 1 Apol. 66.1. 
The participants experienced the meal as a gathering of the new family of the children of God. In their view, it expressed their community and unity "in Christ." Looked at sociologically, it helped to mark the boundaries between them as Christians and the outside world.

In summary, in studying the origins and early history of the Christian gathering, it is necessary to take into account the banquet traditions of the Hellenistic world at large as well as being aware of the contribution made by the Jewish and Christian communities as their specific traditions developed.

\section{A BRIEF SURVEY OF PREVIOUS RESEARCH}

The history of the Christian gathering has aroused the interest of scholars throughout the twentieth century. Scholars who tried to describe what early Christians did in their meetings during the first three centuries, usually took their subject matter either as a history of the "Christian liturgy" or as a history of early "Christian worship." It looks as if Catholic authors tended to conceive the history of the Christian gathering as a history of the "liturgy" because for them the later Roman-Catholic liturgy was the continuation of the Church's rites during the first three centuries. ${ }^{24}$ They instinctively looked for a pre-history of the Mass and thus found in the first centuries much that resembled their modern practice. Protestant authors, on the other hand, understood their task of describing the early Christian gathering rather as the history of early Christian "worship" or "Gottesdienst." This clearly reflects the emphasis in their own churches that was put on the elements representing the Word, namely the reading of Scripture and preaching, rather than on the eucharistic meal. ${ }^{25}$

\footnotetext{
${ }^{24}$ See, e.g., W.O.E. Oesterley, The Jewish Background of the Christian Liturgy (Oxford: Clarendon Press, 1925); G. Dix, The Shape of the Liturgy (Glasgow: Glasgow University Press, 1945); J.A. Jungmann, The Early Liturgy to the Time of Gregory the Great (Notre Dame: University of Notre Dame Press, 1959); G.G. Willis, A History of Early Roman Liturgy to the Death of Pope Gregory the Great (London: Boydell Press, 1994).

${ }^{25}$ O. Cullmann, Urchristentum und Gottesdienst (Zürich: Zwingli-Verlag, 1950); G. Delling, Der Gottesdienst im Neuen Testament (Göttingen: Vandenhoeck \& Ruprecht, 1952); F. Hahn, Der urchristliche Gottesdienst (Stuttgart: Katholisches Bibelwerk 1970); Ralph Martin, Worship in the Early Church (Grand Rapids: Eerdmans, 1975); A. Cabaniss, Pattern in Early Christian Worship (Macon, GA: Mercer University Press 1989); L. Hurtado, At the Origins of Christian Worship (Carlisle: Pater Noster Press, 1999).
} 
Scholars from both these groups, either independently or as a result of common presuppositions, used to conclude that the early Christian forms of liturgy or worship, consisting of the reading of Scripture, sermon, prayer and Eucharist, arose as a blend of the synagogue's alleged "liturgy of the Word" with Jewish meal traditions. It was generally assumed that early Christians adopted and merged these Jewish practices because they were Jews themselves: they would have known no form of religious meeting other than the one taking place in the synagogue on the Sabbath.

In the middle of the twentieth century, Gregory Dix, in his magisterial work The Shape of the Liturgy, forcefully argued that the meeting of Christians was a combination of two separate assemblies: the synaxis and the Eucharist. In Dix' view, the synaxis was in its shape just a continuation of the Jewish synagogue service of Jesus' days; the Jewish nucleus of the earliest Christian Church would have carried it straight over into the Church in the first decade after Jesus' death. The Eucharist would be a purely Christian creation, rooted in one of the Jewish types of meal: the Passover meal, religious household meals, or meals held by Jewish religious brotherhoods. ${ }^{26}$ Dix preferred to explain the early Christian meal as having evolved out of the Jewish celebration of Passover and did so by tracing the Christian meal back to Jesus' Last Supper, a Passover meal, as recorded in Paul and the Synoptic Gospels. ${ }^{27}$ A variant of this view derived the Eucharist from Jesus' Easter meals with his disciples. ${ }^{28}$ The reason why Dix and some other scholars explained the origin of the Christian liturgical gathering as a combination of the synagogal "service of the Word" and a tradition that sprang from Jesus' Last Supper is that, according to the mid-second century data preserved in Justin's 1 Apologia, the reading out of texts, the sermon and prayers all preceded the eucharistic celebration. The confluence of the two traditions would have resulted in what early Christians called the Lord's Supper or Eucharist.

${ }^{26}$ Gregory Dix, The Shape of the Liturgy, 36.

${ }_{27}$ See Howard Marshall, Last Supper and Lord's Supper (Grand Rapids: Eerdmans, 1980), 107-108. The view that the Eucharistic gathering of Christians had its origin in the Jewish Passover meal held by Jesus during his Last Supper had already been eloquently rejected by H. Lietzmann, Mass and Lord's Supper (originally Bonn: Marcus and Weber, 1926; English version Leiden: Brill, 1979), 172-174.

${ }^{28}$ O. Cullmann, Early Christian Worship (Philadelphia: Westminster Press, 1953), 15; W. Rordorf, Der Sonntag. Geschichte des Ruhe- und Gottesdiensttages im ältesten Christentum (Zürich: Zwingli Verlag, 1962), 228-231. 
However, after Dix it became axiomatic to trace the origins of every aspect of early Christian liturgical practice back to Jewish antecedents. ${ }^{29}$ Later on, other scholars tried to prove that the worship of the early Church was influenced to a considerable extent by the pattern of Jewish worship as practised not only in the synagogue service, but also in the cult of the Jerusalem Temple. ${ }^{30}$

Some authors have tried to discover continuity with Jewish rites in almost every element of the early Christian gathering. Others have minimised the connection between Church and Synagogue, often seemingly on the basis of the dogmatic conviction that for the Christian faith to become a religion on its own, it had to either radically change or reject the religious traditions from which it stemmed. ${ }^{31}$ Without exception, these scholarly positions continued to sustain the common view that the liturgical gathering of the early Church evolved organically out of Jewish rites.

A remarkable feature of the study of the Christian gathering during the twentieth century was that scholars investigated the origins of the meal, or the Eucharist, separately from those of the other components of the Christian gathering. At the same time, much more attention was given to the eucharistic meal than to the other activities that took place in the gathering. The major study was H. Lietzmann's Messe und Herrenmahl. ${ }^{32}$ He came to the conclusion that the Lord's Supper had its origin in a festive Jewish chabura meal, ${ }^{33}$ that is, the meal of a group of friends coming together for religious purposes. Lietzmann also tried to reconstruct the evolution of the eucharistic communion service, arguing that the Eucharist was the result of the fusion of two distinct types of early Christian meals: the eschatological fellowship meal of the Jewish-Christian community in Jerusalem and the Pauline type of Eucharist celebrated in commemoration of Jesus' death. ${ }^{34}$

${ }^{29}$ Paul Bradshaw, The Search for the Origins of Christian Worship, 23.

${ }^{30}$ Ralph Martin, Worship in the Early Church, 18-27.

${ }^{31}$ Paul Bradshaw, The Search for the Origins of Christian Worship, 49.

${ }^{32}$ Hans Lietzmann, Messe und Herrenmahl: eine Studie zur Geschichte der Liturgie (Bonn: Marcus und Weber, 1926). English translation Mass and Lord's Supper (Leiden: Brill, 1979).

${ }^{33}$ H. Lietzmann, Mass and Lord's Supper, 185. For a critique of this view, see J. Jeremias, Die Abendmahlsworte Jesu, 3rd ed. (Göttingen: Vandenhoeck \& Ruprecht, 1960), 23-25.

${ }^{34}$ H. Lietzmann, Mass and Lord's Supper, 209-215. 
Another feature of the quest for the origins of the Eucharist was the researchers' one-sided preoccupation with liturgical texts. They often tried to show that the Christian eucharistic prayer derived from the Jewish prayer of grace offered after meals. These attempts were affected by the assumptions that in the first century CE the text of the birkat ha-mazon was more or less fixed and that it was in general use: both of these were unwarranted suppositions. ${ }^{35}$

Twentieth-century research into the early history of the Eucharist generally came to the conclusion, albeit presented in several variations, that the early Eucharist followed the pattern of the Last Supper with the blessing of the bread preceding that of the wine, the institution narrative recited during the eucharistic prayer, and the ritual as a whole primarily commemorating the death of the Lord.

As to the research into the so-called "service of the Word," several scholars tended to suppose that, from the beginning of the Church, besides their communal supper (the Eucharist), Christians held a separate gathering, without a Eucharist, for the purpose of reading, preaching and other oral activities. ${ }^{36}$ Furthermore, authors who investigated the genesis and development of individual elements of the Christian gathering, such as preaching, singing, prayer and the ordination of officers, invariably tried to trace the origin of these liturgical elements back to traditions supposedly practised in the synagogue. ${ }^{37}$

The view that each and every element of the early Christian gathering could be derived from the synagogue service on the Sabbath began to lose ground during the last decade of the twentieth century. The change that was taking place is illustrated by a telling statement made by Harry Gamble in 1995: "It is easily assumed that the early Church simply transported synagogue practice into its own context, but this cannot be taken for granted." 38 Some of the factors that contributed to this change have already been mentioned above, such as a more

${ }_{35}$ Paul Bradshaw, The Search for the Origins of Christian Worship, 139.

${ }^{36}$ Walter Bauer, Der Wortgottesdienst der ältesten Christen (Tübingen: Mohr (Siebeck), 1930).

${ }^{37}$ E. Lohse, Die Ordination im Spätjudentum und im Neuen Testament (Göttingen: Vandenhoeck \& Ruprecht, 1951), 29-35; C.H. Kraeling, "Music in the Bible," in New Oxford History of Music, vol. 1, Ancient and Oriental Music, ed. E. Wellez (London: Oxford University Press, 1957), 303; Cheslyn Jones et al. (eds.), The Study of Liturgy (London: SPCK, 1992), 68-79, 339-347; O.C. Edwards, A History of Preaching (Nashville: Abingdon Press, 2004), 11.

${ }^{38}$ Harry Gamble, Books and Readers in the Early Church, 211. 
sociological approach to early Christianity and a better understanding of the nature of Graeco-Roman culture. Another factor was the ongoing research into Judaism practised during the Graeco-Roman period which revealed that very little is known about worship in the synagogue before $70 \mathrm{CE} .{ }^{39}$ As a result, attempts to find the roots of the components of the Christian gathering in traditions of the synagogue lost cogency.

The older approach to the study of the Christian gathering also shows three other weaknesses. First, it was often assumed too readily that liturgical customs found in later centuries had been in continuous existence from the first century onwards..$^{40}$ Secondly, historians of early Christian worship often attempted to harmonize disparate pieces of evidence to form a single and homogeneous, composite picture of the history of the liturgy. ${ }^{41}$ Thirdly, research was often based on a limited selection of sources: sources that did not fit the authors' conclusions were easily dismissed as heterodox or marginal. ${ }^{42}$

A new model for researching the origins and development of the early Christian gathering was advocated by M. Klinghardt (1995), H.J. de Jonge (2001) and D. Smith (2003). They argued that the periodical suppers of the early Christian communities, in shape, function and symbolic significance, fitted in with, and were part of, the common banquet culture in the Graeco-Roman world. Early Christian groups adopted the generally current banquet tradition and adapted it to suit their own needs and purposes. Although the new model takes the periodical association banquet as its reference point, it allows for the great variety of data reflecting the different ways in which early Christians practised their communal meals. Only after a long process of standardization, which did not come to a close before the fourth or fifth centuries, were these different practices reduced to a limited number of "orthodox" liturgies. ${ }^{43}$

${ }^{39}$ See, e.g., Heather McKay, Sabbath and Synagogue. The Question of Sabbath Worship in Ancient Judaism (Leiden: Brill, 1994).

${ }_{40}$ Paul Bradshaw, The Search for the Origins of Christian Worship, 51.

${ }^{41} \mathrm{Ib} ., 52$.

42 This has rightly been observed by G. Rouwhorst, "The Roots of the Early Christian Eucharist: Jewish Blessings or Hellenistic Symposia?", 298, 300.

${ }^{43}$ Dennis Smith, From Symposium to Eucharist, 5. Smith's From Symposium to Eucharist of 2003 was preceded by his "Social Obligation in the Context of Communal Meals: A Study of the Christian Meal in 1 Corinthians in Comparison with GraecoRoman Meals" (PhD diss. Harvard University, 1980; not seen). 
Andrew McGowan's study of early Christian eucharistic meals in which only bread and water but no wine was consumed led him to propose a model of their origins which differs from that developed by Klinghardt, De Jonge and Smith. Ultimately, Smith traces back the history of the Christian assembly to one single, very early tradition of Christians coming together, holding a community supper and staying together for further exchange of thoughts and feelings. According to McGowan, however, the history of the Eucharist cannot be traced back to either one single or two "sources." He believes that there existed a broad range of different meal practices in Graeco-Roman culture; this would make it necessary for historians of the Eucharist to pay attention to the specifics of each particular early Christian meal in order to determine which type of meal in the surrounding culture it belonged to. McGowan wishes to distinguish between the various types of Christian gatherings that, in different ways, followed the common pattern of Graeco-Roman meals. According to McGowan, one should beware of downplaying the relevance of specific features of these Christian rituals in the interest of fitting these rituals into the taxonomy of meals in Graeco-Roman culture in general. It remains necessary to pay close attention to formal aspects of each Christian gathering mentioned in the literary sources, not only in terms of its shape and order, the times when, and the places where, they took place, but also the officials who presided over them, as well as components such as reading out of texts, preaching, singing and other ritual actions. ${ }^{44}$

\section{THE PRESENT STUdY}

The following chapters will investigate the origins and development of the Christian gathering until the middle of the third century. This study aims to look afresh at the evidence and seeks to understand both the Christian gatherings as a whole and their constitutive elements in light of the dining practices in the Graeco-Roman world at large.

The first chapter will highlight the essential similarities and dissimilarities between the early Christian gathering and the gatherings of other religious associations in the Graeco-Roman world, especially with regard to dining customs. This chapter will also discuss the ques-

\footnotetext{
${ }^{44}$ Andrew McGowan, Ascetic Eucharists: Food and Drink in Early Christian Ritual Meals (Oxford: Clarendon Press, 1999), 250.
} 
tion why the Sunday became the day for Christian gatherings. Furthermore, it will examine the evidence concerning the physical spaces in which these gatherings took place, their content, the order in which the various components took place and the question who presided over the Christian gatherings.

The second chapter will deal with the question why early Christians introduced a gathering in the morning alongside the regular gathering on the Sunday evening; there will also be an investigation into how the morning gathering developed.

In chapters three to six, this study will investigate the genesis and development of the major components of the Christian gathering, among them the meal proper or Eucharist, the reading of Scripture, preaching, singing and prayer. Finally, chapter seven will briefly explore the origin and function of some other ritual actions that could occur within the framework of the Christian meetings. These actions include the holy kiss, the ordination of office holders, laying on of hands, anointing with oil, liturgical acclamations, collections and giving of alms, foot washing, exorcisms and healings. 



\section{THE ORIGIN OF THE WEEKLY GATHERING IN THE EARLY CHURCH}

\section{INTRODUCTION}

Christians began to hold periodical gatherings not later than the middle of the first century, twenty years after Jesus' death. ${ }^{1}$ In shape and function, the gatherings of Christian communities had much in common with those of voluntary associations, mystery cults and religious societies in the Graeco-Roman world. This chapter will discuss the origins of the Christian gathering within the context of the customs and practices that were characteristic of contemporary religious associations.

Insofar as the sources allow any inference, the periodical gatherings of Christians took place on Sundays; they could be held at various locations, although most took place in private houses. The choice of the Sunday as the day of their communal feasts will be examined in detail in this chapter. The form and content of the Christian gatherings and the order of the proceedings that took place will also be considered. It will appear that, in many respects, the gatherings of Christians followed the format of the Graeco-Roman banquets, such as those held by pagan as well as Jewish individuals, voluntary associations and cult societies. Finally, the question will be discussed as to who presided at the Christian gatherings in the first three centuries.

\section{The early Christian gatherings in the CONTEXT of Graeco-Roman culture}

\section{a. Gatherings of voluntary associations}

During the Hellenistic age, clubs and associations began to proliferate, as the Greek city-states lost importance as the primary focus for their citizens. The result of this development was that during the first centuries of the Common Era, voluntary associations could be found

\footnotetext{
${ }^{1}$ S.R. Llewelyn, "The Use of Sunday for Meetings of Believers in the New Testament," NovT 43 (2001), 205-223.
} 
in cities throughout the Graeco-Roman world. There were many types of associations, although in the Hellenistic period, if not earlier, the formal designations had lost precision. Such groups were known as:

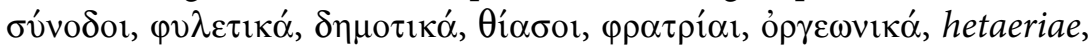
collegia, corpora, sodalitates, etc. ${ }^{2}$ Almost all of these societies were local, consisting of people living in the same city; in general, they were small, with an average membership of less than fifty. ${ }^{3}$ There were associations for honouring certain gods, guilds of workmen of the same trade such as carpenters or silversmiths, societies for volunteer firemen, music associations and philosophical clubs, etc. In these clubs

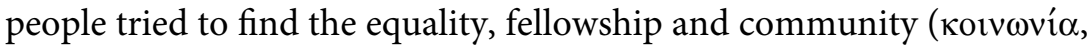
communitas) which society as a whole could not give them. Here, the socially less successful members found some compensation for the lack of recognition which was their part outside of the club.

The common feature of all clubs and associations was that on certain occasions their members dined together. ${ }^{4}$ Communal feasts were held at regular intervals, such as each year on the feast-day of the god whom the club venerated or on the anniversary of the club's foundation. They could also be held more frequently, for instance, once a month, depending on the aim and the statutes of the association. The meetings had a bipartite structure: they consisted of a supper ( $\delta \varepsilon i \pi v o v$ ) and a symposium ( $\sigma v \mu \pi$ ó $\sigma$ เov) afterwards. ${ }^{5}$

2 Athen., Deipn. 5.186f. Athenaeus shows the virtual interchangeability of these terms in his time (ca. $200 \mathrm{CE})$.

${ }^{3}$ Robert Wilken, The Christians as the Romans Saw Them (New Haven and London: Yale University Press, 1984), 35.

${ }^{4}$ See E. Ziebarth, Das griechische Vereinswesen (Leipzig: Hirzel, 1896, repr. Wiesbaden: Martin Sandig, 1969); F. Poland, Geschichte des griechischen Vereinswesens (Leipzig: Teubner, 1909); M. San Nicolò, Ägyptisches Vereinswesen zur Zeit der Ptolemäer und Römer, 2 vols. (München: Beck, 1972); J.S. Kloppenborg and S.G. Wilson (eds.), Voluntary Associations in the Graeco-Roman World (London: Routledge, 1996); Philip Harland, Associations, Synagogues, and Congregations (Minneapolis: Fortress, 2003); E.A. Judge, "Kultgemeinde (Kultverein)," in Realenzyklopädie für Antike und Christentum, vol. 22 (Stuttgart: Hiersemann, 2009), 393-438, esp. 395-407 (Greek), 407-408 (Roman), 409-414 (Jewish). On association meals, see F.W. Danker, "Associations, Clubs, Thiasoi," in ABD 1:501-503; W. Meeks, The First Urban Christians (New Haven and London: Yale University Press, 1983), 31-32, 77-80; E. Ferguson, Backgrounds of Early Christianity (Grand Rapids: Eerdmans, 1993), 131-136; M.N. Tod and S. Hornblower, "clubs, Greek," and G.H. Stevenson and A.W. Lintott, "clubs, Roman," in OCD 351-353; A. Baumgarten, "Graeco-Roman Voluntary Associations and Ancient Jewish Sects," in Jews in a Graeco-Roman World, ed. M. Goodman (Oxford: Clarendon Press, 1988), 93-111.

${ }^{5}$ On this bipartite structure of the banquet in the Hellenistic world, see M. Klinghardt, Gemeinschaftsmahl und Mahlgemeinschaft, 99-129; E. Ferguson, Backgrounds 
The periodical meal served by an association enabled its members to eat better quality food than they were used to on most ordinary days. For the majority of people in the Graeco-Roman world, the daily diet consisted of bread or some kind of cereal, as well as a limited amount of vegetables, fruit, oil and salt according to the circumstances. ${ }^{6}$ In sources describing daily rations meat is rarely mentioned and for most people it was certainly not eaten on regular basis. ${ }^{7}$ Often those who intended to participate in a meal sent baskets of provisions to the host's home and a room was made available for the dinner party guests; however, it was more usual for each participant to contribute a certain amount of money, thus helping to cover the cost of the meal. Alternatively, the host could provide the food at his own expense. The meal could also take place in the precincts of a temple or shrine, or at another place provided or rented specifically for that purpose.

The gathering of an association normally comprised inter alia certain religious activities. Nearly every ancient Mediterranean banquet included some form of religious rite, usually prayer and libation, thus recognizing the presence of the particular divinity the banqueters wished to honour. The libation was a ceremony in which a special cup of wine, customarily the first of the course, was dedicated to a specific deity, often Zeus Soter or a manifestation of Dionysus. During the libation an acclamation such as "To the Good Deity" was spoken and a small quantity of the wine was poured out of the cup on the ground. Almost every association had a reasonably close link with a particular god or hero, quite irrespective of whether the association pursued religious, scientific, artistic, societal or sociable aims. ${ }^{9}$

The course of proceedings during a gathering of a voluntary association generally followed a set pattern. ${ }^{10}$ First of all, the members,

of Early Christianity, 98; for a clear example of the bipartite structure of the banquet, see Luc., Asin. 3.

${ }^{6}$ Cato, De agri cultura, 56-58. In this passage, Cato does not mention milk, cheese or other milk products.

${ }^{7}$ Andrew Dalby, Siren Feasts: A History of Food and Gastronomy in Greece (London: Routledge, 1996), 24-29.

${ }^{8}$ Athen., Deipn. 11.486f-487b; 15.675 b-c.

${ }^{9}$ H.-J. Klauck, The Religious Context of Early Christianity. A Guide to GraecoRoman Religions (London and New York: T \& T Clark, 2000), 44.

${ }_{10}$ The proceedings of an association banquet in the Graeco-Roman world described in this section are those of banquets in general, including those held by rich people for their family and guests. 
having taken a bath prior to their arrival at the host's house, ${ }^{11}$ took their places on the couches ( $\kappa \lambda^{\prime} v \alpha l$ ) provided for them. Servants then washed their feet in basins brought in for this specific purpose. Afterwards guests reclined three to a couch and in lying down they normally rested on their left elbow, ${ }^{12}$ the right arm was left free for taking the food from the table. The practice of reclining at meals spread first in Greek and then Roman society through the class system: originally an aristocratic custom, taken over from wealthy circles in the Middle East, it was imitated in Greece and Rome by lower social groups. To what extent indigenous customs of sitting to eat persisted in different regions is hard to assess. Variation must certainly be allowed for, but evidence for reclining can be found in almost every region of the Roman Empire, especially in the architectural forms of the dining rooms. ${ }^{13}$

After lying down, the participants washed their hands in bowls which were passed round. Food was arranged on the tables on dishes or plates, and always cut in small pieces, as forks were never used at table. Normally, the meal comprised three courses, the first of which consisted of vegetables, herbs and olives. The second course was the meal proper consisting of meat, fowl and/or fish. The third course was the dessert, which played an important part at large dinners, and consisted of cheese, all kinds of fruit, and cakes. ${ }^{14}$

Allusions in literary sources show that some drinking could occur already during the dinner but only in moderation as opposed to the amount of wine consumed during the symposium that followed the meal. ${ }^{15}$ During the meal one drank only with the view to quenching one's thirst. ${ }^{16}$ In the classical period, Greeks kept the meal separate from the symposium. In formal dining, eating was confined to the first

\footnotetext{
11 Apul., Met. 9.24; Luc., Asin. 3.

12 That one normally reclined on the left elbow is clear from ancient vase-paintings, sculptured reliefs, mosaics and wall paintings; see the plates in W.J. Slater (ed.), Dining in a Classical Context (Ann Arbor: The University of Michigan Press, 1991); and M.B. Roller, Dining Posture in Ancient Rome (Princeton: Princeton University Press, 2006). The same attitude is implied in Apul., Met. 2.21.

${ }^{13}$ Katherine Dunbabin, The Roman Banquet. Images of Conviviality (Cambridge: Cambridge University Press, 2003), 19, 21.

${ }^{14}$ J.P.V.D. Balsdon, Life and Leisure in Ancient Rome (New York: McGraw-Hill, 1969), 41-42.

${ }_{15}$ Andrew McGowan, "The Inordinate Cup: Issues of Order in Early Eucharistic Drinking," SP 35 (2001), 283-291, esp. 288-289.

${ }_{16}$ Plut., Quaest. conv. 8.733f-734a.
} 
part of the evening, the meal, whereas drinking took place mainly during the symposium. In the Hellenistic period, the wine accompanied the meal throughout, ${ }^{17}$ and was also served as an aperitif. Moreover, in Hellenistic and Roman times the distinction between meal and symposium increasingly began to be blurred so that it was often difficult to determine when the former ended and the latter began. ${ }^{18}$

The symposium normally comprised a number of fixed components. The drinking cups, bowls, cooling vessels, plates with all kinds of dessert, and dainties that would induce thirst, were arranged on the tables. Sometimes wreaths were given to the guests to adorn their heads and sweet-scented ointments were handed around. Meanwhile, the servants brought in the wine in large mixing bowls, generally three at the beginning of the feast, and later more, as occasion required.

The customary drink at these feasts was a mixture of wine and water. Generally, at the beginning of every symposium, a president or toastmaster ( $\sigma \nu \mu \pi \sigma \sigma i \alpha \rho \chi 0 \varsigma)$ was appointed by lot or dice to take command for the rest of the evening. His was the duty to determine the strength of the mixture, for the wine was never drunk undiluted and the proportions of wine and water could vary considerably. The share of the wine in the mixture could be small: sometimes one even drank three parts of wine to five of water or one to three. ${ }^{19}$

The symposium began with libations, offered to the deity who was considered the patron of the society or party at issue. Sometimes incense was burned. If a flute girl was present at the beginning of the symposium, the solemn proceedings were probably accompanied by flute playing. Every guest had to obey the ordinances of the toastmaster, who exercised unlimited authority in the matter of drinking, unless one had agreed from the beginning that everyone was allowed to drink as much or as little as he liked during that evening. ${ }^{20}$

During the symposium various useful, amusing and edifying activities could take place: conversations, speeches, recitation of poetry,

\footnotetext{
17 See, for instance, Apul., Met. 4.8: "estur ac potatur incondite."

18 George Paul, "Symposia and Deipna in Plutarch's Lives and in Other Historical Writings," in Dining in a Classical Context, ed. William Slater (Michigan: University of Michigan Press, 1991), 157-170, esp. 158.

19 Athen., Deipn. 10.423-427; Plut., Quaest. conv. 3.657.

20 Plut., Quaest. conv. 1.620a-622b.
} 
reading of literary works, as well as singing, making music and dancing. All this entertainment was accompanied by the drinking of wine. ${ }^{21}$

As a rule, music played an important part at symposia in the Hellenistic period. The guests took part in both singing and playing instruments. There were three kinds of singing; choruses, sung all together; part songs, in which all shared, not together, but each in his turn; and solos, sung by those who had special musical ability and education. The flute or harp girls commonly entertained the guests by playing and singing, and probably also by dancing. On a higher level were those social entertainments that made an appeal to the intelligence and wit of the participants.

Much time at the symposium was devoted to free conversation, dealing with current events, politics, literature, etc. The participants also amused themselves with party games, brain twisters, riddles and the like. Although the wine was mixed with a large amount of water, drinking could go on far into the night and as considerable amounts of drink could be consumed, this often resulted in drunkenness and misconduct.

Participation in association meals was mostly restricted to men, except that on occasion prostitutes or hetaerae were present to gratify the men. The flute girls, dancers, and other entertainers present were certainly prostitutes, and the presence of such women was often considered essential for the success of a symposium. ${ }^{22}$ The hetaerae, unlike men's wives, were allowed to recline next to the men, rather than being seated at their feet. ${ }^{23}$ Apart from their providing entertainment and sexual services, some of these women attending banquets were also known for their ability to participate in the conversation between males. ${ }^{24}$

The role of women at group meals was changing in the first century CE. Unlike their Greek counterparts, free Roman women could join the men at formal, well structured meals in social, religious, and philosophical settings. The Gospel of Thomas even depicts Salome and Jesus

${ }^{21}$ The symposium of the bandits in Apul., Met. 4.8-22, for instance, comprises singing, playing jokes on one another, speeches, story-telling, libations and chanting hymns in honour to their patron Mars.

${ }^{22}$ Luc., Symp. 46; Athen., Deipn. 4.129, 131, 150; 8.349; Plut., Sept. sap. conv. 150d.

${ }_{23}$ M. Vickers, Greek Symposia (London: Association of Classical Teachers, 1978), 5.

${ }^{24}$ A great number of sayings attributed to courtesans has been preserved; see, e.g., Athen., Deipn. 13.584a. 
reclining on one dining couch and eating from the same table. ${ }^{25}$ Such an innovation in meal practice threatened the class-based hierarchy of Graeco-Roman society. ${ }^{26}$

The clubs and associations referred to above were intrinsically cohesive groups that became the social setting for many of the ordinary as well as extraordinary events in people's life. Associations also provided a context for practising one's personal beneficence and charity whereby other members received help for their subsistence. Furthermore, the banquets of many associations gave their members a good opportunity to do business and provided room for cultural activities and for showing one's literary and artistic ambitions. Finally, associations could have a function in the social and public life of the cities in that they played a role in the festivals of the city. Clubs and private associations took an active part, for instance, in the Roman imperial cult in Asia Minor. ${ }^{27}$

Associations enriched the lives of their members, both men and women, by providing them with a social and religious context more inclusive than the family but smaller than the city. They were larger than the narrow confines of the family yet intimate enough for one to feel at home in them. Associations had rules and regulations governing their activities; there were offices to be held, honours to be received; and one could be confident that, on one's death, one's fellows would see to it that one received a decent burial.

\section{b. Gatherings of pagan cult associations}

Mystery cults and cult associations were operating throughout the Graeco-Roman world. Sociologically, they can be considered as a subgroup of the general class of voluntary associations. The most popular mystery cults were the one in Eleusis, the Sibylline cult at Rome, the Mithras cult, and the cults of Isis and Serapis. Cult associations are well attested by inscriptions, for instance, those drawn up by the association

${ }^{25}$ Coptic Gos. Thom. 61. Salome is one of the Galilean women and disciples that accompanied Jesus to Jerusalem; Mk. 15:40; 16:1.

${ }^{26}$ Kathleen Corley, Private Women, Public Meals: Social Conflict in the Synoptic Tradition (Peabody: Hendrickson, 1993), 23.

27 S.R.F. Price, Rituals and Power. The Roman Imperial Cult in Asia Minor (Cambridge: Cambridge University Press, 1984), 111, 118. 
of Diana and Antinous at Lanuvium (Latium), ${ }^{28}$ the Iobacchoi society in Athens ${ }^{29}$ and the association dedicated to Zeus (or Theos) Hypsistos in Anatolia and Philadelphia, Egypt. ${ }^{30}$

Gods to whom little attention was paid in the public cult could become the object of special veneration in associations. A private cult association was also an ideal organizational form for foreign cults from the Orient that sought to establish themselves in Greece or Rome.

All ancient cults had one thing in common: their adherents assembled at set times for feasting with an opulent meal. Such communal suppers are well attested, for instance, for the cults of Isis and Serapis. Adherents of these cults assembled periodically in a house or temple and reclined on couches ( $\kappa \lambda \hat{i} v \alpha \mathrm{l}$ ), set up for this purpose, for ceremonial eating and drinking. The Oxyrhynchus papyri include at least twelve invitations to the $\kappa \lambda$ ív vivial party in honour of this deity. Some of these dinners took place in a Serapis temple, others in a temple dining-room or in private houses. Other Oxyrhynchus papyri are invitations to the klinê of Anubis, or to a supper on the occasion of an offering to Isis. ${ }^{31}$ According to Josephus, members of an Isis community in Rome were in the habit of being invited to a supper in the Isis temple. ${ }^{32}$ This was most certainly a ceremonial rather than a private feast.

The Mithras cult is well known for its dining practices. ${ }^{33}$ In Mithraea, the remnants of couches which have been excavated show that they were not used for kneeling down in prayer, but for reclining during

${ }^{28}$ For the text of the inscription, see H. Dessau (ed.), Inscriptiones Latinae Selectae, 5 vols. (Berlin: Weidmann, 1892-1916), vol. 2, n. 7212.

29 The Iobacchoi inscription can be found in J. Kirchner (ed.), Inscriptiones Graecae $\mathrm{II}^{2}$ I, 1-2: Inscriptiones Atticae Euclidis anno posteriores (Berlin: Reimer, 1913), n. 1368 , pp. $650-651$.

${ }^{30}$ For the inscription of Zeus Hypsistos association see, PLond $2710=$ F. Preisigke et al. (eds), Sammelbuch griechischer Urkunden aus Ägypten, Fünfter Band (Wiesbaden: Harassowitz, 1955), n. 7835.

${ }^{31}$ G.H.R. Horsley, New Documents Illustrating Early Christianity, vol. 1 (North Ryde, Australia: The Ancient History Documentary Research Centre, Macquarie University, 1981), 5-9; D. Montserrat in The Oxyrhynchus Papyri, vol. 64, edited with translations and notes by N. Gonis (London: Egypt Exploration Society, 1999), n. 4540 , pp. $227-228$.

32 Jos., Ant. 18.65-80. The episode in question can be dated to ca. 19 CE.

${ }^{33}$ Sarah Iles Johnston, "Mysteries," in Religions of the Ancient World, ed. Sarah I. Johnston (Cambridge, MA: Belknap Press, 2004), 103-104; Roger Beck, The Religion of the Mithras Cult in the Roman Empire. Mysteries of the Unconquered Sun (Oxford: Oxford University Press, 2006), 21-22, 27-28. 
elaborate meals. Cult meals were sumptuous, enjoyable festivities with plenty of food, in contrast to the rather parsimonious meals with which most people had to be content on ordinary days. The mystery cult of Mithras comprised a ritual meal with water and bread that resembled the Christian Eucharist, so much so that Justin could accuse the Mithraists of copying the weekly sacrament of the Christians. ${ }^{34}$

The association of worshippers of Diana and Antinous at Lanuvium, some 70 kilometers south-east of Rome (ca. 136 CE), held communal suppers six times a year. ${ }^{35}$ The association's principal objective was to take care of the decent burial of its members, but it also gathered in regular, periodical meetings, which included a meal, a drinking party and religious rituals. These meetings were occasions for eating, drinking, conversation and entertainment. The gatherings gave the participants not only relief from the daily round of work, but also moral and material support; they gave them opportunities for recognition and honour by which ordinary men could feel a sense of worth and self-respect. The society also enabled its members to give expression to their religious feelings in a setting that was supportive, personal and familiar. ${ }^{36}$

The society of worshippers of Bacchus, the Iobacchoi, existed in Athens during many years in the second century CE. On the occasion of the resignation of its president and the appointment of a new one, shortly before $178 \mathrm{CE}$, the society decided to have its statutes engraved on a stone column. The statutes present a clear-cut picture of the functioning of the society. They include, for instance, rules for admission and regulations for meetings. There are also regulations for those who fail to pay their dues and for those who cause disturbances during the meetings. At the yearly festival, the head of the Iobacchoi ( $\alpha \rho \chi i \beta \alpha \kappa \chi 0 \varsigma)$ performed the customary rituals, such as libations, and delivered a sermon $(\theta \varepsilon o \lambda o \gamma i \alpha)$. The Iobacchoi met on the ninth of each month, on the anniversary of the society's foundation, and on the festivals and extraordinary feasts of Bacchus. On the society's annual foundation day, the archibacchos offered a sacrifice and a drink-offering to Bacchus. Whenever portions of food (meat)

\footnotetext{
34 Just., 1 Apol. 66.4.

35 H. Dessau (ed.), Inscriptiones Latinae Selectae, 5 vols. (Berlin: Weidmann, 18921916), vol. 2, n. 7212, discussed by H.-J. Klauck, Herrenmahl und hellenistischer Kult (Münster: Aschendorff, 1982), 70; Robert Wilken, The Christians as the Romans Saw Them (New Haven and London: Yale University Press, 1984), 36-39.

36 R. Wilken, The Christians as the Romans Saw Them, 36-39.
} 
were distributed, the officers of the society received their portion in the following order: priest, vice-priest, archibacchos, treasurer, boukolikos, Dionysos, Kore, Palaimon, Aphrodite, and Proteurythmos. ${ }^{37}$ The Iobacchoi operated as a cult association: they held communal meals with an ensuing symposium. ${ }^{38}$

According to the statutes of an Egyptian association, the Guild of Zeus Hypsistos (first century BCE, probably between 69-58 BCE), its members held a monthly banquet in the sanctuary of Zeus at which they offered a libation, prayed and performed other rites on behalf of their god and lord, the king. The members of the association were supposed to obey the president and his servant in matters pertaining to the association. The members were not allowed to cause discord or abuse one another at the banquet. ${ }^{39}$

A cult association devoted to Men at Sounion in Attica (second century CE) asked no fees from its members, but stipulated that they bring meat, oil, wine, cake and fruit for the common banquets of the association. $^{40}$

To sum up, the meetings of religious associations comprised meals and social intercourse, worship and instruction. The associations had their officers who were responsible for the smooth running of the meetings. The members were supposed to respect and observe certain rules and to contribute financially to the association. In mystery cults and other pagan cult associations the entertainment during the symposium was a form of community worship.

37 D. Smith, From Symposium to Eucharist, 130-131.

38 Another Dionysiac association is attested by a long inscription discovered two kilometres from Torre Nova in the Roman Campagna, in the environs of Rome, dating to $c a$. 150 CE. The inscription (IGUR I, 160; ed. L. Moretti, Rome, 1968-1991) offers much information about the organizational model, internal structures, membership and recruitment of the association, but does not mention the meals or symposia held by this association. See Bradley H. McLean, "The Agrippinilla Inscription: Religious Associations and Early Church Formation," in Origins and Method: Towards a New Understanding of Judaism and Christianity; Essays in Honour of John C. Hurd, ed. by Bradley H. McLean (JSNT SS 86; Sheffield: JSOT Press, 1993), 239-270.

${ }^{39}$ See text and translation in Colin Roberts, T.C. Skeat and A.D. Nock, "The Guild of Zeus Hypsistos," HTR 29 (1936), 39-88, esp. 41-42.

${ }^{40}$ E.N. Lane, Corpus monumentorum religionis dei Menis, 4 vols. (Leiden: Brill, 1971-1978), n. 13, 1.8-10; 3.7-16; see J.S. Kloppenborg, "Edwin Hatch, Churches and Collegia," in Origins and Method: Towards a New Understanding of Judaism and Christianity; Essays in Honour of John C. Hurd, ed. Bradley H. McLean (JSNT SS 86; Sheffield: JSOT Press, 1993), 212-238, esp. 236. 


\section{c. Gatherings of Jewish associations}

The phenomenon of associations holding banquets and symposia spread all through the Hellenistic world and penetrated groups that were originally from different backgrounds and cultures. ${ }^{41}$ Just as other people in the Graeco-Roman milieu, Jews had their associations with their concomitant communal banquets. Evidence of periodical meals held by Jewish associations occurs in the works of Philo, the writings of Qumran, Josephus, and 3 Maccabees.

According to Philo, the Therapeutae came together to share a common supper in celebration of the Pannychis of Pentecost. ${ }^{42}$ Philo gives a rather idealised picture of the Therapeutaean banquet in contrast with the decadence seen at many pagan banquets. ${ }^{43}$ The gathering of the Therapeutae consisted of two parts. During the first part, the person who presided at the feast gave a long homily. In the second part the participants formed choirs, sang sacred songs, performed dances, and were in "sober drunkenness" until sunrise. ${ }^{44}$

Another Jewish example of a Hellenistic community supper is the congregation meal for which the Community Rule in the Qumran writings gives directions: "They shall eat in common and pray in common; and they shall deliberate in common." ${ }^{55}$ The former part, the eating, was introduced by blessings over the bread and the wine. The latter part comprised, among other elements, the study and discussion of the Law. ${ }^{46}$ The community suppers referred to here were held on a daily basis.

Further instances of common meals held by Jews are the $\sigma v v \delta \varepsilon i \pi v \alpha$ mentioned by Julius Caesar in a letter to the magistrates of Parium, a place on the coast of the Troad, east of the Hellespont. Caesar decrees that the magistrates of Parium permit the Jews of their town "to collect money for common meals and sacred rites." According to Caesar, the Jews were allowed to collect money and to hold common suppers even in Rome. ${ }^{47}$ While it is clear that Caesar is referring here to periodical

${ }^{41}$ K. Dunbabin, The Roman Banquet, 34.

${ }^{42}$ Philo, Contempl. 66-82. For a recent study of the Therapeutae, see Joan E. Taylor, Jewish Women Philosophers of First-Century Alexandria. Philo's 'Therapeutae' Reconsidered (Oxford: Oxford University Press, 2003), 3-170.

${ }^{43}$ Philo, Contempl. 40-63.

${ }_{44}$ Philo, Contempl. 66-90.

45 1QS 6.2-13.

${ }^{46}$ The same injunctions are given in 1QSa 2.17-21.

${ }^{47}$ Jos., Ant. 14.214-216. 
suppers held by Jews, it is not clear whether these suppers in Parium and Rome were events which took place weekly, monthly, yearly, or at other intervals.

In Jerusalem, the Pharisees formed an association. ${ }^{48}$ Similarly, Jews who had lived outside Judea and returned to Jerusalem organized their societies there, as for example, Cyrenian and Alexandrian Jews and Jews from Cilicia and Asia. ${ }^{49}$ First-century BCE papyri from Egypt contain the resolutions of a Jewish burial association and a list of contributions made by the members of the Jewish dining club in Apollinopolis Magna. ${ }^{50}$

For the custom of holding a weekly association supper, there is no pre-70 Jewish analogy. There are only remote parallels, such as the weekly Sabbath gathering held by the Therapeutae. ${ }^{51}$ Philo reports that the Therapeutae held their cultic assembly on the Sabbath. At this gathering, the most qualified members of the group delivered an address. Subsequently, after sunset, those present retired to their rooms and their bread with salt was consumed alone; the supper was not taken in common. The usual order, namely, supper and ensuing gathering with edifying activity, is attested by 1QS 6.2-13 and 1QSa 2.17-21, but in the latter case it is not clear with which frequency these meals and meetings took place; in the former case, the meal and the following conversation were daily routine. Furthermore, there is solid evidence from the second century BCE to the first century $\mathrm{CE}$ of the existence of weekly meetings held by Jews in their $\pi \rho 0 \sigma \varepsilon v \chi \alpha i$ or synagogues for the study of the Law. ${ }^{52}$ However, these synagogal meetings on Sabbath were not followed by a common meal. Philo states that on Sabbath, Jews used to study the Law "till about the late afternoon"

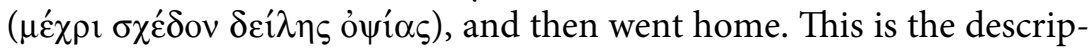
tion of the Sabbath meeting provided by Philo:

Moses required them [i.e., the Jews] to assemble in the same place on these seventh days, and sitting together in a respectful and orderly

${ }^{48}$ Jos., BJ 2.166 .

49 Acts 6:9.

${ }^{50}$ Victor A. Tcherikover (ed.), Corpus Papyrorum Judaicarum, vol. 1 (Cambridge, MA: Harvard University Press, 1957), ns. 138-139, pp. 252-255.

51 Philo, Contempl. 30-33.

52 Philo, Mos. 2.215-216; cf. Spec. 2.62-63; Acts 13:14-15. A. Kasher, "Synagogues as 'Houses of Prayer' and 'Holy Places' in the Jewish Communities of Hellenistic and Roman Egypt," in Ancient Synagogues: Historical Analysis \& Archaeological Discovery, vol. 1, eds. D. Urman and P.V.M. Flesher (Leiden: Brill, 1995), 211-212. 
manner hear the laws read so that none should be ignorant of them and indeed they do always assemble and sit together, most of them in silence except when it is the practice to add something to signify approval of what is read. But some priest who is present or one of the elders reads the holy laws to them and expounds them point by point till about the late afternoon, when they depart having gained both expert knowledge of the holy laws and considerable advance in piety. ${ }^{53}$

Something similar is reported by Agatharchides (2nd century BCE), who observes that on the Sabbath Jews meet in their sacred places

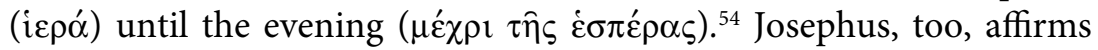
that Moses ordained that every week Jewish men "should desert their other occupations and assemble to listen to the Law and to obtain a thorough and accurate knowledge of it." ${ }^{5}$ But none of these testimonies says that the synagogal study of the Law on Sabbath was concluded with a common supper.

Archaeological evidence of ancient synagogues shows that several ancient synagogues contained rooms where food could be prepared for meals, or rooms where meals could be served. But this evidence is second century CE (Ostia) or later (third century: Stobi in Macedonia) ${ }^{56}$ and in any case it does not prove that, if communal meals took place in synagogues, they took place every week or every Sabbath. In the first century CE, however, Jews did follow the common Graeco-Roman practice of dining and following it with a symposium, both at home in the family circle and in associations. Discussion of the Torah at meals

${ }^{53}$ Philo, Hyp., apud Euseb., Praep. ev. 8.7.12-13 (tra. F.H. Colson).

${ }^{54}$ Quoted by Josephus in Jos., Ap. 1.210.

55 Jos., Ap. 2.175. See also Philo, Opif. 128: Moses ordained the Jews "to keep a seventh day holy, abstaining from other work that has to do with seeking and gaining a livelihood, and giving their time to the one sole object of philosophy [i.e., the Law] with a view to the improvement of character and submission to the scrutiny of conscience;" Jos., Ant. 16.44: "We give every seventh day over to the study of our customs and law," in a speech of Nicolas of Damascus to Agrippa on behalf of the Jews of Ionia, ca. 14 BCE. In Jos., Vit. 279, he relates that a synagogal meeting on Sabbath was sojourned at "the sixth hour" (i.e., at noon) "at which it is our custom on the

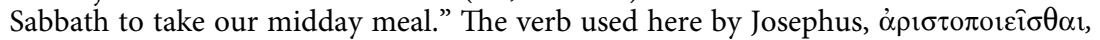
refers to luncheon, not to supper. But Josephus does make it clear that Jews used to take lunch on Sabbath at home, not in the synagogue.

${ }^{56}$ L.V. Rutgers, The Hidden Heritage of Diaspora Judaism, 2nd ed. (Leuven: Peeters, 1998), 117; somewhat more optimistically R.E. Oster, "Supposed Anachronism in Luke-Acts' Use of synagoge: A Rejoinder to H.C. Kee," NTS 39 (1993), 200. But even Oster adduces no evidence for synagogal suppers which took place every week. 
was highly commended in Judaism ${ }^{57}$ and various types of entertainment were provided: speeches, music and dancing. ${ }^{58}$

3 Maccabees, written around $100 \mathrm{BCE}$, contains an aetiological festival legend for a feast celebrated among Egyptian Jews in the author's time, perhaps an Egyptian counterpart of the feast of Purim: ${ }^{59}$

The Jews, as we have said before, arranged the aforementioned choral group and passed the time in feasting to the accompaniment of joyous thanksgiving and psalms. And when they had ordained a public rite for these things in their whole community and for their descendants, they instituted the observance of the aforesaid days as a festival, not for drinking and gluttony, but because of the deliverance that had come to them through God. ${ }^{60}$

The festival clearly included a luxurious meal and a drinking party (6:36), in accordance with the bipartite structure of the Hellenistic supper and symposium in general. However, this festival of the Jews in Alexandria was probably celebrated annually, rather than on a weekly basis. Similarly, the book of Esther (third century BCE) is an aetiology of the annual festival of Purim, celebrated with feasting and gladness; see 9:16-32.

The literary evidence concerning Jewish associations and festivals shows that, like other people in the Graeco-Roman world, Jews formed associations in which they held communal meals and concluded by drinking together as well as engaging in other social activities.

\section{d. Gatherings of Christian communities}

Even before the middle of the first century CE, Christians gathered together at set times during the evening in order to eat together and enjoy one another's company. In this respect early Christian communities were easily compatible with the social and cultural milieu of the Graeco-Roman world; in both secular and religious circles, formal banquets comprising a supper and a symposium were the most common means of giving expression to one's sense of belonging to a group. ${ }^{61} \mathrm{~A}$ supper with an ensuing symposium was the setting in which the followers of Jesus, Pauline groups as well as other Christian

57 Sir. 9:15-16; Philo, Contempl. 75-78.

58 Sir. 32:3-6.

59 H. Anderson, “3 Maccabees," in OTP, vol. 2, pp. 515, 527.

603 Macc. 6:35-36.

${ }^{61}$ Burton Mack, Myth of Innocence (Philadelphia: Fortress Press, 1988), 81-83. 
communities, came together for sharing their beliefs, their joys and their concerns. ${ }^{62}$

Thus, the most conspicuous feature of the early Christian movement was the periodical, in this case weekly, communal dining of its adherents. The earliest description of these Christian gatherings is from shortly after the year $50 \mathrm{CE}$. It concerns the common meals held by the Christian community in Corinth which were followed by an informal convivial party where the supper guests socialized with one another. ${ }^{63}$ Paul discusses the course of these gatherings in 1 Corinthians 10:16-23 and 11:17-14:40. The latter passage is one coherent section of Paul's letter, dealing with the regular gatherings of the Corinthian Christians, as is made clear by the occurrence of the verb

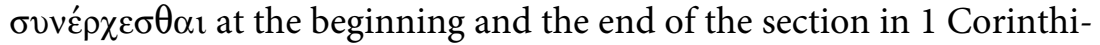
ans $11: 17,18,20,33,34 ; 14: 23$, 26. See, for instance, 11:17 "when you come together" and 14:26 "when you come together."

In writing to the Christians in Corinth, Paul's purpose was to expose and correct some abuses that had crept into their communal gatherings: some participants got drunk, whereas others ate excessively, to the detriment of less well-to-do participants who had to leave hungry because they received little to eat. ${ }^{64}$

The basic pattern of the Christian gatherings, according to Paul, was

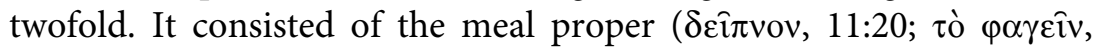
11:33) and a session after the meal with a variety of activities (e.g., prayer, singing, teaching, preaching; 14:13-15, 26, 29-31). These activities roughly corresponded to what happened at banquets in the Hellenistic world in general. A particularity of the assembly of Corinthian Christians was that some of them fell into ecstasy: they uttered streams of inarticulate and incomprehensible sounds ${ }^{65}$ However, other participants produced intelligible speech in the form of teaching, revelations, hymns, preaching ( $\pi \rho \circ \varphi \eta \tau \varepsilon v i \varepsilon ı v)$, and the passing on of wisdom and knowledge. These oral contributions were presented and exchanged in the same gathering as the common meal, however, they took place during the second part of the assembly, after the meal had finished.

${ }^{62}$ K. Corley, Private Women, Public Meals, 17.

${ }_{63} 1$ Cor. 11:17-14:40.

${ }^{64} 1$ Cor. 11:21.

651 Cor. 14. Glossolalia, a form of inarticulate speech produced by a speaker who temporarily loses control over his larynx, is a so-called single limb dissociation, a kind of hyperkinetical dissociation, occurring in the case of altered state of consciousness. 
The twofold structure of the early Christian community gathering also appears in Luke's story where he tells of a supper shared by Paul and the Christian congregation at Troas. ${ }^{66}$ Luke probably means to say that the breaking of the bread at Troas took place during the night of Sunday to Monday ${ }^{67}$ Owing to certain circumstances the meal could not begin until midnight. When the meal was over, the meeting carried on: a session followed where Paul delivered a long homily, which lasted until dawn.

Another important early source of information concerning the form of the Christian gathering is the Didache, mostly dated to the early second century. It is true that the instructions given for the celebration of the Eucharist in chapters 9 and 10 do not speak explicitly about the second part of the gathering, but it is evident why this is so. The author wished to give directions only for formulating the eucharistic prayers: "Let your prayer of thanksgiving run as follows..." $(9.1 ; 10.1)$. The author limits himself to giving models of the prayers to be said before and after the meal. That this is the case is clear from his final remark on the subject: prophets must be left as free as possible to formulate the prayers of thanksgiving (10.7). It is not impossible and even probable that next to the Eucharist the Didache is acquainted with a second part of the gathering. For at what other moment would all those other activities have to take place which the Didache supposes the congregation to accomplish: the election of bishops and deacons (15.1); reprimanding one another (15.3); teaching (11.1-2); welcoming and listening to visiting apostles and prophets (11.1-3) and examining them (12.1-2); settlement of disputes (4.3) and so forth? There is sufficient reason to assume, therefore, that the Didache, too, presupposes the twofold program that was normal for group banquets at the time.

The same twofold pattern is still attested by Tertullian (197 CE, Carthage), who describes the weekly community meal as consisting of a supper (cena) and an after-supper session devoted to the singing of hymns, taken from the Scriptures as well as new compositions, and prayer. $^{68}$

66 Acts 20:7-11.

${ }^{67}$ In the next section, $2 \mathrm{a}$, the question of what Luke means by the evening of "the first day of the week" (Acts 20:7) will be discussed in detail.

${ }^{68}$ Designated by Tertullian, Apol. 39.16-18, as cena nostra, agape (as in Jude 12), and convivium. 
From the earliest account of the communal meal in 1 Corinthians 10-14 it is clear that in order to experience the joy of community Christians gathered around the dinner table and partook of a communal meal, in the same manner as the members of other clubs and associations. At pagan meals the participants became one with the

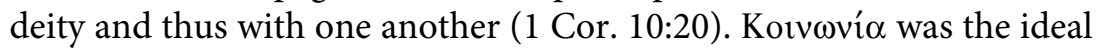
of numerous voluntary associations; it was realized in particular by participating in the common meal in the presence of a deity. Because the Corinthian church shows serious lack of community, Paul finds it necessary to remind the Corinthians of the fact that in principle the Lord's Supper is the expression of the congregation's community with Christ (1 Cor. 10:16) and, as a result, should lead to divisions and factions among them becoming inadmissible. In order to restore and reinforce the Korvwví $\alpha$ of the Corinthians with Christ, Paul adduces the tradition concerning the Last Supper, which, as it appears from Acts and the Didache, originally had played no role in the celebration of the Christians' communal meal. Paul adduces this tradition because it implies the soteriological effect of Jesus' death and resurrection for his followers ("for you," "the new covenant") and, thus, the corporate unity of Christ and his followers which is the presupposition of this soteriological effect. ${ }^{69}$

To the casual observer in the Roman world, Christian communities in the cities throughout the Roman Empire looked like voluntary associations, of which there were so many during that time. Just like these associations, Christian communities held periodical gatherings; they had their own ritual initiation, rules of conduct and requirements for membership. During their meetings Christians held a meal that involved the recitation of prayers and drinking of wine; they listened to speeches; they prayed and sang hymns. They also elected fellow members to serve as officers and administrators of the association's affairs. Just like other associations, the Christian congregation had a common fund containing the contributions of its members; it was used to meet the needs of its members and provide a decent burial for its members. Just as devotees of Asclepius were called Asclepiasts and those of Isis

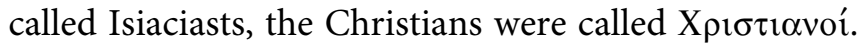

${ }^{69}$ Daniel Powers, Salvation Through Participation. An Examination of the Notion of the Believers' Corporate Unity with Christ in Early Christian Soteriology (Leuven: Peeters, 2001), 180. 
Christian churches were considered by outsiders as religious associations or clubs. In the beginning of the second century Pliny the Younger equates the Christian assemblies with associations (hetaeriae).$^{70}$ Other pagan authors of the second century also used the language of associations to categorize Christian communities. Lucian, the second-century satirist, uses the word $\theta 1 \alpha \sigma \alpha \operatorname{\rho } \rho \eta \varsigma$, "leader of a thiasos (a religious confraternity)," to designate the head of an association of Christians who worship "the man who was crucified in Palestine."71 One of the chief points of Celsus's book against Christianity (178 CE) is that Christians formed illegal associations. Instead of joining in with the public religious rites of the cities, like other associations did, they refused to have anything to do with others and carried on their affairs in the fashion of an obscure and secret association. ${ }^{72}$

In the second century, Christian apologists also provide numerous testimonies that show that pagans conceived of Christian gatherings as communal feasts of religious associations. ${ }^{73}$ According to Justin, Christians were slandered as people who "feasted on human flesh." ${ }^{4}$ This is an indication that the Christian gathering was a banquet which took place in the evening, contrary to what is usually thought with regard to Justin's account of the Eucharist in his 1 Apology 67. That in Justin's view the Christian gathering took place in the evening is confirmed beyond any doubt by a passage in his Dialogue with Tryphon. In it he asks the pagan opponents of Christianity:

Are our lives and customs also slandered among you? And I ask this: have you also believed concerning us, that we eat men; and that after the feast, having extinguished the lights, we engage in promiscuous

${ }^{70}$ Plin., Ep. 10.96.7.

${ }^{71}$ Luc., Peregr. 11.

72 Or., C. Cels. $1.1 ; 8.17$.

${ }^{73}$ Athenag., Plea 3; 31; Theophil., Autol. 3.4; Tert., Apol. 7; Nat. 1.2; 1.7; Min. Fel., Oct. 8.4; 9.6; 31.1, 5; Cornelius Fronto makes observations about the feasts and banquets of Christians at which they worshiped their God. Or., C. Cels. 1.1; 8.32. Accusations of clandestine feasts with human sacrifices and licentious acts were a common means in the Graeco-Roman world to discredit one's opponents. These accusations do not mean that Christians actually committed these acts. Mary Beard, John North and Simon Price, Religions of Rome. A History, vol. 1 (Cambridge: Cambridge University Press, 1998), 225-226. However, Christians do not deny that they have their gatherings in the evening. They themselves used the same strategy for discrediting certain groups of heretics. See, e.g., Iren., Haer. 1.13.4; 1.25.5.

74 Just., 2 Apol. 12. 
concubinage? Or do you condemn us in this alone, that we adhere to such tenets, and believe in an opinion, untrue, as you think? $?^{75}$

As to the view of Christian gatherings as meetings of associations, Christian authors themselves compared their gatherings with those of pagan cult associations. In 1 Corinthians 8-10 Paul argues that Christians should not partake in the meals of such associations. According to 1 Corinthians 10:19-22, Paul believes that demons exist but cannot possess a "strong," that is, not overscrupulous, Christian. The idols are no match for a strong believer and have no influence on him. Paul distinguishes between strong and weak Christians. For the sake of weak Christians the strong Christians should not partake in pagan meals. However, in principle Christians can participate in pagan meals because normally they can resist demons. In Graeco-Roman society much of professional life and business networking took place at symposia in pagan temples. For that reason Christians felt that it was inevitable for them to attend pagan meals. The temptation to go to such meals was all the stronger because the meals presented an opportunity to eat meat, something very few people could afford every day. For the purpose of the present study, 1 Corinthians 8-10 shows that, in Paul's perception, the Lord's Supper was the Christian counterpart of pagan cult meals like those held in honour of pagan deities and such gods as Serapis, Anubis and Isis.

In the middle of the second century Justin Martyr, as has already been stated, holds the demons responsible for the fact that the Christian Eucharist is imitated in the initiation rites of the Mithras cult in the form of eating bread and drinking a cup of water. ${ }^{76}$ This is again an indication that the Christian group meal and pagan cult meals were sociologically analogous phenomena.

About 200 CE Tertullian compares the meals of Christian communities with meals of various religious associations such as the collegia Saliorum and the associations for the Dionysus and Serapis cults. ${ }^{77}$ Tertullian also designates the religious community of the Valentinians as a society, collegium, with many members. ${ }^{78}$ Evidently, Christian communities were regarded as a sort of voluntary association,

\footnotetext{
75 Just., Dial. 10 (tra. A. Cleveland Coxe in ANF).

${ }^{76}$ Just., 1 Apol. 66.4.

77 Tert., Apol. 39.15.

78 Tert., Val. 1.1: "Valentiniani frequentissimum plane collegium inter haereticos...."
} 
in particular as a religious cult association, both by Christians themselves and non-Christians. ${ }^{79}$ For understanding the form and content of the Christian gathering and the way it functioned it may be helpful, therefore, to compare it with those of other associations, especially cult associations of the time.

As far as the terminology for designating Christian associations is concerned, Christians themselves often used the word $\dot{\varepsilon} \kappa \kappa \lambda \eta \sigma i \alpha,{ }^{80}$ not one of the numerous words by which pagan associations were desig-

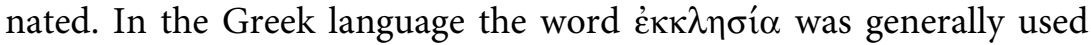
to denote an assembly duly convened, as well as meetings of the representatives of a people or a city population, such as city assemblies, in Athens, and the Roman comitia. ${ }^{81}$ Greek speaking Jews often used $\dot{\varepsilon} \kappa \kappa \lambda \eta \sigma i \alpha$ to denote the gathering of the people of Israel in the past, frequently in the Septuagint, but also to designate a gathering of Jews in their own time. ${ }^{82}$ By adopting this term Christians implicitly made the claim that from now on they were the continuation of Israel, the people of God. ${ }^{83}$ Pagan observers, such as Pliny in the passage just mentioned, were unfamiliar with the theological self-definition of the early Christians as $\dot{\varepsilon} \kappa \kappa \lambda \eta \sigma i \alpha .{ }^{84}$ Instead, they applied the vocabulary commonly used for Graeco-Roman associations to the Christian

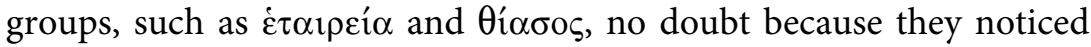
the formal agreements between the gatherings of Christian communities and those of pagan associations.

${ }^{79}$ One other designation of Christian communities by Christians is fraternitas. See, e.g., Acta Petri 16. The Latin here probably translates $\varphi \rho \alpha \tau$ pí $\alpha$, a common term for an association in later Greek.

${ }^{80}$ Besides "disciples," "holy ones," "brothers," "the elect," and “(followers of) the Way."

${ }^{81}$ For the historical background of the use of $\dot{\kappa} \kappa \lambda \eta \sigma^{\prime} \alpha$ for Christian communities, see W.O. McCready, "Ekklêsia and Voluntary Associations," in Voluntary Associations in the Graeco-Roman World, eds. John Kloppenborg and Stephen G. Wilson (London: Routledge, 1996), 59-73.

82 E.g., Jos., Vit. 268.

${ }^{83}$ The cultural background(s) of $\dot{\varepsilon} \kappa \kappa \lambda \eta \sigma i \alpha$ as a designation of the Christian community is still a much debated problem. For a recent treatment of this issue, see A.B. du Toit, "Paulus Oecumenicus. Interculturality in the Shaping of Paul's Theology,"

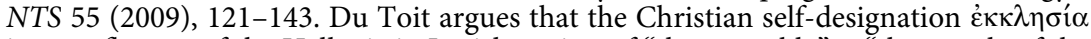
is a confluence of the Hellenistic-Jewish notion of "the assembly" = "the people of the Lord" and the Greek notion of غккк $\lambda \eta \sigma^{\prime} \alpha$ as a local, individual group. Whether it is necessary, however, to suppose pagan Greek influence in this case is questionable; the shift of meaning from "inclusive assembly" to "local congregation" is foreshadowed in Deut. 23; Neh. 13:1-3; Lam. 1:10; Philo, Virt. 108, as Du Toit indicates himself.

${ }^{84}$ However, Pliny does know the Latin noun ecclesia for the assembly of the people of a Greek town; see Ep. 10.110.1. 
Contrary to what has often been maintained, the origins of the Christian gathering cannot be found in a specifically Jewish form of meeting, a meal or assembly. ${ }^{85}$ The periodical supper held by voluntary associations was a generally Hellenistic practice. This practice was shared by pagans and Jews alike. In this respect pagans and Jews shared the same cultural tradition. It is impossible, therefore, to differentiate between periodical community suppers held by pagans and similar suppers held by Jews. Consequently, it is impossible and pointless to derive the Christian community supper from a specifically Jewish meal. Rather, the Christian community supper is a specimen, alongside many similar specimens which were practised by pagans as well as Jews, of the generally Hellenistic periodical community supper.

The bipartite agenda of the Christian gathering, consisting of a supper and an ensuing meeting, shows that it was the Christian actualization of a generally Hellenistic practice. ${ }^{86}$ The most one can say is that this Christian variant of the Hellenistic community supper betrays Jewish influence in two aspects, namely, in its weekly repetition and in its introductory prayers. Its weekly repetition must have been borrowed from the Jewish custom to meet on the Sabbath for a good meal in the family circle. ${ }^{87}$ The practice of "saying grace" before a meal was a typically and, as it seems, exclusively Jewish custom. ${ }^{88}$ These influences do

${ }^{85}$ G. Dix, The Shape of the Liturgy (Glasgow: University Press, 1945), 36; R. Martin, Worship in the Early Church (Grand Rapids: Eerdmans, 1975), 18-27; H.I. Marshall, Last Supper and Lord's Supper (Grand Rapids: Eerdmans, 1980), 18-29.

${ }^{86}$ Cf. H.-J. Klauck, "Lord's Supper," in ABD 4:362-372, esp. 370 on pagan suppers followed by social parties "The sequence of [a] the main meal, including a drink offering for the gods, [and b] philosophical discussions, musical-artistic presentations, speeches and songs at a symposium, could provide a structural equivalent to a church's celebration with [a] a meal (1 Cor. 11:20-21), eucharistic double action (1 Cor. 10:16-17), [and b] worship in word with prophecy, speaking in tongues, the reading of scripture, interpretation, psalms, songs and prayers (1 Cor. 14)."

${ }^{87}$ The evidence for a weekly Jewish family meal on Saturday includes Mk. 1:31: "she served them" (the Sabbath is mentioned in v. 21); Jn. 12:2; Persius 5.182-184; Plut., Quaest. conv. 4.672a; Tert., Apol. 16.11; Nat. 1.13.

${ }_{88}$ Jos. Asen. 8.5; Sib. Or. 4.26; cf. 1QS 6.4-5 and Josephus on the Essenes, BJ 2.131, "The priest says grace before the meal; to taste the food before this prayer is forbidden (...), for at beginning and end they give thanks to God as the giver of life." The prayer said at the beginning of Jewish meals, however, can be considered the counterpart of the libation which often preceded suppers among the gentiles. Such libations were performed, e.g., at the banquets of the society devoted to Diana and Antinous in Lanuvium and at the monthly banquets of the society of Zeus Hypsistos attested in PLond 2710 = F. Preisigke et al. (eds.), Sammelbuch griechischer Urkunden aus Ägypten, Fünfter Band (Wiesbaden: Harassowitz, 1955), n. 7835, discussed by H.-J. Klauck, Herrenmahl und hellenistischer Kult, 70. Epictetus, Discourses 2.23.5, admonishes his 
not alter the fact, however, that the Christian gatherings originated as a Christian form derived from the generally Hellenistic phenomenon of voluntary associations holding periodical suppers. Sociologically, the Christian gathering was not something entirely new; in principle, it was the continuation of the current phenomenon of the banquet with symposium. The basic format did not need to be transformed into something new. The pattern was available and widely popular, but contents and interpretation naturally took on a Christian character, as we shall see in what follows.

During the first century of their existence, the course of the Christian gatherings was probably not very different from that of contemporary religious associations, except for the topics of conversation discussed by the participants and the hymns sung. The way of meeting in houses and the role played by patrons and servants may have been by and large the same. ${ }^{89}$ After-dinner discussions naturally varied and developed according to the subjects that interested the group. Instead of Homer and Menander, new Christian compositions, especially letters, and Jewish Scriptures came to be read during the gathering of the Christians. Trying out a poem or a newly composed hymn to Christ would be in order and often appreciated.

In conclusion of this section it may be helpful to compare the way Graeco-Roman associations and Christian communities functioned and to present similarities and differences in a table. The table necessarily implies a certain degree of generalization; special features of specific associations will be omitted.

pupils to be grateful to God: "For life itself and for what is conducive to it, for dry

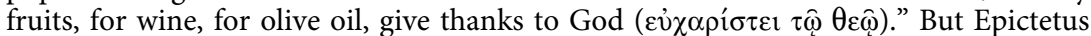
does not say that they must give expression to this gratitude in prayers at the beginning of meals.

${ }_{89}$ One noteworthy difference, however, is that pagan associations could also meet in temples, temple precincts and rooms belonging to temples. 


\section{Voluntary associations and pagan Christian communities}

cult associations

Associations gave their members a certain degree of social recognition and self-esteem which they could not attain on their own. There was a sense of fraternity among its members, often

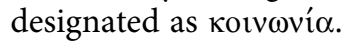

Every association had its divine protector(s) deemed to be present in the gathering.

Associations honored certain heroes or deities who were often regarded as their founders.

Associations met in temples, dining halls or private houses.

Gatherings of associations had a bipartite structure comprising a supper and a symposium following. The meal was a real meal but also had a sacramental significance.

Associations often took care of the decent burial of their members. Donations to a common fund were given voluntarily or according to common rules. They practised charity.

Associations had elected officers, inter $a l i a$, to preside over their meetings.

Associations depended to some extent on the beneficence of wealthier members who acted as patrons.
Christians gathered to experience

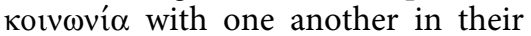
group..$^{90}$ The members of Christian communities called each other brothers and sisters. ${ }^{91}$

God and Jesus Christ were considered to be the divine protectors of Christians and to be present in the gathering. ${ }^{92}$

Jesus Christ was considered the founder of the Church and thus, indirectly, of each congregation. ${ }^{93}$

Christians met in private households and possibly in other places. ${ }^{94}$

Christians had the Lord's Supper or Eucharist followed by a symposium. The supper was a real meal but also had a sacramental significance. ${ }^{95}$

Christian congregations often took care of the burial of their members ${ }^{96}$ and practised charity. ${ }^{97}$

Christian congregations had elected officers, inter alia, to preside over their meetings. ${ }^{98}$

Wealthier Christians served as hosts of the congregational gatherings and often provided food for the common meals. ${ }^{99}$

901 Cor. 10:16-17.

91 Cor. 11:33; 12:1; 14:6, 20, 26, 39. Cf. Rom. 15:5.

92 Rom. 8:31; 2 Thess. 3:3; Tert., Apol. 39.4.

93 Eph. 1:22-23; 2:19-22; Cf. 1 Cor. 11:23; Mt. 16:18; Heb. 12:2.

941 Cor. 16:19; Rom. 16:5; Col. 4:15; Phlm. 2; Cf. Acts 19:9.

951 Cor. 11-14. For the meaning of "sacramental," see the beginning of Chapter 3.

96 Tert., Apol. 39.6; Cypr., Ep. 8.3.2; Trad. ap. 40.

97 Jas. 1:27; 1 Tim. 5:3, 16.

98 Just., 1 Apol. 67.4; Tert., Apol. 39.4.

99 Trad. ap. 28.3; 30; Cf. Acts 16:15. 
2. Time and place of the gatherings of the early Church

\section{a. The Sunday as the day for Christian community gatherings}

From a sociological point of view the gathering of the early Christians is comparable to the periodical banquets of Graeco-Roman clubs and associations, from which the Christian gathering borrowed its bipartite structure. Apart from the supper, it comprised a symposium with various oral contributions and communal activities. As far as the evidence allows for any conclusion, Christians in the second half of the first century held their communal gatherings on Sunday evening. There are reasons to assume that this tradition has its roots in the early JewishChristian communities during the forties and thirties. In the Roman Empire of the first century CE the Sunday was a working day. For Christians, the only difference between this day and other weekdays was that on Sunday evening they met after work to enjoy a common supper followed by a social gathering. As will be seen presently, they experienced the meal and the gathering as a joyful event. ${ }^{100}$ Christians seem to have eagerly anticipated their communal supper and, consequently, the Sunday, although a working day, became a special day for them.

Paul does not say on which particular day the Lord's Supper was held by the Corinthian Christians, but in view of the collection for the poor of the Jerusalem church, Paul advises the Corinthian Christians to put aside money at home on the first day of the week. ${ }^{101}$ The most plausible explanation of this mention of the first day is that this day was already an important one for the addressees as Christians. And if it was an important day for them as Christians, it probably was so because it was the day on which they gathered for table-fellowship with one another in the presence of the risen Lord.

The author of Acts 20:7 puts the gathering of Christians explicitly on the first day of the week. It has sometimes been suggested that in this passage the phrase "on the first day of the week" means on Saturday

100 The joy had its ground in the Christians' belief in Jesus' presence at the meal as an anticipation of his second coming and in their view of the Supper as an anticipation of the eschatological banquet; see A.B. du Toit, Der Aspect der Freude im urchristlichen Abendmahl (Winterthur: Keller, 1965), 116-118.

1011 Cor. 16:2. 
evening. This, however, is improbable. ${ }^{102}$ In his Gospel, Luke, rather differently from Mark, brings the disciples together on Sunday evening to celebrate a communal meal. ${ }^{103}$ Luke probably does so because he was acquainted with the Christian custom of coming together on Sunday evening for breaking bread and staying together in a social gathering. The evangelist John even brings the disciples together on two successive Sunday evenings after Jesus' death. ${ }^{104}$ This seems to reflect the Church's practice to gather on Sunday evening. ${ }^{105}$

In this connection, special importance has sometimes been attached to Luke's use of $\tau \hat{n} \dot{\varepsilon} \pi \alpha$ v́piov in Acts 20:7. This phrase has been taken by some interpreters as an indication that "the first day of the week" in this verse means Saturday. ${ }^{106}$ For if $\tau \hat{n} \varepsilon \dot{\varepsilon} \pi \alpha v ́ p$ sense of "the next morning," no new day needs to have begun when Paul left Troas. In that case Luke could have regarded the evening of the meeting at Troas as belonging to the next day and designated that evening as "the first day of the week." Then the gathering in Troas would have started on Saturday evening. However, there is little rea-

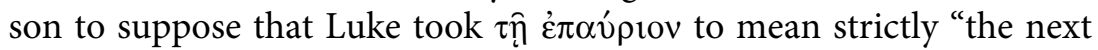
morning"; he uses the phrase no less than ten times in Acts and in no case is there any necessity to interpret it as "the next morning." Luke clearly uses it naively with the obvious, natural and common meaning of "on the next day." See, e.g., Acts 10:9: "Next day at noon." The Vulgate translates all ten instances of $\tau \hat{n} \dot{\varepsilon} \pi \alpha u ́ p$ a phrase meaning "next day," 107 never with a phrase meaning "next morning." Everything seems to indicate that for Luke days ran from

${ }^{102}$ For detailed discussions of the passage at issue, see, inter alios, W.A. Rordorf, Der Sonntag (Zürich: Zwingli, 1962), 198-199; M. Klinghardt, Gemeinschaftsmahl und Mahlgemeinschaft, 328; C.K. Barrett, The Acts of the Apostles, vol. 2 (London and New York: T \& T Clark, 1998), 951-952; S.R. Llewelyn, "The Use of Sunday for Meetings of Believers in the New Testament," NovT 43 (2001), 205-223, esp. 210-213.

${ }^{103}$ Lk. 24:33-43.

${ }^{104}$ Jn. 20:19, 26.

105 M. de Jonge, Johannes: een praktische bijbelverklaring (Kampen: Kok, 1996), 242.

106 See, e.g., The New English Bible. New Testament (Oxford and Cambridge: OUP and CUP, 1961): "On the Saturday night;" Bonnes nouvelles aujourd'hui. Le Nouveau Testament traduit en français courant (Paris: Alliance Biblique Universelle/Société biblique française, 1972): "Le samedi soir."

${ }_{107}$ Postera die (10:9; 14:20; 22:30; 23:22); altera die (10:24; 25:6; 25:23); sequenti die (10:23); in crastinum (20:7); alia die (21:8). 
dawn to sunset (with the night between the days) or from midnight to midnight, not from sunset to sunset. ${ }^{108}$

Recently, Johannes Tromp has devoted a special study to the chronological problem of Acts 20:7. ${ }^{109}$ On the basis of numerous Jewish sources of the Hellenistic age he shows that Jews of that period, with a view to the oncoming Sabbath, wanted to keep the later part of the Friday afternoon free from work, but did not regard the evening of the Friday as part of the Sabbath. The Sabbath was the Saturday from sunrise to sunset. Tromp concludes that the meal that Paul and his companions are said to have had in Troas on the first day of the week, is situated by the author of Acts in the late afternoon or evening of Sunday. ${ }^{110}$

The author of the book of Revelation says he received his revelation on "the Lord's day." 111 This phrase has been interpreted in various ways but the most plausible interpretation remains that it refers to the Sunday. ${ }^{112}$ If so, the Sunday received a special Christian name because of the communal gatherings that were held on that day. The

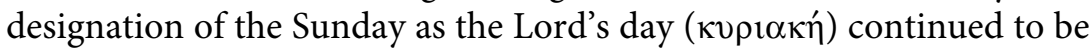
used by Christian authors in the second century. ${ }^{113}$ It became the usual name of the Sunday in Greek until the present day.

Pliny says that Christians came together for their common meal on a fixed weekday (stato die), but he does not say on which day. ${ }^{114}$ Ignatius, however, who wrote his letters in the same period and broadly

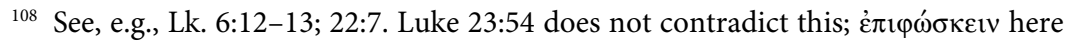
means "to be approaching," not "to dawn;" see J. Tromp, "Night and Day. A propos Acts 20:7," in Jesus, Paul and Early Christianity, eds. R. Buitenwerf, H.W. Hollander, J. Tromp (Leiden: Brill, 2008), 363-375, esp. 370-371, note 28.

109 J. Tromp, "Night and Day. A propos Acts 20:7," in Jesus, Paul and Early Christianity, eds. R. Buitenwerf, H.W. Hollander, J. Tromp (Leiden: Brill, 2008), 363-375.

${ }_{110}$ J. Tromp, "Night and Day. A propos Acts 20:7," 373.

111 Rev. 1:10.

112 S.R. Llewelyn, "The Use of Sunday for Meetings of Believers in the New Testament," NovT 43 (2001), 220-222.

${ }_{113}$ Did. 14.1; Ign., Magn. 9.1; Ep. ap. 18; Gos. Peter 35; 50; Dionysius of Corinth, Ep. ad Rom. apud Euseb., HE 4.23.9; Clem. Al., Ex. ex Theod. 63.1; Str. 5.106.2; Euseb., $H E$ 3.27. Latin authors simply used the Latin equivalent of кvрıккn, "dies dominicus," see, e.g., Tert., Idol. 14.7; Cor. 3.4; cf. Ieiun. 15.2.

114 Plin., Ep. 10.96.7. In the first and second centuries the gatherings of Christians were held on Sundays in the evening. In the early second century, as appears from Pliny, a morning gathering was introduced besides the evening meeting. This morning gathering gradually spread to all other days of the week. By the end of the second century several sources speak about daily gatherings of Christians in the morning. This whole development will be discussed in the second chapter. 
speaking in the same region as Pliny, ${ }_{115}$ says, "those who had lived in antiquated practices [i.e., the Jews] came to newness of hope, no longer keeping the Sabbath but living in accordance with the Lord's day." "116 Barnabas mentions that Christians met on the "eighth day," that is, on Sunday. ${ }^{117}$ The author of the Didache tells us that Christians gathered to break bread and give thanks on "the Lord's day." 118 The author of the Gospel of Peter replaces the phrase "on the first day of the

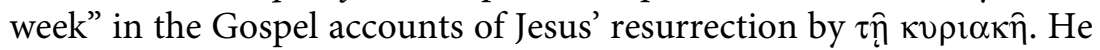
apparently does so because in his time кирıккn is already the generally accepted Christian term for Sunday. ${ }^{119}$ In the middle of the second century Justin states that the weekly Christian gathering takes place on Sunday. ${ }^{120}$ In the second half of the second century, Dionysius, Bishop of Corinth, writes to Soter of Rome: "Today being the Lord's Day, we kept it as a holy day." 121 According to Eusebius, second-century Ebionites celebrated certain rites in memory of the Saviour's resurrection "on the Lord's day." 122

As appears from the passages mentioned above, the evidence for Sunday as the day on which Christians gathered is widely spread: Dionysius (170 CE), Justin Martyr (150 CE), Gospel of Peter (130), Didache (120 CE), Ignatius (110 CE), Revelation (ca. $110 \mathrm{CE})$, John (ca. $90 \mathrm{CE}$ ), Acts $(c a .85 \mathrm{CE})$ and Luke $(c a .80 \mathrm{CE}) .{ }^{123}$ Moreover, there is an independent testimony concerning a Christian appreciation of the first day of the week in 1 Corinthians 16:2 (55 CE). The witnesses mentioned for the Sunday as the day of the Christian gathering must reflect independently a common underlying practice. This practice is so widespread and so consistent that it is best explained as deriving from the

115 Recently, Timothy D. Barnes, “The Date of Ignatius," $\operatorname{ExpT} 120$, n. 3 (2008), 119-130, has argued that Ignatius' letters presuppose knowledge of the Gnostic Ptolemaeus and have to be dated therefore to the reign of the Emperor Antonius Pius (138-161 CE). In several respects, however, Barnes' argumentation seems to be rather speculative.

${ }_{116}$ Ign., Magn. 9.1. R. Bauckham rightly points out that it would seem that Ignatius is referring here to the Sunday as the day when Christians hold their communal gatherings. See R.J. Bauckham, "The Lord's Day," in From Sabbath to Lord's Day, ed. D. Carson (Grand Rapids: Zondervan, 1982), 228-229.

117 Barn. 15.9.

118 Did. 14.1.

119 Gos. Peter 35; 50.

${ }^{120}$ Just., 1 Apol. 67.3.

${ }^{121}$ Euseb., HE 4.23.9.

${ }_{122}$ Euseb., HE 3.27.

123 The dates mentioned in this paragraph are only meant as approximate. 
practice of one early Christian community. The best candidate is the Christian community of Jerusalem in the thirties and forties CE. ${ }^{124}$

Because of the supper held on Sunday evening, the Sunday as a whole became a day of joy. Barnabas says: "We celebrate the eighth day with gladness." ${ }^{125}$ When Tertullian blames Christians for participating in pagan festivals, he says that they do not need such festivals because Christians have a feast every eighth day. Elsewhere he speaks of the festival of the Lord, obviously referring to the Christian Sunday as a joyful "festival." ${ }^{26}$ Tertullian also remarks: "We make Sunday a day of festivity." ${ }^{27}$ Other Christian authors, too, speak about the joyful character of the Sunday. ${ }^{128}$ Christians celebrated the Sunday with joy because it was the day of their community assembly, consisting of a supper and a social gathering. This assembly was the Christian counterpart of the periodical banquets of numerous Graeco-Roman cults and associations where food, wine and conviviality created a festive atmosphere, fellowship and gladness of heart.

In the twentieth century scholars have proposed various reasons why Christians chose the Sunday evening as the time for their meetings. Some explanations try to account for the choice of the Sunday by referring to the importance of the cult of the Sun in certain pagan or Jewish circles. However, around the beginning of the Common Era, groups venerating the Sun did not choose the Sunday for their Sun worship. Neither in the Mithras cult, ${ }^{129}$ nor in any group standing behind the Qumran writings, did the Sunday become a special day for

124 The weekly frequency of coming together for supper and conviviality is not without analogy in the Graeco-Roman world. Aulus Gellius (ca. 125-180), NA 7.13.2-3; 15.2.3, says that the Athenian philosopher Calvenus Taurus held banquets with his students hebdomadibus lunae; this means "on every seventh day of the moon" (Lewis and Short, A Latin Dictionary, s.v. hebdomas), "at the beginning of each week" (J.C. Rolfe in LCL, followed by Dennis Smith, From Symposium to Eucharist, 47), or "each seventh day in the moon's cycle" (P.G.W. Glare, Oxford Latin Dictionary, 1973, s.v. hebdomas), that is, on a weekly basis. The meetings consisted of a meal (cena) followed by a convivium during which philosophical discussions took place.

125 Barn. 15.9.

126 Tert., Idol. 14.6-7; Fug. 14.1; Ieiun. 14.1-2.

127 Tert., Nat. 1.13.1; also Apol. 16.11: "We devote the Sunday to rejoicing."

${ }^{128}$ Min. Fel., Oct. 9; 31. Christians are said to gather for a communal feast on a sacred day. Minucius intends to defend the modesty of Christian gatherings against accusations but still describes them as joyful banquets. The author of the Did. ap. 5.10, speaks about the Sunday as the day when people rejoice and enjoy themselves.

${ }^{229}$ W.A. Rordorf, "Origine et signification de la célébration du dimanche dans le christianisme primitif," in Liturgie, foi et vie des premiers chrétiens. Études patristiques (Paris: Beauchesne, 1986), 38. 
worship of the Sun. Consequently, the Christian Sunday cannot be a Christian adaptation of a pagan or a Jewish festival.

There are also some other current explanations for the choice of the Sunday as the day of the Christian gathering. The usual explanation is that it is the day of Christ's resurrection. This interpretation of the Sunday, however, is late and secondary. It appears first in Ignatius. Until the second century CE the resurrection of Jesus on Easter Sunday is not mentioned as a motif for meeting on Sunday. ${ }^{130}$ It is of course true that Mark 16:1 and the other Gospels date the resurrection of Jesus "on the first day of the week." But saying that "Jesus has risen on the first day of the week" is not the same thing as saying that "the first day of every week is the day of Jesus' resurrection." The former is an historical statement, the latter a liturgical one. It is quite a distance to come from the one to the other. Moreover, during the first century $\mathrm{CE}$, Christian Sunday celebrations took place in the evening and not in the early morning, the time mentioned for Jesus' resurrection in the Gospels. It is more probable that Mark dated Jesus' resurrection on a Sunday because Sunday already was the day of the Christian gathering rather than that Sunday was chosen for the gathering because of Jesus' resurrection. The reason why this is the more probable option is that the evidence for the existence of Sunday as a celebration day is earlier (the common tradition attested independently by 1 Cor. 16, Acts 20 and Rev. 1) than the connection of Jesus' resurrection with the Sunday (at first in Ignatius). ${ }^{131}$

Another explanation tries to link Sunday with the first day of the creation in Genesis 1:3-5. In about 150 CE Justin explains that Christians celebrate Sunday because it is the first day of the creation, on which God changed darkness into light and created matter. ${ }^{132}$ However, this explanation turns up so late that it is difficult to assume that it was the reason why Christians chose the Sunday evening for gathering.

Still another theory suggests that originally Christians gathered on Saturday evening, not on Sunday. ${ }^{133}$ According to this view, Christians

${ }^{130}$ Ign., Magn. 9.1-2; Barn. 15.9; Just., 1 Apol. 67.7.

131 The same conclusion has been drawn by Rudolf Bultmann, Die Geschichte der synoptischen Tradition (Göttingen: Vandenhoeck \& Ruprecht, 4th edition, 1958), 316.

${ }^{132}$ Just., 1 Apol. 67.7. For other early Christian witnesses of this view, see H.J. de Jonge, "Zondag en schepping. De zondag als hernieuwing van de schepping en als nieuwe schepping in de vroegchristelijke traditie," Eredienstvaardig 24, n. 5(2008), 6-11.

133 Harald Riesenfeld, "The Sabbath and the Lord's Day in Judaism, the Preaching of Jesus and Early Christianity," in The Gospel Tradition, essays by H. Riesenfeld (Philadelphia: Fortress Press, 1970), 111-138. 
came together to break bread on Saturday after sunset when the Sabbath was over. This ceremony would have lasted the whole night until Sunday morning. Only in the second century the Eucharist would have been transferred to Sunday morning as remembrance of Christ's resurrection. This theory is most improbable because it is difficult to believe that Christians kept a weekly vigil from Saturday to Sunday. In particular, however, this theory fails to do justice to the evidence that Christians gathered on Sunday evening ${ }^{134}$ for supper and only later, in the second century, began to gather also on Sunday morning. ${ }^{135}$ The whole assumption is based exclusively on Acts 20:7, which on a natural reading refers to a meal and gathering on Sunday evening (see above).

One further theory sees the Christian supper and meeting on Sunday evening as a continuation of the meetings of the risen Lord with his disciples. Willy Rordorf states that the breaking of bread in the earliest Christian community was a continuation of the disciples' table-fellowship with the risen Lord on the evening of the day of his resurrection. ${ }^{136}$ It should be noted, however, that no Christian source explicitly claims this. Moreover, table-fellowship of the risen Lord with the disciples on Sunday evening is something mentioned only in Luke and John, not in Paul and Mark. Luke's and John's narratives seem to be dependent here on the Christian practice to meet on Sunday, rather than on an archaic tradition concerning Jesus' having supper with his disciples on the day of his resurrection.

In sum, none of the theories used to explain why Christians chose the Sunday for their common supper is particularly satisfactory. To deal with this question again it may be helpful to take into consideration how Jews celebrated the Sabbath.

Many Jews observed the Sabbath as a day of rest. The Friday, $\pi \alpha \rho \alpha \sigma \kappa \varepsilon \cup \eta$ (i.e. Preparation Day), was devoted to the preparation of food for the next day. On Saturday morning, in many places, there was a synagogue gathering for reading and studying the Law and in the evening Jews celebrated the Sabbath meal at home in the circle of family and guests; this practice is attested by Jewish, pagan and Christian

${ }_{134}$ Did. 9-10, 14.1; the Ebionites according to Euseb., HE 3.27; Just., 1 Apol. 67. This widely spread evidence points to a common tradition in the first century. 1 Cor. 11-14 together with 16:2 may be a witness of this tradition in the first century.

${ }_{135}$ Plin., Ep. 10.96; Tert., Cor. 3.

136 W.A. Rordorf, Der Sonntag, 238. 
sources. The author of Jubilees (100 BCE) says that the Sabbath was the day appointed by God for eating, drinking and feasting. ${ }^{137}$ In the first century CE Philo says that the Therapeutae, who on the Sabbath met together for a general assembly in the daytime, had a convivial supper in their private houses in the evening. ${ }^{138}$

The Latin satirist Persius (34-62 CE) speaks of the Jewish family meal on Saturday evening ${ }^{139}$ and around 100 CE Plutarch points out that Jews keep the Sabbath by inviting each other to a symposium. ${ }^{140}$ By "Sabbath" Plutarch can only mean the Saturday, not the Friday. In spite of allegations to the contrary, there is no evidence that in the first century CE Jews had a special festive meal on Friday evening.

As for Christian authors, the serving by Peter's mother-in-law in Mark 1:31 concerned a meal on Saturday evening, after Jesus had taught in the synagogue on the Sabbath (v. 21). ${ }^{141}$ The evening meal in the house of Lazarus in John 12:2 is undoubtedly placed by the evangelist on a Saturday. ${ }^{142}$

One century later Tertullian reports that Jews devote Saturday to leisure and sumptuous eating ${ }^{143}$ he uses the phrase dies Saturni which means that these festive meals took place on Saturday, not on Friday. The author of the Didascalia (ca. $230 \mathrm{CE}$ ) says that Jews prepared their Sabbath meal "on the evening before." 144 This can only mean that the preparation of food took place on Friday and the meal was on Saturday.

It now becomes clear why Jewish Christians, who wanted to have a common supper for their Christian group, did not put it on Saturday evening. That evening was already reserved for the family meal, in

137 Jub. 50.9-10.

138 Philo, Contempl. 30; 36-37; 73.

139 Persius 5.182-184. To Persius "sabbata" can only mean "celebration of the Sabbath" on Saturday, not on Friday.

140 Plut., Quaest. conv. 4.672a.

141 "The service was probably rendered at the Sabbath meal" (italics mine), H.B. Swete, The Gospel according to St. Mark (London: McMillan, 1909), 24; "She served them, i.e., at table. Mark wants to show that the cure was quick and complete," D.E. Nineham, The Gospel of St. Mark (Harmondsworth: Penguin Books, 1973), 81; "Das Fieber verlässt sie, und zum Erweis dessen wird konstatiert, dass sie den Männern

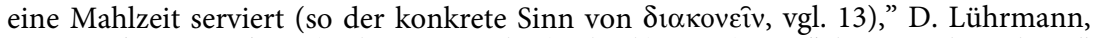
Das Markusevangelium (Tübingen: Mohr (Siebeck), 1987), 52; "She waited on them," thus M.D. Hooker, The Gospel according to St Mark (London: Black, 1991), 70. For

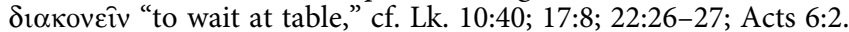

142 The next day is Palm Sunday, Jn. 12:12-19.

143 Tert., Apol. 16.11. The same idea occurs in Tert., Nat. 1.13.4.

144 Did. ap. 5.20. 
which they continued to participate as Jews. Therefore, Jewish Christians had to choose another evening for their Christian group supper. They chose the earliest possible opportunity: Sunday evening, after working hours, for Sunday was a working day until $325 \mathrm{CE}$ when Constantine made it a day of rest. The early Jewish Christians held their communal Christian supper as soon as possible after their Sabbath meal. They probably did so because they considered the Lord's Supper more valuable than their Jewish family meal. At the Lord's Supper, they experienced their new identity and their relationship with Christ. During this gathering they could share their new beliefs and anticipate their ideal future in the Kingdom of God. For them, the Christian group supper surpassed the Jewish family meal on Saturday in significance and value. The Christian meal was felt to surpass the Sabbath meal in importance and in order to emphasise this, the meal needed to be held as soon as possible. Since for Jewish Christians the Lord's Supper rivaled and outshone the Sabbath meal in value, they held the Lord's Supper on the first possible evening after the Sabbath meal, that is, on Sunday evening.

Early Christians regularly compared their Sunday with the Jewish Sabbath and, as a result, considered the Sunday to be superior. Ignatius says that it is better for Christians to celebrate Sunday than the Sabbath ${ }^{145}$ and Barnabas calls Sunday "the eighth day." 146 This designation hinted at the superiority of Sunday as compared to the seventh day or the Sabbath. ${ }^{147}$ The Christian author, who rewrote a Jewish prayer for the Sabbath in order to change it into a Christian prayer for Sunday, now preserved in the Apostolic Constitutions, explicitly says that Sunday surpasses the Sabbath in importance. ${ }^{148}$ These passages make it clear that Christians regarded their weekly ceremony as an improvement on the celebration of the Sabbath. This valuation of their Christian group meal probably led them to put it on Sunday

From what has been argued so far, it should be clear that the Sunday evening ceremony of Christians originated as a phenomenon independent of, and parallel to the Jewish Sabbath ceremonies. The Christian gathering on Sunday was not a continuation of any Jewish gathering on Sabbath. It did not evolve out of the Jewish meeting on Sabbath in

\footnotetext{
145 Ign., Magn. 9.1.

146 Barn. 15.9.

147 Rordorf, Der Sonntag, 271-280.

148 Const. ap. 7.36.6: "But Sunday surpasses all that."
} 
the synagogue, for the latter did not include a meal, whereas the Christian gathering was essentially a supper. Nor was the Christian meeting on Sunday evening a continuation of the Jewish family supper on Sabbath, since the latter was essentially a family meal, whereas the Lord's Supper of the Christians was an association meal. The Sunday evening gathering of the Christians originated as a new initiative, independent of, and parallel to, the Jewish Sabbath meal, from which it inherited its weekly rhythm. We know that certain Jewish Christians participated in both meals, one on the Sabbath and one on the Sunday. ${ }^{149}$

In summary, the weekly gatherings of Christians in the first century $\mathrm{CE}$ followed the analogy of pagan and Jewish association banquets in the Graeco-Roman world at large. The Christian meetings took place on Sunday evening and consisted of a meal and a subsequent symposium. This practice goes back to the earliest communities in Palestine in the thirties and forties of the first century. The gatherings had a festive and joyful character. The choice of Sunday evening for this group event is best explained by the existence of the Jewish family meal on Saturday, which forced Jewish Christians to choose another evening for their group supper. They chose the next day because they felt their Christian supper to be more important for them than the Jewish family meal on the Sabbath. The Sunday evening gathering of Christians made the Sunday as a whole a special day for them. The Christian Sunday therefore originated as an addition to the Sabbath, not as a continuation of the Sabbath.

\section{b. The meeting places of the early Christians}

For early Christian communities the private house was the most obvious place for a communal gathering. This was also the setting in which numerous Graeco-Roman cults and associations held their meetings, but other places were also used, such as rooms or precincts of temples. Early Christian literature yields a wealth of information concerning the use of private houses for Christian meetings. ${ }^{150}$

Towards the close of 1 Corinthians, probably written in Ephesus, Paul passes on greetings to his readers from Prisca and Aquila,

149 Euseb., HE 3.27.

150 H.-J. Klauck, Hausgemeinde und Hauskirche im frühen Christentum (Stuttgart: Katholisches Bibelwerk, 1981). 
"together with the church in their house."151 This is the first time in Paul's letters that we hear him speak about a church "in (someone's) house." "In the house of" can mean either of two things: the word oîkos, house, can refer to the quarters that Prisca and Aquila occupied, part of which they used to shelter a Christian community. Alternatively, it can mean that one whole household or extended family, living in one house, formed a Christian community on its own.

In 1 Corinthians Paul alludes to an occasion on which "the whole church assembled." 152 This seems to imply that at other times the Christians in Corinth came together in smaller groups, quite possibly as "churches." This implication is confirmed by Paul's comments in Romans 16 about various Christian groups in Rome. There is no suggestion that the Christians of Rome ever met as a whole in one place, which is presumably due to the size of the city. As to Rome, mention is made only of smaller groups of believers. ${ }^{153}$ One of those is the group associated with Prisca and Aquila who were now back in Rome and again there is reference to "the church in their house." 154 The other groups listed in Romans 16 are not specifically described as churches but rather as households. ${ }^{155}$

In the concluding section of Romans, most probably written in Corinth, Paul includes a greeting from one Gaius whom he describes as "host to me and to the whole church." 156 Gaius was probably one of the more well-to-do Corinthians whose house could accommodate a Christian community assembling for their periodical meal and other activities. For such a meeting ample space would be required and that is what Gaius seems to have provided. On important occasions, when it was necessary for the "whole church" assembly to gather together, then a very large domus or rented hall was used for the occasion. ${ }^{157}$ A further reference to a house church of the Pauline circle concerns "the church that meets at Philemon's house, together with Apphia, our

1511 Cor. 16:19.

1521 Cor. 14:23.

153 Peter Lampe, From Paul to Valentinus. Christians at Rome in the First Two Centuries (Minneapolis: Fortress Press, 2003).

154 Rom. 16:5.

155 Rom. 16:10-11, 14-16.

156 Rom. 16:23.

157 Cf. Acts 19:9, where Paul is said to have held daily discussions in the lecture hall of Tyrannus in Ephesus. 
sister, and Archippus." ${ }^{158}$ Colossians 4:15 suggests that an otherwise unknown Nympha hosts a church in her house in Laodicea.

Acts, too, especially in some summary passages, pictures early Christians as meeting in private houses. ${ }^{159}$ In spite of the redactional and generalizing character of these passages, there is no reason to doubt that first-century Christian communities gathered in houses. Acts describes meetings of such house churches both in Jerusalem ${ }^{160}$ and in the territory of the Pauline mission. ${ }^{161}$ The picture of Christian communities meeting as house churches, as described in the second half of Acts, is confirmed by the evidence of the Pauline letters. The

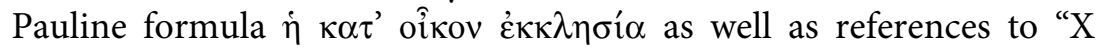
and his house" in Acts reflect the first-century practice of Christians assembling in house churches. ${ }^{162}$ The mention of household baptisms in Acts may indicate that in certain cases an extended family, probably including slaves, formed a house church of its own. ${ }^{163}$

According to Acts 20:8-9, the Christian community in Troas gathered "in a room upstairs;" 164 Eutychus, who was sitting in the window, was so overcome by sleep that he "fell to the ground three floors below." This story seems to picture a Christian congregation gathering in an apartment building or insula, a house which was rented out to several families, rather than in a domus, the ground-floor mansion of a well-to-do family.

The Johannine epistles reflect the setting of a local house church in the beginning of the second century. ${ }^{165}$ This is also how the organization and activity of Christian groups is pictured in the Pastoral epistles (written in Ephesus?), the letters of Ignatius, the letter of Polycarp and 2 Peter. ${ }^{166}$ The Sitz im Leben of the Pastorals is the household church such as known from Pauline letters. Household language and imagery are used to describe the church itself. It is the household of God, ${ }^{167}$

158 Phlm. 2.

159 Acts $1: 13 ; 2: 46 ; 5: 42$.

160 Acts $4: 31 ; 8: 3 ; 12: 12$.

161 Acts $17: 5 ; 20: 7-12,20 ; 21: 16 ; 28: 30$.

162 Acts 16:15, 31-34; 18:8; cf. 1 Cor. 1:14-16. Alistair Campbell, The Elders. Seniority within Earliest Christianity (Edinburgh: T \& T Clark, 1994), 152-153.

163 Acts 10:48; 16:15, 33; 18:8.

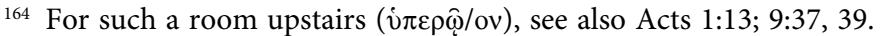

1652 Jn. 10.

1662 Pet. 2:13.

1671 Tim. 3:15. 
the great house, ${ }^{168}$ the overseer of which can be called a steward. ${ }^{169}$ The life of the Christian community is to be regulated and furthered by Christians learning to relate to one another as would members of a private household. ${ }^{170}$

During the second century Christians continued to meet in private houses. In answer to a question of the urban prefect of Rome, Justin tells him that the Christians hold assemblies in several places in Rome, "wherever it is each one's preference or opportunity." insists and asks: "Tell me, where do you meet, in what place?" The account of the interrogation continues as follows: "Justin said: 'I have been living above the baths of Myrtinus...; and I have known no other meeting-place but here. Anyone who wished could come to my abode and I would impart to him the words of truth.' " This is what is told in the so-called short recension (A) of Justin's Martyrdom. The text may imply that in his living quarters Justin only gave lessons and that no eucharistic meetings took place here but the long recension $(C)$ takes it for granted that Justin used his dwelling-place also to celebrate services.

The prefect said: "And where do you hold your meetings and celebrate the relevant services and teach those doctrines?" The saint said: "We Christians do not hold our assembly in a single place, as you think, prefect....We worship and praise him everywhere." The magistrate said: "Then where do you meet with these disciples of yours?" "Here, in the city," replied the martyr, "wherever evening chances to overtake us.... And I instruct them in the word of truth that abides with me."172

According to this version Justin used the house in which he lived not only for teaching his pupils, but also for holding religious gatherings. This may well be a correct understanding of recension A.

Various apocryphal Acts depict the gatherings of Christian communities in houses. In the Acts of Paul, for instance, Paul preaches in the private house of Onesiphorus. ${ }^{173}$ It is true that the Acts of Paul also depict a large crowded assembly of Christians in a warehouse

1682 Tim. 2:20.

169 Tit. 1:7.

170 D.C. Verner, The Household of God: The Social World of the Pastoral Epistles (Chico, CA: SBL, 1983); A. Campbell, The Elders. Seniority within Earliest Christianity, 194.

${ }_{171}$ M. Iust. (recension A) 3 (H. Musurillo, pp. 44-45).

${ }_{172}$ M. Iust. (recension C) 2 (H. Musurillo, pp. 56-57).

${ }^{173}$ Acta Pauli 3.5-7 (J.K. Elliott, p. 365). 
(horreum) on the outskirts of Rome. Still, by far the most common setting for Christian gatherings in the first two centuries, especially in the apocryphal Acts, is that of the private house. ${ }^{174}$

In the Acts of Peter, the patron of the Christian community in Rome is Marcellus; he hosts the gatherings of this community in his house. ${ }^{175}$ When Marcellus is temporarily under the spell of Simon the magician, the gatherings of the community take place in the house of Narcissus, the presbyter of the church. ${ }^{176}$

The Clementine Recognitions 10.71 make mention of the generosity of Theophilus of Antioch, who "with all eagerness of desire consecrated the great place of his house under the name of a church."177

On the basis of archaeological data concerning the structure of domestic buildings, one can try to envision the physical setting in which the Christian gatherings took place. It is probable that, in the earliest period, perhaps until the middle of the second century, the houses where Christians met were either only slightly modified for the Christians' activities or were left in their original state. In the main groups adapted themselves to the structures available. The size of the meeting space in the largest house available must have determined the size limit of a community. The normal meeting place in the house for Christians would be the triclinium or dining room. Dining rooms could be small or large, ${ }^{178}$ ranging from six places in a small room (biclinium) to about one hundred in a dining hall inside an insula.

Often the triclinium was the largest area in the house and the most suitable for a gathering of a Christian congregation. ${ }^{179}$ There is both literary and archaeological evidence that the Hellenistic triclinium was often marked by the Pi-shaped layout of the couches. However, the word triclinium eventually referred to a dining room regardless of size and shape. The triclinium, in its original form, seems designed to

174 Acta Pauli 11.1 (J.K. Elliott, p. 385). Michael L. White, Building God's House in the Roman World (Baltimore: John Hopkins University Press, 1990), 105.

${ }^{175}$ Acta Petri $8 ; 19-21$. In chapter 20 and 21 the author states explicitly that Christians met in the dining-room of Marcellus (J.K. Elliott, pp. 405, 413-415).

176 Acta Petri 13 (J.K. Elliott, p. 409).

177 Floyd Filson, “The Significance of the Early House Churches," JBL 58 (1939), 107.

${ }^{178}$ Even within one villa: Plin., Ep. 1.3.

179 Tertullian, Apol. 39.15, designates the gathering of Christians as a triclinium. 
reinforce group solidarity, to favour close contact between the diners, and to encourage discussion between all the participants. ${ }^{180}$

A later development in the arrangement of the dining room was the appearance of the continuous semicircular couch known as stibadium or sigma, the latter name taken from its resemblance to the form of the Greek capital letter (C). ${ }^{181}$ The stibadium was introduced in the late first century $\mathrm{CE}$ and could seat between five and seven diners. ${ }^{182}$ Depictions of the heavenly meal (refrigerium) in the catacombs portray such a sigma type layout of couches. These portrayals most likely reflect the dining arrangements in Christian gatherings in the third century CE. ${ }^{183}$

If no members of the community possessed a house large enough to shelter the Christian community, which was probably often the case, the group would have to gather elsewhere, for instance, in one or two rooms of an apartment of an insula, possibly in a large ground-floor room. This is how the devotees of Mithras gathered in one of their fourteen sanctuaries in Ostia, the House of Diana. The earliest church buildings of San Giovanni e Paolo and San Clemente in Rome seem to have been built over older insula apartments. Although there is no archaeological evidence for Christian habitation in the insulae in question, one has to ask why these particular locations were later chosen as sites on which Christian churches were built. It is quite possible that these are examples of locations where the earliest Christian meetings took place in a room or apartment within the original insula. ${ }^{184}$ Paul's late-night discourse in the third-story room at Troas may be an example of this practice. Occasionally neighbours may have been unaware that a meeting was being held by Christians in a nearby apartment. However, in the case of meetings held in an insula, there could be no question of secrecy, for practically everyone in the building must have known everyone else's business. Recall that 1 Corinthians 14:23 seems to suggest that outsiders regularly were invited or perhaps even wandered into Christian meetings. It would be a mistake, therefore, to envision every Christian gathering at this time in a spacious pri-

${ }^{180}$ Katherine Dunbabin, "Ut Graeco more bibetur: Greeks and Romans on a Dining Couch," in Meals in a Social Context, eds. Inge Nielsen and H.S. Nielsen (Aarhus: Aarhus University Press, 1998), 89.

${ }^{181}$ Katherine Dunbabin, The Roman Banquet. Images of Conviviality, 43.

182 S.P. Ellis, Roman Housing (London: Duckworth, 2000), 148.

183 R.M. Jensen, Understanding Early Christian Art (London and New York: Routledge, 2000), 53.

${ }_{184}$ Or., C. Cels. 3.55. 
vate house, or even operating with full privacy. ${ }^{185}$ From Acts 1:13 and 20:7-12 it can be inferred that Christian gatherings sometimes took place in rooms upstairs, possibly in the upstairs dining-rooms which were a feature of eastern houses, ${ }^{186}$ or in an apartment located on an upper floor of an insula.

In the third century Christians began to adapt houses for their meetings. The earliest surviving example of a Christian meeting place has been found in the town of Dura-Europos on the Euphrates. The building lies in a residential quarter of the town and is itself an atypical private house slightly modified to adapt to its religious use. The house was built in around $232 \mathrm{CE}$; its conversion into a Christian meeting place must have taken place therefore between that date and the capture of Dura by the Persians in $256 \mathrm{CE}$. The two most significant rooms are the assembly hall and the baptistery. The hall was created by knocking down a wall between two smaller rooms and placing a low platform at the eastern end of the room, which could now hold perhaps sixty people. ${ }^{187}$

Another archaeologically secured early Christian meeting hall is a large residential building, dating from the third century CE, that was exposed during the excavation at Kefar 'Othnay (near Megiddo) in Israel in 1995. Finds from this building indicate that it was used by soldiers of the Roman army and show that one of its wings functioned as a prayer hall for a local Christian community. This hall is dated to the period prior to the official recognition of Christianity (313 CE). The mosaic panels, the podium and the mention of a table $(\tau \rho \alpha \pi \dot{\varepsilon} \zeta \alpha)$ in one of the inscriptions found indicate that the hall served a Christian cult. However, unlike church structures known from later centuries, this hall lacks exterior architectural elements emphasizing its function, such as an apse, atrium or orientation to the east. ${ }^{188}$

The first literary references to church buildings are sometimes said to occur in Clement of Alexandria, but there seems to be no reason to presume that $\dot{\varepsilon} \kappa \kappa \eta\rceil{ }^{\prime} \alpha$ here means anything other than the common

185 Carolyn Osiek and David L. Balch, Families in the New Testament World. Households and House Churches (Louisville: Westminster John Knox Press, 1997), 34-35.

186 Joan Petersen, "House-Churches in Rome," VC 23 (1969), 264.

187 A.D. Lee, Pagans and Christians in Late Antiquity. A Sourcebook (London and New York: Routledge, 2000), 40. For plans of the two Christian gathering places discussed here, see Appendix 5 below.

188 Yotam Tepper and Leah Di Segni, A Christian Prayer Hall of the Third Century CE at Kefar 'Othnay (Legio) (Jerusalem: The Israel Antiquities Authority, 2006), 5, 26. 
meaning of the word: "assembly." 189 The Syriac Chronicle of Edessa says that a "holy place of the congregation of the Christians" was destroyed in a flood in 201 or $202 \mathrm{CE} .{ }^{190}$ However, this building need not have

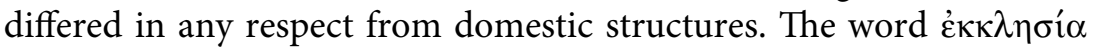
was used for a church building not later than the time of Origen. ${ }^{191}$

Architecturally speaking, before the Constantinian peace all church buildings known from literature were really house churches. ${ }^{192}$ The usual course of things in the second and third century must have been that wealthy Christians made rooms in their houses available for Christian meetings. In the next stage of the development, Christians acquired a house and remodeled it as a church building. The evidence for Christian communities possessing houses includes the decree of the emperor Gallienus who, in putting an end to the Valerian persecution of $260 \mathrm{CE}$, stipulated that all places of worship should be restored to their owners. ${ }^{193}$

The author of the Didascalia describes the sitting position of the members of a Christian congregation. Here, emphasis is placed on having good order in the gathering where everyone is required to sit in his or her allotted place. The presbyters should be given places in the eastern part of the house; the bishop takes place on a throne which is placed in their midst. Then the other members of the congregation take their places with men and women sitting separately. Those who are young ought to sit separately as well as those who are advanced in years; children should stand on one side and young girls should sit separately. Young women who are married and have children should also sit apart, as should the elderly women and widows. The deacon should see that each one entering the room goes to the area that is appropriate for him. And if anyone is found to be sitting out of his place, the deacon should reprove such a person, ensuring that he or

${ }_{189}$ Clem. Al., Paed. 3.79.3; Str. 3.108.2; 7.29.4.

190 See J.K. Zangenberg, "Visual Representations. Christianity," in Religions of the Ancient World, ed. Sarah Iles Johnston (Cambridge, MA: Belknap Press, 2004), 619-621, esp. 620. This chronicle was written shortly after 540 CE, but uses archival material from Edessa.

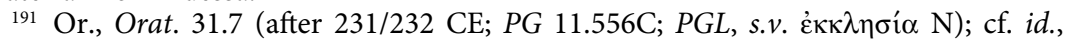
Hom. Gen. 10.1: "Quid de absentibus conqueror? Praesentes etiam et in ecclesia positi, non estis intenti, sed communes ex usu fabulas teritis, verbo dei...terga convertis" (between 231 and 244 CE; PG $12.251 \mathrm{~B}-\mathrm{C}$; PGL, ib.).

192 E. Ferguson, Early Christians Speak (Austin: Sweet Publishing, 1971), 76.

${ }^{193}$ Lact., Mort. pers. 48.9; Euseb., HE 7.13.1. 
she moves and sits elsewhere. ${ }^{194}$ Judging by these instructions in the Didascalia, third-century assembly rooms of Christians could have a fixed arrangement of seats for the members of the community. This may mean that such rooms were already reserved especially for the community gatherings and were no longer just dining rooms of ordinary houses as was the case in the first century.

To conclude this section it can be stated that the earliest locations used by Christians for their gatherings were private houses, in most cases houses of comparatively richer Christians with sufficient economic resources to have space to accommodate their coreligionists' meetings. Since the common meal was a central component of the first-century Christian gathering, the setting may often have been the dining area of a house. Excavations of houses belonging to wealthy persons in Roman cities show that dining rooms could rarely accommodate groups of more than nine or so, when one allows for the couches on which diners reclined in the Hellenistic fashion that was so widely followed in the Roman period. If those present did not recline but sit, as seems to have been the case in the Corinthian congregation to which Paul wrote his letters (1 Cor. 14:30: $\kappa \alpha \theta \eta \mu \varepsilon ́ v \omega)$, the room may have accommodated twice as many participants. Even if the atrium area of a Roman villa were used for additional dining space, most villas could have accommodated a group of no larger than forty to fifty. ${ }^{195}$ Thus, the domestic setting, the size of the house-church group, and the centrality of a shared meal in the community's life could all contribute to a certain intimacy and strong solidarity among the members.

\section{CONTENT AND ORDER OF THE COMMUNITY GATHERINGS IN THE EARLY CHURCH}

\section{a. The suppers of early Christian communities}

This section will discuss how the Christian evening gatherings were conducted in terms of customary procedures and the kinds of food and drink which were consumed. Christian meetings probably commenced

\footnotetext{
194 Did. ap. 2.57.

195 Larry Hurtado, At the Origins of Christian Worship (Carlisle: Pater Noster, 1999), 41.
} 
with a collection of the food brought by community members. ${ }^{196}$ Often when a rich member of the community hosted the gatherings, then the host would provide food for all concerned; the participants reclined or sat down, and the host said grace over the food and the drink. The bread was broken and the participants proceeded to eat. This ordinary pattern for the communal meal may have varied in details from place to place, but it seems to have remained the normal format for the Christian community supper until the middle of the third century. ${ }^{197}$

In general, the range of food and drink consumed at Christian suppers reflected that provided at most of the suppers in the GraecoRoman world. Bread and wine featured as the main elements of most evening meals consumed by ordinary people in antiquity. They constituted the central components of the Christian group supper as soon as it became historically perceptible, around the middle of the first century CE. The use of bread and wine is attested in numerous accounts of early Christian group meals beginning from Paul. ${ }^{198}$

In the Graeco-Roman world at large the use of wine was appropriate to any communal festive meal. In the first, second and third centuries, as is clear from Paul, Ephesians, the Didache, Justin, Tertullian and the Apostolic Tradition, wine was also a self-evident element of the meals of Christian communities. ${ }^{199}$ However, this practice was not without exception; Irenaeus, Clement and Cyprian had to argue against the exclusive use of water at the eucharistic meals of certain groups of Christians. ${ }^{200}$ Andrew McGowan has shown that there was a widespread bread-andwater tradition in the early Church. ${ }^{201}$ On the other hand, the Apostolic Tradition testifies to a eucharistic practice in which no less then three different cups with three kinds of drink were used. At the Eucharist celebrated after the baptismal ceremony, the bishop would say grace first over the cup of mixed wine, then over the cup of milk mixed with honey, and finally over the cup of water only. ${ }^{202}$ Wine could be used not only during the symposium, but also during the preceding supper.

\footnotetext{
196 In the Corinthian community as depicted by Paul in 1 Cor. 11:20-21 the participants failed to share with one another what they had brought to the gathering.

1971 Cor. 10:16-17; Just., 1 Apol. 67.5; Tert., Apol. 39.17-18; Trad. ap. 25-29.

1981 Cor. 10:1; 11:26-28.

199 Andrew McGowan, Ascetic Eucharists (Oxford: Clarendon Press, 1999), 93.

${ }^{200}$ Iren., Haer. 5.1.3; Clem. Al., Paed. 2.32.1-33.1; Str. 1.96; Cypr., Ep. 63.1, 16.

201 A. McGowan, Ascetic Eucharists, 143-217.

202 Trad. ap. 21.
} 
Whether other sorts of food and drink were consumed at the Christian community meal, apart from bread and wine, may well have depended on their availability in the region or the season and on the importance of the occasion. The food normally offered at the Christian meal may not have been especially appealing, except to the poorest members who had little to eat on their own. ${ }^{203}$

Ordinary meals in the Graeco-Roman world centered on bread and wine, but could also include cheese, vegetables, fish, fowl or meat. According to the Apostolic Tradition, cheese and olives were consumed at the eucharistic meal that followed the ordination of a bishop. ${ }^{204}$ There are only a few indications that at Christian group meals oil was used as a dish in itself. ${ }^{205}$ Generally, olive oil was regarded as a kind of food which could be expected to appear on dinner tables in a variety of social and religious settings. ${ }^{206}$ In the Apostolic Tradition the bishop is supposed to say grace over the oil in the same way as he does over the bread and the wine. The text of the prayer over the oil suggests that it was used for both unction and ingestion: "O God, sanctify this oil: grant holiness to all who use it and who receive it, and as you anointed kings, priests and prophets, so may it give strength to all who consume it and health to all who use it." ${ }^{207}$ The use of oil at the eucharistic meal is also mentioned in the Acts of Thomas; here the apostle is said to have taken "bread, oil, vegetables and salt, blessed them and given them to those present." ${ }^{208}$ Clement of Alexandria makes mention of the use of oil during meals in Valentinian communities: "Both the bread and the oil are sanctified by the power of the name of God...."209

The clearest references to the use of salt at eucharistic meals may be found in the Pseudo-Clementine Homilies. ${ }^{210}$ At a meal following a baptism Peter "broke the bread with thanksgiving, put salt on it, gave it first to our mother and after her to us, her sons. Thus we both

${ }^{203}$ Andrew McGowan, "Food, Ritual, and Power," in Late Ancient Christianity, ed. Virginia Burrus (Minneapolis: Fortress Press, 2005), 148.

204 Trad. ap. 6.

${ }^{205}$ The oil which according to Did. 13.6 had to be given to the prophets was probably meant to be consumed by them privately, not to be used during the Eucharist.

206 A. McGowan, Ascetic Eucharists, 115.

207 Trad. ap. 5.2 (tra. A. Stewart-Sykes).

208 Acta Thom. 29.

${ }^{209}$ Clem. Al., Ex. Theod. 82.1. Clement seems to be quoting here the Valentinian author Theodotus. The Excerpta ex Theodoto are notes and extracts from Theodotus.

${ }^{210}$ The Homilies have been preserved in a fourth-century recension based on material stemming from the first half of the third or the later half of the second century. 
ate with her and blessed God." ${ }^{211}$ In the Letter of Clement to James, ${ }^{212}$ prefixed to the Homilies in the manuscripts, the eating of salt stands explicitly for the sharing of table fellowship. It can even be an expression of love of one table companion toward another: "I know that these things will be done by you, if you establish love in your mind. To this end there is one sure means, the common partaking of salt." ${ }^{213}$ It would be wrong to regard the role of salt in these meals as specifically sacramental. Along with bread and drink, salt was the most basic component of any meal in the Graeco-Roman period. ${ }^{214}$ Salt and herbs are mentioned as condiments at the simple meals of the Therapeutae; ${ }^{215}$ salt together with vegetables is also mentioned as a type of food in the frugal meals of the Acts of Thomas 29.

The prominence of fish in several feeding stories in the Gospels and the depictions of fish in early Christian art and inscriptions raise the question as to whether fish was ever a dish at early Christian eucharistic meals. Stories about Jesus eating fish with his disciples on the Sunday of his resurrection (Lk. 24:42) or some time later (Jn. 21:9, 13: "Jesus took the bread and gave it to them and the fish in the same way") ${ }^{216}$ seem to suggest that fish may sometimes have been used as a dish at eucharistic meals. It is true that literary sources outside the Gospels are almost completely silent about the use of fish at eucharistic meals. ${ }^{217}$ However, the occurrence of fish in visualizations of the heavenly banquet (refrigerium) in many early Christian mosaics, frescoes and sculptures probably indicates that fish could figure as a dish at group meals of certain Christians. Confirmation of this may be found in the Greek epitaph of Pectorius, the original version of which is dated to the second century. Referring to the eucharistic meal it invites the readers: "eat, you who are hungry, keeping the fish in your hands." ${ }^{218}$ The late

211 Ps.-Clem., Hom. 14.1.4.

${ }^{212}$ Dated to the second half of the second century or the early third century.

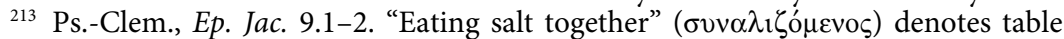
fellowship also in Acts 1:4, cf. 10:41.

214 A. McGowan, Ascetic Eucharists, 119-120.

${ }^{215}$ Philo, Contempl. 73.

${ }^{216}$ Cf. Jn. 6:11, where almost the same words are used: "Then Jesus took the loaves, and when he had given thanks, he distributed them to those who were seated; so also the fish, as much as they wanted."

217 A. McGowan, Ascetic Eucharists, 129.

${ }^{218}$ For the Greek text see G. Rauschen, Florilegium Patristicum, Fasciculus 7, Monumenta eucharistica et liturgica vetustissima (Bonn: Hanstein, 1914), 22-23. Line 6

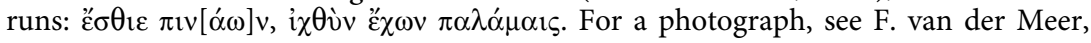


second-century epitaph of Abercius found at Hierapolis (Phrygia) and also written in Greek, mentions the fish, symbolizing Christ, and the bread and wine of the Eucharist all together: "Wherever I came, the Christian faith offered me fish from the source for food, very big and pure, which the holy Virgin [i.e., the Church] had caught. And she gave the fish to eat to her friends all the time, with salutary wine, offering a mixed cup with bread." 219

Insofar as other kinds of food are concerned, there is very little evidence that Christians at their group suppers ever ate meat. ${ }^{220}$ This may be explained by their absolute wish to avoid consuming meat sacrificed to pagan gods: much of the meat sold at the market place came from temples where it had been sacrificed to pagan gods. Justin and Irenaeus observe that Gnostic Christians did not hesitate to eat meat sacrificed to pagan gods without fearing that they would suffer any harm in consequence. ${ }^{221}$ But this information seems to concern the Gnostics' eating habits in general, not their eucharistic meals. However, the possibility that they used meat also at their group meals cannot be ruled out altogether. The reason why they did not reject the consumption of meat must have been that, according to their dualistic beliefs, matter could not harm their inner, spiritual man.

To conclude this section one can state that the evidence for the eucharistic use of food other than bread is not particularly abundant, neither is it absent. Bread and wine are always the major elements of the Christian group supper and in places, fish may have been on the

Chr. Mohrman, Atlas van de oud-christelijke wereld, 2nd ed. (Elsevier: Amsterdam, 1961), 43. The fragments of this inscription were found in Autun, France. They are dated to the third to fifth centuries, but the text has been copied from an earlier, possibly second-century example. B. Altaner and A. Stuiber, Patrologie, 8th ed. (Freiburg/ Basel/Vienna: Herder, 1978), 98.

${ }^{219}$ For the Greek text see G. Rauschen, Florilegium Patristicum, Fasciculus 7, Monumenta eucharistica et liturgica vetustissima (Bonn: Hanstein, 1914), 20, see lines 13-15. For a photograph, see F. van der Meer, Chr. Mohrman, Atlas van de oud-christelijke wereld, 43. For a discussion of the use of fish in Christian meals as reflected by early Christian art, see R.M. Jensen, Understanding Early Christian Art, 53-55. "There are good arguments for finding eucharistic symbolism in the meal of John xxi," R.E. Brown, The Gospel according to John XII-XXI (New York, etc.: Doubleday, 1970), 1099; J. Zumstein, L'évangile selon Saint Jean (13-21) (Genève: Labor et fides, 2007), 308, points out that John 21:13 "a une tonalité eucharistique."

${ }^{220}$ Yet, in view of verses 15 and 21, Paul's instruction about the consumption of meat in Rom. 14:13-21 may well be meant to refer to the occasional use of meat at eucharistic banquets in Christian communities.

${ }^{221}$ Just., Dial. 35.1; Iren., Haer. 1.6.3; 1.24.5; 1.26.3. 
menu. Meat was normally lacking, unless perhaps in Gnostic circles; oil, vegetables, cheese, and salt could compensate for the absence of meat.

\section{b. Christian symposia}

The second part of the periodical gatherings of Graeco-Roman associations consisted of a symposium. Similarly, the Christian group supper in the first century CE was followed by a gathering in which drinking, singing and conversation could take place, speeches could be given and texts could be read aloud, more or less in accordance with what happened at other after-supper symposia. Paul's and Luke's version of the story of Jesus' Last Supper also reflects the way group suppers usually took place in the Graeco-Roman world: the meal proper was followed by a session of the same participants during which wine was drunk..$^{222}$

The earliest discussion of the Christian symposium occurs in 1 Corinthians 12-14. Here Paul mentions various kinds of oral interventions by which those present could entertain one another. In 1 Corinthians 12:4-6 the apostle speaks about the variety of "gifts," "services" and "activities" through which they should serve and edify the community in its gatherings. Paul gives a list of nine such "gifts," most of which would normally be manifested in the second part of the gathering of the community. They include the utterance of wisdom and knowledge, prophecy, tongues, the interpretation of tongues, and the discernment of spirits. ${ }^{223}$ The other gifts, viz. faith, healing, and special

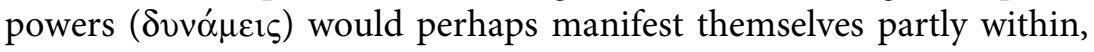
partly outside the (symposium part of the) gathering.

Wisdom, knowledge and "prophecy" were put forward in speeches or talks at the symposium. These were different types of preaching. Speeches could convey knowledge, for instance, about persons or events in biblical history. They could also convey wisdom, for instance, about God's plan for the salvation of mankind. "Prophetic" utterances served the edification of the community and provided exhortation to good behaviour and consolation. Glossolalia and interpretation of glossolalia were not lacking. However, Paul insists that articulate,

\footnotetext{
${ }^{222} 1$ Cor. 11:25: “...he took the cup, after supper, saying...;" Lk. 22:20: "And he did the same with the cup, after supper, saying..."

${ }^{223} 1$ Cor. 12:8-10.
} 
comprehensible speaking is to be preferred to glossolalia, for speaking with one's mind is useful for other people's instruction. ${ }^{224}$ Paul also mentions prayer and singing "in a tongue" and prayer and singing "with the mind." ${ }^{225} \mathrm{He}$ does not forbid glossolalia but insists that it has always to be accompanied by interpretation. ${ }^{226}$

Oral contributions by participants in the gathering could also include blessings ( $\varepsilon \dot{\lambda} \lambda$ orial) of God in the form of praise and expressions of gratitude. ${ }^{227}$ The discernment of spirits served to ascertain whether speakers, especially visiting preachers, were trustworthy in what they taught and not false teachers or mere charlatans. Some people contributed by singing psalms, teaching, or by passing on revelations they believed to have received, for instance, in the form of dreams or other experiences, which they communicated and interpreted to the audience. ${ }^{228}$ Furthermore, debates could take place with unbelievers who accidentally entered into the gathering of the Christian community. Finally, Paul mentions that some members possess the gift of healing and other special powers ( $\left.\delta v v \alpha{ }^{\prime} \mu \varepsilon 1 \varsigma\right)$, possibly comprising the capacity of exorcising evil spirits. These healings and exorcisms may sometimes have taken place in the gathering, sometimes outside of it.

There was, then, a great variety of different gifts and services manifested and activities developed in the symposium part of the Christian community in Corinth, but there was no fixed order in which all these activities had to be performed. People at the meeting were in high spirits as, in their gathering, they felt united with the risen Lord (1 Cor. 10:16) and believed that God's Spirit was active in them (1 Cor. 12:6-11). At the same time the influence of alcohol was also strong. Paul speaks about some who became drunk during the gathering. ${ }^{229}$

The symposium part of the early Christian gathering must also have been the social context in which words of Jesus were passed on and stories about him were told. Part of the material incorporated in the Gospels, including sayings of Jesus and narratives, has been shaped and transmitted, if not created, by the preaching of the earliest generations

\footnotetext{
2241 Cor. 14:2, 19, 23.

2251 Cor. 14:14-15.

2261 Cor. 14:26-28, 39.

2271 Cor. 14:16.

2281 Cor. 14:6, 26.

2291 Cor. 11:21.
} 
of Christians. This insight is one of the lasting results of Form Criticism. ${ }^{230}$ At least part of this preaching must have taken place within the context of the community gathering, for instance in the form of "prophesying," speaking with wisdom or knowledge, teaching, exhortation, encouragement and consolation. In particular, ethical admonition could easily bring with it the quotation of sayings of Jesus, as 1 Corinthians 7:10 and 9:14 show. ${ }^{231}$ In any case, one should imagine that at least some of the traditions about, and sayings of, Jesus have been preserved owing to their use in the oral interventions exchanged in the gatherings of early Christian communities.

Another element of the symposium part of the early Church's gatherings was the reading of authoritative texts. Paul says nothing about this in 1 Corinthians, but he does mention the reading of his "first" letter to the Thessalonians in 1 Thessalonians 5:27. He must have supposed that this letter would be read in a gathering of the Christians in Thessalonica. He even solemnly commands them to read his letter "to all brothers and sisters" of the community. ${ }^{232}$ This could only be effectuated in their communal gathering. Paul's admonitions in the passage in question (1 Thess. 5:11-27) gained in power of expression at the moment of their being read in the context of the gathering. True, the admonitions he is giving here are certainly relevant and valid for the behaviour of the Thessalonian Christians among themselves in general but they are also directly applicable to their behaviour in the gathering of their Christian community. There should be a joyful atmosphere; they should always pray and give thanks; certain people should take the floor and preach and others should judge what had been said (1 Thess. 5:20-21). There should also be intercessory prayer. ${ }^{233}$ The gathering was probably to be concluded with a holy kiss. ${ }^{234}$ Paul enjoined the Thessalonian Christians to encourage and to build up one another. ${ }^{235}$ However, his admonitions in 1 Thessalonians

${ }^{230}$ E.g., R. Bultmann, Die Geschichte der synoptischen Tradition, 64: "Die biographischen Apophthegmata sind in der Tat am besten als erbauliche Paradigmen der Predigt begreiflich" and M. Dibelius, Die Formgeschichte des Evangeliums, 3rd ed. (Tübingen: Mohr (Siebeck), 1959), 66: "In der Predigt liegen wie in einer Urzelle die Elemente der künftigen christlichen Literatur beisammen."

${ }^{231}$ H.W. Hollander, "The Words of Jesus: from Oral Traditions to Written Record in Paul and Q," NovT 42 (2000), 340-357.

2321 Thess. 5:27.

${ }^{233} 1$ Thess. 5:21, 25.

2341 Thess. 5:26.

${ }^{235} 1$ Thess. 5:11. 
5:11-25 should not be taken as applying exclusively to their conduct within the Christian gathering. ${ }^{236}$

Summarizing, it may be said that what first-century Christians did during the symposium part of their gathering conformed by and large to what happened during symposia in the Graeco-Roman world in general. However, Christians could try, with varying success, to make their activities at the symposium serviceable to the building up of their Christian identity and morals.

\section{c. The order of the Christian gathering}

Paul's comments on the Christian assembly in Corinth do not present much information with regard to the order in which the various components of the gathering succeeded one another. It is clear that the gathering began with eating and drinking, that is, with the celebration of the Lord's Supper, and that subsequently there were other activities during the symposium part of the evening. According to Paul, there were serious abuses with respect to eating, drinking and speaking in tongues. He encourages the Corinthian Christians, therefore, to set things right both during the meal and the symposium part of the gathering. ${ }^{237}$ As to speaking in tongues, it should be limited to only two or at most three speakers, each taking their turn, "and let one interpret: if there is no one to interpret, let them be silent in church." ${ }^{238}$ However, not only glossolalia but also articulate and comprehensible speech (prophecy) has to be regulated in an orderly fashion. Only two or three speakers are allowed to take the floor, they have to speak one by one, and others must judge what they have said. Paul's insistence that all interventions should take place decently and in order, seems to indicate that during the first century the various actions and interventions accompanying the Christian symposium did not yet succeed one another in a fixed order.

In the second century the growth of the Christian churches and other practical reasons gave rise to the establishment of some order (in the sense of a certain sequence of the components) in the gatherings

${ }^{236}$ Paul's admonitions in 1 Thess. 5:12-25 also apply to the daily life of the members of the community. They should rejoice always and not only in their gathering. They had to give thanks in all circumstances. They should hold fast to what was good and abstain from evil every day, etc.

${ }^{237} 1$ Cor. $11: 17-34 ; 14: 27-33$.

2381 Cor. $14: 27-28$. 
of Christians. According to Justin, the different parts of the Christian gatherings in Rome took place in the following order: (1) reading of Gospels or Prophets; (2) an allocution given by the president; (3) communal prayer; (4) presentation of food and drink; (5) eucharistic prayer; (6) distribution of food; (7) the meal; (8) collection. ${ }^{239}$ Elsewhere Justin mentions the singing of hymns but it is not clear precisely at what moment of the meeting this singing took place. ${ }^{240}$

Clement of Alexandria gives a list of activities through which a believer can "thank God": (1) the reading of Scripture; (2) interpretation; (3) the eucharistic meal; (4) prayer; (5) the singing of songs and hymns of praise. ${ }^{241}$ Clement may very well be referring here to the activities that took place in the Christian meetings, the eucharistic celebrations, in the order in which he mentions them here.

At the end of the second century Tertullian gives a glimpse into the order of the components of the Christian assembly in several of his writings. According to his Apologeticum 39, the order of the service is the following: (1) prayer of petition and intercessory prayer; (2) reading of Scripture; (3) sermon; (4) collection; ${ }^{242}$ (5) eucharistic prayer; (6) meal; (7) singing; (8) closing prayer. Elsewhere, in De anima, Tertullian makes mention of the same order of the liturgical proceedings whilst at the same time leaving out some of the elements mentioned in his Apologeticum. In this case he refers to a meeting on Sunday. He mentions: (1) reading of Scripture; (2) singing; (3) preaching; (4) prayers, probably eucharistic; (5) after the dismissal of the people at the conclusion of the service, visions of a prophetess are discussed. ${ }^{243}$ Even in the frivolous gatherings of certain heretics, as Tertullian puts it, the order of the proceedings agrees broadly with that mentioned in his Apologeticum, although he fails to mention the eucharistic meal explicitly: ${ }^{244}$ (1) reading of the Scriptures; (2) teaching; (3) disputes; (4) exorcisms; (5) healings. ${ }^{245}$ Irenaeus contends that the gatherings of

\footnotetext{
${ }^{239}$ Just., 1 Apol. 67.3-6.

240 Just., 1 Apol. 13.

${ }^{241}$ Clem. Al., Str. 6.113.3.

${ }^{242}$ It cannot be concluded with certainty that the collection took place precisely at this moment. Tertullian may be referring to it in general without implying anything with regard to its place in the order of the assembly.

${ }_{243}$ Tert., $A n$. 9.4.

${ }^{244}$ This is clear from Tert., Praescr. 41.2: "That which is holy they will cast to the dogs, and their pearls they will fling to the swine." Tert., Marc. $1.14 ; 1.23 ; 4.40$.

${ }_{245}$ Tert., Praescr. 41.2-8.
} 
Valentinian Gnostics began with the eucharistic meal and then were continued with various prophetic discourses, in accordance with the usual bipartite pattern of meal plus symposium. ${ }^{246}$

The insertion of the reading of Scripture and preaching before the eucharistic celebration in the order of the Christian gathering as attested by Justin, Clement and Tertullian reflects an important change in the programme of the Christian assembly in the second century. The catechumens were no longer allowed to participate in the eucharistic meal $;{ }^{247}$ from then on it was more practical to place the reading and the sermon before the Eucharist so that the non-initiated could leave the gathering and the faithful could stay and proceed to the celebration of their meal.

The accounts of the Christian gathering occurring in the apocryphal Acts describe the ceremony in varying orders. According to the Acts of John, the gatherings of Christians took place in the following order: (1) sermon; (2) prayer; (3) eucharistic prayer; (4) eucharistic meal. ${ }^{248}$ In the Acts of Peter two different orders are found: (1) eucharistic meal; (2) admonition; (3) intercessory prayer; ${ }^{249}$ and (1) reading of Scripture; (2) sermon; (3) prayer; (4) healings; (5) eucharistic meal. ${ }^{250}$ In the Acts of Paul there are also two distinctive patterns of order: (1) prayer; (2) breaking of bread; (3) sermon, ${ }^{251}$ and (1) prophetic discourse; (2) eucharistic meal; (3) singing. ${ }^{252}$ The two different orders of the service that are found in the Acts of Paul correspond to the two liturgical patterns known from the first and second century: (a) first meal and then the symposium (as in Paul), and (b) first the reading and/or sermon and then the Eucharist (as attested for the first time by Justin).

In the third century, evening gatherings centring around an extensive meal continued to exist, besides a gathering in the morning. A series of chapters of the Apostolic Tradition describes the sequence of such Christian gatherings in the evening. They still comprise a real, full, ceremonial meal of sacramental character. This meal, called "the Supper of the Lord" (ch. 27), is opened by prayers of thanksgiving

\footnotetext{
246 Iren., Haer. 1.13.2-4.

${ }^{247}$ Did. 9.5; Tert., Praescr. 41.2. Tertullian blames the heretics for giving all people, including catechumens, indiscriminately access to the eucharistic gathering.

${ }^{248}$ Acta Ioan. 106-110 (J.K. Elliott, pp. 335-336).

249 Acta Petri 1-2 (Elliott, pp. 399-400).

250 Acta Petri 20-22 (Elliott, pp. 413-415).

251 Acta Pauli 3.5 (Elliott, p. 365).

252 Acta Pauli 9 (Elliott, p. 383). One sings psalms of David and hymns.
} 


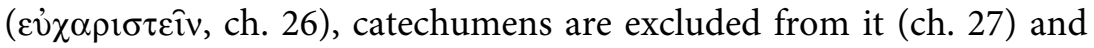

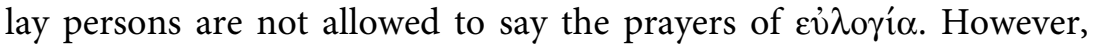
the author of the Apostolic Tradition does not want this meal to be considered any more "the Eucharist" of the congregation. He calls it

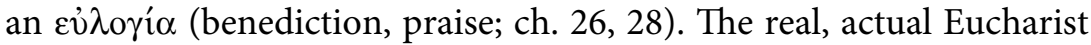
is now the ceremony held in the morning (ch. 36), especially on Sunday morning, but also on other days of the week (ch. 22). The morn-

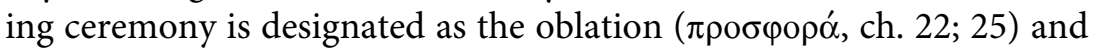
as the Eucharist ( $\dot{0} \chi \alpha \rho i \sigma \tau i \alpha, c h .36 ; 37$ ). The order of the communal gathering in the evening was the following: (1) salutation by the bishop; (2) eucharistic prayer; (3) communal prayer; (4) recitation of psalms; (5) benediction over the cup and distribution of bread by the bishop; (6) eating and drinking; (7) during the meal, instruction by the bishop; (8) after the meal, distribution of apophoreta. ${ }^{253}$ It seems that elements of the traditional symposium (psalms, prayer, instruction) have been telescoped here with the Eucharist.

The Apostolic Tradition does not provide a full description of the general gathering in the morning on Sunday or on other days of the week. It does give separate descriptions of how the reading, ${ }^{254}$ followed by instruction, and the Eucharist were conducted. ${ }^{255}$ Although regional differences must have continued to exist, there is no doubt that in the third century the structure consisting of reading, sermon and Eucharist became the customary backbone of the Christian gathering. It also occurs in the Didascalia, which observes that the bishop could pronounce an exhortation and then proceed to the celebration of the Eucharist. ${ }^{256}$ According to the Didascalia, this was the order of the service: (1) prayer; (2) reading of Scripture; (3) sermon; (4) eucharistic prayer; (5) Eucharist. ${ }^{257}$ This order, concluded by singing and prayer,

${ }^{253}$ This presentation of the order of the service is based on an interpretation of Trad. ap. 25-29, which cannot be set forth in detail here.

${ }^{254}$ That the reading was performed may be inferred from a reference to the reader in Trad. ap. 11.

${ }_{255}$ Trad. ap. 18-19; 39; 41 (for reading, instruction and prayer) and 4; 22 (for the Eucharist on Sunday morning, cf. ch. 36, and on other mornings). The material in chapters 35-38 may well reflect the order of, first, instruction and then, after the catechumens had left, the Eucharist. Several passages in Cyprian attest the daily routine of both the reading of Scripture and the Eucharist; Cypr., Ep. 39.4.1; 57.3; 58.1. It is most plausible that, in the situation Cyprian had in mind, the reading and the Eucharist took place in the same meetings.

${ }^{256}$ Did. ap. 2.58.

${ }^{257}$ Did. ap. 2.58; 6.21. 
spread in the third century and became the pattern for the liturgy in the fourth century. ${ }^{258}$

\section{The leaders of the gatherings in the EARly CHURCH}

As long as Christian communities gathered as house churches, their gatherings were most likely conducted by the person who hosted the group in his house, such as Philemon, probably in Colossae (Phlm. 2), and Aquila in Ephesus (1 Cor. 16:19) and Rome (Rom. 16:4). In this respect, the gatherings of Christians conformed to the pattern of Graeco-Roman banquets where the host would normally serve as chairperson. On occasion, itinerant apostles, prophets, teachers and evangelists could conduct the gathering of Christian communities. According to Acts 20:7-11, for instance, Paul as such a visiting apostle conducted a gathering of the Christian community in Troas: "he broke the bread" and "preached during a long time, until dawn" (20:11). Itinerant clergy continued to conduct eucharistic meals for some time into the second century. ${ }^{259}$

Hellenistic associations had office holders who exercised authority in such matters as assigning places and inviting participants to speak. ${ }^{260}$ Such officers could say prayers during the gathering and benefit from the honour connected with the role of host. The physical setting and the roles exercised by individuals at banquets played an important part in the creation of patronage, the fundamental structure of obligation and dependence in Graeco-Roman culture. The ministerial offices of the early Christian communities that developed by the end of the first century were inevitably linked with ideas of leadership and patronage at banquets. ${ }^{261}$

To refer to those who were in charge in the Thessalonian church, Paul speaks of oi $\pi \rho 0 \ddot{\sigma} \tau \alpha \dot{\mu} \mu \varepsilon v o r$ i $\mu \omega \hat{\omega} v$ (1 Thess. 5:12). He designates "some-

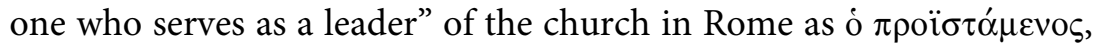
used absolutely (Rom. 12:8). The participles in these phrases are not

\footnotetext{
${ }^{258}$ For a survey of the different sequences of the proceedings in Christian gatherings in the first to third centuries, see Appendix 2 below.

${ }^{259}$ Did. 10.7; 15.1-2; and the apocryphal Acts as cited below.

${ }^{260}$ See, e.g., the statutes of the Iobacchoi (Athens, second century CE), containing directions for their club banquets, verses 65-67, in J. Kirchner (ed.), Inscriptiones Graecae II I, 1-2 (Berlin: Reimer, 1913), n. 1368 (ca. 178 CE).

261 A. McGowan, "Food, Ritual, and Power," 159.
} 
set titles of office holders but general designations of people fulfilling leading functions in the community. However, their group is likely to have included the persons who presided over the gatherings of the community.

In discussing the gathering of the Corinthian church, in addition to apostles, prophets and teachers, Paul mentions church members who have various useful competences, including forms of leadership

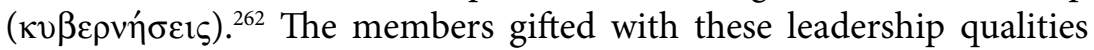
probably included persons capable of chairing the gatherings of the Christian community. However, Paul puts the apostles first in the list and may have supposed that, if an apostle were present, this apostle would conduct the gathering. ${ }^{263}$ If not, the master of the house and host of the meeting would normally play this part, or one of the members who were able to hold a leading position.

As householders, women, too, could perform leadership roles and possibly even conduct Christian gatherings, serving as patrons or hosts. A case in point is Lydia, who, according to Luke, hosted a church in her house in Philippi. When Paul and Silas were released from this town's prison, they went to Lydia's house, where they met and encouraged the brothers and sisters. ${ }^{264}$ Nympha in Laodicea, too, is presented as hosting a church that meets in her house. ${ }^{265}$ True, the person who hosted a church in her or his house need not always have been the conductor of that church's gatherings. However, pagan Greek women could certainly organise and preside over banquets in their house, as is illustrated by a passage in Apuleius' Metamorphoses ${ }^{266} \mathrm{In}$ this passage, the main character of the book, Lucius, attends a supper and drinking party in the house of Byrrhaena, a distinguished lady at Hypata, a small town in Thessaly. There is no reason to assume that Christian women could not preside over a meal of the church meeting in her house. ${ }^{267}$

2621 Cor. $12: 28$.

2631 Cor. 12:28-29.

264 Acts 16:40.

265 Col. 4:15.

266 Apul., Met. 2.18-19.

267 This is the tenor of Carolyn Osiek, A Woman's Place. House Churches in Earliest Christianity (Minneapolis: Fortress Press, 2006), see pp. 159-163. Epigraphic evidence dating from $27 \mathrm{BCE}$ to the sixth century CE shows that women could be called leaders in a number of synagogues in Italy, Asia Minor, Egypt and Palestine. See Bernadette J. Brooten, Women Leaders in the Ancient Synagogue (Chico: Scholars Press, 1982). 
To designate leading functionaries of a church, Paul uses the term غ̇лíбколо for the first time in his letter to the Philippians. The letter mentioned is addressed "to all the saints in Christ Jesus who are in

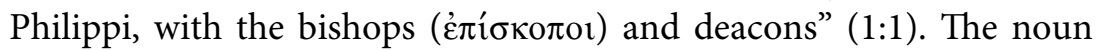
غ̇лі́кколо $\varsigma$ means "one who watches over...," "overseer," "guardian," "supervisor." The word apparently reflects the original role of the غ̇лíбколо in watching over, and keeping order in, the community's meals and gatherings. ${ }^{268}$ Christians were not the first to employ this designation for the person who chaired their meetings. Also in the Greek speaking world at large, the highest officers of several asso-

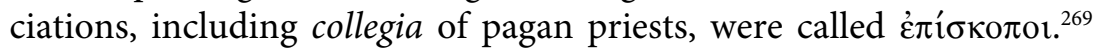
Among Christians, such "overseers" must often have had the responsibility of presiding over the communal meals. Originally, the word referred to an activity or a function that could be performed by various members of a Christian community. In the case of the Philippian church, there were clearly several persons functioning as overseers at the same time, either in different congregations or in one congregation in rotation. With time, the term came to be used to denote the person who presided over the gatherings of a church on a regular basis and in this way it became a title. This seems to be the case already in the

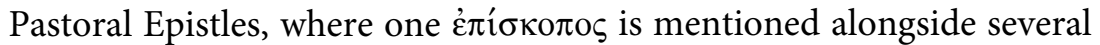
$\delta$ iókovor in one church. ${ }^{270}$

Itinerant apostles and prophets continued to conduct gatherings and communal meals of Christian communities during the first half of the second century, as appears from the Didache. ${ }^{271}$ The apocryphal Acts, too, often present apostles as presiding at Christian gatherings and conducting eucharistic meals. ${ }^{272}$ These narratives are legendary to

However, the evidence does not indicate that these women hosted a Jewish community or presided over community meals.

268 The Christian term $\delta$ iókovor likewise originally denoted people serving at the Christian group meal: waiters. This origin of the term is still clearly reflected in Luke's

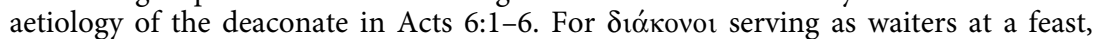
see Jn. 2:5.

${ }^{269}$ Claudia Rapp, Holy Bishops in Late Antiquity (Los Angeles and London: University of California Press, 2005), 24.

2701 Tim. 3:2, 8 .

271 Did. 10.7 (prophets preside over the Eucharist); 11.3 ("apostles and prophets"); 11.4 (an apostle should be received as the Lord); 15.1 (local bishops and deacons should take over the work of itinerant prophets and teachers).

${ }^{272}$ Acta Ioan. 46; 106-110 (J.K. Elliott, pp. 324; 335-336); Acta Petri 2; 7; 20; 29 (Elliott, pp. 400; 404-405; 413-414; 421); Acta Thom. 29 (Elliott, p. 459); Acta Pauli 3.5-7 (Elliott, p. 365). 
a large extent but reflect correctly the practice of travelling apostles and prophets conducting gatherings of Christian communities in the first and early second century.

Presbyters or elders ( $\left.\pi \rho \varepsilon \sigma \beta v_{\tau \varepsilon \rho \rho}\right)^{273}$ appear as leaders of Christian communities in the epistles dating from the end of the first century and the beginning of the second century: the Pastorals, ${ }^{274} 1$ Peter, ${ }^{275} 1$ Clement ${ }^{276}$ and the letters of Ignatius. ${ }^{277}$ Luke, too, took it for granted that Paul appointed and met with elders in the churches he founded. ${ }^{278}$ There is a general probability but little clear evidence that around 100 CE presbyters presided over communal meals and gatherings of early Christian communities. However, one indisputable indication that presbyters administered the Eucharist occurs in 1 Clement. The author of this writing reproaches the Corinthian Christians for removing presbyters from the ministry-presbyters "who offer the gifts in a blameless and holy way." 279 There can be no doubt that the ministry of "offering the gifts" was that of celebrating the Eucharist. ${ }^{280}$ Remarkably, 1 Clement designates the office of the presbyters also as their $\dot{\varepsilon} \pi \imath \sigma \kappa о \pi \eta$ (office of overseer) ${ }^{281}$ Obviously, there is still little difference

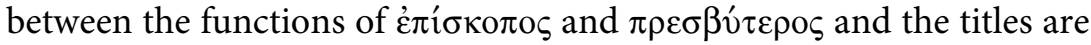
still interchangeable. Such passages as Acts 20:17, 28 and Titus 1:5-7 confirm that the terms were originally interchangeable.

In the second century the presidency over the Christian gathering passed from apostles and prophets to bishops and presbyters. The performance of the liturgical actions came to be reserved to sedentary

${ }^{273}$ On the use of $\pi \rho \varepsilon \sigma \beta v i \tau \varepsilon \rho \varsigma$ in connection with Hellenistic associations, see John S. Kloppenborg, "Edwin Hatch, Churches and Collegia," in Origins and Method: Towards a New Understanding of Judaism and Christianity, ed. B.H. Maclean (Sheffield: JSOT Press, 1993), 212-238, esp. 231-234; Philip A. Harland, Associations, Synagogues, and Congregations (Minneapolis: Fortress Press, 2003), 299, n. 4. The earliest clearly dated evidence for the titular use of $\pi \rho \varepsilon \sigma \beta u ́ \tau \varepsilon \rho о \varsigma$ among the Jews of the Diaspora is provided by the inscriptions from the synagogue of Dura-Europos, from 244-245 CE, followed by the imperial pronouncements from the fourth century onwards; Emil Schürer, Geza Vermes, Fergus Millar, Martin Goodman, The History of the Jewish People in the Age of Jesus Christ, vol. 3 (Edinburg: T \& T Clark, 1973-1987), 102.

2741 Tim. 5:17-22; Tit. 1:5.

2751 Pet. 5:1-5.

2761 Clem. $1.3 ; 21.6 ; 44.5 ; 47.6$.

277 Ign., Eph. 2.2; Magn. 6.1; Trall. 2.2; 3.1; Smyr. 8.1.

278 Acts 14:23; 20:17; Alastair Campbell, The Elders. Seniority within Earliest Christianity, 97.

279 Clem. 44.1-5.

280 A. Jaubert, Clément de Rome. Epître aux Corinthiens (Paris: Cerf, 1971), 173.

${ }^{281} 1$ Clem. 44.4. 
officers. Presbyters and bishops elected by the community took on them the responsibilities previously fulfilled by "charismatic" preachers: apostles and prophets. The newer clergy took over all their functions, especially that of presiding over the periodical gathering.

Ignatius repeatedly insists that Christian assemblies should be conducted by the (monarchic) bishop assisted by presbyters and deacons. ${ }^{282} \mathrm{He}$ complains that certain Christians, obviously Christians who hold views different from his, have their communal meals without the bishop. ${ }^{283}$ To discourage this abuse, Ignatius claims:

Only that Eucharist which is under the authority of the bishop (or whomever he himself designates) is to be considered valid. Wherever the bishop appears, there let the congregation be; just as wherever Jesus Christ is, there is the catholic church. It is not permissible either to baptize or to hold love feast without the bishop. ${ }^{284}$

This passage indicates that, even in Ignatius' view, the Eucharist could occasionally be administered by presbyters and possibly even by deacons.

By the time the Didache was being composed, local leaders of Christian communities, namely bishops and deacons, were taking over the functions of itinerant apostles, prophets and teachers. ${ }^{285}$ The author of the Didache warns his readers to hold the sedentary clergy in the same honour as the itinerant prophets and teachers: "Do not disregard them, for they are the persons who hold a place of honour among you, on a par with the prophets and the teachers." ${ }^{186}$ Didache 10.7 states that the prophets are allowed to extemporize the eucharistic prayers, which implies that they could preside over the eucharistic celebra-

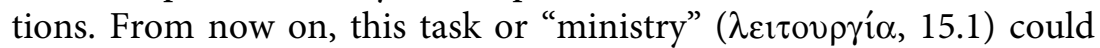
be performed as well by bishops and deacons. We are witnessing here how bishops, assisted by deacons, gradually became the conductors of Christian congregation gatherings. ${ }^{287}$

Some decades later, Justin in Rome refers to the person who delivered the sermon in the Christian assembly and conducted the

\footnotetext{
${ }^{282}$ Ign., Magn. 6.1; Trall. 2.2-3; 3.1; 7.2; Phild. 4.1; Eph. 20.2.

283 Ign., Magn. 4.

${ }^{284}$ Ign., Smyr. 8.1 (tra. Michael W. Holmes). For similar directives, see Ign., Magn.

7.1; Trall. 2.2; 7.2; Eph. 20.2; Phild. 4.1.

${ }^{285}$ Did. $15.1-2$.

${ }^{286}$ Did. 15.2.

${ }^{287}$ Did. 15.1.
} 
Eucharist as "the president" (ó $\pi \rho 0 \varepsilon \sigma \tau \omega ́ \varsigma) .{ }^{288}$ Justin does not call him a bishop, probably because he is writing here an apologia addressed to the Roman Emperor. In this context he understandably prefers a generally current term, $\pi \rho 0 \varepsilon \sigma \tau \omega ́ \varsigma$, to the more specifically Christian

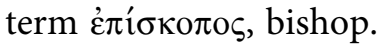

When the occasion presented itself, a bishop could renounce his right to conduct the gathering of his church in favour of a visiting bishop. Thus, Anicetus, bishop of Rome (ca. 154-166), made way for Polycarp, bishop of Smyrna, to celebrate the Eucharist, obviously out of respect, for the two bishops had differences of opinion on several theological issues. ${ }^{289}$ During Anicetus' episcopate, a certain Marcellina, a women who held Gnostic views, came to Rome and by her teaching "led multitudes astray." 290 Marcellina probably conducted gatherings of her own group, but our informant, Irenaeus, does not explicitly say so. ${ }^{291}$

Just like Justin, and for the same reason, Tertullian in his Apologeticum avoids using the technical term in designating the officers who presided at the assemblies of Christian congregations: "Our presidents are men of advanced age and approved character." 292 As a rule, the Eucharist and the gathering as a whole was conducted by a church minister, preferably the bishop. Only in exceptional cases, if the celebration of the Eucharist was an urgent necessity and no member of the clergy (ordo) was present, every baptized member could accomplish this sacrament. ${ }^{293}$

Tertullian blames people he regards as "heretics" for not taking seriously the weight and dignity of the offices and allowing laypersons recklessly to fulfill priestly tasks: "It comes to pass [among the "heretics"] that today one man is their bishop, tomorrow another; today he is a deacon who tomorrow is a reader; today he is a presbyter who

${ }^{288}$ Just., 1 Apol. 67.4-5. This term is a usual designation of leaders of professional corporations in papyri of the first and second century CE; see, e.g., P. Vindob. G 24508 (33/34 CE), line 30-31 and the commentary on this passage in F.A.J. Hoogendijk, Tien papyrologische bijdragen tot de geschiedenis van Romeins en Byzantijns Egypte (Leiden: Papyrologisch Instituut, 2008), 169.

${ }_{289}$ Euseb., HE 5.24.27.

290 Iren., Haer. 1.25.6.

${ }^{291}$ Irenaeus, Haer. 1.13.2, also mentions gatherings of Valentinian Gnostics in which the leader Mark, the magician, allowed women to say eucharistic prayers and to prophesy but only under his supervision.

${ }_{292}$ Tert., Apol. 39.5.

${ }^{293}$ Tert., Cast. 7.3. 
tomorrow is a layman. For even on laymen do they impose the functions of priesthood." ${ }^{294}$ Tertullian also criticizes the "heretics" for permitting women to teach, engage in disputes, perform exorcisms, and "perhaps to baptize." ${ }^{295}$ Apparently, Tertullian could not reproach the heretics with allowing women to preside over eucharistic gatherings. In his own circles the behaviour of women fulfilling priestly functions, such as conducting the Eucharist, was regarded as an outrage. ${ }^{296}$

In the first half of the third century, Christian gatherings were normally directed by bishops. According to the Apostolic Tradition, the bishop conducts the Eucharist by saying the prayer and distributing the bread to the members of the community, while the presbyters and deacons assist him in breaking the bread. ${ }^{297}$ The bishop does so during the morning and the evening gatherings of the community. ${ }^{298} \mathrm{He}$ controls the whole ceremony and prescribes how things should be done; for instance, he can determine the number of psalms to be sung. When he begins to speak everyone keeps silent. When the bishop is absent, the gathering is conducted by one of the presbyters or deacons. ${ }^{299}$

The Didascalia, too, attests that the whole of the assembly is directed by the bishop, whereas presbyters attend sitting on both sides of the bishop, and deacons stand by the offering and serve in the church, seeing to it that everything be done with all decent order. ${ }^{300} \mathrm{~A}$ similar picture of the roles played by bishops, presbyters and deacons in Christian assemblies emerges from the writings of Origen and Cyprian. ${ }^{301}$ However, the author of the Didascalia has reason to warn his readers against allowing women to act as teachers in their communities: "It is neither right nor necessary that women should be teachers, and especially concerning the name of Christ and the redemption of his passion." ${ }^{302}$ Women had a better chance of obtaining leading positions

\footnotetext{
${ }^{294}$ Tert., Praescr. 41.8 (tra. Peter Holmes in ANF). This passage shows that in Tertullian's perception a system of Church officers was in place which comprised episcopi, presbyteri, diaconi and lectores.

295 Tert., Praescr. 41.5.

296 Tert., Vir. vel. 9.2.

297 Trad. ap. 4 (Eucharist following the consecration of a bishop); 22 (Eucharist in a morning service); 25 (Eulogy in an evening service).

298 Trad. ap. 22; 25; 28.

299 Trad. ap. 28.5: "Etiamsi absque episocopo in cena ( $\delta \varepsilon i ̂ \pi v o v)$ adfuerint fideles, praesente presbytero aut diacono similiter honeste percipiant."

${ }^{300}$ Did. ap. 2.53-59.

301 Or., Hom. Jos. 2.1; Cypr., Ep. 1.1; 63.14.4; 76.3.

${ }^{302}$ Did. ap. 3.6.
} 
and the presidency of communal gatherings in "heterodox" circles than in mainstream Christianity. This is illustrated by the following episode.

Shortly after $235 \mathrm{CE}$, among the Christians in the province Cappadocia and Pontus, a woman arose who pretended to be a prophetess. She attracted many followers by her ecstatic teaching. She often conducted gatherings in which she herself said the eucharistic prayers, sanctified the bread, and offered the sacrifice to God. She also held baptismal services and baptized many people. In all this, she used the customary liturgical formulas of the Church, "so that nothing might seem to be different from the Rule of the Church." ${ }^{303}$ This is a clear case of a woman conducting Church gatherings and the eucharistic meal, albeit outside of the prevailing Church.

In the third century, presiding over the eucharistic gathering was, as a rule, the task of the bishop. As we have seen, this function could be exercised by a presbyter only in the absence of the bishop. In that case, the function seems to be regarded as delegated by the bishop to the presbyter. As a consequence of the proliferation of eucharistic offices, the growth of Christianity outside the cities and towns, and the rise of churches in the country, the services of presbyters became increasingly needed. Consequently, the presbyters received more and more the bishop's responsibility as officiant of the Eucharist. ${ }^{304}$ In due course, the competence of presbyters to celebrate the Eucharist independently in churches in remote places was formally recognized, for instance, as noted by Innocentius I, Bishop of Rome, in his letter to Decentius, Bishop of Eugebium of 19 March 416. ${ }^{305}$

\section{Conclusions}

In the first century $\mathrm{CE}$ banquets and feasts were held periodically by all sorts of clubs, societies, associations, religious guilds, and other

${ }^{303}$ Firmilianus (bishop of Cappadocian Caesarea) to Cyprian, in the latter's correspondence, Ep. 75 (74).10.

${ }_{304}$ The possibility cannot even be ruled out that in the third to fifth centuries, female presbyters conducted the Eucharist. Epigraphic sources mention Ammion, a woman presbyter in Phrygia in the third century, and Kale, a woman presbyter in Sicily in the fourth or fifth centuries. See Ross S. Kraemer, Women's Religions in the Graeco-Roman World (Oxford: Oxford University Press, 2004), 256-257.

${ }_{305}$ G.A. Michell, Landmarks in Liturgy (London: Darton, Longman and Todd, 1961), 220-224. 
groups. During their meals the members of those groups wanted to give shape to their ideal of unity, solidarity, equality, and brotherhood. In holding their weekly meeting, Christian communities during the first three centuries conformed to the custom of numerous groups in the Graeco-Roman world to assemble regularly for such a supper and a symposium.

Christian communities assembled for their communal meals on Sunday evening. They probably chose the Sunday because they felt their group meal to exceed in importance that of the Jewish family meal on Sabbath. As a "corrective" of the Sabbath meal, the Christian group supper could best be held on the next day. Just as with other associations, Christian communities met as a rule in private households where the host usually provided an assembly room and food; alternatively, the participants could bring the food themselves.

The main types of food and drink consumed at the Christian meals were bread and water mixed with wine; this could be supplemented with oil, vegetables, cheese, salt and perhaps fish. To prevent their gatherings from being associated too readily with pagan banquets, some Christians drank no wine but only water during their meals. Meat is neither mentioned nor explicitly excluded as a dish on the menu of the early Christian group meals. Christians may have avoided eating it in order to exclude the risk of consuming eidolothyton (meat offered to an idol) and defiling themselves thereby. During the second part of the Christian gathering the participants exchanged various kinds of oral contributions, such as allocutions, teachings, revelations, ecstatic utterances, readings of authoritative texts, singing and prayer. At first, the programme of the gathering conformed in general to the pattern of the Graeco-Roman banquet, consisting of a meal plus a symposium. However, in the second century the reading and the sermon were placed before the meal, probably because this was the easiest way to exclude non-initiated members of the community from participating in the Eucharist, yet to make them attend the instruction consisting of reading and sermon.

The household setting, in which most of the Christian gatherings were held originally, also provided the leadership of the church; besides, during the first and second centuries, there were itinerant officers (apostles, teachers and prophets) who could preside at the Christian gatherings. The first sedentary officers were called bishops and deacons, or bishops and presbyters, without there being much difference between the bishops and the presbyters. In the second and 
third centuries the bishops became almost the only conductors of the Christian gathering; presbyters and deacons helped them or, if necessary, replaced them in performing the Eucharist. In the third and fourth century the presbyter obtained a more independent position as officiant of the Eucharist. 
CHAPTER TWO

\section{THE GATHERINGS OF CHRISTIANS IN THE MORNING}

\section{INTRODUCTION}

In the first chapter it has been argued that in the thirties and forties of the first century Christians began to hold communal suppers once a week, namely on Sunday evening. From the beginning of the second century Christians began to come together more frequently. In addition to their gatherings on Sunday evening, they began to meet early in the morning, first on one day, later on more days of the week. This chapter will examine first the origin of the early morning gathering and then the development of the morning gatherings in the second and third centuries.

\section{The origin of the Christian gathering In the MORNING}

During the first century Christians held their communal gatherings on Sunday evening. From the beginning of the second century at the latest, Christians felt the need to hold more meetings. Alongside the supper held on Sunday evening, a cultic assembly began to be held early in the morning before dawn, probably also on Sunday. The earliest evidence for Christian gatherings early in the morning comes from Pliny the Younger, who was the Roman governor of Bithynia-Pontus in $c a .110-112$ CE. In a letter to Trajan, Pliny asks the Emperor how to deal with Christians who were denounced to him. Pliny had interrogated some apostate Christians and this is what he had learned about their practices:

They declared that the sum total of their guilt or error amounted to no more than this: they had met regularly before dawn on a fixed day to chant verses alternately among themselves in honour of Christ as if to a god, and also to bind themselves by oath (sacramentum), not for any criminal purpose, but to abstain from theft, robbery and adultery, to commit no breach of trust and not to deny a deposit when called upon to restore it. After this ceremony it had been their custom to disperse and reassemble later to take food of an ordinary, harmless kind; but they 
had in fact given up this practice since my edict, issued on your instructions, which banned all political societies (hetaeriae). ${ }^{1}$

Since these Christians declared that, on the day on which they assembled before dawn, they were in the habit of reconvening in order to have their common supper, the "fixed day" on which the morning gathering took place was almost certainly the Sunday.

Scholarly opinions are divided with respect to the character of the morning gathering mentioned by Pliny. According to one interpretation, the morning meeting of Christians described by Pliny was a kind of "business meeting" during which the members of the Christian community settled their internal conflicts, just as other people did in their Greek and Roman clubs. ${ }^{2}$ This interpretation is based on a juridical understanding of the term sacramentum (solemn engagement). However, Pliny's account of the meeting suggests that it had a religious rather than businesslike, forensic or juridical character. Moreover, it is improbable that in order to settle quarrels within their community Christians met before dawn. Since they had to go to work at daybreak, this timing of their meeting would put their dealings under an inconvenient time pressure.

According to another interpretation, the morning gathering in question was a "service of the Word," consisting of Scripture readings, a sermon and prayer, and was concluded (as a result of Pliny's edict) by a eucharistic celebration. This interpretation would imply that, until Pliny took his measures against Christians, the evening meeting consisted of the Eucharist and an agape meal. As a consequence of Pliny's ban on associations, the Christians in Bithynia and Pontus abandoned the agape meal in the evening and transferred the Eucharist to their "service of the Word" at dawn. ${ }^{3}$ However, this interpretation must be considered highly improbable. There is no indication that in the early second century Eucharist and agape were distinct rites. In the first and second centuries, up to and including Tertullian's days, the weekly communal supper of Christian communities, that is, the Eucharist, and the agape meal were one and the same event, taking place in the

Plin., Ep. 10.96.7 (tra. Betty Radice).

2 Dennis Smith, From Symposium to Eucharist, 202-203.

3 A.N. Sherwin-White, The Letters of Pliny. A Historical and Social Commentary (Oxford: Clarendon Press, 1966), 704-708; Jörg Salzmann, "Pliny (ep. 10,96) and Christian Liturgy-A Reconsideration,” SP 20 (1989), 389-395, esp. 394-395. 
evening. ${ }^{4}$ More importantly, there is no sign whatsoever in Pliny's account that the meeting before dawn comprised the celebration of the Eucharist. Pliny may be correct in stating that some former Christians, now apostates, had ceased to attend the Sunday evening meetings of their congregations. However, there is no ground for the supposition that, as a consequence of Pliny's ban on associations, these Christian congregations discontinued the celebration of the Eucharist on Sunday evening and moved it to the Sunday morning. It cannot be argued that the meeting at dawn comprised a Eucharist just on the grounds that the Eucharist in the evening had been discontinued, for there is no reason to believe that it had been discontinued in the evening. It had only been abandoned by those who later became apostates, at least according to their declaration given to Pliny.

Still another interpretation sees the Christian gathering in the morning described by Pliny as a Christian counterpart of the Jewish gathering in the synagogue on Sabbath. ${ }^{5}$ It is highly implausible, though, that Christians initiated morning gatherings using the analogy of the meetings of Jews in the synagogue on the Sabbath. The Christian and the Jewish meeting were of an entirely different character. First, an important element of the Christian ceremony was the antiphonal singing of hymns of praise. The accounts of meetings in the synagogue on the Sabbath, on the other hand, make no mention of any singing whatsoever. Second, the main objective of the synagogal meetings on the Sabbath was the reading and discussion of the Law. However, the Christian meetings mentioned by Pliny did not include the reading or discussion of any text. Third, in the synagogal meeting on the Sabbath, the participants quietly took their time, sometimes "till about the late afternoon" ${ }^{\circ}$ or "until the evening"7 or at

${ }^{4}$ The separation between Eucharist and agape becomes only visible in the third century, in the Trad. ap. and Cyprian. One should beware of projecting this separation back into the second century. This has now rightly been seen by Andrew McGowan, "Rethinking Agape and Eucharist in Early North African Christianity," SL 34 (2004), 165-176, esp. 166, and Paul Bradshaw, Eucharistic Origins (Oxford: Oxford University Press, 2004), 29-30, 99.

${ }^{5}$ Graham N. Stanton, "Aspects of Early Christian and Jewish Worship: Pliny and the Kerygma Petrou," in Worship, Theology and Ministry in the Early Church. Essays in Honor of Ralph P. Martin (Sheffield: JSOT Press, 1992), 84-98, esp. 85-93.

${ }^{6}$ Philo, Hyp., apud Euseb., Praep. ev. 8.7.12-13.

7 Jos., Ap. 1.210 . 
least until noon. ${ }^{8}$ They were in no particular hurry. ${ }^{9}$ Christians, on the other hand, had to meet before dawn because the Sunday was a working day; they must have held their morning ceremony under a certain amount of time pressure.

Finally, there are interpretations of Pliny's letter that assume that in his account of the Christian practices he is misrepresenting what his informants had told him. These former Christians would have explained to Pliny that before being baptized as Christians they had made the promise to forsake all forms of evil behaviour. Pliny would then have thought that Christians made this promise every Sunday. ${ }^{10}$ But why would the persons whom Pliny interrogated about the activities in their weekly gathering before sunrise, have spoken about their baptism? And why would they have spoken of a vow (sacramentum) and not of the ritual of immersion?

According to still another interpretation, Pliny's informants would have described a "service of the Word," consisting of a reading and a sermon. Trying to plead not guilty, they would have stressed the severity of the moral admonitions contained in the sermon so strongly that Pliny had concluded that they had pledged every Sunday to refrain from all evil. ${ }^{11}$

It is obviously true that Pliny's account of the Christian morning services may distort or misrepresent the report he had received from his informants, either because he misunderstood their information, or because he adapted it consciously or unconsciously to his or Trajan's frame of reference. However, this view of Pliny's report is liable to lead to uncontrollable speculation. In fact, Pliny says nothing about baptism, reading of any Scriptures, or a homily. There is little point in replacing Pliny's account by a hypothetical construct consisting of elements (e.g., reading, homily) that Pliny does not mention. It seems methodically more sensible to take Pliny's words more seriously and to assume that he really wanted to say that on a fixed day of the week

${ }^{8}$ Jos., Vit. 279.

${ }^{9}$ Philo, Som. 2.127.

${ }^{10}$ Jörg Salzmann "Pliny (ep. 10,96) and Christian Liturgy-A Reconsideration," $S P$ 20 (1989), 393-394. He suggests that the apostate Christians told Pliny about a "service of the Word" (reading and homily), tried to plead not guilty and thus stressed the moral exhortations of the Sunday morning sermons.

${ }_{11}$ Paul Bradshaw, Daily Prayer in the Early Church (London: Alcuin/SPCK, 1981), 43. 
Christians in Bithynia met before sunrise, sang hymns to Christ, and took a vow to abstain from evil. There is no reason to assume that the gathering comprised a Eucharist. Whether it took place in some room of a house or in the open, is a moot question.

Whatever the precise content of the Christian morning service in Bithynia may have been, this ceremony is the earliest traceable stage of the Church's tradition of worshipping on a Sunday morning.

In view of the fact that the Christians traditionally gathered (and continued to gather) in the evening for their common supper, the question must be asked as to why the Bithynian Christians initiated meetings in the early morning next to those in the evening. Since the letter of Pliny does not contain an answer to this question, let us ask if there are historical analogies which may explain why the Bithynian Christians began to hold meetings before sunrise.

In the Graeco-Roman world religious meetings at dawn were held by various pagan and Jewish groups. According to Josephus, the Essenes in Judea and elsewhere in Palestine assembled before sunrise and "offered to Him [the Sun] ${ }^{12}$ some traditional prayers as if beseeching him to appear."13 After this the Essenes went to their work and in the evening they reassembled for supper. ${ }^{14}$ Thus, the Christians of Bithynia and the Essenes had more or less the same schedule for the day (worship before sunrise, daily work, ${ }^{15}$ common supper), with the only significant differences being that the Essenes performed this programme every day of the week, rather than once a week on a Sunday, as was the Bithynian Christians' practice. The Essenes also had a common meal at noon.

Another example of communal worship before sunrise is the finale of the Pannychis celebrated by the Therapeutae near Alexandria. Philo relates that at the end of the night during which they celebrated this festival, that is, at dawn,

${ }_{12}$ Whether the Essenes really prayed to the Sun, as Josephus claims, or to God, addressing the Sun only as an image of God, is a much-debated question. The former seems more probable, as has been argued on good grounds by T.M. Jonquière, Prayer in Josephus (Leiden: Brill, 2007), 54-55.

${ }_{13}$ Jos., BJ 2.128-129.

${ }^{14}$ Jos., BJ 2.132.

15 Except that the Essenes did not work on the Sabbath. 
they stand with their faces and whole body turned to the east and when they see the sun rising they stretch their hands up to heaven and pray for bright days and knowledge of the truth and the power of keen sighted thinking. And after the prayers they depart each to his private sanctuary. ${ }^{16}$

This morning prayer, however, is the communal variant of the morning prayer which each of the Therapeutae prayed individually every morning at sunrise. ${ }^{17}$

One of the manuscripts from Qumran, 4Q503, contains the texts of prayers for each day of the month. ${ }^{18}$ The composition of the text is dated to the first century BCE. Since the persons who were supposed to use these prayers refer to themselves in the first person plural ("our deliverance," "we, his holy people," "for us," "our joy," etc.), the prayers seem to be meant as community prayers. A number of them had to be said "at the rising of the sun"; the manuscript has been preserved only in fragments, but there is the possibility that it once contained prayers for each day of a particular month. It remains unclear as to whether the cycle of this month started anew each month or only once a year.

The Christians of Bithynia met weekly for morning prayer, in contradistinction to several Jewish groups: the Essenes met daily, the Therapeutae yearly at the end of their Pannychis, and the group behind 4Q503 daily, either during a certain month of the year or during the whole year. The cycle of the Christian worship at sunrise in Bithynia thus differs clearly from that of the Jewish groups mentioned. However, the importance of the testimonies adduced so far is that they show how Jews gathered communally and prayed to God at sunrise. Many other groups in the Mediterranean region did the same, as we shall see presently.

Prayer or singing at sunrise facing the east, either daily or less frequently, was also a widely spread phenomenon among non-Jews in the

${ }^{16}$ Philo, Contempl. 89 (tra. F.H. Colson).

${ }_{17}$ Philo, Contempl. 27. For daily prayers before sunrise or in the morning, see also Ber. 1.2 and 1.4, but these are individual prayers.

${ }_{18}$ F. García Martínez and E.J. Tigchelaar, The Dead Sea Scrolls Study Edition, vol. 1 (Leiden: Brill, 1997-1998), 999-1009. 
Graeco-Roman world. ${ }^{19}$ Pagans could pray to their gods individually ${ }^{20}$ or communally in or outside their temples and shrines. ${ }^{21}$

The evidence for worship of the gods at dawn among pagans includes the following indications and allusions. Not all of these concern historically established practices, but they all prove that worship at dawn, including prayer and singing, was a well-known concept in the Graeco-Roman world: many people would be acquainted with it and few would be surprised if they came in contact with it.

(1) A Greek inscription from Teos from the beginning of the Roman imperial time prescribes that a hymn should be sung every morning at the opening of the Temple of Dionysus. ${ }^{22}$

(2) According to Apuleius, midway through the second century, "a choir saluted the breaking day with the loud hymn that they always sang at the hour of prime" in the Isis temple at Corinth. ${ }^{23}$

(3) During a visit to Smyrna about $170 \mathrm{CE}$, Aelius Aristides dreamed that in the Temple of Asclepius he heard the temple servants sing an old hymn to Zeus at dawn: "I praise Zeus, the highest of all." ${ }^{24}$ On

${ }^{19}$ For an intriguing and most instructive visualisation of this practice, see the painting "Pythagoreans celebrate sunrise" by the Russian artist Fyodor Bronnikov (1869), now in the State Tretyakov Gallery, Moscow. See Masterpieces of Russian Art. Шедевры русской нсивописи, руководитель проекта Андрей Астахов (Москва: Беый город, 2006), 284-285 and Appendix IV below. That Neo-Pythagoreans adored the sun at sunrise was a 19th-century theory, advocated among others by E. Zeller in his influential Die Philosophie der Griechen, 3 vols. (Tübingen: Fues, 1844-1852), vol. 3 , section 2 (1852), 583, 591. The theory was based on scanty indications, mainly Diog. Laert. 8.17 and Philostr., Vita Apol. 6.10. It has convincingly been confuted by J.B. Lightfoot, "On Some Points Connected with the Essenes," in his Saint Paul's Epistles to the Colossians and to Philemon, 5ed. ed. (London: Macmillan, 1875; 1880), 380-382, 387.

${ }^{20}$ Cf. Virgil, Aeneid 8.68, where Aeneas prays at sunrise facing the east; and Philostr., Vita Apol. 6.10, where Philostratus states that the Neo-Pythagorean philosopher Apollonius of Tyana, in Cappadocia, in the first century CE, was used to pray at dawn to the sun.

${ }^{21}$ Corpus Inscriptionum Graecarum III, 1-2, n. 171 (Berlin: Reimer, 1878) = II ${ }^{2}$ III, $1-2$, n. 4533 (Berlin: de Gruyter, 1935) is an example of communal morning prayer to Asclepius, Hygieia and Telesphorus (2nd century CE). For the date of the inscription see Édouard des Places, La religion grecque (Paris: Picard, 1969), 168; J. Quasten, Musik und Gesang in den Kulten der heidnischen Antike und christlichen Frühzeit (Münster: Aschendorff, 1973), 65. Quasten deals with prayer during the liturgy of an Isis cult association.

${ }^{22}$ Louis Robert, Études anatoliennes: recherches sur les inscriptions grecques de l'Asie mineure (Paris: De Boccard, 1937), 18-21.

${ }^{23}$ Apul., Met. 11.20 (tra. R. Graves, p. 238).

${ }^{24}$ Aelius Aristides, Sacred Tales 1.30. For other examples of pagan singing in the morning see Martin P. Nilsson, "Pagan Divine Service in Late Antiquity," HTR 38 (1945), 63-69, esp. 66-68. 
another occasion he dreamed that at sunrise, a crowd in the marketplace of Smyrna recited the prayer "O Sun, turning round the flame by swift horses." 25

(4) Lucian in his satire On Dances (or On Pantomime) claims that the Indians venerated the sun at the beginning of every day, not by saying prayers but by dancing: "The Indians, when they rise to offer their morning salutation to the Sun, turn to the east and silently greet the God with movements that are designed to represent his own course through the heavens."26

(5) In his Metamorphoses, Apuleius mentions an Egyptian prophet who, in the company of others, prays to the sun facing the east. ${ }^{27}$

(6) The fact that certain pagan groups offered prayers at sunrise was not unknown among the Christians, at least from Tertullian onwards. Already in 197 CE he wrote:

[Some pagans] imagine that the sun is the Christian god. They have observed that when we pray, we face to the east and we rejoice on the day of the sun. Do you do anything less than this? Do you not sometimes cause your lips to quiver toward the rising sun as an act of adoration?28

What Tertullian knew about pagans praying at sunrise at the end of the second century, the Bithynian Christians may have known at the beginning of that century.

(7) The assiduity with which gentiles used to assemble early in the morning to worship their gods is even held up as an example to Christians by the Apostolic Constitutions:

The Gentiles every day, when they arise from sleep, run to their idols to worship them, and before all their work and all their labours do first of all pray to them.... If, therefore, those who are not saved frequently assemble together for such purposes as do not profit them, what apology will you make to the Lord God, you who forsake His Church, not imitating so much the heathen, but by your absence grow slothful, or turn apostate, or act wickedness? ${ }^{29}$

${ }^{25}$ Aelius Aristides, Sacred Tales 1.22. The prayer quoted comes from Euripides, Phoenissae 3.

${ }^{26}$ Luc., Dances 17 (tra. H.W. and F.G. Fowler).

27 Apul., Met. 2.28.

${ }^{28}$ Tert., Nat. 1.13 (tra. Q. Howe in ANF). Cf. Apol. 16.11: "Many of you with an affectation of sometimes worshipping heavenly bodies move your lips towards the rising sun" (tra. T.R. Glover in LCL).

${ }_{29}$ Const. ap. 2.60 (tra. James Donaldson, adapted). 
(8) A geographically close analogy to the Christian worship at dawn in Bithynia is the morning prayer of a private association at Oinoanda in Lycia, attested by the inscription SEG 933 (3rd century CE). ${ }^{30}$ The prayer is addressed to a deity "dwelling in fire," "Aither," identified with Theos Hypsistos and Helios. The inscription invites its readers "to pray looking to him at dawn, as you look towards the east." ${ }^{31}$

(9) The rites of another group of worshippers of Theos Hypsistos, the pagan Messalians, are described by Epiphanius. He seems to locate them somewhere in Syria, perhaps in the second or third century CE. This is, among other things, what he has to say about their gatherings:

They would gather in the evening and at dawn with much lighting of lamps and torches and lengthy singing of hymns and acclamations to God by the zealous among them, through which hymns and acclamations they fondly think to conciliate God. ${ }^{32}$

The above evidence from Jewish, pagan, and Christian sources shows that coming together in the early morning for worship was a widespread phenomenon in the Graeco-Roman world. For Christians in Asia Minor about $100 \mathrm{CE}$, the idea of assembling by sunrise for worship was not something very difficult to conceive, therefore. They could simply follow the analogy of many other religious groups and associations.

Why the Christians in Bithynia placed their morning service on Sunday remains a matter for conjecture. The fact that they placed it on the day of their communal supper may be an indication that the morning gathering served as a kind of preparation for the evening gathering. By taking the vows of perfect honesty, fidelity and trustworthiness in the morning they may have intended to attain the ceremonial purity which enabled them to participate freely in the Eucharist later that day. Another reason may have been that Christians longed so much for the joy of their weekly meeting on Sunday that they could

${ }^{30}$ S. Mitchell, "The Cult of Theos Hypsistos between Pagans, Jews, and Christians," in Pagan Monotheism in Late Antiquity, eds. P. Athanassiadi and M. Frede (Oxford: Clarendon Press, 1999), 81-148, esp. 86-108.

${ }^{31}$ See G.H.R. Horsley, "Answer from an Oracle," in New Documents Illustrating Early Christianity, vol. 2 (North Ryde, Australia: The Ancient History Documentary Research Centre, Macquarie University, 1982), 37-44, esp. 39.

${ }^{32}$ Epiph., Panar. 80.2. See S. Mitchell, "The Cult of Theos Hypsistos," 92-93; Frank Williams (tra.), The Panarion of Epiphanius of Salamis, Books II and III (Leiden: Brill, 1994), 629-630. 
not wait until the supper and anticipated that festive event by gathering already at the beginning of the day. ${ }^{33}$ They may also have wished to pay respect to Christ before coming to the meal where he was their host and they his guests. Finally, the accounts of Jesus' resurrection on Sunday before dawn may also have played a part in their decision to gather on Sunday morning; after all, the Sunday was now beginning to be regarded as the day of Jesus' resurrection, as noted for the first time by Ignatius. ${ }^{34}$

From the beginning of the second century, Christians began to hold more morning meetings during the week, not only on Sunday morning, but also on other mornings. This proliferation of meetings is evidenced by Ignatius, the Didache, Barnabas, 2 Clement and other authors. ${ }^{35}$

The reason for this innovation probably was that there were several other religious groups, both Jewish and pagan, which met on a daily basis. This applies, for instance, to the Essenes, as we have seen above, and to the Isis cult in Corinth in the middle of the second century. ${ }^{36}$ The inscription from Teos mentioned above, which prescribes the singing of a hymn to Dionysus, also stipulates that it should be sung every day at the opening of the temple.

The increase of the number of Christian meetings in the morning, on Sunday as well as on other days, may have been furthered by the changing position of the leaders of congregations. In the second century the sedentary clergy were increasingly supported by their congregations; they no longer needed to practise a trade to earn a living. Supporting clergy with food and money probably began as early as the first century ${ }^{37}$ and became more common in the second century. The Didache, for instance, urges Christians to provide food for prophets and teachers who settle in a community in order to serve it; in this way the ministers were exempted from the necessity to earn their cost of living by doing other work. ${ }^{38}$ The ministry of the prophets and teachers could also be taken over by appointed overseers (bishops) and ser-

\footnotetext{
${ }^{33}$ See A.B. du Toit, Der Aspect der Freude im urchristlichen Abendmahl (Winterthur: Keller, 1965), esp. 116-118.

34 Ign., Magn. 9.1-2.

${ }^{35}$ The testimony of these authors will be discussed below.

36 Apul., Met. 11.20.

${ }^{37}$ Gal. 6:6; 1 Tim. 5:17-18.

${ }^{38}$ Did. 13.1-7.
} 
vants (deacons). According to the Didache, these latter officials must not be despised; this probably means that they could also look to the congregation for material support. ${ }^{39}$

Once Church officials were supported by their congregations they were in a position to arrange more meetings a week. Many of them did so, not only to build up, strengthen and reinforce their congregation, but possibly also to meet the needs and wishes of members of their congregation. Several second-century Christian authors urge their addressees to gather more frequently. From the contexts in which these admonitions appear, it is clear that the main reason why these authors urged Christians to meet more often was that they regarded more frequent meetings as a means to strengthen the Christians' faith and to prevent them from sliding into laxity, their former religion or "heresy." Thus the concern for the believers' "orthodoxy" may have been another reason for the clergy to increase the number of gatherings.

One of the authors who urge Christians to come together more often is Ignatius in his letter to the Ephesians: "Be eager, therefore, to come together more frequently ( $\pi v \kappa v o ́ \tau \varepsilon \rho o v)$ to give thanks and glory to God. For when you frequently ( $\pi \nu \kappa \nu \hat{\omega} \varsigma$ ) gather as a congregation, the powers of Satan are destroyed...."40 A similar admonition occurs in his letter to Polycarp when he states that Christian assemblies should be held more frequently ( $\pi v \kappa v o ́ \tau \varepsilon \rho o v) .{ }^{41}$ These admonitions mean that Ignatius wanted his hearers to hold more meetings in a given space of time than they already did, that is, more than once a week. By using $\pi \cup \kappa v o ́ \tau \varepsilon \rho o v$ in his letters to the Ephesians and Polycarp, Ignatius did not mean to say that Christians should not miss the weekly gatherings or should come together "more tightly," that is, in greater numbers. ${ }^{42}$ He means that Christians should gather more frequently than once a week, as Bart Ehrman has indicated correctly in his translation: "Let

${ }^{39}$ Did. 15.1-2.

${ }^{40}$ Ign., Eph. 13.1 (tra. Bart Ehrman).

${ }^{41}$ Ign., Pol. 4.2.

${ }^{42}$ As suggested by Th. Zahn, Ignatius von Antiochien (Gotha: Perthes, 1873), 345, note 1; William R. Schoedel, Ignatius of Antioch (Philadelphia: Fortress Press, 1985), 74, note 1; Taras Khomych, "The Notion of puknôs as a Distinctive Characteristic of Liturgical Celebrations in the Letters of St Ignatius of Antioch," SP 40 (2006), 441-

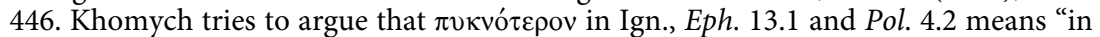
concord," "in peace," but his argumentation does not carry conviction: the leap from "tightly" to "in concord" is too far. 
there be more frequent gatherings." ${ }^{33}$ The admonition to have more frequent meetings with a Church's officers was also meant to prevent people from going to unauthorized meetings held by competing false teachers and prophets. ${ }^{44}$

The Didache also admonishes its addressees to come together frequently, that is, more often than only for the meeting on Sunday, as was standard practice (Did. 14.1): "Gather together frequently ( $\pi \nu \kappa v \hat{\omega} \varsigma$ ), seeking the things that benefit your souls, for all the time you have believed will be of no use to you if you are not found perfect in the last time." ${ }^{45}$ The context of this passage shows the author's anxiety for his readers to attain perfection in their Christian life, prepare themselves for the end of times and the Day of Judgement, and guard themselves against false teachers. In order to protect themselves from all kinds of danger and to be saved on the Last Day, Christians would do well to gather more frequently.

The same idea is expressed by the author of 2 Clement:

Let us think about paying attention and believing not only now, while we are being admonished by the elders, but also when we have returned home, let us remember the Lord's commands and not allow ourselves to be dragged off the other way by worldly desires, but let us come here

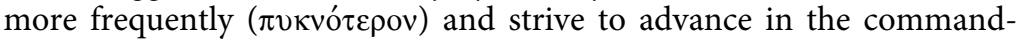
ments of the Lord, in order that all of us, being of one mind, may be gathered together into life. ${ }^{46}$

The passages just quoted from Ignatius, the Didache and 2 Clement suggest that in the beginning of the second century the number of weekly gatherings increased from one, on Sunday evening, to more, namely on Sunday morning and on other days of the week. The author of the Epistle of Barnabas goes so far as to urge his audience "to seek the faces of the saints daily." ${ }^{47}$ This is arguably the earliest evidence for

${ }^{43}$ Ign., Pol. 4.2 (tra. Bart Ehrman). See also J.B. Lightfoot, The Apostolic Fathers, Part II, vol. 2 (London: Macmillan, 1989), 66. He argues that Ignatius means that Christians should meet more frequently.

${ }^{44}$ Harry Maier, "Heresy, Households, and the Disciplining of Diversity," in Late Ancient Christianity, vol. 2, A People's History of Christianity, ed. Virginia Burrus (Minneapolis: Fortress Press, 2005), 219.

${ }^{45}$ Did. 16.2 (tra. Michael W. Holmes). Taras Khomych, "The Admonition to assemble Together in Didache 16.2 Reappraised," VC 61 (2007), 121-141, argues that

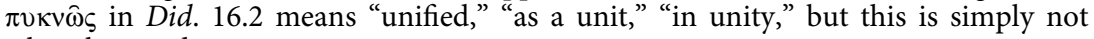
what the word means.

${ }_{46} 2$ Clem. 17.3 (tra. Michael W. Holmes).

47 Barn. 19.10. 
the existence, at least in one place, of a schedule of Christian meetings on every day of the week.

That Christians met more frequently than only on the Lord's day is also the impression one obtains from the Didache. Christian communities had to receive visiting apostles and prophets "as the Lord." 48 Yet, these visitors were not allowed to stay for more than one or two days, ${ }^{49}$ during which they were supposed to preach and teach in one or more of the community meetings. ${ }^{50}$ In these meetings, a meal could be served, although not at the instigation of the visiting apostle or prophet..$^{51}$ Since it is unthinkable that apostles and prophets arrived in a Christian community always on Saturday or Sunday, the conclusion is inescapable that the congregations the Didachist has in mind, held more gatherings a week than the standard eucharistic celebration on Sunday alone. ${ }^{52}$

Summarising, it may be stated that from the beginning of the second century at the latest, Christians began to have more than one meeting a week. In addition to their gathering on Sunday evening, they began to meet for worship at dawn. In this, they followed the example of many other religious groups in the Graeco-Roman world. This development was furthered by the fact that more and more local Church officials were supported by their congregation. This enabled them to organize and conduct more than one or two weekly gatherings on Sunday. The weekly gatherings at sunrise, first mentioned by Pliny as a feature of Christianity in Bithynia-Pontus, spread from the Sunday to all other days of the week. In the eyes of the Church officials, holding more gatherings a week was a means of strengthening the faith of the members of their congregations, as well as protecting them from slipping into religious negligence or "unorthodox" ideas.

\section{THE MORNING GATHERINGS IN THE SECOND AND THIRD CENTURIES}

The evidence for the history of the Christian morning gathering in the second and third centuries is scanty and hardly allows of a satisfactory

${ }^{48}$ Did. 11.4.

${ }^{49}$ Did. 11.5.

${ }^{50}$ Did. $11.7-12$.

${ }^{51}$ Did. 11.9.

${ }^{52}$ Did. 14.1. 
reconstruction of that history. One should beware of perceiving it simply as a linear process. Basically, three changes took place: (1) the morning gathering spread from the Sunday to other mornings, and in certain cases to all mornings of the week; (2) the morning gatherings were extended to include a Eucharist, Scripture reading and a sermon; and (3) the Sunday evening gathering with its communal meal lost its importance in favour of the Sunday morning gathering. From the middle of the third century, the Sunday evening meal continued to exist as an agape, but the really significant gathering became that on Sunday morning, including the Eucharist. These changes did not occur everywhere at the same pace. Considerable allowance should be made for regional differences. This makes it difficult to describe the history of the Christian gathering in the second and third centuries as one continuous history. In this section therefore only the literary data that illustrate how the morning gatherings of Christians in the second and third centuries developed in different places and times will be presented and discussed.

In the second century, besides coming together on Sunday evening and Sunday morning, Christians began to gather also on other mornings of the week; morning services such as recorded by Pliny as taking place on Sundays also began to be held on other days of the week..$^{53}$ At first, these gatherings did not yet comprise a meal but with time they came to include a eucharistic meal, probably a simple, modest form of breakfast with bread and wine; this communal breakfast became the daily morning Eucharist. Obviously, certain Christians felt that one Eucharist a week, on Sunday evening, was not enough. Longing for the community with the Lord and their fellow Christians, they began to celebrate the Eucharist also on one or more mornings of the week. Tertullian makes it clear that in his time the Eucharist was celebrated early in the morning, not only on the Christian fast days, that is, on Wednesday and Friday but also on the other days of the week. ${ }^{54}$ For

${ }_{53}$ These services took place sometime early in the morning before work. The growing number of morning services, first without and then with the celebration of the Eucharist, mirrors the wish expressed by the author of the Did.: "Frequent the company of the saints daily, so as to be edified by their conversation" (4:2) and "Come often together for spiritual improvement" (16:2). For the third century, see Trad. ap. 35 and 39.

${ }^{54}$ Tert., Or. 19.1-4 (dated to 198-204 CE), states that certain Christians, who were willing to receive the Eucharist daily in morning services, refused to do so on fast days, Wednesday and Friday, because they did not want to break their fast. For "sta- 
second-century Christians, the eucharistic bread represented "the medicine of immortality" ( $\varphi \alpha ́ \rho \mu \alpha \kappa o v ~ \alpha \dot{\theta} \alpha v \alpha \sigma i \alpha \varsigma$ ), as Ignatius calls it. ${ }^{55}$ $\mathrm{He}$ also remarks that "unless one is within the place of sacrifice he is deprived of the bread of God." ${ }^{56}$ Such interpretations of the Eucharist make it understandable that Christians longed to partake of it more often and sometimes even saved the bread in order to take it home and eat it the following morning. ${ }^{57}$

The earliest reference to eucharistic celebrations at dawn probably occurs in Apuleius' Metamorphoses (ca. 150-170 CE). The main character of this novel, after having been changed into an ass, is bought by a baker in a Thessalian town. Apuleius portrays the baker's wife as an extremely malicious, immoral and perverse woman. Among other things, this is what he says about her:

She scorned and spurned all the gods in heaven, and, instead of holding a definite faith, she used the false sacrilegious presumption of a god, whom she would call "the only One", to invent meaningless rites to cheat everyone and deceive her wretched husband, having sold her body to drink from dawn and to debauchery the whole day. ${ }^{58}$

Most interpreters of this passage have regarded the baker's wife as Christian, whereas others have taken her to be Jewish or admit both possibilities. ${ }^{59}$ However, in Apuleius' biased description the woman not only calls her God "the only God" (unicus) but also participates in certain rites involving the consumption of wine, which enable her to become drunk from early in the morning. This is an indication that Apuleius is depicting her as a Christian, for, as stated above, there is indisputable evidence in Tertullian that some decades later the Eucharist was celebrated in the early morning of various or all weekdays. ${ }^{60} \mathrm{It}$

tio solvenda sit accepto corpore Domini," that is, "in receiving the body of the Lord they have to break the fast." This passage shows that in North-Africa about $200 \mathrm{CE}$ the Eucharist was celebrated early in the morning at least on Wednesday and Friday and probably on all days of the week. For further evidence for daily celebrations of the Eucharist, see below.

${ }^{55}$ Ign., Eph. 20.2.

56 Ign., Eph. 5.2.

57 Tert., Or. 19.1-2; Ad ux. 2.5 .

58 Apul., Met. 9.14 (tra. J.A. Hanson, slightly adapted).

${ }^{59}$ For a useful discussion of this problem, see B.L. Hijmans (Jr.) et al., Apuleius Madaurensis. Metamorphoses. Book IX. Text, Introduction and Commentary (Groningen: Forsten, 1995), 380-382.

60 Tert., Cor. 3.3: "Eucharistiae sacramentum... etiam antelucanis coetibus...sumimus." From Tert., Or. 19 it is clear that certain members of a Christian congregation, 
may be relevant here to note that both Apuleius and Tertullian were active as rhetor in and near Carthage. Apuleius' allegation that the eucharistic meeting also gave the woman occasion for sexually immoral behaviour may be seen as a confirmation that he is portraying her as a Christian. The accusation that Christians at their common meals gave themselves over to sexual misconduct was a standard element in second-century pagan anti-Christian propaganda. ${ }^{61}$ Consequently, there are good reasons to assume that the passage under consideration is the earliest witness for eucharistic celebrations in the morning.

Historians of the Christian liturgy have thought for a long time that the Sunday gatherings of Christians described by Justin also took place in the morning. ${ }^{62}$ Other scholars have stated that Justin says nothing with regard to the hour of the day at which his Eucharist took place and that, as a result, it cannot be ascertained whether it took place in the morning or in the evening: it could be either. ${ }^{63}$ However, some elements in Justin's account of the meetings at issue seem to suggest that they took place on Sunday evening rather than on Sunday morning. First, Justin observes that deacons brought what remained of the meal to the orphans, the widows, the sick, the needy, the prisoners and travellers passing through. ${ }^{64}$ This suggests that what was distributed consisted of substantial portions sufficient to feed people, and that the meal itself was not a small or symbolic, but a sizable meal, that is, a supper. ${ }^{65}$ Second, the meeting described by Justin comprised so many

who wanted to fast on Wednesday and Friday, refused to receive the Eucharist in the morning gathering in order not to break their fast. However, the passage makes it clear that on Wednesday and Friday morning the Eucharist was celebrated and distributed. According to Tert., Idol. 7 there were Christians who "mangled His body daily"; in the context, "daily" must mean every morning.

${ }_{61}$ See, e.g., Just., 1 Apol. 26.7; Athenag., Plea 3; 31; Tert., Apol. 7.2; and Min. Fel., Oct. 9.7; 28.3, 5; 31.1 .

${ }_{62}$ E.g., Hans Lietzmann, Mass and Lord's Supper (Leiden: Brill, 1979; originally Messe und Herrenmahl, Bonn: Marcus and Weber, 1926), 211.

${ }_{63}$ Paul Bradshaw, Eucharistic Origins, 69. See also Maxwell E. Johnson, "The Apostolic Tradition," in The Oxford History of Christian Worship, eds. Geoffrey Wainwright and Karen B. Westerfield Tucker (Oxford: Oxford University Press, 2006), 50.

${ }^{64}$ Just., 1 Apol. 67.6.

${ }^{65}$ That the so-called apophoreta were substantial, not only symbolic, small portions of food, is clear from Trad. ap. 28, where it is supposed that all participants in the Lord's Supper eat their fill, not only those present but also those to whom the apophoreta are brought. It also appears from Trad. ap. 24 where those who have to bring the apophoreta to widows and sick are admonished to bring it the same day, that is, the same evening, not the next day, since the recipients are poor people who need the food for their nourishment. 
activities that it is difficult to imagine that all these took place early in the morning before the participants went to their work. Finally, the reason why Justin does not mention the hour at which his Sunday meeting was held may be precisely because he wanted to avoid revealing that it was an evening meeting. After all, he is writing here an apologia in defence of the Christians; it was safer not to present the Christian meetings here as the evening meeting of an association, for such evening meetings could easily be suspected of being a breeding place of political subversivity. It was against such evening meetings that Pliny had taken his measures in Bithynia-Pontus. All in all, the Sunday gathering described by Justin is likely to have taken place in the evening, not in the morning.

The first author to attest explicitly the daily celebration of the Eucharist in the morning is Clement of Alexandria in his Quis dives salvetur. Here Clement introduces Christ as saying: "I am your nurse, giving myself for bread, which none who taste have any longer trial of death,

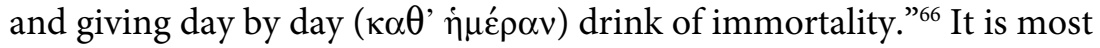
likely that these celebrations took place in morning gatherings, for in the first three centuries of Christianity we never hear of eucharistic celebrations being held on every evening of the week. ${ }^{67}$ Elsewhere, Clement goes into a consideration of the time during which Christian married couples could or should not engage in sexual intercourse. He observes that they must certainly not do this "after coming home from church, or from the market, early in the morning in the way of a cock," but in the evening after supper. ${ }^{68}$ Clement here conceives of the Christian gathering as taking place early in the morning on several or all days of the week. The same conclusion can be drawn from a passage in his Paedagogus in which he criticizes Christians who, on random days of the week, participate in the Christian gathering in the morning but give themselves over to worldly amusement in the evening:

After having paid reverence to the discourse about God, they leave within the church what they have heard. And outside they foolishly amuse themselves with impious playing, and amatory quavering, occupied with flute-playing, and dancing, and intoxication, and all kinds of trash. They who sing thus, and sing in response, are those who before hymned

${ }^{66}$ Clem. Al., Q.d.s. 23 (tra. G.W. Butterworth).

${ }^{67}$ Acta Petri 13, where the Roman church is said to meet "day and night" with their presbyter (see below), cannot be used as evidence to the contrary.

${ }^{68}$ Clem. Al., Paed. 2.96. 
immortality,-found at last wicked and wickedly singing this most pernicious palinode, "Let us eat and drink, for tomorrow we die."

The implication of this passage is that Christians went to church in the morning on several days of the week and could perhaps do so every day.

At the end of the second century, the custom of Christians to meet daily is also the supposition of the Acts of Peter (180-200 CE). According to this work, the Christians of Rome "met day and night in the house of Narcissus the presbyter." 70 This passage may give an exaggerated image of the religious zeal of the Christian community in Rome but the mention of daily gatherings, also referred to in other passages of these Acts, probably does reflect the situation in the author's church at the end of the second century.

Tertullian, in several of his works, takes it for granted that Christians meet every day of the week before dawn to celebrate the Eucharist. ${ }^{71}$ Recently, some scholars have argued that the rite in these morning assemblies was not the celebration of the Eucharist, but just the distribution of bread, sanctified during the supper (or agape) of a preceding evening, and not eaten until the end of the fast. ${ }^{72}$ However, this is an unlikely interpretation of the evidence in Tertullian. First, in De

${ }^{69}$ Clem. Al., Paed. 3.80 .4 (tra. B.P. Prattein in ANF). It is true that this passage does not mention the Eucharist but the daily celebration of the Eucharist is clearly referred to in Clem. Al., Q.d.s. 23, quoted above.

${ }^{70}$ Acta Petri 13 (tra. J.K. Elliott, p. 409). Cf. Acta Petri 7; 20; 29; 30; 31.

${ }^{71}$ Tert., Or. 19; the refusal of certain Christians to partake of the Eucharist on fast days implies that it was celebrated at least on Wednesday and Friday. Idol. 7.1-3: "quotidie corpus eius lacessunt." The daily celebration of the Eucharist mentioned here must have taken place at dawn, for it is unimaginable that people would gather for a communal meal every evening. See also Apol. 7.4: "Quotidie obsidemur, quotidie prodimur, in ipsis etiam plurimum coetibus et congregationibus nostris opprimimur." Cf. Nat. 1.7. Some authors have argued that these passages may indicate that in Tertullian's time a daily service for prayer but not a Eucharist was held; they assume that eucharistic celebrations were held only on Sunday, Wednesday and Friday. People could take the bread from these celebrations home and eat it on other days and, thus, eat Christ's body daily even when there was no Eucharist. See, e.g., P.G. van der Nat, Quinti Septimi Florentis Tertulliani de Idololatria (Leiden: Saint Lucas Society, 1960), 93-94. However, the context of Idol. 7.1-3 clearly speaks about various activities taking place in church and within the eucharistic gathering, not at home, so the "lacessere" (assailing, stirring, moving) of Christ's body must also be something taking place in the gathering. Moreover, a daily Eucharist with consumption of the elements is the practice known to Traditio apostolica (chs. 22; 35-37). There is little reason, therefore, to try to deny the same situation for Tertullian.

${ }_{72}$ Andrew McGowan, "Rethinking Agape and Eucharist in Early North African Christianity," 167-172; P. Bradshaw, Eucharistic Origins, 99-103; recently followed 
corona 3.3 Tertullian means to say that the Eucharist, which Jesus had ordered to celebrate at suppertime, was celebrated by the Christians of his time in meetings before daybreak. In this context Tertullian speaks of the celebration of the Eucharist as "Eucharistiae sacramentum... sumimus." Here "sumimus" does not mean that the participants only received the bread and the wine without consuming them; it means that they consumed them at a time not indicated by Jesus. Secondly, it is true that, according to De oratione 19 , some believers refused to attend the morning assembly on fast days because they did not wish to break their fast. However, Tertullian points out that receiving the body of the Lord does not break the fast. From this it is clear that the gatherings on fast days comprised a Eucharist with the consumption of the eucharistic elements. Moreover, those who refused to come were only a small group out of the number of those who participated normally in the Eucharist on those days.

An account of a morning gathering with Eucharist occurs in the Acts of Thomas (Syria, third century?). ${ }^{73}$ The gathering described takes place at dawn and consists of prayer, an admonition by the apostle and a eucharistic meal. The Acts of Thomas reflect a situation in which meetings of Christians were held in the morning on several days of the week (chapters 27-29).

The Apostolic Tradition records morning services on all days of the week (including Sundays), before working hours. ${ }^{74}$ These services included the reading of Scripture, an instruction, the exchange of the kiss of peace, prayer, and the Eucharist. Catechumens were not allowed to practise the holy kiss, ${ }^{75}$ nor of course to participate in the Eucharist. Before the Eucharist, the officiant prayed for them with imposition of hands and then dismissed them. ${ }^{76}$ The Traditio apostolica allows for the possibility that at places, due to the lack of competent clergy, the morning gatherings could not be held every day. Wherever this

by G. Rouwhorst, "The Roots of the Early Christian Eucharist: Jewish Blessings or Hellenistic Symposia?” 298-299.

${ }^{73}$ Acta Thom. 29 (J.K. Elliott, p. 459). In this case the gathering at daybreak took place on Sunday. For a similar gathering with Eucharist at dawn but on another day than Sunday, see ch. 27.

${ }^{74}$ Trad. ap. $22 ; 35+36+37$. From ch. 25 "He [the bishop] should not say "sursum corda," for that is said in the morning Eucharist ['ंv $\alpha \varphi \rho \rho \alpha$, oblatio]," it can be gathered that a Eucharist at dawn took place on Sunday morning, in addition to the Sunday evening meeting, that is the charitable кvpıккòv $\delta \varepsilon i \pi v o v$ (= the eulogia, chs. 25-28).

75 Trad. ap. 18.

76 Trad. ap. 19; 37. 
was the case, the faithful should begin the day by praying and reading "a holy book" in private. ${ }^{77}$ However, in principle "the deacons and presbyters should come together every day at the place appointed by the bishop, unless sickness prevents them from coming," teach those who have come to church. Apparently, it was obligatory for the clergy to be available on a daily basis at these morning gatherings so that lay persons could come to church on any particular morning and receive instruction.

In the third century, morning gatherings on weekdays are attested not only for North-Africa and Rome but also for Syria and Palestine. In Syria, morning gatherings are mentioned by the Didascalia. ${ }^{79}$ In Palestine it is Origen who speaks about meetings taking place on several successive days of the week: in his sermons he repeatedly points out that the Scripture reading of the day is the continuation of the reading of the previous day. ${ }^{80}$

An important change in the history of the Christian gathering took place by the middle of the third century. Traditionally, the gathering on Sunday evening had been regarded as the main weekly event in the Christian community, also after a eucharistic celebration had been added on Sunday morning and other mornings of the week. By the middle of the third century, the Eucharist on Sunday evening proves to lose much of its significance in favour of the Eucharist on Sunday morning. This development is documented by the Traditio apostolica and Cyprian.

Cyprian is familiar with weekly communal meals on Sunday evening as well as eucharistic gatherings, including the reading of Scripture, on every morning during the week. ${ }^{81}$ In one passage he mentions, next to the traditional gathering on Sunday evening, the daily celebration of the sacrament in the morning.

But for us, beloved brethren, besides the hours of prayer observed of old, both the times and the sacraments have now increased in number. For

77 Trad. ap. 35; 41.

78 Trad. ap. 39.

${ }^{79}$ Did. ap. 2.27-28, 58-59, 61; cf. 6.22 .

80 Or., Hom. Gen. 10.3; Hom. Jos. 4.1. It has been suggested that according to Or., C. Cels. 8.22, the Christian gathering on station day was on Friday evening. See P. Nautin, Origène. Sa vie et son oeuvre (Paris: Beauchesne, 1972), 391. However, there is nothing in the text to substantiate this view.

${ }^{81}$ Cypr., Or. Dom. 18; Op. eleem. 15; Ep. 29.1.1; 39.4.1; 57.3; 58.1. 
we must also pray in the morning, that the Lord's resurrection may be celebrated by morning prayer. ${ }^{82}$

However, in his famous Epistle 63, where he deals with the problem of some people using water at the Eucharist in the morning and wine only at the eucharistic celebration in the evening, he gives the morning ceremony much greater significance than that of the evening. The reason he gives for this appreciation is that the Christian community could not participate as a whole in the communal supper; and if not all members could participate, the supper was not the "sacrament." Obviously, all members could participate in the Eucharist on Sunday morning but not in the supper on Sunday evening. Why this was so remains a matter for conjecture. One possibility is that, if the supper was still a real, full meal, the members of the community were too numerous logistically to allow them all to participate in the supper. The Eucharist in the morning is likely to have been a much simpler sort of meal than the supper. Another possibility is that the supper had taken the character of a charity meal for the poorer members of the community and that the more well-to-do Church members disdained making use of this social service or mingling with those who did make use of it. However, according to Cyprian, it may be that not all Church members could attend the supper, although they could attend the Eucharist in the morning. That is the reason why he did not consider the supper any longer as the eucharistic sacrament: that function was now ascribed only to the Eucharist in the morning.

When we dine we cannot call all the people together to share in our meal; we cannot celebrate the full truth of this sacrament if we do not have all of the brethren present.... Whereas for us we celebrate the resurrection of the Lord in the morning. ${ }^{83}$

Thus, according to Cyprian, the most important meeting on Sunday was the one held in the morning, whereas the evening meeting continued to exist as an agape meal whilst losing its function as a sacrament.

The same development can be observed in the Traditio apostolica. The chapters 25-28 give detailed instructions for the celebration of a ceremony which takes place in the evening and consists, inter alia, of

82 Cypr., Or. Dom. 35 (tra. Ernest Wallis in ANF).

${ }^{83}$ Cypr., Ep. 63.16.1-2 (tra. G.W. Clarke). 
a prayer of thanksgiving, recitation of psalms by children, a deacon and the bishop, a benediction over the cup of wine, the distribution of bread, drinking and eating. What one eats and drinks is a full, substantial meal, not the ritual consumption of small symbolic portions of food and drink. The participants are invited to eat their fill but are warned to eat and drink decently and with moderation and not to become drunk. ${ }^{84}$ The meal is called "the Supper of the Lord" ( $\delta \varepsilon i \pi v o v$

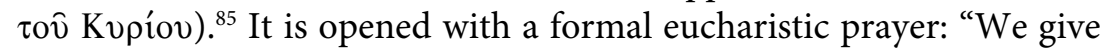
thanks to thee, Lord, through your Son Jesus Christ, our Lord, through whom you have illuminated us by revealing to us the incorruptible light, etcetera." 86 This meal is the traditional Lord's Supper held on Sunday evening. However, the description of this communal meal contains several hints that, according to the author of the Traditio apostolica, this meal was of less significance than the Eucharist celebrated in the morning. At the beginning of the ceremony, for instance, the bishop must not say "Lift up your hearts"; the reason is that "this is said during the oblation," that is, during the Eucharist in the morning. Furthermore, when the eating begins, the participants should take first a piece of bread from the hand of the bishop and then break their own bread, for this meal "is a benediction ( $\varepsilon \dot{\lambda} \lambda \mathrm{\gamma} \gamma i \alpha)$, not a Eucharist

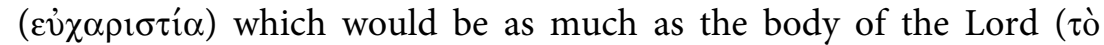

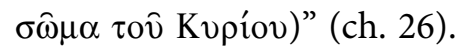

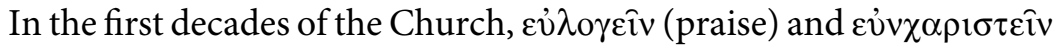
(say grace) had practically been synonyms ${ }^{87}$ as well as when they were used for the saying of grace over food or drink. ${ }^{88}$ Now all of a sudden

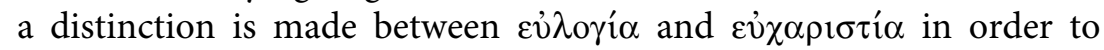
reduce the significance of the Lord's Supper being celebrated in the evening, in comparison with the Eucharist celebrated in the morning. It is even claimed that at the Lord's Supper one does not eat the body of the Lord, with the implication that the body of Christ is eaten only during the morning Eucharist.

Everything indicates that the evening meal served to allow poorer members of the congregation to eat a good meal at least once a week. This may explain why the whole section on this supper is concluded

\footnotetext{
84 Trad. ap. 28.

85 Trad. ap. 27.

${ }^{86}$ Trad. ap. 27.

87 See, e.g., 1 Cor. 14:16, where these verbs are used side by side.

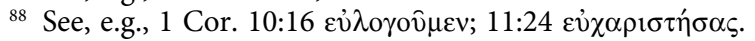


with warnings to the effect that the participants in this meal should behave decently. They should not become drunk, turn themselves into an object of derision, nor should they finish all the food; rather they should leave some for those absent. Further instructions were that they should not quarrel, speak unless the bishop asks something, and keep silent when the bishop speaks. One gains the impression that the author of this passage has a low opinion of the participants' table manners as they consumed the supper on Sunday. In his view, this supper was a charity meal, but no longer the sacramental meal of the community.

Here one witnesses how the Lord's Supper on Sunday evening loses its function as the congregation's sacramental meal in favour of the Eucharist celebrated on Sunday morning. It is the same process as we observed in Cyprian. The Sunday evening meal retained the character of charity institution or welfare provision. This charity supper, for which the name agape was reserved from now on, continued to exist for centuries. ${ }^{89}$ By the year $400 \mathrm{CE}$, Augustine describes it as a selfevident reality. ${ }^{90}$ It is still mentioned by the Trullan Synod of $692 .{ }^{91}$

\section{Conclusions}

At the beginning of the second century at the latest, Christians began to hold services of prayer and singing on Sunday morning before work. These morning services took place next to the eucharistic gatherings on Sunday evening. The morning gathering formed the Christian counterpart of the meetings for prayer and worship which were held by many other religious groups in the Graeco-Roman world, including pagan and Jewish worshippers.

In the course of the second century, such morning services, mainly consisting of prayer and singing, spread over the other days of the week, possibly first the fast days, Wednesday and Friday, and later all other days of the week. Later in the second century, the morning gatherings were enlarged to include a sober form of Eucharist,

${ }^{89}$ For the later history of the agape, see W.-D. Hauschild, "Agapen I," in Theologische Realenzyklopädie, vol. 1 (Berlin: De Gruyter, 1977), 748-753, esp. 752.

${ }^{90}$ Augustine, Contra Faustum 20.20: "Our agapai nourish the poor."

${ }^{91}$ Concilium quinisextum, canon 74 , containing a prohibition of agape celebrations in Church buildings. 
the reading of Scripture and a sermon or instruction. As a result, the morning gathering of Christians in the third century contained the reading of Scripture, a sermon or instruction, prayer, and the celebration of the Eucharist. On Sunday, this gathering was held in addition to the meeting in the evening, in which the traditional Lord's Supper was celebrated as a full meal.

However, from about 230 onwards, the Lord's Supper began to lose its function as the main ritual of the Christian community, whereas the Sunday morning meeting gained in significance, mainly because many more people attended the morning Eucharist than the evening meal. The latter became a charity meal for the less well-off members of the congregation. Thus, the Sunday evening meal was reduced to a form of Christian welfare, the agape meal, whereas the Sunday morning gathering with its simpler form of Eucharist became the central ritual of the Church.

Originally, the Lord's Supper and the agape had been one and the same eucharistic meal, celebrated on Sunday evening. In the third century the Lord's Supper became a charity meal, for which the term agape came to be reserved. The Sunday morning Eucharist became the more important of the two rituals and as a result the Lord's Supper held in the evening gradually lost its sacramental character. 
CHAPTER THREE

THE LORD'S SUPPER IN THE EARLY CHURCH

\section{INTRODUCTION}

This chapter will discuss the origin and development of the Lord's Supper (or the Eucharist) as celebrated in the context of the Christian gathering during the first three centuries. Originally the Lord's Supper was celebrated as a full meal within the framework of the Sunday evening gathering. In the second half of the second century, the Eucharist, in a more modest form, was introduced into the morning gatherings on several days of the week, including on Sunday. The Eucharist was also celebrated in baptismal gatherings and at the tombs of deceased Christians; however, discussion here will be restricted to those eucharistic celebrations which took place during the periodical gatherings of Christians, held in houses or apartment buildings. The origins of the Lord's Supper, how it was conducted and what it meant to the participants, will also be investigated. Finally, the tradition concerning Jesus' Last Supper will be examined as to how it originated in the context of the celebration of the Lord's Supper and what its function was in this context.

\section{The EARLiest history OF THE LORD's Supper}

\section{a. The shape and function of the Lord's Supper}

The earliest account of the Lord's Supper is found in Paul's first letter to the Corinthian church, probably written in the year $55 \mathrm{CE}$. Paul does not discuss the theme of the Lord's Supper in order to elaborate upon its theological significance, but rather to correct certain abuses that had crept into the celebration of the communal meal. Thus, Paul's principal concern in discussing the Lord's Supper in 1 Corinthians is not to provide a theological exposition of the meal, instead he uses it to challenge the Corinthian Christians' behaviour. ${ }^{1}$ In 1 Corinthians

${ }^{1}$ Daniel Powers, Salvation Through Participation. An Examination of the Notion of the Believers' Corporate Unity with Christ in Early Christian Soteriology (Leuven: Peeters, 2001), 179-180. 
10:14-22 Paul argues that idol worship and the participation in the Lord's Supper are incompatible. Paul wants the Christians in Corinth to stop participating in any other cultic meals since, in his view, they could not be partners with both demons and the Lord at the same time (1 Cor. 10:20-21). In 1 Corinthians 11:17-34 he discusses the divisions within the Corinthian community which, in his view, were connected with that community's malpractices in the celebration of the Lord's Supper. From these admonitory passages information can be gleaned about the shape and the function of the Lord's Supper in Corinth.

According to Paul, the Corinthian community meal was a $\delta \varepsilon i \pi v o v$, that is to say, the main meal at the end of the day: "When you come together, it is not really to eat the Lord's supper. For when the time comes to eat, each of you goes ahead with your own supper, and one goes hungry and another becomes drunk." ${ }^{2}$ The Lord's Supper was clearly a real meal; it was meant to satisfy the participants' hunger. In principle, the idea was that the more well-to-do members of the community would share food with poorer members. ${ }^{3}$ This sharing of food gave the Lord's Supper, inter alia, the function of a charity meal. That is why other sources call it also an agape (love-feast, $\dot{\alpha} \gamma \alpha \dot{\alpha} \pi \eta) .{ }^{4}$

However, the supper in the Corinthian church was also more than just an ordinary meal; in Paul's opinion, it had, what could be called, a sacramental function. It was sacramental because, according to Paul, ${ }^{5}$ it made the participants unite with the blood and body of Jesus Christ and, thus, share in his death and resurrection. Through the Eucharist they participated in the resurrection life of Jesus Christ. This is what made it a sacrament: it adumbrated, reflected and represented the participants' salvation.

Participation in the Lord's Supper encouraged a strong sense of community amongst the members of the congregation: "Because there is one bread, we who are many are one body, for we all partake of the

21 Cor. 11:20-21.

31 Cor. 11:22.

${ }^{4}$ Jude 12; Ign., Smyr. 7.1; 8.2; Clem. Al., Paed. 2.4.3; 2.4.5; Tert., Apol. 39.16; M. Perp. 17. Andrew McGowan, "Food, Ritual, and Power," in Late Ancient Christianity, ed. Virginia Burrus (Minneapolis: Fortress Press, 2005), 155-156, rightly argues that Eucharist and agape were originally different designations of one and the same ritual.

${ }^{5} \mathrm{He}$ had transmitted this view of the Lord's Supper to the Corinthian Christians during his preceding visit to Corinth; 1 Cor. 11:23. 
one bread." $"$ The purpose of the community meal, among other aims, was to realize the communion (fellowship, solidarity and brotherhood) between the members of the congregation; a communion they sorely missed in the harsh, hierarchical class society of the outside world. The Lord's Supper was intended to unite the participants, whether they were "Jews or Greeks, slaves or free." This unity came about through the participants' eating of the bread and drinking from the cup, in other words, through their becoming the body of Christ. ${ }^{8}$

The abuse which Paul wanted to correct among the Corinthians, stemmed from their failure to share their food with each other. Instead of gathering in all of the food before the meal started and then dividing it in equal portions among the participants, each of them ate the portion that he or she had brought with him or her. ${ }^{9}$ The result was that the wealthier members ate larger and better portions than the poorer members. This accentuated the social differences between the members of the community rather than diminishing and abolishing them. The individualistic and selfish behaviour of the participants had a devastating effect on the unity and coherence of the community and, as a result, the community fell into sharply divided groups. ${ }^{10}$ Thus Paul could say: "When you come together it is not for the better but for the worse."11

It was not only the unity of the community which suffered by the misbehaviour of some participants but individual members of the community were harmed by it as well. The harm done to the community manifested itself, according to Paul, in illness and deaths in the Corinthian church. ${ }^{12}$

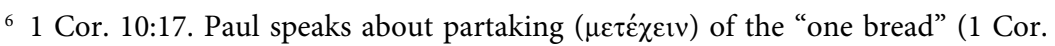
10:17) and of the "table of the Lord" (1 Cor. 10:21) in the sense of "sharing."

71 Cor. 12:13.

81 Cor. 10:17; 11:29; 12:12, 27; Rom. 12:5.

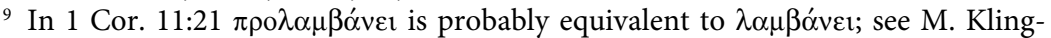
hardt, Gemeinschaftsmahl und Mahlgemeinschaft, 288-289.

101 Cor. 11:18. These groups were neither the parties mentioned in 1 Cor. 1:10-12, nor the ethnic and social groups mentioned in 1 Cor. 12:13 (Jews, gentiles, slaves, and free men), but groups belonging to different households or families. People of one household refused to share the food they had brought with them with people of other households.

111 Cor. 11:17.

121 Cor. 11:30. 
To put an end to the abuses in Corinth, Paul adduces the Last Supper tradition that speaks about the institution of the Lord's Supper by Jesus. ${ }^{13}$ With the help of this tradition Paul tries to argue that a Christian congregation forms a unity and, as a consequence, has to behave accordingly. The unity has been brought about by Jesus' death "for" his followers: trusting in the saving effect of Jesus' death, they believe to become one with Christ in his death and resurrection. Their unity is based on Jesus' death "for them." The fact that Paul chose to castigate the Corinthians' misbehavior with the help of the tradition concerning Jesus' institution of the Christian community supper, shows that, in his view, the Corinthians were not, or not always, alive to its theological implications. Neither were they seemingly aware of the consequences it ought to have for the community spirit in the congregation.

Paul quotes the Last Supper tradition with the obvious intention of admonishing the Corinthians, thus urging them to behave in a more socially-minded manner. It is less clear, however, why he tries to attain his end by the express mention of the theme of Jesus' death: "For as often as you eat this bread and drink this cup, you proclaim the Lord's death until he comes." 14

One part of the answer must certainly be that, traditionally, the narrative of the institution of the Lord's Supper already referred to Jesus' death anyhow, a theme to which, according to Paul, the ritual of the Lord's Supper alluded as well. That the narrative of the Last Supper referred to Jesus' death is clear from the rudimentary "surrender formula" in Paul's version of the story in 1 Corinthians 11:24: "This is my body that is for you." ${ }^{15}$ But this is only part of the answer. Another part of the answer must be that Paul was strongly preoccupied with the idea that the Christian community owed its very existence to the participation of the believers in the death and resurrection of Christ. ${ }^{16}$

\footnotetext{
131 Cor. 11:23-25.

141 Cor. 11:26.

${ }^{15}$ An element of this formula, in German Dahingabeformel, is also transmitted in Mark's version of the Last Supper: "This is my blood..., poured out for many" (Mk. $14: 24)$.

${ }^{16}$ It is true that when Paul interprets the eating of the bread and the drinking of the cup as a proclamation of the death of the Lord (1 Cor. 11:26), he does not add "and of his resurrection." Yet this is what he had in mind, for the fact that he adds "until he comes" (1 Cor. 11:26) shows that in his view the one whose death is proclaimed is the Lord who is now living with God in heaven, from where he will come again. This understanding of the Lord's Supper is made explicit in the eucharistic prayer in Trad.
} 
In agreement with earlier Christian tradition, Paul considered Jesus' death an event which had provoked God's grace, not only towards Jesus (whom God had vindicated by raising him from the dead), but also towards Jesus' followers, whom God released from their sins, restored in his favour, and with whom God entered into a new covenant (all this is what Paul also calls justification and reconciliation). In his reaction to Jesus' death, God treated Jesus and his followers as members of one corporate entity: on the one hand, he vindicated Jesus, and on the other hand, he justified those who remained faithful to Jesus after his death. ${ }^{17}$ Thus, in responding to Jesus' death, God confirmed the corporate unity of Jesus and his followers. Therefore, Paul can take the death of Jesus as an event of fundamental significance with regard to the unity of Christ and his followers. Consequently, when Paul wanted to urge the Corinthian Christians to adopt a more socially-minded behaviour, it was quite natural for him to use the theme of Jesus' death as a reference point: this death was the fundament of the post-Easter Church; that is, of the unity of Christ and his Church.

After quoting the Last Supper tradition, Paul gives several practical suggestions on how to adjust the problem of disorder at the Lord's Supper in Corinth. He begins by warning those who eat the bread or drink the cup of the Lord in an unworthy manner. This unworthiness consists in their failing to discern the body; ${ }^{18}$ these members of the community will be answerable for their actions and be severely judged. ${ }^{19}$ Therefore, Christians have to examine themselves before participating in the Lord's Supper and take care of each other's needs instead of eating one's own food. ${ }^{20}$ Paul goes on to warn those who cannot content themselves with the equally divided portions assigned

ap. 4: "Memores igitur mortis et resurrectionis eius, offerimus tibi panem et calicem, gratias tibi agents...." Cf. Cypr., Ep. 63.16.2: "Nos autem resurrectionem Domini mane celebramus," where the celebration of the "resurrectio Domini" stands for the celebration of the Eucharist.

${ }^{17}$ See H.J. de Jonge, "De plaats van de verzoening in de vroegchristelijke theologie," in Verzoening of koninkrijk: Over de prioriteit in de verkondiging, eds. A.A. van Houwelingen et al. (Baarn: Callenbach, 1998), 63-88.

181 Cor. 11:29. Some manuscripts read "the body of the Lord," christologically. However, the "body" here has probably to be taken ecclesiologically, as standing for the congregation. When believers neither discern nor are concerned about each other's needs, the body (of the congregation) is disregarded and neglected.

191 Cor. 11:27, 29, 31, 32.

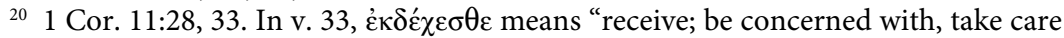
of, meet with a warm welcome." 
to them: "If you are hungry, eat at home, so that when you come together, it will not be for your condemnation." ${ }^{21}$ Paul's repeated warnings and admonitions have only one purpose: to stop the misuse of the Lord's Supper in Corinth.

Summarizing this section, it can be stated that the Lord's Supper in Corinth was both a real and a sacramental meal. Its function was to feed the participants and bring about their unity with the risen Lord, as well as the community among themselves. The participants in the Lord's Supper were supposed to share food with each other, realizing that they partook of the Lord's table and that the food represented Christ in his death and resurrection. In partaking of the Lord's Supper the participants re-enacted in a way and experienced their salvation through Jesus' death and resurrection.

\section{b. The Lord's Supper and the Eucharist in Paul and the Didache}

Another early account of the weekly communal supper of early Christian congregations, now designated as the Eucharist, is found in the Didache (ca. $120 \mathrm{CE}$ ). The liturgical sections of the Didache, especially chapters 9 and 10, provide models of prayers that had to be said before and after the meal, as well as comments concerning the way the eucharistic meal had to be celebrated. Those who have not been baptized are definitely forbidden to participate in the eucharistic meal. ${ }^{22}$ Didache 14 mentions the same meal as chapters 9-10, namely the weekly community supper on Sunday evening. It just adds the requirement that before celebrating the Lord's Supper the participants should confess their faults in order to avoid any profanation of the sacrament. ${ }^{23}$ From the prayers and liturgical directions one can form an image of how the community the author had in mind celebrated the Eucharist.

The supper pictured by the Didache was both a real and a sacramental meal. On the one hand, the participants are expected to eat their fill. ${ }^{24}$ On the other hand, this meal allows the members of the community to participate proleptically in the ideal reality of the eschatological future, the coming kingdom of Jesus, the renewed kingdom

\footnotetext{
211 Cor. 11:34.

22 Did. 9.5 .

${ }^{23}$ H.J. de Jonge, “The Early History of the Lord's Supper," in Religious Identity and the Invention of Tradition. Studies in Theology and Religion, eds. J.W. van Henten and A. Houtepen (Assen: Van Gorcum, 2001), 222.

${ }^{24}$ Did. $10.1 ; 14.1$.
} 
of David. ${ }^{25}$ The function of the meal is also to bring about the unity of the congregation. In the case of the Didache, however, this unity is not founded in the participants' uniting with the dying and resurrecting Jesus (as in Paul), but in the fact that the bread that is broken at the beginning of the meal, "once dispersed over the hills, was brought together and became one loaf." ${ }^{26}$ In eating from this loaf, the congregation becomes one. Thus, the celebration of this supper is supposed to reflect in more than one way the participants' eschatological salvation; it can be regarded, therefore, as sacramental.

On the face of it the Eucharist described in the Didache seems to differ remarkably from the Lord's Supper in Corinth. The communal meal in the Didache begins with prayers over the wine and then over the bread. Another prayer is said after the meal. In the prayers it is not said that bread and wine represent Jesus' body and blood. The Didache does not know the interpretation of bread and wine as standing for Christ's body and blood. Thus, for the author of the Didache the meaning of the community's meal is not found in the participants' communion with Christ.

Differences between the accounts of the eucharistic celebration in Paul and the Didache have led many scholars to the assumption that the meal described in the Didache is either a Eucharist of a type different from that of the Eucharist more commonly practised in the early Church, or a charity meal, designated elsewhere as agape. ${ }^{27}$ Still another interpretation suggests that the Didache reflects an early form of the Eucharist in which references to Jesus' death or the Last Supper were still lacking. ${ }^{28}$ According to a recent interpretation, the meal in the Didache simply reflects one of a number of different types of meals

25 Did. 9.2.

${ }^{26}$ Did. 9.4. The idea is traditional, for it also occurs in Paul; see 1 Cor. 10:17.

${ }_{27}$ See, e.g., R. Knopf, Lehre der zwölf Apostel (Tübingen: Mohr, 1920), "agape." According to H. Lietzmann, Messe und Herrenmahl (Bonn: Marcus \& Weber, 1926), chapter 9 contains eucharistic prayers, whereas chapter 10 speaks about an agape meal. W. Rordorf \& A. Tuilier, Doctrine des douze apôtres (SC 248; Paris: Cerf, 1978), "agape;" K. Wengst, Didache (Darmstadt: WBG, 1984), 43-57: "non-sacramental communal meal;" Conzelmann-Lindemann, Arbeitsbuch zum Neuen Testament, 14th ed. (Tübingen: UTB, 2004), 432: “ob das Abendmahl gemeint ist, ist unklar,..." M. Klinghardt, Gemeinschaftsmahl und Mahlgemeinschaft, sees in 1 Cor. 10-14 and Did. 9-10; 14 exactly the same meal.

28 Adolf von Harnack, Die Lehre der zwölf Apostel nebst Untersuchungen zur ältesten Geschichte der Kirchenverfassung und des Kirchenrechts (Leipzig: Hinrich, 1884, repr. 1893), 28-36; Arthur Vööbus, Liturgical Traditions in the Didache (Stockholm: ETSE, 1968), 63-74. 
that existed side-by-side in early Christianity, each representing the local practice of a particular community or group of communities. ${ }^{29}$

However, the Didache basically describes the same ritual as the one that took place in Corinth. This is probable for several reasons. In both cases, the meal was a community supper that took place on Sunday evening where the participants could eat their fill, rather than purely a symbolic ritual. ${ }^{30}$ Also in both cases the meal began with separate benedictions over the cup of wine and over the bread; special meaning was given to the fact that at the beginning of the meal one loaf of bread was broken and subsequently the participants took and ate the pieces: in both cases the original unity of the bread symbolized the unity of the participants that came about through the communal eating of the bread. In this interpretation of the bread, which stood for the unity of the congregation, Paul and the Didache undeniably follow one common tradition.

In its form and function the supper described in the Didache is related to that found in 1 Corinthians, but the interpretation of the meal is different in so far as the Didache does not connect the sacramental significance of the meal with the death of Jesus. However, Didache 9-10 is far from being the only instance of an early Christian Eucharist in which references to Jesus' death, his body and blood, and his institution of the rite are lacking. ${ }^{31}$ The fact that the eucharistic prayers in Paul may have differed from those in the Didache does not rule out the tradition-historical relationship and affinity between the community meal in Corinth and that in the Didache. Indeed, Paul provides no information about the form and the content of the eucharistic prayer in Corinth except that it included a reference to the unity of the bread representing the unity of the community, an element that also occurs in the eucharistic prayer of the Didache. The possibility cannot be ruled out that the prayers in Corinth were more or less the same as those in the Didache, and that those given in the Didache are an expansion of those mentioned by Paul. It should also be noted that the eucharistic prayers in the Didache were not meant as fixed

29 Paul Bradshaw, Eucharistic Origins, 32.

${ }^{30}$ Did. 14:1. The Lord's Supper in Corinth probably took place on Sunday, just like the Eucharist in the Didache. Otherwise it is difficult to explain why in 1 Cor. 16:2 the Sunday is already a special day for Christians.

31 Other instances are the earliest traceable form of the Anaphora of Serapion, Acta Ioannis 109-110, the East-Syrian Anaphora of Addai and Mari, and the Egyptian Anaphora of Mark in the early recension of Papyrus Strasbourg gr. 254. 
prayer formulas. They were meant as examples which the leaders of the meal could vary freely, as is clear from the author's remark that prophets should be allowed to make the eucharistic prayers as long or as short as they wished. ${ }^{32}$ This indicates that the prayer texts in Didache 9-10 are no unchangeable ritual texts, but rather models that suggest which themes and motifs could be used by those who had to say the prayers.

It is highly probable, therefore, that the Lord's Supper in Corinth and the Eucharist of the Didache resembled each other in form much more than is generally supposed. However, it is clear that Paul's interpretation of the meal differs from that given in the Didache. According to Paul, the bread and the wine stand for Jesus' body and blood; this interpretation would derive from Jesus himself; Jesus would also have instituted the celebration of the supper. All this is lacking in the Didache, although it is undeniably a very old tradition and one which Paul adopts and recognizes. The existence of this tradition is confirmed by Mark who, independently from Paul, shares his interpretation of the supper. ${ }^{33}$

However, although Paul's and Mark's interpretation of the community meal is very old, it is likely to be secondary compared to the Didache's view of the meal. As argued above, the meal mentioned in 1 Corinthians and that described in the Didache must have a common root in the earliest Christian tradition. The question then is whether the Pauline and Markan concept of the meal (including the interpretation of the elements as Jesus' body and blood; the attribution of this interpretation to Jesus; and the attribution of the institution of the meal to Jesus) is a later development of the simpler concept of the meal in the Didache, or the Didache type of meal a simplification of the Pauline type of meal. In the latter case, the concept given in the Didache would be due to reduction of Paul's concept of the meal. However, the former option seems to be more probable. There is no convincing reason why, if Paul's interpretation of the meal is "original," it would have given way to the Eucharist of the type described in the Didache: it was theologically perfectly acceptable and too attractive to be forfeited.

32 Did. 10.7.

${ }^{33}$ Mk. 14:22-25. Mark does not have the institution words but does imply that during the Last Supper Jesus instituted the celebration of the Lord's Supper. 
Interestingly, the book of Acts repeatedly mentions the celebration of the Lord's Supper (the breaking of the bread in Acts 2:42, $46 ; 20: 7,11)$ without ever alluding to the interpretation of the elements as Christ's body and blood or to the institution of the meal by Jesus, although Luke does give these interpretations in his Gospel. It is

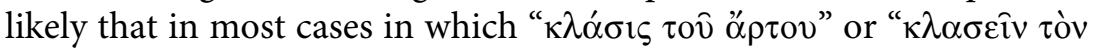

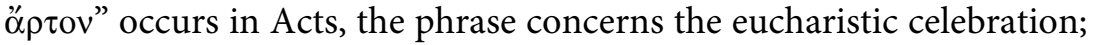
the exception is Acts 27:35-36, where it rather concerns an ordinary meal. $^{34}$

It is true that several twentieth-century exegetes have interpreted the breaking of bread in Acts 2:42-46 as referring, not to the Eucharist or Lord's Supper, but to celebrations of other joyful meals or agapae. $^{35}$ In their view, it is improbable that the common meal of the first Christians mentioned by the author of Acts was identical with the Lord's Supper precisely because the text does not say that this meal was connected with Jesus' death. ${ }^{36}$ However, this view is based on three unwarranted presuppositions. First, it is assumed that originally there existed two different types of Christian meals, the Lord's Supper or Eucharist and another common meal often designated as agape. But in 1 Corinthians 10:16, Didache 14.1 and Ignatius, Ephesians 20.4, the "breaking of bread" is clearly the same rite as the Lord's Supper or the Eucharist. Second, the assumption is that each and every celebration of the Lord's Supper or Eucharist implied that the elements were interpreted as Jesus' body and blood and their consumption as representing Jesus' death. But the Didache and, as we shall see, many early eucharistic traditions show that this is not the case. Third, it is supposed that Luke in narrating Acts 2:42 and 46 used early tradition and had reliable knowledge of what happened in the earliest Christian community in Jerusalem during the weeks after Jesus' death. But Acts 2:41-47 is a typically redactional "summary." Such summaries are

${ }^{34}$ See F.F. Bruce, The Book of the Acts (Grand Rapids: Eerdmans, 1988), 73; C.K. Barrett, The Acts of the Apostles, vol. 1 (London and New York: T\&T Clark, 1998), 164-165; Joseph A. Fitzmyer, The Acts of the Apostles (New York: Doubleday, 1998), $269-271$.

${ }^{35}$ For a detailed presentation of various views see, e.g., Reta Finger, Of Widows and Meals. Communal Meals in the Book of Acts (Grand Rapids: Eerdmans, 2007), $55-79$. 155.

${ }^{36}$ Jacob Jervell, Die Apostelgeschichte (Göttingen: Vandenhoeck \& Ruprecht, 1998), 
now generally regarded as not based on tradition; they are due to the redactional activity of the author and reflect his historical imagination. They help him to sketch a general historical development at points where he had no knowledge deriving from tradition. It is much safer, therefore, to assume that Luke, in his idealizing image of the earliest Christian community in Jerusalem, wanted to include, inter alia, the celebration of the sacramental meal of the Church, the Eucharist, as he knew it in his own days. He used language that was not unknown in the early second century to describe it: "breaking the bread." ${ }^{37}$ The fact that Acts and the Didache agree in not connecting the Eucharist with Jesus' death, indicates that they follow a common early tradition. Why Luke chooses to use this tradition, in contravention to what he does in his Gospel (22:17-20), remains a matter of speculation: possibly because in his later work he conformed to the interpretation of the Eucharist current in the church(es) to which he belonged.

The conclusion remains inescapable, however, that a form and concept of the supper as described in the Didache underlies the form and concept of the Lord's Supper of Paul. In essence, although not in all details, the Eucharist of the Didache is older than the Lord's Supper known to Paul. The features of the meal as mentioned by Paul (the interpretation of the elements as Jesus' body and blood; the attribution of this interpretation to Jesus; and the attribution of the institution of the meal to Jesus) represent a secondary development in the interpretation of the meal. On the other hand, the extensive prayers accompanying the meal according to the Didache (over wine and bread before the meal and over both after the meal) may reflect a later development of the prayers mentioned by Paul.

It must be concluded that the origins of the Lord's Supper celebrated in Corinth and those of the Eucharist mentioned in the Didache can be traced back to an earlier form of community supper, celebrated as early as the thirties of the first century, which must have clearly resembled that of the Didache. The prayers may have differed, but bread and wine were not yet interpreted as Jesus' body and blood; the meal was not yet regarded as instituted by Jesus; and although the meal was seen

${ }^{37}$ Ign., Eph. 20.2; Did. 14.1; see also Acta Pauli (Papyrus Hamburg, 4, line 4; Elliott, p. 378; Hennecke-Schneemelcher, vol. 2 (1989), p. 229). 
as a representation of the participants' salvation, this salvation was not yet seen as brought about by Jesus' death and resurrection.

\section{The Last Supper of Jesus and the Lord's Supper}

\section{a. The origin and function of the Last Supper tradition}

During the twentieth century and the beginning of the present century, there has been an ongoing scholarly interest in the tradition concerning the Last Supper of Jesus, especially in the institution narrative and the interpretation words. A plethora of studies has dealt with various aspects of the Last Supper tradition. In this section the discussion will be limited to only two questions: How did the narrative about the Last Supper originate and how did Christian authors and participants in the Christian gathering use the Last Supper tradition during the first three centuries?

The earliest account of Jesus' Last Supper is found in Paul's first epistle to the Corinthian church:

For I received from the Lord what I also handed on to you, that the Lord Jesus on the night when he was betrayed took a loaf of bread, and when he had given thanks, he broke it and said, "This is my body that is for you. Do this in remembrance of me." In the same way he took the cup also, after supper, saying, "This cup is the new covenant in my blood. Do this, as often as you drink it, in remembrance of me." ${ }^{38}$

Paul quotes this tradition in order to point out the unacceptable behaviour of the Corinthian Christians during their celebration of the Lord's Supper. He claims that he had already used the same tradition in order to explain the meaning of the Lord's Supper to them during his first stay in Corinth. ${ }^{39}$ This may be correct, but there is no reason to assume that the tradition concerning Jesus' institution of the Lord's Supper formed a fixed part of the words that were spoken during the celebration of the Eucharist in Corinth. True, the blessings with which the Lord's Supper in Corinth started may have expressed now and then the idea that the eating of the bread and the drinking of the cup

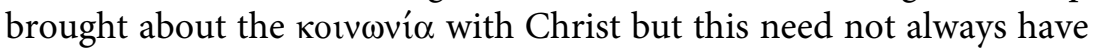
been the case. Even if it happened, this does not imply that the story of the Last Supper, including the institution words ("Keep doing this....")

\footnotetext{
${ }^{38} 1$ Cor. 11:23-25.

39 1 Cor. 11:23.
} 
and the interpretation words ("This is..., this is...."), was narrated. Some authors have already supposed that the institution narrative was not related during the type of Eucharist reflected in 1 Corinthians 10:16-17, Luke 22:15-19a (Western text), and Didache 9-10. ${ }^{40}$ However, it was probably not even related during the Eucharist referred to by Paul in 1 Corinthians 11 . Nor need one assume that 1 Corinthians 10:16-17, Luke 22:15-19a (Western text), and Didache 9-10 reflect a common tradition of the celebration of the Eucharist which differed from that in 1 Corinthians $11,{ }^{41}$ for Paul does not say at all that the institution narrative was used at the meals in the Corinthian church. If the Last Supper story was not related during the eucharistic meals of the first generation of Christians, the question arises when and how it was at all.

Before trying to deal with this question it is necessary to investigate how the Last Supper tradition originated. This tradition is about Jesus having his last supper with his disciples, interpreting the elements of the bread and wine as his body and blood and commissioning the disciples to regularly repeat the meal in his remembrance. The core question is how the idea occurred to the followers of Christ that the bread and the wine stood for Jesus and that they united with him through eating the bread and drinking the wine.

In order to explain how the Eucharist became a commemoration of Jesus's death, resulting in the identification of the eucharistic elements with the body and blood of Jesus, G. Rouwhorst has suggested several times that this may be due to the influence of the Eucharist celebrated at the yearly Christian Quartodeciman Passover. ${ }^{42}$ According to Rouwhorst's hypothesis, the meals which the earliest Christians held during the annual Passover vigil must have had the character of a commemoration of Jesus' passion and death. This character of commemoration may have provoked the recitation of the institution

\footnotetext{
${ }^{40}$ See, e.g., Gerard Rouwhorst, De viering van de eucharistie in de vroege kerk (Utrecht: Katholieke Theologische Universiteit, 1992), 8-18.

${ }^{41}$ H.J. de Jonge, "The Early History of the Lord's Supper," 211.

${ }^{42}$ Gerard Rouwhorst, "La célébration de l'eucharistie dans l'église primitive" $Q L$ 74 (1993), 89-111, esp. 109-111; id., "Didache 9-10: A Litmus Test for the Research on Early Christian Liturgy Eucharist," in Matthew and Didache. Two Documents from the Same Jewish Christian Milieu?, ed. Huub van de Sandt (Minneapolis and Assen: Fortress and Van Gorcum, 2005), 155; id., "Christlicher Gottesdienst und der Gottesdienst Israels. Forschungsgeschichte, historische Interaktionen, Theologie," in Gottesdienst der Kirche. Handbuch der Liturgiewissenschaft, Part 2, vol. 2, Gottesdienst im Leben der Christen. Christliche und jüdische Liturgie, eds. M. Klöckener, A.A. Häußling, R. Messner (Regensburg: Pustet, 2008), 556.
} 
narrative and, subsequently, the interpretation of bread and wine as Jesus' body and blood during the weekly meal. However, it is not easy to believe that the interpretation of a feast celebrated only once a year on 14 Nisan and, consequently, on different days of the week, could influence the interpretation of the Lord's Supper which, from very early times, was a weekly event on a fixed day, the Sunday. The rise of the view that bread and wine stand for Jesus' body and blood seems to ask for another explanation.

The idea that Christians united with their Lord not only played a part during their communal meals; many Christians also believed they lived united with Christ also outside the context of the meal. This is the presupposition of the very early Christian expressions "Christ died for us" 43 and Christ "gave himself up for us." ${ }^{44}$ By these phrases they meant that Jesus had been killed by his earthly opponents but had been vindicated by God who had raised him to a new life. Jesus' followers believed that they shared in his vindication and resurrection life, so that they could say that Jesus had died for them, that is, for their salvation. They regarded Jesus Christ as being one of them, so much so that his death was in a certain sense their death and his glorification their glorification. ${ }^{45}$ The death of Jesus was believed to entail the vindication, justification and salvation of his followers because by putting all their trust in Jesus Christ they united with him and participated not only in his suffering and death but also in his glorification and renewed life. The Christians' belief in their being saved by Christ had as its supposition that they were one with him. ${ }^{46}$

For the first generation of Christians, their unity with Christ was not a metaphor but an ontological reality, designated as "body": Christians regarded themselves as members of the body of Christ. This body was not perceived in a metaphorical sense but as a concrete reality. This becomes clear from the fact that Paul could say that since Chris-

${ }^{43}$ E.g., 1 Thess. 5:10; 1 Cor. 15:3; 2 Cor. 5:14, 15 bis; Rom. 5:6, 8; 14:15.

${ }^{44}$ E.g., Gal. 1:4; 2:20; Rom. 4:25; 8:32; Eph. 5:2, 25; Mk. 10:45/Mt. 20:28; 1 Tim. 2:6; Tit. 2:14; Mk. 16:8 Freer Logion: “...I was delivered unto death that they may return unto the truth."

${ }^{45}$ See 1 Cor. 12:26: "If one member suffers, all suffer together with it; if one member is honoured, all rejoice together with it."

${ }^{46}$ Daniel Powers, Salvation through Participation: An Examination of the Believers' Corporate Unity with Christ in Early Christian Soteriology (Leuven: Peeters, 2001); M. Ploeger, "Life-Death-Resurrection-Church. On the Coherence of Some Central Christian Notions," Internationale Kirchliche Zeitschrift 96 (2006), 45-50. 
tians were members of Christ, they were not allowed to unite with the body of a prostitute. ${ }^{47} \mathrm{He}$ also states that some members of the Christian community fell ill and died because they misbehaved and, as a result, ceased to function as members of the body of Christ. ${ }^{48}$ The possibility of the Christians' salvation depends upon the reality of the corporal unity between Christ and his followers. This corporal unity made it possible for the grace God bestowed on Jesus at his glorification and exaltation to overflow to Jesus' followers. ${ }^{49}$ Since the soteriological expressions "Christ died for us" resp. "gave himself up for us" belong to the earliest convictions Christians ever held, ${ }^{50}$ the idea of the corporate unity of Jesus and his followers must also have existed from very early on.

Thus, it may be clear that Christians regarded themselves as corporally united with Jesus also outside the context of their communal gatherings. It was then only a small step to see this unity reflected and actualized in their consuming the bread and wine of their communal supper. It was still one further small step to take the bread and the wine as representing Jesus' body and blood.

This new interpretation of bread and wine as Jesus' body and blood becomes apparent in the narratives of the Last Supper in Paul and Mark, the two earliest, mutually independent witnesses of this tradition. Both witnesses interpret the bread and the wine of the Last Supper-and thus, indirectly, the bread and the wine of the Lord's Supper of the Church-as the body and blood of Jesus. However, they do not interpret them as Jesus' person in general, but rather as the dying and risen Jesus. This is clear from the words through which Paul and Mark effectuate the interpretation of the elements. Paul states that the bread is the body of Jesus "for you" ( $\dot{v} \pi \dot{\varepsilon} \rho \dot{v} \mu \hat{\omega} v$ ). Mark states that the wine is Jesus' blood which is poured out "for many" ( $(\pi \bar{\varepsilon} \rho \pi \mathrm{o} \lambda \lambda \hat{\omega} v) .{ }^{51}$ The phrases "for you" and "for many" are traces of the traditional, very old "surrender formula" which declares that Christ "gave himself for us." ${ }^{52}$ Obviously, the interpretation of bread and wine as standing for

471 Cor. 6:14-15.

481 Cor. 11:30.

49 Rom. 5:15.

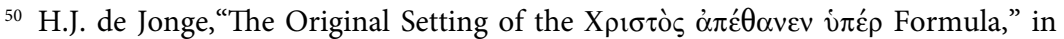
The Thessalonian Correspondence, ed. Raymond F. Collins (Leuven: Peeters, Leuven University Press, 1990), 229-235, esp. 235.

51 1 Cor. 11:24; Mk. 14:24.

${ }^{52}$ See note 44 above. 
Jesus' body and blood is closely linked to the idea that Jesus died for others as well as to the notion of the corporate unity of Jesus and his followers, through which the latter could share in Jesus' resurrection

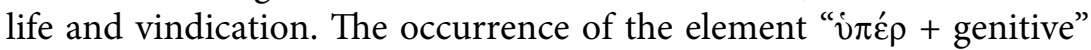
in the interpretation words in Paul and Mark shows that the bread and wine stand for Jesus in his death and resurrection and that, in Paul's and Mark's view, in celebrating the Lord's Supper, one participates in his death and resurrection.

Subsequently, this interpretation was ascribed to Jesus himself. ${ }^{53}$ Out of respect for Jesus Christians traced their communal meal back to a commission of Jesus himself. Christians now presented the Lord's Supper as deriving from Jesus' commandment by having him say the words "do this...," which, noting the present tense of the imperative, can be translated better as "keep doing this" ( These words make Jesus the founder of the Church's Lord's Supper. The interpretation of the bread and wine used at the Lord's Supper as Jesus' body and blood and the institution words that make Jesus the founder of the celebration of the Lord's Supper were incorporated in a story about the last evening of Jesus' life and the last meal he held with his disciples. This story, enriched with the new elements mentioned just now, was transmitted by Paul and, independently from him, by Mark. This Last Supper tradition is very old but nevertheless secondary. There is an almost general agreement among scholars about the origin of this tradition: it arose in explanation of the existence and meaning of the ecclesiastical group meal called by Paul the Lord's Supper. ${ }^{54}$ The tradition took shape within the Christian community and in the context of the celebration of the weekly meal for the purpose of explaining the existing meal practice. The tradition is thus considered

${ }^{53}$ In the Hellenistic world many of those who adhered to a certain religious institution or cult liked to trace the origin of this institution or cult to an illustrious founder, preferably a god or a hero. For two examples of this tendency, see H.J. de Jonge, "The Early History of the Lord's Supper," 219.

${ }_{54}$ R. Bultmann, Geschichte der synoptischen Tradition, 4th ed. (Göttingen: Vandenhoeck \& Ruprecht, 1958), 285: "eine Kultuslegende;" 286: "Kultlegende aus hellenistischen Kreisen." M. Dibelius, Die Formgeschichte des Evangeliums, 3rd ed. (Tübingen: Mohr (Siebeck), 1959), 210: "wir müssen damit rechnen, dass die Traditionsbildung von Anfang an unter eigentlich kultischem Interesse gestanden hat." A. Lindemann, Der erste Korintherbrief (Tübingen: Mohr (Siebeck), 2000), 258: "Vieles spricht für die Vermutung, dass der Wortlaut der Mahlüberlieferung seinen Ursprung in der griechischsprechenden Gemeinde (Jerusalems?) gehabt hat." 
an aetiology of the ecclesiastical Lord's Supper; it must have originated very early, probably as early as the thirties of the first century, and possibly in Jerusalem.

The alternative view, according to which the institution narrative reflects an historical episode that took place on the last evening of Jesus' life, is indeed much less plausible. It is very difficult to assume that the common tradition underlying the Last Supper story in Mark 14:22-26a and 1 Corinthians 11:23-25 goes back to a historical institution of the Eucharist by Jesus himself. First, if Jesus instituted the Eucharist, how can one explain that Didache 9-10, in contrast to 1 Corinthians 11:20-26, preserves no reference whatsoever either to the institution by Jesus, or to his interpretation of the bread and wine as his body and blood? Second, already Jesus' word "Do this, as often as you drink it, in remembrance of me" in 1 Corinthians 11:25 logically presupposes the custom of drinking the cup. The word only intends to influence an existing custom by adding the instruction to drink the wine in remembrance of Jesus. There can be little doubt that the word "Do this in remembrance of me" in 11:24, pronounced over the bread, also means: "Do this, as often as you eat it, in remembrance of me." This is at least how Paul understands it in 11:26: "For as often as you eat this bread and drink the cup,...." Third, the soteriological interpretation of Jesus' death reflected in the use of such phrases as "for you" (1 Cor. 11:24) and "for many" (Mk. 14:24), probably indicates that, when the interpretation words were composed, Jesus' death was already something of the past. In other words: the interpretation words concerned are of post-Easter origin. Fourth, in the institution narrative, the breaking of the bread and the consumption of both the bread and the wine refer to Jesus' death. Moreover, Jesus' words “Truly I tell you, I will never again drink of the fruit of the vine until that day when I drink it new in the kingdom of God" (Mk. 14:25) and "Do this in remembrance of me" (1 Cor. 11:25) depict a Jesus who knows for sure that his death is impending and that he will die very soon. But how could he be so certain that his death was at hand? These words, especially those in Mark 14:25, could hardly be formulated without the risk of being falsified by the facts until after Jesus' death and resurrection. In all likelihood the story about the institution of the Lord's Supper is not based on tradition reaching back to the last evening of Jesus' earthly ministry. The origin of this story has to be accounted for in another way. The most likely possibility is that the story originated 
as an attempt to trace back the origin of the Lord's Supper to Jesus, that is, as an aetiology.

This aetiology should not be understood as an attempt at deceit. The Christians in whose circle this view of the weekly meal's origin was formed, experienced the world as a meaningful whole in which God, Jesus Christ and his death and resurrection were decisive points of reference. In this symbolic universe Jesus had brought about the believers' salvation through his death and resurrection. The community meal was in fact the representation of this symbolic universe on a small, compact scale. The meal allowed the participants to experience their salvation through Jesus' death and resurrection. If this salvation was due to Jesus' acceptance of his death and his vindication, it was only a small and logical step for his followers to make him also the founder of the meal that mirrored the way in which he had saved them. They did so in a creative manner, namely by narrating that Jesus had commissioned his disciples to regularly repeat his last supper with them. Thus, they traced the existing rite of the weekly meal back to a commission given by Jesus. It was an attempt, no doubt in good faith, to underscore the soteriological import of the community meal and to do justice to Jesus' crucial role in the soteriology involved. This attempt was to be successful. References to the story of the Last Supper, including Jesus' institution and interpretation words, appear with increasing frequency in the writings of Christians from the beginning of the second century onwards. ${ }^{55}$ Finally, in the third and fourth centuries, the Last Supper tradition was incorporated in the texts of prayers said during the celebration of the Eucharist. ${ }^{56}$

The origins of the tradition concerning the Last Supper and how it is used by Paul have now been discussed. An examination will now follow as to how it was used by subsequent generations of Christians before the institution narrative and interpretation words were included in the eucharistic prayers. Recently it has been suggested that originally the institution narrative was neither a liturgical text to be recited at the celebration of the Lord's Supper, nor a liturgical instruction to regulate that rite. Rather, it was a piece of catechetical instruction, which probably developed over time and was transmitted during

${ }_{55}$ Just., 1 Apol. 66.2; Dial. 70.4; Iren., Haer. 4.17.5; 5.33.1; Clem. Al., Paed. 2.32.2; Tert., Or. 6; Marc. 4.40.3; Cypr., Ep. 63.9. For a more detailed discussion of the use of the Last Supper tradition by second and third-century authors, see below.

${ }^{56}$ The evolution of the eucharistic prayers is discussed in chapter 6. 
the symposium part of the Christian gathering, in clarification of the origins of the preceding community meal. ${ }^{57}$ This seems to be indeed the most likely context in which the story of the Last Supper came into being and was used, especially since we know from Paul that in

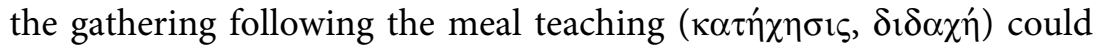
take place ${ }^{58}$ However, the possibility cannot be ruled out that the topic of the meal's origins sometimes arose already during the meal itself outside the prayers.

In the second part of the first century the Last Supper tradition was adopted by the authors of the Synoptic Gospels: they incorporated it as a biographical element in their accounts of Jesus' last days. Mark is the first author, after Paul, known to use this tradition:

While they were eating, he took a loaf of bread, and after blessing it he broke it, gave it to them, and said, "Take, this is my body." Then he took a cup, and after giving thanks he gave it to them, and all of them drank from it. He said to them, "This is my blood of the covenant, which is poured out for many. Truly I tell you, I will never again drink of the fruit of the vine until that day when I drink it new in the Kingdom of God." 59

Mark presents Jesus as taking a loaf of bread, breaking it after a blessing and then interpreting the bread as being his body. Subsequently, Jesus interprets the wine as being his blood of the covenant, that is, as his blood through which a new covenant between God and men is inaugurated. The blessings over the bread and the wine, in this order, are features of the story that Mark and Paul have in common. Another feature Mark and Paul have in common is their use of part of the old "surrender formula," as mentioned earlier. The agreements between Mark's and Paul's account of the Last Supper warrant the conclusion that in this story the two authors are using a common tradition. Their stories have so much in common that one cannot but conclude that both authors use one more or less fixed oral tradition. However, Mark and Paul use this tradition differently. For theological reasons, Mark presents the Last Supper of Jesus as a Passover meal; ${ }^{60}$ there is not

57 Paul Bradshaw, Eucharistic Origins, 14.

581 Cor. $14: 19,26$ and 6.

${ }_{59}$ Mk. 14:22-25.

${ }^{60}$ Mk. 14:12, 14, 16. See G. Rouwhorst, "Christlicher Gottesdienst und der Gottesdienst Israels. Forschungsgeschichte, historische Interaktionen, Theologie," 556: " $\mathrm{Da}$ die Historizität der sogenannten synoptischen Passionschronologie erhebliche 
the slightest hint that it was such a meal in Paul. Further, contrary to Paul, Mark does not give Jesus' institution words, although he certainly supposes the ecclesiastical Supper to have its roots in the Last Supper. Furthermore, Paul places the blessing over the cup after the meal whereas, in Mark's account it is impossible to know whether the drinking of the cup and the blessing over it took place after or during the meal. In addition, the phrase about the covenant in Mark differs slightly from that in Paul's writings. Besides, Mark does not give Jesus' institution command to hold the Supper in his remembrance. Instead, Mark has Jesus say that he will not drink from the fruit of the vine until he drinks it new in the Kingdom of God. Accordingly, Mark intends presenting Jesus here as being aware that the meal in question was to be his last meal in his earthly ministry and thus as predicting his imminent death.

One very striking difference between Mark and Paul is that the latter puts the blessing over the bread at the opening of the meal whereas the evangelist says that it took place in the course of the meal: "while they were eating." This may have to do with two strategies on Mark's side. First, he turns the Last Supper into a Passover meal; this makes it difficult to have Jesus open the meal with a blessing containing the words "This is my body;" second, Mark, more expressly than Paul, uses the Last Supper story with the intention of presenting Jesus as the founder of the Church's community meal. This results in his putting Jesus' words "Take, this is my body" in the middle, rather than at the beginning of the story. From the discrepancies between Paul's and Mark's versions of the Last Supper tradition, it is clear that they used this tradition in different ways, each of them in accordance with his own exhortatory, literary and theological purposes.

Matthew's presentation of the Last Supper ${ }^{61}$ follows that of Mark rather closely but deviates from it in two respects. First of all, Matthew inserts the command "eat" in Jesus' words over the bread, after Mark's use of the word "take." Matthew also changes Mark's indicative "they drank" into the imperative "drink." Thus Matthew stresses that the eating and drinking at the Last Supper and especially that at the Eucharist take place on the instructions of Jesus. Secondly, Mat-

\footnotetext{
Probleme hervorruft,..., liegt die Annahme nahe, daß ihr eine theologische Intention zugrunde liegt."

${ }^{61}$ Mt. 26:26-29.
} 
thew enlarges Jesus' words over the wine, "poured out for many," to include the phrase "for the forgiveness of sins." In this way, Matthew adds a soteriological interpretation of Jesus' death and, indirectly, of the Eucharist.

In his turn, Luke also uses Mark's narrative of Jesus' Last Supper but expands it considerably with elements reminiscent of Paul's version of the story:

When the hour came, he took his place at the table, and the apostles with him. He said to them, "I have eagerly desired to eat this Passover with you before I suffer; for I tell you, I will not eat it until it is fulfilled in the kingdom of God." Then he took a cup, and after giving thanks he said, "Take this and divide it among yourselves; for I tell you that from now on I will not drink of the fruit of the vine until the kingdom of God comes." Then he took a loaf of bread, and when he had given thanks, he broke it and gave it to them, saying, "This is my body, which is given for you. Do this in remembrance of me." And he did the same with the cup after supper, saying, "This cup that is poured out for you is the new covenant in my blood."

This version of the Last Supper story may best be explained as follows. In principle, Luke adopts Mark's pericope 14:22-24, leaving out v. 25, where Jesus predicts his imminent death, and using its material for an introduction to the whole narrative: Luke 22:16, 18. Luke thus commences his version of the story by making the meaning of Mark 14:25 explicit in his opening verse (22:15): the particular part of this meal is that it is the last meal before Jesus' passion, "before my suffering (including Jesus' death)." Furthermore, on two occasions Luke inserts elements from Paul's first letter to the Corinthians 11 or from tradition related to Paul's Last Supper story. First, in his introductory passage, between verses 16 and 18, Luke has Jesus open the meal by taking the cup, saying grace, and presenting it to the disciples. This is the order we know from Didache 9 and possibly 1 Corinthians 10:1617; the opening cup is now prefixed to the order in Mark, so that Luke has Jesus present a cup both before and after the meal. Second, within the material taken over from Mark, that is, in Luke 22:19 (= Mark 14:22), Luke inserts a passage that also occurs in 1 Corinthians 11:24 with only slight variations: "which is given for you; keep doing this in remembrance of me." This insertion, based on traditional material,

${ }^{62}$ Lk. 22:14-20. 
makes it more explicit than Mark does that the Last Supper is the basis of the Eucharist of the Church.

Moreover, Luke postpones the distribution of the second cup (Mark's only cup) until "after the supper" with the same words as

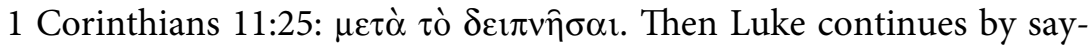
ing with Paul and in deviation from Mark: "... saying 'This cupthis the new covenant in my blood.' " This phrase is a soteriological interpretation of Jesus' death as well as of the Eucharist, but now in the wording of Paul (or his tradition) instead of that of Mark.

One of the results of Luke's redaction of the Last Supper story is that, in contradistinction to Mark's version, it includes the institution word: "Keep doing this" (22:19), which makes the Eucharist an institution of Jesus more clearly than Mark's text does.

Luke's version of the Last Supper narrative shows an interesting textual problem. Part of the manuscript tradition (Codex Bezae, Vetus Syra and part of the Vetus Latina) omits the surrender formula connected with the bread/body in Luke 22:19 as well as the entire verse 20 which contains the mention of a second cup and its interpretation. ${ }^{63}$ The shorter text is likely to be secondary: ${ }^{64}$ it looks like an attempt to bring the number of cups into conformity with the number in Mark, Matthew and Paul. ${ }^{65}$ But Luke may have had a good reason to insert a cup right at the beginning of the Last Supper: he was probably acquainted with the eucharistic practice in which the meal began with a blessing over the cup (Did. 9.1; cf. 1 Cor. 10:16). Luke allowed this practice to influence his narrative of the Last Supper, but saw no reason to drop the cup mentioned by Mark, so that in his narrative a cup is mentioned twice.

In any case it is clear that the authors of the synoptic Gospels, in including and elaborating the story of the Last Supper in their books, made use of an existing tradition and that each of them adapted it to his "biographical," literary, theological and didactic purposes.

${ }^{63}$ For a discussion of this problem, see Paul Bradshaw, Eucharistic Origins, 3-5.

${ }^{64}$ Thus, correctly, G. Rouwhorst, "Bread and Cup in Early Christian Eucharist Celebrations," in Bread from Heaven. Customs and Practices Surrounding Holy Communion. Essays in the History of Liturgy and Culture, eds. Charles Caspers, Gerard Lukken and Gerard Rouwhorst (Kampen: Kok Pharos, 1995), 11-39, esp. 23.

${ }^{65}$ For more considerations in favour of the longer text, see Bruce M. Metzger, $A$ Textual Commentary on the Greek New Testament, 2nd ed. (Stuttgart: United Bible Societies, 1994), 148-150, esp. 148. 
In the second century the institution narrative and interpretation words are mentioned by several Christian authors. The earliest author to use the institution narratives is Justin Martyr. He is also the earliest author in the second century to quote the institution words, although

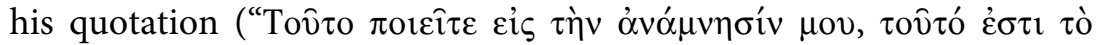
$\sigma \hat{\omega} \mu \alpha$ ' $\mu \mathrm{ov}$ ") does not correspond precisely with the text of any of the canonical Gospels, nor with that of Paul for that matter. ${ }^{66}$ Justin relates the institution narrative in order to explain why the bread and the wine consumed during the Eucharist are interpreted as Jesus' flesh and blood. The reason is that Jesus said so during the Last Supper:

The food which has been made Eucharist through prayer of a word from him ... is both the flesh and blood of that Jesus who was made flesh. The Apostles in the memoirs which are called Gospels, have handed down what Jesus ordered them; that he took bread and, after giving thanks, said: "Do this in memory of me; this is my body." Similarly, he also took the cup, and after giving thanks said: "This is my blood;" and to them only did he give it. ${ }^{67}$

In this context the institution narrative is used as an aetiology of the Eucharist rather than as a biographical episode. Justin clearly regards the institution narrative as a passage occurring in the written Gospels rather than as an oral tradition, whether or not transmitted during the celebration of the Eucharist.

The institution words are also cited twice in Justin's Dialogue with Trypho, chapters 41 and 70, both times in the context of a controversy about the typological meaning of Scripture and with reference to the practice of the celebration of the Eucharist. Both these passages present the same dual structure as the passage in 1 Apologia 66: first a description of the ritual and then an interpretation of the eucharistic elements. ${ }^{68}$

Justin's varied terminology suggests that the relevance of the institution narrative mainly is that it allows him to reflect upon the meaning of the Eucharist, rather than that it is a text to be recited during the

\footnotetext{
${ }^{66}$ See H. Koester, Ancient Christian Gospels (Philadelphia: Trinity Press, 1990), 360-402.

67 Just., 1 Apol. 66.2-3.

${ }^{68}$ Andrew McGowan, "Is There a Liturgical Text in This Gospel?": The Institution Narratives and Their Early Interpretive Communities," JBL 118 (1999), 73-87, esp. 82 .
} 
eucharistic ritual. For Justin and his community, the institution narrative has not so much a liturgical as a catechetical function: it serves to interpret the meal. This follows on from the way he uses the narrative as a backdrop to his admonitions concerning the eucharistic rite. In terms of the apologetic context of the passages in question, he also tries to use the Last Supper narrative to instruct his audience about certain features of the Christian faith and life with the aid of an aetiology rather than in straightforward explanatory language. ${ }^{69}$ It cannot be deduced from Justin's references to the Last Supper stories that the institution narrative or the interpretation words played a role in the eucharistic ritual of his community.

Irenaeus in his Adversus haereses repeatedly refers to the Last Supper story. He uses it, for instance, to support his statement that the Lord gave directions to his disciples to offer to God, in the Eucharist, the first-fruits of his creation. Although Irenaeus has Jesus pronounce the interpretation words and institute the sacrament, he does not have him say that the Eucharist has to be celebrated "in my remembrance":

Jesus took that created thing, bread, and gave thanks, and said, "This is my body." And the cup likewise, which is part of that creation to which we belong, he confessed to be his blood, and taught the new oblation of the new covenant; which the Church receiving from the apostles, offers to God throughout all the world. ${ }^{70}$

Neither does Irenaeus mention the setting in which Jesus spoke the interpretation and institution words. The context in which Irenaeus himself uses this tradition is didactic rather than liturgical.

In another passage Irenaeus quotes part of the Last Supper account as occurring in Matthew 26:27b-29. ${ }^{71}$ In this case, however, he provides additional information about Jesus drinking from the cup after saying grace and before giving the cup to the disciples and pronouncing the interpretation words.

In the third century the Last Supper tradition is used in connection with the Eucharist in the Traditio apostolica. This is the first known instance of the use of the institution narrative as part of the prayer to

\footnotetext{
${ }^{69} \mathrm{Ib} ., 83$.

${ }^{70}$ Iren., Haer. 4.17 .5 (tra. Cleveland Coxe in ANF).

${ }^{71}$ Iren., Haer. 5.33.1.
} 
be recited over the bread and cup of the Eucharist. ${ }^{72}$ In this case, the account of the Last Supper is part of an extensive prayer of thanksgiving, which recounts the saving deeds of Christ. In this context, the actions Jesus accomplished during the Last Supper are emphasized within, but not separated from, the extensive schematic account running from Jesus' incarnation to his redemptive suffering and resurrection. The way the words of institution and interpretation are used in the eucharistic prayer of the Traditio apostolica seems to reflect the transition from their being used in explanation of the meal to their fixation as a liturgical text to be recited as part of the eucharistic prayer. This is the innovation which the use of the Last Supper tradition in the context of the eucharistic celebration underwent during the third century. ${ }^{73}$

In the period prior to the composition of the Gospels, any indication that the interpretation or institution words were part of the prayers accompanying the meal is lacking. They only served to explain and clarify the meaning of the meal (1 Cor. 10:16-22; 11:17-34). It is reasonable to assume, therefore, that originally the institution narratives, however formulaic, were not liturgical prayer texts but interpretative, explanatory texts and aetiologies of a didactic or catechetical nature. Accordingly, the institution narratives can still rightly be regarded as having originated as "cult narratives" or "cult legends." "74

The issue here is whether the institution narratives originated as primarily "historical" reports about the last meal of Jesus and his disciples or as stories that emanated in one way or another from the group meal of the earliest Christians. The last-mentioned alternative, for which the majority of scholars appear to opt currently, occurs in two variants. Some maintain, at least to a certain degree, the historical character of the institution narrative and, in addition, argue that the Christians modeled their periodical group meals on the pattern of the meal described in this narrative. ${ }^{75}$ Others deny or strongly relativize

72 Trad. ap. 4.

${ }^{73}$ For a discussion of the eucharistic prayer in the Apostolic Tradition, see chapter 6 below.

${ }_{74}$ Andrew McGowan, “Is There a Liturgical Text in This Gospel?”, 86. Cf. R. Bultmann, Die Geschichte der synoptischen Tradition, 4th ed. (Göttingen: Vandenhoeck \& Ruprecht, 1958), 285: "Dass Mk. 14,22-25 eine Kultuslegende vorliegt, brauche ich nach Eichhorn und Heitmüller nicht mehr zu beweisen.”

${ }_{75}$ This position is defended in Joachim Jeremias' classical work Die Abendmahlsworte Jesu (Göttingen: Vandenhoeck \& Ruprecht, 1967). 
the historical character of the institution narratives, while at the same time ascribing them a primarily aetiological function. Scholars who hold the latter position argue that the institution narrative came into being to explain the existence and the meaning of the communal meal of the early Christians. ${ }^{76}$ Since the Last Supper tradition plays no role in descriptions of the Eucharist in the Didache, Acts and a wide range of apocryphal Acts and eastern liturgical texts, there is a good case for the latter position.

\section{b. The Lord's Supper in the Gospel tradition}

In this section it will be investigated whether the authors of the Gospels included in the New Testament, apart from knowing and using the tradition about the Last Supper, were also acquainted with the practice of the periodical meal of Christian communities, the Lord's Supper. Insofar as this will prove to be the case it may be worthwhile to examine as well whether their knowledge of the rite influenced their redaction of the Last Supper story.

In all likelihood, Mark was familiar with the rite of the Christian community supper; 10:38 and 14:36 presuppose the existence of the Lord's Supper and point to Mark's acquaintance with it. ${ }^{77}$ In Mark 10:38 Jesus asks: "Are you able to drink the cup that I drink, or be baptized with the baptism I am baptized with?" In this context drinking the cup and being baptized are images for the passion which Jesus is to undergo. But the very selection and combination of the images of "drinking" and "being baptized" indicate that Mark is thinking here of the two constitutive rites of the Church, the Lord's Supper and baptism. In 14:36 Jesus prays: "Remove this cup from me." Many exegetes have explained "this cup" by referring to the Old Testament image of the cup (or scale) of God's wrath. But the idea of God's wrath does not fit in the context of Mark 14:36. It is more probable that the startingpoint of Mark's imagery here is the cup of the Lord's Supper. ${ }^{78}$ In

${ }^{76}$ H.J. de Jonge, "The Early History of the Lord's Supper," 217-220; Avondmaal en symposium. Oorsprong en eerste ontwikkeling van de vroegchristelijke samenkomst (Leiden: Universiteit Leiden, 2007), 8-11.

77 The following discussion of Mark's and John's acquaintance with the rite of the Eucharist owes much to the treatment of this topic in H.J. de Jonge, "The Early History of the Lord's Supper," 217-221.

${ }_{78}$ D. Lührmann, Das Markusevangelium (Tübingen: Mohr (Siebeck), 1987), 244: "Das Bild vom Trinken des Bechers für Jesu Tod weist zurück auf 10:38;" 180, ad 10:38: "Die eigene Taufe erinnert den Tod Jesu ebenso, wie es das Abendmahl tut 
the tradition concerning Jesus' Last Supper (used by Mark in the preceding pericope, 14:22-25) this cup was taken as a symbol of Jesus' death. ${ }^{79}$ Hence, Mark could designate the fate Jesus faced in Gethsemane, that is, his suffering and death, as "this cup." Mark 10:38 and 14:36 can be considered, therefore, as indicative of Mark's familiarity with the Lord's Supper.

Mark's narrative of the Last Supper, including Jesus' words about the bread and the wine, clearly derives from the same tradition as Paul's account of Jesus' Last Supper in 1 Corinthians 11:23-25. This was, as argued above, a tradition that was transmitted in the context of the celebration of the Eucharist. Thus, there are strong indications that Mark was acquainted with the rite of the Lord's Supper or Eucharist.

Mark's story of the Last Supper (Mk. 14:22-26a) of Jesus with his disciples may well reflect the twofold format of the Christian group supper: after supper Jesus and his disciples sang songs or hymns. ${ }^{80}$ Mark does not specify what exactly they sang. Commentators and translators are quick to take this singing to be the singing of "the Passover hymn." ${ }^{11}$ However, Mark does not say that they "sang the hymn" (NRSV), let alone that they sang the Hallel (Ps. 114 or 115-118). Since Mark's story of the last Supper is influenced anyhow by current eucharistic practice, the singing of Mark 14:26 is best taken to correspond to the singing during the after-supper gathering of Christians and thus to the singing after formal suppers in the Hellenistic world in general. ${ }^{82}$

Just like Mark, Luke was familiar with the Eucharist celebrated in a Christian community. This appears from his use of the institution word "Keep doing this..." (22:19) which is an undeniable reference to the practice of the Lord's Supper. It also appears from Luke 24:33-43, where the evangelist brings the disciples together on Sunday evening around a meal. Confirmation that Luke knew the Eucharist can be found in several passages in Acts (e.g., 20:7). As to Luke's version of the Last Supper, his story, differently from Mark, begins with Jesus reclining at the table with the disciples (22:14). Then, after some introductory words (vv. 15-16), Jesus takes a cup and after saying grace he

(vgl. 14:22-25), der "Becher" auf den hier angespielt ist. Taufe und Abendmahlthsind vorausgesetzt."

${ }^{79}$ Mk. 14:24.

${ }^{80}$ Mk. 14:26.

81 The Revised English Bible with the Apocrypha, ed. W.D. McHardy (Oxford and Cambridge: Oxford University Press and Cambridge University Press, 1989).

${ }^{82}$ Cf. 1 Cor. 14:15, 26; on singing at suppers, see chapter 6 below. 
tells the disciples to share it amongst themselves. After that he takes a loaf of bread, says grace, breaks it and gives it to the disciples while pronouncing both the interpretation and the institution words. Luke differs from Mark in that he inserts the cup at the beginning of the meal, before the distribution of the bread, whereas he puts the cup mentioned by Mark at the end of the meal, in accordance with 1 Corinthians 11:25, $\mu \varepsilon \tau \grave{\alpha} \tau$ ò $\delta \varepsilon ı \pi v \hat{\eta} \sigma \alpha$. The order of first the cup and then the bread may have been the sequence Luke knew from practice, now applied by him to Mark's version of the story of the Last Supper.

The author of the fourth Gospel, too, was familiar with the Eucharist. It is true that, although he probably knew, directly or indirectly, one or more of the Synoptic gospels, he did not adopt the Last Supper tradition in his description of Jesus' final meal with his disciples. ${ }^{83}$ Yet, his acquaintance with the practice of the Eucharist is evident from John 6:51c-58. The language of this passage is strongly reminiscent of the terminology used for the Eucharist: bread, flesh, blood, eating and drinking. From the middle of the twentieth century, scholars have explained this language in three different ways.

Bultmann, followed by others, suggested that John 6:51c-58 is a later, redactional development of John's text; in this more recent layer of the text, Jesus is indeed spoken of as the eucharistic bread but not yet in the older text. In the redactional layer of the text, the redactor would have wanted to give his interpretation of the Eucharist. ${ }^{84}$

Other scholars find here a Christological exposition on Jesus as lifegiving bread from heaven. From the perspective of this position, the evangelist uses eucharistic terminology; however, not in order to clarify the Eucharist, but simply to illustrate how, or how intensively, one should believe in Jesus. The message is that one must absorb Jesus in one's faith just as concretely as one consumes the eucharistic elements in participating in the Lord's Supper. ${ }^{85}$

${ }^{83}$ Jn. 13:2-18:1.

${ }^{84}$ R. Bultmann, Das Evangelium des Johannes (Göttingen: Vandenhoeck \& Ruprecht, 1952), 174-177; P.N. Anderson, The Christology of the Fourth Gospel: Its Unity and Disunity in the Light of John 6 (Tübingen: Mohr, 1996-1997), 110-136. Some exegetes in this category admit the possibility that the redactor is the evangelist himself; see, e.g., R. Schnackenburg, Das Johannesevangelium, 4 vols. (Freiburg: Herder, 1967-1984), 2:83-96.

${ }^{85}$ U. Schnelle, Das Evangelium nach Johannes (Leipzig: Evangelische Verlagsanstalt, 2000), 140. 
A third group of exegetes regard this passage only as a continuation and elaboration of the theme of Jesus as the bread from heaven. ${ }^{86}$ Some of them interpret the words "bread," "flesh" and "blood" as used in this passage as Christological and sometimes anti-Docetic references to the person of Jesus, not as terms referring to the elements of the Eucharist. ${ }^{87}$

A middle position between the second and third views mentioned is that of Peder Borgen ${ }^{88}$ who argues that John 6:51-58 draws on eucharistic terminology and ideas. However, the purpose of the passage is not to give doctrinal instruction about the Eucharist, but rather to use the eucharistic ideas to throw light upon the reality of the incarnation. The eating and drinking in the Eucharist mean eating and drinking the Son, not spiritually but concretely as "flesh and blood." The tenor of the passage is Christological and anti-Docetic.

However, the second position mentioned seems to be the most plausible. The agreements between John's language and the eucharistic terminology are too striking to be incidental. The term "flesh" (instead of "body," 6:51-56) occurs in a eucharistic context in Ignatius. ${ }^{89}$ It is hard to assume that a phrase like "I give my flesh for the life of the world"90 has nothing to do with Jesus' death. It is no less hard to believe that phrases like "Those who eat my flesh and drink my blood..."91 and "for my flesh is true food and my blood is true drink" ${ }^{22}$ have nothing to do with the Church's rite of the Lord's Supper. What John 6:51c58 means to say is that one has to appropriate Jesus in one's faith as concretely as one consumes the elements of the Eucharist and, thus, to take the salvific meaning of Jesus' death and resurrection seriously.

This message need not have an anti-gnostic intention. Participation in the Eucharist serves here as an analogy or image of the true way of believing in Christ. Eucharistic language is used here to describe the

\footnotetext{
${ }^{86}$ M. Klinghardt, Gemeinschaftsmahl und Mahlgemeinschaft, 438-440.

87 M.J.J. Menken, “John 6,51c-58: Eucharist or Christology?" Biblica 74 (1993), $1-26$.

${ }^{88}$ Peder Borgen, Bread from Heaven (Leiden: Brill, 1965), esp. 90-92, 185-187.

89 See, e.g., Ign., Phild. 4 (next to "blood") and Smyr. 7:1. Ign., Rom. 7:3 mentions "the flesh $(\sigma \alpha \dot{\rho} \xi)$ of Jesus Christ" and "his blood" as the heavenly food and drink which the martyr hopes to enjoy after his death. But it is unclear whether he hopes (a) to be united with Jesus' person, or (b) to enjoy a heavenly meal. Yet, even in the former case the terminology Ignatius uses here is eucharistic.

${ }^{90}$ Jn. 6:51.

91 Jn. $6: 54,56$.

92 Jn. 6:55.
} 
Johannine concept of faith in Christ. If this interpretation is correct, then John 6:51c-58 does not shed much light on John's view of the Eucharist, but it does show that John knew the Eucharist: he used the tradition which interpreted the bread and the wine of the community's supper as Jesus and the consumption of the elements as a representation of his death, as was the case in the tradition used by Paul, Mark, and Luke, but not by the Didache.

This section may be summarized in two points. First, the story of the Last Supper of Jesus with his disciples is best understood as an aetiology of the Lord's Supper as celebrated by early Christian communities. This story arose and was transmitted in certain Christian communities, either during the symposium part of their gathering or during the supper, to explain the origins and meaning of the communal meal. Not until the third century, was it incorporated in the prayers accompanying the meal. Interpretations of the meal which connect it with the Last Supper are secondary as compared to interpretations of the meal which do not link it with the Last Supper. Secondly, Mark, Luke and John were familiar with the rite of the Lord's Supper or Eucharist. In the case of Mark and Luke, their experience with the rite seems to have influenced their account of the Last Supper.

\section{The Eucharist In The SECOND AND THIRD CENTURIES}

\section{a. The Eucharist in the second century}

Besides the eucharistic passages in the Didache, Christian literature of the second century refers many more times to the celebration of the Eucharist. Unfortunately, only a few writings inform us in detail as to how the eucharistic meal was conducted or how it was understood by the participants. However, there is enough information to suggest that throughout the second century the Eucharist continued to be celebrated as a full meal in the context of the evening gatherings. In the second century, the supper on Sunday evening remained both a sacramental and a real meal. People participated in it "ad capiendum cibum."93

Some early testimonies concerning the Eucharist in the second century occur in the letters of Ignatius. In his letter to the Christians in

${ }^{93}$ Plin., Ep. 10.96. 
Ephesus, he urges them to come to the community gathering; here the prayer of the bishop and the whole congregation has great power and the Eucharist is also celebrated. Taking part in the Eucharist is of crucial importance, for, as Ignatius remarks: "Let no one be deceived. Anyone who is not inside the sanctuary lacks the bread of God." ${ }^{\prime 4}$ By the end of the same letter Ignatius admonishes his addressees again:

All of you to a person, gather together one by one by name, ... so that you may obey the bishop and the presbytery with an undisturbed mind, breaking one bread, which is a medicine that brings immortality, an antidote that allows us not to die but to live at all times in Jesus Christ. ${ }^{95}$

Ignatius is urging here his audience to gather diligently in order to celebrate the eucharistic meal. The bread is understood to be a medicine bringing immortality.

The phrase "medication toward immortality" ( $\left.\varphi \alpha \rho_{\rho} \mu \alpha \kappa o v \dot{\alpha} \theta \alpha v \alpha \sigma i \alpha \varsigma\right)$ originally was a popular medical term. ${ }^{96}$ It designated an ointment or elixir which, according to legend, had been invented by Isis and was said to cure all sorts of diseases. The idea that the Eucharist was

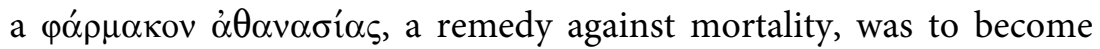
popular in early Christianity. ${ }^{97}$ A similar notion occurs in Joseph and Aseneth (1st-2nd century CE?). Here, at the moment of Aseneth's conversion to the one true faith, an angel feeds her a piece of honeycomb which he calls "bread of life, a cup of immortality and an ointment of incorruptibility" (16.16); "everyone who eats of it will not die forever" (16.8). ${ }^{98}$ It is hard to believe that these passages are not of Christian origin. In this case, the interpretation of the honeycomb as "bread of life and cup of immortality" may have been influenced by en early Christian concept of the Eucharist as articulated by Ignatius. However, if the passages quoted are Jewish, the Ignatian view of the Eucharist as "medicine bringing immortality," on the one hand, and the designation of the honeycomb as "cup of immortality," on the other hand,

\footnotetext{
${ }^{94}$ Ign., Eph. 5.2 (tra. Bart Ehrman).

95 Ign., Eph. 20.2 (tra. Bart Ehrman, slightly adapted).

96 See, e.g., Diodorus Siculus 1.25.6.

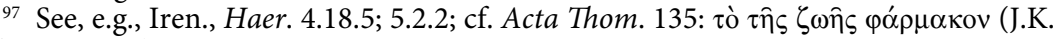
Elliott, p. 498).

${ }^{98}$ For the Greek text, see Chr. Burchard, C. Burfeind, U.B. Fink (eds.), Joseph und Aseneth (Leiden: Brill, 2003), 212.
} 
may go back, mutually independently, to the popular notion of the

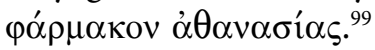

Ignatius views the bread eaten at the community meal not only as bringing about eternal life for the participants, but also as the "flesh of Christ":

Be eager to celebrate just one Eucharist. For there is one flesh of our Lord Jesus Christ and one cup that brings the unity of his blood, and one altar as there is one bishop together with the presbytery and the deacons, my fellow slaves. ${ }^{100}$

The use of the word "flesh" ( $\sigma \alpha \dot{\rho} \xi)$ rather than "body" $(\sigma \hat{\omega} \mu \alpha)$ in this context reflects a tradition also known from the Gospel of John. ${ }^{101}$ By means of this term "flesh," Ignatius stresses the reality of Christ's incarnation and at the same time the reality of Christ's presence in the Eucharist. ${ }^{102}$

Ignatius repeatedly insists on the importance of all Christians congregating in a particular town partaking of just one Eucharist. He does so, for instance, in his letter to the Christian community in Smyrna, in which he warns his audience against Christians holding deviating opinions; he refers to those who "abstain from the Eucharist and prayer, since they do not confess that the Eucharist is the flesh of our saviour Jesus Christ." ${ }^{103}$ It has recently been suggested that the Christians whom Ignatius considers here as entertaining a deficient eucharistic theology, are people with a more primitive and simple understanding of the Eucharist in which the bread and the wine were not interpreted as Christ's flesh and blood. ${ }^{104}$ However, it is also possible that Ignatius is referring here to Docetists or Gnostics who, since they denied that Jesus had had a real human body, denied all the more that the eucharistic elements could represent Jesus' body and blood. ${ }^{105}$

99 See Th. Scherman, "Zur Erklärung der Stelle Epist. ad Eph. 20,2 des Ignatius von Antiocheia," Theologische Quartalschrift 92 (1910), 6-19; R. Bultmann, " $\alpha \theta \alpha v \alpha \sigma i \alpha$," in ThDNT, vol. 3, pp. 23-24; M. Philonenko, Joseph et Aséneth (Leiden: Brill, 1968), 155.

${ }_{100}$ Ign., Phild. 4.1 (tra. Bart Ehrman). Cf. Ign., Rom. 7.3.

101 Jn. 6:51, 53.

102 Paul Bradshaw, Eucharistic Origins, 87.

103 Ign., Smyr. 7.1 (tra. Bart Ehrman).

104 Paul Bradshaw, Eucharistic Origins, 88.

${ }^{105}$ For a fierce repudiation of the Eucharist from a Gnostic perspective, see, e.g., the Gospel of Judas 33.22-34.11, on which see below. 
With the intention of protecting the Christian communities against the influence of dissenting groups, Ignatius admonishes his addressees to do nothing other than under the central authority and supervision of the monarchical bishop:

Let no one do anything involving the church without the bishop. Let that Eucharist be considered valid that occurs under the bishop or the one to whom he entrusts it. Let the congregation be wherever the bishop is.... It is not permitted either to baptize or to hold a love feast without the bishop. ${ }^{106}$

This passage shows that in Ignatius' view the eucharistic meal was conducted under the supervision of the local bishop. A passage in his letter to the Trallians shows that Ignatius could also imagine that "the bishop, the presbytery and the deacons" conducted the Christian gathering. ${ }^{107}$ It is most likely that Ignatius conceived of the Eucharist as being celebrated on Sunday. ${ }^{108}$

A relatively full account of the celebration of the Eucharist on Sunday evening ${ }^{109}$ is given in Justin Martyr's 1 Apologia:

Then we all stand up together and offer prayers; and as we said before, when we have finished the prayer, bread is brought and wine and water, and the president likewise offers up prayers and thanksgivings to the best of his ability, and the people assent, saying the Amen; and the distribution and the partaking of the eucharistized elements is to each, and to those who are absent a portion is sent by the deacons. ${ }^{110}$

Contrary to Ignatius, Justin mentions expressly the order in which the successive components forming the eucharistic meal take place. He mentions the food and drinks consumed: bread, wine and water. Elsewhere, Justin writes about the elements of the meal as "food, dry and liquid." 111 After the food is brought in, the president says a prayer; the distribution and consumption of the bread, wine and water then

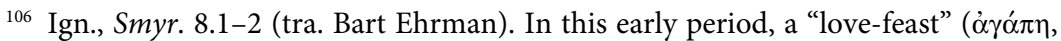
see also Jude 12) is still in principle the same meal as the Lord's Supper of 1 Cor.

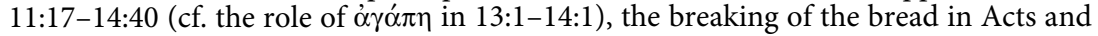
the Eucharist in Did. 9-10; 14.

107 Ign., Trall. 7.2.

108 Ign., Magn. 9.1: Christians are supposed to live "according to the Lord's day, on which also our life arose through him."

${ }^{109}$ For arguments in favour of the idea that Justin's Eucharist took place in the evening, see chapter 2 .

${ }^{110}$ Just., 1 Apol. 67.5 (tra. L.W. Barnard).

111 Just., Dial. 117.3. 
begins. Justin also states that afterwards substantial amounts of food are brought to those who are absent, especially the destitute and solitary. He mentions this sending of food to those in want in order to make it clear that the Eucharist also had the character of a charity meal.

In the preceding chapter of 1 Apology the author discusses the function he believed the Eucharist has for the participants. Christians do not take the eucharistic elements as common bread and drink but as "the flesh and blood of that Jesus who became incarnate

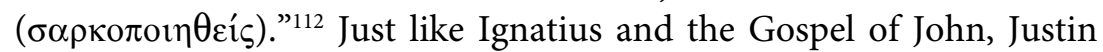
here speaks of "flesh" rather than "body." According to a recent interpretation of this passage, Justin's view of the Eucharist would reflect an early tradition in which the bread and the wine were not yet seen as representing Jesus' body and blood, as they are in the Last Supper accounts in 1 Corinthians 11 and the Gospels. ${ }^{113}$ However, Justin here expressly stresses that Jesus in his earthly ministry "assumed flesh and blood for our salvation" and that "we have been taught that the eucharistic food is the flesh and blood of Jesus incarnate." Justin strongly emphasizes the physical reality of Jesus both in his earthly existence and in his presence in the eucharistic elements so much so that one gets the impression that he is opposing here a Gnostic Christology according to which Jesus did not assume an earthly body but was and remained a heavenly being. Consequently, he can regard the eucharistic bread as a reminiscence of Christ's incarnation. ${ }^{114}$

When Justin remarks that his view of the Eucharist was what "we have been taught," he means that Jesus had taught it during the Last Supper. In what immediately follows, Justin refers to the scene of the Last Supper and quotes Jesus' interpretation words in extenso. ${ }^{115}$

Clearly, Justin's view of the Eucharist is that the participants in the meal associate bodily with the bodily Jesus Christ; this results in their salvation. In addition, Justin finds that the world-wide celebration of the Eucharist glorifies the name of God. ${ }^{116}$ Obviously, he regards the Eucharist as the cultic form par excellence in which Christians give shape to, and express, their religion.

\footnotetext{
112 Just., 1 Apol. 66.2 (tra. L.W. Barnard).

113 Paul Bradshaw, Eucharistic Origins, 89.

114 Just., Dial. 70.4.

115 Just., 1 Apol. 66.2-3.

116 Just., Dial. 41.3.
} 
The Eucharist also plays a part in the Gnostic writings Gospel of Judas and Gospel of Philip. The opening scene of the recently published Gospel of Judas (ca. $150 \mathrm{CE}$ ) describes how one day Jesus found his disciples celebrating the Eucharist and how he rebuked them for this:

One day he was with his disciples in Judea, and he found them seated and gathered together practising their piety. When he [approached] his disciples, gathered together and seated and offering a prayer of thanksgiving over the bread, [he] laughed. [And] the disciples said to him, "Master, why are you laughing at [our] prayer of thanksgiving? Or what did we do? [This] is what is right." He answered and said to them, "I am not laughing at you. You are not doing this because of your own will but because it is through this that your god [will receive] thanksgiving." 117

The author here projects the eucharistic practice of the Church of his days onto the pre-Easter period in which Jesus conversed with his disciples. Through Jesus' words, the author criticizes the most conspicuous religious practice of the majority Church, the Eucharist. He rejects it out of hand as a completely misguided form of worship: traditional Christians believe they are worshiping the Father of Jesus, the Great Invisible Spirit, whereas in reality they are serving the inferior demiurge and creator god, the God of Israel. According to the Gospel of Judas, the Church is mistaken in thinking that Jesus has appeared on earth as a physical body. Rather he was a spiritual person from the divine realm, who could not die. This Gnostic Christology rules out the possibility that the eucharistic elements represent Jesus' body and blood. It also excludes the possibility that the Eucharist reflects Jesus' death and resurrection, for Jesus has neither died nor arisen: his divine person has only been liberated from a mortal body, "the man who carried him" (56.20), probably at the moment of his transfiguration, not long before Judas handed him over to the high-priests and scribes. ${ }^{118}$

The Gospel of Philip (ca. $180 \mathrm{CE}$ ) gives some glimpses into the eucharistic practice of another group of Gnostics. The author of this treatise does not hesitate to state that "the Eucharist is Jesus" and "when Christ came, he brought bread from heaven in order that man might

${ }^{117}$ Gos. Jud. 33.22-34.10 (tra. Rodolphe Kasser, Marvin Meyer, and Gregor Wurst).

118 Gos. Jud. 57.17-24. The subject of "he entered it (i.e., the luminous cloud)" is best taken to be Jesus, as Gesine Schenke Robinson, following a suggestion of Sasagu Arai, has argued; "Judas, a Hero or a Villain?" in The Gospel of Judas, eds. R. Kasser, M. Meyer, G. Wurst (Washington DC: National Geographic Society, 2006), 155-168, esp. 162-164. 
be nourished with the food of man." 119 The author is clearly acquainted with the traditional interpretation of the eucharistic elements as the flesh and blood of Jesus. To explain what the Eucharist is, he can use traditional language. Through the eating of the bread, the participants receive nourishment. "The cup of prayer contains wine and water since it is...the type of the blood for which thanks is given." ${ }^{120}$ Through the eucharistic prayer, the bishop consecrates the bread and the wine. ${ }^{121}$ As a result, "it is full of the Holy Spirit and it belongs to the wholly perfect man." 122 In several respects, the Eucharist in the Gospel of Philip resembles that of the more traditional Christian communities. The elements are bread and wine mixed with water, interpreted as Jesus' flesh and blood. The bishop consecrates the bread and the cup through a prayer of thanksgiving. Yet, there is a striking difference between the way the Gospel of Philip interprets the Eucharist and the way it is interpreted by Ignatius, Justin and later Irenaeus. According to the Gospel of Philip, when the participants "drink the cup they receive for themselves the perfect man." 123 Those who take part in the Eucharist, become a perfect person in which all division is removed. It is not said that they participate in Jesus' death and resurrection and thus share in his glorification. Thus, the Eucharist described in the Gospel of Philip has much in common with that of the majority Church; yet the interpretation provided for it is clearly Gnostic. ${ }^{124}$

The Gospel of Philip is generally Valentinian in character. ${ }^{125}$ A picture of the Eucharist celebrated by Valentinian Gnostics is given by Irenaeus. In certain Gnostic communities in the Rhône valley, in the middle of the second century, Mark, the magician, is said to have celebrated the Eucharist with a chalice of wine mixed with water. According to Irenaeus, this Eucharist took place during the first part of the Sunday evening gathering; ${ }^{126}$ it was followed by a symposium during which, in addition to other activities, oracles and instructions were

119 Gos. Phil. 63.21; 55.5-24 (tra. Wesley W. Isenberg).

${ }_{120}$ Gos. Phil. 75.14.

${ }^{121}$ Gos. Phil. 77.2-8.

122 Gos. Phil. 75.18-19.

${ }^{123}$ Gos. Phil. 75.14-25.

124 W.W. Isenberg, "The Gospel of Philip (II,3)," in The Nag Hammadi Library, ed. James M. Robinson (Leiden: Brill, 1977), 131.

${ }^{125}$ Isenberg, $i b$.

126 That Markosian Eucharist took place in the evening is clear from Iren., Haer. 1.13.4. 
given. At the beginning of the meal, Mark used to say a long prayer of invocation ${ }^{127}$ and make "the cup appear purple and red so that the Grace from the regions above all may be supposed to distil its blood in his chalice." 128 As a result of the invocation and the supposed reactions in the cup, the participants in the meal would feel a strong desire to taste from the cup in order to receive the Grace from above. Mark also engaged women to say eucharistic prayers. It seems that Irenaeus, in giving his rather biased picture of Mark and the Marcosians, was so intent on describing their magical rites over the cup that he forgot to mention the bread used at their Eucharist.

Describing the Eucharist of more traditional Christians, Irenaeus points out that at this meal the cup mixed with wine and the bread receive the Word of God and become the Eucharist of the blood and body of Christ. ${ }^{129}$ In this context, Irenaeus uses the word "Eucharist" to designate the consecrated elements rather than the rite. The spiritual transformation of the elements takes place through a prayer of invocation:

For the bread, which is produced from the earth, when it receives the invocation of God, is no longer common bread, but the Eucharist-consisting of two realities, earthly and heavenly. So also our bodies, when they receive the Eucharist, are no longer corruptible, having the hope of the resurrection of eternity. ${ }^{130}$

According to Irenaeus, partaking in the Eucharist results in the participants' incorruptibility and the perspective of eternal life.

In Clement of Alexandria (ca. 200) one finds only brief allusions to the celebration of the Eucharist. According to this author, the Christian gathering comprises a sermon followed by "the holy oblation." ${ }^{31}$ In reference to the lavish feasts of some well-to-do Christians, possibly also eucharistic in character, he criticizes the organizers for calling these feasts agapae. ${ }^{132}$ According to Clement, they dishonour the true

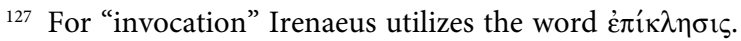

${ }^{128}$ Iren., Haer. 1.13.2 (tra. Robert M. Grant).

${ }^{129}$ Iren., Haer. 5.2.3.

130 Iren., Haer. 4.18.5 (tra. A. Cleveland Coxe in ANF).

131 Clem. Al., Str. 6.113.3.

132 About $200 \mathrm{CE}$, Tertullian, too, stresses the function of the Eucharist as a charity meal. See Tert., Apol. 39.14-19, where he remarks that the caritas with which people love each other in the Christian community takes shape in their common meals, convivia, and that that these meals are called agapae. These meals are full suppers at which the participants discumbunt and saturantur. 
agape which is essentially a heavenly meal and a spiritual feast. ${ }^{133} \mathrm{Clem}-$ ent takes the eucharistic elements, bread and wine mixed with water, to represent the body and blood of Christ. By drinking his blood, the participants share in the Lord's immortality while their body and soul are sanctified. ${ }^{134}$

Several passages in the Acts of Peter, Acts of Paul and Acts of John describe apostles conducting eucharistic meals. These writings are dated to the second half of the second century and undoubtedly reflect the eucharistic practices of that period.

In the Acts of Peter, a Eucharist is celebrated at the moment when Paul is leaving Rome for Spain. He is given bread and water to make a sacrifice (optulerunt sacrificium Paulo pane et aqua $[$ sic $])^{135}$ and then offers a eucharistic prayer and distributes the gifts among those present. ${ }^{136}$ The emphasis is on the distribution of the elements rather than on the prayer. An incident occurring during the distribution shows that admission to the Eucharist was reserved for persons in the right spiritual condition. A woman called Rufina wanted to receive the Eucharist from Paul's hands. Paul, who knew that she had intercourse with an adulterer, admonished her to repent, otherwise she would not be worthy to receive the Eucharist and, subsequently, would be punished. This episode reflects the regulation mentioned in the Didache 14.1 which stipulates that those who want to partake of the Eucharist should confess first their unlawful deeds, "that your sacrifice may be pure." Other passages of the Acts of Peter relate that Peter, in the context of Christian gatherings, ministered to the virgins and widows from his own hands. ${ }^{137}$ This ministry is most likely the distribution of the Eucharist. The passages at issue may be indicative of eucharistic gatherings held for virgins and widows at the end of the second century.

A relatively detailed description of a eucharistic gathering occurs in the Acts of Paul. ${ }^{138}$ Paul travels from Antioch to Iconium, where he meets Onesiphorus, a man well disposed towards the Christian

3 Clem. Al., Paed. 2.4.3-5.

${ }_{134}$ Clem. Al., Paed. 2.19.3.

135 The Latin is taken here from Acta Apostolorum Apocrypha, eds. Richard Lipsius and Max Bonnet, vol. 1 (Leipzig: Mendelssohn, 1891), 46.

${ }_{136}$ Acta Petri 2 (tra. J.K. Elliott, p. 399).

137 Acta Petri 22; 29 (tra. J.K. Elliott, pp. 415, 421).

${ }^{138}$ Acta Pauli (= Pauli et Theclae) 3.5 (tra. J.K. Elliott, p. 365). 
faith. When Paul enters the house of Onesiphorus there is a great joy. The believers kneel, break bread and hear a sermon about abstinence, virginity and the resurrection of the blessed at the end of time. The components of the eucharistic gathering recorded here are the same as those mentioned in other stories about Eucharists in the apocryphal Acts: meeting in a house, joy, kneeling, breaking of bread and teaching.

The Hamburg papyrus of the Acts of Paul, too, contains an account of a Eucharist. When the time drew near for Paul to depart for Rome, "an offering was celebrated by Paul." The members of the community, gathered in the house of Epiphanius, were deeply distressed by the prospect of Paul's departure. However, Myrta encouraged them by explaining that Paul would save many in Rome and nourish innumerable people with the Word, "so that there will be great grace in Rome." Thereupon, "each one partook of the bread and feasted according to custom... amid the singing of psalms of David and of hymns. And Paul too was glad." 139

In the Acts of John, one eucharistic celebration takes place in the house of Andronicus at Ephesus, probably in the evening. ${ }^{140}$ The gathering, conducted by John, consists of a homily, a prayer, the celebration of the Eucharist and the laying on of hands on each person assembled. Another eucharistic ceremony, also conducted by John, is explicitly said to have taken place on Sunday. After a prayer, John asks for bread and says grace, glorifying Jesus who is the resurrection and the root of immortality. After that John breaks the bread, distributes it and prays for each brother in order that he would be worthy to receive the Lord's grace and the holy Eucharist. ${ }^{141}$

The stories about the Eucharist in the apocryphal Acts may reflect to some extent the practice of the eucharistic meals as held in the context of Christian gatherings at the end of the second century. During the meal one ate bread and drank wine or simply water. The meal was a real, substantial supper as well as a sacramental rite; only initiated, that is, baptised members of Christian communities were allowed to participate in it.

139 Acta Pauli 9 (tra. J.K. Elliott, p. 383).

140 Acta Ioan. 46.

${ }^{141}$ Acta Ioan. 106-110 (tra. J.K. Elliott, pp. 335-336). 


\section{b. The Eucharist in the third century}

In the third century, the way the Eucharist was celebrated in the gathering of Christian communities underwent some important changes. In the first place, the food distributed in the morning service could become considerably less substantial than that in the evening; after all, this meal was a breakfast rather than a supper. Secondly, in the morning assembly the wine was often replaced by water; ${ }^{142}$ in this, too, besides ascetic reasons, practical considerations may have played a role. Moreover, there was probably no time to eat and drink at one's ease whilst reclining on couches. Consequently, as a matter of course, the Eucharist conducted in early morning gatherings could take on a more ritualistic character than most "ordinary" meals, including the Eucharist in the evening. This changed the nature of both the Eucharist held early in the morning and that held in the evening.

Of the two meals that were now held in the Christian community on Sunday, the simpler, more compact meal that took place in the morning gradually became more important than the real meal held in the evening. The reason for this was that "the whole community" 143 began attending the Sunday morning rite, whereas the supper was attended increasingly by those who used it as a form of social support.

For Tertullian, the Sunday evening meal was still meant for all members of the community. ${ }^{144} \mathrm{He}$ designates it as agape: "Our dinner shows its idea in its name; it is called by the Greek name for love." 145 Scholars have long thought that this designation of the evening meal as agape refers to a non-eucharistic supper. However, from the first quarter of the second century onwards at the latest, agape is a usual

${ }_{142}$ This was the case, for instance, at Smyrna about 250 CE; see M. Pion. 3 "... and after they had prayed and taken the sacred bread with water..." About the same time, Cyprian, bishop of Carthage, felt compelled to take action against the use of water in lieu of wine in the early morning meetings in Carthage. This is the issue of his Ep. 63. In the second century the Ebionites and Tatian are on record as having used water instead of wine; see Epiph., Panar. 30.16 and 46.2. About 200, Clement of Alexandria, Str. 1.96.1, expressed his disapproval of certain heretics who used water instead of wine in the Eucharist. Later these heretics were labeled Aquarians, e.g., by Philaster of Brescia (ca. $385 \mathrm{CE}$ ), De haeresibus 77 and Augustine, De haeresibus 64. See A. McGowan, Ascetic Eucharists, 211-217.

${ }_{143}$ Trad. ap. 22.

144 Tert., Apol. 39.2-3, 16-17.

145 Tert., Apol. 39.16 (tra. T.R. Glover). 
appellation for the eucharistic meal. ${ }^{146}$ Moreover, although Tertullian is aquainted with Eucharists celebrated in the morning, he often speaks of Eucharists which are held in the evening, as appears from such designations as "God's supper," "the Lord's banquet" and "God's banquet." 147 In the case of Tertullian, all agapae are evening Eucharists and full suppers, whereas morning Eucharists are neither agapae nor substantial meals. Recent scholarship confirms that in the third century the celebration of the Eucharist in the context of the Sunday evening gathering was still the common practice. ${ }^{148}$ In contradistinction to the agape in the evening, Tertullian designates the eucharistic meal in the morning as "the sacrament of the Eucharist" (eucharistiae sacramentum).${ }^{149}$ It would seem that as from about 200 CE Christians began to feel the need to distinguish terminologically between the eucharistic celebration in the morning and that in the evening.

As to Tertullian's interpretation of the Eucharist, he declares that the bread is the Lord's body and the wine his blood. ${ }^{150} \mathrm{He}$ also states that in celebrating the Eucharist, the participants are convinced of God's presence: "certi de Dei conspectu." 151

According to the Apostolic Tradition, the evening meal was attended, not by the whole community, but only by part of the members of the community; the author speaks of those gathered as "those faithful who are present," 152 meaning "those among the faithful who happen to be there." Thus, a distinction developed between the more important service held on Sunday morning, attended (in principle) by the whole community, and the supper that continued to be held as a charity meal on Sunday evening. The difference in status between the two ceremonies is already reflected in the terminology the Apostolic Tradition uses for each of them. He refers to the assembly of the whole community as the "Eucharist" (eucharistia) and to the supper as a "benediction" (eulogia). ${ }^{153}$ In contradistinction to the food consumed during the

\footnotetext{
146 Jude 12; Ign., Smyr. 8.2; Acta Pauli (= Acta Pauli et Theclae) 3.25; Clem. Al., Paed. 2.4.

147 Tert., Spect. 13: "cena Dei;" Ad uxor. 2.4: "convivium dominicum;" 2.8: "convivium Dei."

${ }_{148}$ Andrew McGowan, "Rethinking Agape and Eucharist in Early North African Christianity," SL 34 (2004), 165-176; Paul Bradshaw, Eucharistic Origins, 99.

149 Tert., Cor. 3.3.

${ }^{150}$ See, e.g., Tert., Or. 19; Idol. 7; Paul Bradshaw, Eucharistic Origins, 94-96.

151 Tert., Apol. 39.4

152 Trad. ap. 26.

153 Trad. ap. 26; 28.
} 
Eucharist, the bread of the Sunday supper is "not the sign of the body of the Lord." 154

About the middle of the third century, Cyprian points out what he sees as the difference between the two Sunday meals of the Christian community, that is, the Eucharist celebrated in the morning (sacrificium matutinum) and that celebrated in the evening (cena, convivium nostrum). ${ }^{155}$ In his view, the difference is that at the Eucharist in the morning, the community as a whole (omnis fraternitas) is present, whereas for logistical reasons the supper is only attended by some of the members of the community. For this reason, Cyprian can say: "The 'true sacrament' is the one we celebrate in the presence of the entire congregation." ${ }^{156}$ Here, we witness how the eucharistic ritual in the morning is considered the main sacrament of the Christian Sunday, while the Sunday evening meal, which was originally the only and, subsequently, the more significant rite of the Christian community, is given less importance. Cyprian does not yet deny that the supper is a sacrament. However, it is clear that for Cyprian the Eucharist celebrated early in the morning is a more important rite than the one celebrated in the evening. The reason for this shift in the appreciation of the two ceremonies is simply that the morning Eucharist was the sacrament in which the whole of the community took part, whereas in the evening gathering only part of the community participated, and probably the less well-to-do part at that. Cyprian also makes it clear that the differentiation in status between Eucharist and agape was occasioned by the growth of the congregation. It was now impossible for the congregation as a whole to participate in the supper. However, if the members of the congregation cannot all be present, the community cannot "celebrate the truth of the sacrament."157

\footnotetext{
154 Trad. ap. 26.

155 Cypr., Ep. 63.15.1; 63.16.1-2.

156 Cypr., Ep. 63.16.1: "Cum cenamus, ad convivium nostrum plebem convocare non possumus, ut sacramenti veritatem fraternitate omni praesente celebremus," that is, "when we have supper, we cannot invite the whole congregation to our common meal, with the result that the true sacrament is the one we celebrate in the presence of the whole congregation (i.e., the Eucharist celebrated in the morning)." See M. Klinghardt, Gemeinschaftsmahl und Mahlgemeinschaft, 516-517. H.J. de Jonge, "The Early History of the Lord's Supper," 233-234.

${ }^{157}$ Cypr., Ep. 63.16.1; see previous note.
} 
As to the meaning of the eucharistic meal in the third century, one witness characterizes the elements as "divine food which abides forever." 158 The food consumed in the Eucharist is sanctified by means of invocations through the Holy Spirit. ${ }^{159}$ Cyprian observes that the eucharistic bread which one receives daily is the food of salvation. ${ }^{160}$ Origen states that the sanctified bread consumed during the eucharistic meal "through prayer becomes a sacred body and sanctifies those who sincerely partake of it." ${ }^{161}$ There is a tendency to conceive of the Eucharist as a meal where the food and drink have a redemptive effect. Yet, the idea is never far away that this effect depends on the death and resurrection of Jesus Christ and the participants' association with him. Cyprian, for instance, also asserts that in every celebration of the Eucharist, Christians make mention of the suffering of the Lord and "offer the cup in remembrance of the Lord and his passion." 162 Here Cyprian makes a close connection between the eucharistic offering and Christ's death, but in the Eucharist the participants shared not only in Christ's death but also in his resurrection: "in the morning we celebrate the resurrection of the Lord." 163 The same idea is present in the Traditio apostolica: "Wherefore, having in remembrance his death and resurrection, we offer unto thee this bread and this cup, thanking thee...." ${ }^{164}$ In the case of the Traditio apostolica, the story of Jesus' passion, including the Last Supper story and the interpretation words, has even been incorporated into the eucharistic prayer. Judging by Cyprian's words "during all our oblations we make mention of his passion," this author, too, may have been acquainted with eucharistic prayers which included explicit references to Jesus' Last Supper, passion and death. In any case, it is clear that in the third century the narratives of the Lord's Supper occurring in Paul and the Synoptic tradition increasingly influenced the form and meaning of eucharistic celebrations.

${ }^{158}$ Did. ap. 2.59 (tra. Sebastian Brock).

159 Did. ap. 6.21-22.

160 Cypr., Or. Dom. 18.

161 Or., C. Cel. 8.33 .

${ }^{162}$ Cypr., Ep. 63.17.1: "passionis eius mentionem in sacrificiis omnibus facimus, passio est enim Domini sacrificium quod offerimus."

${ }_{163}$ Cypr., Ep. 63.16.2: "Nos autem resurrectionem Domini mane celebramus."

164 Trad. ap. 4: "Memores igitur mortis et resurrectionis eius, offerimus tibi panem et calicem, gratias tibi agents...." 


\section{Conclusions}

In reconstructing the earliest history of the Eucharist, 1 Corinthians and the Didache should and can be used as the main sources; they are mutually independent witnesses of a common, earlier tradition. The primary function of the Lord's Supper was to establish the fellowship, communion, and unity among the participants. This meal was the expression of their being a community. It was also an anticipation of the ideal situation of the world to come. However, the interpretation of the community gathered for the supper as the "body of Christ," the interpretation of the bread and the wine as Jesus' body and blood, and the attribution of the ceremony's origins to an institution by the historical Jesus himself, must all be regarded as early, yet secondary developments.

It has proved to be difficult to regard the Lord's Supper historically as a continuation of Jesus' Last Supper. The story of the Last Supper, which is the story about the institution of the ecclesiastical communal meal, rather originated secondarily in explanation of the existence of the Lord's Supper or Eucharist. This explains why the tradition about the Last Supper is absent in the Didache and other accounts of the Eucharist in the East.

In the first half of the second century, besides the communal supper on Sunday evening, Eucharistic celebrations were incorporated into the prayer meetings held in the early morning. In these morning sessions the meal could not be, and did not need to be, as substantial as in the evening; the portions of food and wine used in the morning service were probably less sizeable than those provided at the supper on Sunday evening. As a result of practical constraints the Eucharist in the morning was probably ritualized to a certain extent.

At the same time, owing to the growth of the Christian communities and the proliferation of morning services, the supper on Sunday evening began to lose importance and recognition as a sacrament, whereas the Eucharists celebrated on Sunday morning and the mornings of other days gained significance. This development resulted in the morning ceremony being regarded as the real sacrament, while the Sunday Supper gradually ceased to be considered eucharistic and as such became a charity meal for the less well-off members of the community. 


\section{THE READING OF SCRIPTURE IN THE GATHERING OF THE EARLY CHURCH}

\section{INTRODUCTION}

The phenomenon of public reading of Scripture in the context of the gathering of early Christian communities has repeatedly received the scholarly attention of both historians of the early Church and liturgiologists. However, most studies on the subject seem to depart from questionable historical premises and, as a consequence, lead to unconvincing results. Therefore, this chapter will reconsider the history of public reading in the Christian assemblies and, in particular, the origin and development of public reading of Scripture during the first three centuries of the Church's existence. Particular attention will be given to the questions of which genres of writings were read in the communal gatherings and how the role and office of reader originated and developed.

1. The origin of SCRipture ReAding In the CHRISTIAN GATHERING

\section{a. Public reading at the Graeco-Roman banquet}

Before exploring the issue of the origin of Scripture reading in the early Christian gathering it may be helpful to review how public reading functioned in late antiquity in general. The normal way to read a text was to read it out loud, whether before an audience, in the company of friends or alone. However, silent reading was not unknown, and there is ample evidence for such practice in antiquity. ${ }^{1}$ Reading aloud was part of ancient education and it was regarded as the only recognized means of gaining the full meaning of the written page. Reading aloud even to oneself was the usual custom of antiquity as

\footnotetext{
${ }^{1}$ B. Knox, "Silent Reading in Antiquity," GRBS 9 (1968), 421-435.
} 
is illustrated by the example from Acts 8:30 where Philip hears the Ethiopian eunuch reading from the prophet Isaiah. ${ }^{2}$ Vocalized reading also occurred at public presentations of literary compositions. Authors gave public performances of their works with some regularity, and one of the characteristics of public games was a poet reading aloud from his writings. Reading aloud written texts also became typical of early Christian gatherings from the middle of the first century onwards. ${ }^{3}$

In Graeco-Roman antiquity, texts were generally written with the intention of being reproduced as oral presentations. Gamble observes that:

Christianity's orientation to texts was, moreover, something that stood out in the eyes of its ancient critics. When in the middle of the second century Lucian of Samosata satirized the figure of Peregrinus (De morte Peregrini 11), what especially caught his attention about Christianity was its penchant for writing and interpreting books. ${ }^{4}$

Audible reading was also necessary because in antiquity, texts were written in scriptio continua: there was little or no division between words, sentences, or paragraphs, and little or no punctuation. Therefore, the reader was obliged to constitute the sense of a text by vocalizing it, and in this manner, the reader converted the written into the oral. $^{5}$

Public reading could be performed, as in modern times, in different life contexts. Dio Chrysostom describes how, walking through the hippodrome, he encountered people playing the flute, dancing, performing tricks, reading out a poem, singing, and recounting a history or tale. ${ }^{6}$ A very common context, however, was the after-dinner symposium. $^{7}$

At the symposium various types of texts could be read: philosophy, scientific treatises, history, poetry, and comedy. According to Aulus Gellius, at a banquet of the philosopher Taurus the Symposium of

2 G. Hendrickson, “Ancient Reading,” CJ 15 (1929-1930), 186-193.

${ }^{3}$ P. Achtemeier, "Omne Verbum Sonat: The New Testament and the Oral Environment of Late Western Antiquity," JBL 109 (1990), 16.

${ }^{4}$ H. Gamble, "Literacy, Liturgy, and the Shaping of the New Testament Canon," in The Contribution of the Chester Beatty Gospel Codex P45, ed. Charles Horton (London and New York: T \& T Clark, Continuum, 2004), 27-39, esp. 29.

${ }^{5}$ H. Gamble, Books and Readers in the Early Church: A History of Early Christian Texts (New Haven and London: Yale University Press, 1995), 204.

${ }^{6}$ Dio Chrys. 20.10.

7 Plut., Quaest. conv. 7.711b-712c; Plin., Ep. 1.15.2. 
Plato was read. ${ }^{8}$ At the dinner of the philosopher Favorinus "there was usually read either an old song of the lyric poets, or something from history, now in Greek and now in Latin." Gellius once heard the reading of a passage from the treatise of Gavius Bassus On the Origin of Verbs and Substantives. ${ }^{10}$ Plutarch notices that, as entertainment at a banquet, the dialogues of Plato could be recited and even performed. ${ }^{11}$ According to Lucian, the blessed ones who live on the Isle of the Blest enjoy a symposium accompanied by poetry and songs. Here, mostly the poems of Homer are read or recited. ${ }^{12}$ In Lucian's Symposion, the grammarian Histiaios recited a combination of verses of Pindar, Hesiod and Anacreon. ${ }^{13}$ Plutarch states that the comedian Menander is particularly fit to be read at symposia. ${ }^{14}$

The reading at symposia could be performed by persons of various statuses. First, the person who read the literary text could be the author of the text himself, who by reading his composition hoped to elicit the comments and reactions of the participants in the banquet. ${ }^{15}$ Petronius relates that Trimalchio at his banquet read his last will and also some poetry of his own making as well as a long passage from Publilius Syrus, the composer of mimes. ${ }^{16}$ Second, the reading could be performed by the host of the banquet. Third, the task of reading

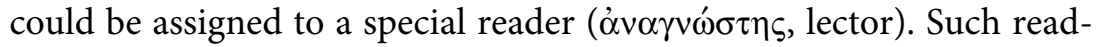
ers would often be educated slaves, whose duty in Roman houses was to entertain their master and his guests at table by a recitation in Greek and/or Latin. ${ }^{17}$ Atticus, for instance, had very good readers, whom he thought indispensable at dinner parties. ${ }^{18}$ Gellius relates that a slave usually stood by the table at dinner with the philosopher Favorinus. ${ }^{19}$ Plutarch states that slaves could be charged with the recitation and

8 Aul. Gel., NA 17.20.

9 Aul. Gel., NA 2.22.

10 Aul. Gel., NA 3.19.

${ }^{11}$ Plut., Quaest. conv. 7.711c.

12 Luc., Ver. hist. 2.15.

${ }^{13}$ Luc., Symp. 17.

${ }^{14}$ Plut., Quaest. conv. 7.712b.

15 E.J. Kenney "Books and Readers in the Roman World," in The Cambridge History of Classical Literature, Volume II, Latin Literature, eds. E.J. Kenney and W.V. Clausen (Cambridge: Cambridge University Press, 1982), 11; Raymond Starr, "The Circulation of Literary Texts in the Roman World," CQ 37 (1987), 213.

${ }_{16}$ Petr., Satyr. 71.4; 55.

${ }^{17}$ See J.W. Duff and A.J.S. Spawforth, “anagnostes," in $O C D$, p. 80.

${ }_{18}$ Nep., Att. 13.3; 14.1.

19 Aul. Gel., NA 3.19. 
performance of Plato's dialogues. ${ }^{20}$ These data may suffice to warrant the conclusion that reading of literary compositions was a well-known practice at the Graeco-Roman banquet.

\section{b. Reading of Scripture in Jewish communal gatherings}

For the purpose of the present research it is important to look at the background of the reading of Scripture by first-century CE Jews in their synagogues and by Jewish groups as, for instance, those whose practices are reflected in the Qumran scrolls and the Therapeutae. Pierre Grelot points out that the available references to Jewish liturgical reading of Scriptures in the synagogue come from a relatively late time. Even then descriptions of Sabbath assemblies give no clear and detailed picture. Scripture readings in Palestinian and Babylonian communities were not fixed. But it is clear that essential elements which formed part of the synagogue liturgy according to rabbinic sources, such as the reading of Scripture, existed already in the synagogue in the time of Jesus and the apostles. ${ }^{21}$ The Jewish synagogue was used for many communal activities; however, as Josephus asserts, it was in the first place a center of study for the entire community. ${ }^{22}$ Philo speaks in the same vein: "He [Augustus] knew therefore that they have houses of prayer and meet together in them, particularly on the sacred Sabbaths when they receive as a body a training in their ancestral philosophy." 23

Several sources, among them Philo, Josephus, the inscription of Theodotus and the book of Acts, show that in the first century CE the reading of the Torah constituted the primary and almost exclusive function of the religious activity in the synagogue. ${ }^{24}$ In an account of Jews gathering in the synagogue Philo says: "And will you sit in your conventicles and assemble your regular company and read in security your holy books, expounding any obscure point and in leisurely comfort discussing at length your ancestral philosophy?" 25 According to

\footnotetext{
20 Plut., Quaest. conv. 7.711c.

21 Pierre Grelot, La liturgie dans le Nouveau Testament (Paris: Desclée, 1991), $32-33$.

22 Jos., Ant. 16.2.4; Mk. 1:21; 6:2.

23 Philo, Legat. 156 (tra. F.H. Colson).

24 Lee Levine, “The Second Temple Synagogue: The Formative Years," in The Synagogue in Late Antiquity, ed. Lee Levine (Philadelphia: Asor, 1987), 14-15.

${ }_{25}$ Philo, Som. 2.127 (tra. G.H. Whitaker and F.H. Colson).
} 
Philo, at least two people participated in the reading and interpretation of the Scriptures in the Alexandrian synagogues:

For that day has been set apart to be kept holy and on it they abstain from all other work and proceed to sacred spots which they call synagogues. There, arranged in rows according to their ages, the younger below the elder, they sit decorously as befits the occasion with attentive ears. Then one takes the books and reads aloud and another of special proficiency comes forward and expounds what is not understood. ${ }^{26}$

In the surviving excerpts of his Hypothetica, Philo says that Jews gather on the Sabbath in certain habitual places for the reading of the Law:

And indeed they do always assemble and sit together, most of them in silence except when it is the practice to add something to signify approval of what is read. But some priest who is present or one of the elders reads holy laws to them and expounds them point by point till about the late afternoon. ${ }^{27}$

Josephus also says:

[Moses] appointed the Law to be the most excellent and necessary form of instruction, ordaining, not that it should be heard once for all or twice or on several occasions, but that every week men should desert their other occupations and assemble to listen to the Law and to obtain a thorough and accurate knowledge of it, a practice which all other legislators seem to have neglected. ${ }^{28}$

This literary evidence from Philo and Josephus is confirmed by the Jewish inscription of Theodotus (Jerusalem, before $70 \mathrm{CE}$ ) which tells us that the synagogue he built was meant for the reading of the Law and instruction about it. This is how the inscription reads: "Theodotus, son of Vettenus, priest and archisynagogos, son of an archisynagogos, grandson of an archisynagogos, constructed the synagogue for the reading of the Law and the teaching of the commandments...."29

In his remarks about what happened in the Jewish synagogues on the Sabbath, Luke, too, intimates that the reading of the Law was a weekly practice. He has James say: "For in every city, for generations

\footnotetext{
${ }^{26}$ Philo, Quod omn. prob. 81-82 (tra. F.H. Colson).

${ }_{27}$ Philo, Hyp. in Euseb., Praep. ev. 8.7.12-13 (tra. F.H. Colson).

${ }^{28}$ Jos., Ap. 2.175 (tra. H.St.J. Thackeray). Cf. Jos., Ant. 16.44.

${ }^{29}$ Charles Perrot, "The Reading of the Bible in the Ancient Synagogue," in Mikra. Text, Translation, Reading, and Interpretation of the Hebrew Bible in Ancient Judaism and Early Christianity, ed. M.J. Mulder (Assen: Van Gorcum; Philadelphia: Fortress, 1988), 137.
} 
past, Moses has had those who proclaim him, for he has been read aloud every Sabbath in the synagogues." ${ }^{30}$

All in all, the evidence available from the first century CE seems to justify the conclusion that, in that century, the synagogue was the place for reading and studying the Jewish sacred books, in contrast to the Temple cult, which mainly consisted of sacrificial rites.

Later, at the end of the second or beginning of the third century $\mathrm{CE}$, the service of the synagogue consisted of the Shema', prayer, the reading of the Law and the Prophets, and the Blessing. ${ }^{31}$ The reading from the Law followed a triennial cycle that completed the Pentateuch once every three years, a system believed by some to go back to the first century BCE. ${ }^{32}$ However, in the first century, at least until $70 \mathrm{CE}$, there is no reference to the synagogal reading of the Prophets in Jewish sources. ${ }^{33}$ The story about Jesus reading Isaiah $61: 1-2$ in Luke 4:16-17 cannot be used as evidence to the contrary, since the story is clearly composed by Luke to have Jesus himself prove his messiahship on the basis of an Old Testament prophecy. ${ }^{34}$ In the account of Paul visiting Antioch in Pisidia, there is a reference to a reading of the Prophets (Acts 13:15), but the expression "of the Prophets" here seems to be due to Luke's use of the standard phrase "the Law (or Moses) and the Prophets." ${ }^{\prime 35}$ At the same time, Luke 4:16-17 and Acts 13:15 reflect the situation of Christian communities at the end of the first century,

30 Acts 15:21.

31 Mishnah, Meg. 4.3.

32 H.H. Rowley, Worship in Ancient Israel. Its Forms and Meaning (London: SPCK, 1967), 234-235.

${ }^{33}$ In this context it may be significant that the works of Philo of Alexandria include a considerable number of commentaries on the books of Moses but not a single commentary on any of the Prophets. Naomi G. Cohen, Philo's Scriptures: Citations from the Prophets and Writings (Leiden: Brill, 2007), argues that Philo's citations from the Prophets and writings indicate that a Haftarah Cycle was already on the way to become customary in Alexandria in the first century CE. However, the evidence discussed by Cohen does not justify her conclusion. An early indication of the reading of "Prophets" in the synagogue in the first century is 2 Bar. 86.1-2.

${ }^{34}$ The episode Lk. 4:17-21 (the reading from Isaiah) does not rest on tradition from Mark or Q. It has been created by Luke as an expansion of Mk. 6:1-2 and inserted in Mk. 6:2. Moreover, the "quotation" from Isaiah is not a coherent biblical passage but a combination of Isaiah 61:1-2 and 58:6, which forms a text which could hardly have chosen as Scripture reading, "gewiss in keiner Prophetenrolle zu finden," H. Schürmann, Das Lukasevangelium, vol. 1 (Freiburg, Basel, Wien: Herder, 1969), 229.

${ }^{35}$ Cf. Lk. 16:16, 29; 24:27, 44; Acts 13:15; 24:14; 28:23. 
when in their gatherings Christians read the Prophets to sustain their Christological claims about Jesus. ${ }^{36}$

Judging from the writings found at Qumran it was considered important that the public reading of Scripture was performed with great care. A neglectful reading of the Law was regarded as a serious offence. Indistinct reading without sufficient articulation had to be avoided: "And anyone who speaks weakly or staccato, without separating his words to make his voice heard, such men should not read in the book of the Torah, so that he will not lead to error in a capital matter" (4Q266 5.2). A "blasphemous" slip committed in the act of reading or in the saying of prayers, could result in permanent expulsion from the community: "whether blaspheming, or suddenly overtaken by misfortune or for any other reason, $\{\ldots\}$ or reading a book, or blessing, will be excluded and shall not go back ever to the Community council" (1QS 7.1). Of course, these remarks refer to the reading of the Torah, and one should be cautious in making assumptions about the reading of other writings, such as pesher commentaries, in the community concerned. ${ }^{37}$ The author of the Community Rule outlines procedures for a group meeting immediately following the reference to the Torah watch: "And the Many shall be on watch together for a third of each night of the year in order to read the book, explain the regulation, and bless together" (1QS 6.7-8). "The book" (4Q397 14-21) is likely to refer here to the Torah; reading it probably means reading aloud to those assembled. The Rule of the Congregation also alludes to a largegroup gathering. Interestingly, it assumes that women and children will be present when the Law is read and interpreted in the last days: "When they come, they shall assemble all those who come, including children and women, and they shall read into their ears all the precepts of the covenant, and shall instruct them in all their regulations, so that they do not stray in their errors" (1QSa 1.4-5). Just like those who attended the meetings on Sabbath in the synagogues, those who used the Qumran texts devoted themselves to the reading and studying of the Law in their gatherings.

${ }^{36}$ The evidence for the reading of Prophets in early Christian gatherings (from 1 Tim. 4:13 onwards) will be discussed in section 2a below.

${ }_{37}$ Gregory Snyder, Teachers and Texts in the Ancient World (London and New York: Routledge, 2000), 146. 
Led by the evidence concerning the reading of the Law by Jews, generations of scholars agree that the origin of Scripture reading in the Christian communities can be found in the Jewish synagogue. In this traditional and still current view, it has been taken for granted that the reading of Scripture in Christian assemblies has its origins in the reading of the Law in the synagogue if only for the fact that it was the Jewish Scriptures that were read in the Christian gatherings. ${ }^{38}$ The earliest Christians, who were Jews, had passed on the custom of meeting weekly to read and interpret the Law and the Prophets as well as the practice of singing psalms and saying prayers and thanksgivings. Jews had a veneration of their scrolls that was enhanced by ritualized reading in a religious context. In time, reverence for the Word of God and the use of sacred books in religious gatherings became characteristic of Christians as well. ${ }^{39}$ It has sometimes been added as an argument for tracing back the reading of Scripture among Christians to the synagogue, that there are no clear-cut or convincing parallels for it in other religions except Judaism, apart from religions that have been influenced by Christianity. Thus, on the assumption that there was historical continuity between Jewish and Christian cultic practices, Gerard Rouwhorst, for instance, infers that the reading of Scripture in Christian gatherings has its roots in Judaism or has been influenced by Judaism in one way or another. ${ }^{40}$

Some scholars defend the same view on still another ground. They argue that education in religious communities was largely based on the reading of texts. Education in the ancient world in general was to a large extent based upon the reading of literature. In reading and explaining the Scriptures, the synagogue functioned as a school. So did Christian communities, which continued to read and explain the Scriptures in their gatherings. According to this view, Christians took this over as an educational practice; the reading of Scriptures in Chris-

${ }^{38}$ Frances Young, "Christian Teaching," in Cambridge History of Early Christian Literature, eds. F. Young, L. Ayres, and A. Louth (Cambridge: Cambridge University Press, 2004), 91.

${ }^{39} \mathrm{Ib} ., 92$.

${ }^{40}$ G. Rouwhorst, "The Reading of Scripture in Early Christian Liturgy," in What Athens has to do with Jerusalem. Essays on Classical, Jewish, and Early Christian Art and Archaeology in Honor of Gideon Foerster, ed. Leonard Rutgers (Leuven: Peeters, 2002), 305. 
tian gatherings is considered to have had its origins in the reading of Scripture in the synagogue. ${ }^{41}$

However, the view that the reading of texts in Christian communities derives from the practice of reading and studying the Law in Jewish communities does not seem to be confirmed by the data contained in early Christian literature. To decide about the origin of reading the Scripture in the gatherings of Christians it is necessary to look at the data more precisely.

\section{c. Public reading in Christian communities}

Clear evidence concerning the reading of authoritative texts during the Christian Sunday gathering first emerges in Justin's First Apology:

And on the day called Sunday, all who live in cities or in the country gather together to one place, and the memoirs of the apostles or the writings of the prophets are read, as long as time permits; then, when the reader has ceased, the president verbally instructs, and exhorts to the imitation of these good things. ${ }^{42}$

In the same work Justin refers once again to "the memoirs of the apostles" and calls them "gospels." ${ }^{33}$ It may be inferred from the way in which Justin mentions the reading of texts here as something customary that in his time the reading of the Gospels or the Prophets took place because it was already, to a certain extent, an established tradition and not because there were practical reasons to read a particular chosen passage. However, there was no set format for the readings: it could be the Gospels or the Prophets, or perhaps both. The Prophets read in Justin's congregation might well have been the Old Testament Prophets. Canon Muratori (Rome, about $180 \mathrm{CE}$ ) ${ }^{44}$ says that the Pastor of Hermas must not be read in the Church, "neque inter prophetas, completo numero, neque inter apostolos." 45 That is: neither among the Prophets, because their number has been completed (i.e., their canon

${ }^{41}$ F. Young, "Christian Teaching," 469.

42 Just., 1 Apol. 67.3.

${ }^{43}$ Just., 1 Apol. 66.3.

${ }^{44}$ For the date of Canon Muratori, much debated in recent scholarly literature, see J. Verheyden, "The Canon Muratori. A Matter of Dispute," in The Biblical Canons, eds. J.-M. Auwers and H.J. de Jonge, (Leuven: University Press \& Peeters, 2003), 487-556.

${ }^{45}$ Canon Muratori, line 4. 
has been fixed), nor among the Apostles. From the phrase "their number has been completed" it is clear that Canon Muratori is referring to the Prophets of the Old Testament. When Justin says that in the Christian gathering the Prophets were read, he is likely to refer, therefore, to the Old Testament Prophets.

By the end of the second century, Tertullian offers a description of the weekly Christian gathering in the evening. ${ }^{46}$ Speaking about the Scripture reading in the meeting of Christians he says:

We meet to read the books of God-if anything in the nature of the times bids us look to the future or open our eyes to facts. In any case, with those holy word we feed our faith, we lift up our hope, we confirm our confidence; and no less we reinforce our teaching by inculcation of God's precepts. ${ }^{47}$

In another passage Tertullian specifies that in churches the authentic writings of the apostles are read. Elsewhere he also mentions the Scripture reading in the context of a Christian assembly on the Lord's day. ${ }^{48}$

The above evidence shows that the reading of Scripture-that is, of Israelite and Jewish writings that the second-century Church would begin to call the Old Testament, and of new compositions that would later belong to the New Testament-was a regular feature of the meetings of Christians in the second century CE. About $100 \mathrm{CE}$ the author of 1 Timothy admonishes his addressee to devote himself to the public reading of Scripture. ${ }^{49}$ Since there is no evidence that there existed special meetings intended only for the reading of Scripture and preaching, it is probable that portions of the Old Testament in Greek were read in the context of the Sunday gatherings consisting of the supper and the after-supper session. As there is no indication until the third century

46 That Tertullian in Apol. 39. is referring to an evening meal is clear from his terminology: cenulae nostrae (39.14); cena nostra (39.16); convivium (39.17 and 18); per noctem (39.18); lumina (39.18); it is also clear from the fact that participants in the meal are said to invite other participants to sing a song to see if the latter are not drunk (39.18). That Tertullian is speaking here about the Eucharist can be inferred from the fact that he compares the Christians' meal with the sacramental meals of the Dionysian and Attic mysteries and the cultic banquets in honour of Serapis.

${ }^{47}$ Tert., Apol. 39.3.

48 Tert., Praescr. 36; An. 9.

491 Tim. 4:13. 
that Christians in their gatherings read the Law of Moses, ${ }^{50}$ it is most probable that in their gatherings early Christians read other books of the Old Testament, for example, the Prophets.

As far as the reading of Christian texts is concerned, apostolic letters have probably been read in Sunday gatherings of Christians since the middle of the first century. This can be inferred from 1 Thessalonians 5:27, Acts 15:31, Colossians 4:16, Revelation 1:3 and 22:18, and possibly 2 Peter 3:14-16. In the beginning, the reading of apostolic letters was not a liturgical practice. Rather these letters were read just as letters received. A letter brought by a messenger could be read by him to the addressee if he were able to do so. ${ }^{51}$ It is evident from many early Christian letters which have been preserved that they had to be heard by all members of a Christian community, the only possibility for this being in their communal gathering.

However, as has been stated before, Justin mentions the reading, not of letters, but of the Gospels and the Prophets in the assemblies of Christians on Sunday. This raises the question as to why Christians began to read literature in their community gatherings at all. This question will be treated in the following section.

To summarize the present section, the reading of literary compositions in Christian assemblies is likely to have followed the existing model of reading literature in first-century Graeco-Roman culture at large. As has been shown above, the early Christians met in private houses on Sunday evening and held their symposia in a way similar to the way other, non-Christian, groups did in those days. Accordingly, they practised public reading at their symposia and they, too, had special readers to do the reading, at least from some point of time in the second century onwards..$^{52}$ The reading of authoritative writings took place in the social session connected with the supper. That was

${ }^{50}$ Or., Hom. Jos. 4.1; Hom. Gen. 12.1. According to Melito of Sardes, On Pascha, he read Exodus 12 at Easter, but this is of course a special case; it is not the reading in a regular Sunday gathering.

51 There is an interesting parallel to this in Lucian's Symposion 21 that speaks about a certain Stoic, Hetoemocles, who sent his slave to the symposium of his friends with a tablet that contained some of his writing. The slave said that his master had ordered him to read it so that all participants of the banquet could hear it. Than he approached the lamp and read the message after receiving the permission of Aristaenetus, the host.

${ }_{52}$ Tert., Praescr. 41.8. 
the context in which apostolic and other important letters, ${ }^{53}$ Prophets and Gospels were read aloud to the community gathered for its weekly supper and conviviality. There is a close analogy between the reading of texts during non-Christian banquets and that during the Christians' gatherings connected with their weekly supper. This analogy cannot be incidental. We are witnessing here the same phenomenon in nonChristian and Christian contexts. The analogy challenges the current view, recently upheld by Wayne Meeks and Frances Young, according to which the reading of the Scriptures in the gatherings of Christians should be traced back to the Jewish practice of reading and studying the Law of Moses on Sabbath in the synagogue. ${ }^{54}$ More importantly, the reading of the Law on Sabbath in the synagogue did not take place in the context of a meal, as was the case with the reading of texts in Christian gatherings. ${ }^{55}$ Moreover, as was mentioned above, what was read in the weekly gatherings of the Christians was not the Law, whereas what was read and studied in the first-century synagogue was exclusively the Law. There is no continuity between the reading in the synagogue and that in the Church. Therefore it cannot be correct to trace the public reading of Scripture in Christian communities back to a practice of the Jewish synagogue.

\section{Development of the public Reading of Scripture in the Christian COMMUNities}

\section{a. Public reading of Scripture in the early Church in the first century}

Christians began to read apostolic epistles in their gatherings at the latest from the middle of the first century onwards. This can be inferred from 1 Thessalonians 5:27. Probably the earliest information about the actual reading of such a letter is found in Acts 15:22-35. According to

531 Clem. 47.1-3 invites the Corinthian Christians to read Paul's first letter to the Corinthian church. The author must mean that the letter should be read aloud in the community. Similarly, his own letter, 1 Clement, was possibly read aloud in the gathering of Corinthian Christians by the messengers from Rome, Claudius Ephebus, Valerius Bito and Fortunatus, mentioned in 65.1.

${ }^{54}$ F. Young, "Christian Teaching," 91-104; Wayne Meeks, "Social and Ecclesial Life of the Earliest Christians," in The Cambridge History of Christianity, vol. 1, Origins to Constantine, eds. Frances M. Young and Margaret M. Mitchell (Cambridge: Cambridge University Press, 2006), 167.

${ }_{55}$ See, e.g., Just., 1 Apol. 67; Tert., Apol. 39. 
this passage, the apostles and elders of the Jerusalem church sent Judas, Silas, Paul, and Barnabas to Antioch with the letter that contained the decision of the Jerusalem council. On their arrival in Antioch they gathered the whole community ( $\tau$ ò $\pi \lambda \hat{\eta} \theta 0 \varsigma$ ) and delivered the letter. Luke remarks that the people rejoiced at the exhortation, thus making it clear that he means that the letter was read aloud. Moreover, the address on the letter (Acts 15:23) shows that Luke meant it to be a circular letter, addressed to Christian communities in various regions. Obviously, Luke was acquainted with the phenomenon of letters being copied and circulated by messengers to several places, where they had to be read aloud to the local audiences. ${ }^{56}$

At the end of the second century, Clement of Alexandria speaks of this letter mentioned in Acts 15:30 as "the Catholic epistle of all the Apostles" that was "conveyed to all the faithful by the hands of Paul himself" and was later incorporated into the book of Acts. ${ }^{57}$ It seems that when Luke was writing Acts he knew about the existing practice of Paul and probably other apostles sending letters to be read in the churches they wanted to instruct or encourage. The letter read to the assembly in Antioch represented the voice of the apostles and Judas and Silas were sent along as the confirmation of their voice and message. The author of Colossians (about $80 \mathrm{CE}$ ) presupposes the same practice when he represents Paul sending his fellow workers along with his letter..$^{58}$

Reminiscences of readings in Christian meetings occur repeatedly in Paul's writings. 1 Thessalonians 5:27 already presupposes the reading of this letter in the gathering of the Christian congregation at Thessalonica, probably in the gathering following the weekly supper. Paul solemnly charges the Christians in the Thessalonian church to read his epistle "to all the brothers." The instructions he gives in the letter are of important relevance to all members of the church and that is why he uses the strong word غंvоркí $\omega$ (which means "to place someone under a solemn charge") to emphasize that his letter should be read to the whole congregation.

\footnotetext{
${ }^{56}$ Craig Keener, The IVP Bible Background Commentary: New Testament (Downers Grove: InterVarsity Press, 1993), 366.

${ }^{57}$ Clem. Al., Str. 4.15.

${ }^{58}$ Col. 4:7-8.
} 
Even a seemingly private letter as that of Paul to Philemon was likely intended to be read in the gathering of a Christian congregation, namely, in the church that met in Philemon's house. The letter is addressed "to Philemon our dear friend and fellow worker, to Apphia our sister, to Archippus our fellow soldier and to the church that meets in your home." 59 This seems to indicate that this personal letter was intended to be read to the whole congregation.

The main reason why Paul wanted his letters to be read publicly was the low literacy level among the members of any congregation. Most of them were unable to read. The best way to be informed of the content of Paul's message was to have it read during the church's meeting. Another reason was that the apostle could not be present continuously in all of the churches he wanted to instruct. ${ }^{60}$ In antiquity, however, letters were often regarded as a replacement for oral communication and fulfilling the functions of oral speech. ${ }^{61}$ Since letters could take the place of the sender and his message, the reading of the apostle's letter could compensate for the absence of the apostle. ${ }^{62}$

An indication showing that the reading of Paul's letters in Christian congregations had become something usual may be found in Ephesians 3:4. Here, the author says: "Reading this, then, you will be able to perceive my understanding of the mystery of Christ." Since the author is addressing here a whole congregation, the reading mentioned was probably something that took place in the congregation's gathering. It seems that with time the practice of reading Paul's letters in church meetings had established itself.

Besides the epistles written to a specific church there are letters addressed to a number of churches. A case in point is Paul's letter to the Galatians. ${ }^{63}$ Precisely which churches Paul is addressing here is a much-debated question which can be left aside here. In any case it is clear that Paul is writing to several churches founded by him. In these churches problems had arisen and he seeks to solve these with this letter. Meeks rightly points out that the plural in the address of the letter to the Galatians makes it plain that several communities are

\footnotetext{
${ }_{59}$ Phlm. 1-2.

${ }^{60}$ Moody Smith, "When did the Gospels Become Scripture?" JBL 119 (2000), 5.

${ }^{61}$ David Aune, The New Testament and Its Literary Environment (Philadelphia: The Westminster Press, 1987), 158.

${ }_{62}$ Klaus Traede, Grundzüge griechisch-römischer Brieftopik (München: Beck, 1970), 95-106.

${ }^{63}$ Gal. 1:2.
} 
expected to hear it read to them, probably in successive meetings as Paul's messenger took it from one place to the next. Possibly in some cities the letter was read in individual households rather than to "the whole assembly" gathered at one single place like Gaius' house in Corinth. ${ }^{64}$

Another instance of a letter being read in more than one congregation is 2 Corinthians. Paul addresses this letter to the church in Corinth with "all the saints throughout the whole of Achaia." ${ }^{65}$ This address seems to imply that Paul supposed his letter to be read not only in a gathering of the Corinthian church, but also in gatherings of other churches in Achaia.

A further example of a letter intended to be read in more than one church is Colossians. Colossians 4:16 states: "When this letter has been read among you, have it read also in the church of the Laodiceans; and see that you read also the letter from Laodicea." From this passage it is clear that Paul's letters, at least according to the author to the Colossians, were read more widely than in the communities to which Paul had sent them originally. Obviously, Paul's letters were read in various churches because he was considered to be a prominent apostle by them, not because he addressed a letter to them. In light of the pseudepigraphical character of the epistle to the Colossians, one cannot even be sure that it was meant to be read specifically in Colossae and Laodicea. The author may well have intended it to be read to a wider circle of churches in Asia.

The letter to the Ephesians, too, has the character of a circular letter. Its purpose is to convey to a number of churches in the province of Asia the idea of the unity of the Church composed of Jews and nonJews. From some important textual witnesses (Papyrus 46, the first hand of Sinaiticus and Vaticanus and some minuscules) "in Ephesus" in Ephesians 1:1 is absent. If "in Ephesus" was indeed not part of the original text, this might indicate that this letter "was intended as an encyclical, copies being sent to various churches." ${ }^{\prime 66}$ Other letters from other writers, such as James and 1 Peter, also have the character of a

${ }^{64}$ Wayne Meeks, The First Urban Christians (New Haven and London: Yale University Press, 1983), 143.

652 Cor. 1:1.

${ }^{66}$ Bruce M. Metzger, A Textual Commentary on the Greek New Testament, 2nd ed. (Stuttgart: United Bible Societies, 1994), 532. 
circular letter and most likely were composed to be read publicly in several churches.

Paul's letters were naturally first read in the gathering of the churches to which they were addressed. Later on, such churches proceeded to read the same letter again and even to repeat the reading of that letter regularly. There is a somewhat late testimony attesting to this in Tertullian who says that letters of Paul and other apostles are still being read in the churches to which they had been sent. ${ }^{67}$ The development is also reflected in the letter of Dionysius of Corinth to the church of Rome (ca. 170) in which Dionysius says that on Sunday the Corinthian church regularly read Clement's letter to the Corinthians. ${ }^{68}$

It was a most important development in the history of the gathering of the Christian Church that, during the first century $\mathrm{CE}$, in some Christian congregations, certain apostolic writings came to be read not only once, on their receipt, but repeatedly, for the edification of the hearers. This innovation is reflected in a passage in 1 Timothy in which the author admonishes his addressee to devote his attention to the public reading of the Scriptures. He writes: "Until I arrive, give attention to the public reading of scripture, to exhorting, to teaching." ${ }^{69}$ For "the public reading of scripture", the Greek has simply $\tau \hat{\eta}$ $\dot{\alpha} v \alpha \gamma v \omega ́ \sigma \varepsilon 1$, but from the context ${ }^{70}$ it is clear that the author is referring here to the practice of reading authoritative texts in the community gathering. The author means that the "reading", "exhorting" and "teaching" took place in the same gathering of the congregation, and that the exhortation and teaching were based on what had been read. Certain texts were now read more than once, as a basis for exhortation and teaching. Half a century later, the custom of reading authoritative writings and using the passages read as a starting point for admonitions and exhortations, is clearly attested in Justin. ${ }^{71}$ However, judging from 1 Timothy, in Ephesus, for instance, this custom had established

${ }^{67}$ Tert., Praescr. 36.1-2: "percurre ecclesias apostolicas apud quas ipsae adhuc cathedrae apostolorum suis locis praesident, apud quas ipsae authenticae litterae eorum recitantur sonantes uocem et repraesentantes faciem uniuscuiusque. Proxima est tibi Achaia, habes Corinthum. Si non longe es a Macedonia, habes Philippos; si potes in Asiam tendere, habes Ephesum; si autem Italiae adiaces, habes Romam unde nobis quoque auctoritas praesto est."

${ }^{68}$ Euseb., HE 4.23.11.

691 Tim. 4:13.

${ }^{70} 1$ Tim. 4:11-16; see, e.g., v. 11: "Pass on these orders and these teachings" and v. 16: "by doing so you will further the salvation of yourself and your hearers."

${ }^{71}$ Just., 1 Apol. 67.3 . 
itself as early as the end of the first century. ${ }^{72}$ The author of 1 Timothy expects the leaders of a Christian congregation to regularly read certain authoritative texts in the gatherings of their congregation. It follows that wherever this custom arose, a certain consensus must have existed as to what texts were fit for regular, repeated reading in the gathering of the community.

The author of 1 Timothy does not say which writings he wanted to be read in Christian congregations, but he may well have been thinking of the letters of Paul and the Old Testament Prophets, as will be argued presently.

First, letters of Paul and letters going under the name of Paul, as we have seen above, were read in gatherings of Christian communities from the middle of the first century at the latest.

Second, the author of 1 Timothy himself was not only acquainted with a number of Paul's letters, ${ }^{73}$ but he also was aware that Paul's letters were read publicly in Christian gatherings. This can be inferred from the form of the Pastoral Epistles themselves, which indicates that the author conceived them as texts to be read aloud in meetings of Christian communities, obviously to imitate the public character of Paul's letters. In fact, although each of the Pastoral Epistles is addressed to one person, all three epistles end with a benediction destined for a plural audience: "Grace be with you" or "with you all", with the personal pronoun in the plural. ${ }^{74}$ The plural suggests that the addressees of the benediction were hearers in a church gathering, at least in the fiction of these letters. If so, the author must have known the custom of reading Paul's letters in such gatherings. In that case, the final words of each of the Pastoral Epistles confirm our suggestion that the reading mentioned in 1 Timothy 4:13 comprised, inter alia, the reading of letters of Paul.

Finally, the tradition of reading apostolic epistles, including those of Paul, in Church gatherings is clearly attested about 180 CE by Canon Muratori. From the way this document speaks about the reading of "apostles" in church it is clear that he is referring to a well-established

\footnotetext{
${ }^{72} 1$ Tim. 1:3 locates Timothy in Ephesus.

${ }^{73}$ See, e.g., how he imitates Paul's letters in the beginning of 1 and 2 Tim. and Tit.

${ }^{74}$ In the Byzantine text of 1 Tim. 6:21; 2 Tim. 4:22 and Tit. 3:15 the plural of the personal pronoun is replaced by the singular form to make it consistent with the rest of the letter.
} 
custom. The apostolic letters which Canon Muratori regards as being read publicly in church gatherings include those of Paul to the Corinthians, Ephesians, Philippians, Colossians, Galatians, Thessalonians, Romans, Philemon, Titus and Timothy as well as the Catholic Epistles of Jude and John. ${ }^{75}$

All in all, then, it may be concluded that the "reading" mentioned in 1 Timothy 4:13 may well apply to the reading of Paul.

Many scholars believe that, in mentioning the reading of certain texts in Church, the author of 1 Timothy was also thinking of the Old Testament Prophets (4:13). ${ }^{76}$ This is probably correct. We know from Justin and Canon Muratori that the Old Testament Prophets were read in church gatherings. ${ }^{77}$ The possibility cannot be ruled out, therefore, that the author of 1 Timothy, too, had the reading of the Old Testament Prophets in mind. They would, of course, be read as confirmation that all that had happened with Jesus and the Church was in accordance with the Scriptures. ${ }^{78}$

It is very improbable, however, that the writings which, according to 1 Timothy 4:13, had to be read in the churches included any Gospels. True, the Gospel of Mark (and Q) already existed, but this work (these works) does (do) not seem to have circulated widely. The other gospels only began to appear at the time. Justin is the first to inform us that, in the gatherings of Christians, Gospels were read. As pointed out above, there is no evidence that in the gatherings of Christians the Law was read prior to the third century. Thus, it seems probable that, according to the author of 1 Timothy, the writings being read were apostolic letters, especially those of Paul, and Old Testament Prophets.

${ }^{75}$ Canon Muratori, lines 50-59: "Hermas...publicare vero in ecclesia populo, neque inter prophetas, completo numero, neque inter apostolos, ... potest."

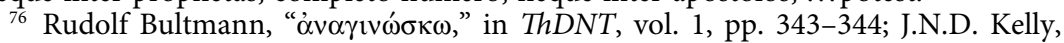
Pastoral Epistles (London: Adam and Charles Black, 1963), 105; Ralph Martin, Worship in the Early Church (Grand Rapids: Eerdmans, 1975), 70; Claude E. Cox, "The Reading of the Personal Letter as the Background for the Reading of the Scriptures in the Early Church," in The Early Church in Its Context, eds. A.J. Malherbe, F.W. Norris, J.W. Thompson (Leiden: Brill, 1998), 74-91, esp. 84-85.

77 Just., 1 Apol. 67; Canon Muratori, lines 79-80.

${ }^{78}$ Cf., e.g., 1 Cor. 15:3; 2 Cor. 3:12-16; Rom. 16:25-27; Mk. 14:27, 49, 61; Lk. 4:1721; 24:25-26; Acts 7:52. Justin Meggitt, "The First Churches: Religious Practice," in The Biblical World, vol. 2, ed. John Barton (London and New York: Routledge, 2002), 164; C.H. Dodd, According to the Scriptures: The Sub-structure of New Testament Theology (London: Nisbet, 1953). 
From 1 Thessalonians 5:27 and Colossians 4:16 it is evident that the reading of apostolic letters was at first not a "liturgical" act, unless in the limited sense that it occurred in the context of the gathering of the Christian community. The texts were not regarded as cultic or liturgical documents, let alone as Scripture, either by their authors or by their addressees. ${ }^{79}$ From the beginning, however, they did have a special status as documents of apostolic authority. As a result, they were read, not only once or twice, but repeatedly, and not only in the churches to which they had been sent, but also in other churches. The recognition of the authoritative character of Paul's letters is reflected, e.g., in 2 Thessalonians 3:14: "If anyone disobeys the instructions given in my letter, single him out, and have nothing to do with him until he is ashamed of himself." By the middle of the second century, the author of 2 Peter puts Paul's letters on a par with "the Scriptures", that is, with the Scriptures of the Old Testament. ${ }^{80}$ Thus, Paul's letters were first read as apostolic messages, then re-read and acknowledged because of their apostolic authority and theological relevance. With time, they were accepted as Scripture by ever growing circles in the Church.

It is precisely the reading of Paul's and other apostolic letters in gatherings of Christian communities that seems to have suggested the possibility of reading the Prophets of the Old Testament as well. Historically speaking, the reading of the Prophets in Christian gatherings can be explained most easily as a phenomenon that arose on the analogy of the reading of apostolic letters. We noticed the first signs of this new phenomenon in 1 Timothy 4:13: "Give attention to the public reading of Scripture," where Scripture is most likely to include the Prophets of Israel, next to the letters of Paul.

An important reason why Christians began to read the Prophets in their gatherings must have been that, as noted above, they felt the Prophets helped them to interpret Jesus' person, work and fate as part of God's plan for Israel and mankind. In the first century, Christians understood Jesus more and more in light of Israel's Prophets. For example, they said that Jesus was raised to life "on the third day, in accordance with the Scriptures," ${ }^{\prime 1}$ probably referring to Hosea 6:2.

\footnotetext{
${ }^{79}$ H. Gamble, Books and Readers in the Early Church, 206.

802 Pet. 3:16.

811 Cor. 15:4.
} 
They said that Jesus' death founded a "new covenant," ${ }^{2}$ with an expression borrowed from Jeremiah 31:31. They said that Jesus had been "handed over to death for our trespasses" 83 in words that were reminiscent of Isaiah 53:12. Thus, in reading the Prophets, Christians increasingly discovered who Jesus was and how his ministry had to be understood. In the second half of the first century, then, the reading of the Prophets began to become part of the gathering of the Christian community. ${ }^{84}$ The phenomenon is illustrated by Luke $4: 16-20$, the episode of Jesus in the synagogue in Nazareth. This episode mirrors, if anything, the situation of Luke's own days, in the last decades of the first century CE. In the gathering of a Christian community someone could take a scroll of the prophet Isaiah, read a passage and explain it by saying that this scripture had been fulfilled in Jesus. The reading of the Prophets in gatherings of Christians probably started with the reading of passages that served to sustain and develop early Christian Christology. In the time of Canon Muratori and Justin, reading of the Prophets had become a normal component of the meeting of Christians, at least in Rome.

From the above it may have become clear that in their gatherings first-century Christians began to read apostolic letters and Old Testament Prophets, and their reasons for doing so. There is no explicit evidence that they also read narrative texts such as "gospels" or "acts." Apart from Mark (and Q), which was (were) available about $70 \mathrm{CE}$ at the latest, the Gospels did not originate until the late first century or in the second century. Yet the reading of Gospels in the Church is considered so self-evident in the second century ${ }^{85}$ that the custom may go back to the practice of some communities in the late first century.

If the reading of Gospels in Church gatherings started as early as the last decades of the first century, the question can be asked what prompted the rise of this practice. There can be little doubt that there

821 Cor. 11:25.

${ }^{83}$ Rom. 5:24.

${ }^{84} 1 \mathrm{Tim}$. 4:13. Paul does not yet mention the reading of Old Testament Prophets in gatherings of Christian communities. He does say that in the gathering some people offered instruction ( $\delta 1 \delta \alpha \chi \eta \dot{v} ; 1$ Cor. 14:26). If this was teaching on Jesus' role and significance, it may have implied the reading of passages from Old Testament Prophets; but this remains speculation.

${ }^{85}$ Just., 1 Apol. 67; Canon Muratori, lines 1-9 (on Mt., Mk., Lk. and Jn. with lines 66 and 72 on writings not admitted for public reading); Acta Petri (last decades of the second century, Rome?) 20: "When Peter came into the dining-room he saw that the gospel was being read." 
was a tradition of telling stories about Jesus in gatherings of Christian congregations from his own lifetime onwards. One important reason to tell stories about Jesus was that they supported the ethical teaching transmitted in the Church. As Harm Hollander has argued, the meeting of Christians was an occasion par excellence for telling stories about Jesus in support of moral instruction. ${ }^{86}$ Other scholars have studied the transmission and codification of other synoptic material: aphorisms, sayings on the Kingdom of God, etcetera ${ }^{87}$ Much of the synoptic tradition originated as oral tradition or Church creation (Gemeindebildung) in the Christian community, especially in the Christian gathering. From about the sixties or seventies of the first century $\mathrm{CE}$ onwards, part of the oral tradition was gradually transformed into written texts, for reasons that need not be discussed here. ${ }^{88}$ The writings that were later called "Gospels" came into existence as parallels to the continuing oral tradition. Once written Gospels were available, they could be read in community gatherings. Reasons as to why any Gospels came to be read in Church gatherings may have included, first, the existing practice of reading apostolic epistles and Prophets and, second, the greater convenience of reading stories from a book rather than telling them from memory.

In a sense, the public reading in the gathering was a practical necessity. Few individual Christians possessed the sacred books and even fewer could afford to pay a scribe to make a copy for them. ${ }^{89}$ Moreover, since the great majority of each congregation's members were illiterate, many Christians could take cognizance of texts only by listening to someone who read them out in the gathering of the community. The composition, circulation, and use of Christian writings in the early Church are evident proof of Christian literacy, but the literature that survives reflects the capacities and viewpoints of Christian literati, who cannot be taken to represent Christians generally.

${ }^{86}$ Harm Hollander, "The Words of Jesus: From Oral Traditions to Written Record in Paul and Q," NovT 42 (2000), 340-344.

${ }^{87}$ See David E. Aune, "Oral Tradition and the Aphorisms of Jesus," and Birger Gerhardsson, "Illuminating the Kingdom: Narrative Meshalim in the Synoptic Gospels," both in Jesus and the Oral Gospel Tradition, ed. Henry Wansbrough (Sheffield: Sheffield Academic Press, 1991), 211-265; 266-309. The classical treatment of the subject is R. Bultmann, Die Geschichte der synoptischen Tradition (Gottingen: Vandenhoeck \& Ruprecht, 1958).

${ }_{88}$ See, e.g., H.N. Roskam, The Purpose of the Gospel of Mark in its Historical and Social Context (Leiden: Brill, 2004), esp. the literature quoted on pp. 223-230.

${ }_{89}$ Claude Cox, "The Reading of the Personal Letter," 85. 
To conclude this section, the rise of the reading of texts in the first century Christian community gatherings can be historically accounted for from four impulses. First of all, reading of texts was a standard element of post-supper symposia in the Graeco-Roman world in general. Second, ever since the days of Paul, apostolic letters were read in Christian gatherings. Once such letters were read, other texts, such as Prophets and Gospels, could be read as well. Third, the Old Testament Prophets began to be read to support Christological teaching. Fourth, Gospels began to be read as a continuation of the story-telling about Jesus. Initially, this story-telling was not based on written texts and served the moral instruction in the Christian gathering; later the stories were written down. From then on, they could be read from written texts such as the "Gospels," and this is what actually happened.

\section{b. Public reading of Scripture in the second century}

In the second century letters of Paul continued to be read in gatherings of Christians. Tertullian testifies to this when he writes that passages from Paul's letters warning against bigamy were being read in assemblies presided over by bishops who themselves committed bigamy.${ }^{90}$ In his De praescriptione haereticorum (about $200 \mathrm{CE}$ ), Tertullian claims, probably with some rhetorical exaggeration, that in cities like Corinth, Philippi, Thessalonica, Ephesus and Rome, the autographed copies of the letters Paul addressed to the Christians there, were still being read in the gatherings of Christians. ${ }^{91}$ This shows at least that Paul's letters were continuing to be read in a number of churches throughout the Mediterranean, although this did not necessarily include the autographs.

Apart from the letters of Paul, other apostolic letters were read in churches in the second century. Eusebius states of the General Epistles of James, Jude, 2 Peter and 2 and 3 John, that "although they were disputed, were nevertheless constantly used publicly in very many churches." 92

90 Tert., Mon. 12.6.

91 Tert., Praescr. 36.1-2.

${ }_{92}$ Euseb., HE 3.31 (my translation). Eusebius enumerates the disputed books at issue in $H E$ 3.25.3. 
In their meetings, Christians read not only letters written by, or in the name, of apostles, but also writings by other Christian authors. Dionysius of Corinth states that on Sundays his church regularly read 1 Clement and a letter of the Roman bishop Soter, both addressed to the Corinthian church. Dionysius says in a letter to Soter: "Today being the Lord's day, we kept it as a holy day and read your [Soter's] epistle, which we shall read frequently for its valuable advice, like the earlier epistle which Clement wrote on your behalf." ${ }^{\text {93 }}$

Another reference to the public reading of an authoritative text in the second century occurs in the sermon 2 Clement: "So then, brothers and sisters, now that we have heard the God of Truth, I am making a request to pay attention to what has been written, so that you may save yourselves and the one who is reading this to you." ${ }^{4}$ With the words "now that we have heard the God of truth" and "pay attention to what has been written" this passage refers to the reading out of a section chosen from apostolic or prophetic writings. ${ }^{95}$ It is not clear which "Scriptural" passages were read, nor can it be ascertained whether the reader of the sermon, 2 Clement itself, was also the reader of the Scriptures.

It may have been with a view to the public reading of letters in the gatherings of their community that the Christians of Philippi asked Polycarp, and subsequently received from him, collected letters of Ignatius. Polycarp sent them these letters with the following note: "We are sending you herewith the letters of Ignatius that he sent to us, along with all the others we had with us, just as you directed us to do. These accompany this letter; you will be able to profit greatly from them." ${ }^{96}$ Polycarp points out that the content of the letters could serve the believers' edification towards the Lord, obviously supposing that Ignatius' letters would be read in the gatherings of the Philippian church.

${ }^{93}$ Euseb., HE 4.23 (tra. G.A. Williamson).

942 Clem. 19.1.

${ }^{95}$ See J.B. Lightfoot, The Apostolic Fathers. Part 1. S. Clement of Rome, vol. 2 (London: MacMillan, 1890), 257, note to line 14; K. Wengst, Didache (Apostellehre), Barnabasbrief, Zweiter Klemensbrief, 216: “... die Mahnung, 'auf das Geschriebene (...) achtzugeben,' kann nicht gut anders verstanden werden denn als Hinweis auf eine vorangegangene Schriftlesung."

${ }^{96}$ Poly., Phil. 13.2. 
There is also evidence for the public reading of writings of another genre: apocalypses. A case in point is the Revelation of John, probably written at the beginning of the second century CE. ${ }^{97}$ The book of Revelation presents itself as a letter addressed to the seven churches in Asia Minor. ${ }^{98}$ The whole epistolary form of Revelation (1:4) as well as Revelation 1:3-8, 11, chapters 2 and 3, and 22:18 reflect the author's supposition that the book would be read in Christian communities, possibly on Sunday, the day already distinguished from other week days by its designation as "the day of the Lord" (1:10). ${ }^{99}$ The first of the seven beatitudes concerns the person who read the text of Revelation in a Christian assembly and his hearers: "Blessed is the one who reads aloud the words of the prophecy, and blessed are those who hear and who keep what is written in it" (Rev. 1:3). The passage just quoted attests that John's Apocalypse was meant for public reading in gatherings of Christian churches. ${ }^{100}$

From Canon Muratori it is clear that later in the second century the Apocalypse of John belonged indeed to the books that were read out regularly in Christian communities. Canon Muratori goes on to say, "some people among us do not want the Apocalypse of Peter to be read in Church." This shows that at least some people accepted the reading of the Apocalypse of Peter in Church. The same applies to the Pastor of Hermas, the public reading of which in Church was accepted by some people, but rejected by Canon Muratori. ${ }^{101}$ This ambiguous situation is confirmed by Eusebius, who states that some authorities in the second century rejected the Pastor of Hermas, whereas others judged it indispensable, especially to those in need of elementary instruction:

${ }^{97}$ H.J. de Jonge, "The Function of Religious Polemics: The Case of the Revelation of John versus the Imperial Cult," in Religious Polemics in Context, eds. T.L. Hettema \& A. van der Kooij (Assen: Van Gorcum, 2004), 276-290, esp. 276-277. This author dates Rev. to 114 C.E. Other authors opt for earlier dates.

${ }_{98}$ J. Leipoldt and S. Morenz, Heilige Schriften (Leipzig: VEB Otto Harrassowitz, 1953), 107.

${ }_{99}$ K. Huber and M. Hasitschka, "Die Offenbarung des Johannes im Kanon der Bibel. Textinterner Geltungsanspruch und Probleme der kanonischen Rezeption," in The Biblical Canons, eds. J.-M. Auwers and H.J. de Jonge (Leuven: University Press \& Peeters, 2003), 611.

100 For an analogy to this phenomenon, see the Syriac Apocalypse of Baruch, written around $100 \mathrm{CE}$, which testifies to the practice of reading apocalyptic writings in the meetings of Jewish congregations: "When therefore you receive this my epistle, read it in your congregations with care" (2 Bar. 86.1-2).

101 Canon Muratori, lines 71-78. 
"Hence-Eusebius says-we know that it has been used before now publicly in a number of churches." 102

Interestingly, the Pastor of Hermas itself refers to the necessity of reading this book, the Pastor, to the Church in Rome:

You will write two little books, sending one to Clement and the other to Grapte. Clement will send his to the foreign cities, for that is his commission. But Grapte will admonish the widows and orphans. And you will read yours in this city, with the presbyters who lead the Church. ${ }^{103}$

This is another indication that an apocalyptic work like the Pastor of Hermas was used for public reading in the Church in the second century.

Apart from letters and apocalypses, the writings read in gatherings of second-century churches could probably also include accounts of Christian martyrdoms. The Martyrdom of Polycarp, usually dated to the middle of the second century CE, states: "When you have learned these things [that is, the contents of the Martyrdom itself], send our letter to the brothers who are further afield, that they may also glorify the Lord." 104 The practice of reading martyrdoms in church is also attested in the Martyrdom of Perpetua and Felicitas. This document is generally thought to have been written not long after 203, the year in which Perpetua died as a Christian martyr somewhere in North Africa, but it seems to mention the reading of martyrdoms in Church gatherings at least as an existing possibility. The author of the literary framework of this work says that "we hold in honour and acknowledge new prophecies and visions such as were promised [namely, in Joel 2:28, as quoted in Acts $2: 17-18] \ldots$ We also deem it imperative to set them forth and to celebrate them by reading them out (lectione celebramus) for the glory of God." 105 This passage betrays that the author knew of the reading of older apocalyptic writings like the Apocalypse of John and the Pastor of Hermas in gatherings of African churches. But the author regards the Martyrdom of Perpetua and Felicitas as a recent apocalypse, which in his opinion deserves no less to be read publicly in churches in Africa. From the passion with which the author pleads for the reading of this particular Martyrdom during Church services

\footnotetext{
102 Euseb., HE 3.3 (my translation).

103 Herm., Vis. 2.8.4 (tra. Bart Ehrman, p. 193).

104 M. Polyc. 20 (tra. Bart Ehrman).

105 M. Perp. 1.5.
} 
it may be gathered that this was not done yet. But this plea also shows that, in principle, the reading of martyrdoms during Church services was considered a good possibility. It should be added that the first official ecclesiastical statement to the effect that martyr acts could be read during Church services is a decision of the Concilium Hipponense of $393 .{ }^{106}$

Clear information about the reading of Gospels during the gatherings of Christians comes, as we have seen above, from Justin Martyr. Justin remarks that in the gathering on Sunday "the memoirs of the apostles or the writings of the prophets are read, as long as time permits." 107 The phrase "as long as time permits" implies that the reading was not of a fixed length.

Precisely what the phrase "as long as time permits" means is not clear. According to one interpretation, it means, "until all the Christians had arrived for the Eucharist." ${ }^{108}$ But this would mean that as soon as all members had arrived, time would no longer allow for the reading to continue. This is a strange supposition, for it implies that the latecomers could do without hearing the reading of the Gospels and Prophets and that listening to the reading of Scriptures was optional. The phrase "as long as time permits" is more likely to have a much more practical meaning. In Justin's church, the reading of Gospels and/or Prophets was followed by a speech, including ethical exhortations and prayers; only then would the supper begin. After the meal, deacons brought food to those members of the church who had not been able to attend the supper, namely, the sick, the disabled and the prisoners. The supper and the distribution of food naturally took some time. In order to allow everybody, including the deacons, to come home not too late at night, the supper had to begin in time. This imposed limitations on the duration of the reading of Gospels and Prophets which preceded the supper.

Canon Muratori notices that some books "cannot be read publicly to the people in the Church" (line 78) and that "some of us are not willing

\footnotetext{
${ }^{106}$ I wish to thank Professor J. den Boeft (Leiden) for bringing this synodal decision to my attention. For the text, see C. Munier (ed.), Concilia Africae A. 345-A. 525 (CCLS 149; Turnhout: Brepols, 1974), 248-253. For the text of Passio Perpetuae, see C.J.M.J. van Beek, Passio Sanctarum Perpetuae et Felicitas, vol. 1 (Nijmegen: Dekker \& van de Vegt, 1936).

107 Just., 1 Apol. 67.3 (tra. L.W. Barnard).

${ }_{108}$ R. Beckwith and W. Stott, The Christian Sunday. A Biblical and Historical Study (Grand Rapids: Baker Book House, 1980), 93.
} 
that (certain writings) be read in Church" (line 72). This implies that other books were actually read publicly in Christian assemblies; Canon Muratori does not say that people objected to these texts being read in Church. This applies, inter alia, to the Gospels of Mark, Matthew, Luke and John. The custom of reading out these Gospels in gatherings seems to have been self-evident to the author of Canon Muratori.

The situation with regard to the reading of the Gospels in the Church, as reflected in Canon Muratori, is confirmed by Irenaeus. This author states: "The entire Scriptures, that is, the Prophets and the Gospels, can be clearly and unambiguously heard by all in the same way, although all do not believe them." ${ }^{109}$ This passage shows that in Irenaeus' church the Gospels were read publicly. It also confirms the information we found in Justin to the effect that Old Testament Prophets and Gospels were the books that were normally read in Church gatherings.

Furthermore, the reading of Gospels in gatherings of Christians is attested by the Acts of Peter, written between 180 and 190 CE. Here Peter is said to have entered the house of Marcellus. When he came into the dining-room (triclinium), "he saw that the gospel was being read. And rolling it up he said, 'Men, who believe in Christ and hope in him, you shall know how the holy Scriptures of our Lord must be explained.... Now I will explain to you that which has been read to you." 110 This account illustrates the established practice of reading from a Gospel in the Christian gathering.

Finally, some testimonies may be mentioned which allude to the reading of Scriptures in gatherings of Christians in the late second century without specifying the type of writing that was read. In his Against Heresies, dating from the years 180-185 CE, Irenaeus argues that true apostolic knowledge is obtained, inter alia, through the reading of Scriptures and the careful explanation in agreement with them. ${ }^{111}$ The reading of Scriptures and their exposition are linked

${ }^{109}$ Iren., Haer. 2.27.2: "Cum itaque universae Scripturae et propheticae, et evangelicae in aperto et sine ambiguitate, et similiter ab omnibus audiri possint etsi non omnes credunt,...."

110 Acta Petri 20 (tra. J.K. Elliott, p. 413).

111 Iren., Haer. 4.33.8: "This is true Gnosis: the teaching of the apostles, and the ancient institution of the church, spread through out the entire world, and the distinctive mark of the body of Christ in accordance with the successions of bishops, to whom the apostles entrusted each local church, and the unfeigned preservation, coming down to us, of the scriptures, with a complete collection allowing for neither addition nor subtraction; a reading without falsification and, in conformity with the 
together here. Since the exposition surely took place in the gathering of the community, one may see here an allusion to the public reading of certain apostolic writings in the meeting of Christians.

Somewhat further on in the same book, in refutation of certain Valentinians who alleged that the prophets uttered some predictions under the inspiration of God, Irenaeus mentions the reading of Scriptures again:

So many are the differences among them on one point, and so many the varied opinions they profess on the same scriptures! When one and the same text has been read, all furrow their brows and shake their head, saying, "This is a very profound word, and not all understand the greatness of the meaning it contains; therefore silence is the greatest thing for the wise." 112

The reading of Scriptures mentioned probably took place during the public service in church where Valentinians heard them read aloud.

In about $200 \mathrm{CE}$, Clement of Alexandria writes about the human soul that tries to approach God by means of several acts of devotion: "A soul giving thanks always for all things to God, by righteous hearing and divine reading, by true investigation, by holy oblation, by blessed prayer; lauding, hymning, blessing, praising, such a soul is never at any time separated from God." ${ }^{113}$ Most likely, Clement is describing here rites that took place during the service of the Christian congregation. Reading and hearing of the divine Scriptures were part of those rites.

At about the same time, Tertullian provides a brief description of the Christian assembly in his Apologeticum. Speaking about the reading of Scriptures in the gathering of Christians he writes:

We assemble to read our sacred writings, if any peculiarity of the times makes either forewarning or reminiscence needful. However it be in that respect, with the sacred words we nourish our faith, we animate our hope, we make our confidence more steadfast; and no less by inculcations of God's precepts we confirm good habits. ${ }^{114}$

scriptures, and interpretation that is legitimate, careful, without danger or blasphemy" (tra. Robert M. Grant).

${ }_{112}$ Iren., Haer. 4.35 .4 (tra. Robert M. Grant).

113 Clem. Al., Str. 6.113.3 (ANF).

114 Tert., Apol. 39.3. For another reference in Tertullian to the regular reading of Scriptures in Church, see An. 9.4: "Whether it be in the reading of Scriptures, or in the chanting of Psalms, or in the preaching of sermons, or in the offering up of prayers, in all these religious services matter and opportunity are afforded to her of seeing 
It is interesting to see Tertullian presenting a pastoral purpose of the reading. Through the hearing of Scripture, faith is nurtured, hope is inspired and piety and discipline are strengthened. It can be inferred from Tertullian that at the turn of the second to the third century the reading of Scripture had become an ordinary phenomenon in the assembly of Christians, at least in certain places.

From the material reviewed above it is clear that in the second century the public reading of Scriptures became a customary component of the services of Christian congregations, although practice may have differed from place to place and from time to time. Among the writings used for public reading were apostolic letters, including those of Paul, apocalypses, martyrdoms, Old Testament Prophets and Gospels. The public reading of these texts was meant to edify the audience in various ways. Whereas at Graeco-Roman symposia the reading of texts normally took place after supper, the evidence in Justin and Tertullian suggests that Christians reversed the order and put the reading before the common supper. The easiest explanation of this reversal is that it allowed those who were not yet full members of the congregation, the catechumens, to participate in the service until the common supper began, from which moment on they were excluded, although probably not until the second century. ${ }^{115}$ If the reading of Scripture took place after supper it was difficult to arrange for the catechumens to arrive precisely in time to hear the reading. It was, thus, much more practical to put the reading together with the exposition before the supper.

\section{c. Public reading of Scripture in the third century}

At several places, in the third century, the gatherings of Christians came to be held daily. As a result, the reading of Scripture became a daily practice. Origen, for instance, says that Christians should come to satisfy their thirst for the Word and eat it every day and not only on feast days. ${ }^{116}$ Here we learn for the first time that the Law is read in the Christian assembly. The reading of Scripture was performed both

visions." (tra. Peter Holmes in ANF). "Her" refers to a sister in a Montanist church who had prophetic gifts.

115 Did. 9.5.

116 Or., Hom. Gen. 10.1, 3. 
for the initiated and catechumens, for Origen states that catechumens heard the Law of God every day. ${ }^{117}$

During the third century the second-century custom of reading Pauline and other apostolic epistles, Gospels and Old Testament Prophets continued, but in addition to these writings other books came to be read: the Law, Psalms, and historical books of the Old Testament. From Origen's homilies we can infer that the following books were read in Church services: the Law, Joshua, Judges, 1 Samuel, Psalms, various Old Testament Prophets, Gospels and Pauline Epistles. Hippolytus, too, mentions the reading of Psalms that preceded his sermons. ${ }^{118}$ Eusebius speaks about the public reading of the so-called Catholic or General Epistles:

These things are recorded in regard to James, who is said to be the author of the first of the so-called Catholic Epistles. But it is to be observed that it is disputed; at least, not many of the ancients have mentioned it, as is the case likewise with the epistle that bears the name of Jude, which is also one of the seven so-called Catholic Epistles. Nevertheless we know that these also, with the rest, have been read publicly in very many churches. ${ }^{119}$

Eusebius also states that 1 Clement continued to be read in churches from the time it was sent to the Corinthians down to his own days: "Clement has left us one recognized epistle.... I have evidence that in many churches this epistle was read aloud to the assembled worshippers in early days, as it is in our own." 120

According to Origen, the reading took place in the following way. A reader read successive passages of one book day by day, in the order of the book; each day he continued reading from where he had finished the day before. After the reading, the preacher gave an exposition of what the reader had read. ${ }^{121}$ In one of his expositions, Origen says that "the reading of today is the continuation of yesterday's reading and since we have little time we are going to explain only a small

117 Or., Hom. Jos. 4.

118 Alistair Stewart-Sykes, "Hermas the Prophet and Hippolytus the Preacher: the Roman Homily and Its Social Context," in Preacher and Audience: Studies in Early Christian and Byzantine Homiletics, eds. Mary Cunningham and Pauline Allen (Leiden: Brill, 1998), 61.

119 Euseb., HE 2.23.

120 Euseb., HE 3.16 (tra. G.A. Williamson).

121 Or., Hom. Num. 15.1. 
amount." ${ }^{122}$ The practice of continuous reading may have been the reason why for some people the reading of Scripture became slightly boring. Several sources say that people attending services in Church paid little or no attention to the reading of Scripture. Origen says that "some people do not even patiently wait while the texts are being read in Church. Others do not even know if they are read, but are occupied with mundane stories in the furthest corners of the Lord's house."123 The author of the Syriac Didascalia (third century) complains about the same problem: people fall asleep or gossip away about some other matter and thus they do not listen to what is spoken or read in the fellowship of the assembly on Sunday. ${ }^{124}$

Among the writings used for the reading of Scripture in Church there are two that have not been mentioned so far: the Gospel of Peter and Tatian's Diatessaron. As to the former document, Eusebius relates that Serapion, bishop of Antioch, was confronted with the issue of whether the Gospel of Peter should continue to be read by Christians in Rhossus. At first, Serapion had allowed the reading of this book, but he later forbade it because he found traces of Docetism in it. ${ }^{125}$ Possibly Serapion intended to forbid in particular the public reading of this Gospel in the Church, not its being read in private.

Tatian composed the Diatessaron, a harmony of the four Gospels, about $170 \mathrm{CE} .{ }^{126}$ It was used for public reading in Syrian churches from that time until the fifth century CE when the four separate Gospels replaced it. ${ }^{127}$ Though Tatian was an Encratite, his Gospel harmony was used in the services of many congregations of the regular Church.

The reading of Scripture also took place during Christian festivals and other types of gatherings such as baptismal rites and the commemoration of the deaths of martyrs. In certain places, such as Syria, a vigil was held before Easter from Saturday evening to dawn on

122 Or., Hom. Lev. 7.1.

123 Or., Hom. Ex. 12.2 .

${ }^{124}$ Did. ap. 3.6.

${ }^{125}$ Euseb., HE 6.12. It is not absolutely clear from this passage that Serapion is opposing the reading of the Gospel of Peter publicly in Church. He may have intended to protest against private reading of the book.

${ }_{126}$ William L. Petersen, Tatian's Diatessaron (Leiden: Brill, 1994), 426-427.

127 Theodoret of Cyrrhus, Treatise on Heresies 1.20; W.L. Petersen, Tatian's Diatessaron, 41-43; P.R. Ackroyd and C.F. Evans (eds.), The Cambridge History of the Bible, vol. 1, From the Beginnings to Jerome (Cambridge: Cambridge University Press, 1970), 567. 
Sunday. The order of this Easter vigil included readings from Scripture and a homily. ${ }^{128}$ The Didascalia says that during the Easter vigil the Scriptures and the Psalms were read. ${ }^{129}$ The Apostolic Tradition gives an account of the reading to the catechumens during the Easter vigil in the night preceding baptism on Sunday morning. ${ }^{130}$ The author of the Didascalia writes that Christians, in accordance with the Gospel and the power of the Holy Spirit, should gather together in the cemeteries and read the Holy Scriptures and perform their ministry and supplications to God. ${ }^{131}$ Thus, during the third century the Scriptures were read on more occasions than just the Sunday gathering.

\section{THE OFFICE OF READER}

The office of "reader" or "lector" has arisen within the Church at the end of the second century: Tertullian in North Africa is the first to attest the existence of the function of reader. ${ }^{132}$ The office surely originated earlier than this testimony.

Before the rise of the office of reader, ordinary members of the community who were capable of reading must have performed the reading of Scripture in Christian gatherings. Testimony of this may be found in Revelation 1:3 which pronounces a blessing upon "the one who reads." Obviously, this reader has no official capacity, for here the par-

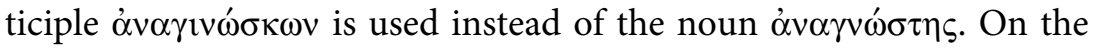
other hand, in 1 Timothy 4:13, the responsibility for reading is laid upon the community leader, that is, "Timothy." Both texts come from Asia Minor and from approximately the same time. At first sight, these writings seem to differ as to the question of who performed the reading in the gathering. But this is probably due only to the character of 1 Timothy, in which "Paul" charges "Timothy" with many sorts of pastoral and liturgical tasks. 1 Timothy does not exclude that the reading was undertaken by people other than the head of the community.

\footnotetext{
${ }_{128}$ Stuart Hall, Doctrine and Practice in the Early Church (Philadelphia: Fortress Press, 1973), 19.

${ }_{129}$ Did. ap. 5.19.

130 Trad. ap. 20.

131 Did. ap. 6.22.

132 Tert., Praescr. 41.8.
} 
As to "the reader" who "must understand" in Mark 13:14 (Mt. 24:15), there is little reason to assume that this is a person who read the Gospel in Church. In fact, what has to be understood here should be understood, not by the lector alone, but by anybody who reads about "the desolating sacrilege" in Daniel 11:31: in light of Daniel 11:31 one should understand that the presence of the Romans in the Jerusalem temple is a sign of the end. Mark 13:14 does not refer to a "liturgical" reader, therefore; it refers to anybody who reads about the "desolating sacrilege" in Daniel 11:31.

Because of the difficult legibility of ancient handwriting, even of book scripts, reading in antiquity was a hard task. ${ }^{133}$ As a result, people who could read a book at sight were admired. ${ }^{134}$ For the same reason, public reading in the ancient world called for some technical accomplishment. It is understandable, therefore, that churches gradually preferred not to rely on the unpredictable presence of someone who was able to read in public, but appointed some educated and trained person in the congregation to serve as official reader. The sociocultural counterpart and analogy of this reader was the reader acting at Graeco-Roman banquets. ${ }^{135}$

Justin's account of the Sunday gathering mentions "the moment when the person who reads [namely a passage from a Gospel or a Prophet] stops reading." ${ }^{36}$ But Justin does not use a noun designating an office and it cannot be deduced from this passage that he already knew the office of lector. Tertullian, however, is acquainted with the reader as an official of the Church. ${ }^{137}$

From the third century onwards the reader appears as an official functionary who, at various places, assists bishops and other clergy in conducting the service of Christian congregations. The ceremony of the appointment of a reader is attested in the Apostolic Tradition: "A reader is installed as the bishop hands him a book. He has no laying on of hands." ${ }^{138}$ Origen states that the reader became a member of the

133 P. Achtemeier, "Omne Verbum Sonat: The New Testament and the Oral Environment of Late Western Antiquity," 17.

134 Petr., Satyr. 75.

135 See, e.g., Nep., Att. 13.3; 14.1; Plin., Ep. 9.17. The phenomenon of the professional reader has been discussed in the beginning of the present chapter.

136 Just., 1 Apol. 67.4.

137 Tert., Praescr. 41.8.

138 Trad. ap. 11 (tra. A. Stewart-Sykes). Cf. Euseb., HE 6.43.11 (Rome, 251 CE). 
clergy in Caesarea. ${ }^{139}$ On the other hand, when Origen enumerates clergy, he does not always mention the reader. ${ }^{140}$

The appointment of lectores is also attested in Carthage. ${ }^{141}$ Cyprian writes that he ordained a certain Saturus as a reader, a man who had been used twice before to read the Scriptures on Easter day. He also speaks about a young Christian, Aurelius, who became twice a confessor and, as a result, merited a higher rank in the clerical order. However, in view of Aurelius' young age Cyprian thought it well for him to begin in the office of reader and use his voice for declaiming the divine Scriptures. ${ }^{142}$ Cyprian regarded the function of reader in the Church as a noble office:

This man [Celerinus] comes to us, my dearly beloved brothers, thus highly favoured by the Lord; he comes illustrious with the testimonyand indeed wonderment - of his very persecutor. There is no place more proper for him to be stationed than on the pulpit, that is to say on the tribunal of the church. In this way, thanks to his elevated position, he may be readily seen by the whole congregation in a manner befitting the brilliance of his honour and there he may read to them those commandments and the Gospel of the Lord which he follows with such fortitude and faithfulness. My hope is that the voice which has confessed the Lord may be daily heard proclaiming the words which the Lord has spoken. There may be, to be sure, higher grades to which one can rise in the Church, but the task by which the confessor can render most profit to his brethren is by reading with his own lips the Gospel. Those who hear may thereby imitate the faith of the reader. ${ }^{143}$

According to Cyprian, the church in Carthage did well to ordain confessors in the rank of reader. His idea was that when those who heard the Scriptures from the lips of a confessor, they would be inspired to follow the example of the confessor's faith. In times of persecution the leadership naturally wanted to encourage all members to stand firm and become good confessors. One of the means to pursue this goal was to assign the office of reader to confessors who had proven themselves in persecution and whose faith and perseverance could serve as examples for those who heard them read the Scriptures.

139 Or., Hom. Num. 15.1.

40 Or., Hom. Jer. 14.4.9; Orat. 28.4.

${ }^{141}$ Cypr., Ep. 29.1 (Carthage, ca. $250 \mathrm{CE}$ ).

${ }_{142}$ Cypr., Ep. 38.2.

${ }^{143}$ Cypr., Ep. 39.4.1-2 (tra. G.W. Clarke). 
In the Didascalia it is not a reader, but the bishop himself who performs the reading from the Scriptures during the Church gathering. He does so in a sitting position. ${ }^{144}$ By contrast, the so-called Apostolic Church Order, probably composed in Egypt at the end of the third century, allows for the possibility of a bishop to be illiterate, but presupposes the presence of a reader in that case. The reader should be tested before being appointed. He should dispose of a great number of moral and other qualities, among which is his habit of arriving early in church on Sunday. ${ }^{145}$ In the middle of the third century, the Christian Latin poet Commodianus composed a poem in which he gives instructions concerning the way the readers in the Christian community should live. They should devote themselves to study and give an example of a virtuous life to the world. They should give honour to the elders in the church, and imitate Christ their master, since they are the lamps of Christ. ${ }^{146}$ From Cyprian and Commodianus it becomes clear that in the third century the office of reader in the Christian assembly became important owing to the fact that it was mainly through the reader that the rest of the assembly could hear and come to know the Scriptures.

\section{Conclusions}

In the twentieth century, scholars who studied the Christian Sunday evening gathering used to trace its pattern back to a supposed Jewish synagogue service. As a result, they were forced to assume that the reading of Scripture as practised in the weekly gathering of Christians was the continuation of the reading of the Law and the Prophets in synagogal services. The present chapter has shown that the reading of Scripture in the Christian gathering is more likely to have its origins in the custom of reading literary works and other writings during the symposium part of banquets in the Graeco-Roman world. Such banquets were held by non-Jews and Jews alike.

In the first century CE the reading of texts in the Christian gathering first had the form and function of the reading of apostolic epistles as "letters received." Subsequently, Christians began to read the same

144 Did. ap. 2.58.

145 Can. apost. 16; 19.

146 Comm., Instr. 26. 
letters repeatedly; several letters were also read in other congregations than the ones to which they had been addressed originally. With time, Christians also began to read portions from the Old Testament Prophets in their assemblies. Once one or more Gospels had been written, these, too, came to be read in gatherings of Christian communities, in some places perhaps from the end of the first century onwards. During the second century various kinds of Christian writings were read publicly in Christian churches: letters of apostles and other Christian authors, apocalypses, Gospels and Prophets. It seems that the public reading of the Law in Christian gatherings did not begin until the third century CE. Finally, this chapter entered into the rise of the office of reader in Christian congregations. Readers were used at banquets all over the Graeco-Roman world. In Christian congregations texts were read at first by members who were capable of doing so. By the end of the second century, the function of reader became an office in the Church. It soon came to be the first or lowest rank in the career path of ecclesiastical office holders. 


\section{PREACHING IN THE GATHERING OF THE EARLY CHURCH}

\section{INTRODUCTION}

The history of preaching in the first centuries of the Christian Church has not yet been investigated satisfactorily in critical scholarly literature. This chapter examines the origin and development of early Christian preaching and teaching. When writing about the preaching of the early Church a distinction has to be made between the preaching of missionary character and the preaching within the gatherings of early Christian communities, both on Sunday evening and on other days of the week. However, only the evidence concerning the preaching in Church gatherings will be examined.

\section{The origin of Preaching in the Christian gathering}

The gatherings of Christians in the first century took place in private houses and centred round the supper. This is the social context in which the Christian homily originated. In the Graeco-Roman world philosophical discourses, speeches and homilies were often pronounced in private, informal settings, for example, at after-dinner symposia. In discussions of Hellenistic symposia several types of oral communication are mentioned: conversation, speeches, teaching and storytelling. ${ }^{1}$ An example of a speech presented at a symposium is the one given by Eumolpus on the frivolity of women at the banquet of Trimalchio in Petronius' Satyrica. ${ }^{2}$ Oral presentations and conversations were also an essential part of Christian symposia. Paul says that, at the after-supper session of the Corinthian congregation, participants would contribute, inter alia, a lesson, a revelation or an interpretation. ${ }^{3}$ This suggests that Christians conformed to the tradition held by

1 See, e.g., Aul. Gel., NA 19.9.4; Suet., De vit. caes. 74.

2 Petr., Satyr. 110.6-112.

31 Cor. 14:26. Paul also mentions here "a tongue", that is, a form of ecstatic speech, not mentioned in other Graeco-Roman symposiastic literature. 
non-Christian contemporaries of enlivening their symposia with talks, exposés, instruction and other oral contributions.

Plutarch in his Quaestiones conviviales informs us about his view of the function of speeches held at symposia. He says that the speeches are a good means to prevent the participants from becoming heavily drunk and from having their minds dissipate completely under the influence of wine. As to the topics for speeches and discussions, Plutarch recommends choosing them from history, contemporary events, philosophy and religion and to treat them in such a way as to encourage the audience towards great deeds and charity. ${ }^{4}$

Speeches and talks were also given at symposia of Graeco-Roman religious associations. The priests of the society of worshippers of Bacchus, the Iobacchoi, in Athens in the middle of the second century CE, for instance, gave homilies $(\theta \varepsilon o \lambda o \gamma i \alpha 1)$ at fixed times at the after-supper symposium. No other participant of the symposium of the Iobacchoi was allowed to deliver a speech unless the priest or vicepriest had given permission; otherwise the offender would be liable to a fine of thirty drachmas for this association. ${ }^{5}$ This evidence shows that participants at the symposium of the Iobacchoi were anxious to give speeches and for this reason the leadership had to take measures to prevent disorder. In much the same way, Paul in his letter to the Corinthian Christians gives them rules to regulate oral presentations in their gathering:

If anyone speaks in a tongue, let there be only two or at most three, and each in turn; and let one interpret. But if there is no one to interpret, let them be silent in church and speak to themselves and to God. Let two or three prophets speak, and let the others weigh what is said. If a revelation is made to someone else sitting nearby, let the first person be silent. For you can all prophesy one by one, so that all may learn and all be encouraged. And the spirits of prophets are subject to the prophets, for God is a God not of disorder but of peace. ${ }^{6}$

According to Paul, the number of speakers had to be restricted. If they spoke in tongues, only two or at most three were allowed to speak, and not without their utterances being interpreted in comprehensible language. Even if speakers expressed themselves in articulate language

${ }^{4}$ Plut., Quaest. conv. 1.614b, 4.660c.

${ }^{5}$ J. Kirchner (ed.), Inscriptiones Graecae II $^{2}$ I, 1-2 (Berlin: Reimer, 1913), n. 1368, vv. $115,107-110$.

${ }^{6} 1$ Cor. 14:27-33. 
(prophecy), only two or three speakers were allowed to take the floor and what they said had to be considered critically by others. Participants had to speak one by one, not at the same time. In Paul's view, the speakers could include women, although under certain restrictions. ${ }^{7}$ According to an interpolation in Paul's text, women had to keep silent during the Christian gathering. ${ }^{8}$

Speeches were meant to entertain the participants in the symposium and serve as contributions to a conversation or a discussion. That is why Plutarch also calls them o $\mu 1 \lambda i_{i \alpha 1 .}{ }^{9}$ The word o $\mu 1 \lambda i i^{\alpha} \alpha$ is related to the verb o $\mu \imath \lambda \varepsilon \dot{\varepsilon} \omega$ which means "to be in company with, to converse with, to speak to, to address, to talk." The noun means "conversation", "instruction" or "lecture." 10 It is no accident that from the end of the first century CE onwards, in Christian writings, this common Greek term came to be used to designate a sermon. ${ }^{11}$ This shows that the origins of the Christian sermon are probably lying in the conversations in the after-supper assemblies of Christians. In Acts 20:11, when Luke writes about Paul's speech in the gathering after the celebration of the Eucharist in Troas, he is already using the verb o $\mu \imath \lambda \varepsilon i v$. In this context ó $\mu \lambda \eta \dot{\sigma} \sigma \alpha \varsigma$ probably means "after delivering a speech," 12 not "after conversing with those present." ${ }^{13}$ The Christian adoption of the term o $\mu \imath \lambda i$ i seems to confirm that the Christian sermon originated as a contribution to the conversation in early Christian gatherings and

71 Cor. 11:5-15.

81 Cor. 14:33b-36. For the view that at least 1 Cor. 14:33b-35 is an interpolation, see, e.g., A. Lindemann, Der erste Korintherbrief (Tübingen: Mohr (Siebeck), 2000), 317-321. The injunction that "women should be silent in the assemblies" appears in some early manuscripts at 1 Cor. 14:33b-35, but in other, "Western", manuscripts after 1 Cor. 14:40. Obviously, an interpolator used Paul's authority to silence women.

9 Plut., Quaest. conv. 1.616e, 9.743b (see here the remark of F.H. Sandbach about o $\mu \imath \lambda i \alpha$, LCL 425, p. 267, footnote d), 9.743e. In other places Plutarch uses simply $\lambda$ ó ${ }^{\prime}$ or to designate speeches at the symposium.

${ }^{10}$ See "ó $\mu \imath \lambda \dot{\varepsilon} \omega, \dot{o} \mu \imath \lambda \dot{i} \alpha$," in $L S J$, p. 1222.

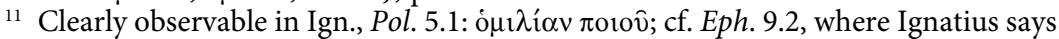
that he has been deemed worthy "to speak with you (the Ephesians)", $\pi \rho \circ \sigma o \mu \imath \lambda \hat{\eta} \sigma \alpha 1$ inîิv. 519.

${ }^{12}$ E. Haenchen, Die Apostelgeschichte (Göttingen: Vandenhoeck \& Ruprecht, 1968),

${ }^{13}$ In the Greek of Acts 20:11 any mention of persons with whom Paul would have conversed is lacking grammatically in contradistinction to Acts 24:26 and Lk. 24:14, 15. In Acts 20:11, many translations freely add the complement: "to converse with

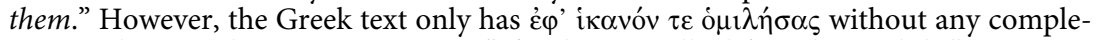
ment indicating the persons present: "after having talked for a long while." 
goes back to the custom of giving speeches at symposia in the GraecoRoman world in general.

The word o $\mu \nu \lambda i \alpha$ that came to be used to designate Christian preaching has a connotation of intimacy and familiarity, of friendly converse and persuasive argumentation, with overtones of serious intent and instruction. ${ }^{14}$

Speaking about the advantage of prophecy, i.e., articulate edifying speech, in preference to speaking in tongues in the Christian gathering, Paul says that he would rather say five words in order to instruct (iv $\alpha$ $\kappa \alpha \tau \eta \chi \eta ் \omega)$ his audience (1 Cor. 14:19) than ten thousand words in a tongue. Since the world of the first century was very open to moralistic discourse, the Church began in a cultural environment in which ethical teaching was a basic mode of communication. Aulus Gellius makes several comments on the teaching activity of L. Calvisius Taurus, a student of Plutarch and for a time Aulus Gellius' own teacher. Taurus often invited those students with whom he was on intimate terms to dinners at his home. Each dinner guest was obliged to bring a problem of a light and entertaining kind, suitable for a mind "enlivened with wine."15 In a similar way, oral communication and exchange took place in the context of the Christian after-supper assembly in Corinth. Paul mentions a number of ways in which Christians could express themselves; he says: "each one has a hymn, a lesson, a revelation, a tongue, or an interpretation. Let all things be done for building up."16 Paul probably means here that members of a Christian congregation should come to their gathering with some idea of what they were going to contribute to the exchange of thoughts at the symposium.

The above evidence seems to support the idea that preaching among Christians originated in the context of their communal gathering. This gathering had its socio-cultural analogy in the banquet of various Hellenistic clubs, associations, and other groups (both non-Jewish and Jewish) which came together periodically for the purpose of communal dining and subsequent fellowship.

Interestingly, scholars who have tried to write a history of Christian preaching have never looked at its origins from the point of view

${ }^{14}$ James McDonald, Kerygma and Didache (Cambridge: Cambridge University Press, 1980), 39.

${ }_{15}$ Aul. Gel., NA 7.13; 17.8; 18.10.5; Gregory Snyder, Teachers and Texts in the Ancient World (London and New York: Routledge, 2000), 114.

161 Cor. 14:26. 
of the social context in which early Christian preaching took place. They unanimously trace the origin of the Christian sermon back to the interpretation of the Law in the Jewish synagogue. ${ }^{17}$ William Howden states, "Christian liturgical preaching was heavily influenced by the pattern of synagogue worship, in which a reading from Scripture was followed by an explanation of the passage." ${ }^{18}$ It is true that Alistair Stewart-Sykes observes that the setting for philosophical discourse was often formed by meals in the Graeco-Roman world; he suggests that, just as philosophical conversation took place at the tables of philosophical schools, so religious intercourse took place at the tables of early Christians and thus became one of the roots of the Christian homily. He assumes, however, that it is quite likely that in the eighties of the first century CE, as a secondary development, the homiletic practice of the synagogue was transferred to the Church. ${ }^{19}$ According to Stewart-Sykes, the Church at the end of the first century, took over the teaching practices of the synagogue, which were used there in the reading and exposition of the Law. Thus, the Church would have replaced the informality of earlier days in which the Scripture was not yet read, with a scholastic expository practice borrowed from the synagogue. ${ }^{20}$ However, it is unnecessary to accept Stewart-Sykes' suggestion that, only after several decades, Christians took over the practice of preaching from the synagogue: Christians gave allocutions in their meetings from the very beginning. Moreover, in the available sources there is little to indicate that the Church changed into a school-like community. ${ }^{21}$ Most importantly, however, teaching in the Christian communities took place in the context of the after-supper symposium on Sunday evening and the context remained the same throughout the second century. The setting and content of Christian

${ }_{17}$ See, e.g., O.C. Edwards, A History of Preaching (Nashville: Abingdon Press, 2004), 11; Frances Young, "Christian Teaching," in Cambridge History of Early Christian Literature, eds. F. Young, L. Ayres and A. Louth (Cambridge: Cambridge University Press, 2004), 92.

${ }^{18}$ W. Howden, "Preaching," in EEC, vol. 2, p. 940.

19 Alistair Stewart-Sykes, From Prophecy to Preaching. A Search for the Origins of the Christian Homily (Leiden: Brill, 2001), 11, 75-77.

${ }^{20} \mathrm{Ib} ., 14$.

${ }^{21}$ Contra F. Young, "Christian Teaching," 469. She claims that education in the ancient world was almost entirely based upon the reading of literature, and the place of Scripture reading in the Jewish synagogue, subsequently adapted by the Christian Church, made both communities analogous to a school. 
admonition and exhortation in no way resembled the study of the Law in the synagogue on the Sabbath.

In order to determine which pattern Christian communities followed in adopting the practice of preaching, it is necessary to look at both the context and manner in which teaching and preaching functioned in the synagogue. In the first century CE, on Sabbath, Jews practised the reading of the Law in groups; it was followed by the interpretation of the passage which had been read. In Alexandria, Philo records the reading and exposition of the books of the Law in the synagogue. ${ }^{22}$ In his Embassy to Gaius, Philo places this activity in the synagogue gathering on the Sabbath, interpreting it as the Jews' training in their ancestral philosophy. ${ }^{23}$ This training in the synagogue, which consisted of reading the Law and its explanation, was conceived as a didactic activity; it was a form of public education in the synagogue. ${ }^{24}$ Elsewhere Philo describes the manner in which the Law was interpreted as follows:

And will you sit in your conventicles and assemble your regular company and read in security your holy books, expounding any obscure point and in leisurely comfort discussing at length your ancestral philosophy?25

This evidence suggests that Jews read the Law and interpreted it in the context of their Saturday gathering in synagogues. These synagogue gatherings were clearly no banquets. Jews in the Diaspora came together to read and study the Law, not to eat and to enjoy conviviality.

In Palestine, too, the synagogue gathering in the first century $\mathrm{CE}$ focused on the study of the Law. Josephus notices that Jews gave every seventh day over to the study of their customs and Law. ${ }^{26}$ In a parallel passage he states that Moses instructed his people as follows: "Every week men should desert their other occupations and assemble to listen to the Law and to obtain a thorough and accurate knowledge of it." 27 It is clear from these passages that Josephus was not only accustomed

${ }^{22}$ Philo, Hyp. in Euseb., Praep. ev. 8.7.12-13 (tra. F.H. Colson).

${ }^{23}$ Philo, Legat. 156.

${ }^{24}$ L. Schiffman, "The Early History of Public Reading of the Torah," in Jews, Christians and Polytheists in the Ancient Synagogue: Cultural Interaction during the GrecoRoman Period, ed. S. Fine (London: Routledge, 1999), 46.

${ }_{25}$ Philo, Som. 2.127 (tra. G.H. Whitaker and F.H. Colson).

${ }^{26}$ Jos., Ant. 16.43.

27 Jos., Ap. 2.175 (tra. H.S.E. Thackeray). 
to the regular reading of the Torah on each Sabbath, ${ }^{28}$ but also saw its purpose as didactic and educational.

Interpreting the Law was also very important in circles from which some of the Qumran writings come. According to the Community Rule (1QS), "in the place in which the Ten assemble there should not be missing a man to interpret the Law day and night, always." ${ }^{29}$ In other cases, the interpretation of the Law clearly took place on the Sabbath. A halakhic text enjoins the members of the community "to study or to read in the Book on the Sabbath." ${ }^{30}$ The evidence mentioned above shows that Jewish communities, both in the Diaspora and in Judea, met on Sabbath for reading, studying and interpreting the Law.

It is difficult to trace the origins of Christian preaching back to synagogue practices. This is so for at least two reasons. First, the social setting for preaching in Christian communities was entirely different from that in synagogues. Early Christian preaching took place in the context of a supper, ${ }^{31}$ not in that of a meeting for the study of, and instruction about, the Law. The assemblies of Christians were not study groups like those Jewish groups meeting on Sabbath in synagogues. Rather they were dining clubs, meeting for supper and religious intercourse. The assemblies of Christians had the same format of the periodical banquets held by Hellenistic associations, as for instance those of the Iobacchoi mentioned above. Even Jewish groups, such as the Therapeutae, had a periodical supper followed by a symposium in accordance with the generally current pattern. During the symposium a sermon was preached: one or two experienced members gave an after-supper speech while the rest of the community listened with rapt attention:

He (the President) discusses some question arising in the Holy Scriptures or solves one that has been propounded by someone else.... His instruction proceeds in a leisurely manner; he lingers over it and spins it out with repetitions, thus permanently imprinting the thoughts in the souls of the hearers. ${ }^{32}$

\footnotetext{
${ }^{28}$ Acts 15:21: "In every city, for generations past, Moses has had those who proclaim him, for he has been read aloud every sabbath in the synagogues."

${ }^{29}$ 1QS 6.6-7.

30 4Q251 1.5.

311 Cor. 12-14; Acts 20:11; Just., 1 Apol. 67.3-5; Acta Ioan. 46; Acta Petri 20; Tert., Apol. 39.4-18.

${ }^{32}$ Philo, Contempl. 75-78 (tra. F.H. Colson).
} 
From Philo's account one can see how, in religious groups, a sermon could be delivered in the context of a periodical meal.

Second, in first-century Christian meetings, preaching could take place without the previous reading of any texts. Originally, in the first century, early Christian preaching and teaching were not based on any reading. In his description of the Christian gathering in 1 Corinthians Paul mentions various types of oral intervention, but no reading of Scripture. ${ }^{33}$ The teaching ( $\left.\delta 1 \delta \alpha \chi \eta\right)$ mentioned there is certainly not the study and exposition of the Law, as it was in the synagogue, nor of any other authoritative text. In Acts 20:11 Paul celebrates the common meal and then preaches to his audience without reading anything. There are other instances, also in the second century, in which a sermon was delivered without the previous public reading of any passage from Scripture. ${ }^{34}$ There is, thus, a clear discontinuity between the oral presentation or discourse in the Jewish synagogue and that in Christian gatherings. In the synagogue, the Law was read, explained and interpreted on Sabbath morning. In the Christian gathering on Sunday evening, preaching was originally performed without any Scripture reading. As has been stated in the previous chapter, the Law was not read publicly in the communal gatherings of Christians until the third century. The extant homilies on the Law come from the time of Origen. One notable exception is the sermon On Pascha by Melito of Sardis from about the middle of the second century. Melito apparently delivered this sermon during the Quartodeciman celebration of Easter. It was preceded by a reading of the Passover account from the book of Exodus, chapter 12.

Justin in his 1 Apology is the first Christian author to inform us explicitly that the sermon in the Sunday gathering of Christians was combined with the reading of some passage from Prophets or Gospels: the sermon followed the reading of prophetic or apostolic texts. ${ }^{35}$ This is the first time that sermon and Scripture are explicitly connected with each other. During the century preceding Justin's account, it is repeat-

\footnotetext{
${ }^{33} 1$ Cor. 14:26.

${ }^{34}$ This is the case with Ign., Pol. 5.1; Acta Pauli 9; Acta Petri 1-2 and Iren., Haer. 1.13.2-4. See also Appendix 2 below.

${ }^{35}$ Justin presents the combination of reading and preaching as an already established custom. This situation resulted from a development during an earlier stage which is reflected in 1 Tim. 4:13: "give attention to the public reading of Scripture, to exhorting, to teaching." In the latter passage, however, it is less clear than in Justin how reading and exhorting are related to each other.
} 
edly said that in Christian gatherings apostolic, prophetic or other texts were read; it is also regularly said that sermons were preached; but not that, as Justin first mentions, the sermon was closely connected with, or based on, a passage read. This is something one hears first from Justin. It is again an indication that the Christian sermon did not arise as continuation of the exposition of the Law in the synagogue.

In conclusion it may be stated that the most probable explanation of the rise of Christian preaching is that in the earliest Christian communities oral interventions took place on the analogy of the speeches given at after-supper symposia in the Hellenistic world at large. After all, the early Christian gathering was a communal supper followed by a convivial assembly. Christian preaching began independently from the reading of Scripture. It was not the exposition of the Jewish Law as it was performed in the Jewish synagogue. Originally there was no exposition of any text whatsoever. The fact that the Christian sermon came to be called a "homily" supports the conclusion that it originated as a contribution to the conversation at Christian banquets. Such oral interventions were typical of many banquets at the time. It was only in the course of time that the Christian sermon came to be closely linked up with the reading of a passage from some authoritative texts; this development is mirrored in Justin and less clearly in 1 Timothy 4:13. ${ }^{36}$ Even then there is no need to assume Jewish influence: the Christian sermon has its background in the symposium, not in the synagogue.

\section{The DeVELOPMENT OF PREACHING IN THE Gatherings OF THE EARLY CHURCH}

\section{a. Preaching in the Christian gathering in the first century}

The first extant reference to Christian preaching occurs in 1 Thessalonians. ${ }^{37}$ This preaching consisted of admonition and encouragement; it is repeatedly referred to as $\pi \alpha \rho \alpha \kappa \alpha \lambda \varepsilon i \hat{v}$ and $\pi \alpha \rho \alpha \dot{\alpha} \lambda \eta \sigma 1$. $^{38}$ These terms refer to preaching in the form of an address containing teaching, admonition, encouragement, and exhortation. There is reason to assume that this type of exhortatory homily has its origins in an early,

\footnotetext{
36 See previous note.

371 Thess. 5:20-21.

381 Thess. 2:3; 3:2; 4:1, 10, 18; 5:11, 14.
} 
Greek-speaking, Christian community, which may well have been that of Jerusalem in the thirties during the first century CE. ${ }^{39}$

In his first letter to the Corinthian Christians Paul asserts that the result of "prophecy", speaking in articulate, edifying language, is that the members of the community learn something and are encouraged:

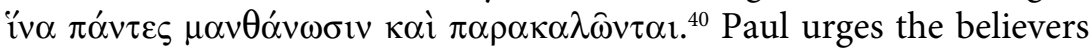
to be eager to "prophesy" rather than to speak in tongues, because the former serves to edify the whole community:

Pursue love and strive for the spiritual gifts, and especially that you may prophesy. For those who speak in a tongue do not speak to other people but to God; for nobody understands them, since they are speaking mysteries in the Spirit. On the other hand, those who prophesy speak to other people for their upbuilding and encouragement and consolation. Those who speak in a tongue build up themselves, but those who prophesy build up the church. ${ }^{41}$

Paul here introduces a certain ranking of the "gifts of the Spirit" according to their importance. Speaking in intelligible speech is more needed than glossolalia because the former serves to encourage the members in faith and love. In 1 Corinthians 12:8 the two first spir-

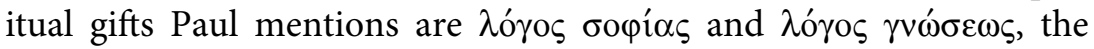
utterance of wisdom and the utterance of knowledge. These forms of speech should probably not be understood as two totally different types of speaking. Both terms seem to refer to a regular activity of proclamation and instruction, as they do in 1 Corinthians 1:17-18 and 2:4. These terms designate the activity of those who instruct the community. ${ }^{42}$ A certain differentiation may have occurred between, on the one hand, proclaiming the gospel and calling to stand by one's faith and, on the other hand, teaching or instruction. The latter form

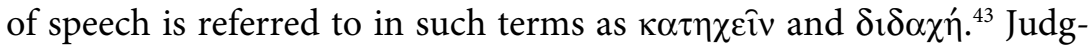
ing by the contents of Paul's letters, teaching could be on aspects of the Christian faith in general (soteriology, eschatology, Christology) or on ethical issues.

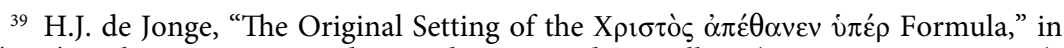
The Thessalonian Correspondence, ed. Raymond F. Collins (Leuven: Peeters, 1990), 234.

401 Cor. $14: 31$.

41 Cor. 14:1-4.

42 Alastair Campbell, The Elders. Seniority within Earliest Christianity (Edinburgh:

T \& T Clark, 1994), 108.

431 Cor. 14:19, 26. 
Paul urges the Corinthian Christians to consider critically anything members of a Christian community say in the assembly. Whenever someone speaks forth in the Christian community the other participants are responsible for passing judgement. Paul says: "Let two or three prophets speak, and let the others pass judgement." ${ }^{44}$ Evidently, the members of the community had to evaluate the messages pronounced to discern whether anything in them was not from God. Paul urges the Thessalonian Christians not to despise the words spoken in the gathering, but to examine them carefully and to hold fast only to what is good. ${ }^{45}$ The author of 1 John exhorts his addressees as follows: "Beloved, do not believe every spirit, but test the spirits to see whether they are from God; because many false prophets have gone out into the world." ${ }^{46}$ In a number of cases, then, Christian communities may have tested and discussed critically the messages delivered in their meetings to assess whether they came from God or not. Whenever this occurred, a speaker's contribution and the reactions it elicited formed a kind of conversation of the type known from symposiastic literature.

By the end of the first century, the oral utterances in the context of the gathering of Christians came to be designated more and more in terms of teaching and preaching and less as "prophecy." In the Pastoral Epistles there are three references to preaching, eleven to teaching given by the communities' leaders, but no reference is made to "prophetic" activity. ${ }^{47}$ In 1 Timothy 5:17, for instance, the author mentions elders who "labour in preaching ( $\lambda$ ó $\gamma \circ \varsigma)$ and teaching $(\delta 1 \delta \alpha \sigma \kappa \alpha \lambda i \alpha)$." In 1 Timothy $6: 2$ the author urges Timothy to "teach and preach

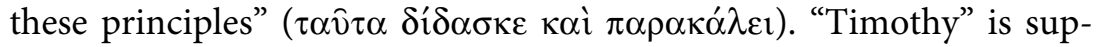
posed to teach slaves to obey their masters. This may reflect the rise of catechetical instruction in the Christian gatherings. Such elementary Christian instruction has its literary counterpart in the Pastorals and 1 Peter in the form of household codes. ${ }^{48}$ Sometimes an entire letter is given over to exhortation and summons to the right faith. The epistle to the Hebrews characterizes itself as such an exhortation: a

\footnotetext{
441 Cor. 14:29.

451 Thess. 5:20-22.

461 Jn. $4: 1$.

47 References to preaching are 1 Tim. 4:13; 5:17; 2 Tim. 4:2; to teaching 1 Tim. 3:2; 4:11, 13; 5:17; 6:2; 2 Tim. 2:2, 24; 3:16; Tit. 1:11; 2:7, 15.

${ }^{48} 1$ Tim. 5:1-22; Tit. 2:2-3:8; 1 Pet. $2: 11-3: 12$.
} 
$\lambda$ ó $\gamma \circ \varsigma \tau \hat{\eta} \varsigma \pi \alpha \rho \alpha \kappa \lambda \eta \dot{\eta} \sigma \varepsilon \omega \varsigma^{49}$ According to Acts 13:14, the officials of the synagogue of Pisidian Antioch expected Paul to deliver such a $\lambda$ ó $\gamma \circ \varsigma$ $\pi \alpha \rho \alpha \kappa \lambda \eta \dot{\sigma \varepsilon} \omega \varsigma$, an exhortatory address.

In 1 Timothy 4:13 the author enumerates the community leaders' three main duties: $\dot{\alpha} v \alpha \dot{\gamma} v \omega \sigma ı,, \pi \alpha \rho \alpha ́ \kappa \lambda \eta \sigma ı \varsigma, \delta 1 \delta \alpha \sigma \kappa \alpha \lambda i \alpha$; reading, exhorting and teaching. Judging from this passage, it is probable that by the time 1 Timothy was composed, Christian preaching began to be linked with the reading of passages from the Prophets. Alistair StewartSykes is probably correct in interpreting the $\pi \alpha \rho \alpha \dot{\alpha} \kappa \eta \eta \sigma 1 \varsigma$ mentioned in 1 Timothy 4:13 as preaching in the assembly, and $\delta 1 \delta \alpha \sigma \kappa \alpha \lambda i \alpha$ as a form of catechesis, perhaps still given within the gathering of the congregation, but distinguishable at least in principle from preaching in general. ${ }^{50}$

To a certain extent the character of preaching in first-century Christian communities can be deduced from the form and nature of a number of early Christian writings. Narrative traditions contained in the Gospels may well reflect the use of these traditions in oral interventions in gatherings of Christian congregations. ${ }^{51}$ Preachers needed such narrative material in their exhortative sermons and catechetical instruction. Other writings, such as 1 Peter and Hebrews, may have been composed to serve as sermons or may at least have reflected the genre of the sermon: as mentioned above, Hebrews describes itself as a "word of exhortation." This is a fair indication of the book's contents. Several scholars think that it was originally a sermon or homily delivered by a Christian preacher in a Christian congregation. ${ }^{52}$ The author may have composed the sermon to be read aloud by him, or possibly he may have written it down after it had been delivered orally.

Since many early Christian writings were composed for reading aloud in the gathering of a Christian community, they may also reflect the nature of first century preaching. Many early Christian writings sprang from early Christian preaching, rather than the other way around. Admittedly, in later centuries, when a number of early Christian writings had obtained a more or less authoritative status,

${ }^{49}$ Heb. 13:22.

50 A. Stewart-Sykes, From Prophecy to Preaching, 14.

${ }^{51}$ O.C. Edwards, A History of Preaching, 8.

${ }^{52}$ Harold A. Attridge, "Hebrews," in The Oxford Bible Commentary, eds. John Barton and John Muddiman (Oxford: Oxford University Press, 2001), 1236. 
preaching tended to become a commentary on these texts. Originally, however, preaching preceded the birth of Christian writings. ${ }^{53}$

To summarize this section, it may be stated that preaching in the Christian Church in the first century took place in the context of the second part of the Christian gathering, which was the equivalent of the symposium held at the Hellenistic group banquet. The preaching consisted of oral interventions in the form of admonitions, teaching, revelations and exhortatory allocutions.

\section{b. Preaching in the Christian gathering in the second century}

The nature of some second-century Christian writings suggests that they were intended to be used homiletically. Certain writings that have been preserved were clearly read as sermons to Christian congregations. The book of Revelation, for instance, says: "Blessed is the one who reads aloud the words of the prophecy [that is, the book of Revelation itself], and blessed are those who hear and who keep what is written in it." ${ }^{24}$ Obviously, Revelation served to be read, either as a whole or in portions, as a sermon in assemblies of Christian congregations. The seven epistolary sermons in the book of Revelation 2:1-3:22 are addressed to specific churches; however, as part of the book as a whole, they were meant to be heard by a wider audience. The warning at the end of the book to preserve its integrity, addressed to "whoever hears the words of the prophecy of this book" (22:18), confirms that the book of Revelation was meant to be read aloud and heard, possibly as a sermon in assemblies.

The so-called second epistle of Clement is a clear example of a second-century sermon ( $\mathrm{ca} .140 \mathrm{CE}){ }^{55}$ It was intended to be read aloud ${ }^{56}$ to one or more of the Christian assemblies, possibly by its author, who as an itinerant preacher may have used this sermon in several congregations. In Chapter 4 it was already pointed out that the reading

${ }^{53}$ Alexander Olivar, "Reflection on Problems Raised by Early Christian Preaching," in Preacher and Audience: Studies in Early Christian and Byzantine Homiletics, eds. Mary Cunningham and Pauline Allen (Leiden: Brill, 1998), 22.

${ }_{54}$ Rev. 1:3.

55 The earliest explicit reference to 2 Clement is Euseb., HE 3.38.4: "It must not be overlooked that there is a second epistle said to be from Clement's pen" (tra. G.A. Williamson). That 2 Clement was regarded as a letter may be due to its being transmitted together with 1 Clement: this is the case in the Alexandrinus, the Hierosolymitanus and the Syriac translation.

${ }_{56} 2$ Clem. 19.1. 
of this sermon was preceded by the reading of Scripture. The text of 2 Clement itself evokes the setting of the Christian assembly in which it was read as a sermon.

And let us think about paying attention and believing not only now, while we are being admonished by the elders, but also when we have returned home $\mathrm{e}^{57}$ let us remember the Lord's commands and not allow ourselves to be dragged off the other way by worldly desires, but let us come here more frequently and strive to advance in the commandments of the Lord, in order that all of us, being of one mind, may be gathered together into life. ${ }^{58}$

This passage gives an interesting glimpse into the social context in which a sermon was pronounced: in the assembly of a congregation, alongside the exhortations uttered by the presbyters or elders. Unfortunately, it is unknown who the author of this sermon is,$^{59}$ nor where it was preached. ${ }^{60}$ It is an exhortation to give gratitude to God for his mercy and salvation, to repent and to strive for moral purity in view of the resurrection and the final judgment. The argument is developed with the frequent use of quotations from the Old Testament and from the tradition of Jesus' sayings.

The letters of Ignatius, somewhat earlier than 2 Clement, are real letters. Sometimes, however, Ignatius himself seems to view them as allocutions or sermons, no doubt owing to the fact that he knew that they would be read aloud in the congregations to which they were addressed. To the Ephesians he says: "I have been deemed worthy to speak with you ( $\pi \rho \circ \sigma o \mu \imath \lambda \hat{\eta} \sigma \alpha i v \mu i v)$ through the things that I write and to rejoice together with you...." ${ }^{\prime 1}$ Ignatius' letter to the Ephesians

57 The phrase "when we have returned home" indicates that the meeting in question took place in the evening; otherwise the participants would have gone to their work. This is confirmed by the fact that not only the present sermon was preached, but also admonitions of presbyters were given; for all this there would hardly have been time in the early morning before working hours.

582 Clem. 17.3 (tra. M.W. Holmes).

${ }^{59}$ Harnack ascribed it to Soter of Rome, but this hypothesis cannot be correct: "your epistle" in Euseb., HE 4.23.11, on which Harnack's view is based, is clearly some recent letter Dionysius received from Soter, not 2 Clement. See John Muddiman, "The Church in Ephesians, 2 Clement, and the Shepherd of Hermas," in Trajectories through the New Testament and the Apostolic Fathers, eds. Andrew F. Gregory and Christopher M. Tuckett (Oxford: Oxford University Press, 2005), 113.

${ }_{60}$ Among the places proposed are Corinth, Rome and Alexandria, but all these suggestions must remain speculative.

${ }_{61}$ Ign., Eph. 9.2. 
was probably to be read in their assembly by their bishop Onesimus. ${ }^{62}$ He had come to meet Ignatius at Smyrna, together with the deacon Burrus, Crocus, Euplus and Fronto. ${ }^{63}$ Ignatius refers very generally to preaching activity in the Ephesian church when he praises the Ephesians for their aversion to heresy and says: "You no longer lis-

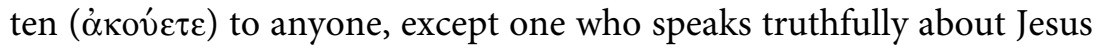
Christ." ${ }^{64}$

A purely paraenetic type of sermon, not connected with the previous reading of Scripture or any other text, is hinted at in Ignatius' letter to Polycarp: "Deliver a sermon $\left(\dot{o} \mu \imath \lambda i^{\prime} \alpha\right)$ about the evil arts. Warn my sisters to love the Lord and to be satisfied with their husbands in flesh and spirit. So too enjoin my brothers in the name of Jesus Christ to love their wives as the Lord loves the Church." 65

That there were different kinds of preaching, however, is clear from the Didache. This writing distinguishes three categories of itinerant preachers: apostles, prophets and teachers. ${ }^{66}$ These officials visited Christian communities and addressed the members, probably in their assemblies. The teachers provided "knowledge of the Lord" and instruction concerning correct behaviour and the Christian ceremonies. ${ }^{67}$ The prophets could "speak in the Spirit", but their work was also to "teach the truth." ${ }^{8}$ "The content of their preaching, therefore, may have been not very different from that of the teachers. The same may apply to the "apostles": the main difference between these apostles and other officials was that the former spoke with greater authority, probably due to their age and the fact that they were closer to the first generation of followers of Jesus. Through their greater authority they also ran the risk of becoming too demanding in their desires vis-àvis the churches they visited. ${ }^{69}$ The Didache mentions various possible contents of preaching: ethics, doctrine and ceremonies. But it is not easy to divide these subjects between the ministries. Nothing indicates that preaching was connected with the reading of texts.

\footnotetext{
62 Ign., Eph. 1.3.

63 Ign., Eph. 2.1.

64 Ign., Eph. 6.2.

65 Ign., Pol. 5.1 (tra. Bart Ehrman, adapted).

66 Did. 11. The sedentary preachers, bishops and deacons, are said to conduct the same ministry as the itinerant prophets and teachers; Did. 15.1.

${ }^{67}$ Did. 11.1-2.

68 Did. 11.7-8.

${ }^{69}$ Did. 11.6.
} 
Now let us look somewhat more precisely at how the preaching took place in the second century. Several sources show that sermons were delivered in the course of Christian gatherings on Sunday. According to Justin, this was already the custom in Rome in the middle of the second century. The practice is mentioned later by Tertullian and in the Acts of Peter. ${ }^{70}$ Justin Martyr describes the preaching in the gatherings of Christians as follows:

On the day called Sunday all who live in cities or in the country gather together in one place, and the memoirs of the apostles or the writings of the prophets are read, as long as time permits. Then, when the reader has finished, the president in a discourse instructs and exhorts to the imitation of these good things. Then we all stand up together and offer prayers; and, as we said before, when we have finished the prayer, bread is brought and wine and water, and the president likewise offers up prayers and thanksgivings to the best of his ability, and the people assent, saying Amen. ${ }^{71}$

According to this account, preaching took place before the celebration of the eucharistic meal. Previously, judging from Paul and Acts, preaching took place after the supper. As mentioned above, the reason why the order was reversed was probably a practical one. In the second century, the catechumens were no longer allowed to participate in the community supper, ${ }^{72}$ but they were allowed to hear the sermon. In order to have them attend the sermon but not the meal, it was best to put the sermon before the supper, for it was difficult to tell beforehand at what moment the catechumens had to appear if the sermon began after the supper. Moreover, for some members of the congregation listening to a sermon at the end of a working day was perhaps easier and more fruitful before than after the supper.

The sermon preceded the supper also in the Christian gatherings as described by Tertullian in his Apologeticum 39. The same order of homily, prayer and Eucharist is attested in the Acts of John. ${ }^{73}$

The description of the Christian gathering on Sunday in Justin also reveals that preaching took place after the reading of authoritative writings, namely Gospels and Prophets. Justin makes it clear that the sermon was based on the passages read from the Scriptures: the preacher

${ }^{70}$ Just., 1 Apol. 67; Tert., An. 9.4; Acta Petri 7; 30.

${ }^{71}$ Just., 1 Apol. 67.3-4 (tra. L.W. Barnard).

72 Did. 9.5.

${ }^{73}$ Acta Ioan. 46. 
exhorted his hearers to imitate the good things they had heard. The relationship between reading and preaching, between Scriptures and sermon, as mentioned by Justin, was already traditional at the time. It may already have been intended by the author of 1 Timothy 4:13: "give attention to the public reading of Scripture, to exhorting, to teaching."

Several Christian writings of the second century confirm Justin's information to the effect that the sermon followed the reading of authoritative texts, in particular Gospels and Prophets. At the end of the second century the author of the Acts of Peter gives an example of a sermon that was an explanation of the Gospel passage previously read in the assembly. The narrator says that Peter entered a Christian gathering in the house of Marcellus at Rome and heard the gospel being read. Peter rolled up the scroll and proceeded to deliver a sermon on the passage read, stating that he would explain what had just been read. This popular account may reflect to a certain degree the manner in which a homily could be preached in a gathering of Christians: first, a passage from the Scriptures was read; second, the passage was explained in a sermon. In the Acts of Peter Peter explicitly mentions his intention to enable his hearers to understand the Scriptures and his purpose to give the elucidation needed by preaching a sermon. ${ }^{74}$ It should be noticed that Peter's sermon in the present case has the character of teaching rather than of an exhortation to good behaviour. ${ }^{75}$

There is also pagan evidence for the Christian sermon being an explanation of a text previously read. The satirist Lucian presents Peregrinus in his Christian period as a prophet who, before Christian audiences in Palestine, interpreted and explained some of their books. ${ }^{76}$

Somewhat indirect information as to preaching in the form of interpretation of the Gospels may be found in the writings of Clement of Alexandria. At the end of the second century Clement composed a homily entitled Who is the Rich Man Who is Saved? that consists of an interpretation of Mark 10:17-31. In it he urges the Alexandrian Christians who were not entirely destitute of worldly goods to detach from them, though not necessarily renounce them. It is possible that

${ }_{74}$ Acta Petri 20.

${ }^{75}$ Cf. 1 Tim. 4:13, where the public reading of Scripture is followed by preaching in the form of exhortation and teaching.

${ }^{76}$ Luc., Peregr. 11. 
Clement preached this sermon in his community, but it cannot be ascertained whether this actually was the case.

According to the Acts of Peter, sermons could be based not only on the Gospels, but also on Old Testament prophetical writings. Peter, together with other believers, gathered daily in the house of Narcissus, the presbyter of the Christian community in Rome. There Peter spoke to the assembly "of the prophetical writings and other things done by our Lord Jesus Christ in word and deed." 77 This passage seems to suggest that, according to the author, Peter in his sermons could point out how certain passages in the Old Testament prophets had been fulfilled in Jesus' life. The exegetical nature of many early Christian homilies ties in with the liturgical setting in which sermons were delivered: they seek to interpret Scripture passages that are read out to the congregation.

Another instance of a sermon that is an explanation of a text read to the audience is Melito of Sardes' On Pascha (ca. $140 \mathrm{CE}$ ). The sermon is an interpretation of the account of the Passover in Exodus as a foreshadowing or "type" of the death and resurrection of Christ. ${ }^{78}$ Melito's sermon reflects the practice of preaching based on a passage from Scripture; however, it is an exceptional case because at that time the Law was not regularly read in Christian communities.

A different type of preaching is mentioned by Justin Martyr. He describes an assembly in which after the readings the president speaks

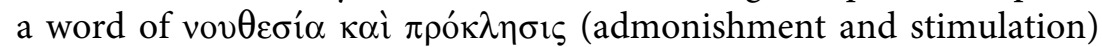
to call on his hearers to the "imitation of the good contained therein."79 This characterization of the sermon points to a homiletic genre standing halfway between ethical exhortation and the scriptural homily: Scripture is read, but as a source for moral guidance and a model for imitation. It seems that during the second century preachers began to use readings from the Prophets and early Christian writings in order to support their instruction about Christian behaviour.

A similar type of preaching is described by Tertullian. Here the reading of the divine Scriptures is followed by "exhortations, warnings, reprimands." ${ }^{80}$ But in Tertullian the relationship between the sermon and the reading of Scripture is also more complex. In the sermon the preacher considers the question whether, in light of the Scriptures, the

\footnotetext{
77 Acta Petri 13.

78 O.C. Edwards, A History of Preaching, 18-19.

79 Just., 1 Apol. 67.4.

80 Tert., Apol. 39.4.
} 
present time forces one to find in the passage read any admonition for the future or interpretation of the past. Furthermore, the preacher uses the "holy words" of Scripture "to nourish our faith, to renew our hope, to strengthen our trust and to intensify our discipline." ${ }^{11}$ According to Tertullian, the sermon served to help the hearers both to understand the signs of times and to mend their ways.

During periods of doctrinal controversy, sermons were often used to expose the errors of theological opponents and to defend the true teaching. For Irenaeus preaching was the means by which the tradition of the faith was explained, clarified, and passed on to others. ${ }^{82}$ In Against Heresies he argues that true apostolic knowledge can be obtained through sound preaching in accordance with the Scriptures: "secundum Scripturas expositio legitima et diligens et sine periculo et sine blasphemia." ${ }^{83}$ Alongside the exposition of points of doctrine, exhortation to live a proper Christian life continued to be a usual topic of sermons. Preaching sought to promote both the knowledge of Christian doctrine and the practice of Christian faith. In its sermons, the Church proclaimed Jesus Christ and interpreted what it meant to be his Church in everyday life.

In the second century some authors discern a genre of Christian preaching they designate as "prophecy", "prophetic" or "of a prophet." 84 Echoes of preaching viewed as "prophetic" can be found in the Pastor of Hermas (ca. 140-155). According to the Mandates, the true prophet speaks in the gathering of upright men when the Spirit of prophecy is opened to him. ${ }^{85}$ Hermas presents himself as such a prophetic leader of his congregation. He wrote at least part of his work as texts to be read as homilies. This is clear from Vision 5:

I wrote the commandments and parables, just as he [the Shepherd] commanded me. If then, after you hear them, you keep them and walk in them and accomplish them with a pure heart, you will receive from the Lord everything he promised you. But if you do not repent once you have heard them, but increase your sins still further, you will receive the opposite from the Lord. The shepherd, the angel of repentance, thus commanded me to write all these things ${ }^{86}$

\footnotetext{
81 Tert., Apol. 39.3.

82 Iren., Haer. 1.10.

83 Iren., Haer. 4.33.8.

84 A case in point is Rev. 1:3.

85 Herm., Mand. 43.9.

${ }^{86}$ Herm., Vis. 5.25 .7 (tra. Bart Ehrman, p. 237).
} 
In the following Mandates, Hermas gives us his teaching on Christian behaviour and virtues, such as faith in one God, truthfulness, charity, etcetera. ${ }^{87}$ As Hermas remarks himself, his work was written for Christian addressees to be heard, observed and complied with. To a certain extent his work must reflect, therefore, the prophetic preaching Hermas himself performed in his Roman congregation. ${ }^{88}$ This may also explain the frequent use of the vocative $\dot{\alpha} \delta \varepsilon \lambda \varphi$ oi (brethren) in his work, as well as the designation of his hearers as $\tau \varepsilon$ kv $\alpha$ and $\tau \grave{\alpha}$

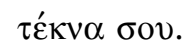

To conclude this section on preaching in the second century, it may be said that during this period two changes took place: (1) more and more, sermons came to be preceded by the reading of passages from authoritative texts; (2) the sermon changed places with the supper: it was moved from after the supper to before it. Sermons could be delivered through reading aloud a written text. A number of such written sermons have been preserved. The content could be paraenetic, but also didactic, doctrinal or prophetic.

\section{c. Preaching in the Christian gathering in the third century}

In the third century, the sermon was normally part of a gathering which also included the Eucharist. According to several third-century authors, in Egypt, Carthage and Rome, the Eucharist was celebrated daily, ${ }^{89}$ that is, in the early morning of each of the seven days of the week and moreover on Sunday evening. ${ }^{90}$ The sermon served as instruction ( $\kappa \alpha \tau \eta \chi \eta \sigma i \varsigma)$, not only of the catechumens, but also of the

${ }^{87}$ See "Hermas," in ODCC, p. 760.

88 A. Stewart-Sykes, "Hermas the Prophet and Hippolytus the Preacher: the Roman Homily and Its Social Context," in Preacher and Audience: Studies in Early Christian and Byzantine Homiletics, eds. Mary Cunningham and Pauline Allen (Leiden: Brill, 1998), 38.

${ }^{89}$ Clem. Al., Q.d.s. 23; Tert., Or. 19.1; Idol. 7.1-3; Cypr., Or. Dom. 18: “eucharistiam eius cotidie ad cibum salutis accipimus"; Ep. 57.3; 58.1; Trad. ap. 22; 35+36+37.

${ }_{90}$ Contra inter alios P. Nautin, Origène. Sa vie et son oeuvre (Paris: Beauchesne, 1972), 391-393. The passages used by Nautin to argue that services did not include a Eucharist (Trad. ap. 39; Or., Hom. Gen. 10.3; Hom. Jos. 4.1; C. Cel. 8.22) do not prove this. With regard to C. Cel. 8.22, Nautin's reasoning runs as follows: "Comment les vendredis pouvaient-ils être considérés comme jours de fête à côté des dimanches et des fêtes de Pâques et Pentecôte si ce n'est parce qu'ils étaient come eux jours d'eucharistie?" The argument contained in this rhetorical question does not hold water. It suffices to suppose that in Origen's church more people used to attend the gatherings on Friday and Sunday than on other days. This is precisely what Origen says in Hom. Isa. 5.2. 
baptized members. ${ }^{91}$ As a rule the morning services comprised both the instruction and the Eucharist but sometimes the instruction was lacking. ${ }^{92}$ If, however, instruction was given, it was part of the eucharistic service and all members were urged to attend the instruction. ${ }^{93}$

Although preaching played a prominent role in the life of the Church, there are only a few sermons extant from before the middle of the third century. Prior to Origen few sermons have survived anyhow.

The content of most third-century sermons is to a greater or lesser degree bound up with Scripture, in particular with the passages which had been read out in the course of the liturgical celebration. The homilies of Origen, however, stand out by offering a systematic commentary on Scripture and by using intensively the allegorical method of interpretation. ${ }^{94}$ Origen's more exegetical style of preaching has its background in Alexandria, where interpreting and commenting texts had become an important scholarly activity since the days of Aristarchus of Samothrace (ca. 216-144 BCE). Here various types of exegesis, literal as well as allegorical, had developed among pagans, Jews (e.g., Philo) and Christians (e.g., Clement of Alexandria). At Alexandria, Origen was trained in the Catechetical School under Clement. Philo's and Clement's allegorical exposition of Scripture points the way to Origen's homilies. He was acquainted with Philo's works. ${ }^{95}$

From the time of Origen onwards, the most common form of sermon was the exegetical homily, the phrase-by-phrase exposition of a particular passage, usually the text read for the day. In such homilies, apart from the passage under discussion, many other biblical passages could be quoted. Yet the goal of preaching was never simply that the hearers understood Scripture. The purpose was not purely cognitive or intellectual; the sermon had to edify the hearers too. The exposition of the biblical text was accompanied, therefore, by application; it called on the hearers to respond to the message found in the Scriptures. Old Testament passages were often interpreted typologically or allegorically, so that a Christian message could be derived from them.

${ }_{91}$ Trad. ap. 18 "the catechumens" and "the believers"; 35 fideles, $36 \pi \hat{\alpha} \varsigma \pi \imath \sigma \tau$ ó, 37 omnis, 39 doceant illos qui sunt in ecclesia.

92 Trad. ap. 35; 41.

${ }_{93}$ Trad. ap. $35+36+37$.

${ }^{94}$ Mary Cunningham and Pauline Allen (eds.), Preacher and Audience: Studies in Early Christian and Byzantine Homiletics (Leiden: Brill, 1998), 10.

${ }_{95}$ See David T. Runia, Philo in Early Christian Literature. A Survey (Assen: Van Gorcum, 1993), 160-173. 
Origen preached not only in gatherings on Sunday, but also in services on other weekdays: his congregation met on several days a week, sometimes on successive days. ${ }^{96}$ In these gatherings a lector read a passage from Scripture. ${ }^{97}$ The preacher, surrounded by other members of the clergy, ${ }^{98}$ delivered the homily. The homily ended with a doxology and the invitation to those present to stand and pray. ${ }^{99}$

More specifically, the setting for preaching in Origen's time was the morning gathering, both on Sundays and other days of the week. Origen's sermons were naturally limited in length by the duration of the gathering as a whole, the structure of the liturgy and the congregation's span of attention. ${ }^{100}$ As to the duration of the gathering as a whole, Origen points out on one occasion that it lasted hardly one hour. ${ }^{101}$ His congregation was of varied composition and included catechumens and baptized members; there were both simple people and those who were more educated or spiritually advanced. ${ }^{102}$ Origen's sermons were not addressed exclusively to catechumens; these sermons were not catechetical homilies. At Caesarea, all the faithful, both baptized members and catechumens, were expected to attend the morning services; the sermons served the instruction of the Christian community as a whole. ${ }^{103}$ From the Apostolic Tradition it is clear that

${ }_{96}$ Or., Hom. Num. 13.1; Hom. Ex. 7.5.

97 Or., Hom. Num. 20.1.

98 Or., Hom. Jud. 3.2.

99 Or., Hom. Isa. 4.3; Hom. Luc. 36; Adele Castagno, "Origen the Scholar and Pastor," in Preacher and Audience: Studies in Early Christian and Byzantine Homiletics, eds. Mary Cunningham and Pauline Allen (Leiden: Brill, 1998), 66.

${ }_{100}$ In several sermons Origen remarks that since he has little time he will explain only a small portion of the biblical text. Or., Hom. Jer. 15.6.1-3; Hom. Num. 14.1; Hom. Lev. $1.1 ; 2.1$.

101 P. Nautin, Origène. Homélies sur Jérémie, vol. 1 (Paris: Cerf, 1976), 111: “...ces réunions duraient environ une heure," with reference to Or., Hom. Ex. 13.3: "It would be a gigantic work to discuss all things we have read one by one. But of what benefit will it be to deal with all things in my homily? They are despised by hearers who are absorbed in other things and attend the Word of God only during the short time of hardly one hour, whereby all I say gets lost." This is Rufinus' Latin: “... singula discutere opus ingens. Verum quid proderit, ut nostro quidem sermone dicantur, ab occupatis vero auditoribus et vix unius horae puncto verbo Dei assistentibus spernantur et pereant?"

102 Or., Hom. Lev. 1.4; Hom. Gen. 10.1.

${ }^{103}$ See also Trad. ap. 18. Here it appears that the catechumens and the baptized members are together in one meeting which began with instruction and continued with the Eucharist. Cf. Joseph Lienhard, "Origen as Homilist," in Preaching in the Patristic Age: Studies in Honor of Walter J. Burghardt, ed. David Hunter (New York: Paulist Press, 1989), 43. 
the catechumens were usually supposed to attend this instruction during a three-year period. ${ }^{104}$

Origen once complains about low attendance at the sermon and lack of attention: "Does it not cause sadness and sorrow when you do not gather to hear the word of God? And scarcely on feast days do you proceed to the Church, and you do this not so much from a desire for the word as from a fondness for the festival and to obtain, in a certain manner, common relaxation." ${ }^{105}$ In another sermon Origen complains that some do not stay for the homily: "Some of you leave immediately after you have heard the selected texts which are read." 106 Origen's annoyance grew when he noticed that his congregation became impatient with his explanation of details in the book of Exodus. ${ }^{107}$ People paid little or no attention to Origen's preaching and some even turned their backs to chat with others.

The third-century Didascalia gives an equally disappointing image of the gathering of the Christian congregation. The author of the Didascalia urges bishops to exhort the people to stay in the assembly of the church during the time when instruction is given and not to walk away. ${ }^{108} \mathrm{He}$ also advises the local bishops to give an opportunity to visiting bishops to preach to his congregation because he thinks that the exhortation and admonition by strangers is very useful. ${ }^{109}$ Obviously there was reason to fear that the preaching of the local bishop could become so boring for the congregation that the opportunity to bring in some variation had to be seized with both hands.

\section{Preachers in the gatherings of the early Church}

With regard to the question as to who acted as speakers in the gatherings of the early Church, our earliest information comes from Paul. In 1 Corinthians 14:26 Paul says that each participant in a Church meeting has something to contribute, for instance, a lesson, a revelation or an interpretation.

\footnotetext{
104 Trad. ap. 17.

105 Or., Hom. Gen. 10.1, 3.

106 Or., Hom. Ex. 12.2.

107 Or., Hom. Ex. 13.3.

108 Did. ap. 2.57; 2.59.

109 Did. ap. 2.58.
} 
Apparently, any member of a Christian community was allowed to contribute orally to the meeting. Yet it is most probable that from the beginning some members were more capable of teaching and preaching than others. In answering the Corinthians' question about "spiritual things" (1 Cor. 12:1), Paul speaks of them as "gifts" (1 Cor. 12:4) and lists people having these gifts as first apostles, second prophets, third teachers... (1 Cor. 12:28). Paul probably regarded those who had these gifts as responsible for the teaching and speaking in the gatherings of the community. But their role as speakers was not yet an office or ministry.

In Romans 12:4 Paul says that not all the members of the Church have the same function since their gifts differ. Among the gifts he distinguishes here are prophetic speech ( $\pi \rho \circ \varphi \eta \tau \varepsilon i \alpha)$, teaching ( $\delta 1 \delta \alpha \sigma \kappa \alpha \lambda i \alpha)$ and exhortation ( $\pi \alpha \rho \alpha ́ \kappa \lambda \eta \sigma ı \varsigma ; 12: 6-8)$. Paul does not assign these different ways of speaking to specific functionaries. He supposes that the members of the congregation in general were "filled with all knowl-

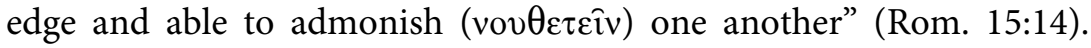
Speaking and admonishing in the gathering of the congregation is not yet reserved to certain office holders.

Later in the first century the situation changes gradually. The author of Colossians still urges his readers indiscriminately: "Let the word of Christ dwell in you richly; teach and admonish one another in all wis-

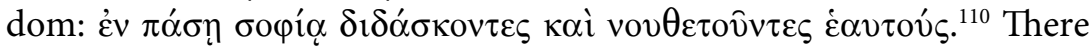
is no doubt that this exhortation concerns the teaching and admonishing in the gathering of the community, as appears from the subsequent exhortation to sing psalms, hymns and spiritual songs to God. The author of Hebrews is of the opinion that, considering the long period his addressees had been Christians, in principle all of them, without distinction, ought to be able to act as teachers. ${ }^{111}$

By the end of the first century, however, the idea arose that not all members of a congregation were equally qualified to act as speakers and teachers. In view of the mistakes one who teaches can make and the strictness with which he or she will be judged, the letter of James clearly states: "not many of you should become teachers, my brothers and sisters." 112 Here, one witnesses how the competence to speak in

\footnotetext{
110 Col. 3:16.

111 Heb. 5:12.

112 Jas. 3:1.
} 
the community gathering is restricted to persons who were deemed to be suitably qualified.

This can also be observed in some later Pauline letters. The author of the Pastoral Epistles wants elders to be appointed in every town (Tit.

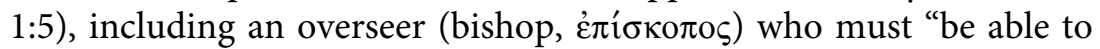
preach with sound doctrine" (Tit. 1:7). The bishop must be "an apt teacher" (1 Tim. 3:2). Elders are described as people "who work hard at preaching and teaching" (1 Tim. 5:7). Apparently, preaching and teaching were becoming the task of the leaders of the congregations, bishops and elders.

According to the author of Ephesians, Christ has given certain people special gifts for building up the Church: apostles, prophets, evangelists and pastors-and-teachers. They have "to equip the saints for the work of ministry." 113 The apostles, prophets and evangelists may have been itinerant preachers, the pastors-and-teachers local, sedentary officials, but the names of all these officials indicate that they were the people who were supposed to speak in the Christian gatherings. However, Ephesians does not say that these people were the only ones to be allowed to speak in the church. In connection with this it should be noted that at the end of the first century the terms غं $\pi$ írколо $\pi \rho \varepsilon \sigma \beta \hat{\tau} \tau \varepsilon \rho о \varsigma$ and $\delta 1 \delta \alpha ́ \sigma \kappa \alpha \lambda$ o were still largely interchangeable. ${ }^{114}$ As the local leaders of Christian communities, they were no doubt the main speakers in the community gatherings, but perhaps not the only ones.

In the second century, the Didache still regards itinerant apostles, prophets and teachers as the ministers of the Church par excellence, whose role was to preach and teach in the congregations they visited. Hermas speaks of apostles and teachers of the Son of God who preached. ${ }^{115}$ Local sedentary bishops and deacons, however, were taking over the work of the itinerant prophets and teachers. ${ }^{116}$ Preaching and teaching now becomes the special task of office holders. According to 2 Clement $17.3-5$, by the middle of the second century, preaching was the normal task of elders ( $\pi \rho \varepsilon \sigma \beta \hat{v} \tau \varepsilon \rho o 1$, presbyters). Justin says that the sermon was given by the president, o $\pi \rho 0 \varepsilon \sigma \tau \omega \varsigma .{ }^{117}$ In Justin's

\footnotetext{
113 Eph. 4:11-12.

114 Acts 20:17, 28; Tit. 1:5-7; 1 Pet. 5:1-4.

115 Herm., Sim. 9.16.5.

116 Did. 15.1-2.

117 Just., 1 Apol. 67.4.
} 
apologetic writing the general, secular term $\pi \rho 0 \varepsilon \sigma \tau \omega \dot{s}$ replaces the

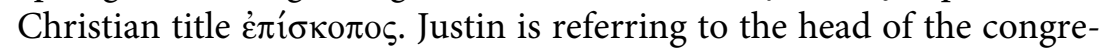
gation, who was responsible for preaching.

By the third century, the office of preaching was generally, but not exclusively, restricted to presbyters and bishops. Eusebius quotes a letter in which bishops Alexander of Jerusalem and Theoctistus of Caesarea defend themselves against Demetrius of Alexandria's charge that they were wrong to allow Origen, then a layman, to preach. According to Alexander and Theoctistus, it is not (as Demetrius had claimed)

an unheard-of, unprecedented thing that where bishops were present laymen should preach.... In case where persons are found duly qualified to assist the clergy, they are called on by the holy bishops to preach the laity; e.g., in Laranda, Euelpius; in Iconium, Paulinus; in Synnada, Theodore were called on respectively by Neon, Celsus, and Atticus, our blessed brother-bishops. Probably there are other places too where this happens, unknown to us. ${ }^{118}$

Objections against the preaching or teaching by women in Christian gatherings are put forward in 1 Timothy 2:11-12, and in the interpolated passage 1 Corinthians 14:33b-36. ${ }^{119}$ Titus 2:3 knows of older women who "are to teach what is good", but apparently only to young women (2:4) and not in the gathering of the community as a whole. ${ }^{120}$

According to Irenaeus, women acted as prophetesses in the community of Mark the magician. Mark used to make certain women he deemed worthy prophesy. On one occasion, after a eucharistic meal, he hypnotized a woman: "She grows daring and speaks delirious words and whatever comes to mind, foolishly and boldly, in the heat of the empty spirit. From that moment she considers herself a prophetess." ${ }^{21}$

\footnotetext{
118 Euseb., HE 6.19 (tra. G.A. Williamson).

119 Whether Luke wants us to imagine the four daughters of Philip, who were prophetesses, as speaking in gatherings of the Caesarean church cannot be ascertained. See Acts 21:9; cf. Euseb., HE 3.31.

${ }^{120}$ For the teaching and preaching of women in gatherings of early churches, see Tert., Res. 11.2 (the prophetess Prisca); Hippol., Refut. 8.19; 10.25-26 (the prophetesses Priscilla and Maximilla); Euseb., HE 4.27 (prophetesses accompanying Montanus); Euseb., HE 5.16.17 (the prophetess Maximilla); Did. ap. 3.6 (women should not be teachers in the church gatherings; obviously women did teach); and possibly Herm., Vis. 2.4.3 (women teaching other women and children).

${ }^{121}$ Iren., Haer. 1.13 .3 (tra. Robert Grant).
} 
About 200 CE the exclusion of women from preaching is well attested by Tertullian. Taking Paul as his authority, Tertullian exclaims, “... how credible would it seem, that he who has not permitted a woman even to learn with overboldness, should give a female the power of teaching and of baptizing." 122 Elsewhere Tertullian states: "It is not permitted to a woman to speak in the church...." ${ }^{123}$ However, in some communities women were still allowed to speak and to teach. In the Acts of Paul, for instance, a woman called Myrta is said to address the Corinthian church in the house of Epiphanius. ${ }^{124}$ Tertullian writes about gatherings of certain "heretic" groups in which women are bold enough to teach and to dispute ("quae audeant docere, contendere"). ${ }^{125}$ In Tertullian's own community a woman who received visions and revelations during the assembly was not allowed to report to the people in church what she had seen or experienced until after the formal closing of the gathering:

After the people are dismissed at the conclusion of the sacred services, she is in the regular habit of reporting to us whatever things she may have seen in vision (for all her communications are examined with the most scrupulous care, in order that their truth may be probed). ${ }^{126}$

Insofar as the posture of the preacher is concerned, he usually sat and spoke freely. Eusebius quotes Irenaeus as saying that he remembered "the very place where the blessed Polycarp was accustomed to sit and discourse." 127 The author of the Didascalia attests the same and says that the bishop sits while he speaks the Word of God. ${ }^{128}$ In GraecoRoman culture, sitting is the typical attitude of the teacher, ${ }^{129}$ whereas orators stand.

122 Tert., Bapt. 17.4.

123 Tert., Vir. vel. 9.

${ }^{124}$ Acta Pauli 9 (J.K. Elliott, p. 383). There is no reason to assume that the author, in introducing a woman speaking in the first-century Church, is trying to reconstruct an archaic situation.

125 Tert., Praescr. 41.5.

126 Tert., An. 9.4 (tra. Peter Holmes).

127 Euseb., HE 5.20.

128 Did. ap. 2.58.

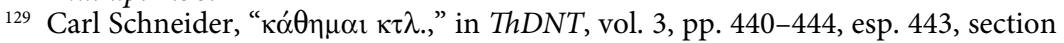
$2 \mathrm{~d}$. For the typical attitude of the orator, see, e.g., Acts $2: 14 ; 17: 22 ; 21: 40$. 


\section{Conclusions}

Summarizing this chapter it can be said that preaching began as an oral contribution to the Christian assembly following the celebration of the Lord's Supper. Originally any participant was allowed to make such a contribution, but already Paul tends to restrict the right to preach and teach to those who were qualified for it by their gifts. From the first century to the early second century-along with the local preacherstraveling apostles, prophets, evangelists and teachers were allowed to preach during the communal gatherings. The tendency in the second century is to restrict the role of preacher to the local clergy, bishops, presbyters and deacons, in particular to the bishops. From the end of the first century, teaching and preaching gradually became exclusively the task of male officials.

In the second century, for practical reasons, the sermon was put before the supper. In the first and second centuries the sermon usually had the character of admonition and exhortation. It came to be preceded by and connected with the reading of authoritative texts. In the third century the sermon became increasingly an explanation of the Scripture passage read to the congregation. 


\section{SINGING AND PRAYER IN THE GATHERING OF THE EARLY CHURCH}

\section{INTRODUCTION}

This chapter will investigate how singing and prayer in the gatherings of Christians came into existence and developed and how they functioned in the context of these gatherings in the first three centuries. Singing was an important feature of Graeco-Roman culture in general, including Judaism; however, scholars do not agree as to the origin of singing in the Christian Church. Prayer was also a constitutive element in gatherings and at communal meals of numerous groups in the Hellenistic world, both pagan and Jewish. Carrying on a Jewish practice, the early Christians blessed God at the celebration of their eucharistic supper; they also prayed other types of prayers during their gathering. In this chapter both eucharistic and other types of prayer as performed in the Christian gathering, will be discussed.

\section{Singing in the gathering of the Early Church}

a. The origin and locus of singing in the gathering of the early Church The format of the Christian gathering on Sunday evening, consisting of a supper plus an after-supper session, goes back to that of religious and other associations in the Graeco-Roman world. Singing was indeed a regular ingredient of the Hellenistic banquet. Examples of this abound in Greek and Roman literature. Petronius mentions music and community singing after supper and solo singing during the symposium. ${ }^{1}$ He has the drunk Trimalchio sing at the obscenely lavish dinner party he hosts. ${ }^{2}$ Longus speaks about a banquet during which libations were offered and hymns sung to the Nymphs: Chloe sang while Daphnis played the flute. At the banquet of peasants they sang songs of harvesters,

\footnotetext{
1 Petr., Satyr. 23.1-2; 70.7; 109.6.

2 Petr., Satyr. 73.
} 
played syrinx and flute and danced. ${ }^{3}$ In less humble circles it was customary for dinner guests to sing a paean in unison after the libations between dinner and the symposium. Paeans were addressed to the gods and as such were solemn songs. The songs called $\sigma \kappa o ́ \lambda t \alpha$ were more varied. While they could include short paeans, their content was predominantly proverbial, didactic and sometimes satirical. ${ }^{4}$

Plutarch states that at the symposium it is advisable to sing $\sigma \kappa o ́ \lambda \iota 1 \alpha$. He points out the risk that if some of the guests cannot follow a discussion, they throw themselves into the singing of any kind of song. ${ }^{5}$ It is better, therefore, to have the guests sing $\sigma \kappa o ́ \lambda t \alpha$ in a more organized and orderly manner. Plutarch also describes how singing at a symposium took place. First of all, the guests sang the god's or the gods' song together, all raising their voice in unison. Subsequently, the lyre was passed around and the guest who could play the instrument would take it, tune it and sing. ${ }^{6}$

It is clear that at the Graeco-Roman banquet both instrumental music and singing were common activities and could be an expression of piety, a form of entertainment or both. The custom of singing hymns during and after festive meals was so common that it also spread to Jewish circles. Jesus Sira already speaks of "music at a banquet of wine" and of "the melody of music with good wine." Philo says that Jews celebrated their annual Passover at home with a meal ( $\sigma v \sigma \sigma i \tau i o v)$, more solemn than other banquets $(\sigma \nu \mu \pi$ ó $\sigma 1 \alpha)$, and

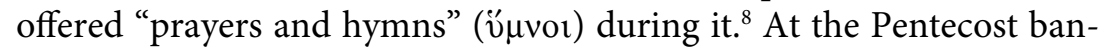

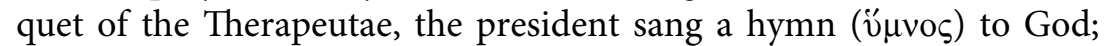
after him, all others took their turn and sang a song, the closing lines or refrains of which were chanted by all those present together. ${ }^{9}$ After the supper the participants formed two choirs to sing still more hymns to God. ${ }^{10}$ According to Mark, Jesus' last supper with his disciples, a Passover meal, was also concluded with singing together. ${ }^{11}$

${ }^{3}$ Longus, Daphnis and Chloe 2.31.1-3; 4.38.3.

${ }^{4}$ Charles Cosgrove, "Clement of Alexandria and Early Christian Music," JECS 14 (2006), 262.

${ }^{5}$ Plut., Quaest. conv. 1.615b.

${ }^{6} \mathrm{Ib}$.

7 Sir. 32:5-6.

${ }^{8}$ Philo, Spec. 2.148.

${ }^{9}$ Philo, Contempl. 80.

${ }^{10}$ Philo, Contempl. 84.

${ }^{11}$ Mk. 14:26. Many commentators remark that Mark is thinking here of the second part of the Hallel (Pss. 114/5-118), but Dieter Lührmann rightly observes that Mark 
This widespread custom of singing at festive group meals did not leave the early Christians unaffected. As to singing at their community meals, they conformed to the practice of their contemporaries. Since there are almost no sources that inform us directly about the musical practices of Christians in the first two or three centuries, such as musical notations, ${ }^{12}$ manuals for singing and making music, or instruments played, information about their singing and music has to be gleaned from literary sources.

Sources about singing by Christians in the first three centuries show that it took place mostly after communal meals during the symposium part of their gatherings. From the way Paul speaks about the Christian gathering in Corinth, it appears that in his time singing in the Christian gatherings was already a normal activity. He writes that when Christians gathered together, each of them had a psalm to sing. ${ }^{13}$ The singing took place, besides other activities, during the social gathering following the Lord's Supper.

The author of Ephesians admonishes his readers not to get drunk but "to sing psalms and hymns and spiritual songs among yourselves, singing and making melody to the Lord in your hearts." 14 The author is probably referring here to the singing during the Christian symposium: he encourages his addressees to use their time spent in the symposium singing rather than drinking. Another possible reminiscence of the custom of singing in the Christian assembly is found in James 5:13 where Christians are advised to sing songs of praise when they are cheerful.

In the middle of the second century Justin Martyr says that Christians express their gratitude to God by invocations and singing hymns. Since he is contrasting here the praises of Christians with sacrifices and libations of pagans, ${ }^{15}$ he must be thinking of the singing in the Christian assemblies. He affirms that Christians worship God rather by singing than by making libations, as pagans do during their banquets.

\footnotetext{
does not say this directly: "the reader is rather reminded of the general custom of singing hymns in cultic gatherings" (my italics). Dieter Lührmann, Das Markusevangelium (Tübingen: Mohr (Siebeck), 1987), 242.

12 A notable exception is POxy. 1786 (third century) containing a Christian hymn with musical notation which will be discussed further down in this chapter.

131 Cor. 14:26.

${ }^{14}$ Eph. 5:19. This passage is an elaboration of Col. 3:16.

15 Just., 1 Apol. 13.1-2.
} 
At the end of the second century Clement of Alexandria observes:

As it is befitting, before partaking of food, that we should bless the Creator of all; so also in drinking it is suitable to praise ( $\psi \alpha \dot{\alpha} \lambda \lambda \varepsilon ı v)$ Him on partaking of His creatures. For the psalm is a melodious and sober blessing. The apostle calls the psalm "a spiritual song."

This passage shows that singing took place, probably during the symposium part of the Christian gathering. This becomes clear from the comparison Clement makes somewhat further down between the singing at Greek banquets and that in the gathering of Christians:

Further, among the ancient Greeks, in their banquets over the brimming cups, a song was sung called a skolion, after the manner of the Hebrew psalms, all together raising the paean with the voice, and sometimes also taking turns in the song while they drank healths round; while those that were more musical than the rest sang to the lyre. But let amatory songs be banished far away, and let our songs be hymns to God. ${ }^{17}$

In this passage Clement suggests that Christians sing their hymns in the manner of the Greeks singing at their banquets. In their turn, the Greeks would sing their $\sigma \kappa o ́ \lambda 1 \alpha$ based on the analogy of the Jewish custom of singing psalms to God.

At about the same time as Clement, Tertullian gave his account of the Christian symposium. In it, he mentions the singing in the following manner: "After the bringing in of water for washing the hands, and lights, each is invited to sing publicly to God as he is able from his knowledge of Holy Scripture or from his own mind; thus it can be tested how he has drunk." ${ }^{18}$ Here, too, singing takes place after the supper (cena).

Some of the authors quoted above say explicitly that the singing of Christians took place during the after-supper party, that is, during the second part of the community gathering. This symposiastic context of the Christians' singing is in conformity with that of the singing at the Graeco-Roman banquet in general. This analogy, as well as the fact that early Christian authors themselves point out the similarity between the singing of Christians and that of pagans, indicate that Christians, in

${ }^{16}$ Clem. Al., Paed. 2.44.1. For the phrase "spiritual song," see Col. 3:16 and Eph. 5:19.

${ }^{17}$ Clem. Al., Paed. 2.44.3-4.

${ }_{18}$ Tert., Apol. 39.18. 
singing hymns in their gatherings after the supper, adopted a practice of their non-Christian contemporaries.

Several scholars trace the Christians' singing of psalms and hymns to Jewish worship in the temple, the synagogue or still other Jewish settings, for example Qumran or the Therapeutae. ${ }^{19}$ Others regard singing in Graeco-Roman cults in general, including Judaism, as the background of the singing in early Christian communities. ${ }^{20}$ However, in view of the data mentioned above, the notion that early Christians practised singing and psalmody in their gatherings on the pattern of the singing in the Jewish temple cult or synagogue worship must be considered most unlikely. There is no evidence of singing on the Sabbath in the synagogue in the first century. Nor is there any reason to derive the hymnody as practised by Christians in their after-supper gatherings from any cultic singing, since singing at banquets and during symposia was a widely spread phenomenon in the GraecoRoman world. This general phenomenon accounts sufficiently both for the singing of the Therapeutae at the banquet celebrated on the Feast of Pentecost, the possible after-supper use of psalms and hymns in the Qumran community, and for the singing in the early Christian gatherings.

\section{b. Singing and music in the Christian gathering during the first three centuries}

As has been stated above the singing usually took place in the second part of the gathering. This section will discuss both the various types of songs that were sung in the gatherings of Christians and the function of the singing itself.

19 2Q14 (remains of Psalms 103 and 104), 1QH (Thanksgiving Hymns), 4Q400 (Songs of the Sabbath Sacrifice); Philo, Contempl. 80; Test. Job 14. C.H. Kraeling, "Music in the Bible," in New Oxford History of Music, vol. 1, Ancient and Oriental Music, ed. E. Wellez (London: Oxford University Press, 1957), 303. As an argument for tracing back the singing of early Christians to that in the synagogue, it is sometimes said that instruments accompanied neither. But about singing in the synagogue in the first centuries BCE and CE nothing is known and the possibility that Christians used instruments cannot be ruled out.

${ }^{20}$ Justin Meggitt, "The First Churches: Religious Practice," in The Biblical World, ed. John Barton, vol. 2 (London and New York: Routledge, 2002), 163; Wayne Meeks, "Social and Ecclesial Life of the Earliest Christians," in The Cambridge History of Christianity, vol. 1, Origins to Constantine, eds. Frances M. Young and Margaret M. Mitchell (Cambridge: Cambridge University Press, 2006), 167. 
In 1 Corinthians Paul writes about singing praise ( $\psi \alpha \dot{\alpha} \lambda \lambda \varepsilon v v$ ) in the community. ${ }^{21}$ Paul distinguishes between singing praise with the spirit, that is, in a trance, and singing praise with the mind, that is, in intelligible words. Furthermore, Paul says that in the Christian gathering each one has a hymn ( $\psi \alpha \lambda \mu$ ó $\varsigma) .{ }^{22}$ James McKinnon is probably right in suggesting that since the context is Paul's attempt to restrain the tendency to rely excessively upon inspired gifts, the "psalm" mentioned here is likely to be a spontaneous creation rather than an Old Testament psalm. ${ }^{23}$

The author of Colossians enumerates several kinds of songs that should be sung in a Christian gathering: "With gratitude in your

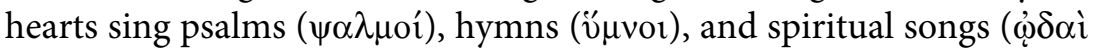
$\pi v \varepsilon v \mu \alpha \tau \imath \kappa \alpha i)$ to God." ${ }^{24}$ It is not clear whether the songs last mentioned include Paul's category of songs sung "with the spirit." Neither is it possible to determine with any precision how the three groups of songs differed from each other. The passage offers no proof that Davidic psalms were used in early Christian gatherings. ${ }^{25}$

A special type of singing is alluded to by Ignatius at the beginning of the second century. In writing his letters, Ignatius' intention was to promote the unity of Christian communities, supported by a hierarchical structure of the local leadership and the central authority of the bishop. He describes the harmony in the functioning of the hierarchy in terms of the singing of a Christian choir. ${ }^{26}$ This suggests that Ignatius was acquainted with the singing of choirs in Christian congregations. This is confirmed by the fact that he admonishes the Christians in Rome to form a chorus in love and sing forth to the Father in Jesus Christ.

A collection of 42 early Christian "odes" has been preserved in the pseudepigraphical work Odes of Solomon. It is uncertain when, where and in what language they were composed, but a composition in the

\footnotetext{
${ }^{21} 1$ Cor. 14:15.

221 Cor. 14:26.

${ }^{23}$ James McKinnon, Music in Early Christian Literature (Cambridge: Cambridge University Press, 1987), 15.

${ }^{24}$ Col. 3:16. The distinction of psalms, hymns and spiritual songs occurs also in the parallel passage Eph. 5:19.

${ }^{25}$ Edward Foley, Foundations of Christian Music. The Music of pre-Constantinian Christianity (Collegeville, MN: Liturgical Press, 1996), 86.

${ }^{26}$ Ign., Rom. 2.2.
} 
second century, somewhere in Syria and in Syriac seems most likely. ${ }^{27}$ A recent translator claims that "the Odes are a window through which we can occasionally glimpse the earliest Christians at worship." ${ }^{28}$ It is indeed highly possible that (a number of) these Odes were sung in early Christian gatherings. They sometimes use the first person plural to designate the people speaking in them:

You [God] have given to us your fellowship,

Not that you were in need of us,

But that we are always in need of you. ${ }^{29}$

Some of these Odes breath a spirit of mysticism directed at God or Christ:

I have been united (to him [God]), because the lover has found the Beloved,

Because I love him that is the son, I shall become a son..$^{30}$

Many of the Odes look like personal religious lyrics, but this does not exclude that solo singers in the gathering of a Christian community sang them. We know that singing in the gathering could be performed by single persons:

I poured out praise to the Lord,

because I am his own.

And I will recite his holy ode,

because my heart is with him.

For his harp is in my hand,

and the odes of his rest shall not be silent.

I will call unto him with all my heart,

I will praise and exalt him with all my members. ${ }^{31}$

Sometimes the odist calls upon the faithful to join in his praise:

Let all the Lord's babes praise him, and let us receive the truth of his faith.

Let us, all of us agree in the name of the Lord

${ }^{27}$ J.A. Emerton, "The Odes of Solomon," in The Apocryphal Old Testament, ed. H.F.D. Sparks (Oxford: Clarendon Press, 1984), 686-687: “ca. AD 100-200.” See also J.H. Charlesworth, "Odes of Solomon," in OTP, vol. 2, 725-771, esp. 725-728. Charlesworth tends to date the Odes to around 100 CE.

${ }^{28}$ J.H. Charlesworth, "Odes of Solomon," in OTP, vol. 2, p. 728.

${ }^{29}$ Od. Sol. 4.9 (tra. J.H. Charlesworth).

${ }^{30}$ Od. Sol. 3.7.

${ }^{31}$ Od. Sol. 26.1-4. 
and let us honour him in his goodness.

Let us exult with the exultation of the Lord.

A new chant (is) for the Lord from those that love him.

Hallelujah. ${ }^{32}$

In any case the author(s) of the Odes was (were) also acquainted with the phenomenon of community singing in a Christian congregation:

Let the singers sing the grace of the Lord Most High, and let them offer their songs.

And let their heart be like the day,

and their gentle voices like the majestic beauty of the Lord.

And let there not be any person

that is without knowledge or voice.

For he gave a mouth to his creation,

to open the voice of the mouth toward him,

and to praise him.

Praise his power

and declare his grace.

Hallelujah. ${ }^{33}$

In Ode of Solomon 16, the poet reflects explicitly upon his work of composing psalms and singing praise to the Lord:

As the work of the plowman is the plowshare, and the work of the helmsman is the steering of the ship, so also my work is the psalm of the Lord in his praises.

My art and my service are in his praises, because his love has nourished my heart, and his fruits he poured unto my lips.

For my love is the Lord;

hence I shall sing unto him. ${ }^{34}$

It is likely that these hymns were sung or recited in gatherings of some early Christian community or communities.

POxy. 1786, contains an early Christian hymn with musical notation. The papyrus is of the later third century, but the music and text of this hymn may go back to the second century. From the text it may be inferred that the hymn was meant to be sung in a gathering and perhaps by a number of people together. Its text runs as follows:

${ }^{32}$ Od. Sol. 41.1, 5, 7, 16.

${ }^{33}$ Od. Sol. 7.22-26.

${ }^{34}$ Od. Sol. 16.1-3. 
Let it be silent, let the luminous stars not shine,

let the winds (?) and all the noisy rivers die down;

and as we hymn the Father, the Son, and the Holy Spirit,

let all the powers add "Amen, amen".

Empire, praise always, and glory to God,

the sole giver of all good things. Amen, amen. ${ }^{35}$

At the end of the second century, Clement of Alexandria enumerates a number of types of songs that were sung in Christian gatherings: chants, hymns, benedictions, and psalms. ${ }^{36}$ It is probable that the category last mentioned included psalms from the Old Testament. Tertullian does not only state that singing of psalms was an ordinary element of the Christian gathering on Sunday, ${ }^{37}$ he also remarks that certain songs sung in the gatherings of Christians could be taken from Scripture. ${ }^{38} \mathrm{He}$ is probably thinking here of Old Testament psalms, for in one passage he says explicitly that Psalms of David were sung in church. ${ }^{39}$ This information is confirmed by the author of the Acts of Paul (ca. $190 \mathrm{CE}$ ), who observes that Christians in Corinth, after partaking in the Eucharist, sang psalms of David and hymns. ${ }^{40}$

Tertullian also notes that when Christians gathered for common prayer, "the more diligent in prayer were accustomed to add in their prayers the "alleluia" and such kind of psalms at the close of which the company may respond." 41 This suggests that the community knew "responsorial forms in which "alleluia" or some other responsory... were chosen so that the company could respond at the end of the verses." 42 All Odes of Solomon end with "alleluia", which may have been meant as a responsory to be sung by the audience. ${ }^{43}$ Responding to psalms with "alleluia" is attested in the Apostolic Tradition in a passage dealing with the order of the communal gathering in the evening:

35 M.L. West, Ancient Greek Music (Oxford: Clarendon Press, 1992), 324-326.

Clem. Al., Str. 6.113.3.

37 Tert., An. 9.

${ }^{38}$ Tert., Apol. 39.18.

39 Tert., Carn. Chr. 20.3.

${ }^{40}$ Acta Pauli 9 (J.K. Elliott, p. 383).

${ }^{41}$ Tert., Or. 27.17.

${ }^{42}$ Robert Taft, The Liturgy of the Hours in East and West (Collegeville, MN: Liturgical Press, 1986), 18.

${ }_{43}$ The "Alleluia" is missing only at the end of Ode 1, probably because the ending of this Ode has gone lost together with the whole of Ode 2. 
All of them, as he [the bishop] recites the psalms, shall say "alleluia," which is to say "We praise him who is God most high; glorified and praised is he who founded all the world with one word." And likewise, when the psalm is completed, he shall give thanks over the cup and give of the fragments to all the faithful. ${ }^{44}$

Another type of Christian psalm chanted in alternation between a precentor or reader and the community is the Psalmus responsorius, an specimen of which is preserved in a Latin papyrus, P. Barc. $149 \mathrm{~b}-153 .{ }^{45}$ The papyrus is early fourth-century, but the hymn has sometimes been dated to the end of the second century. ${ }^{46}$ Even if this is too optimistic, this date may well apply to the genre of the Psalmus responsorius. The precentor or reader chanted the strophes, which are of varying lengths, the community answered each strophe by singing the refrain of four lines. The strophes contain a life of Jesus harmonized from canonical and non-canonical traditions. ${ }^{47}$ The Psalmus is rhythmical and also contains some rhyming sections; the surviving strophes begin with the letters of the alphabet: we possess the $\mathrm{A}$ to $\mathrm{M}$ strophes complete and parts of the $\mathrm{N}, \mathrm{O}$ and $\mathrm{P}$ strophes. ${ }^{48}$

The refrain of the Psalmus responsorius runs as follows:

Father, you who rule all things,

I pray that you may know us as the heirs of Christ.

Christ, born by the word, ${ }^{49}$

By whom the people have been set free.

${ }^{44}$ Trad. ap. 25 (tra. A. Stewart-Sykes, adapted).

45 Aniello Salzano, Agli inizi della poesia cristiana latina (Salerno: Edisud Salerno, 2007), the first poem. Editio princeps: R. Roca-Puig, Himne a la Verge Maria. "Psalmus Responsorius" (Barcelona: Asociación de Bibliofilos de Barcelona, 1965).

${ }^{46}$ A.F.J. Klijn, Apokriefen van het Nieuwe Testament, vol. 1 (Kampen: Kok, 1984), 96.

${ }^{47}$ For further studies on this hymn, see Alanna Nobbs, "A Fourth-Century Hymn to the Virgin Mary? Psalmus responsorius: P. Barc. 149b-153," Proceedings of the XIV International Congress of Papyrologists (Oxford, 24-31 July 1974) = Graeco-Roman Memoirs 61 (London: Egypt Exploration Society, 1975), 97-102; ead., "The Subject of Psalmus responsorius: P. Barc. 149b-153," Museum Philologicum Londiniense 2 (1977), 99-108; A.M. Emmett, "A Fourth-Century Hymn to the Virgin Mary?" New Documents Illustrating Early Christianity, vol. 2, ed. G.H.R. Horsley (North Ryde, Australia: The Ancient History Documentary Research Centre, Macquarie University, 1982), 141-146.

48 A.M. Emmett, pp. 142-143.

49 That is, by the word of the angel. 
This is the last surviving strophe of the fragmentary text:

He (Jesus) performed a great miracle

in Galilee, where he first went.

There was a celebration of a marriage in that place

and being invited he went there

with his disciples, whom he chose for himself.

Then it was said to him, "There is no wine."

He replied, "Woman, what is that to me and you?"

He summoned to him the servants of the water:

"Fill the measures of water....

In his tract On Fasting Tertullian mentions Psalm 133 (LXX and Vulgate 132) and says that it is not easy to sing this psalm except for those who are enjoying a supper (cena) with a number of other people. ${ }^{51} \mathrm{He}$ is probably referring here to the community gathering of Christians.

Tertullian also claims that in their gatherings Christians sang not only existing, Old Testament psalms, but also newly composed psalms. ${ }^{52}$ That new psalms were written appears from what the Canon Muratori remarks about "a new book of psalms" composed for Marcion. ${ }^{53}$ This psalter was probably designed for the use in meetings of Marcionite communities. Canon Muratori states that Arsinous, Valentinus and Miltiades, together with Basilides, were its authors. The text and its precise meaning are slightly uncertain, but that Valentinus and Basilides wrote psalms and hymns is confirmed by Clement of Alexandria, ${ }^{54}$ and confirmation of Valentinus' activity as a composer of psalms comes from Tertullian. ${ }^{55}$ An anonymous Christian writer at the end of the second century notices that "from the beginning" of the Christian Church faithful brethren wrote numerous "psalms and hymns", "in which Christ is spoken of as God." ${ }^{56}$ Moreover, about the middle of the third century, an Egyptian bishop called Nepos "wrote

${ }^{50}$ Translation by A.M. Emmett in New Documents Illustrating Early Christianity, vol. 2, ed. G.H.R. Horsley, 141-146.

51 Tert., Ieiun. 13.7. The Psalm is "How very good and pleasant it is, when kindred live together in unity."

${ }_{52}$ Tert., Apol. 39.18.

53 Canon Muratori, lines 81-85.

${ }^{54}$ Clem. Al., Str. 4.12.

55 Tert., Carn. Chr. 20.3.

${ }^{56}$ Euseb., HE 5.28. 
many psalms", which remained a source of comfort to many Christians there for some time. ${ }^{57}$

The function of singing in the gatherings of Christians was the glorification of God and Christ, and the edification of the members of the congregation. Paul notices that the singing of hymns, just like all other activities in the Christian gathering, should contribute to "the building up" of the community. ${ }^{58}$ In their hymns Christians addressed God and Christ and gave them glory. The author of Colossians urges his addressees to sing psalms, hymns and spiritual songs to God with gratitude in their hearts. ${ }^{59}$ In much the same way participants in pagan banquets sang their paeans and hymns to honour and thank their gods. ${ }^{60}$

Pliny's account of Christian meetings (ca. $112 \mathrm{CE}$ ) mentions that Christians met on a fixed day before dawn and sang in alternate verses a hymn to Christ as to God. ${ }^{61}$ True, this singing took place in the early morning, not in the context of a supper or Eucharist. Nevertheless, the passage in Pliny shows that a Christ-centred content could be characteristic of Christian hymns. Whether Philippians 2:6-11 goes back to such a hymn, as is often contended, ${ }^{62}$ cannot be ascertained. ${ }^{63}$

Christian songs glorifying Christ occur in the book of Revelation, ${ }^{64}$ but we cannot be sure that these reflect hymns sung in any church. The same applies to the song of Moses from Exodus 15:1-18, quoted

${ }^{57}$ According to Dionysius, bishop of Alexandria (247-264 CE), quoted in Euseb., HE 7.24.

581 Cor. 11:26.

${ }^{59}$ Col. 3:16.

${ }^{60}$ See, e.g., Athen., Deipn. 5.179d (a paean to the god); 15.701f-702a (a paean to the goddess Hygieia); 14.628a (hymns for the gods).

${ }_{61}^{61}$ Plin., Ep. 10.96.8.

${ }^{62}$ For a discussion of the topic, see Ralph Martin, Carmen Christi: Philippians 2:511 in Recent Interpretation and in the Setting of Early Christian Worship (Cambridge: Cambridge University Press, 1967).

${ }_{63}$ As it stands, this passage is certainly not a hymn, but Paul's prose. It is stylistically more elevated than the context and contains traditional, pre-Pauline elements, but also Pauline features. Rather than a hymn, this is a specimen of "Asianism", a new style of oratory developed during the Hellenistic period. See "Asianism," in $O C D$, p. 191. For a forceful defence of the view that Phil. 2:6-11 is lofty, rhetorical prose, and no hymn, see Gordon Fee, "Philippians 2:5-11: Hymn or Exalted Pauline Prose?" BBR 2 (1992), 29-46.

${ }^{64}$ E.g., in Rev. 5:9-12. Donald Guthrie rightly suggests that the hymns in Revelation are the work of the author himself; Donald Guthrie, "Aspects of Worship in the Book of Revelation," in Worship, Theology and Ministry in the Early Church. Essays in Honour of Ralph P. Martin, eds. Michael J. Wilkins and Terence Paige (Sheffield: JSOT Press, 1992), 70-83, esp. 71. 
in Revelation 15:3-4 and now called "the song of the Lamb." It is not impossible that the author of Revelation included songs used by Christians in their gatherings, but there is nothing to verify this.

As regards the rationale of the singing, second-century authors give clear information about the function of singing in the community. Justin Martyr notices that by singing hymns Christians express their gratitude to God. ${ }^{65}$ In a polemical context, Clement of Alexandria states that the purpose of singing at pagan banquets was for the participants' entertainment; ${ }^{66}$ however, the evidence testifies to the contrary: pagans sang at their banquets in honour of their gods just like Christians did in honour of God and Christ. The Odes of Solomon praise, glorify and thank God and Christ and express the odist's trust in God. An early Christian hymn preserved by Clement of Alexandria, the well-known hymn "Bridle of colts untamed," is a hymn to Christ. ${ }^{67}$ Clement of Alexandria also characterizes the singing of Christians in their gathering as "hymning immortality." Since the Christians' singing in Church was "hymning immortality" they were not to "foolishly amuse themselves with impious playing, and amatory quavering, with flute-playing, and dancing, and intoxication, and all kinds of trash" later on.$^{68}$ In the third century Origen states explicitly that Christians sing hymns to honour God and Christ:

Celsus says that we would seem to honour the great God better if we would sing hymns to the sun and Athena. We, however, know it to be the opposite. For we sing hymns to the one God who is over all and his only begotten Word, who is God also. So we sing to God and his only begotten as do the sun, the moon, the stars and the entire heavenly host. $^{69}$

Furthermore, Christian and non-Christian authors agree in recognizing that singing after supper is useful in preventing the participants from getting drunk. Plutarch observes that singing can help to prevent disorders and foolish arguments at the banquet. ${ }^{70}$ Similarly, Athenaeus states that "the ancients...included in their customs and laws the

${ }^{65}$ Just., 1 Apol. 13.2.

${ }^{66}$ Clem. Al., Paed. 2.44.4.

${ }^{67}$ Clem. Al., Paed. 3.81-88. To be sure, it is unclear whether this hymn was used in Christian gatherings in Clement's time.

${ }^{68}$ Clem. Al., Paed. 3.80.4.

${ }^{69}$ Or., C. Cels. 8.67 (tra. James McKinnon, Music in Early Christian Literature, 15).

${ }^{70}$ Plut., Quaest. conv. 1.614f-615b. 
singing of praises to the gods by all who attended feasts, in order that our dignity and sobriety might be retained through their help." ${ }^{.11} \mathrm{~A}$ similar admonition occurs in Ephesians 5:18-20:

Do not get drunk with wine, for that is debauchery; but be filled with the Spirit, as you sing psalms and hymns and spiritual songs among yourselves, singing and making melody to the Lord in your hearts, giving thanks to God the Father at all times and for everything in the name of our Lord Jesus Christ.

The author of Ephesians urges Christians not to get drunk during their gathering since this may lead to debauchery. Instead, they should channel their spiritual élan into the singing of psalms, hymns, and spiritual songs among each other, thus making melody to the Lord. Indeed the purpose of singing in the gatherings of Christians was to give glory to God and add to the proper entertainment through avoiding drunkenness and disorder. Tertullian, too, states that singing served to check drunkenness. According to him, participants in the Christian symposium are invited to sing a hymn in order to see whether they have not drunk too much. ${ }^{72}$

Very interesting information about singing in the gathering of a Christian Church comes from the second half of the third century. Paul of Samosata, the Adoptionist bishop of Antioch (260-272 CE), forbade the singing of hymns to Christ as the Son of God who had come from above. A number of other bishops protested in a circular letter (269 CE) in which they say:

All hymns to our Lord Jesus Christ he has banned as modern compositions of modern writers, but he arranges for women to sing hymns ( $\psi \alpha \lambda \mu \omega \delta \varepsilon i v)$ to himself in the middle of the church on the great day of the Easter festival: one would shudder to hear them!... Those who sing hymns and praises to him in the congregation say that their blasphemous teacher [Paul of Samosata] is an angel come down from heaven. ${ }^{73}$

This account may not be historically trustworthy in every detail, but it certainly is a clear witness to the singing of hymns in Church, especially of hymns which praise Jesus as God.

A new development in Christian community singing took place in the course of the third century. From now on, the singing by choirs of

${ }^{71}$ Athen., Deipn. 14.627f-628a.

72 Tert., Apol. 39.18.

${ }^{73}$ Euseb., HE 7.30.10-11 (tra. G.A. Williamson). 
children became a prominent feature of the Christian gathering. The custom to invite children to sing hymns and songs was widespread in Graeco-Roman antiquity. Lucian narrates that at the symposium on the Isle of the Blest, participants listen to the singing of choruses of boys and girls. ${ }^{74}$ Aulus Gellius writes about a young man giving a banquet for his friends and teachers:

When there was an end of eating and drinking, and the time came for conversation, Julianus asked that the singers and lyre-players be produced, the most skilful of both sexes, whom he knew that the young man had at hand. And when the boys and girls were brought in, they sang in a most charming way several odes of Anacreon and Sappho, as well as some erotic elegies of more recent poets that were sweet and graceful. ${ }^{75}$

Similarly, the author of the Apostolic Tradition speaks about children who recite psalms after supper. ${ }^{76}$ This account of singing poetry by a group of children has much in common with Aulus Gellius' account of post-supper singing by choirs of children quoted above.

As to the use of musical instruments by Christians, it has been supposed that the discreet accompaniment of the cithara or lyre has been fairly common in the hymnody that was heard in the homes of wellto-do Christians. ${ }^{77}$ As far as the use of instruments in the gatherings of Christians is concerned, there is evidence that harps (or citharas) were used to accompany the singing of odes in the second century at the latest, namely in the Odes of Solomon 14.8 and 26.3 (quoted below). Paul mentions musical instruments like flute, harp and trumpet in his discussion of the gathering of the Christian congregation in Corinth (1 Cor. 14:7-8; cf. 13:1). This mention appears in a passage that cautions against placing too high a value on speaking in tongues. An essential characteristic of this is its audibility without being intelligible. Here Paul compares human utterances with musical instruments "that produce sound, such as the flute or the harp. If they do not give distinct notes, how will anyone know what is being played?"78 This passage implies that if musical instruments are played well, so that they produce distinct notes, one knows what is being played. In the

\footnotetext{
74 Luc., Ver. hist. 2.15.

75 Aul. Gel., NA 19.9.

76 Trad. ap. 25: "Et surgent ergo post cenam orantes, pueri dicent psalmos."

77 Maxwell Johnson, "Worship, Practice and Belief," in The Early Christian World, ed. Philip Esler, vol. 2 (London and New York: Routledge, 2004), 777.

78 James McKinnon, Music in Early Christian Literature, 14.
} 
same way, Christians should preferably speak in articulate language, so that one can know what they say. However, how much Paul's mention of musical instruments here contributes to our knowledge of the use of those instruments in the Christian gathering of his time remains unclear.

The use of instruments, namely, harps or citharas, is also mentioned in the description of heavenly worship in the book of Revelation (Rev. 5:8). In Ode of Solomon 14.8 the odist prays: "Open to me the harp (or cithara) of your Holy Spirit, so that with every note I may praise you, O Lord," and in 26.3 he says: "For his harp (or cithara) is in my hand, and the odes of his rest shall not be silent." These latter passages seem to indicate that the singing of any of the Odes of Solomon could be accompanied by the harp (or cithara). If this is correct for some of the Odes of Solomon, then the author of Revelation and perhaps even Paul may also have known about the use of a harp (or cithara) or other instruments in Christian gatherings.

At the end of the second century Clement of Alexandria provides clear information about the use of music in the Christian Church:

This is the mountain beloved of God, not the subject of tragedies like Cithaeron, but one devoted to the dramas of the truth, a wineless mountain, shaded by hallowed groves. Therein revel no Maenades, the sisters of "thunder-smitten" Semele, who are initiated in the loathsome distribution of raw flesh, but the daughters of God, the beautiful lambs, who declare the solemn rites of the Word, assembling a sober company. The righteous form this company; and their song is a hymn in praise of the King of all. The maidens play the harp, the angels give glory, prophets speak, a noise of music rises: swiftly they pursue the sacred band, those who have been called hasting with eager longing to receive the Father. ${ }^{79}$

Clement's description of the use of music in the gathering is somewhat lofty, but it is clear that choirs of women and men sang hymns and maidens played the lyre. It may be noted in passing that choirs of women also sang hymns in pagan cults as, for instance, in the worship of Eileithyia at Elis. Here "maidens and matrons waited in the sanctuary of Eileithyia chanting a hymn." ${ }^{80}$ In Asia Minor, organizations of girls who regularly sang in the context of civic cults and festivals were

79 Clem. Al., Protr. 12.92 (tra. G.W. Butterworth).

${ }^{80}$ Pausan., Descr. Graec. 5.20.2-3. See R.S. Kraemer (ed.), Women's Religions in the Greco-Roman World. A Sourcebook (Oxford: Oxford University Press, 2004), 41. 
quite common. ${ }^{81}$ The Therapeutae had two choirs, one of men and one of women, which performed sometimes separately, sometimes together. ${ }^{82}$

Clement of Alexandria, however, also condemns an excessive use of refined instruments by Christians in their gatherings. Such instruments are to be abandoned because Clement associates them with the arousing of the passions to drunkenness, eroticism, sensuality and violent aggression. ${ }^{83}$ However, he does not prohibit the use of simple instruments, such as the lyre and the cithara: "If you wish to sing to and play the cithara or lyre, this is not a disgrace; you would imitate the righteous Hebrew king in his thanksgiving to God." 84

In summary, it may be said that in the second century at the latest, when the Odes of Solomon were composed, musical instruments, especially the harp or cithara, were used in the communal gatherings of Christians. This may already have been the case in the time of Revelation, if not already in the time of Paul. In this Christians conformed to the practice of the Hellenistic symposium. At banquets in the GraecoRoman world, musicians, among others flute-players, took care not only of the instrumental music and the support of the singing, but also of the accompaniment of the dancing. By the time of Clement of Alexandria the use of instruments in the Christian gathering was so usual that he deemed it necessary to warn Christians against their excessive use and against the use of certain instruments (tympanum, cymbal, syrinx, aulos). However, he did not forbid the use of the harp, cithara or lyre. ${ }^{85}$

${ }^{81}$ Philip Harland, Associations, Synagogues, and Congregations (Minneapolis: Fortress Press, 2003), 72.

${ }_{82}$ Philo, Contempl. 83-87.

${ }^{83}$ Clem. Al., Paed. 2.40-41; 2.42.1; 3.80.4.

${ }^{84}$ Clem. Al., Paed. 2.43.3. According to Johannes Quasten, Musik und Gesang (1930, English ed. 1973), Clement is making here an exception for the use of the cithara and the lyre in both private dinner parties and communal gatherings of Christians. James McKinnon (1965), however, has argued that Clement allows instruments only for private hymn-singing. In a later publication (1987), McKinnon suggests that Clement's acceptence of lyre and cithara is to be taken allegorically. See also Charles Cosgrove, "Clement of Alexandria and Early Christian Music," JECS 14 (2006), 255-282, esp. 260.

${ }^{85}$ How the musical instruments mentioned in this section looked like in antiquity, may be seen from the photographs of archaeological objects at the end of James McKinnon, Musique, chant et psalmodie. Les textes de l'Antiquité chrétienne (Turnhout: Brepols, 2006), 272-287. See also the illustrations in Andrew Barker, Greek Musical Writings, vol. I (Cambridge: Cambridge University Press, 1984); M.L. West, Ancient 


\section{Prayer in the gathering of the early Church}

\section{a. The origin of prayer in the gatherings of the early Church}

In the Graeco-Roman world, in which religion played a preponderant role in everyday life, prayer was a widespread phenomenon. People prayed to gods on different occasions: in religious rituals, at public events and at home before the lares. ${ }^{86}$ It was also customary among non-Jews to say prayers to the gods at their banquets. Athenaeus describes banquets at which the gods were invoked: "But with the first cup of mixed wine given after the dinner they [the Greeks] call upon Zeus the Saviour." ${ }^{87}$ Prayer was also usual at the closing of a symposium: "(Then Larensis, our host), having performed the rite of purification with frankincense... prayed to all the gods and goddesses." 88 Gatherings of various associations and religious clubs were held in honour of their patron deities and it was inevitable that during the meetings these gods were invoked through prayers. According to the statutes of an Egyptian association, the Guild of Zeus Hypsistos (first century BCE, probably between 69-58 BCE), its members held a banquet once a month at which they "poured libation, prayed and performed other customary rites on behalf of the god and lord, the king." ${ }^{89}$ Thus, whenever people in the Graeco-Roman world gathered for a communal banquet they found it natural to pray to their gods.

Prayer was also an essential element of the Jewish religion. The earliest Jewish places of assembly in Egypt were called $\pi \rho 0 \sigma \varepsilon v \chi \alpha i$, "houses of prayer." Besides communal prayers and prayers at the religious ceremonies, ${ }^{90}$ Jews prayed and blessed God before eating and sometimes after it. ${ }^{91}$ It is probable that this was part of a more widely spread, ancient practice. $^{92}$ Athenaeus describes the banquets of Dionysus and

Greek Music (Oxford: Clarendon Press, 1992). For pictures of ancient stringed instruments, see also Warren D. Anderson, Music and Musicians in Ancient Greece (Ithaca, NY: Cornell University Press, 1997), 172-173 and passim.

${ }^{86}$ For the occasions of prayer see Simon Pulleyn, Prayer in Greek Religion (Oxford: Clarendon Press, 1997), 156-195.

${ }^{87}$ Athen., Deipn. 15.675b-c.

${ }^{88}$ Athen., Deipn. 15.701f-702b.

89 See text and translation in Colin Roberts, T.C. Skeat and A.D. Nock, "The Gild of Zeus Hypsistos," HTR 29 (1936), 39-88, esp. 41-42.

${ }^{90}$ Sir. 50:19; Jos., Ap. 2.196.

91 Jub. 22.6; Jos. Asen. 8.5; Sib. Or. 4.26; Jos., BJ 2.131.

92 Homer, Iliad 9.219; Odyssey 9.231; Xen., Symp. 2.1. 
Apollo in Naucratis, Egypt, which the participants began with libation and prayer:

They lie down, and then rise again to their knees and join in a libation as the sacred herald recites the ancestral prayers. After this they lie down, and each of them gets two kotuali of wine, except for the priests of Pythian Apollo and Dionysus, each of whom, is given twice as much wine, as well as his portion of everything else. Then each man is served a flat loaf of good bread, with another loaf of bread.... ${ }^{93}$

Philo writes about communal meals of the Therapeutae in Egypt during which "they pray to God that their feasting may be acceptable and proceed as he would have it. After prayer the seniors recline...."94

According to the Qumran Community Rule, the members of the community gathered for communal meals and prayed before they began eating:

They shall eat together, together they shall bless and together they shall take counsel.... And when they prepare the table to dine or the new wine for drinking, the priest shall stretch out his hand as the first to bless the first fruits of the bread and the new wine. ${ }^{95}$

The priest who presided over the community meal took charge of the procedure by saying grace before the meal began. As stated above, it was a common practice for Jews, both in Palestine and in the Diaspora, to begin their meals with a blessing over the food. ${ }^{96}$

Besides saying grace before and after the partaking of a communal meal Jews prayed also during the symposium part of their gatherings. Among various instructions as to what people should do at the communal banquet, Jesus Sira advises that one should above all "bless God" who fills people with his good gifts. ${ }^{97}$ The Qumran writings, too, suggest that during the gathering following the communal meal, after the reading of the Law and its explanation, Jews spent time praying: "And the many shall be on watch together for a third of each night of

93 Athen., Deipn. 4.149e-f.

${ }_{94}$ Philo, Contempl. 66-67.

95 1QS 6.3, 5; cf. the Messianic Rule or Rule of the Congregation, 1QSa 2.18-19, in which similar instructions are given for the meal of the congregation in the last days.

96 The Gospels reflect this practice of saying grace before the partaking of the food. See, e.g., Mk. 6:41 (Mt. 14:19; Lk. 9:16); Mk. 8:6 (Mt. 15:36); Lk. 24:30; Jn. 6:11.

${ }^{97}$ Sir. 32:13. 
the year in order to read the book, explain the regulation, and bless together." 98

From the evidence presented above it can be concluded that in the Graeco-Roman world of the first century CE, people, both pagans and Jews, prayed at their communal meals. Perhaps Jews were more diligent in saying grace before and after meals than non-Jews, but non-Jewish people were certainly also acquainted with the custom of praying during supper and before and after drinking.

In light of the above, it was quite natural for Christians to pray at their communal meals in accordance with the common practice in the Hellenistic world. Since most of the first Christians were of Jewish origin, they continued to pray according to the Jewish custom of blessing God before the meal. The prayer is sometimes designated as

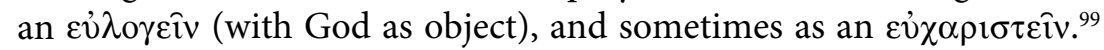
This prayer over the elements of the meal later became the liturgical eucharistic prayer.

In addition to the eucharistic prayers, early Christians also offered God other kinds of prayer, namely during the symposium part of their meetings. These prayers were praises, petitions, supplications, intercessions, thanksgivings, and benedictions. In praying in their communal gatherings, Christians followed the custom widely accepted in the Graeco-Roman world of praying at the symposium, a custom which, as was mentioned above, had also spread among Jews.

According to the earliest accounts of the Christian gatherings, the participants prayed during both parts of the gathering, the supper and the after-supper meeting. At the supper they said benedictions to God over the wine and the bread; ${ }^{100}$ during the symposium part of their gathering they said other prayers. ${ }^{101}$ Paul mentions explicitly the blessing over the cup of wine during the first part of the meeting: "The cup of blessing that we bless..." 102 Early gentile Christians, like those in Corinth, inherited the custom of blessing or thanking God before partaking of the food from Jewish Christians. The extant example of such a eucharistic prayer is preserved in the Didache which reflects Jewish

\footnotetext{
98 1QS 6.7-8.

99 See, for instance, 1 Cor. 10:16 and Did. 9.1; Ign., Smyr. 8.1 respectively.

1001 Cor. 10:16; Did. 9.2-4.

1011 Cor. 14:13, 14, 15: prayer; v. 16: thanksgiving.

1021 Cor. 10:16.
} 
prayer traditions. ${ }^{103}$ It is probable that grace was said both over the cup and the bread before the meal began, as seems to be the case in the Didache. ${ }^{104}$ Both 1 Corinthians 10:16 and Didache 9 give the order of the prayers as first over the cup and then over the bread. This is likely to reflect an early common tradition.

In 1 Corinthians 14:14-16 Paul mentions the other prayers that were offered in the communal gathering. He states that one can pray in a tongue and with one's mind. ${ }^{105}$ It is obvious that these prayers are not the prayers of blessing before the consumption of the food. These prayers are praises and petitions to God that take place in between or after hymns, teachings and revelations. The purpose of these prayers differs clearly from that of the eucharistic prayers mentioned in 1 Corinthians 10:16.

As to the origin of these non-eucharistic prayers, Wayne Meeks suggests that the early Pauline groups adapted the Jewish style of prayer, the Tefillah ("prayer"), from the synagogue liturgy. He underpins this suggestion by referring to a number of benedictions in Paul's letters, which he takes to be echoes of synagogal prayers, as for instance 2 Corinthians 1:3: "Blessed be the God and Father of our Lord Jesus Christ, the Father of mercies and God of consolation, who consoles us in our every affliction...." ${ }^{106}$ However, first, it is unknown whether the non-eucharistic prayers said in the Christian gathering took the form "Blessed be God" or "Blessed be the Lord." Secondly, praying occurred in the context of many Hellenistic banquets, both non-Jewish and Jewish. In offering prayers after their communal suppers, Christians and Jews probably shared the widely attested Graeco-Roman practice of praying during the after-supper party or symposium.

The topic of prayer in the early Church is extremely broad and much has been written about it in recent years. Much scholarly effort has been devoted to the study of daily prayers of Christians and the

${ }^{103}$ G. Rouwhorst, "Didache 9-10: A Litmus Test for the Research on Early Christian Liturgy Eucharist," in Matthew and Didache. Two Documents from the Same Jewish Christian Milieu? ed. Huub van de Sandt (Minneapolis and Assen: Fortress and Van Gorcum, 2005), 143-156, esp. 149-151.

104 According to Did. 9.1-4, the eucharistic prayer began with prayer over the cup and continued with prayer over the bread.

1051 Cor. 14:14-15.

106 Wayne Meeks, The First Urban Christians, 147-148. 
study of the eucharistic prayers. ${ }^{107}$ Nevertheless, there are only a few recent monographs that pursue the question of prayers in the context of the Christian gathering. ${ }^{108}$ In the following two paragraphs, both the practice of eucharistic prayers and that of the other prayers in the context of the Christian gathering will be discussed.

\section{b. The evolution of the eucharistic prayers during the first three centuries}

In this section the setting, background and function of the eucharistic prayers within the Christian gathering will be discussed. Early Christian writings often refer to the custom of saying grace before the communal meal and thus give us some information about the order of the prayers over the eucharistic elements, their length, the themes touched upon in them as well as information as to who performed them. Only a few examples of eucharistic prayers occur in Christian writings during the first three centuries, but these do help us to form an idea about the structure and function of early eucharistic prayers, their development and the origin of certain patterns of thought occurring in them.

Paul notices that in celebrating the Lord's Supper in their communal gathering the Corinthian Christians pronounce a benediction over "the cup of blessing." 109 However, nothing can be inferred from this brief remark as to how this rite of saying grace was performed. Paul merely mentions the benediction over the cup and the breaking of the bread. He probably presupposes that a benediction was said over the bread as well. It is most likely that Paul and the early Christians said grace ( $\varepsilon \dot{\lambda} \lambda$ oyí $\alpha$ ) over both the cup and the bread before they proceeded to eat their communal supper. From 1 Corinthians 10:16 it cannot be deduced with absolute certainty whether the blessing over cup and bread took place in one or in two benedictions, nor in what order cup and bread occurred in the benediction(s). However, according to the

${ }_{107}$ See Paul Bradshaw, Daily Prayer in the Early Church (London: Alcuin Club/ SPCK, 1981); Paul Bradshaw, Eucharistic Origins (Oxford: Oxford University Press, 2004); E. Mazza, "L'eucaristia: dalla preghiera giudaica alla preghiera cristiana," in $L a$ preghiera nel tardo antico. Dalle origini ad Agostino (Rome: Institutum Patristicum Augustinianum, 1999), 25-52.

${ }_{108}$ A. Hamman, "La prière chrétienne et la prière païenne, formes et differences," in ANRW II 23.2, ed. Wolfgang Haase (Berlin: Walter de Gruyter, 1988), 1190-1247; Hermut Löhr, Studien zum frühchristlichen und frühjüdischen Gebet (Tübingen: Mohr (Siebeck), 2003), 395-435.

1091 Cor. 10:16. 
Didache, grace is said before the meal in two separate thanksgivings, first over the cup, then over the bread; this may also have been the case in Corinth.

In 1 Corinthians 11:23-25, Paul contends that at the Last Supper Jesus first of all said grace ( $\varepsilon \dot{\chi} \chi \alpha \rho \imath \sigma \eta \dot{\eta} \sigma \alpha \varsigma$ ) over the bread and then concluded the meal by saying grace over the cup. As we have seen before, according to 1 Corinthians 10:16, the blessings at the Lord's Supper were said in the order of cup then bread. Scholars have suggested various explanations to reconcile the difference between the order of the prayers of thanksgiving in 1 Corinthians 10:16 and in the institution narrative in 1 Corinthians 11:23-25. ${ }^{110}$ However, it seems better to distinguish Paul's account of the ecclesiastical rite of the Lord's Supper carefully from the story about Jesus' Last Supper. The account of the periodical communal meal of the Christian congregations should not be played off against, or harmonized with, the stories about Jesus' Last Supper. There is no need to explain away the differences between the account of the Lord's Supper or Eucharist of the Church and the aetiological story about Jesus' Last Supper. The Last Supper is not a Lord's Supper, even if the story of the Last Supper originated as aetiology of the Lord's Supper. ${ }^{111}$ However, if an explanation of the difference between 1 Corinthians 10:16 and Didache 9, on the one hand, and 1 Corinthians 11:23-25, on the other hand, must be given, it is probably best to say that 1 Corinthians 10:16 and Didache 9, where the order of the prayers is first over the cup then over the bread, both before the meal, reflect an existing "liturgical" order known to Paul, the Corinthian Christians and the Didachist. By contrast, the narrative of the Last Supper in 1 Corinthians 11:23-25 does not claim to mirror any "liturgy" of the Eucharist at all, but just wants to narrate the institution of the Eucharist during the Last Supper. The Last Supper story places the blessing over the bread, not before the meal, but halfway through the meal; see Mark 14:23: "While they were having supper," "During supper." This is at least compatible with 1 Corinthians 11:24, which does not specify at what moment Jesus, when

${ }^{110}$ G. Rouwhorst, "Bread and Cup in Early Christian Eucharist Celebrations," in Bread from Heaven. Customs and Practices Surrounding Holy Communion. Essays in the History of Liturgy and Culture, eds. Charles Caspers, Gerard Lukken and Gerard Rouwhorst (Kampen: Kok Pharos, 1995), 11-39, esp. 23-28.

${ }^{111}$ For the interpretation of the Last Supper story as an aetiology of the Lord's Supper, see Chapter 3, section 2. 
he instituted the Lord's Supper, said the grace over the bread. The cup "after the meal" mentioned in 1 Corinthians 11:25 may be the cup which usually marked the transition from the supper to the aftersupper session (to which session Mark may be referring by mentioning the singing after the supper; 14:26).

The order of the eucharistic prayers (first over the cup, then over the bread) and their position before the meal, as mentioned by Paul, are also attested in the Didache 9. They are confirmed by Luke's heavily reworked account of the Last Supper in Luke 22:17-19, ${ }^{112}$ in which, contrary to Mark 14:22-23, blessings over the cup and then the bread are placed before the supper. Luke's revision can best be understood as an attempt to bring the account of the Last Supper into line with the ecclesiastical practice of the Lord's Supper as he knew it. The author of the Didache implies that separate eucharistic prayers over the cup and then over the bread should take place before the beginning of the meal. ${ }^{113}$ It seems reasonable to assume that this is the ecclesiastical practice referred to by Paul in 1 Corinthians 10:16 and underlying Luke's drastic reworking of the narrative of the Last Supper in Luke 22:17-19.

Ignatius does not provide us with precise information about how eucharistic prayers were performed nor about their order. He states that some Christians with heretical opinions "abstain from Eucharist and prayer, since they do not confess that the Eucharist is the flesh of our Saviour Jesus Christ." 114 Ignatius enjoins the Christians in Philadelphia to "be eager to celebrate just one [that is, a common] Eucharist. For there is one flesh of our Lord Jesus Christ and one cup that brings the unity of his blood...."115 However, this passage does not prove that eucharistic prayers were supposed to be performed first over the bread and then over the cup.

From the middle of second century Christian authors give more explicit information about the eucharistic prayers and notice that prayers were said first over the bread and then over the cup. However, there are still second-century references and allusions to eucharistic

112 See, e.g., G. Rouwhorst, "La célébration de l'Eucharistie dans l'Eglise primitive," QL 74 (1993), 89-112, esp. 96-98.

${ }_{113}$ Did. 9.1-3, 5; 10.1.

${ }^{114}$ Ign., Smyr. 7.1 (tra. Bart Erhman).

115 Ign., Phild. 4.1 (tra. Bart Erhman). 
prayers in which thanksgivings over the cup preceded those over the bread. ${ }^{116}$

From the description of a Christian Sunday gathering in Justin it can be inferred that besides prayers performed by the assembly after the sermon (preceding the meal), there was another prayer that was extemporized by the president. This prayer introduced the meal. The

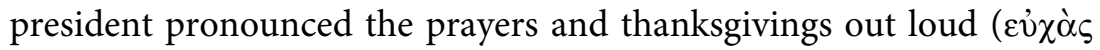

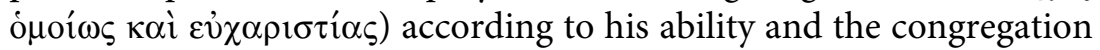
expressed its assent by saying "Amen." 117 In his description of another eucharistic ceremony, namely the meal following baptism, Justin gives some particulars concerning the content of the eucharistic prayer and the way it was said:

Then there is brought to the president of the brothers and sisters bread and a cup of water and one of wine mixed with water, and he taking them sends up praise and glory to the Father of the universe through the name of the Son and of the Holy Spirit, and offers thanksgiving at some length for our being accounted worthy to receive these things from him. ${ }^{118}$

According to Justin's account, eucharistic prayers consisted of praises and thanksgivings to God through the name of the Son and the Holy Spirit. These prayers were performed at some length. Elsewhere, Justin gives additional hints with regard to the content of eucharistic prayers; he states that Christians thank God for the creation of the world, liberation from evil and destruction of principalities and powers. ${ }^{119}$

It is probable that in Justin's church in Rome the eucharistic prayers were said in the bread then cup order which spread under the influence of the institution narrative in Paul, Mark and Matthew. Speaking about the elements of the Eucharist, he puts the bread first and then the drink:

116 E.g., apart from Did. 9; Iren., Haer. 5.2.2-3. Andrew McGowan, “First Regarding the Cup...': Papias and the Diversity of Early Eucharistic Practice," JTS 46 (1995), 551-555, esp. 554, states that "it seems reasonable to suggest that an allusion is being made to the eucharistic elements of bread and wine" in Papias' description of the Millennium preserved in Iren., Haer. 5.33.3-4. However, McGowan is overinterpreting Papias here.

117 Just., 1 Apol. 67.5.

118 Just., 1 Apol. 65.3 (tra. L.W. Barnard, adapted).

119 Just., Dial. 41.1. 
For not as common bread or common drink do we receive these things; but just as our saviour Jesus Christ, being incarnate through the word of God, took both flesh and blood for our salvation, so too we have been taught that the food over which thanks have been given through a word of prayer which is from him, from which our blood and flesh are fed by transformation (metabolh,), is both the flesh and blood of that incarnate Jesus. ${ }^{120}$

In this explanation of the function of the eucharistic meal, Justin presents a theory of consecration through the eucharistic prayer. As a result of the prayer, the food and the drink of the Eucharist become

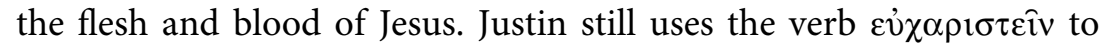
designate the eucharistic prayer, ${ }^{121}$ which shows that thanksgiving was the primary and dominant aspect of the eucharistic celebration. However, one also witnesses here the new movement towards the understanding of the eucharistic prayer as effectuating a transformation of the elements. ${ }^{122}$

Irenaeus makes several allusions to eucharistic prayers said during Christian communal gatherings. He criticizes the Gnostics who recognize the bread over which thanks have been given as the body of their Lord and the cup as his blood, but refuse to call Jesus the Son of the Creator. ${ }^{123}$ Irenaeus gives as an example the eucharistic celebrations by a Valentinian gnostic, Mark the magician, who says a long prayer of invocation ( $\dot{\pi} \boldsymbol{i}_{\kappa} \boldsymbol{\lambda} \eta \sigma \imath \varsigma$ ) over the cup of wine mixed with water. "He makes the cup appear purple and red so that the Grace from the regions above all may be supposed to distill its blood in his chalice through his invocation...."124 Just like the leader of Justin's church, gnostic leaders took time to say long eucharistic prayers. There is no indication that in the communities known to Irenaeus eucharistic prayers had a fixed form or included the institution narrative.

Just like Justin, Irenaeus comments upon the function of the eucharistic prayer: it effects a transformation of the elements: "The bread, which is produced from the earth, when it receives the invocation of God, is no longer common bread, but the Eucharist, consisting of two realities, earthly and heavenly." ${ }^{125}$ And: "The cup of mixed wine

\footnotetext{
120 Just., 1 Apol. 66.2 (tra. L.W. Barnard).

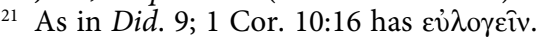

122 Paul Bradshaw, Eucharistic Origins, 91.

123 Iren., Haer. 4.18.5.

124 Iren., Haer. 1.13.2 (tra. Robert M. Grant).

125 Iren., Haer. 4.18.4.
} 
and the bread that is made receive the Word of God and become the Eucharist of the blood and the body of Christ." ${ }^{26}$

The earliest extant text of a eucharistic prayer is preserved in chapters 9 and 10 of the Didache. The author presents texts of three prayers: first, a thanksgiving over the cup; second, a thanksgiving over the broken bread; and finally, a thanksgiving after the consumption of the meal.

Now concerning the Eucharist, give thanks as follows. First, concerning the cup: We give you thanks, our Father, for the holy vine of David, your servant, which you have made known to us through Jesus, your servant; to you be the glory forever.

And concerning the broken bread: We give you thanks, our Father, for the life and knowledge which you have made known to us through Jesus, your servant; to you be the glory forever. Just as this broken bread was scattered upon the mountains and then was gathered together and became one, so may your church be gathered together from the ends of the earth into your kingdom; for yours is the glory and power through Jesus Christ forever. ${ }^{127}$

And after you have had enough, give thanks as follows: We give you thanks, Holy Father, for your holy name which you have caused to dwell in our hearts, and for the knowledge and faith and immortality which you have made known to us through Jesus your servant; to you be the glory forever. You almighty Master, created all things for your name's sake, and gave food and drink to men to enjoy, that they might give you thanks; but to us you have graciously given spiritual food and drink, and eternal life through your servant. Above all we give thanks because you are mighty; to you be the glory forever. Remember your church, Lord, to deliver it from evil and to make it perfect in your love; and gather it, the one that has been sanctified, from the four winds into your kingdom, which you have prepared for it; for yours is the power and the glory forever. May grace come, and may this world pass away. Hosanna to the God of David. If anyone is holy, let him come; if anyone is not, let him repent. Maranatha! Amen. ${ }^{128}$

Scholars have observed a close relationship between the prayers in the Didache and a number of Jewish prayer texts known from later Jewish sources. ${ }^{129}$ There are indeed obvious similarities between the prayers in

${ }^{126}$ Iren., Haer. 5.2.3.

127 Did. 9.1-4 (tra. M.W. Holmes).

${ }_{128}$ Did. 10.1-6 (tra. M.W. Holmes).

${ }^{129}$ Klaus Wengst, Didache (Apostellehre), Barnabasbrief, Zweiter Klemensbrief, Schrift an Diognet (Darmstadt: WBG, 1984), 47-53; Huub van de Sandt and David 
the Didache and later Jewish berakhot over wine and bread. ${ }^{130}$ Didache 9 gives two prayers for saying grace, the first over the cup of wine, the second over the bread; ${ }^{131}$ each concluded with a doxology. The author probably means that this is the order in which the prayers were said at the beginning of the meal. There is also an additional thanksgiving prayer with supplication and concluding doxology said after the meal. It has been suggested that this after-meal prayer reflects the Jewish practice of the Birkat ha-mazon, the benediction or common grace after the meal. ${ }^{132}$

There are several typically Jewish elements in the Didache prayers. In 9.4 and 10.5, for instance, God is asked to gather his people from the ends of the earth. These prayers are phrased in language strongly reminiscent of passages in Jewish literature that express the hope that in the imminent time of eschatological salvation, God would assemble the Children of Israel, temporarily spread over the world in the Diaspora, into his Kingdom. ${ }^{133}$

The prayers of the Didache also show, however, some distinctive Christian features. The "vine of David" is said to have been made known to the congregation "through Jesus," the servant of God. Similarly, "life and knowledge" and "knowledge, faith and immortality" are said to have been made known to them "through Jesus, the servant of God." God is said to have given spiritual food, drink and eternal life "through his servant."

Flusser, The Didache: Its Jewish Sources and Its Place in Early Judaism and Christianity (Assen: Van Gorcum, 2002), 310-313.

130 For such berakhot, see Mishnah, Ber. 6.

${ }^{131}$ Why this is the order is not clear, except that it was already ecclesiastical practice in the author's community. This order is not found in contemporary Jewish sources, not even in the Mishnah. In any case it does not follow from Mishnah, Ber. 6.

${ }_{132}$ Paul Bradshaw rightly observes that it is wrong to trace the origin of Christian eucharistic prayers to this custom of Jewish prayers said at the end of the meal. However, the after-meal prayers in the Didache reflect most likely the earlier custom of saying prayers after the meal in the Jewish-Christian communities. These after-meal prayers later became lengthy post-communion prayers as reflected in Const. ap. 7.26; De virginitate 13 that was formerly believed to have been the work of Athanasius but is now generally acknowledged to be of Cappadocian origin and dating from the second half of the fourth century. See Paul Bradshaw, Eucharistic Origins, 116-120. For Jewish benedictions or common grace after the meal, see Mishnah, Ber. 6.5-8; 7.1-5.

${ }^{133}$ L. Clerici, Einsammlung der Zerstreuten. Liturgiegeschichtliche Untersuchung zur Vor- und Nachgeschichte der Fürbitte für die Kirche in Didache 9.4 und 10.5 (Münster: Aschendorff, 1966), 8-94, esp. 65-92. 
The most natural way to explain the presence of both Jewish and Christian elements in the eucharistic prayers of the Didache is to suppose that these prayers took shape in a context in which Christian Jews or Jewish Christians continued to use Jewish prayer traditions to say grace at the communal Sunday evening supper of their Christian community.

The eucharistic prayers in the Didache were meant as examples to be used by the local ministers of a Christian congregation: bishops and deacons. Itinerant prophets were allowed to give thanks however they wished. ${ }^{134}$

There has been protracted debate about the absence of the institution narrative in the Didache prayers. The fact that the institution narrative is lacking here has led many authors on the subject to explain these prayers as non-eucharistic. ${ }^{135} \mathrm{~A}$ number of scholars, however, have always considered the prayers in the Didache as eucharistic, ${ }^{136}$ and rightly so. The pattern and content of the prayers correspond sufficiently with those of the Lord's Supper of Paul in the first century and with those of eucharistic prayers in the third and fourth centuries to warrant this conclusion.

There are several eucharistic prayers from later centuries which agree with those of the Didache in that they lack the institution narrative or any other reference to the Last Supper or the death of Christ. These include the eucharistic prayers in the Acts of John and some Eastern anaphoras, in particular that of Addai and Mari and the oldest core of the Egyptian Anaphora of Mark in the early recension of Papyrus Strasbourg gr. 254. There are also texts of eucharistic prayers from the fourth century that are close to the prayers in the Didache as regards content and, just as those in the Didache, contain a post-communion thanksgiving. These later prayers include those in the Apostolic Constitutions 7.25-26, those in the liturgy of Serapion 1 and those in De virginitate 12-13. These texts bear witness to the fact that eucharistic prayers without the institution narrative continued to be widely used in several areas of Christianity for a considerable period of time. Some

\footnotetext{
134 Did. 10.7.

135 E.g., R. Knopf (1920), W. Rordorf and A. Tuilier (1978), and K. Wengst (1984).

136 See Allan Bouley, From Freedom to Formula. The Evolution of the Eucharistic Prayer from Oral Improvisation to Written Texts (Washington: Catholic University of America, 1981), 90, note 16; M. Klinghardt (1996).
} 
of these prayers, however, were later adapted to contain, and follow the order of, the institution narrative. ${ }^{137}$

The Acts of John give an example of a eucharistic prayer said during the Sunday Christian community gathering in Ephesus:

What praise or what sort of offering or what thanksgiving shall we invoke as we break the bread, but you only, Lord Jesus? We glorify the name spoken by the Father. We glorify the name spoken through the Son. We glorify you as the entrance door; we glorify your resurrection manifested to us through you. We glorify your way; we glorify your seed, your word, your grace, your faith, your salt, your unspeakable pearl, your treasure, your plough, net, greatness, diadem, him called Son of man for our sakes, who has given us truth, rest, knowledge, power, commandment, trust, hope, love, freedom, and place of refuge in you. For you alone, $\mathrm{O}$ Lord, are the root of immortality and the fountain of incorruption, and seat of the ages; you have been called all these names for our sakes, so that now we, calling upon you through them, may recognize your greatness, which we cannot see at the present, but which is only visible to the pure, solely in the image of the man portrayed in you! $!^{138}$

This eucharistic prayer lacks any reference to the institution of the sacrament. It seems to be said only over the bread: there is no mention of wine either in the prayer or in the description of the eucharistic celebration at issue. John, who presides over the communal gathering, says the prayer. The content of the prayer is praise and glorification of Jesus for various benefactions he has conferred on the believers. The general thrust of this prayer and the themes it refers to may well reflect a current practice of praying before the Eucharist in the second century. This is certainly not a fixed formulaic prayer. The same applies to another eucharistic prayer cited in the Acts of John, a prayer which is said during a Eucharist held at a tomb. ${ }^{139}$ In the second century, eucharistic prayers continued to be said extempore by the leading members of Christian communities who presided over the eucharistic meals.

Although the Anaphora of Addai and Mari is only preserved in Syriac manuscripts, it represents an archaic version of the eucharistic prayers. True, it is impossible to prove conclusively that the earliest core of this anaphora goes back to the beginning of the third

137 Paul Bradshaw, Eucharistic Origins, 121.

${ }_{138}$ Acta Ioan. 109 (tra. J.K. Elliott, p. 336).

139 Acta Ioan. 85. 
century, but there are strong indications that an early form of this prayer originated at that date. If so, this eucharistic prayer would be the earliest extant anaphora to have been preserved from ancient Christianity without a narrative context. ${ }^{140}$ The Anaphora of Addai and Mari has attracted much scholarly attention because it does not contain the institution account. ${ }^{141}$ It is probable that this anaphora continues the older practice, especially attested in Syriac tradition, in which eucharistic prayers did not contain the institution words.

Anthony Gelston has presented a reconstruction of an early form of the Anaphora of Addai and Mari that consists of several clearly identifiable sections:

A. Introductory dialogue

B. Praise of the name of God Creator and Redeemer

C. Reference to the worship of the heavenly hosts, leading into the Sanctus

D. Thanksgiving for grace and redemption, with doxology

E. Remembrance of the fathers in the body and blood of Christ offered on the altar

F. "That all the inhabitants of the earth may know that you alone are God...."

G. Commemoration of Christ

H. Epiclesis

I. Doxology $y^{142}$

The intention of the eucharistic meal is supposed to be made sufficiently clear by the invocation of the Holy Spirit $(\mathrm{H})$ and the thanksgiving (D). The prayer is addressed to the Father, the Son and the Holy Spirit at the beginning and to the Father at the end; another section (D) is addressed in part to Christ, in part to the Father. ${ }^{143}$ Very remarkable

\footnotetext{
140 Anthony Gelston, The Eucharistic Prayer of Addai and Mari (Oxford: Oxford University Press, 1992), 11.

${ }^{141}$ For a review of research on the Anaphora of Addai and Mari see Stephen B. Wilson, "The Anaphora of the Apostles Addai and Mari," in Essays on Early Eastern Eucharistic Prayers, ed. Paul Bradshaw (Collegeville, MN: Liturgical Press, 1997), 19-37, esp. 20-26.

${ }_{142}$ Paul Bradshaw, Eucharistic Origins, 130. For the Syriac text with English translation, see A. Gelston, The Eucharistic Prayer of Addai and Mari, 48-55.

${ }_{143}$ Peter Cobb, "The Anaphora of Addai and Mari," in The Study of Liturgy, eds. Chesly Jones et al. (London: SPCK, 1992), 218.
} 
is the use of the Sanctus in section C. In section G, the prayer speaks about the commemoration of the body and blood of Christ and refers to the passion, death and resurrection of Jesus Christ.

A more developed form of the eucharistic prayer may be found in the Apostolic Tradition. It is an example of how the bishop should pray if it is he who conducts the Eucharist:

We give thanks to you God, through your beloved child Jesus Christ, whom, in the last times, you sent to us as Saviour and Redeemer and Messenger of your will, who is your inseparable Word, through whom you made all things and who was well pleasing to you. You sent him from heaven into the womb of a virgin, and he was conceived and made flesh in the womb and shown to be your Son, born of the Holy Spirit and the virgin. He fulfilled your will and won for you a holy people, opening wide his hands when he suffered that he might set free from suffering those who believed in you. When he was handed over to voluntary suffering, in order to dissolve death and break the chains of the devil and harrow hell and illuminate the just and fix a boundary and manifest the resurrection, he took bread and giving thanks to you he said, "Take, eat, for this is my body which will be broken for you." Likewise the cup, saying, "This is my blood which is poured out for you. Whenever you do this, you perform my commemoration." Remembering therefore his death and resurrection, we offer you bread and cup, giving thanks to you because you have held us worthy to stand before you and to minister to you as priest. And we ask that you should send your Holy Spirit to the oblation of the holy church. Gathering <us> into one, may you grant to all the saints who receive for the fullness of the Holy Spirit, for the confirmation of the faith in truth, that we may praise and glorify you, through your child Jesus Christ, through whom be glory and honour to you, with the Holy Spirit, in your holy church both now and to the ages of the ages. Amen. ${ }^{144}$

This prayer consists of several elements: thanksgiving to God through Jesus Christ, mention of Christ's mission and work, institution narrative, anamnesis, epiclesis and doxology. The prayer does not contain the Sanctus and thanksgiving for the creation which is known to Justin. ${ }^{145}$

Here one encounters for the first time in a eucharistic prayer the words by which the elements bread and wine are interpreted as Jesus' body and blood ("This is...;" "This is....") and the institution words.

${ }^{144}$ Trad. ap. 4.4-13 (tra. A. Stewart-Sykes, adapted). For the Latin text, see Bernard Botte, La tradition apostolique (SC 11 bis. Paris: Editions du Cerf, 1984), 46-54.

${ }^{145}$ Just., Dial. 41.1. 
They have been taken over and conflated from the Synoptic gospels and 1 Corinthians 11:23-26. Scholars in the twentieth century have long thought that the interpretation words and institution narrative were a standard element of the eucharistic prayers from the beginning. This view has usually been supported by referring to the fact that the tradition about the institution of the Lord's Supper (i.e., the account of the Last Supper) is very early since it is already found in Paul. It was assumed that if Paul mentioned it, this necessarily meant that it was used in the early eucharistic prayers. However, the earliest example of a eucharistic prayer containing the interpretation and institution words is found in the Apostolic Tradition in the third century. Earlier references to, and accounts of, eucharistic prayers show no trace of the institution narrative. As has been stated above, there are even eucharistic prayers from the fourth century in which the institution narrative is still lacking. Everything seems to indicate, therefore, that the incorporation of the institution narrative in the eucharistic prayers in the Apostolic Tradition is an innovation of the third century. However, this innovation was remarkably successful: it won ground and became more wide-spread, thus becoming standard practice in the later history of the eucharistic prayer.

The Apostolic Tradition supposes that eucharistic prayers would normally be said by bishops. It has often been suggested that until the middle of the third century, bishops were free to improvise the text of the eucharistic prayer and that from the time of the Apostolic Tradition onwards, the prayer became a fixed text. ${ }^{146}$ However, the Apostolic Tradition discourages the bishop to reproduce the text literally:

When the Bishop gives thanks in accordance with what was said above it is not absolutely incumbent on him that he recite the identical words which we stated above as though performing a set declamatory exercise! In giving thanks to God let each pray according to his ability. If he has the ability to pray easily in sophisticated manner then that is good. If someone, when he prays, offers a mean prayer do not seek to prevent him, only he must pray in an orthodox manner. ${ }^{147}$

146 A. Gelston, The Eucharistic Prayer of Addai and Mari, 11. Allan Bouley, From Freedom to Formula, 122-123, however, rightly argued that even in the Apostolic Tradition, the eucharistic prayer was still a non-fixed extemporaneous prayer.

${ }^{147}$ Trad. ap. 9.3-5 (tra. A. Stewart-Sykes). 
This passage seems to indicate that the eucharistic prayers in the Apostolic Tradition, just like those in the Didache, were only given as examples, not as fixed formulas.

According to Origen's Dialogue with Heracleides, the bishop, when composing his own anaphora, had only to respect some simple "conventions":

The offering (prosfora,) is always made to Almighty God through Jesus Christ, as related to the Father in respect of his divinity. Let the offering be made, not twice over, but to God through God. I shall seem to be speaking boldly: when praying we must abide by agreements.... If it seems good to you, let these agreements be observed. ${ }^{148}$

The freedom of bishops to compose the eucharistic prayers continued to exist for a considerable time, probably until the middle of the fourth century when liturgies began to come into being whose full texts were more or less fixed. ${ }^{149}$ The standardization of the texts of the anaphora was closely related to the Church's wish to use liturgical texts to defend orthodox teaching against heresies as well as to the increasing lack of proficient extemporizers during the post-Constantinian era. ${ }^{150}$

In Apostolic Tradition 4 the eucharistic prayer over bread and wine has clearly become one single prayer. At about the same time, however, the prayers over the two elements could still be conceived as two different prayers. From the Didascalia one can see how the two thanksgivings could be pronounced by different persons. When a bishop conducted a eucharistic meal in the presence of a visiting bishop, the former could invite the latter to say the eucharistic prayers. But according to the Didascalia, if the visiting bishop was wise, refused to offer the Eucharist, and gave the honour to the local bishop, the local bishop should at least let him speak the words over the cup. ${ }^{151}$ This advice implies that in the third century eucharistic prayers could still be seen as two separate thanksgivings.

The author of the Apostolic Tradition also provides examples of prayers when an offering of oil is made. The bishop shall give thanks in the same manner as for the oblation of the bread and wine. He does not

\footnotetext{
148 See A. Gelston, The Eucharistic Prayer of Addai and Mari, 12-13.

149 Anaphora of St. Mark, Anaphora of Addai and Mari, Anaphora of St. James, Anaphora of St. Basil and the Roman Canon.

${ }^{150}$ Maxwell E. Johnson, "Worship, Practice and Belief," in The Early Christian World, vol. 1, ed. Philip F. Esler (London and New York: Routledge, 2000), 491.

${ }^{151}$ Did. ap. 2.58.
} 
give thanks with the same words, but with very similar words: "O God, sanctify this oil: grant holiness to all who use it and who receive it, and as you anointed kings, priests and prophets, so may it give strength to all who consume it and health to all who use it." ${ }^{152}$ There are also examples of eucharistic prayers for the blessing of cheese and olives. In that case the bishop is supposed to say:

Sanctify this milk which is congealed, and congeal us with your love. Let this fruit of the olive, which is an example of your richness, not depart from your sweetness, which you poured out from the tree into the life of those who hope in you. However, in every blessing shall be said: To you be glory, to the Father and the Son with the Holy Spirit, in the holy church both now and forever and into all the ages of the ages. ${ }^{153}$

These examples of prayers over oil, and over cheese and olives, show that the ceremonies in question were conceived as sacraments and the prayers as real eucharistic prayers.

In conclusion it may be stated that from the beginning Christians celebrated their communal meals with benedictions or prayers of thanksgiving, usually said by the presiding hosts. The prayers reflected Jewish patterns of saying grace before meals. The order of the prayers, at least in one strand of the tradition, was first over the cup and then over the bread, but the reversed order also occurred. During the second century the two prayers gradually became one and the order in which the elements were mentioned was reversed, probably under the influence of the institution narrative. During the second century eucharistic prayers were said extempore by the presiding officers, especially prophets, but there begin to appear models for saying the eucharistic prayers, meant for local, sedentary clergy. This process continued into the third century: the form of the prayers was still free then, but at least at some places the prayers were supposed to conform to certain conventions and "orthodoxy."

In the third century, the institution narrative with the interpretation words were incorporated into the eucharistic prayers and this form of the prayers became prevalent, although eucharistic prayers without a reference to the account of the Last Supper continued to exist in later centuries.

${ }^{152}$ Trad. ap. 5.2 (tra. A. Stewart-Sykes).

${ }^{153}$ Trad. ap. 6.2-4 (tra. A. Stewart-Sykes). 


\section{c. Non-Eucharistic prayers in the Christian gatherings during the first three centuries}

In this section the place of non-eucharistic prayers in the context of the Christian gathering will be examined. Then the question will be discussed of which types these non-eucharistic prayers were and for what the early Christians prayed. Finally, some prayer postures that occurred in the gatherings of early Christian communities will be considered.

The writings included in the New Testament do not provide much information about the place of non-eucharistic prayer in the gatherings of Christians in the first century. Early Christian authors admonish their readers to say communal prayers but these admonitions do not shed much light on how the prayers fitted in the context of the Christians' periodical gatherings.

According to Paul, prayer took place in the second part of the gathering. The apostle found that speaking in tongues featured too conspicuously in the Corinthian congregation. He urges the Corinthian Christians, therefore, to pray with their minds and to say their prayers in articulate speech so that the other participants of the assembly can endorse these prayers:

If I pray in a tongue, my spirit prays but my mind is unproductive. What should I do then? I will pray with the spirit, but I will pray with the mind also; I will sing praise with the spirit, but I will sing praise with the mind also. Otherwise, if you say a blessing with the spirit, how can anyone in the position of an outsider say the "Amen" to your thanksgiving, since the outsider does not know what you are saying? ${ }^{154}$

According to Paul, prayers had to build up all members of the community. ${ }^{155}$

In 1 Thessalonians Paul urges the believers to pray for him and his coworkers in the ministry. ${ }^{156}$ Paul probably means that the members of the Thessalonian church should pray together in their communal gathering. ${ }^{157}$ If the letter were addressed to the whole church and Paul wanted it to be read to the whole community, the most plau-

\footnotetext{
1541 Cor. 14:14-16.

1551 Cor. 14:17.

1561 Thess. 5:25.

157 Similar requests to pray for Paul in communal gatherings may be intended in both Paul's own and other Pauline epistles. See Rom. 15:30-31; 2 Thess. 3:1-2; Eph. 6:19-20; Col. 4:3-4; cf. Heb. 13:18-19.
} 
sible explanation is that after having heard Paul's request to pray for him and his ministry, the members of the community would pray for him in the assembly and not just after returning home. These prayers would be communal petitions and intercessions for Paul and his fellow workers.

The author of Acts takes it for granted that the earliest Christians prayed when they gathered together. ${ }^{158}$ The author of Ephesians admonishes Christians to "give thanks to God the Father at all times and for everything in the name of our Lord Jesus Christ." 159 This admonition to give thanks to God is preceded by the exhortations to sing psalms and hymns; therefore, the thanksgiving as meant here must also be a joint activity, that is, a communal practice. The possibility cannot be ruled out that the author meant that this thanksgiving was the content of the singing, however, the text can equally well mean that the addressees had to sing as well as say prayers of thanks to God, as separate actions. The phrase "at all times" ( $\pi$ óv $\tau 0 \tau \varepsilon)$ seems to indicate that the author meant that the thanksgiving should not remain restricted to the hours of the communal gathering.

In the second century, Ignatius admonishes Christians not to hold private meetings without the bishop and the presbyters present but to have common meetings where all members of the congregation are present and can offer common prayers and petitions to God. ${ }^{160}$ According to Ignatius, the prayer of the bishop and the entire church has greater power than the prayer of one or two individuals. ${ }^{161} \mathrm{He}$ also urges Christians in Ephesus to come together more frequently "to give thanks and glory to God." 162 From the letters of Ignatius one may infer that he knew about communal prayers said by Christians during their gatherings. The prayers had the form of praises and petitions. But Ignatius' main concern was to urge Christians to pray in the presence of the bishop; prayers offered under the bishop's leadership had the greatest efficacy. However, Ignatius does not specify at what precise moment the prayers were uttered during the Christian gathering.

According to Justin, the congregation stood up after the sermon to pray together out loud. After the prayer was finished, bread, wine and

\footnotetext{
158 Acts $1: 14 ; 2: 4 ; 4: 24-31$.

159 Eph. 5:20.

160 Ign., Magn. 7.2.

161 Ign., Eph. 5.2-3.

162 Ign., Eph. 13.1.
} 
water were brought in to celebrate the eucharistic meal. ${ }^{163}$ At the end of the second century Tertullian attests the same order of the sermon followed by a prayer. ${ }^{164}$ The pattern of homily and prayer preceding the Eucharist, as attested by Justin and Tertullian, is also found in some apocryphal Acts. ${ }^{165}$ Furthermore, Tertullian states that the Christian gathering ended with prayer, in the same way as it began. ${ }^{166}$

In the third century, just as in the second century, a prayer usually concluded the sermon or teaching in the assembly of Christians. ${ }^{167}$ Origen, for example, invites his audience to stand up and pray after his sermons. ${ }^{168}$ According to the Apostolic Tradition, prayers were also said during gatherings for special occasions. For instance, during the ceremony of ordination of a bishop on the Lord's day, people were supposed to be praying in their hearts for the descent of the Spirit, whilst at the same time it was intended that one of the bishops should say a prayer out loud. ${ }^{169}$

There were various types of non-eucharistic prayer offered by early Christians in their gatherings. The prayers were mostly praises, thanksgivings, petitions and intercessions. Praises and thanksgivings were addressed to God and to Christ. Petitions were said by Christians for themselves, for other believers and for the secular authorities. Intercessions took place in the community when the congregation prayed for the repentant sinner.

The author of 1 Timothy gives a list of different types of prayer that could be said by the members of the community, most likely in their communal assembly: "First of all, then, I urge that supplications, prayers, intercessions, and thanksgivings be made for everyone, for kings and all who are in high positions...."170

1 Clement 59.1-61.3 offers an example of a communal prayer. This prayer text surely reflects the style and form of prayer that was common in Clement's community in Rome. ${ }^{171}$ The prayer gives praise to

\footnotetext{
163 Just., 1 Apol. 67.5.

164 Tert., Apol. 39.6; An. 9.4. Cf. Clem. Al., Str. 6.113.3. Clement mentions prayers after the Eucharist.

165 Acta Ioan. 46; 106-109; Acta Andr. 20 (in Gregory of Tours' Epitome, J.K. Elliott, p. 278).

166 Tert., Apol. 39.18.

167 Trad. ap. 39.

168 Or., Hom. Jer. 20.9; Hom. Num. 11.9; Hom. Luc. 12.6; 34.3; 39.7.

169 Trad. ap. 2.

1701 Tim. 2:1-2

171 Barbara Bowe, "Prayer Rendered For Caesar? 1 Clement 59.3-61.3," in The Lord's Prayer and Other Prayer Texts From the Greco-Roman Era, eds. James H. Charles-
} 
God and continues with petitions for forgiveness, salvation and peace, and with an intercession for the rulers. ${ }^{172}$ Elsewhere Clement urges his addressees to say the communal prayer unanimously: "Let us, therefore, conscientiously gather together in harmony, cry to him earnestly, as with one mouth, that we may be made partakers of his great and glorious promises." 173

A list of people Christians should pray for, similar to the one in 1 Timothy, occurs in Polycarp's letter to the Philippians: "Pray for all the saints. Pray also for kings, and potentates, and princes, and for those that persecute and hate you, and for the enemies of the cross, that your fruit may be manifest to all, and that you may be perfect in Him." 174 Tertullian states that Christians offer "sacrifices" and prayers for the emperor and other authorities. ${ }^{175} \mathrm{He}$ explains that the "sacrifices" of Christians are "prayer and giving of thanks in the Church through Jesus Christ." 176 According to Tertullian, Christians pray not only for the authorities, but also for the security of the world, peace on earth and postponement of the end. ${ }^{177}$

Justin in his description of the baptismal assembly specifies the persons for whom prayers were said. The members of the community fervently prayed for themselves, for the person to receive baptism and for other people in every place. The purpose of these prayers was, Justin says, "that we may be counted worthy, now that we have learned the truth, by our works also to be found good citizens and keepers of the commandments, so that we may be saved with an everlasting salvation." ${ }^{178}$

An example of a prayer including petitions occurs in the Acts of John. It is a prayer said after the sermon and before the Eucharist in a gathering on Sunday.

worth with Mark Harding and Mark Hiley (Valley Forge, Pennsylvania: Trinity Press International, 1994), 85.

172 The combination of praise to God or Christ with subsequent short petitions occurs frequently in the apocryphal Acts: Acta Ioan. 108; Acta Thom. 67; Acta Petri 2; Acta Pauli 9.

173 1 Clem. 34.7.

174 Poly., Phil. 12.3.

175 Tert., Apol. 30.1-4; 32.1; Scap. 2.8-9.

176 Tert., Marc. 4.9.

177 Tert., Apol. 39.2.

${ }^{178}$ Just., 1 Apol. 65.1. 
Jesus, who have woven this crown by your twining, who have inserted these many flowers into the everlasting flower of your countenance, ${ }^{179}$ who have sown these words into my soul, who are the only protector and physician of your servants, who heal freely; you who are benign and not haughty, alone merciful and kind, alone a Saviour and righteous; you who always see what concerns all, and are in all, and everywhere present, comprising all and replenishing all, Christ Jesus, God, Lord, who with your gifts and your compassion protect those who hope in you; who know intimately all the cunnings and threats by which our adversary contrives against us everywhere. O Lord, only help your servants with your watchful care. So be it, Lord. ${ }^{180}$

This prayer comprises three parts: invocation, argument and petitions. This pattern reflects the standard formal structure of prayers in the Graeco-Roman world in general. ${ }^{181}$

A type of prayer that occurred frequently in the communal gatherings was the intercession for sinners. Tertullian asserts that members of the Christian community who had sinned were banned from the communal prayer in the assembly. ${ }^{182}$ However, the goal of this excommunication was their reconciliation with God and the community. According to the Didascalia, the congregation was supposed to intercede for the repentant brother while he was in the process of being reconciled with, and admitted again to, the communal gathering. ${ }^{183}$ The Acts of Peter include an interesting account of how all members of a congregation became remorseful for their sins and asked Paul to pray for them. One day, when Paul was presiding over a eucharistic gathering in Rome, a women who had committed a sin came forward to receive the Eucharist from the hands of Paul. He saw through her intentions and reprimanded her. This caused all participants in the gathering to repent of their former sins and to ask Paul to intercede for them. ${ }^{184}$

In the third century Christian authorities tended to admonish the faithful to be one and unanimous in praying in the communal gatherings. Accordingly, Cyprian urges Christians to pray not only for them-

179 The phrases "this crown" and "the flower of your countenance" seem to be metaphors of the circle of Christians and the Church.

${ }^{180}$ Acta Ioan. 108 (tra. J.K. Elliott, p. 336).

${ }^{181}$ See, e.g., Larry Alderink and Luther Martin, "Prayer in Greco-Roman Religions," in Prayer from Alexander to Constantine, eds. Mark Kiley et al. (London and New York: Routledge, 1997), 123-127.

182 Tert., Apol. 39.4.

183 Did. ap. 2.40.

${ }^{184}$ Acta Petri 2 (tra. J.K. Elliott, pp. 399-400). 
selves but also for others: "Our prayer is public and common; and when we pray, we pray not for one, but for the whole people, because we the whole people are one." 185 Cyprian also notices that when the Lord sees that certain Christians are humble and united, he will protect them from the attacks of the enemy. ${ }^{186}$ When Christians come together, they should pray with modesty and in subdued language:

When we meet together with the brethren in one place, and celebrate divine sacrifices with God's priest, we ought to be mindful of modesty and discipline-not to throw abroad our prayers indiscriminately, with unsubdued voices, nor to cast to God with tumultuous wordiness a petition that ought to be commended to God by modesty; for God is the hearer, not of the voice, but of the heart. ${ }^{187}$

These recommendations concern the style of the prayer. As to content, Cyprian wants Christians to pray "with moderate petitions." 188

The author of the Apostolic Tradition points out the benefit of praying in the morning gathering: "For he who prays in the church will be able to pass by the wickedness of the day." 189

The author of the Didascalia, in admonishing widows to be diligent in prayer, urges them to focus their minds on it and to offer it to God with all their heart. ${ }^{190}$ In the third century leaders of Christian communities repeatedly felt the need to encourage their members to pray actively and with one accord.

In praying during their communal gatherings, Christians could adopt various postures. Christian authors attest that, while praying, Christians could sit, stand, kneel, bow or prostrate. Early Christians accepted both standing and kneeling as suitable postures for prayer. ${ }^{191}$ Kneeling expressed humility and penitence; this posture was assumed, therefore, on fast days. ${ }^{192}$ Standing expressed joy and confidence; consequently, this was the attitude adopted for praying on Sundays. ${ }^{193}$ Prayer was often performed standing and facing the east. ${ }^{194}$

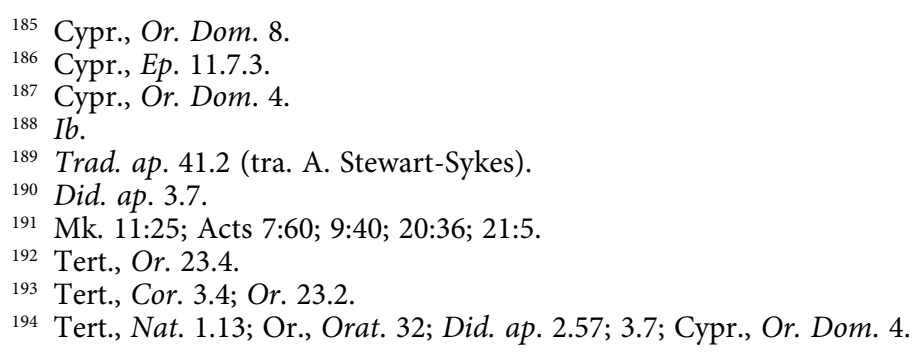


Various forms of bowing, such as prostration and bending forward with the upper part of the body and with eyes downcast, were symbolic actions conveying subjection or subservience. According to Paul, in the assembly of a Christian congregation one could "fall down and worship God." 195 The mention of "bending the knee" in Philippians 2:10 suggests that kneeling as a posture of prayer occurred in at

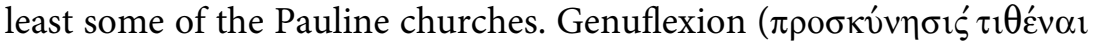

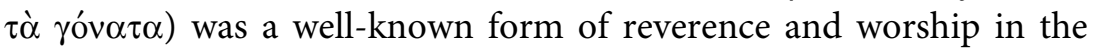
Roman Empire, both in court ceremonies ${ }^{196}$ and in religion. ${ }^{197}$ It was practised by Jews and could be combined with the spreading of arms: the Assumptio Mosis announces the coming of a great intercessor who "will spread his arms, bend his knees and pray for them...."198 Kneeling was also adopted by Christians and practised in their gatherings. ${ }^{199}$ 1 Clement enjoins Christians to kneel before the Lord. ${ }^{200}$ Tertullian says that on fast days "no prayer is to be performed without kneeling." ${ }^{201}$ According to the Apostolic Constitutions, at the beginning of the anaphora, after penitents and catechumens had left, the deacon said: "All who are faithful, let us bend our knees." ${ }^{202}$ Christians especially kneeled down or bent down their bodies when confessing their sins. ${ }^{203}$

In keeping with a common practice of praying in the GraecoRoman world, ${ }^{204}$ Christians could also pray standing with the arms

1951 Cor. 14:25, said of outsiders who come to recognize that God is among the members of the congregation.

${ }_{196}$ I. Spatharakis, "The Proskynesis in Byzantine Art," Bulletin Antieke Beschaving 49 (1974), 190-205.

197 Cf. Rev. 5:14; 7:11; 11:16; 15:4; 16:2; 19:4; 1 Cor. 14:25.

198 Ass. Mos. 4.1; see J. Tromp, The Assumption of Moses. A Critical Edition with Commentary (Leiden: Brill, 1993), 174: "Spreading one's arms and kneeling are common prayer gestures. The very same words are used in Ezra 9:5; 3 Macc. 2:1.”

${ }_{199}$ On the history of kneeling as a posture of Christian prayer, see PGL, s.v. yóvv,

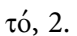

${ }^{200} 1$ Clem. 48.1. The expression may be meant metaphorically, but Spatharakis' article shows that kneeling down as a prayer posture existed.

201 Tert., Or. 23.4.

202 Const. ap. 2.22.14.

203 Or., Hom. Num. 5.1; 11.9.

${ }^{204}$ Ps.-Aristotle, De mundo 6; Apul., De mundo 33. See T. Baarda, "'Het uitbreiden van mijn handen is zijn teken.' Enkele notities bij de gebedshouding in de Oden van Salomo," in Loven en geloven. FS. Nic. H. Ridderbos, eds. M.H. van Es et al. (Amsterdam: Bolland, 1975), 245-259. 
outstretched and the hands slightly elevated. ${ }^{205}$ This prayer attitude also occurred among Jews in synagogue gatherings. ${ }^{206} \mathrm{It}$ is the posture of the orante, known from so many depictions in early Christian art. Another very common gesture during prayer is the laying on of hands that will be discussed in the following chapter.

\section{Conclusions}

During their assemblies the early Christians sang psalms, odes and hymns. They did so in conformity with the singing at symposia in the Graeco-Roman world. The singing could be accompanied by the music of stringed instruments such as lyre, cithara or harp. During their gatherings, the early Christians also prayed. In the first century Christians prayed before and after sharing the communal meal as well as during the symposium part of their gathering. The prayers before and after the meal were said by the person who chaired the gathering, often the one in whose house the Christian congregation met and who acted as host.

In the second century, when the reading of texts and their explanation in a sermon took place before the meal, a prayer usually concluded the sermon. Non-eucharistic prayers included prayers of various types: praises, petitions, thanksgivings, benedictions and intercessions. In intercessory prayers, Christians usually prayed for fellow-believers, for the authorities and for themselves. During prayer various postures were taken, often orientated towards the east.

During the whole period dealt with in this chapter, eucharistic prayers had no fixed form: they were extemporized by the leader of the congregation or itinerant officials. The story of the institution of the Lord's Supper was not included in the eucharistic prayers until the middle of the third century.

${ }^{205} 1$ Tim. 2:8; 1 Clem. 2.3; Od. Sol. 37.1; 27.1; 42.1; Or., Orat. 31.2; Cypr., Or. Dom. $4 ; 6$.

${ }^{206}$ Agatharchides (2nd century BCE), apud Jos., Ap. 1.209. 



\section{CHAPTER SEVEN}

\section{OTHER RITUAL ACTIONS IN THE GATHERINGS OF THE EARLY CHURCH}

\section{INTRODUCTION}

During their communal assemblies, besides eating and drinking, reading and preaching, singing and praying, Christians performed various other actions which became more or less fixed rituals. This chapter will examine these ritual acts, which include the holy kiss, the ordination of office holders, laying on of hands, anointing with oil, liturgical acclamations, collections and giving of alms, footwashing, exorcisms and healings.

\section{The HOLY KISS}

The ritual of the "holy kiss" was one of the most common elements of the early Christian assembly and was practised by believers in combination with other rituals, for instance, to conclude or to introduce prayer, Eucharist, baptism, and ordination. ${ }^{1}$ Although this rite is mentioned frequently in early Christian writings, modern historians of the early Christian gathering mostly ignore it. This section will discuss the practice and function of kissing in the context of the early Christian gathering as well as its abuse.

The "holy kiss", originally an expression of Christian love and fellowship, later became a liturgical act in the gatherings of the early Christian communities. Paul speaks about the "holy kiss" in several of his letters. Concluding his letter to the Thessalonians he urges his addressees to "greet all brothers and sisters with a holy kiss" ( $\varphi$ í $\lambda \eta \mu \alpha$ ó $\gamma 10 v) .{ }^{2}$ The exhortation appears in the concluding passage of the letter where the apostle gives his readers and hearers several directions with regard to what they should do in their communal gatherings:

${ }^{1}$ Michael Penn, Kissing Christians. Ritual and Community in the Late Ancient Church (Philadelphia: University of Pennsylvania Press, 2005), 2.

21 Thess. 5:26. 
inter alia, admonish the idlers, encourage the faint-hearted, help the weak, pray without ceasing, give thanks, pray for Paul and read aloud his letter to all members of the community. Obviously, the exchange of kisses is to be performed in the context of the gathering.

Not surprisingly, 1 and 2 Corinthians and the letter to the Romans end with the same exhortation. ${ }^{3}$ In all cases Paul's exhortation is connected with the exhortation to greet all members of the community or with the conveyance of greetings from the community from which Paul is writing. The exchange of the kiss seems to have been conceived, therefore, as part of the exchange of greetings between Christians in general: greetings were exchanged between Christians who were geographically separated; kisses were between Christians gathered at one place. The relative frequency of the admonition to kiss one another in Paul's letters suggests that he wanted to encourage this practice. ${ }^{4}$

Probably in imitation of Paul, the author of 1 Peter, too, concludes his letter by exhorting his audience to "greet one another with a kiss of love" ( $\left.\dot{i}^{\prime} \lambda \eta \mu \alpha \dot{\alpha} \gamma \alpha \dot{\alpha} \pi \eta \varsigma\right) .{ }^{5}$ The phrase "kiss of love" clearly indicates the meaning of the rite: it is an expression of mutual love among Christians. Just like Paul, the author of 1 Peter gives no explanation of the recommendation to kiss each other; he clearly supposes his audience knows this ritual act as well as its meaning. ${ }^{6}$

In the Christian communities where the holy kiss was practised, it was regarded as a manifestation of deep sympathy and a rite of inclusion. It had the same meaning among other people in the GraecoRoman world. ${ }^{7}$ In the Christian communities the most natural and plausible context for exchanging kisses was the believers' gathering for the communal meal. This practice expressed the mutual closeness of people who came from different social classes and was intended to transcend gender, religious, national, and ethnic divisions among people who believed that they were one in Christ. However, it did not develop as a spontaneous initiative in each new Christian community. The Christian practice of kissing was already part of the kissing ritual practised in society at large of which Christians formed part. The early

\footnotetext{
31 Cor. 16:20; 2 Cor. 13:12; Rom. 16:16.

${ }^{4}$ William Klassen, "The Sacred Kiss in the New Testament," NTS 39 (1993), 122135, esp. 130.

51 Pet. 5:14.

${ }^{6}$ M. Penn, Kissing Christians, 21.

${ }^{7}$ M. Penn, Kissing Christians, 133-134, see notes 25, 26, 31, 33.
} 
Christian use of the kiss as a rite of inclusion was influenced by the Graeco-Roman kiss of greeting: not without reason the New Testament writings speak of it as a greeting. ${ }^{8}$

In the Graeco-Roman world kisses were often exchanged between family members. About twenty-five percent of pagan references to the kiss relate to familial kissing. ${ }^{9}$ Accordingly, since Paul viewed Christian congregations as communities of brothers and sisters, he exhorted the members of such communities to express their unity by kissing each other. Kisses were also exchanged between the host and his guests at banquets, a custom referred to in Luke 7:45, where Jesus rebukes Simon for not giving him a kiss when he, Jesus, came to Simon's house for a meal. ${ }^{10}$ From a component of the ordinary social procedures of (a) salutation between family members, relatives and friends, and (b) welcoming guests at meals, the Christian kiss developed into a ritual act performed in the course of the Christians' meetings.

After Paul and the author of 1 Peter, Justin Martyr is the first Christian author to refer to the practice of the holy kiss. He mentions it in connection with the eucharistic service that takes place after the baptismal rite. The participants in this ceremony greet each other with a kiss immediately after prayers and before the blessing over, and distribution of, the eucharistic elements. ${ }^{11}$ It has been suggested that from Justin's time onwards the kiss became a sign of peace and reconciliation; in any case, from now on it is often called the "kiss of peace" or pax, as for instance in chapter 18 of Tertullian's treatise On Prayer. ${ }^{12}$

The early Church at the end of the second century faced a certain abuse of the practice of kissing. Some Christians kissed each other on the lips, ${ }^{13}$ even when the kiss was just a greeting. But kissing on the mouth posed problems if it turned cordiality into an erotic experience of some kind. The apologist Athenagoras reflected on the danger of the kiss as follows:

We consider them as brothers and sisters and give them other names of kinship, and therefore we set great store by keeping their bodies free

${ }^{8}$ M. Penn, Kissing Christians, 13.

${ }^{9}$ Ib., 13. Cf. Cic., Fam. 16.27.2; Athen., Deipn. 15.666; Apul., Met. 4.1; 7.9.

${ }^{10}$ Lk. 7:45.

${ }^{11}$ Just., 1 Apol. 65.2.

12 Stephen Benko, Pagan Rome and the Early Christians (Bloomington: Indiana University Press, 1984), 81.

${ }^{13}$ Cypr., Ep. 6.1; Gos. Phil. 59. 
from violation and corruption. Our law says furthermore: "If any man takes a second kiss for the motive of pleasure, [he sins];" adding, "We have thus to be precise about the kiss, or rather the salutation, since if any one of us was even in the least stirred to passion in thought thereby, God would set him outside eternal life."14

It is unclear whether Athenagoras' last words quoted refer to a specific Scripture passage, but obviously he was familiar with some cases in which a brother and a sister liked to kiss each other a second time. These could not have been isolated incidents because in that case there would have been no need to lay down written rules against them. Athenagoras recognized the danger of a holy kiss turning into a carnal one and warned that the liturgical kiss must be "carefully guarded." 15

A contemporary of Athenagoras, Clement of Alexandria, too, recommended the holy kiss to remain pure:

And if we are called to the Kingdom of God, let us walk worthy of the Kingdom, loving God and our neighbour. But love is not proved by a kiss, but by kind feelings. But there are those that do nothing but make the churches resound with a kiss, not having love itself within. For this very thing, the shameless use of a kiss, which ought to be mystic, occasions foul suspicions and evil reports. The apostle calls the kiss holy. ${ }^{16}$ When the kingdom is worthily tested, we dispense the affection of the soul by a chaste and closed mouth, by which chiefly gentle manners are expressed. But there is another, unholy kiss, full of poison, counterfeiting sanctity. Do you know that spiders, merely by touching the mouth, afflict men with pain? And often kisses inject the poison of licentiousness. It is then very manifest to us, that a kiss is not love. ${ }^{17}$

Clement's remarks about the kiss show that it was abused by some who did not give it with due decency. The practice that was meant as a symbol of brotherly love and holiness within the community, became an occasion for licentiousness. For a similar reason, Tertullian blames heretics for "exchanging the kiss indiscriminately." 18 The same idea must have been on Tertullian's mind when he claimed that a pagan husband would not tolerate his wife "to meet any of the brethren to exchange the kiss." ${ }^{19}$ A Gnostic author even created a justification for

\footnotetext{
${ }^{14}$ Athenag., Plea 32 (tra. J.H. Crehan, adapted).

${ }^{15}$ Stephen Benko, Pagan Rome and the Early Christians, 84.

161 Thess. 5:26.

${ }^{17}$ Clem. Al., Paed. 3.81.1-82.1 (tra. B.P. Pratten in ANF).

18 Tert., Praescr. 41.3.

19 Tert., Ad. ux. 2.4 .
} 
the practice of kissing by writing in the Gospel of Philip: "The perfect conceive and give birth through a kiss. That is why we also kiss each another. We conceive from the grace within each other." ${ }^{20}$

In the third century Christians introduced some rules for the exchange of the "holy kiss", in order to remedy the abuse. The author of the Apostolic Tradition says:

The women should stand and pray by themselves in another place in the church, both faithful women and women catechumens. When they have prayed they shall not give the kiss of peace for their kiss is not yet holy. The faithful should greet one another, the men with each other and the women with each other. No man should greet a woman. ${ }^{21}$

This Church discipline also mentions the kiss of peace that "all" have to give to the newly ordained bishop. In his turn, the bishop gives the kiss of peace when he greets a newly baptized member of the community. In the latter case the kiss was given just before the bishop conducted the Eucharist in which the new member of the congregation would receive communion for the first time. ${ }^{22}$

Origen, too, mentions a holy kiss that is exchanged between brothers after prayer. ${ }^{23}$ In his commentary on the Song of Songs, he states that the holy kiss is given only at the eucharistic celebration. ${ }^{24}$ Cyprian alludes to the exchange of the kiss of peace that took place before the celebration of the Eucharist. ${ }^{25}$ For him, this kiss is the expression of mutual love and unity among the members of the congregation; he compares it to the way two doves can "kiss" each other ${ }^{26}$ Cyprian also lays great emphasis on the importance of the kiss of peace to be given to lapsi as a sign of reconciliation with the Church. ${ }^{27}$

${ }^{20}$ Gos. Phil. 59 (tra. Marvin Meyer).

${ }^{21}$ Trad. ap. 18.2-4 (tra. A. Stewart-Sykes).

${ }_{22}$ Trad. ap. 4; 21.

${ }^{23}$ Or., Comm. Rom. 10.33 .

${ }^{24}$ Or., Hom. Cant. 1.

${ }^{25}$ Cypr., Or. Dom. 23; 24; Unit. eccl. 13. The holy kiss survived, at least for some time, in the liturgy of Chrysostom where shortly before the Holy Communion the

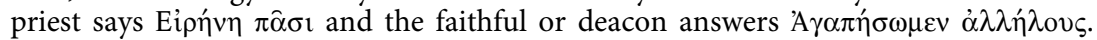
In certain editions this section is headed "The kiss of peace"; see La divine liturgie de notre Saint Père Jean Chrysostome (Rome: Ste Marie in Cosmedin, 1974), 34.

${ }^{26}$ Cypr., Unit. eccl. 9.

${ }^{27}$ See the references in V. Saxer, Vie liturgique et quotidienne à Carthage vers le milieu du III siècle (Rome: Pontifico Istituto di Archeologia Cristiana, 1969), 242, note 175 . 
With regard to the history of the "holy kiss" in the early Church, it may be concluded that the practice of kissing in the Christian gatherings began early as an act of salutation that expressed mutual love and unity among the participants. It originated as a gesture of greeting between friends and family who gathered at the communal banquet. Later on the practice became a ritual act that was performed in the gatherings of Christians after the prayers that concluded the instruction and before the celebration of the Eucharist. In the Eucharist the unity of the congregation was expressed in that the believers drank from a common cup and ate from one loaf of bread. This explains why the kiss was often exchanged just before the eucharistic celebration, since it, too, served as a sign of mutual love and unity.

\section{The LAYING ON OF HANDS AND ORDINATION}

Among the rites that could take place during the gathering of Christians, several early Christian writings mention the practice of the laying on of hands. The laying on of hands was often an act accompanying the prayer that marked the appointment or ordination of a Church officer. It could also accompany the benediction, healing of community members, or the rite through which former Church members, banned or lapsed persons, were reconciled with the Church.

The Christian terminology concerning the laying on of hands

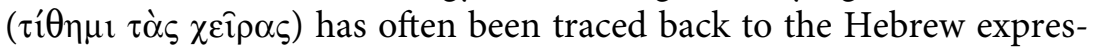
sions sāmak jādim and sìm jādim and the usage itself to a rite of imposition of hands in Judaism..$^{28}$ The most frequent use of the imposition of hands in the Christian Church was that at the ordination or commissioning of officers. A corresponding practice is often attested in Jewish literature, but only from the Mishnah onwards. ${ }^{29}$ Seeing the relative dates of the Christian ${ }^{30}$ and Jewish literary evidence, it is hard to assume that the Christian imposition of hands at the ordination of

${ }^{28}$ See, e.g., J.K. Parratt, "The Laying on of Hands in the New Testament. A Reexamination in the Light of Hebrew Terminology," ExpT 80 (1969), 210-214; E. Ferguson, "Laying on of Hands: Its Significance in Ordination," JTS 26 (1975), 1-13.

${ }_{29}$ E.g., Mishnah, Sanh. 1.3. For the Jewish material, see E. Lohse, Die Ordination im Spätjudentum und im Neuen Testament (Göttingen: Vandenhoeck \& Ruprecht, 1951), 29-35; see also Lawrence Hoffman, "Jewish Ordination on the Eve of Christianity," StLit 2 (1979), 11-41, esp. 13.

${ }^{30}$ Acts 6:5-6; 13:3; 1 Tim. 4:14; 5:22; all late first-century. 
officers was something Christians adopted from Jewish practice. ${ }^{31}$ It may as well have been the other way around. However, on the whole, it is perhaps safest to conclude that the imposition of hands for the ordination of officers arose simultaneously among Christians and Jews, in one common or two parallel developments, possibly in accordance with the passage on the consecration of Levites in Numbers 8:10 or with the narrative of the institution of Joshua in Numbers 27:21-23. A pagan background seems to be out of the question: the only analogy known from pagan literature is the inauguration of Numa Pompilius as priest-king of Rome described by Livy in 1.18. Here the augur is said to have laid his right hand on the head of Numa and uttered a prayer. But this is not even a proper imposition of hands and it is unclear to what extent such inaugurations took place in reality. The whole question of the origins of the imposition of hands at ordinations needs further investigation; see also below, on the consecration of Jewish Levites.

Luke mentions the ordination of seven men in the ministry of the daily food distribution. ${ }^{32}$ According to Luke's narrative, the ordination of these "deacons" took place in the gathering of a Jerusalem community. The men who were to be ordained were standing before the apostles, whereas the latter prayed for them and laid their hands on them. Luke mentions the same combination of prayer and the imposition of hands in his story about Barnabas and Paul being appointed by the church of Antioch to undertake missionary work in Asia Minor. ${ }^{33}$ The imposition of hands accompanied not only the ordination of office holders, but also the appointment of Christians for fulfilling a specific official task. It was viewed as the transmission of the Spirit and the commissioning of authority to the person who received the imposition of hands.

The author of 1 Timothy writes to "Timothy": "Do not neglect the gift that is in you, which was given to you through prophecy with the

${ }^{31}$ Pace E. Lohse, s.v. $\chi \varepsilon i$, in ThDNT, vol. 9, p. 429, who admits that the evidence is rabbinic and late, but argues "one may confidently assume that Rabbinic ordination goes back earlier and that it must have arisen with the development of the scribes as a specific group," in the second and first centuries BCE. He argued the same way in his monograph Die Ordination, see, e.g., 64.

${ }^{32}$ Acts 6:5-6.

${ }^{33}$ Acts 13:3. 
laying on of hands by the council of elders." ${ }^{34}$ The same author urges his readers not to ordain (lay hands on) anyone hastily. ${ }^{35}$

The data quoted above from Acts and 1 Timothy reflect a late firstcentury practice of the imposition of hands accompanying the ordination of Church officers. However, this need not have been a custom that took place in all Christian communities. There are no references to imposition of hands, for instance, in Paul and in the writings of the Apostolic Fathers. ${ }^{36}$ It is quite possible that at places the imposition of hands did not accompany the ordination of Church officers.

The imposition of hands also accompanied benedictions, ${ }^{37}$ or prayers for healing, ${ }^{38}$ or the prayer for forgiveness and readmission of repentant sinners to the fellowship of the Church. The author of the Acts of John describes the order of a eucharistic gathering in Ephesus in the following way: “After John's homily to the brethren, prayer and eucharist, and the laying on of hands on each person assembled...." 39 It seems that after the celebration of the Eucharist the apostle blessed all members of the congregation by laying his hands on each of them. As narrated in the Acts of Peter, Peter prayed for an old woman, asked God to restore her sight and placed his hand upon her..$^{40}$ The author of the Didascalia points out that the reacceptance of the fallen members was accompanied by the imposition of hands:

Then afterwards, as each of them repents and shows the fruits of repentance, receive him to the prayer, as in the case of a heathen person: just as you first baptize a heathen and receive him, so also lay hands on this man, while all are praying for him, and then bring him in and let him receive communion with the church. For him the imposition of the hand shall take the place of baptism: for whether it be by the imposition of hand, or by baptism, they then receive the communion of the Holy Spirit. ${ }^{41}$

\footnotetext{
341 Tim. 4:14.

351 Tim. 5:22.

${ }^{36}$ Except in Barn. 13.5, where in accordance with Gen. 48:14 Jacob is said to have blessed Joseph's sons by placing his hands on their heads.

${ }_{37}$ Acta Thom. 29 (J.K. Elliott, p. 459); cf. Jos. Asen. 21.6.

${ }^{38}$ For a Jewish example of such a prayer for healing with imposition of hands, see 1QapGen 20.28-29. Christian examples occur in Mk. 5:23; 7:32 and Acts 9:12, 17, where the prayer is not mentioned but probably presupposed.

${ }^{39}$ Acta Ioan. 46 (J.K. Elliott, p. 324).

${ }_{40}$ Acta Petri 20 (J.K. Elliott, p. 413).

${ }^{41}$ Did. ap. 2.40.
} 
Eusebius records that Dionysius of Alexandria, who opposed Cyprian on the issue of rebaptizing heretics (264 CE), claimed that there was an old, long-standing custom to readmit such people through a prayer combined with the laying on of hands. ${ }^{42}$

Hands were also laid on the heads of catechumens before they were dismissed from the communal gathering after they had been instructed: "When the teacher lays his hand on the catechumens after their prayer he should pray and dismiss them." ${ }^{43}$ Such an imposition of hands also accompanied the daily exorcisms of catechumens. ${ }^{44}$ In Palestine, in the third century, Origen speaks of the imposition of hands as a procedure used by exorcists against unclean spirits. ${ }^{45}$

In all cases the laying on of hands on Christians accompanied a prayer. The prayer usually explained the blessing that was invoked from God for, and bestowed on, the person concerned; imposition of hands identified the individual for whom the divine favour was asked. Since the prayer was said by the bishop or another officer, the imposition of hands also symbolized the transferral of the blessing: the minister served as a sort of mediator between God and the person on whom hands were laid and the blessing was bestowed. ${ }^{46}$

With regard to the ordination rite in itself as practised in the early Church at the end of the first century, it should be observed that there is no scholarly consensus concerning the origin of this rite either ${ }^{47}$ None of the theories given to account for the rise of this rite explains satisfactorily why the early Christians began to install their officers through prayer and imposition of hands. The election and appointment of officials (presidents, priests, etc.) in Graeco-Roman clubs and

${ }^{42}$ Euseb., HE 7.2.1.

${ }^{43}$ Trad. ap. 19.1 (tra. A. Stewart-Sykes).

${ }^{44}$ Trad. ap. 20.3.

45 Or., Hom. Jos. 24.1.

${ }^{46}$ Cypr., Ep. 9.2 (according to the numbering of the letters in ANF).

${ }^{47}$ During the twentieth century various theories have been propounded to explain the origins of Christian ordination. E. Lohse and J. Behm asserted that Christian ordination was structured on the model of the ordination of the Jewish teacher, but filled with new meaning by early Christians. A. Ehrhardt conjectured that the Hebrew Scriptures directly influenced both the Jewish and Christian practice. E. Ferguson and C. Spicq argued that the Christian rite of ordination has an exclusively Christian origin. O. Bârlea compared the church disciplines of Jerusalem and Antioch and argued that they gradually influenced one another and were conflated. The result was a harmonization of the two systems, as presented in the Apostolic Tradition. See Edward Kilmartin, "Ministry and Ordination in Early Christianity against a Jewish Background," StLit 2 (1979), 42-69, esp. 43-45. 
associations may have been the general background for the ordination of clergy in the Christian communities, and a partial explanation of the emergence of Christian ordination rites, but consecration by imposition of hands is not a rite known from pagan associations. The possibility cannot be ruled out therefore that Numbers 8:10 or a Jewish practice based on that passage played a role. According to Numbers 8:10, part of the consecration of the Levites was an imposition of hands. That Levites served as ministers in the Jerusalem temple and in synagogues in the first century CE, is confirmed by Luke 10:32; John 1:19; 1QS 2.11; 4Q266 14.3-5; and 1QS 1.21-22. ${ }^{48}$ However, it cannot be ascertained whether Levites were ordained through the imposition of hands. ${ }^{49}$

Besides the passages in Acts and 1 Timothy discussed above, there are several other references to the ordination of officers in early Church gatherings. At the end of the first century Clement of Rome speaks about presbyters in the Corinthian church who had been appointed to the ministry by prominent members of the congregation, with the entire church giving its approval. In this case the clergy chose the candidates, whereas the congregation gave its consent. ${ }^{50}$ The Didache speaks about the election of local, sedentary bishops and deacons. These positions had to be assigned to men worthy of the Lord and equipped with the required qualities. The congregation should not look down on them, but honour them along with the itinerant prophets and teachers. ${ }^{51}$

Tertullian provides little or no information about the ordination of officers in the church at Carthage. However, he does blame the heretics for ordaining anybody at anytime within their communities. ${ }^{52}$

In the second century the consent of the whole community was necessary for the elected leaders to be able to minister in that com-

\footnotetext{
48 "Apart from their liturgical functions, the Levites' duties consisted in administration in association with the lay leaders," E. Schürer, G. Vermes, F. Millar, The History of the Jewish People in the Age of Jesus Christ, vol. 2 (Edinburgh: T \& T Clark, 1979), 251.

49 4Q175 contains a blessing of the Levites, but without a reference to an imposition of hands. It may be of some relevance here that in Christian Greek and Latin from the

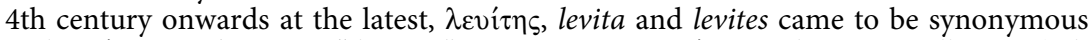

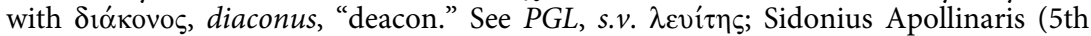
century), Epistulae 9.2. In the Middle Ages the term levitae continued to be used for deacons; ODCC, s.v. "Levites."

501 Clem. 44.3; Did. 15.1.

${ }^{51}$ Did. 15.1-2.

52 Tert., Praescr. 41.6-8.
} 
munity. This continued to be the practice in the third century. Cyprian writes about the election of Cornelius to the bishopric in Rome. ${ }^{53}$ During these early centuries the community leaders were chosen by the whole congregation; the elections thus took place during communal gatherings.

By the middle of the third century, it becomes clear again that ordination was accompanied by the laying on of hands, as it was at the end of the first century (Acts, 1 Timothy). The Apostolic Tradition mentions various rites of ordination accompanied by the laying on of hands, all performed during the gatherings of the community. When a new bishop is ordained, the other bishops place their hands upon him:

With the assent of all, the bishops will place their hands upon him, with the council of elders standing by, quietly. Everyone will keep silent, praying in their hearts for the descent of the Spirit. After this, one of the bishops present, at the request of all, shall lay his hand upon him who is being ordained bishop, and pray.... ${ }^{54}$

This is confirmed by Cyprian who states that the rite of the ordination of bishops is based on divine teaching and apostolic observance and was followed by Christians in all provinces:

When an Episcopal appointment is to be duly solemnized, all the neighbouring bishops in the same province convene for the purpose along with the people for whom the leader is to be appointed; the bishop is then selected in the presence of those people, for they are the ones who are acquainted most intimately with the way each man has lived his life and they had the opportunity thoroughly to observe his conduct and behaviour. And we note that this procedure was indeed observed in your own case when our colleague Sabinus was being appointed: the office of bishop was conferred upon him and hands were laid upon him in replacement of Basilides, following the verdict of the whole congregation and in conformity with the judgement of the bishops who had there convened with the congregation.... ${ }^{55}$

According to the Apostolic Tradition, imposition of hands was also necessary for an ordinary member of the Church to be ordained to the rank of deacon or presbyter. ${ }^{56}$ Eusebius records that Origen received

${ }^{53}$ Cypr., Ep. 55.8.4. Cf. Ep. 67.5.1.

${ }^{54}$ Trad. ap. 2 (tra. A. Stewart-Sykes).

${ }^{55}$ Cypr., Ep. 67.5.1-2 (tra. G.W. Clarke).

56 Trad. ap. 7; 8. 
imposition of hands when he was promoted to the presbyterate in Caesarea. ${ }^{57}$ The ordination of a confessor to the rank of deacon or presbyter did not demand the imposition of hands because he had already been shown to possess the honour of a deacon or presbyter through the very act of his confession. For a confessor, imposition of hands was only necessary when he was ordained to the bishopric. ${ }^{58}$ The laying on of hands at ordinations was regarded as a gesture through which a blessing was bestowed on, or passed on to, the person who received ministerial responsibility in the Christian community.

\section{Ritual Footwashing AND OIL ANOINTING}

The practice of footwashing was an act of hospitality at banquets in Graeco-Roman society. ${ }^{59}$ It also served a practical purpose in terms of personal hygiene because, when people ate and drank reclining on couches, their feet had to be clean. In his Gospel Luke indicates that washing of feet was part of the customary hospitality surrounding a meal. ${ }^{60}$ The author of the Fourth Gospel presents Jesus washing the feet of his disciples as an expression of servitude. ${ }^{61}$ Slaves or women of the house in the Graeco-Roman world often performed this act of attentiveness. ${ }^{62}$ The early Christians followed this practice. 1 Timothy mentions footwashing as one of the requirements for a widow to fulfil in order to be enrolled for service in the Church. ${ }^{63}$ Tertullian, too, records that Christian women washed the saints' feet. ${ }^{64}$ Other Christian authors of the third century show that the washing of feet continued to be a part of the life of Christians and regard it as a sign of hospitality and as an expression of humble obligingness. ${ }^{65}$ The washing

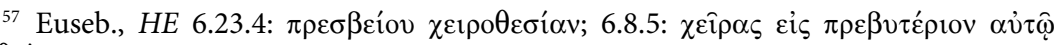
$\tau \varepsilon \theta$ cík $\alpha \sigma ı v$.

${ }^{58}$ Trad. ap. 8.1; 9.1.

59 Petr., Satyr. 31.3; Plut., Sept. sap. conv. 151e; Athen., Deipn. 4.168f; Tert., Cor. 8.3. Tertullian notices that when Jesus washed the disciples' feet, he followed a customary practice of Graeco-Roman culture, a custom Christians in Tertullian's time continued to observe.

${ }^{60}$ Lk. 7:44.

${ }^{61}$ Jn. 13:1-20.

62 Plato, Symposium 174e-175a; Petr., Satyr. 70.8; Clem. Al., Str. 4.123.1.

${ }_{63} 1$ Tim. 5:9-10.

${ }^{64}$ Tert., Ad ux. 2.4.

${ }^{65}$ Or., Hom. Gen. 4.2; Hom. Isa. 6.3; Cypr., Ep. 14.2.
} 
of feet probably continued to be practised also in the evening gatherings, where it was necessary for practical reasons. There is no evidence that this act was performed in the morning gatherings held by Christian communities.

In Luke's story of Jesus attending a meal given by Simon, a Pharisee, Jesus rebukes the host for failing to anoint Jesus' head, kiss him and give him water for washing his feet. ${ }^{66}$ At Graeco-Roman banquets, anointing with odoriferous oil was a widespread practice. ${ }^{67}$ The oil functioned as perfume: it was sprinkled on the hair, and rubbed over the forehead and face, of the participants in the banquet. They could do this themselves either before coming to the gathering or during it; it could also be done by a servant of the host. ${ }^{68}$ The host of a banquet could do his guests a special favour by offering them the anointing oil.

To mark the importance of certain moments in their communal life, Christians, too, practised oil anointing in their gatherings. The most common use of oil anointing was at baptism and during the rituals of healing the sick. There is very little evidence for the use of ointment at the communal meals and symposia of Christians in the first and second centuries. This is probably due to the modest social status of many Christian congregations. In the Graeco-Roman world, it was especially at the banquets of well-to-do people that anointment with odoriferous oil, an expensive substance, took place. Among Christians the practice does not seem to have expanded enormously.

According to the Apostolic Tradition, a priest anointed those who were baptized directly before and directly after baptism; subsequently, the bishop anointed the newly baptized for a third time to mark the moment of their admission to the Eucharist: "After this, pouring the sanctified oil from his hand and putting it on his head, he [the bishop] shall say: "I anoint you with holy oil in God the Father Almighty and

${ }^{66}$ Lk. 7:44-46.

67 Petr., Satyr. 28. Trimalchio appears at the supper with much anointing oil poured over him; Jos., Ant. 19.358. After the death of Agrippa I the residents of Caesarea conducted banquets at which the participants reclined with crowns and anointed themselves with oil; Cic., Verr. 3.25 "... in the middle of Apronius' banquet [convivium], while Apronius in the meantime was rubbing his head and face with ointment." See also Jos., Ant. 19.239; Mart. 3.12.4; Athen., Deipn. 15.688 and following.

${ }_{68}$ Pouring the perfume over someone's feet was regarded as extravagant luxury and, consequently, as an extraordinary mark of respect. Petr., Satyr. 70.8; Lk. 7:38; Jn. 12:3. 
Christ Jesus and the Holy Spirit." ${ }^{69}$ Cyprian seems to testify to a similar practice:

It is through the Eucharist that the oil with which the baptized are anointed is sanctified upon the altar. But someone who has had neither altar nor Church could not sanctify the material substance of oil. It follows that neither can there be any spiritual anointing among heretics, since it is manifest that oil cannot possibly be sanctified and the Eucharist celebrated among them. ${ }^{70}$

In the second century Christians began to gather on Sunday before dawn. By the end of that century this practice of meeting early in the morning spread throughout the whole week. In the course of the third century the morning gatherings became even more important than the gatherings in the evening. For practical purposes, the customs of footwashing before the meal and oil anointing before or during the meal, which may have played some (albeit a modest) role at Christian banquets in the evening, were not performed in the morning gatherings. The reason for this must have been a practical one: during their morning gatherings Christians did not recline and the morning ceremony was more austere and much more restricted by time limits than the evening meeting. The oil anointing kept its place mainly as part of baptismal ceremonies.

\section{Collections, Almsgiving AND OfFERINGS}

Since early times Christians attached great value to collecting material as well as financial gifts during their communal gatherings. Financial collections were held to sustain churches in other regions as well as to support the ministry of traveling apostles and other preachers. Paul mentions the collection he held in the Corinthian church for the Jewish Christians in Jerusalem. He urges the Corinthian Christians to put aside money on the first day of every week but this does not mean that a collection took place during the communal gathering. ${ }^{71}$ Paul simply wanted his addressees to put money aside and keep it safe till

${ }^{69}$ Trad. ap. 21.22 (tra. A. Stewart-Sykes).

${ }^{70}$ Cypr., Ep. 70.2 (ANF).

${ }^{71}$ N.H. Young, "The Use of Sunday for Meetings of Believers in the New Testament': a Response," NovT 45 (2003), 111-122, esp. 112-114. 
his arrival when he would come to collect it. ${ }^{72}$ In this way he would probably receive more money for Jerusalem than if, on his coming, he had to content himself with the money people would happen to have available without having saved any prior to his arrival.

Paul also makes mention of the collections of the Christian community in Corinth in support of his ministry. ${ }^{73}$ It is probable that Christians, both in Corinth and elsewhere, saved up money for this purpose at home and occasionally brought the result to the communal gathering on Sunday to deliver it to the people for whom it was intended. This would either have been for an apostle, another preacher, and representatives of another Christian congregation, or envoys who were sent to a congregation in need in order to transfer the financial aid. This custom of churches supporting each other is reflected in the letter of bishop Dionysius of Corinth to the church in Rome (ca. 170 $\mathrm{CE}$ ). Dionysius praises the Roman Christians for sending "from the beginning, financial contributions to many churches in every city" and for providing for their brothers toiling in the mines. Thus they have observed an ancestral Roman custom. According to Dionysius, the Roman bishop Soter maintained and enlarged this custom by generously providing abundant supplies from the church in Rome to God's people all over the Roman Empire. ${ }^{74}$

Another type of collecting and distributing funds in the early Christian communities was the giving of alms to those who could not provide for their daily needs. The custom of collecting funds for helping the poor in Christian churches probably goes back to the practice of certain clubs and associations in the Graeco-Roman world, especially the collegia tenuiorum (associations of the poor), which met periodically for a common meal and collected regular dues. Local branches of the community of Pythagoreans exercised charity, for instance, in the form of mutual financial support between their members. ${ }^{75}$ Other societies provided meals for their poorer members, offered financial help to fellow-members who urgently needed it, and secured the proper burial of their members. In Amisus (Asia Minor), Emperor Trajan permitted the existence of charity societies ("

721 Cor. $16: 1-3$

732 Cor. 8:1-15; 9:1-15.

${ }^{74}$ Euseb., HE 4.23.10.

${ }^{75} \mathrm{H}$. Bolkestein, Wohltätigkeit und Armenpflege im vorchristlichen Altertum (Groningen: Bouma, 1967), 239. 
financial contributions not for riotous and unlawful assemblies, but to relieve cases of hardship among the poor." ${ }^{\prime 6}$ Many of such associations had wealthy patrons who provided funds and other resources for poorer people, presided over their meetings and sometimes hosted the association in their house. Tertullian deliberately describes the collections in Christian communities in terms that make them recognizable to outsiders who were acquainted with fundraising in "associations of the poor" and burial clubs. ${ }^{77}$

The practice of charity and poor relief was adopted by Christian communities and probably became more usual in the second century. It is alluded to in some passages in the letters of Ignatius. Ignatius insists that widows should not be neglected and Christians who are slaves should not desire to be freed at the church's expense. ${ }^{78}$ Elsewhere he contends that the heretics have no concern for widows, orphans, oppressed, prisoners, and released. ${ }^{79}$ The heretics abstain from the communal gatherings and thus fail to engage in acts of love towards the underprivileged and needy. ${ }^{80}$

Some decades later Justin Martyr explicitly mentions the weekly collections in the gatherings of Christians:

Those who prosper, and so wish, contribute what each thinks fit; and what is collected is deposited with the president, who takes care of the orphans and widows and those who, on account of sickness or any other cause, are in want, and those who are in bonds and the strangers who are sojourners among us, and in a word takes care of all who are in need ${ }^{81}$

Justin's account of how money for the needy was collected is perhaps somewhat biased by his apologetic motives. He states that only rich

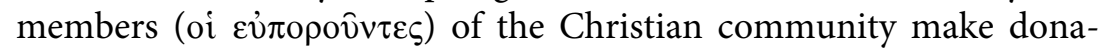
tions and do so in accordance with their own wish. There is no fixed or expected amount to be given. Each donor determines the amount of his gift himself. The president of the Christian congregation receives

${ }^{76}$ Plin., Ep. 10.93, quoted by Bolkestein, p. 470: "Es müssen also jedenfalls in Kleinasien Vereine bestanden haben, die sich mit Armenpflege beschäftigten."

77 Tert., Apol. 39.5-6. J.P. Waltzing, Tertullien. Apologétique. Commentaire (Paris: Les belles lettres, 1931), 250.

${ }^{78}$ Ign., Pol. 4.1, 3.

79 Ign., Smyr. 6.2.

${ }^{80}$ Ign., Smyr. 7.1.

${ }^{81}$ Just., 1 Apol. 67.6-7 (tra. L.W. Barnard, adapted). 
and keeps the money and also distributes it to the people in need. The needy are orphans, widows, sick, prisoners and strangers. However, it is unlikely that the bishop alone took care of all these people. According to the Pastor Hermae, the task of administering the congregation's help to the destitute was assigned to deacons. Hermas makes mention of deacons who abused their responsibilities and profited themselves from what should have been given to the widows and orphans. ${ }^{82}$ Justin seems to exaggerate the spontaneity of the donors and their eagerness to give, and to simplify the picture as a whole for easy reference.

Just like Justin, Tertullian gives a description of Christian charity:

Even if there is a chest of a sort, it is not made up of money paid in entrance-fees, as if religion were a matter of contract. Every man once a month brings some modest coin-or whenever he wishes, and only if he does wish, and if he can; for nobody is compelled; it is a voluntary offering. You might call them the trust funds of piety. For they are not spent upon banquets nor drinking parties nor thankless eating-houses; but to feed the poor and to bury them, for boys and girls who lack property and parents, and then for slaves grown old and shipwrecked mariners; and any who may be in the mines, islands or prisons, provided that, for the sake of God's school, they become the beneficiaries of their confession. ${ }^{83}$

Still more emphatically than Justin, Tertullian stresses here the voluntary character of the donations made in the assemblies of Christians. He compares the way Christians spend their communal finances with the way pagan people spend money on lavish banquets, in order to accentuate the charitable character of the Christian distribution of funds. Tertullian also mentions the frequency with which people donate money to the congregation's treasury: they do so once a month or as often as they want to do so.

From the beginning the Christians could bring different types of food as provision for their common meals. Bread and wine soon became the main components of the eucharistic meal. In light of Luke 24:42 ("a piece of broiled fish") and John 21:9 ("fish and bread"; cf. 6:9), it is most likely that the menu of the early Christian communal

${ }^{82}$ Herm., Sim. 9.26.2.

83 Tert., Apol. 39.5-6 (tra. T.R. Glower, adapted). 
supper could also include fish. ${ }^{84}$ Other food was also offered to God and eaten by the participants. ${ }^{85}$

There was a widespread custom in the Graeco-Roman world for participants in religious cults to bring first-fruit offerings to their sanctuaries. They could bring there a little of everything which the seasons brought; seasonal gifts such as ears of corn, or bread, figs and olives, grapes, wine, honey and milk. Such gifts dedicated in small shrines were a favourite theme of Hellenistic epigrams. ${ }^{86}$ The gifts were partly sacrificed to the god(s) and partly consumed by the priests as well as perhaps other officers.

In the third century a similar practice came into use in Christian congregations. Members brought various kinds of food to the church gathering and offered them to the bishop. Subsequently, the food was partly reserved for consumption by members of the clergy and partly distributed to the poor members of the congregation. In his treatise On Works and Alms, Cyprian rebukes a rich woman who came to the Sunday gathering of the church without any sacrifice and instead ate at the Lord's Supper food which poorer people had offered for the needy. ${ }^{87}$

The author of the Didascalia devotes one chapter to the issue of how people should honour their bishop through their offerings. Then the author explains how people should present their offerings and how the bishop should proceed to distribute them with care:

Therefore, present your offerings to the bishop, either you yourselves, or through the deacons; and when he has received them, he will distribute them justly. For the bishop is well acquainted with those who are in distress, and he dispenses and gives to each what is appropriate; in the way

${ }^{84}$ Cf., e.g., R.E. Brown, The Gospel according to John (New York: Doubleday, 1970), 1073, on John 21:9: "the author wished to illustrate the theme of unity at a sacral meal...." Fish is mentioned as eucharistic food in the Inscription of Abercius (ca. 200 $\mathrm{CE}$ ). It is also often found in combination with bread and wine in second and thirdcentury paintings of the refrigerium (heavenly meal) in Christian catacombs.

${ }^{85}$ Cf. Trad. ap. 5; 6. Here oil, cheese and olives are offered as part of a eucharistic meal.

${ }^{86}$ Walter Burkert, Greek Religion (Cambridge, MA: Harvard University Press, 1985), 66-67.

${ }^{87}$ Cypr., Op. eleem. 15: "Locuples et dives es et dominicum celebrare te credis, quae corban omnino non respicis, quae in dominicum sine sacrificio venis, quae partem de sacrificio, quod pauper optulit, sumis." 
one person will not receive several times over on the same day or the same week, while another does not receive even a small amount. ${ }^{88}$

People provided the bishop with material necessaries of life. Subsequently, he redistributed them to deacons, widows, orphans, poor people and travellers:

As then you have undertaken the burden of all, so also ought you to receive from all your people the ministration of food and clothing, and of other things needful. And so again, from the same gifts that are given you by the people which is under your charge, do you nourish the deacons and widows and orphans, and those who are in want, and strangers. ${ }^{89}$

In addition to assisting the poor and needy, the congregation had to provide for the ministers of the Church. On a limited scale, this had already been so in the first century. In 1 Corinthians 9, Paul defends the right of an apostle to receive material support from the church in which he is working. In Galatians 6:6 he insists that Christians "who are taught the word must share in all good things with their teacher." According to Q, ${ }^{90}$ "the workman is worthy of his hire," a saying probably meant to express the idea that travelling preachers who proclaimed the gospel should get their living from those to whom they proclaimed it. Didache 13.1 applies this rule to itinerant as well as sedentary clergy: "Every true prophet who wishes to stay with you is worthy of his keep, just as a true teacher is also, like a worker, worthy of his keep." According to 1 Timothy 5:17-18, "presbyters who do well as leaders should be reckoned worthy of a double stipend." 1

During the second century it gradually became common practice for clergy to engage themselves full time in the Church's work, while the number of communal gatherings increased. Whereas in the first century the Sunday evening meal and gathering was the only assembly in the week, in the second century the weekly gatherings proliferated and came to be held, besides on Sunday evening, on Sunday morning

${ }^{88}$ Did. ap. 2.27 (tra. Sebastian Brock). It seems that in the third century there was a centralized system of distributing material help in Christian congregations in order to avoid abuse. This was done in the context of the Christian gathering, probably, at the end of the service. However, personal distribution of alms was also practised; see, e.g., Herm., Sim. 5.3.7.

${ }_{89}$ Did. ap. 2.25 (tra. H.R. Connolly).

${ }^{90}$ Lk. 10:7; Mt. 10:10.

${ }^{91}$ On the whole topic, see A.E. Harvey, "The Workman is Worthy of His Hire," NovT 24 (1982), 209-221. 
and, at some places, on more or even all other mornings of the week. This made it all the more necessary for clergy to receive material support from the members of the congregation in which they were working.

Third-century Christian authors unanimously declare that the faithful have to support the clergy. The Apostolic Tradition specifies which fruits and vegetables the members of a Church are supposed to offer to the bishop. ${ }^{92}$ The Didascalia attests the same practice: the faithful have to set apart special offerings and tithes that were destined to be used by the clergy..$^{93}$ Cyprian, too, expects Christians to give their tithes to support the priests and to enable them to perform their ministry without having to do other work for their living. ${ }^{94}$ Finally, Origen wants the members of the Christian community to provide for the priests and give them a share of the crops from their gardens, fields and orchards. ${ }^{95}$

In the third century, besides food and money offerings (as mentioned above), Christians were also expected to give tithes, that is, one-tenth of their income, to the Church. In discussing the necessity for clergy to serve full time at God's altar, Cyprian points out that in order to enable them to do so, the other Christians have to bring their tithes and offerings. ${ }^{96}$ The Didascalia offers a somewhat strange justification of the believers' duty to cede one-tenth of all their income: "Set apart special offerings and tithes and first-fruits for Christ the true high priest, and for his ministers, as tithes of salvation; for the beginning of his name is given by the number ten." ${ }^{\text {97 }}$ It looks as if Church leaders could avail themselves of any argument to justify their wish to be provided for financially and materially and to perform their clerical activities without being hampered by labour or other professional duties.

\footnotetext{
92 Trad. ap. 31.

${ }^{93}$ Did. ap. 2.26.

${ }^{94}$ Cypr., Ep. 1.1.1-2; Unit. eccl. 26.

95 Or., Hom. Jos. 17.3; Hom. Num. 11.2.2.

${ }^{96}$ Cypr., Ep. 1.1.1-2; Unit. eccl. 26.

${ }_{97}$ Did. ap. 2.26. The first letter of the name of Jesus, in Syriac Y and in Greek I, has the numerical value of ten.
} 


\section{HeAling AND EXORCism}

Healing and exorcism were part of several pagan religious cults in the Graeco-Roman world. Literary sources provide a wealth of information about healers and exorcists who claimed to be able to cure sick and possessed people by reciting formulas and performing ritual actions. ${ }^{98}$ In the Hellenistic world, healings and exorcisms were widespread phenomena, not only among pagans, but also among Jews. ${ }^{99}$

Healings and exorcisms performed by early Christians carried on the practices in this field in Graeco-Roman culture at large. They took place mostly in the context of missionary activity and were often performed to convert or to impress unbelievers. ${ }^{100}$ In the first, second and third centuries, however, these acts were sometimes performed in the context of Christian gatherings.

Paul observes that in the Christian gatherings some members have gifts of healing. It is most likely that these gifts of healing, just like the other gifts Paul mentions as conducive to the community's edification and unity, were put into practice during the communal gathering. ${ }^{101}$ Luke narrates the raising of Eutychus, who was picked up dead after falling from a third story window while listening to Paul; this took place during a communal gathering. ${ }^{102}$

The Acts of Peter contain various accounts of healings performed by Peter in the context of Christian gatherings. For instance, during a Christian community meeting in Rome, Peter heals a blind woman in the house of Marcellus. ${ }^{103}$ Peter performs another healing at the end of the same gathering after the prayers of the ninth hour. In this case several blind widows ask Peter to restore their sight. Peter instructs them about the necessity of believing in Christ as a prerequisite to receiving healing. Subsequently, the community prays and the widows regain their sight. The episode is concluded by Peter giving praise to God. ${ }^{104}$

${ }_{98}$ See, e.g., Xenophon, Ephesian Tales 1.5; Plut., Quaest. conv. 7.706e; Luc., Lover of Lies 16; Philostr., Vita Apol. 2.4; 3.38; 4.4, 20, 25, 44.

${ }_{99}$ Acts 13:6; 19:14; Jos., Ant. 8.46-49.

100 For healing accounts see Acts 3:6-10; 5:12-16; 9:32-35; Acta Petri 29; 31; Acta Ioan. 19-25; 30-37. For exorcisms, see Acts 8:7; 16:16-18; Acta Petri 11; Acta Andr. 5 (in Gregory of Tours' Epitome, J.K. Elliott, pp. 273-274).

1011 Cor. 12:9, 28, 30.

102 Acts 20:7-12.

${ }^{103}$ Acta Petri 20-21 (J.K. Elliott, pp. 413-414).

104 Acta Petri 21 (J.K. Elliott, pp. 414-415). 
The Pseudo-Clementine Homilies, which probably contain secondcentury material in a fourth-century redaction, present Peter performing several healings in gatherings of Christians. ${ }^{105}$ Tertullian notices, not without aversion, that in the gatherings of "heretics" women perform exorcisms and healings. ${ }^{106}$ The author of the Apostolic Tradition points out that those members of a church who possess the gift of healing and are ordained to some office, do not need to receive an imposition of hands, since through the healings they perform, it is already obvious that the Spirit works in them. ${ }^{107}$ From the data adduced it may probably be concluded that in the third century healings continued to take place in Church services.

In the third century exorcism was usually part of pre-baptismal and baptismal ceremonies. ${ }^{108}$ According to the Apostolic Tradition, however, catechumens underwent exorcism daily in the gathering in which they heard the gospel and were instructed in the basics of the Christian faith: "From the time they [the catechumens] are set apart, a hand is laid on them daily whilst they are exorcised." 109 In this passage the author does not say precisely which minister performed these daily exorcisms, but in the previous section the author explains that the catechumens are dismissed with an imposition of hands by "the instructor, whether he is a member of the clergy or a layman." The daily exorcism may also have been performed, therefore, by the instructor, either a clergyman or a layman. ${ }^{110}$ Origen makes mention of the numerous invocations pronounced by Christian exorcists, probably over catechumens in Christian gatherings. ${ }^{111}$ According to bishop Cornelius (251-253 CE), there were no less than fifty-two exorcists in the church of Rome in his days. ${ }^{112}$ The large number of these exorcists most likely confirms the information given by the Apostolic Tradition according to which the catechumens had to be exorcized daily.

\footnotetext{
105 Ps.-Clem., Hom. 8.24; 9.23.

106 Tert., Praescr. 41.5.

107 Trad. ap. 14.

108 Trad. ap. 20.8; Or., Hom. Ex. 8.4; Cypr., Ep. 69.15.2.

109 Trad. ap. 20.3 (tra. A. Stewart-Sykes).

110 Trad. ap. 19.2.

111 Or., Hom. Jos. 24.1.

112 Euseb., HE 6.43.8.
} 


\section{LiturgicAl ACCLAMATIONS AND DOXOlOgieS}

In the accounts of early Christian gatherings one often comes across short, standardized phrases that were uttered as liturgical exclamations by participants in those gatherings. Most of these formulaic phrases are of Hebrew or Aramaic origin and must go back to Jewish Christian prayer forms, some of them (but not all) to pre-Christian Jewish prayer tradition. However, some of the exclamations are Greek and may be Christian in origin, although they have sometimes been traced back to pagan tradition. It is true that acclamations were widely used in the Graeco-Roman world, both in cultic and other settings. ${ }^{113} \mathrm{Cul}-$ tic associations used acclamations during their banquets. The record of the proceedings of the association of the Iobacchoi, for instance, shows that the participants expressed their approval through certain acclamations, introduced in the text by $\dot{\varepsilon} \xi\left(\varepsilon \beta \operatorname{on}_{\eta} \sigma \alpha v\right) .{ }^{114}$ In general, the phenomenon of exclamations by Christians in their gatherings was in accordance with the use of exclamations in the wider GraecoRoman world; ${ }^{115}$ however, their wording reflects Jewish and Christian traditions.

In the first three centuries of the Church, when the eucharistic liturgy had not yet taken definite shape, spontaneous acclamations represented the active part that the participants played in the communal gathering. ${ }^{116}$ Although literary accounts of Christian gatherings contain many examples of acclamations and exclamations, it is sometimes difficult to see how exactly they were used. In this section the following liturgical exclamations will be considered: Amen, Hosanna, Alleluia, Maranatha, Kyrie eleison and Anô (hymôn) tas kardias/Anô ton noun. The first four acclamations are of Hebrew or Aramaic origin; at first, they were used by Jewish members of the earliest Christian communities and then taken over by Greek speaking Christians. Besides these Hebrew and Aramaic exclamations, purely Greek expressions like Kyrie eleison and Anô (hymôn) tas kardias/Anô ton noun came into practice. Later on formulas like Sursum corda and others ${ }^{117}$ came into

113 Charlotte Roueché, “Acclamation in the Later Roman Empire: New Evidence from Aphrodisias,” JRS 74 (1984), 181-189, esp. 181-183.

114 J. Kirchner (ed.), Inscriptiones Graecae II ${ }^{2}$ I, 1-2, n. 1368, line 24.

115 Grant Sperry-White, “Acclamations," in EEC, vol. 1, p. 10.

116 E. Werner, Sacred Bridge, vol. 1 (London: Dennis Dobson, 1959), 264.

117 Dominus vobiscum, Oremus, Gratias agamus Deo Domino nostro. 
use in areas where Latin was the language of the Christian churches, many of them as translations from the Greek.

The most frequently used acclamation among early Christians is the Hebrew word Amen. This acclamation had been used in gatherings of Jewish communities for a long time past; it served to express the audience's consent with a speaker's utterance. ${ }^{118}$ The earliest Christians being Jews used it and passed it on as a liturgical expression to gentile believers. Early Christians used Amen in three different ways: as an affirmative response to the prayer of another Christian; as a response in worship; and as the conclusion of a doxology. ${ }^{119}$

Paul warns the Corinthian Christians that "if you say a blessing with the Spirit, how can anyone in the position of an outsider say the 'Amen' to your thanksgiving, since the outsider does not know what you are saying?" 120 From this passage it can be inferred that Amen could be used as a communal exclamation to express consent to the prayer of another person during the Christian after-supper assembly.

The exclamatory Amen was also used during and in response to the eucharistic prayers. Justin Martyr in his first Apology signals this use and explains the word Amen: "When he [the president] has concluded the prayers and thanksgivings, all the people express their assent by saying Amen. This word Amen answers in the Hebrew language to $\gamma \varepsilon$ Évor $\tau$ [so be it]." ${ }^{121}$ According to the Didache, the person who presided over the Eucharist was supposed to use Amen at the end of the concluding prayer. ${ }^{122}$ Tertullian observes that during the Eucharist Christians say Amen on receiving the holy food. ${ }^{123}$

In the middle of the third century, prayers were often concluded with Amen; thus, for instance, after the prayer for a bishop's ordination, or the eucharistic prayer for the blessing of bread and wine, or for the blessing of cheese and olives. ${ }^{124}$ In accordance with what Tertullian says on the subject, the participant in the eucharistic meal said Amen personally on receiving the elements. ${ }^{125}$

${ }_{118}$ Deut. 27:15-26; Neh. 5:13; 8:6; 1 Chron. 16:36; Tob. 8:8. See also 1QS 1.20; 2.10, 18; Mishnah, Ber. 5.4; Taan. 2.5.

119 J.M. Ross, “Amen,” ExpT 102 (1990-1991), 166-171, esp. 168.

1201 Cor. $14: 16$.

${ }^{121}$ Just., 1 Apol. 65.3; cf. 67.7.

122 Did. 10.6.

123 Tert., Spect. 25.5. See also Acta Thom. 29.

124 Trad. ap. $3 ; 4 ; 6$.

125 Trad. ap. 21.36. 
Besides Amen, there are two other Hebrew words that were used as a congregational response by early Christians: Hosanna and Alleluia. ${ }^{126}$ "Hosanna to the God of David" occurs in Didache 10.6 at the end of the eucharistic meal, where it precedes the invitation: "If anyone is holy, let him come; if anyone is not, let him repent." This restricted invitation seems to point to the prayers which followed the final prayer pronounced by the leader of the meal. After this final prayer there followed an open situation with the possibility for the participants to utter liturgical exclamations. ${ }^{127}$ The acclamation Hosanna later became a more or less fixed element of the eucharistic prayer, for instance in the Anaphora of Addai and Mari and the Liturgy of Chrysostom.

The Hebrew word Alleluia ${ }^{128}$ was used by Jews as an expression of praise to God and was also adopted by early Christians, albeit untranslated, for expressing joy and gratitude. The author of Revelation uses Alleluia in his description of the heavenly liturgy and this may reflect its use in the gatherings of Christians at moments when they wanted to give praise to God. ${ }^{129}$ Tertullian confirms this use of Alleluia in the Christian gathering:

The more conscientious in prayer are accustomed to append to their prayers Alleluia and such manner of psalms, so that those who are present may respond with the endings of them. And it is certainly an excellent custom to present, like a rich oblation, a prayer fattened with all that conduces to setting forth the dignity and honour of God. ${ }^{130}$

The use of Alleluia during the celebration of Eucharist is attested in the Apostolic Tradition. Before the blessing is said over the cup and bread is distributed, the bishop recites a psalm appropriate to the cup and all members of the community respond with Alleluia. ${ }^{131}$ Here the congregation's acclamation of Alleluia is clearly inspired by the psalms with Alleluia that were recited by the bishop and other clergy

${ }^{126}$ For Hosanna, see Ps. 118 (Hebrew), 25a: “Save, we beseech Thee.” As part of the Hallel (Ps. 113-118, recited at many Jewish festivals), this expression must have been well known to many Jews.

${ }^{127}$ Dieter-Alex Koch, "The Eucharistic Prayers in Didache 9 and 10 and the Riddle of Didache 10:6," in Abstracts of the Society of Biblical Literature Annual Meeting in San Diego, CA, November 17-20, 2007 (San Diego: SBL, 2007), 265.

128 "Praise Jahwe." Often in the Psalms, e.g., Ps. 104 (105):1, where the LXX has $\dot{\alpha} \lambda \lambda \eta \lambda$ oúï $\alpha$.

${ }_{129}$ Rev. 19:1, 3, 4.

130 Tert., Or. 27.17.

131 Trad. ap. 25. 
as framework of the eucharistic celebration. These psalms were probably taken from the biblical Psalter: Psalms 111-117, 106, 135 (LXX $110-118,106,135)$.

At the close of 1 Corinthians Paul uses the Aramaic phrase $\mu \alpha \rho \alpha$ ó $\alpha$ $\theta \dot{\alpha}$, "Our Lord, come." 132 It seems fairly certain that this phrase is an invocation addressed to Christ. Similar expressions are found in the book of Revelation, whereas the Didache uses exactly the same formula in the prayer that concludes the celebration of the Lord's Supper. ${ }^{133}$ The use of an Aramaic phrase $\mu \alpha \rho \alpha^{\prime} \alpha \alpha \theta \dot{\alpha}$ can only be satisfactorily explained on the basis of its regular use in some early communities in Palestine in which Aramaic was spoken; it is hard to imagine why Paul would use this phrase in a letter addressed to Greek speaking Christians if it were not yet a traditional Christian exclamation.

Greek speaking Christians introduced short Greek liturgical phrases

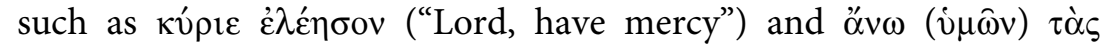

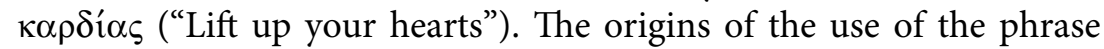

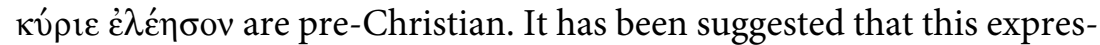
sion was used in the Graeco-Roman emperor cult. ${ }^{134}$ However, there is no convincing proof of that. In the first place, as a prayer, кúple $\dot{\varepsilon} \lambda \varepsilon ́ \eta \sigma o v$ also occurs in pagan Greek outside the emperor cult. ${ }^{135}$ In the second place, and more importantly, it occurs in such Psalms as 40 (41):4, 10; cf. 9:13; 29 (30):10; 85 (86):3; 122 (123):3. It is most prob-

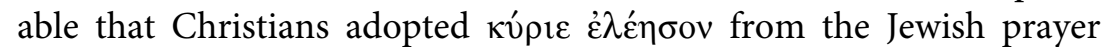
tradition as a short supplication at the end of the eucharistic prayer. The existence of this formulaic prayer is clear in the liturgies of the fourth century. ${ }^{136}$ Egeria attests the use of this acclamation in the lighting of lamps ceremony during vespers in Jerusalem. ${ }^{137}$ The same prayer occurs in the liturgical sections of the Apostolic Constitutions. ${ }^{138}$ Although the earliest evidence comes from the fourth century, it is

\footnotetext{
1321 Cor. 16:22.

133 Rev. 22:20; Did. 10.6.

${ }_{134}$ Franz Dölger, Sol Salutis. Gebet und Gesang im christlichen Altertum (Münster: Aschendorff, 1925), 77-82.

${ }_{135}$ Epict. 2.7.12.

${ }^{136}$ John Baldovin, The Urban Character of Christian Worship (Rome: Pontificum Institutum Studiorum Orientalium, 1987), 242.

${ }^{137}$ Itin. Eg. 24.5.

${ }^{138}$ Const. ap. 8.6-10, in 8.6.4 with reference to prayer for catechumens. As a prayer before the collect in the Liturgy of James (ed. B.-Ch. Mercier, p. 166.16) and after the

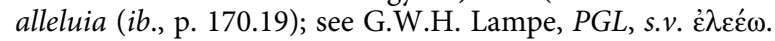




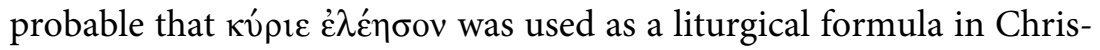
tian assemblies as early as the third century.

Another liturgical exclamation was ö $v \omega(\dot{\nu} \mu \omega \hat{\omega} v) \tau \grave{\alpha} \varsigma \kappa \alpha \rho \delta i \alpha \varsigma_{,}{ }^{139}$ recognizable as underlying the Sahidic version of Traditio apostolica 4. It served as an introduction to the liturgical dialogue that preceded the eucharistic prayer:

The Lord be with you. And all reply: And with your spirit. The bishop says: Lift up your hearts. The people respond: We have them with the Lord. The bishop says: Let us give thanks to the Lord. The people respond: It is proper and just. ${ }^{140}$

According to this passage in the Apostolic Tradition, the bishop pronounced this acclamation and people resounded it. It was probably an invitation, addressed to the people, to rise and prepare for the eucharistic prayer and for receiving the elements. Cyprian explains the reason why this liturgical exclamation was used:

Moreover, when we stand praying, beloved brethren, we ought to be watchful and earnest with our whole heart, intent on our prayers. Let all carnal and worldly thoughts pass away, nor let the soul at that time think on anything but the object only of its prayer. For this reason also the priest, by way of preface before his prayer, prepares the minds of the brethren by saying, "Lift up your hearts," [sursum corda] that so upon the people's response, "We lift them up unto the Lord," [Habemus ad Dominum] he may be reminded that he himself ought to think of nothing but the Lord. ${ }^{141}$

The Latin phrase sursum corda translates the Greek öv $(\dot{\nu} \mu \hat{\omega} v) \tau \dot{\alpha} \varsigma$

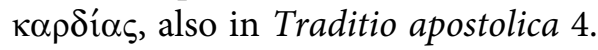

Other fixed acclamations that were used in the early Christian assemblies are doxologies. Doxologies are short liturgical formulas that basically ascribe glory to God, the Son and/or the Holy Spirit. Early Christian writings contain many different types of doxologies, for example, in 1 Clement: "Jesus Christ, through whom be glory and majesty, might and honour to him, both now and forever and ever. Amen." ${ }^{42}$ Doxologies usually contain four main elements: the mention of God, Christ or the Spirit; the mention of specific attributes

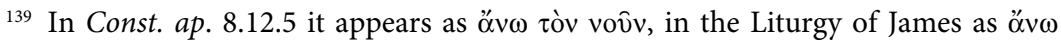

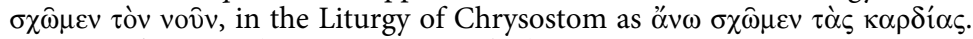

${ }_{140}$ Trad. ap. 4.3 (tra. A. Stewart-Sykes).

${ }^{141}$ Cypr., Or. Dom. 31 (tra. Ernest Wallis in ANF).

1421 Clem. 64.2. 
ascribed to them; a formula expressing that the glory ascribed to God etc. pertains to him forever and a concluding Amen. The fact that doxologies are found both within and at the end of early Christian writings suggests that they were used in a similar way to conclude a liturgical sequence in Christian gatherings. ${ }^{143}$ This seems to be confirmed by the fact that doxologies are used to conclude prayers offered in Christian services. ${ }^{144}$ Further evidence for the liturgical use of doxologies comes from Tertullian and the Apostolic Tradition. Tertullian warns his readers that Christians cannot cry out loud "forever and ever" at the gladiatorial fights and use the same words for God and Christ in an assembly of Christians. ${ }^{145}$ According to the Apostolic Tradition, the bishop who ordains another bishop in a eucharistic gathering on Sunday, concludes his prayer with the following doxology: "Through your child Jesus Christ, through whom be glory and might and honour to you, with the Holy Spirit in the holy church, now and to the ages of the ages. Amen." 146

The use of various short, more or less fixed, formulas in the context of Christian gatherings in the first three centuries had its analogy in the use of such formulas in religious contexts in the wider GraecoRoman world. By using acclamations, members of a Christian congregation reacted to the actions that were taking place during the meeting. On the one hand, acclamations were used during the celebration of a common meal when a community wanted to respond to what the leader of the session said and did. On the other hand, acclamations were responses to prayers, the reading of psalms, or the sermons of the persons conducting the meeting. Liturgical acclamations helped to keep the communication between the leaders of a community and its members going and allowed the latter to participate actively in the ceremony.

${ }_{143} 2$ Clem. 20.5; Rom. 11:36; 1 Tim. 1:7; 1 Clem. 20.12.

144 Rev. 10:2; Did. 10.2.

145 Tert., Spect. 25.

146 Trad. ap. 3.6 (tra. A. Stewart-Sykes). It should perhaps be observed that such doxologies are weak spots in the textual tradition of ancient texts and liable to change and expansion in the process of textual transmission. 


\section{Conclusions}

Besides the meal, the reading of authoritative texts, preaching, singing and prayer, there was a variety of actions in the communal gathering of early Christians, which, in the course of time, became fixed ritual acts: the holy kiss, the laying on of hands, footwashing, anointing, collections of money and offerings of food, liturgical acclamations, exorcisms and healings. These actions made up the course of the gatherings in the first centuries of the Christian Church. Christians practised these rituals in a way comparable to how the same or similar ritual acts were performed at banquets held by Graeco-Roman clubs and associations. With time, some of the Christian practices were abandoned in the morning gatherings, whereas others came to be heavily ritualized. 



\section{GENERAL CONCLUSIONS}

The aim of this study was to give a reconstruction of the earliest history of the Christian gathering. The main objective was to trace the origins of the early Christian gathering within the context of the Mediterranean culture during the first century CE. The second purpose was to examine the development of the Christian gathering during the first two and a half centuries of its existence, as well as the main components of which it comprised. The results of the research described above may be summarized as follows.

1 . The weekly gathering of the early Christians proves to conform to the pattern of the periodical group supper in the Graeco-Roman world. Such a periodical group supper was practised by pagan, Jewish and Christian groups alike. As regards the practice of celebrating periodical suppers, these groups shared a common widespread Hellenistic socio-cultural tradition. In the matter of periodical suppers held by clubs and religious associations, gentiles and Jews did not behave differently. It is impossible, therefore, to trace the Christian communal gathering exclusively to a Jewish or a pagan tradition. The Christian gathering did not evolve out of a Jewish meal or synagogue assembly. It arose as the Christian analogy to the periodical suppers in which numerous associations and religious groups, both Jewish and pagan, gave shape to their ideals of equality, fellowship, unity, and community. True, some features of the Christian supper are signs that it arose within a Jewish context: attested to by the fact that, for instance, it was held on a weekly basis and that prayers of thanksgiving were offered at the beginning of the meal. Yet, the supper of the Christian community cannot be derived from any specific Jewish meal or meeting.

2. The Christian gathering consisted of a meal and a contiguous symposium, although it cannot be ascertained in all cases precisely when the meal ended and the symposium began: sometimes the transition between the meal and the social gathering could be smooth and the two parts of the evening could merge into one another. Originally, the first part of the gathering was the Lord's Supper or Eucharist; it consisted of a communal meal, preceded by a prayer of thanksgiving, and the drinking of wine. The second part of the gathering comprised the reading aloud of authoritative literary compositions, teaching, 
preaching, the passing on of revelations, singing, prayer, acclamations and other ritual actions. This two-fold pattern, which reproduces the bipartite structure of the Graeco-Roman association supper consisting of a deipnon and symposion, is discernible in various accounts of Christian gatherings in the first, second and third centuries. In the second century, at certain places, one of which being Rome, the reading of authoritative texts and the sermon were moved forward, thus being placed before the Eucharist. This probably had a practical application and was established in order to restrict participation in the meal so that only initiated members of the community could take part.

3. The communal gatherings of the early Christians were held on Sunday evening. This practice goes back to the earliest communities in Judea/Palestine in the thirties and forties of the first century. The choice of the Sunday evening for holding the Christian community meal is best explained as a result of the Christians' feeling that their group meal was theologically more important to them than the Jewish family meal which, as members of their Jewish families, they attended on Saturday evening. Since the Christian group meal was considered to be a particular improvement on the Jewish family meal, the Christian group supper was best held as soon as possible after the Jewish family supper, that is, on Sunday evening. Subsequently, the Sunday evening gathering of the Christians, spent in joy and festivity, lent its festive character to the Sunday as a whole; this made the Sunday a special day for them. The Christian Sunday thus originated as a new feast-day alongside the Jewish Sabbath, rather than being in any sense its continuation.

4. The Christian morning gathering did not come into being, as is often believed, as a result of a process through which the Eucharist broke away from the Sunday evening meal; it would then have survived only as an agape. Until the middle of the third century, the communal supper that Christians held on Sunday came to be known as Eucharist or agape, as well as having other appellations for that matter. As well as the development of the meal on Sunday evening a meeting in the early morning was also introduced, before the participants had to go to their work. This morning meeting passed through various phases. First, in the beginning of the second century, Christians adopted the practice used by various other religious groups in the Graeco-Roman world and began to hold services on Sunday at dawn in which they sang hymns to Christ and pledged to refrain from all evil. 
Subsequently, these meetings spread over to other days of the week, probably first to the fast days, Wednesday and Friday, later to other days as well. From about the middle of the second century onwards, these morning services on Sundays and weekdays were expanded to include a simple form of meal, also called the Eucharist, an appellation used for the Sunday evening meal as well. For practical reasons, during these early morning Eucharists, food and drink could be distributed in much smaller portions than in the evening. After all, this meal did not need to surpass the proportions of a breakfast. Yet, however simplified, the service was a real Eucharist, accompanied by prayers of thanksgiving. The eucharistic elements distributed in the morning were not just bread and wine consecrated during the Eucharist of the preceding Sunday evening and thus kept for the morning gatherings during the rest of the week. Finally, the Sunday morning Eucharist gained importance at the expense of the Eucharist (or agape) on Sunday evening because the morning service, owing to the simplified form of the meal, could accommodate the congregation as a whole more easily than the evening gathering. The latter assembly, with its full supper and longer duration, could not so easily welcome all members of the congregation and tended to attract in particular those who needed a free supper once a week.

5. In reconstructing the earliest history of the Eucharist, 1 Corinthians 11:17-33 and Didache 9-10 can and should be used as the main sources; they are mutually independent witnesses of a common, earlier tradition. The primary function of the Lord's Supper was to establish the fellowship, communion, and unity among the participants. The interpretation of the community gathered for the supper as "the body of Christ," the interpretation of the bread and the wine as Jesus' body and blood, and the attribution of the ceremony's origins to an institution by the historical Jesus himself, must all be regarded as very early, yet secondary developments. The reduction of the Eucharist from a simple but real meal to a purely symbolic ritual, during which the elements were distributed in only very small quantities, gradually took place about the middle of the third century or even later. At the same time, the Sunday evening Eucharist lost its sacramental character in favour of the morning Eucharist and became a charity meal.

6. The origins of the reading of Scripture in the Christian gathering can be found in the custom of reading aloud literary works and other written texts during the symposium part of banquets in the Graeco- 
Roman world. Similarly, preaching in the Christian gathering has its origins in the custom of delivering speeches and homilies at the Graeco-Roman symposium. In the same way, the singing of psalms and hymns in the Christian gathering reflects the tradition of singing during symposia in the Graeco-Roman world in general. The singing among Christians could be accompanied by the sound of stringed instruments such as the lyre, cithara or harp. The use of these instruments in the gatherings of Christians is clearly attested from the latter half of the second century at the latest; however, the possibility cannot be ruled out that Christians used such instruments in their gatherings already in the days of Paul.

In their communal gatherings, Christians prayed not only before and after sharing the communal meal but also at certain moments in the second part of the evening. During the first three centuries, eucharistic prayers had no fixed form: they were extemporized by the leader of the congregation or itinerant officials. The earliest signs that the text of the eucharistic prayer was assuming a fixed form may be observed in the Apostolic Tradition (Rome, ca. 230 CE?). The narrative about the institution of the Lord's Supper by Jesus, containing the institution and interpretation words, was not included in eucharistic prayers until the middle of the third century. Even then these prayers did not adopt a fixed form, nor did they supplant all other eucharistic prayers: alongside prayers including the institution and/or interpretation words, eucharistic prayers continued to be used in which any reference to the institution or interpretation words was lacking. This was the case in several quarters of the Church, especially in the East.

7. In the first centuries of the Christian Church, besides the eucharistic meal, the reading out of texts, preaching, singing and prayer, there were a number of other actions Christians could perform in their communal gatherings: the holy kiss, the laying on of hands, footwashing, anointing, collections of money and offerings of food, liturgical acclamations, exorcisms and healings. All these actions can be shown to have had their counterpart in customs practised at banquets held by Graeco-Roman clubs and associations. In the course of time, some of the practices mentioned were abandoned, at least in the morning gatherings, whereas others came to be heavily ritualized.

Historically and formally, the Christians' periodical meal, the contiguous gathering, the reading of Scripture, preaching and singing can all be accounted for as the continuation of customs that were part of 
the banquet traditions. These traditions were current in the GraecoRoman world and were practised by pagans as well as Jews. A theory which can derive the early Christian gathering both as a whole and with its individual components satisfactorily from one single tradition is preferable to theories that explain this gathering using several different traditions, such as Jewish meals, the supposed synagogue service and the Hellenistic banquet. 

APPENDICES 



\section{The earliest history of The Christian Gathering*}

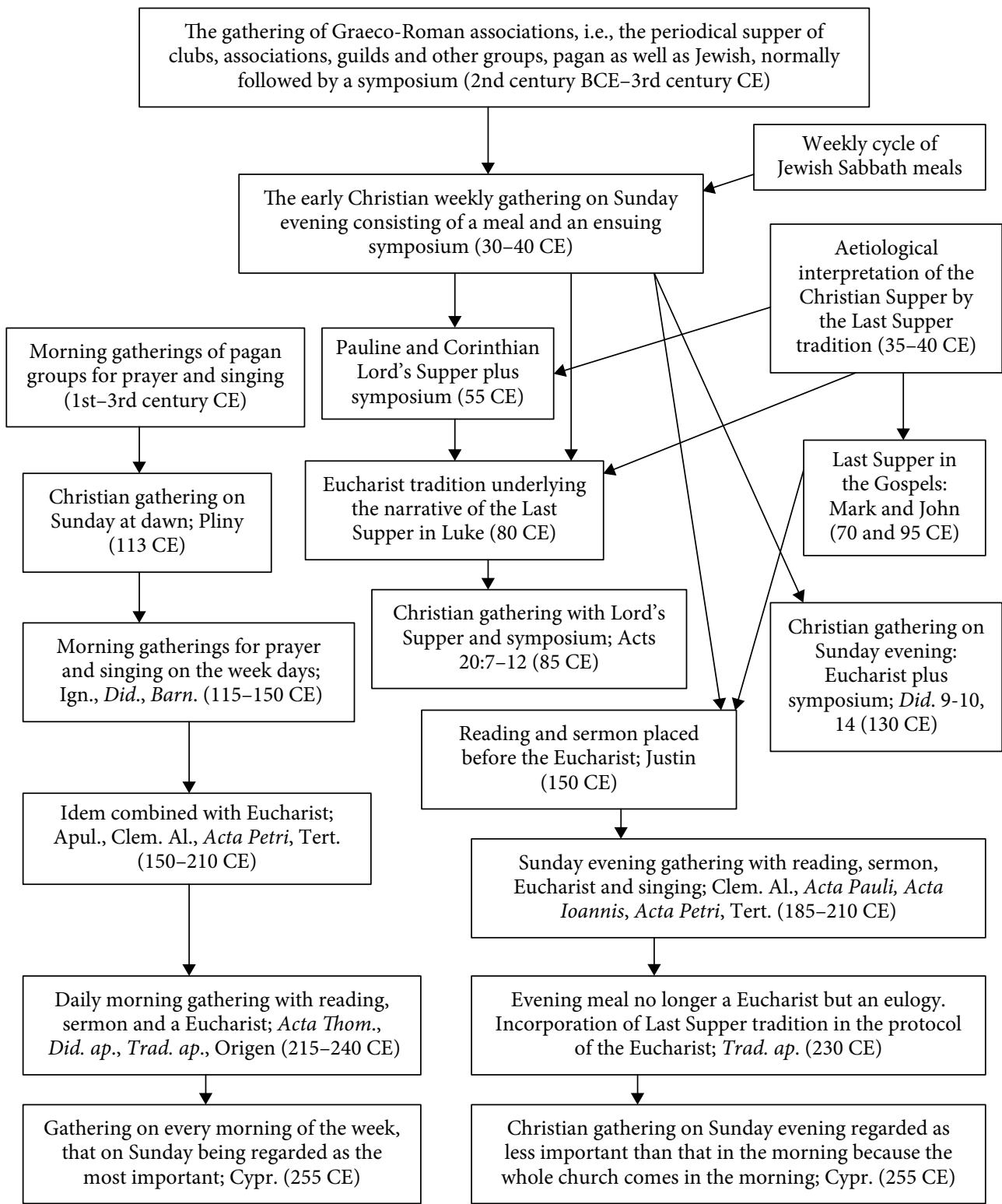

* Dates given in this diagram are approximative. 
APPENDIX TWO

2. The order of the PROCEedings in the Christian gathering

\begin{tabular}{|l|}
\hline \multicolumn{1}{|c|}{$\begin{array}{c}\text { Paul 1 Cor. 10:16 and } \\
11: 17-14: 40\end{array}$} \\
\hline $\begin{array}{l}\text { Blessings over cup and } \\
\text { bread }\end{array}$ \\
\hline Lord's Supper \\
\hline Singing \\
\hline Teaching \\
\hline Revelations \\
\hline Tongues \\
\hline Interpretations \\
\hline
\end{tabular}

\begin{tabular}{|l|}
\hline \multicolumn{1}{|c|}{ Acts of Paul 9} \\
\hline Prophetic discourse \\
\hline Eucharistic meal \\
\hline Singing \\
\hline
\end{tabular}

\begin{tabular}{|l|}
\hline \multicolumn{1}{|c|}{ Acts of Peter $20-22$} \\
\hline Reading of Scripture \\
\hline Sermon \\
\hline Intercessory prayer \\
\hline Healings \\
\hline Eucharistic meal \\
\hline
\end{tabular}

Justin, 1 Apologia 67.3-5

Reading of Gospels or Prophets

Allocution

Communal prayer

Acts 20:7-11

Speaking

Breaking of bread

Sermon

\begin{tabular}{|l|}
\hline \multicolumn{1}{|c|}{ Didache $9-10$} \\
\hline Confession of sins \\
\hline Eucharistic prayers \\
\hline Eucharistic meal \\
\hline Thanksgiving prayers \\
\hline $\begin{array}{l}\text { Teaching and other } \\
\text { activities }\end{array}$ \\
\hline
\end{tabular}

\begin{tabular}{|l|}
\hline \multicolumn{1}{|c|}{ Acts of Peter 1-2 } \\
\hline Eucharistic meal \\
\hline Admonition \\
\hline Intercessory prayer \\
\hline
\end{tabular}

\begin{tabular}{|l|}
\hline \multicolumn{1}{|c|}{ Acts of John 46} \\
\hline Sermon \\
\hline Prayer \\
\hline Eucharist \\
\hline Imposition of hands \\
\hline Healing \\
\hline
\end{tabular}

Presentation of food and drink

Eucharistic prayer

Distribution of food

Meal

Collection
Acts of John 106-110

Sermon

Intercessory prayer

Eucharistic prayer

Eucharistic meal 


\begin{tabular}{|l|}
\hline \multicolumn{1}{|c|}{$\begin{array}{c}\text { Acts of Paul and } \\
\text { Thecla } 3.5\end{array}$} \\
\hline Prayer \\
\hline Eucharistic meal \\
\hline Sermon \\
\hline
\end{tabular}

\begin{tabular}{|l|}
\hline \multicolumn{1}{|c|}{$\begin{array}{c}\text { Irenaeus Adversus } \\
\text { haereses } 1.13 .2-4\end{array}$} \\
\hline Prayer of invocation \\
\hline $\begin{array}{l}\text { Prayer of thanks over the } \\
\text { elements }\end{array}$ \\
\hline Eucharist \\
\hline Prophesying \\
\hline
\end{tabular}

\begin{tabular}{|l|}
\hline \multicolumn{1}{|c|}{$\begin{array}{c}\text { Clement of Alexandria, } \\
\text { Stromateis } 6.113 .3\end{array}$} \\
\hline Reading of Scripture \\
\hline Interpretation \\
\hline Eucharistic meal \\
\hline Prayer \\
\hline $\begin{array}{l}\text { Singing of songs and } \\
\text { hymns of praise }\end{array}$ \\
\hline
\end{tabular}

\begin{tabular}{|l|}
\hline \multicolumn{1}{|c|}{$\begin{array}{c}\text { Tertullian, } \\
\text { De anima } 9.4\end{array}$} \\
\hline Reading of Scripture \\
\hline Singing \\
\hline Preaching \\
\hline Eucharistic prayers \\
\hline Eucharistic meal (?) \\
\hline Testing of visions \\
\hline
\end{tabular}

\begin{tabular}{|l|}
\hline \multicolumn{1}{|c|}{$\begin{array}{c}\text { Tertullian, } \\
\text { Apologeticum } 39\end{array}$} \\
\hline $\begin{array}{l}\text { Prayer of petition and } \\
\text { intercessory prayer }\end{array}$ \\
\hline Reading of Scripture \\
\hline Sermon \\
\hline Collection \\
\hline Eucharistic prayer \\
\hline Eucharistic meal \\
\hline Singing \\
\hline Closing prayer \\
\hline
\end{tabular}

\begin{tabular}{|l|}
\hline $\begin{array}{c}\text { Didascalia apostolorum } \\
2.58 ; 6.21\end{array}$ \\
\hline Prayer \\
\hline Reading of Scripture \\
\hline Sermon \\
\hline Eucharistic prayer \\
\hline Eucharist \\
\hline
\end{tabular}

\begin{tabular}{|l|}
\hline \multicolumn{1}{|c|}{$\begin{array}{c}\text { Traditio apostolica } \\
22+35-37 \text { (morning) }\end{array}$} \\
\hline Reading of Scripture \\
\hline Instruction \\
\hline Holy kiss \\
\hline Prayer \\
\hline $\begin{array}{l}\text { Dismissal of } \\
\text { catechumens }\end{array}$ \\
\hline Eucharist \\
\hline
\end{tabular}

\begin{tabular}{|l|}
\hline \multicolumn{1}{|c|}{$\begin{array}{c}\text { Traditio apostolica } \\
\text { 25-29 (evening) }\end{array}$} \\
\hline Salutation by the bishop \\
\hline Eucharistic prayer \\
\hline Communal prayer \\
\hline Recitation of psalms \\
\hline $\begin{array}{l}\text { Benediction over the cup } \\
\text { and distribution of bread } \\
\text { by the bishop }\end{array}$ \\
\hline Eating and drinking \\
\hline $\begin{array}{l}\text { During the meal, } \\
\text { instruction by the bishop }\end{array}$ \\
\hline $\begin{array}{l}\text { After the meal, } \\
\text { distribution of } \\
\text { apophoreta }\end{array}$ \\
\hline
\end{tabular}

\begin{tabular}{|l|}
\hline \multicolumn{1}{|c|}{$\begin{array}{c}\text { Origen, Homiliae in } \\
\text { Exodum } 12.2\end{array}$} \\
\hline Reading of Scripture \\
\hline Sermon \\
\hline Prayer \\
\hline Eucharist \\
\hline
\end{tabular}


3. THE FREQUenCy OF THE Christian Gatherings AND THEIR DISTRIBUTION OVER THE MORNING AND THE EVENING DURING THE FIRST THREE CENTURIES ${ }^{*}$

evening gathering morning gathering no gathering

Paul (55 CE), 1 Corinthians 11:20; 16:2; Acts (85 CE) 20:7.

\begin{tabular}{|c|c|c|c|c|c|c|c|c|c|c|c|c|}
\hline Sunday & \multicolumn{2}{|c|}{ Monday } & \multicolumn{2}{|c|}{ Tuesday } & \multicolumn{2}{|c|}{ Wednesday } & \multicolumn{2}{|c|}{ Thursday } & \multicolumn{2}{|c|}{ Friday } & \multicolumn{2}{|c|}{ Saturday } \\
\hline Mor. Eve. & Mor. & Eve. & Mor. & Eve. & Mor. & Eve. & Mor. & Eve. & Mor. & Eve. & Mor. & Eve. \\
\hline
\end{tabular}

Pliny (113 CE), Epistula 10.96.7.

\begin{tabular}{|c|c|c|c|c|c|c|c|c|c|c|c|c|c|}
\hline \multicolumn{2}{|c|}{ Sunday } & \multicolumn{2}{|c|}{ Monday } & \multicolumn{2}{|c|}{ Tuesday } & \multicolumn{2}{|c|}{ Wednesday } & \multicolumn{2}{|c|}{ Thursday } & \multicolumn{2}{|c|}{ Friday } & \multicolumn{2}{|c|}{ Saturday } \\
\hline Mor. & Eve. & Mor. & Eve. & Mor. & Eve. & Mor. & Eve. & Mor. & Eve. & Mor. & Eve. & Mor. & Eve. \\
\hline
\end{tabular}

Pliny says that Christians come together on a fixed day (stato die). This is most likely on Sunday.

Justin (150 CE), 1 Apologia 67.3.

\begin{tabular}{|c|c|c|c|c|c|c|c|c|c|c|c|c|c|}
\hline \multicolumn{2}{|c|}{ Sunday } & \multicolumn{2}{|c|}{ Monday } & \multicolumn{2}{|c|}{ Tuesday } & \multicolumn{2}{|c|}{ Wednesday } & \multicolumn{2}{|c|}{ Thursday } & \multicolumn{2}{|c|}{ Friday } & \multicolumn{2}{|c|}{ Saturday } \\
\hline Mor. & Eve. & Mor. & Eve. & Mor. & Eve. & Mor. & Eve. & Mor. & Eve. & Mor. & Eve. & Mor. & Eve. \\
\hline
\end{tabular}

Some scholars have argued that the gathering described by Justin was in the morning, others that it cannot be ascertained if it was in the morning or in the evening.

Acts of Peter (150-200 CE), 7; 13; 20; 29; 30; 31.

\begin{tabular}{|l|l|l|l|l|l|l|l|l|l|l|l|l|l|}
\hline \multicolumn{2}{|l|}{ Sunday } & \multicolumn{2}{l|}{ Monday } & \multicolumn{2}{l|}{ Tuesday } & \multicolumn{2}{l|}{ Wednesday } & \multicolumn{2}{l|}{ Thursday } & \multicolumn{2}{l|}{ Friday } & \multicolumn{2}{l|}{ Saturday } \\
\hline Mor. & Eve. & Mor. & Eve. & Mor. & Eve. & Mor. & Eve. & Mor. & Eve. & Mor. & Eve. & Mor. & Eve. \\
\hline
\end{tabular}

Clement of Alexandria (190 CE), Quis dives salvetur 23; Paedagogus 2.96; 3.80.4.

\begin{tabular}{|c|c|c|c|c|c|c|c|c|c|c|c|c|c|}
\hline \multicolumn{2}{|c|}{ Sunday } & \multicolumn{2}{|c|}{ Monday } & \multicolumn{2}{|c|}{ Tuesday } & \multicolumn{2}{|c|}{ Wednesday } & \multicolumn{2}{|c|}{ Thursday } & \multicolumn{2}{|c|}{ Friday } & \multicolumn{2}{|c|}{ Saturday } \\
\hline Mor. & Eve. & Mor. & Eve. & Mor. & Eve. & Mor. & Eve. & Mor. & Eve. & Mor. & Eve. & Mor. & Eve. \\
\hline
\end{tabular}

* Dates given in this Appendix are approximative. Mor. = morning; Eve. = evening. 
Tertullian (197-207 CE), De Oratione 19.1; 23; De idololatria 7.1-3; De corona militis 3.3-4; De anima 9.4.

\begin{tabular}{|c|c|c|c|c|c|c|c|c|c|c|c|c|c|}
\hline \multicolumn{2}{|c|}{ Sunday } & \multicolumn{2}{|c|}{ Monday } & \multicolumn{2}{|c|}{ Tuesday } & \multicolumn{2}{|c|}{ Wednesday } & \multicolumn{2}{|c|}{ Thursday } & \multicolumn{2}{|c|}{ Friday } & \multicolumn{2}{|c|}{ Saturday } \\
\hline Mor. & Eve. & Mor. & Eve. & Mor. & Eve. & Mor. & Eve. & Mor. & Eve. & Mor. & Eve. & Mor. & Eve. \\
\hline
\end{tabular}

Tertullian does not specify on what day the evening gathering took place (Apol. 39). Pierre Nautin has suggested that the eucharistic gatherings on station days, Wednesday and Friday (Tert., Or. 19.1; Ieiun. 10.6), were in the evening.

Didascalia apostolorum (215 CE), 2.27-28; 58-59; 61; cf. 6.22 .

\begin{tabular}{|l|l|l|l|l|l|l|l|l|l|l|l|l|l|}
\hline \multicolumn{2}{|l|}{ Sunday } & \multicolumn{2}{l|}{ Monday } & \multicolumn{2}{l|}{ Tuesday } & \multicolumn{2}{l|}{ Wednesday } & \multicolumn{2}{l|}{ Thursday } & \multicolumn{2}{l|}{ Friday } & \multicolumn{2}{l|}{ Saturday } \\
\hline Mor. & Eve. & Mor. & Eve. & Mor. & Eve. & Mor. & Eve. & Mor. & Eve. & Mor. & Eve. & Mor. & Eve. \\
\hline
\end{tabular}

Traditio apostolica (230 CE), 2; 22; 35+36+37.

\begin{tabular}{|c|c|c|c|c|c|c|c|c|c|c|c|c|c|}
\hline \multicolumn{2}{|c|}{ Sunday } & \multicolumn{2}{|c|}{ Monday } & \multicolumn{2}{|c|}{ Tuesday } & \multicolumn{2}{|c|}{ Wednesday } & \multicolumn{2}{|c|}{ Thursday } & \multicolumn{2}{|c|}{ Friday } & \multicolumn{2}{|c|}{ Saturday } \\
\hline Mor. & Eve. & Mor. & Eve. & Mor. & Eve. & Mor. & Eve. & Mor. & Eve. & Mor. & Eve. & Mor. & Eve. \\
\hline
\end{tabular}

Morning gatherings were not always held during the week; the wording of Trad. ap. 35; 41 implies that on some days no service took place.

Origen (245 CE), Homiliae in Genesim 10.3; Homiliae in Joshuam 4.1.

\begin{tabular}{|l|l|l|l|l|l|l|l|l|l|l|l|l|l|}
\hline \multicolumn{2}{|l|}{ Sunday } & \multicolumn{2}{l|}{ Monday } & \multicolumn{2}{l|}{ Tuesday } & \multicolumn{2}{l|}{ Wednesday } & \multicolumn{2}{l|}{ Thursday } & \multicolumn{2}{l|}{ Friday } & \multicolumn{2}{l|}{ Saturday } \\
\hline Mor. & Eve. & Mor. & Eve. & Mor. & Eve. & Mor. & Eve. & Mor. & Eve. & Mor. & Eve. & Mor. & Eve. \\
\hline
\end{tabular}

Passages in Hom. Ex. 11.7 and Hom. Lev. 13.5 point to the celebration of a Eucharist following on the reading of Scripture and preaching, which took place in the morning.

Cyprian (250 CE), De oratione Dominica 18; De opere et eleemosynis 15; Epistulae 29.1.1; 39.4.1; 57.3; 58.1.

\begin{tabular}{|c|c|c|c|c|c|c|c|c|c|c|c|c|c|}
\hline \multicolumn{2}{|c|}{ Sunday } & \multicolumn{2}{|c|}{ Monday } & \multicolumn{2}{|c|}{ Tuesday } & \multicolumn{2}{|c|}{ Wednesday } & \multicolumn{2}{|c|}{ Thursday } & \multicolumn{2}{|c|}{ Friday } & \multicolumn{2}{|c|}{ Saturday } \\
\hline Mor. & Eve. & Mor. & Eve. & Mor. & Eve. & Mor. & Eve. & Mor. & Eve. & Mor. & Eve. & Mor. & Eve. \\
\hline
\end{tabular}

The Sunday evening gathering is now regarded as of lesser importance than that in the morning because not everybody can attend the evening gathering (Cypr., Ep. 63.16.2). 
4. An Ancient Religious Community Meeting at Sunrise

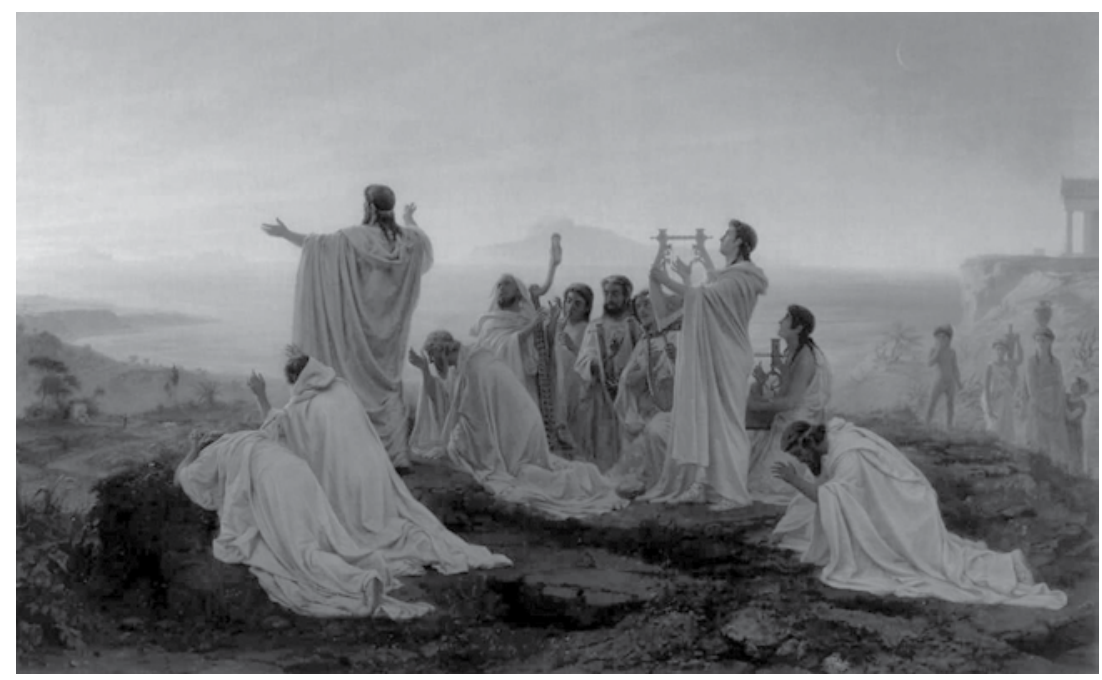

Fyodor Bronnikov, Pythagorean community singing a hymn to the rising sun. 1869 . Oil on canvas, $161 \times 100 \mathrm{~cm}$. State Tretyakov Gallery, Moscow. See chapter 2.

(For a full-colour reproduction, see http://www.freebase.com/view/ wikipedia/images/commons_id/2591309) 
5. Plans of two third-Century Christian gathering Places

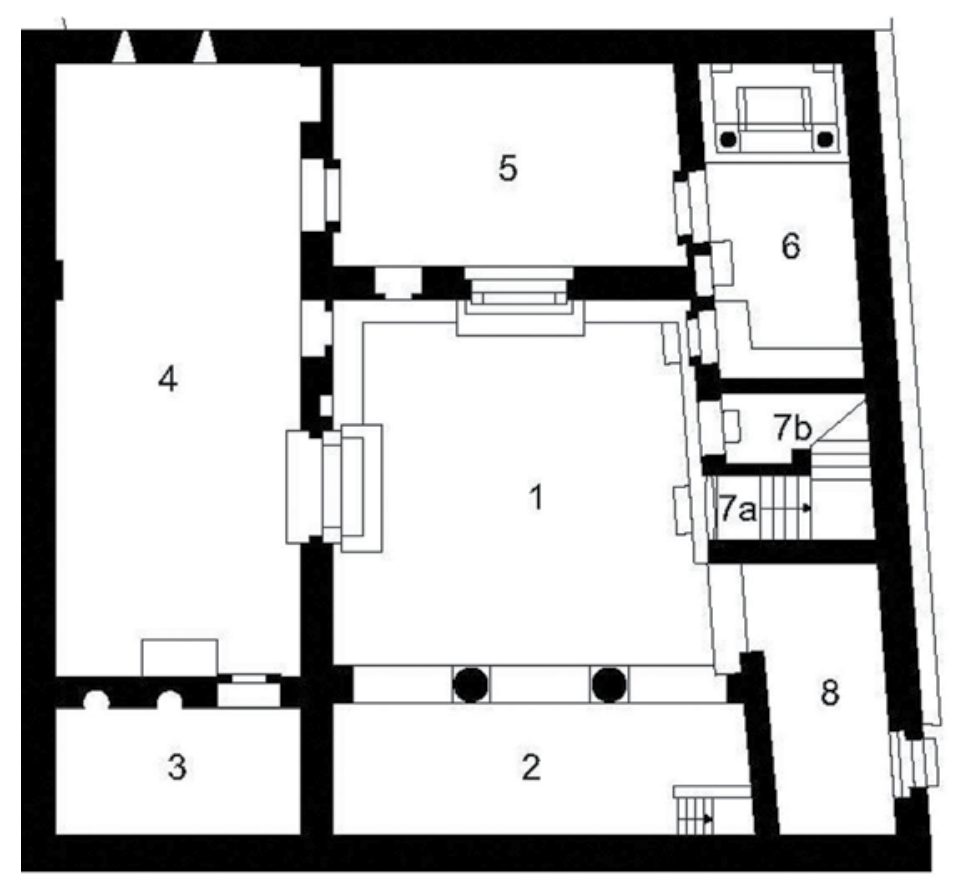

After renovation

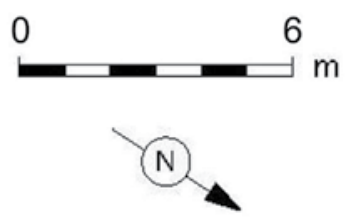

Plan of the Christian meeting place at Dura-Europos, ca. 232; after L.M. White, The Social Origins of Christian Architecture (1997), p. 126. Room $4(12.9 \times 5.15 \mathrm{~m})$ is the Christian assembly hall. 


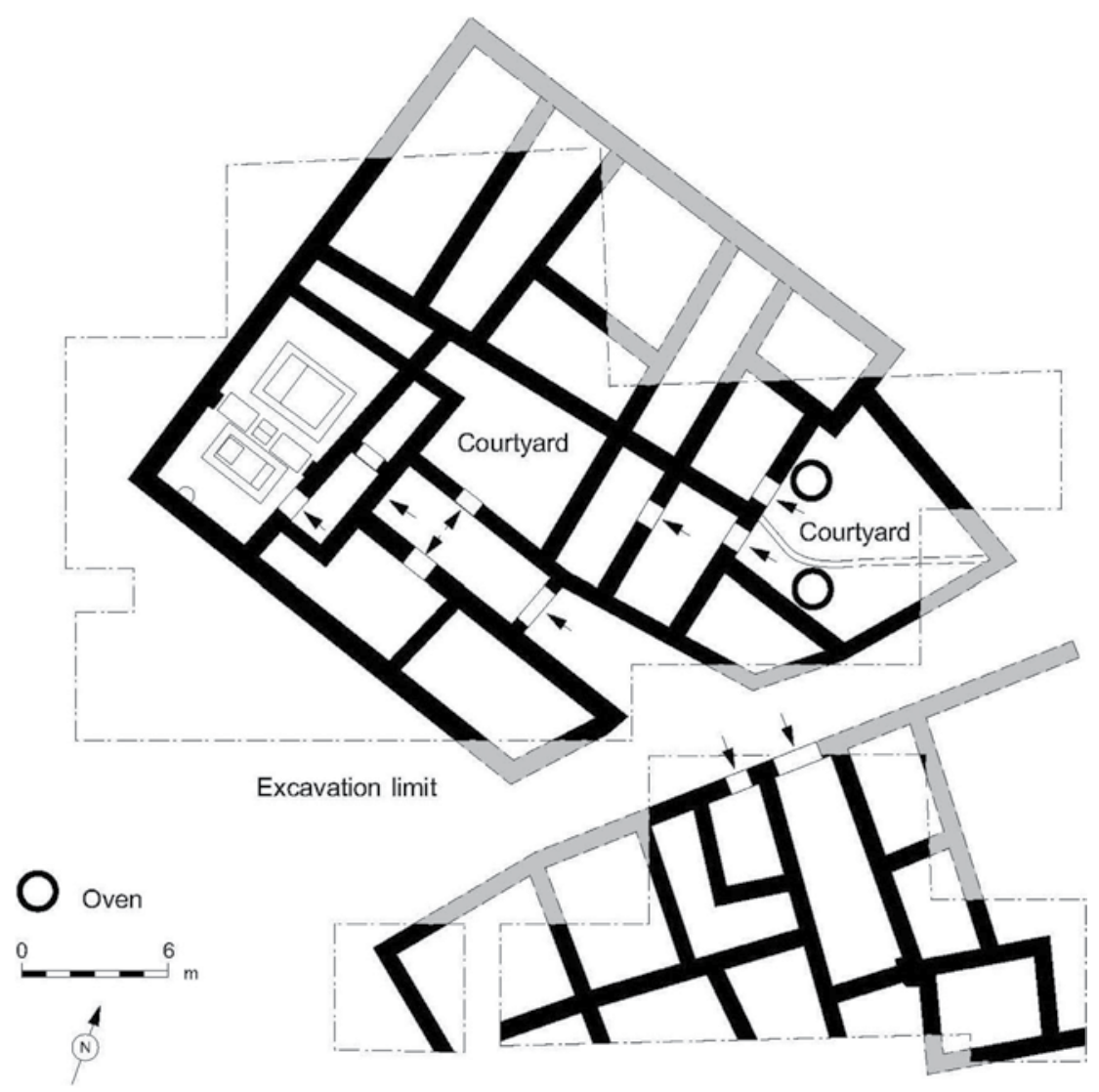

Plan of the Christian meeting place at Kefar 'Othnay (Legio), third century CE; after Y. Tepper and L. Di Segni, A Christian Prayer Hall of the Third century CE (2006), p. 21. The Christian prayer hall $(5 \times 10 \mathrm{~m})$ is situated in the utmost western corner of the complex. 


\section{BIBLIOGRAPHY}

\section{1, Primary Sources (Editions and Translations)}

\section{a. Old and New Testament}

Aland, K., Aland, B., Karavidopoulos, J., Martini, C.M., Metzger, B.M. (eds.), Novum Testamentum graece. 27. revidierte Auflage, 8th printing. Stuttgart: Deutsche Bibelgesellschaft, 2001.

Barker, Kenneth L. et al. (eds.), The Holy Bible, Containing the Old Testament and The New Testament: New International Version. Colorado Springs: International Bible Society, 1984.

Bonnes nouvelles aujourd'hui. Le Nouveau Testament traduit en français courant. Paris: Alliance biblique universelle/Société biblique française, 1972.

McHardy, W.D. (ed.), The Revised English Bible with the Apocrypha. Oxford and Cambridge: OUP and CUP, 1989.

Metzger, B.M., et al. (eds.), The Holy Bible, Containing the Old Testament and The New Testament with the Apocryphal/Deuterocanonical Books: New Revised Standard Version. New York/Oxford: Oxford University Press, 1989.

The New English Bible. New Testament. Oxford and Cambridge: OUP and CUP, 1961.

Rahlfs, A. (ed.), Septuaginta, id est Vetus Testamentum graece iuxta LXX interpretes, I-II. Stuttgart: Deutsche Bibelgesellschaft, 1935.

\section{b. Apocrypha and Pseudepigrapha}

Burchard, Christoph, Burfeind, C., Fink, U.B. (eds.), Joseph und Aseneth. Leiden: Brill, 2003.

Charlesworth, J.H. (ed.), The Old Testament Pseudepigrapha, 2 vols. New York/London: Doubleday, 1983-1985.

Martínez, García and Eibert J.C. Tigchelaar (eds.), The Dead Sea Scrolls Study Edition, 2 vols. Leiden: Brill, 1997-1998.

Philonenko, M. Joseph et Aséneth. Leiden: Brill, 1968.

Sparks, H.F.D. (ed.), The Apocryphal Old Testament. Oxford: Clarendon Press, 1984.

Tromp, Johannes. The Assumption of Moses. A Critical Edition with Commentary. Leiden: Brill, 1993.

\section{c. Further Jewish Literature}

Josephus

The Jewish Antiquities, Books 14-19, tra. H.S.J. Thackeray, vols. X-XII. LCL 489, 410, 433. Cambridge MA: Harvard University Press, 1930-1965.

The Jewish War, tra. H.S.J. Thackeray, vol. II. LCL 203. London and Cambridge MA: Heineman, Harvard University Press, 1926.

The Life. Against Apion, tra. H.S.J. Thackeray, vol. I. LCL 186. London and Cambridge MA: Heineman, Harvard University Press, 1926.

Mishna

The Mishnah: A New Translation, ed. and tra. Jacob Neusner. New Haven: Yale University Press, 1988. 
Philo

Every Good Man is Free. On the Contemplative Life. On the Eternity of the World. Against Flaccus. Apology for the Jews. On Providence, tra. F.H. Colson, vol. IX. LCL 363. Cambridge MA: Harvard University Press, 1943.

On Abraham. On Joseph. On Moses, tra. F.H. Colson, vol. VI. LCL 289. Cambridge MA: Harvard University Press, 1935.

On Flight and Finding. On the Change of Names. On Dreams, tra. F.H. Colson and G.H. Whitaker, vol. V. LCL 275. Cambridge MA: Harvard University Press, 1934.

On the Creation. Allegorical Interpretation of Genesis 2 and 3, tra. F.H. Colson and G.H. Whitaker, vol. I. LCL 226. Cambridge MA: Harvard University Press, 1929.

On the Decalogue. On the Special Laws, Books 1-3, tra. F.H. Colson, vol. VII. LCL 320. Cambridge MA: Harvard University Press, 1937.

On the Special Laws, Book 4. On the Virtues. On Rewards and Punishments, tra. F.H. Colson, vol. VIII. LCL 341. Cambridge MA: Harvard University Press, 1939.

The Embassy to Gaius, tra. F.H. Colson, vol. X. LCL 379. London and Cambridge MA: Heineman, Harvard University Press, 1962.

\section{d. Greek and Roman Literature}

Achilles Tatius, Leucippe and Clitophon, tra. S. Gaselee. LCL 45. London and Cambridge MA: Heineman, Harvard University Press, 1917.

Apuleius, Metamorphoseon libri XI, ed. Rudolf Helm. Leipzig: Teubner, 1931.

-, Metamorphoses (The Golden Ass), tra. J. Arthur Hanson, vols. I-II. LCL 44, 453. Cambridge: Harvard University Press, 1989.

—, The Golden Ass, tra. Robert Graves. Harmondsworth: Penguin Books, 1980.

Aristides, Orationes, ed. Wilhelm Dindorf. Lipsiae: Weidmann, 1829.

Athenaeus, The Deipnosophists, Books 8-15, tra. Charles Gulick, vols. IV-VII. LCL 235, 274, 327, 345. London and Cambridge MA: Heineman, Harvard University Press, 1927-1941.

- The Learned Banqueters, Books 1-7, ed. and tra. S. Douglas Olson, vols. I-III. LCL 204N, 208N, 224N. London and Cambridge MA: Harvard University Press, 2006-2008.

Aulus Gellius, The Attic Nights of Aulus Gellius, tra. John Rolfe, vols. I-III. LCL 195, 200, 212. London and New York: Heineman, Putnam, 1927-1928.

Cato, On Agriculture, tra. William Davis. LCL 283. London and Cambridge MA: Heineman, Harvard University Press, 1935.

Chariton, Calliroe, ed. and tra. G.P. Goold. LCL 481. London and Cambridge MA: Harvard University Press, 1995.

Diogenes Laertius, Lives of Imminent Philosophers, tra. R.D. Hicks, vols. I-II. LCL 184, 185. Cambridge MA: Harvard University Press, 1925.

Epictetus, Discourses, tra. W.A. Oldfather, vols. I-II. LCL 131, 218. London and Cambridge MA: Heineman, Harvard University Press, 1926-1928.

Juvenal and Persius, Satires, tra. S.M. Braund. LCL 91N. Cambridge MA: Harvard University Press, 2004.

Longus, Daphnis and Chloe. Love Romances and Poetical Fragments, tra. George Thornley, J.M. Edmonds, S. Gaselee. LCL 69. London and New York: Heinemann, Putnam, 1916.

Lucian, The Works of Lucian, tra. A.M. Harmon, vols. I-V. LCL 14, 54, 130, 162, 302. London and Cambridge MA: Harvard University Press, 1913-1936.

Petronius, Satyricon, tra. M. Heseltine. LCL 15. London and New York: Heinemann, Putnam, 1930.

Philostratus, Apollonius of Tyana, tra. Christopher Jones, vols. I-II. LCL 16, 17. Cambridge MA: Harvard University Press, 2005. 
Pliny the Yonger, Letters and Panegyricus, tra. Betty Radice, vols. I-II. LCL 55, 59. London and New York: Heinemann, Putnam, 1969.

Plutarch, Moralia, vol. II, tra. Frank C. Babbitt. LCL 222. Cambridge MA and London: Harvard University Press, 1928.

- Moralia, vol. VIII, tra. Paul A. Clement and Herbert B. Hoffleit. LCL 424. Cambridge MA and London: Harvard University Press, 1969, repr. 2006.

— Moralia, vol. IX, tra. Edwin L. Minar, Jr., F.H. Sanbach, W.C. Helmbold. LCL 425. Cambridge MA and London: Harvard University Press, 1961, repr. 1999.

Scriptores Historiae Augustae, Lives of the Emperors, tra. David Magie, vol. I. LCL 139. London: Harvard University Press, 1921.

Suetonius, Lives of the Caesars, tra. John Rolfe, vol. I. LCL 31. Cambridge MA: Harvard University Press, 1998.

Virgil, Aeneid, ed. and tra. H.R. Fairclough, G.P. Goold, vol. II. LCL 64. Cambridge MA: Harvard University Press, 2000.

Vitruvius, On Architecture, tra. Frank Granger, vol. I. LCL 251. London and Cambridge MA: Harvard University Press, 1931.

Xenophon, Memorabilia and Oeconomicus. Symposium and Apology, tra. E.C. Marchant and O.J. Todd, vol. IV. LCL 168. London and Cambridge MA: Harvard University Press, 1923.

\section{e. Early Christian Literature}

Acta Apostolorum Apocrypha, ed. Richard Lipsius and Max Bonnet, 3 vols. Leipzig: Mendelssohn, 1891, 1898, 1903; repr. Darmstadt: Wissenschaftliche Buchgesellschaft, 1959.

Actas de los Martires. Texto Bilingüe, ed. Daniel Ruiz Bueno. Madrid: Biblioteca de autores cristianos, $1968^{2}$.

Acts of the Christian Martyrs, ed. and tra. Herbert Musurillo. Oxford: Clarendon Press, 1972.

Ante-Nicene Fathers, ed. Alexander Roberts, 10 vols. Peabody: Hendrickson, 1994.

Apocryphal New Testament: A Collection of Apocryphal Christian Literature in an English Translation, ed. J.K. Elliott. Oxford: Clarendon Press, 1993.

Apostolic Fathers, ed. and tra. Bart D. Ehrman, 2 vols. LCL 24, 25. Cambridge MA and London: Harvard University Press, 2003.

Apostolic Fathers. Greek Texts and English Translations, ed. Michael Holmes. Grand Rapids: Baker Book House, 1999.

Athenagoras, Embassy for the Christians. The Resurrection of the Dead, tra. J.H. Crehan. London: Longmans, 1956.

_- Supplique au sujet des chrétiens et sur la résurrection des morts, tra. Bernard Pouderon. SC 379. Paris: Éditions du Cerf, 1992.

Canon Muratori. In Some Early Lists of the Books of the New Testament, ed. F.W. Grosheide. Leiden: Brill, 1948.

Clement of Alexandria, Extraits de Théodote, tra. F. Sagnar. SC 23. Paris: Éditions du Cerf, 1948.

—, Paedagogus, ed. M. Markovich. Leiden: Brill, 2002.

— Le Pédagogue II, tra. Claude Mondésert. SC 108. Paris: Éditions du Cerf, 1965.

— Le Pédagogue III, tra. Claude Mondésert. SC 158. Paris: Éditions du Cerf, 1970.

—, Les Stromates I, tra. Marcel Caster. SC 30. Paris: Éditions du Cerf, 1951.

—, Les Stromates VI, tra. Patrick Descourtieux. SC 446. Paris: Éditions du Cerf, 1999.

— Les Stromates VII, tra. Alain Le Boulluec. SC 428. Paris: Éditions du Cerf, 1997.

—, The Exhortation to the Greeks, The Rich Man's Salvation, tra. G.W. Butterworth. LCL 92. London and New York: Heineman and Putnam, 1919.

Commodian, Les instructions de Commodien, tra. Joachim Durel. Paris: Ernest Leroux, 1912. 
Les Constitutions apostoliques, tra. Marcel Metzger, vol. III. SC 336. Paris: Éditions du Cerf, 1987.

Cyprian, La bienfaisance et les aumônes, tra. Michel Poirier. SC 440. Paris: Éditions du Cerf, 1999.

_ L'oraison dominicale, tra. Michel Reveillaud. Paris: Presses Universitaires de France, 1964.

_ _ L'unité de l'église, ed. and tra. Michel Poirier. SC 500. Paris: Éditions du Cerf, 2006.

- Sancti Cypriani Episcopi Opera, eds. M. Simonetti and C. Moreschini. Turnhout: Brepols, 1976.

— Saint Cyprien. Correspondance, tra. L. Bayard. Paris: Les Belles Lettres, 1925.

- The Letters of St. Cyprian of Carthage, tra. G.W. Clarke, vols. 1-4. ACW 43, 44, 46, 47. New York: Newman, 1986.

Didachè. La doctrine des douze apôtres, tra. W. Rordorf and A. Tuilier. SC 248. Paris: Éditions du Cerf, 1998.

Didascalia. The Liturgical Portions of the, tra. S. Brock, introduced by M. Vasey. Bramcote: Grove, 1982.

Didascalia apostolorum, tra. R. Hugh Connolly. Oxford: Clarendon Press, 1929.

Epiphanius, The Panarion of St. Epiphanius, Bishop of Salamis, tra. Philip R. Amidon. New York: Oxford University Press, 1990.

- The Panarion of Epiphanius of Salamis, Books II and III (Sects 47-80, De Fide), tra. Frank Williams. Leiden: Brill, 1994.

Eusebius, Histoire ecclésiastique, tra. Gustave Bardy. SC 31, 41, 55, 73. Paris: Éditions du Cerf, 1952-1960.

—, History of the Church from Christ to Constantine, tra. G.A. Williamson. Harmondsworth: Penguin Books, 1990.

Gospel of Judas, tra. Rodolphe Kasser, Marvin Meyer, Gregor Wurst. 2nd ed. Washington DC: National Geographic Society, 2006.

Gospel of Philip, tra. W.W. Isenberg. In The Nag Hammadi Library, ed. James M. Robinson, pp. 131-151. Leiden: Brill, 1977.

Hippolytus (Ps.-), La Tradition apostolique, tra. Bernard Botte. SC 11 bis. Paris: Éditions du Cerf, 1984.

—, On the Apostolic Tradition, tra. Alistair Stewart-Sykes. Crestwood, NY: St. Vladimir's Seminary Press, 2001.

Irenaeus of Lyons, Against Heresies, tra. Robert M. Grant. London and New York: Routledge, 1997.

—, Contre les hérésies, livre IV, tra. Adelin Rousseau and Bertrand Hemmerdinger, vol. II. SC 100. Paris: Éditions du Cerf, 1965.

_ Paris: Éditions du Cerf, 1969.

Justin Martyr, Apologies, ed. André Wartelle. Paris: Études augustiniennes, 1987.

—, The First and Second Apologies, ed. and tra. L.W. Barnard. ACW 56. New York: Paulist Press, 1997.

- Dialogue avec Tryphon. Édition critique, ed. Philippe Bobichon, vol. I. Fribourg: Academic Press Friburg, 2003.

Minucius Felix, Octavius, ed. Bernhard Kytzler. Leipzig: Teubner, 1982.

Nag Hammadi Codex II, 2-7, ed. B. Layton, vol. 1. Leiden: Brill, 1989.

The Nag Hammadi Library in English, ed. and tra. James M. Robinson. Leiden: Brill, 1977.

The Nag Hammadi Scriptures, ed. Mervin Mayer. New York: HarperCollins, 2007.

Origen, Contre Celse, tra. Marcel Borret, vol. V. SC 227. Paris: Éditions du Cerf, 1976.

_. Homélies sur le Cantique des cantiques, tra. O. Rousseau. SC 37. Paris: Éditions du Cerf, 1954. 
_, Homélies sur l'Exode, tra. P. Fortier, Marcel Borret, vols. I-II. SC 16, 321. Paris: Éditions du Cerf, 1947, 1985.

—, Homélies sur la Génèse, tra. Louis Doutreleau. SC 7. Paris: Éditions du Cerf, 1976.

—. Homélies sur Jérémie, tra. Pierre Husson, vols. I-II. SC 232, 238. Paris: Éditions du Cerf, 1976-1977.

—_ Homélies sur Josué, tra. Annie Jaubert. SC 71. Paris: Éditions du Cerf, 1960.

_. Homélies sur les Juges, tra. Pierre Messié, Louis Neyrand, Marcel Borret. SC 389. Paris: Éditions du Cerf, 1993.

—, Homélies sur le Lévitique, tra. Marcel Borret, vols. I-II. SC 286, 287. Paris: Éditions du Cerf, 1981.

- Homélies sur S. Luc, tra. Henri Crouzel, François Fournier, Pierre Périchon. SC 87. Paris: Éditions du Cerf, 1962.

, Homélies sur les Nombres, ed. Louis Doutreleau, vols. I-II. SC 415, 442. Paris: Éditions du Cerf, 1996, 1999.

— Origen's Treatise on Prayer, tra. Eric George Jay. London: SPCK, 1954.

Praxeis Paulou, Acta Pauli nach dem Papyrus der Hamburger Staats- und UniversitätsBibliothek, ed. Carl Schmidt. Glückstadt and Hamburg: Augustin, 1936.

Pseudoklementinen I: Homilien, eds. Bernhard Rehm, Franz Paschke. Berlin: AkademieVerlag, 1969.

Pseudoklementinen II: Rekognitionen, eds. Bernhard Rehm, Franz Paschke. Berlin: Akademie-Verlag, 1965.

Tertullian, Apologeticum; De spectaculis; Octavius, tra. T.R. Glover. LCL 250. London and Cambridge: Heineman, Harvard University Press, 1977.

—. A son épouse, tra. Charles Munier. SC 273. Paris: Éditions du Cerf, 1980.

_ Ad nationes, ed. and tra. André Schneider. Neuchâtel: Attinger, 1968.

_, Contre Marcion, tra. René Braun, vols. I-V. SC 365, 368, 399, 456, 483. Paris: Éditions du Cerf, 1990-2004.

—, De anima, ed. J.H. Waszink. Amsterdam: Meulenhoff, 1947.

_ De corona, tra. Fabio Ruggiero. Milano: Mondadori, 1992.

_, De fuga in persecutione, tra. J.J. Thierry. Hilversum: Schipper, 1941.

_, De idololatria, eds. J.H. Waszink and J.C.M. van Winden. Leiden: Brill, 1987.

— De oratione, ed. and tra. Frederik Diercks. Bussum: Paul Brand, 1947.

—- De resurrectione carnis liber, ed. and tra. Ernest Evans. London: SPCK, 1960.

_ L La pudicité, tra. Charles Munier, vol. I. SC 394. Paris: Éditions du Cerf, 1993.

_- La toilette des femmes, tra. Marie Turcan. SC 173. Paris: Éditions du Cerf, 1971.

—, Les spectacles, tra. Marie Turcan. SC 332. Paris: Éditions du Cerf, 1986.

_, Traité de la prescription contre les hérétiques, tra. P. de Labriolle. SC 46. Paris: Éditions du Cerf, 1957.

Textos eucaristicos primitivos, ed. Jesus Solano. Madrid: Biblioteca de autores cristianos, 1952.

Théophile d'Antioche, Trois livres à Autolycus, tra. Jean Sender. SC 20. Paris: Éditions du Cerf, 1948.

Vita Polycarpi, ed. and tra. Alistair Stewart-Sykes. Sydney: St. Paul's Publications, 2002.

\section{f. Inscriptions and Papyri}

Corpus Inscriptionum Graecarum III,1-2. Berlin: Reimer, 1878.

Corpus Inscriptionum Graecarum II $^{2}$ I,1-2. Berlin: Reimer, 1913.

Corpus Papyrorum Judaicarum, ed. Victor A. Tcherikover, vol. 1. Cambridge, MA: Harvard University Press, 1957.

Inscriptiones Latinae Selectae, ed. H. Dessau, 5 vols. Berlin: Weidmann, 1892-1916.

The Oxyrhynchus Papyri, ed. and tra. N. Gonis, vol. 64. London: Egypt Exploration Society, 1999. 


\section{ReFERENCE Works}

Aland, K. Synopsis quattuor evangeliorum. 13th ed., third revision. Stuttgart: Würtembergische Bibelanstalt, 1988.

Barton, John and John Muddiman (eds.), The Oxford Bible Commentary. Oxford: Oxford University Press, 2004.

Bauer, W. A Greek-English Lexicon of the New Testament and Other Early Christian Literature. 2nd ed. revised by F. Wilbur Gingrich and Frederick W. Danker. Chicago and London: The University of Chicago Press, 1979.

Bercot, David W. (ed.), A Dictionary of Early Christian Beliefs. Peabody: Hendrickson, 1998.

Cross, F.L. and E.A. Livingstone (eds.), Oxford Dictionary of the Christian Church. 3rd ed. Oxford [etc.]: Oxford University Press, 1997.

Evans, Craig A. and Stanley E. Porter (eds.), Dictionary of New Testament Backgrounds. Downers Grove: InterVarsity Press, 2000.

Ferguson, Everett (ed.), Encyclopedia of Early Christianity, 2 vols. 2nd ed. New York: Garland, 1997.

Freedman, D.N. (ed.), The Anchor Bible Dictionary, 6 vols. New York: Doubleday, 1992.

Glare, P.G.W. (ed.), Oxford Latin Dictionary. Oxford: Clarendon Press, 1968-1982.

Hornblower, S. and A. Spawforth (eds.), The Oxford Classical Dictionary. 3rd ed. Oxford: Oxford University Press, 1996.

Kittel, G. (ed.), Theological Dictionary of the New Testament I-X, tra. G.W. Bromiley. Grand Rapids: Eerdmans, 1964-1976.

Kraft, Henricus. Clavis Patrum Apostolicorum. Darmstadt: Wissenschaftliche Buchgesellschaft, 1963.

Lampe, G.W.H. A Patristic Greek Lexicon. Oxford: Clarendon Press, 1961.

Lewis, Charlton D. and Charles Short. A Latin Dictionary. Oxford: Clarendon Press, 1879.

Liddell, H.G., R. Scott, H.S. Jones, R. McKenzie. A Greek-English Lexicon. 9th ed. Oxford: Clarendon Press, 1940, with a Supplement, 1968 (reprint 1990).

Moulton, W.F., A.S. Geden, H.K. Moulton, A Concordance to the Greek Testament according to the Texts of Westcott and Hort, Tischendorf and the English Revisers. 5th ed. Edinburgh: T \& T Clark, 2002.

Wace, Henry and William Piercy (eds.), A Dictionary of Early Christian Biography. Peabody: Hendrickson, 1999.

\section{Literature}

Achtemeier, Paul. "Omne Verbum Sonat: The New Testament and the Oral Environment of Late Western Antiquity." JBL 109 (1990), 3-27.

Ackroyd, P.R. and C.F. Evans (eds.), The Cambridge History of the Bible, vol. 1. From the Beginnings to Jerome. Cambridge: Cambridge University Press, 1970.

Alderink, Larry and Luther Martin. "Prayer in Greco-Roman Religions." In Prayer from Alexander to Constantine, ed. Mark Kiley et al., pp. 123-127. London and New York: Routledge, 1997.

Altaner, B. and A. Stuiber. Patrologie. 8th ed. Freiburg/Basel/Vienna: Herder, 1978.

Anderson, P.N. The Christology of the Fourth Gospel: Its Unity and Disunity in the Light of John 6. Tübingen: Mohr (Siebeck), 1996-1997.

Anderson, Warren D. Music and Musicians in Ancient Greece. Ithaca, NY: Cornell University Press, 1997.

Arnaoutoglou, Ilias N. "Roman Law and collegia in Asia Minor." Revue internationale des droits de l'Antiquité 49 (2002), 27-44. 
Ascough, R.S. "Translocal Christian Community as a Professional Voluntary Association." JBL 119 (2000), 311-328.

Attridge, Harold A. "Hebrews." In The Oxford Bible Commentary, eds. John Barton and John Muddiman, pp. 1236-1254. Oxford: Oxford University Press, 2001.

Audet, J.-P. La Didachè: Instructions des Apôtres. Paris: Lecofre, 1958.

Aune, David E. "Septem Sapientium Convivium." In Plutarch's Ethical Writings and Early Christian Literature, ed. H.D. Betz, pp. 51-105. Leiden: Brill, 1978.

- Prophecy in Early Christianity and the Ancient Mediterranean World. Grand Rapids: Eerdmans, 1983.

- "Oral Tradition and the Aphorisms of Jesus." In Jesus and the Oral Gospel Tradition, ed. Henry Wansbrough, pp. 211-265. Sheffield: Sheffield Academic Press, 1991.

Baarda, T. "'Het uitbreiden van mijn handen is zijn teken.' Enkele notities bij de gebedshouding in de Oden van Salomo." In Loven en geloven. FS. Nic. H. Ridderbos, eds. M.H. van Es et al., pp. 245-259. Amsterdam: Bolland, 1975.

Bacchiocchi, Samuele. From Sabbath to Sunday. A Historical Investigation of the Rise of Sunday Observance in Early Christianity. Rome: The Pontifical Gregorian University Press, 1977.

Baldovin, John F. The Urban Character of Christian Worship. Rome: Pontificum Institutum Studiorum Orientalium, 1987.

Balsdon, J.P.V.D. Life and Leisure in Ancient Rome. New York: McGraw-Hill, 1969.

Banks, Robert. Paul's Idea of Community. Peabody: Hendrickson, 1994.

Barker, Andrew. Greek Musical Writings, vol. I. Cambridge: Cambridge University Press, 1984.

Barker, Margaret. Temple Themes in Christian Worship. Edinburgh: T \& T Clark, 2008.

Barnes, Timothy D. “The Date of Ignatius." ExpT 120, n. 3 (2008), 119-130.

Barrett, C.K. The Acts of the Apostles, 2 vols. London and New York: T \& T Clark, 1998.

Barton, S.C. and G.H.R. Horsley. "A Hellenistic Cult Group and the New Testament Churches." JAC 24 (1981), 7-41.

Bauckham, R.J. “The Lord's Day.” In From Sabbath to Lord's Day, ed. D. Carson, pp. 221-250. Grand Rapids: Zondervan, 1982.

_- "Sabbath and Sunday in the Post-Apostolic Church." In From Sabbath to Lord's Day, ed. D. Carson, pp. 251-298. Grand Rapids: Zondervan, 1982.

Bauer, W. Der Wortgottesdienst der ältesten Christen. Tübingen: Mohr (Siebeck), 1930.

Baumgarten, A. "Graeco-Roman Voluntary Associations and Ancient Jewish Sects." In Jews in a Graeco-Roman World, ed. M. Goodman, pp. 93-111. Oxford: Clarendon Press, 1988.

Beard, Mary, John North and Simon Price. Religions of Rome. A History, vol. 1. Cambridge: Cambridge University Press, 1998.

Beck, Roger. The Religion of the Mithras Cult in the Roman Empire. Mysteries of the Unconquered Sun. Oxford: Oxford University Press, 2006.

Beckwith, Roger T. Calendar and Chronology, Jewish and Christian. Leiden: Brill, 1996.

- "The Daily and Weekly Worship of the Primitive Church in Relation to its Jewish Antecedents." EvQ 56 (1984), 65-80.

Beckwith, R.T. and Wilfrid Stott. The Christian Sunday. A Biblical and Historical Study. Grand Rapids: Baker Book House, 1980.

Beek, C.J.M.J. van. Passio Sanctorum Perpetuae et Felicitatis. Nijmegen: Dekker \& van de Vegt, 1936.

Benko, Stephen. Pagan Rome and the Early Christians. Bloomington: Indiana University Press, 1984. 
Black, David Alan. “The Peculiarities of Ephesians and the Ephesian Address." GTJ 2 (1981), 59-73.

Bolkestein, H. Wohltätigkeit und Armenpflege im vorchristlichen Altertum. Groningen: Bouma, 1967.

Borgen, Peder. Bread from Heaven. Leiden: Brill, 1965.

Bouley, Allan. From Freedom to Formula. The Evolution of the Eucharistic Prayer from Oral Improvisation to Written Texts. Washington: Catholic University of America, 1981.

Bowe, Barbara E. "Prayer Rendered for Caesar? 1 Clement 59.3-61.3." In The Lord's Prayer and Other Prayer Texts From the Greco-Roman Era, eds. James H. Charlesworth, Mark Harding and Mark Hiley, pp. 85-99. Valley Forge, PA: Trinity Press International, 1994.

Bradshaw, Paul F. Daily Prayer in the Early Church. London: Alcuin Club/SPCK, 1981.

- , "Introduction: The Evolution of Early Anaphoras." In Essays on Early Eastern Eucharistic Prayers, ed. Paul Bradshaw, pp. 1-18. Collegeville, MN: Liturgical Press, 1997.

- The Search for the Origins of Christian Worship. 2nd ed. Oxford: Oxford University Press, 2002.

—, Eucharistic Origins. Oxford: Oxford University Press, 2004.

Branick, Vincent. The House Church in the Writings of Paul. Wilmington: Michael Glazier, 1989.

Brown, R.E. The Gospel according to John XII-XXI. New York: Doubleday, 1970.

— The Death of the Messiah. New York: Doubleday, 1994.

Bruce, F.F. The Book of the Acts. Grand Rapids: Eerdmans, 1988.

Buitenwerf, R., H.W. Hollander, J. Tromp (eds.), Jesus, Paul and Early Christianity. Studies in Honour of Henk Jan de Jonge (Supplements to Novum Testamentum, vol. 130). Leiden: Brill, 2008.

Bultmann, R. Die Geschichte der synoptischen Tradition. 4th ed. Göttingen: Vandenhoeck \& Ruprecht, 1958.

__, Das Evangelium des Johannes. Göttingen: Vandenhoeck \& Ruprecht, 1952.

Burkert, Walter. Greek Religion. Cambridge MA: Harvard University Press, 1985.

—, Ancient Mystery Cults. Cambridge MA and London: Harvard University Press, 1987.

Cabaniss, Alan. Pattern in Early Christian Worship. Macon, GA: Mercer University Press, 1989.

Campbell, Alastair R. The Elders. Seniority within Earliest Christianity. Edinburgh: T \& T Clark, 1994.

Castagno, Adele Monaci. “Origen the Scholar and Pastor.” In Preacher and Audience: Studies in Early Christian and Byzantine Homiletics, eds. Mary B. Cunningham and Pauline Allen, pp. 65-88. Leiden: Brill, 1998.

Clerici, Luigi. Einsammlung der Zerstreuten. Liturgiegeschichtliche Untersuchung zur Vor- und Nachgeschichte der Fürbitte für die Kirche in Didache 9.4 und 10.5. Münster: Aschendorff, 1966.

Cobb, Peter. "The Anaphora of Addai and Mari." In The Study of Liturgy, eds. Chesly Jones et al., pp. 217-219. London: SPCK, 1992.

Cohen, Naomi G. Philo's Scriptures: Citations from the Prophets and Writings. Leiden: Brill, 2007.

Conzelmann, H. and A. Lindemann, Arbeitsbuch zum Neuen Testament, 14th ed. Tübingen: UTB, 2004.

Corley, Kathleen E. Private Women, Public Meals: Social Conflict in the Synoptic Tradition. Peabody: Hendrickson, 1993.

Cosgrove, Charles H. "Clement of Alexandria and Early Christian Music." JECS 14 (2006), 255-282. 
Coutsoumpos, Panayotis. Paul and the Lord's Supper: A Socio-Historical Investigation. New York: Peter Lang, 2005.

Cox, Claude E. "The Reading of the Personal Letter as the Background for the Reading of the Scriptures in the Early Church." In The Early Church in Its Context, eds. A.J. Malherbe, F.W. Norris, J.W. Thompson, pp. 74-91, Leiden: Brill, 1998.

Cullmann, Oscar. Urchristentum und Gottesdienst. Zürich: Zwingli-Verlag, 1950.

—, Early Christian Worship. Philadelphia: Westminster Press, 1953.

__, La foi et le culte de l'église primitive. Neuchâtel: Delachaux et Niestlé, 1963.

Cunningham, Mary B. and Pauline Allen (eds.), Preacher and Audience: Studies in Early Christian and Byzantine Homiletics. Leiden: Brill, 1998.

Dalby, Andrew. Siren Feasts: A History of Food and Gastronomy in Greece. London: Routledge, 1996.

Davies, J.G. The Early Christian Church. Grand Rapids: Baker Book House, 1980.

Delling, Gerhard. Der Gottesdienst im Neuen Testament. Göttingen: Vandenhoeck \& Ruprecht, 1952.

Dibelius, M. Die Formgeschichte des Evangeliums. 3rd ed. Tübingen: Mohr (Siebeck), 1959.

Dix, G. The Shape of the Liturgy. Glasgow: Glasgow University Press, 1945.

Dodd, C.H. According to the Scriptures: The Sub-Structure of New Testament Theology. London: Nisbet, 1953.

Dölger, Franz J. Sol Salutis. Gebet und Gesang im christlichen Altertum. Münster: Aschendorff, 1925.

Dunbabin, Katherine. "Convivial Spaces: Dining and Entertainment in the Roman Villa." JRA 9 (1996), 66-80.

_ - "Ut graeco more bibetur: Greeks and Romans on a Dining Couch." In Meals in a Social Context, eds. Inge Nielsen and H.S. Nielsen, pp. 81-101. Aarhus: Aarhus University Press, 1998.

- The Roman Banquet. Images of Conviviality. Cambridge: Cambridge University Press, 2003.

Dunn-Wilson, David. A Mirror for the Church. Preaching in the First Five Centuries. Grand Rapids: Eerdmans, 2005.

Ebel, Eva. Die Attraktivität früher christlicher Gemeinden. Tübingen: Mohr (Siebeck), 2004.

Edwards, O.C. Jr. A History of Preaching. Nashville: Abingdon Press, 2004.

Ellis, S.P. Roman Housing. London: Duckworth, 2000.

Emerton, J.A. “The Odes of Solomon.” In The Apocryphal Old Testament, ed. H.F.D. Sparks, pp. 683-732. Oxford: Clarendon Press, 1984.

Emmett, A.M. "A Fourth-Century Hymn to the Virgin Mary?" In New Documents Illustrating Early Christianity, ed. G.H.R. Horsley, vol. 2, pp. 141-146. North Ryde, Australia: The Ancient History Documentary Research Centre, Macquarie University, 1982.

Fee, Gordon. "Philippians 2:5-11: Hymn or Exalted Pauline Prose?” BBR 2 (1992), $29-46$.

Ferguson, Everett. Early Christians Speak, 2 vols. Austin: Sweet, 1971.

-, Backgrounds of Early Christianity. 2nd ed. Grand Rapids: Eerdmans, 1993.

Filson, Floyd V. "The Significance of the Early House Churches." JBL 58 (1939), 105112.

Finger, Reta Halteman. Of Widows and Meals. Communal Meals in the Book of Acts. Grand Rapids: Eerdmans, 2007.

Fitzmyer, Joseph A. The Acts of the Apostles. New York: Doubleday, 1998.

Foley, Edward. Foundations of Christian Music. The Music of Pre-Constantinian Christianity. Collegeville, MN: Liturgical Press, 1996.

Frend, W.H.C. The Early Church. Philadelphia: Fortress Press, 1982. 
- The Rise of Christianity. Philadelphia: Fortress Press, 1984.

Fürst, Alfons. Die Liturgie der alten Kirche. Münster: Aschendorff, 2008.

Gager, J.G. Kingdom and Community: The Social World of Early Christianity. Englewood Cliffs: Prentice-Hall, 1975.

Gamble, Harry. The New Testament Canon. Philadelphia: Fortress Press, 1985.

—, Books and Readers in the Early Church: A History of Early Christian Texts. New Haven and London: Yale University Press, 1995.

- "Literacy, Liturgy, and the Shape of the New Testament Canon." In The Contribution of the Chester Beatty Gospel Codex P45, JSNT SS 258, ed. Charles Horton, pp. 27-39. London and New York: T \& T Clark, Continuum, 2004.

Garsney, Peter. Food and Society in Classical Antiquity. Cambridge: Cambridge University Press, 1999.

Gehring, Roger W. House Church and Mission: The Importance of Household Structures in Early Christianity. Peabody: Hendrickson, 2004.

Gelston, A. The Eucharistic Prayer of Addai and Mari. Oxford: Oxford University Press, 1992.

Gerhardsson, Birger. "Illuminating the Kingdom: Narrative Meshalim in the Synoptic Gospels." In Jesus and the Oral Gospel Tradition, ed. Henry Wansbrough, pp. 266309. Sheffield: Sheffield Academic Press, 1991.

Glaue, Paul. Die Vorlesung heiliger Schriften im Gottesdienste. I Teil. Bis zur Entstehung der altkatholischen Kirche. Berlin: Alexander Duncker, 1907.

—_, "Die Vorlesung heiliger Schriften bei Tertullian." ZNW 23 (1924), 141-152.

__, "Die Vorlesung heiliger Schriften bei Cyprian.” ZNW 23 (1924), 201-213.

Goldenberg, Robert. "The Jewish Sabbath in the Roman World up to the Time of Constantine the Great." In ANRW II, 19.1, eds. Hildegard Temporini and Wolfgang Haase, pp. 414-447 Berlin, New York: Walter de Gruyter, 1979.

Gregory, C.R. Canon and Text of the New Testament. New York: Charles and Scribner, 1907.

_ "The Reading of Scripture in the Church in the Second Century." AJT 8 (1908), 86-91.

Grelot, Pierre. La liturgie dans le Nouveau Testament. Paris: Desclée, 1991.

Guthrie, Donald. "Aspects of Worship in the Book of Revelation.” In Worship, Theology and Ministry in the Early Church. Essays in Honour of Ralph P. Martin, eds. Michael J. Wilkins and Terence Paige, pp. 70-83. Sheffield: JSOT Press, 1992.

Haenchen, E. Die Apostelgeschichte. Göttingen: Vandenhoeck \& Ruprecht, 1968.

Hahn, Ferdinand. Der urchristliche Gottesdienst. Stuttgart: Katholisches Bibelwerk, 1970.

Hall, Stuart. Doctrine and Practice in the Early Church. Grand Rapids: Eerdmans, 1991.

Hamman, A. "La prière chrétienne et la prière païenne, formes et differences." In ANRW II, 23.2, ed. Wolfgang Haase, pp. 1190-1247. Berlin: Walter de Gruyter, 1988.

Hannick, Christian. "Music of the Early Christian Church." In The New Grove Dictionary of Music and Musicians, vol. 4, ed. Stanley Sadie, pp. 363-371. London: Macmillan, 1980.

Harland, Philip. Associations, Synagogues, and Congregations. Minneapolis: Fortress Press, 2003.

Harnack, Adolf von. Die Lehre der zwölf Apostel nebst Untersuchungen zur ältesten Geschichte der Kirchenverfassung und des Kirchenrechts. Leipzig: Hinrich, 1884, repr. 1893.

Harris, William. Ancient Literacy. Cambridge MA and London: Harvard University Press, 1989.

Harvey, A.E. “"The Workman is Worthy of His Hire.” NovT 24 (1982), 209-221.

Hauschild, W.-D. “Agapen I.” In Theologische Realenzyklopädie, vol. 1, pp. 748-753. Berlin: De Gruyter, 1977. 
Hendrickson, G.L. “Ancient Reading.” CJ 25 (1929-1930), 182-196.

Hijmans (Jr.), B.L. et al. Apuleius Madaurensis. Metamorphoses. Book IX. Text, Introduction and Commentary. Groningen: Forsten, 1995.

Hill, David. New Testament Prophecy. Atlanta: John Knox Press, 1979.

Hoffman, Lawrence. "Jewish Ordination on the Eve of Christianity." StLit 2 (1979), $11-41$.

Hollander, H.W. 1 Korintiërs, 3 vols. Kampen: Kok, 1996-2007.

- "The Words of Jesus: from Oral Traditions to Written Record in Paul and Q." NovT 42 (2000), 340-357.

—, "The Idea of Fellowship in 1 Corinthians 10.14-22." NTS 55 (2009), 456-470.

Hoogendijk, F.A.J. Tien papyrologische bijdragen tot de geschiedenis van Romeins en Byzantijns Egypte. Leiden: Papyrologisch Instituut, 2008.

Hooker, M.D. The Gospel according to St Mark. London: Black, 1991.

Horsley, G.H.R. "Invitation to the Kline of Sarapis." In New Documents Illustrating Early Christianity, ed. G.H.R. Horsley, vol. 1, pp. 5-9. North Ryde, Australia: The Ancient History Documentary Research Centre, Macquarie University, 1981.

—, "Answer from an Oracle." In New Documents Illustrating Early Christianity, ed. G.H.R. Horsley, vol. 2, pp. 37-44. North Ryde, Australia: The Ancient History Documentary Research Centre, Macquarie University, 1982.

— "Reclining at the Passover Meal." In New Documents Illustrating Early Christianity, ed. G.H.R. Horsley, vol. 2, p. 75. North Ryde, Australia: The Ancient History Documentary Research Centre, Macquarie University, 1982.

Huber, K. and M. Hasitschka. "Die Offenbarung des Johannes im Kanon der Bibel. Textinterner Geltungsanspruch und Probleme der kanonischen Rezeption." In The Biblical Canons, eds. J.-M. Auwers and H.J. de Jonge, pp. 607-618. Leuven: University Press \& Peeters, 2003.

Hurtado, L. At the Origins of Christian Worship. Carlisle: Pater Noster Press, 1999.

Jaubert, A. Clément de Rome. Epître aux Corinthiens. Paris: Éditions du Cerf, 1971.

Jensen, Robin Margaret. Understanding Early Christian Art. London and New York: Routledge, 2000.

Jeremias, J. Die Abendmahlsworte Jesu. Göttingen: Vandenhoeck \& Ruprecht, 1949, 3rd ed. 1960.

Jervell, Jacob. Die Apostelgeschichte. Göttingen: Vandenhoeck \& Ruprecht, 1998.

Jewett, Paul. The Lord's Day. Grand Rapids: Eerdmans, 1971.

Jewett, Robert. "Tenement Churches and Communal Meals in the Early Church: The Implications of a Form-critical Analysis of 2 Thessalonians 3:10.” BR 38 (1993), 23-43.

Johnson, Maxwell. "The Archaic Nature of the Sanctus, Institution Narrative, and Epiclesis of the Logos in the Anaphora Ascribed to Sarapion of Thumis." In Essays on Early Eastern Eucharistic Prayers, ed. Paul Bradshaw, pp. 73-108. Collegeville, MN: Liturgical Press, 1997.

-, "Worship, Practice and Belief." In The Early Christian World, ed. Philip F. Esler, vol. 1, pp. 475-499. London and New York: Routledge, 2000.

- "The Apostolic Tradition." In The Oxford History of Christian Worship, eds. G. Wainwright and Karen Westerfield Tucker, pp. 32-75. New York: Oxford University Press, 2006.

Johnston, Sarah Iles. "Mysteries." In Religions of the Ancient World, ed. Sarah Iles Johnston, pp. 98-111. Cambridge MA: Belknap, 2004.

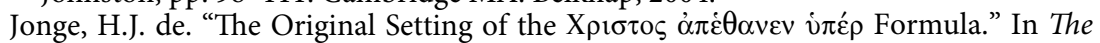
Thessalonian Correspondence, ed. Raymond F. Collins, pp. 229-235. Leuven: Peeters, Leuven University Press, 1990.

_ - "De plaats van de verzoening in de vroegchristelijke theologie." In Verzoening of koninkrijk: Over de prioriteit in de verkondiging, eds. A.A. van Houwelingen et al., pp. 63-88. Baarn: Callenbach, 1998. 
- "The Early History of the Lord's Supper." In Religious Identity and the Invention of Tradition. Studies in Theology and Religion, eds. J.W. van Henten and A. Houtepen, pp. 209-237. Assen: Van Gorcum, 2001.

, "The Function of Religious Polemics: The Case of the Revelation of John versus the Imperial Cult." In Religious Polemics in Context, eds. T.L. Hettema \& A. van der Kooij, pp. 276-290. Assen: Van Gorcum, 2004.

_- Zondag en sabbat. Over het ontstaan van de christelijke zondag. Leiden: Universiteit Leiden, 2006.

—-, Avondmaalen symposium. Oorsprongeneerste ontwikkeling van de vroegchristelijke samenkomst. Leiden: Universiteit Leiden, 2007.

- "Zondag en schepping. De zondag als hernieuwing van de schepping en als nieuwe schepping in de vroegchristelijke traditie." Eredienstvaardig 24, n. 5 (2008), 6-11.

Jonge, M. de. Johannes: een praktische bijbelverklaring. Kampen: Kok, 1996.

- God's Final Envoy: Early Christology and Jesus' Own View of His Mission. Grand Rapids: Eerdmans, 1998.

Jonquière, Tessel M. Prayer in Josephus. Leiden: Brill, 2007.

Judge, E.A. The Social Pattern of Christian Groups in the First Century. London: Tyndale, 1960.

_. "Kultgemeinde (Kultverein)." In Realenzyklopädie für Antike und Christentum, vol. 22, pp. 393-438. Stuttgart: Hiersemann, 2009.

Jungmann, J.A. The Early Liturgy to the Time of Gregory the Great. Notre Dame: University of Notre Dame Press, 1959.

Kasher, A. "Synagogues as 'Houses of Prayer' and 'Holy Places' in the Jewish Communities of Hellenistic and Roman Egypt." In Ancient Synagogues: Historical Analysis and Archaeological Discovery, eds. D. Urman and P.V.M. Flesher, vol. 1, pp. 205-220. Leiden: Brill, 1995.

Keener, Craig. The IVP Bible Background Commentary: New Testament. Downers Grove: InterVarsity Press, 1993.

Kelly, Henry A. The Devil at Baptism. Ritual, Theology, and Drama. Ithaca and London: Cornell University Press, 1985.

Kelly, J.N.D. Pastoral Epistles. London: Adam and Charles Black, 1963.

Kenney, E.J. "Books and Readers in the Roman World." In The Cambridge History of Classical Literature, vol. II, Latin Literature, eds. E.J. Kenney and W.V. Clausen, pp. 3-32. Cambridge: Cambridge University Press, 1982.

Khomych, Taras. "The Notion of puknôs as a Distinctive Characteristic of Liturgical Celebrations in the Letters of St Ignatius of Antioch." SP 40 (2006), 441-446.

Kiley, Mark. Prayer from Alexander to Constantine. London and New York: Routledge, 1997.

Kilmartin, Edward J. "Ministry and Ordination in Early Christianity against a Jewish Background." In Ordination Rites. Papers Read at the 1979 Congress of the Societas Liturgica, eds. Wiebe Vos and Geoffrey Wainwright, pp. 42-69. Rotterdam: Liturgical Ecumenical Center Trust, 1980.

Klassen, William. "The Sacred Kiss in the New Testament." NTS 39 (1993), 122-135.

Klauck, H.-J. Hausgemeinde und Hauskirche im frühen Christentum. Stuttgart: Katholisches Bibelwerk, 1981.

—., Herrenmahl und hellenistischer Kult. Münster: Aschendorff, 1982.

- The Religious Context of Early Christianity. A Guide to Graeco-Roman Religions. London and New York: T \& T Clark, 2000.

Klauser, Theodor. A Short History of the Western Liturgy: An Account and Some Reflections. Oxford: Oxford University Press, 1979.

Klijn, A.F.J. Apokriefen van het Nieuwe Testament, vol. 2. Kampen: Kok, 1984.

Klinghardt, M. Gemeinschaftsmahl und Mahlgemeinschaft. Soziologie und Liturgie frühchristlicher Mahlfeiern. Tübingen/Basel: Francke, 1996. 
Kloppenborg, John S. “Edwin Hatch, Churches and Collegia.” In Origins and Method: Towards a New Understanding of Judaism and Christianity, ed. B.H. Maclean, pp. 212-238. Sheffield: JSOT Press, 1993.

- "Collegia and Thiasoi: Issues in Function, Taxonomy and Membership." In Voluntary Associations in the Graeco-Roman World, eds. John Kloppenborg and Stephen G. Wilson, pp. 16-30. London: Routledge, 1996.

Kloppenborg, John S. and S.G. Wilson (eds.), Voluntary Associations in the GraecoRoman World. London: Routledge, 1996.

Knopf, R. Lehre der zwölf Apostel. Tübingen: Mohr (Siebeck), 1920.

Knox, Bernard. "Silent Reading in Antiquity." GRBS 9 (1968), 421-435.

Koch, D.-A. "The Early History of the Lord's Supper: A Response to Henk Jan de Jonge." In Religious Identity and the Invention of Tradition. Studies in Theology and Religion, eds. J.W. van Henten and A. Houtepen, pp. 238-252. Assen: Van Gorcum, 2001.

—. "Die eucharistischen Gebete von Didache 9 und 10 und das Rätsel von Didache 10:6." In Jesus, Paul and Early Christianity. Studies in Honour of Henk Jan de Jonge, eds. R. Buitenwerf, H.W. Hollander, J. Tromp, pp. 195-211. Leiden: Brill, 2008.

Koester, Helmut. Ancient Christian Gospels. Philadelphia: Trinity Press, 1990.

—_, "Written Gospels or Oral Traditions." JBL 113 (1994), 293-297.

Kraeling, Carl H. "Music in the Bible." In New Oxford History of Music, vol. 1, Ancient and Oriental Music, ed. E. Wellez, pp. 283-312. London: Oxford University Press, 1957.

Kraemer, Ross S. Women's Religions in the Graeco-Roman World. Oxford: Oxford University Press, 2004.

Lampe, Peter. From Paul to Valentinus. Christians at Rome in the First Two Centuries. Minneapolis: Fortress Press, 2003.

Lanfranchi, Pierluigi. "Attitudes to the Sabbath in Three Apostolic Fathers: Didache, Ignatius, and Barnabas." In Jesus, Paul and Early Christianity. Studies in Honour of Henk Jan de Jonge, eds. R. Buitenwerf, H.W. Hollander, J. Tromp, pp. 243-259. Leiden: Brill, 2008.

Lee, A.D. Pagans and Christians in Late Antiquity. A Sourcebook. London and New York: Routledge, 2000.

Leeuwen, Th. Marius van. Van feest naar feest. Over de christelijke feesten-hun geschiedenis en betekenis. Amsterdam: Balans, 2004.

Leipoldt, Johannes and S. Morenz. Heilige Schriften. Betrachtungen zur Religionsgeschichte der antiken Mittelmeerwelt. Leipzig: Harassowitz, 1953.

Levine, L. "The Second Temple Synagogue: The Formative Years." In The Synagogue in Late Antiquity, ed. Lee Levine, pp. 7-31. Philadelphia: ASOR, 1987.

Lienhard, Joseph T. "Origen as Homilist." In Preaching in the Patristic Age: Studies in Honor of Walter J. Burghardt, ed. David Hunter, pp. 36-52. New York/Mahwah: Paulist Press, 1989.

Lietaert Peerbolte, L.J. The Antecedents of Antichrist. Leiden: Brill, 1996.

Lietzmann, Hans. Messe und Herrenmahl: eine Studie zur Geschichte der Liturgie. Bonn: Marcus und Weber, 1926.

Lightfoot, J.B. The Apostolic Fathers, 2 Parts, 5 vols. London: Macmillan, 1889-1890.

Lindemann, A. Der Erste Korintherbrief. Tübingen: Mohr (Siebeck): 2000.

—, "Die Sammlung der Paulusbriefe im 1. und 2. Jahrhundert." In The Biblical Canons, eds. J.-M. Auwers and H.J. de Jonge, pp. 321-351. Leuven: Leuven University Press \& Peeters, 2003.

Llewelyn, S.R. "The Use of Sunday for Meetings of Believers in the New Testament." NovT 43 (2001), 205-223.

Löhr, Hermut. Studien zum frühchristlichen und frühjüdischen Gebet. Tübingen: Mohr (Siebeck), 2003.

Lohse, E. Die Ordination im Spätjudentum und im Neuen Testament. Göttingen: Vandenhoeck \& Ruprecht, 1951. 
Lührmann, Dieter. Das Markusevangelium. Tübingen: Mohr (Siebeck), 1987.

Mack, Burton L. Myth of Innocence. Philadelphia: Fortress Press, 1988.

Maier, Harry O. "Heresy, Households, and the Disciplining of Diversity." In A People's History of Christianity, vol. 2, Late Ancient Christianity, ed. Virginia Burrus, pp. 213233. Minneapolis: Fortress Press, 2005.

Marshall, I.H. Last Supper and Lord's Supper. Grand Rapids: Eerdmans, 1980.

Martin, R.P. "Aspects of Worship in the New Testament Church." Vox Evangelica 2 (1963), 6-32.

$\longrightarrow$, Carmen Christi: Philippians 2:5-11 in Recent Interpretation and in the Setting of Early Christian Worship. Cambridge: Cambridge University Press, 1967.

—, Worship in the Early Church. Grand Rapids: Eerdmans, 1975.

_-, "Patterns of Worship in New Testament Churches." JSNT 37 (1989), 59-85.

Masterpieces of Russian Art. Шедевры русской живописи, руководитель проекта Андрей Астахов. Москва: Белый город, 2006.

Mazza, Enrico. The Celebration of the Eucharist. Collegeville, MN: Liturgical Press, 1999.

—_ "L'eucaristia: dalla preghiera giudaica alla preghiera cristiana." In La preghiera nel tardo Antico. Dalle origini ad Agostino, pp. 25-52. Rome: Institutum Patristicum Augustinianum, 1999.

McCready, Wayne O. "Ekklêsia and Voluntary Associations." In Voluntary Associations in the Graeco-Roman World, eds. John Kloppenborg and Stephen G. Wilson, pp. 59-73. London: Routledge, 1996.

McDonald, James. Kerygma and Didache. The Articulation and Structure of the Earliest Christian Message. Cambridge: Cambridge University Press, 1980.

McGowan, Andrew. "First Regarding the Cup": Papias and the Diversity of Early Eucharistic Practice." JTS 46 (1995), 551-555.

—. Ascetic Eucharists: Food and Drink in Early Christian Ritual Meals. Oxford: Clarendon Press, 1999.

—, "Is There a Liturgical Text in This Gospel?": The Institution Narratives and Their Early Interpretive Communities." JBL 118 (1999), 73-87.

- "The Inordinate Cup: Issues of Order in Early Eucharistic Drinking." SP 35 (2001), 283-291.

- "Rethinking Agape and Eucharist in Early North African Christianity." StLit 34 (2004), 165-176.

— " "Food, Ritual, and Power." In A People's History of Christianity, vol. 2, Late Ancient Christianity, ed. Virginia Burrus, pp. 145-164. Minneapolis: Fortress Press, 2005.

McKay, Heather A. Sabbath and Synagogue. The Question of Sabbath Worship in Ancient Judaism. Leiden: Brill, 1994.

McKinnon, James. "The Meaning of the Patristic Polemic Against Musical Instruments." Current Musicology 1 (1965), 69-82.

—, Music in Early Christian Literature. Cambridge: Cambridge University Press, 1987.

, "Music." In The Early Christian World, ed. Philip Esler, vol. 2, pp. 773-790. London and New York: Routledge, 2004.

- Musique, chant et psalmodie. Les textes de l'Antiquité chrétienne. Turnhout: Brepols, 2006.

McLean, Bradley H. "The Agrippinilla Inscription: Religious Associations and Early Church Formation." In Origins and Method: Towards a New Understanding of Judaism and Christianity; Essays in Honour of John C. Hurd, ed. Bradley H. McLean, pp. 239-270, JSNT SS 86. Sheffield: JSOT Press, 1993.

Meeks, Wayne A. The First Urban Christians. New Haven and London: Yale University Press, 1983. 
- "Social and Ecclesial Life of the Earliest Christians." In The Cambridge History of Christianity, vol. 1, Origins to Constantine, eds. Frances M. Young and Margaret M. Mitchell, pp. 145-173. Cambridge: Cambridge University Press, 2006.

Meer, F. van der and Chr. Mohrman. Atlas van de oud-christelijke wereld. 2nd ed. Elsevier: Amsterdam, 1961.

Meggitt, Justin J. “The First Churches' Religious Practice.” In The Biblical World, ed. John Barton, vol. 2, pp. 157-172. London and New York: Routledge, 2002.

Menken, M.J.J. “John 6,51c-58: Eucharist or Christology?” Biblica 74 (1993), 1-26.

Messner, Reinhold. "Der Gottesdienst in der vornizänischen Kirche." In Die Geschichte des Christentums. Band 1. Die Zeit des Anfangs (bis 250), ed. Luce Pietri, pp. 340-441. Freiburg, Basel, Wien: Herder, 2003.

Metzger, Bruce M. The Canon of the New Testament: Its Origin, Development, and Significance. Oxford: Clarendon Press, 1987.

—, A Textual Commentary on the Greek New Testament. 2nd ed. Stuttgart: United Bible Societies, 1994.

Michell, G.A. Landmarks in Liturgy. London: Darton, Longman and Todd, 1961.

Mitchell, S. "The Cult of Theos Hypsistos between Pagans, Jews, and Christians." In Pagan Monotheism in Late Antiquity, ed. P. Athanassiadi and M. Frede, pp. 81-148. Oxford: Clarendon Press, 1999.

Morris, Leon. "The Saints and the Synagogue." In Worship, Theology and Ministry in the Early Church. Essays in Honour of Ralph P. Martin, eds. M.J. Wilkins and T. Paige, pp. 39-52. Sheffield: JSOT Press, 1992.

Moule, C.F.D. Worship in the New Testament. Richmond: John Knox Press, 1961.

Mowry, Lucetta. "Revelation 4-5 and Early Christian Liturgical Usage." JBL 71 (1952), 75-84.

Muddiman, John. "The Church in Ephesians, 2 Clement, and the Shepherd of Hermas." In Trajectories through the New Testament and the Apostolic Fathers, eds. Andrew F. Gregory and Christopher M. Tuckett, pp. 107-122. Oxford: Oxford University Press, 2005.

Mulder, M.J. and H. Sysling (eds.), Mikra: Text, Translation, Reading and Interpretation of the Hebrew Bible in Ancient Judaism and Early Christianity. Assen: Van Gorcum/ Philadelphia: Fortress Press, 1988.

Munier, Charles (ed.). Concilia Africae A. 345-A. 525. Turnhout: Brepols, 1974.

Murray, Oswyn. "The Greek Symposion in History." In Tria Corda: Scritti in onore di Arnaldo Momigliano, ed. E. Gabba, pp. 257-272. Como: New Press, 1983.

—, Sympotica. A Symposium on the Symposion. Oxford: Clarendon Press, 1990.

Nat, P.G. van der. Quinti Septimi Florentis Tertulliani de Idololatria. Leiden: Saint Lucas Society, 1960.

Nautin, Pierre. Origène. Sa vie et son oeuvre. Paris: Beauchesne, 1972.

Nielen, Josef Maria. Gebet und Gottesdienst im Neuen Testament. Freiburg: Herder, 1963.

Nijf, Onno M. van. The Civic World of Professional Associations in the Roman East. Amsterdam: Gieben, 1997.

Nilsson, Martin P. "Pagan Divine Service in Late Antiquity.” HTR 38 (1945), 63-69.

Nineham, D.E. The Gospel of St Mark. Harmondsworth: Penguin Books, 1973.

Oesterley, W.O.E. The Jewish Background of the Christian Liturgy. Oxford: Clarendon Press, 1925.

Ohlig, K.-H. Die theologische Begründung des neutestamentlichen Kanons. Düsseldorf: Patmos-Verlag, 1972.

Old, Hughes Oliphant. The Reading and Preaching of the Scriptures in the Worship of the Christian Church, vol. 1, The Biblical Period. Grand Rapids and Cambridge: Eerdmans, 1998. 
Olivar, Alexander. "Reflection on Problems Raised by Early Christian Preaching." In Preacher and Audience: Studies in Early Christian and Byzantine Homiletics, eds. Mary B. Cunningham and Pauline Allen, pp. 21-32. Leiden: Brill, 1998.

Osiek, Carolyn. A Woman's Place. House Churches in Earliest Christianity. Minneapolis: Fortress Press, 2006.

Osiek, Carolyn and David L. Balch. Families in the New Testament World. Households and House Churches. Louisville: Westminster John Knox Press, 1997.

Oster, R.E. 'Supposed Anachronism in Luke-Acts' Use of Synagoge: A Rejoinder to H.C. Kee." NTS 39 (1993), 178-208.

Pao, David W. "Physical and Spiritual Restoration: The Role of Healing Miracles in the Acts of Andrew." In The Apocryphal Acts of the Apostles, eds. François Bovon, Ann Graham Brock and Christopher R. Matthews, pp. 259-280. Cambridge MA: Harvard University Press, 1999.

Parratt, J.K. "The Laying on of Hands in the New Testament. A Re-examination in the Light of Hebrew Terminology." ExpT 80 (1969), 210-214.

Parvis, Paul. "2 Clement and the Meaning of the Christian Homily." ExpT 117 (2006), 265-270.

Paul, George. "Symposia and Deipna in Plutarch's Lives and in Other Historical Writings." In Dining in a Classical Context, ed. William Slater, pp. 157-170. Michigan: University of Michigan Press, 1991.

Penn, Michael P. Kissing Christians. Ritual and Community in the Late Ancient Church. Philadelphia: University of Pennsylvania Press, 2005.

Perrot, C. "Luc. 4.16-30 et la lecture biblique de l'ancienne synagogue." Revue des Sciences Religieuses 47 (1973), 324-340.

_- "The Reading of the Bible in the Ancient Synagogue." In Mikra. Text, Translation, Reading, and Interpretation of the Hebrew Bible in Ancient Judaism and Early Christianity, eds. M.J. Mulder and H. Sysling, pp. 137-159. Philadelphia: Fortress Press, 1988.

Petersen, Joan M. “House-Churches in Rome.” VC 23 (1969), 264-272.

Petersen, William L. Tatian's Diatessaron. Leiden: Brill, 1994.

Places, Édouard des. La religion grecque. Paris: Picard, 1969.

Planken, Colette. Rome aan tafel: ideaal en praktijk van het Romeinse diner. [Deventer:] Scriptio, 2007.

Ploeger, M. "Life-Death-Resurrection-Church. On the Coherence of Some Central Christian Notions." Internationale Kirchliche Zeitschrift 96 (2006), 45-50.

Poland, F. Geschichte des griechischen Vereinswesens. Leipzig: Teubner, 1909.

Powers, Daniel G. Salvation Through Participation. An Examination of the Notion of the Believers' Corporate Unity with Christ in Early Christian Soteriology. Leuven: Peeters, 2001.

Price, S.R.F. Rituals and Power. The Roman Imperial Cult in Asia Minor. Cambridge: Cambridge University Press, 1984.

Pulleyn, Simon. Prayer in Greek Religion. Oxford: Clarendon Press, 1997.

Quasten, Johannes. Musik und Gesang in den Kulten der heidnischen Antike und christlichen Frühzeit. Münster: Aschendorff, 1930.

Rankin, O.S. "The Extent of the Influence of the Synagogue Service upon Christian Worship." JJS 1 (1948-1949), 27-32.

Rapp, Claudia. Holy Bishops in Late Antiquity. Los Angeles and London: University of California Press, 2005.

Ray, Walter D. “The Strasbourg Papyrus.” In Essays on Early Eastern Eucharistic Prayers, ed. Paul Bradhsaw, pp. 39-56. Collegeville, MN: Liturgical Press, 1997.

Reumann, John. "A History of Lectionaries: From the Synagogue at Nazareth to PostVatican II.” Interpretation 31 (1977), 116-130. 
Riesenfeld, Harald. "The Sabbath and the Lord's Day in Judaism, the Preaching of Jesus and Early Christianity.” In The Gospel Tradition. Essays by Harald Riesenfeld, pp. 111-138. Philadelphia: Fortress Press, 1970.

Robert, Louis. Études anatoliennes: recherches sur les inscriptions grecques de l'Asie mineure. Paris: De Boccard, 1937.

Roberts, Colin, T.C. Skeat and A.D. Nock, "The Guild of Zeus Hypsistos." HTR 29 (1936), 39-88.

Roller, M.B. Dining Posture in Ancient Rome. Princeton: Princeton University Press, 2006.

Rordorf, W. Der Sonntag. Geschichte des Ruhe- und Gottesdiensttages im ältesten Christentum. Zürich: Zwingli Verlag, 1962.

— Sabbat und Sonntag in der alten Kirche. Zürich: Theologischer Verlag, 1972.

_- L'eucharistie des premiers chrétiens. Paris: Beauchesne, 1976.

_- "Origine et signification de la célébration du dimanche dans le christianisme primitif. État actuel de la recherche." In Liturgie, foi et vie des premiers chrétiens. Études patristiques, ed. W.A. Rordorf, pp. 103-122. Paris: Beauchesne, 1986.

- "The Bible in the Teaching and the Liturgy of Early Christian Communities." In The Bible in Greek Christian Antiquity, ed. Paul Blowers, pp. 69-104. Notre Dame: University of Notre Dame Press, 1997.

Roskam, H.N. The Purpose of the Gospel of Mark in Its Historical and Social Context. Leiden: Brill, 2004.

Ross, J.M. “Amen.” ExpT 102 (1990-1991), 166-171.

Rossing, Barbara R. "Prophets, Prophetic Movements, and the Voices of Women." In Christian Origins. vol. 1, A People's History of Christianity, ed. Richard A. Horsley, pp. 261-286. Minneapolis: Fortress Press, 2005.

Roueché, Charlotte. "Acclamation in the Later Roman Empire: New Evidence from Aphrodisias." JRS 74 (1984), 181-189.

Rouwhorst, Gerard. De viering van de eucharistie in de vroege kerk. Utrecht: Katholieke Theologische Universiteit, 1992.

—_ "La célébration de l'Eucharistie dans l'Eglise primitive." QL 74 (1993), 89-112.

_ _, "De lezing van de Schrift in de vroeg-christelijke liturgie." TL 79 (1995), 330347.

— "Bread and Cup in Early Christian Eucharist Celebrations." In Bread from Heaven. Customs and Practices Surrounding Holy Communion. Essays in the History of Liturgy and Culture, ed. Charles Caspers, Gerard Lukken and Gerard Rouwhorst, pp. 11-39. Kampen: Kok Pharos, 1995.

- "Jewish Liturgical Traditions in Early Syriac Christianity.” VC 51 (1997), 72-93.

- "The Reception of the Jewish Sabbath in Early Christianity." In Christian Feast and Festival, eds. P. Post, G. Rouwhorst et al., pp. 223-266, Leuven: Peeters, 2001.

- "The Reading of Scripture in Early Christian Liturgy." In What Athens has to do with Jerusalem. Essays on Classical, Jewish, and Early Christian Art and Archaeology in Honor of Gideon Foerster, ed. Leonard V. Rutgers, pp. 305-331. Leuven: Peeters, 2002.

_, "Didache 9-10: A Litmus Test for the Research on Early Christian Liturgy Eucharist." In Matthew and Didache. Two Documents from the Same Jewish Christian Milieu?, ed. Huub van de Sandt, pp. 143-156. Minneapolis and Assen: Fortress and Van Gorcum, 2005.

_ _In blijdschap en in een geest van eenvoud." Eredienstvaardig 22, n. 5 (2006), $4-7$.

_ - "Table Community in Early Christianity." In A Holy People. Jewish and Christian Perspectives on Religious Communal Identity, eds. Marcel Poorthuis and Joshua Schwartz, pp. 69-84. Leiden: Brill, 2006.

- "The Roots of the Early Christian Eucharist: Jewish Blessings or Hellenistic Symposia?" In Jewish and Christian Liturgy and Worship. New Insights into Its 
History and Interaction, eds. Albert Gerhards and Clemens Leonhard, pp. 295-308. Leiden: Brill, 2007.

—, "Christlicher Gottesdienst und der Gottesdienst Israels. Forschungsgeschichte, historische Interaktionen, Theologie." In Gottesdienst der Kirche. Handbuch der Liturgiewissenschaft, Part 2, vol. 2, Gottesdienst im Leben der Christen. Christliche und jüdische Liturgie, eds. M. Klöckener, A.A. Häußling, R. Messner, pp. 493-572. Regensburg: Pustet, 2008.

Rowley, H.H. Worship in Ancient Israel. Its Forms and Meaning. London: SPCK, 1967.

Runia, David T. Philo in Early Christian Literature. A Survey. Assen: Van Gorcum, 1993.

Rutgers, L.V. The Hidden Heritage of Diaspora Judaism. 2nd ed. Leuven: Peeters, 1998.

Ruwet, J. "Lecture liturgique et livres saints du Nouveau Testament." Biblica 21 (1940), 378-405.

Salzano, Aniello. Agli inizi della poesia cristiana latina. Salerno: Edisud Salerno, 2007.

Salzmann, Jörg Christian. "Pliny (ep. 10,96) and Christian Liturgy-A Reconsideration." SP 20 (1989), 389-395.

_- Lehren und Ermahnen: Zur Geschichte des christlichen Wortgottesdienstes in den ersten drei Jahrhunderten. Tübingen: Mohr (Siebeck), 1994.

Sandt, H. van de and David Flusser (eds.), The Didache: Its Jewish Sources and Its Place in Early Judaism and Christianity. Assen: Van Gorcum, 2002.

San Nicolò, M. Ägyptisches Vereinswesen zur Zeit der Ptolemäer und Römer, 2 vols. München: Beck, 1972.

Saxer, Victor. Vie liturgique et quotidienne à Carthage vers le milieu du III siècle. Rome: Pontifico Istituto di Archeologia Cristiana, 1969.

Schenke Robinson, Gesine. "Judas, a Hero or a Villain?" In The Gospel of Judas, ed. Rodolphe Kasser, Marvin Meyer, Gregor Wurst, pp. 155-168. 2nd ed. Washington DC: National Geographic Society, 2006.

Schiffman, Lawrence H. "The Early History of Public Reading of the Torah.” In Jews, Christians and Polytheists in the Ancient Synagogue: Cultural Interaction during the Greco-Roman Period, ed. S. Fine, pp. 44-56. London: Routledge, 1999.

Schmithals, Walter. "Gottesdienst im frühen Christentum." In Paulus, die Evangelien und das Urchristentum. Beiträge von und zu Walter Schmithals zu seinem 80. Geburtstag, ed. Cilliers Breytenbach, pp. 615-665. Leiden: Brill, 2004.

Schnackenburg, R. Das Johannesevangelium, 4 vols. Freiburg: Herder, 1967-1984.

Schnelle, Udo. Das Evangelium nach Johannes. Leipzig: Evangelische Verlagsanstalt, 2000.

Schoedel, William R. Ignatius of Antioch. Philadelphia: Fortress Press, 1985.

Schröter, Jens. Das Abendmahl. Frühchristliche Deutungen und Impulse für die Gegenwart. Stuttgart: Katholisches Bibelwerk, 2006.

Schürer, Emil, Geza Vermes, Fergus Millar, Martin Goodman. The History of the Jewish People in the Age of Jesus Christ, 3 vols. Edinburgh: T \& T Clark, 1973-1987.

Sherwine-White, A.N. The Letters of Pliny. A Historical and Social Commentary. Oxford: Clarendon Press, 1966.

Slater, W.J. (ed.), Dining in a Classical Context. Ann Arbor: The University of Michigan Press, 1991.

Slee, Michelle. The Church in Antioch in the First Century CE. Communion and Conflict. Sheffield: Sheffield Academic Press, 2003.

Smith, D.E. From Symposium to Eucharist. The Eucharist in the Early Christian World. Minneapolis: Fortress Press, 2002.

Smith, J.A. "The Ancient Synagogue, the Early Church and Singing." Music and Letters 65 (1984), 1-16.

Smith, Moody. "When did the Gospels Become Scripture?" JBL 119 (2000), 3-20.

Smith, William S. Musical Aspects of the New Testament. Amsterdam: Ten Have, 1962. 
Snyder, Gregory H. Teachers and Texts in the Ancient World. London and New York: Routledge, 2000.

Sorensen, Eric. Possession and Exorcism in the New Testament and Early Christianity. Tübingen: Mohr (Siebeck), 2002.

Spatharakis, I. "The Proskynesis in Byzantine Art." Bulletin Antieke Beschaving 49 (1974), 190-205.

Staats, R. "Die Sonntagnachtgottesdienste der christlichen Frühzeit." ZNW 66 (1975), 242-263.

Stanton, Graham N. "Aspects of Early Christian and Jewish Worship: Pliny and the Kerygma Petrou." In Worship, Theology and Ministry in the Early Church. Essays in Honour of Ralph P. Martin, eds. Michael J. Wilkins and Terence Paige, pp. 84-98. Sheffield: JSOT Press, 1992.

Starr, Raymond J. "Reading Aloud: Lectores and Roman Reading." CJ 86 (1990-1991), 337-343.

Stein, Hans Joachim. Früchristliche Mahlfeiern. Ihre Gestalt und Bedeutung nach der neutestamentlichen Briefliteratur und der Johannesoffenbarung. Tübingen: Mohr Siebeck, 2008 (not seen).

Stein-Hölkeskamp, Elke. Das römische Gastmahl. Eine Kulturgeschichte. München: Beck, 2005.

Stewart-Sykes, Alistair. "Hermas the Prophet and Hippolytus the Preacher: the Roman Homily and Its Social Context." In Preacher and Audience: Studies in Early Christian and Byzantine Homiletics, eds. Mary B. Cunningham and Pauline Allen, pp. 33-64. Leiden: Brill, 1998.

—, From Prophecy to Preaching: A Search for the Origins of the Christian Homily. Leiden: Brill, 2001.

—, On the Apostolic Tradition. Crestwood, NY: St. Vladimir's Seminary Press, 2001.

- The Life of Polycarp. An Anonimous Vita from Third-Century Smyrna. Sydney: St Paul's Publications, 2002.

- "Prophecy and Patronage: the Relationship Between Charismatic Functionaries and Household Officers in Early Christianity." In Trajectories through the New Testament and the Apostolic Fathers, eds. Andrew F. Gregory and Christopher M. Tuckett, pp.165-189. Oxford: Oxford University Press, 2005.

— "The Domestic Origin of the Liturgy of the Word." SP 40 (2006), 115-120.

Stringer, Martin D. A Sociological History of Christian Worship. Cambridge: Cambridge University Press, 2005.

Swete, H.B. The Gospel according to St. Mark. London: McMillan, 1909.

Taft, Robert. The Liturgy of the Hours in East and West. Collegeville, MN: Liturgical Press, 1986.

Taussig, Hal. In the Beginning Was the Meal. Social Experimentation and Early Christian Identity. Minneapolis: Fortress Press, 2009.

Taylor, Joan E. Jewish Women Philosophers of First-Century Alexandria. Philo's 'Therapeutae' Reconsidered. Oxford: Oxford University Press, 2003.

Tepper, Yotam and Leah Di Segni. A Christian Prayer Hall of the Third Century CE at Kefar 'Othnay (Legio). Jerusalem: The Israel Antiquities Authority, 2006.

Thompson, Leonard. "Hymns in Early Christian Worship." ATR 55 (1973), 458-472.

Toit, A.B. du. Der Aspect der Freude im urchristlichen Abendmahl. Winterthur: Keller, 1965.

— "Paulus Oecumenicus. Interculturality in the Shaping of Paul's Theology." NTS 55 (2009), 121-143.

Traede, Klaus. Grundzüge griechisch-römischer Brieftopik. München: Beck, 1970.

Tromp, Johannes. "Night and Day. A propos Acts 20:7." In Jesus, Paul and Early Christianity. Studies in Honour of Henk Jan de Jonge, eds. R. Buitenwerf, H.W. Hollander, J. Tromp, pp. 363-375. Leiden: Brill, 2008. 
Tuckett, Christopher M. "Synoptic Tradition in the Didache." In The New Testament in Early Christianity, ed. J.-M. Sevrin, pp. 197-230. Leuven: Peeters, 1989.

- "The Didache and the Writings that Later Formed the New Testament." In The Reception of the New Testament in the Apostolic Fathers, eds. Andrew F. Gregory and Christopher M. Tuckett, pp. 83-128. Oxford: Oxford University Press, 2005.

Verheyden, J. "The Canon Muratori. A Matter of Dispute." In The Biblical Canons, eds. J.-M. Auwers and H.J. de Jonge, pp. 487-556. Leuven: University Press \& Peeters, 2003.

Verner, D.C. The Household of God: The Social World of the Pastoral Epistles. Chico, CA: SBL, 1983.

Versnel, H.S. "Religious Mentality in Ancient Prayer." In Faith, Hope and Worship. Aspects of Religious Mentality in the Ancient World, ed. H.S. Versnel, pp. 1-64. Leiden: Brill, 1981.

Vickers, Michael. Greek Symposia. London: The Joint Association of Classical Teachers, 1978

Vööbus, Arthur. Liturgical Traditions in the Didache. Stockholm: ETSE, 1968.

Waltzing, J.P. Tertullien. Apologétique. Commentaire. Paris: Les belles lettres, 1931.

Watkins, Morris. Literacy, Bible Reading, and Church Growth through the Ages. South Pasadena, CA: William Carey Library, 1978.

Wengst, K. Didache (Apostellehre), Barnabasbrief, Zweiter Klemensbrief, Schrift an Diognet. Darmstadt: WBG, 1984.

Werner, Eric. The Sacred Bridge, vol. 1. London: Dennis Dobson, 1959.

West, M.L. Ancient Greek Music. Oxford: Clarendon Press, 1992.

White, L. Michael. Building God's House in the Roman World: Architectural Adaptation among Pagans, Jews, and Christians. Baltimore: John Hopkins University Press, 1990

- The Social Origins of Christian Architecture, vol. 2. Valley Forge: Trinity Press International, 1997.

—. "Regulating Fellowship in the Communal Meal: Early Jewish and Christian Evidence." In Meals in a Social Context, eds. Inge Nielsen and H.S. Nielsen, pp. 177205. Aarhus: Aarhus University Press, 1998.

Wilken, Robert L. The Christians as the Romans Saw Them. New Haven and London: Yale University Press, 1984.

Willis, G.G. A History of Early Roman Liturgy to the Death of Pope Gregory the Great. London: Boydell Press, 1994.

Willis, Wendell Lee. Idol Meat in Corinth. The Pauline Argument in 1 Corinthians 8 and 10. Chico: Scholars Press, 1985.

Wilson, Stephen B. "The Anaphora of the Apostles Addai and Mari." In Essays on Early Eastern Eucharistic Prayers, ed. Paul Bradshaw, pp. 19-38. Collegeville, MN: Liturgical Press, 1997.

Witherington III, Ben. Women in the Earliest Churches. Cambridge: Cambridge University Press, 1988.

- Making a Meal of It: Rethinking the Theology of the Lord's Supper. Waco, TX: Baylor University Press, 2007.

Ysebaert, Joseph. "The Eucharist as a Love-Meal." In The Apostolic Age in Patristic Thought, ed. A. Hilhorst, pp. 11-27. Leiden: Brill, 2004.

Young, F. "Christian Teaching." In Cambridge History of Early Christian Literature, eds. F. Young, L. Ayres, A. Louth, pp. 91-104, 464-484. Cambridge: Cambridge University Press, 2004.

—. "Towards a Christian Paideia." In Cambridge History of Early Christian Literature, eds. F. Young, L. Ayres, A. Louth, pp. 485-500. Cambridge: Cambridge University Press, 2004.

Young, N.H. "The Use of Sunday for Meetings of Believers in the New Testament: A Response." NovT 45 (2003), 111-122. 
Zahn, Th. Ignatius von Antiochien. Gotha: Perthes, 1873.

Zangenberg, J.K. "Visual Representations. Christianity." In Religions of the Ancient World, ed. Sarah Iles Johnston, pp. 619-621. Cambridge MA: Belknap, 2004.

Zeller, E. Die Philosophie der Griechen, 3 vols. Tübingen: Fues, 1844-1852.

Ziebarth, E. Das griechische Vereinswesen. Leipzig: Hirzel, 1896; repr. Wiesbaden: Martin Sandig, 1969.

Zimmern, Alice. The Home Life of the Ancient Greeks. New York: Cooper Square Publishers, 1966.

Zumstein, J. L'évangile selon Saint Jean (13-21). Genève: Labor et fides, 2007. 



\section{INDEX OF ANCIENT SOURCES}

1. Old Testament

\begin{tabular}{|c|c|c|c|}
\hline Genesis & & $85: 3$ & 280 \\
\hline $1: 3-5$ & 45 & 103 & $215 n$ \\
\hline \multirow[t]{2}{*}{$48: 14$} & $262 n$ & 104 & $215 n$ \\
\hline & & 104:1 & $279 n$ \\
\hline Exodus & & 106 & 280 \\
\hline 12 & $157 n, 190$ & $111-117$ & 280 \\
\hline \multirow[t]{2}{*}{$15: 1-18$} & 222 & $113-118$ & $279 n$ \\
\hline & & $114-118$ & $212 n$ \\
\hline Numbers & & 114 & 129 \\
\hline $8: 10$ & 261,264 & $115-118$ & 129 \\
\hline \multirow[t]{2}{*}{$27: 21-23$} & 261 & $118: 25$ & $279 n$ \\
\hline & & $122: 3$ & 280 \\
\hline Deuteronomy & & 133 & 221 \\
\hline 23 & $36 n$ & 135 & 280 \\
\hline \multirow[t]{2}{*}{$27: 15-26$} & $278 n$ & & \\
\hline & & Isaiah & \\
\hline 1 Chronicles & & $53: 12$ & 166 \\
\hline \multirow[t]{2}{*}{$16: 36$} & $278 n$ & $58: 6$ & $152 n$ \\
\hline & & $61: 1-2$ & $152,152 n$ \\
\hline \multicolumn{4}{|l|}{ Ezra } \\
\hline \multirow[t]{2}{*}{$9: 5$} & $252 n$ & Jeremiah & \\
\hline & & $31: 31$ & 166 \\
\hline \multicolumn{4}{|l|}{ Nehemiah } \\
\hline $5: 13$ & $278 n$ & Lamentations & \\
\hline $8: 6$ & $278 n$ & $1: 10$ & $36 n$ \\
\hline \multirow[t]{2}{*}{$13: 1-3$} & $36 n$ & & \\
\hline & & Daniel & \\
\hline Esther & & $11: 31$ & 179 \\
\hline \multirow[t]{2}{*}{$9: 16-32$} & 30 & & \\
\hline & & Hosea & \\
\hline Psalms & & $6: 2$ & 165 \\
\hline $9: 13$ & 280 & & \\
\hline 29:10 & 280 & Joel & \\
\hline $40: 4$ & 280 & $2: 28$ & 171 \\
\hline $40: 10$ & 280 & & \\
\hline
\end{tabular}

2. Apocrypha and Pseudepigrapha

Assumptio Mosis

4.1

$252 n$

2 Baruch

$86.1-2$
152 n, $170 n$
Joseph and Asenath

8.5

$37 \mathrm{n}, 228 \mathrm{n}$

$16.8 \quad 133$

$16.16 \quad 133$

$21.6262 n$ 


$\begin{array}{llll}\text { Jubilees } & & 41.1 & 218 \mathrm{n} \\ 22.6 & 228 \mathrm{n} & 41.5 & 218 \mathrm{n} \\ 50.9-10 & 47 \mathrm{n} & 41.7 & 218 \mathrm{n} \\ & & 41.16 & 218 \mathrm{n} \\ 3 \text { Maccabees } & & 42.1 & 253 \mathrm{n} \\ 2: 1 & 252 \mathrm{n} & & \\ 6: 35-36 & 30 \mathrm{n} & \text { Sibylline Oracles } & \\ 6: 36 & 30 & 4.26 & 37 \mathrm{n}, 228 \mathrm{n} \\ & & & \\ \text { Odes of Solomon } & & \text { Sirach } & \\ 1 & 219 \mathrm{n} & 9: 15-16 & 30 \mathrm{n} \\ 2 & 219 \mathrm{n} & 32: 3-6 & 30 \mathrm{n} \\ 3.7 & 217 \mathrm{n} & 32: 5-6 & 212 \mathrm{n} \\ 4.9 & 217 \mathrm{n} & 32: 13 & 229 \mathrm{n} \\ 7.22-26 & 218 \mathrm{n} & 50: 19 & 228 \mathrm{n} \\ 14.8 & 225,226 & & \\ 16 & 218 & \text { Testament of Job } & \\ 16.1-3 & 218 \mathrm{n} & 14 & \\ 26.1-4 & 217 \mathrm{n} & & \\ 26.3 & 225,226 & \text { Tobit } & \\ 27.1 & 253 \mathrm{n} & 8: 8 & 278 \mathrm{n} \\ 37.1 & 253 \mathrm{n} & & \end{array}$

3. Further Jewish Literature

Dead Sea Scrolls

1QapGen

$20.28-29$

1QS

1.20

$1.21-22$

2.10

2.11

2.18

$6.2-13$

6.3

$6.4-5$

6.5

$6.6-7$

$6.7-8$

7.1

1QSa

$1.4-5$

$2.17-21$

$2.18-19$

2Q14

4Q175

$262 n$

$278 n$
264
$278 n$
264
$278 n$
$27 n, 28$
$229 n$
$37 n$
$229 n$
$189 n$
$153,230 n$
153

153

27n, 28

$229 n$

$215 n$

264
4Q251

$1.5 \quad 189$ n

4Q266

$5.2 \quad 153$

14.3-5 264

4Q397

14-21 153

4Q400 215n

4Q503 84

Josephus

Antiquitates Judaicae

8.46-49 275n

$14.214-216 \quad 27 \mathrm{n}$

$16.2 .4 \quad 150 \mathrm{n}$

$16.43 \quad 188 \mathrm{n}$

$16.44 \quad 29 n, 151 n$

18.65-80 24n

$19.239 \quad 267 \mathrm{n}$

$19.358 \quad 267 n$

Contra Apionem

$\begin{array}{ll}1.209 & 253 \mathrm{n} \\ 1.210 & 29 \mathrm{n}, 81 \mathrm{n}\end{array}$




\begin{tabular}{|c|c|c|c|}
\hline 2.175 & $29 n, 151 n, 188 n$ & De somniis & \\
\hline 2.196 & $228 n$ & 2.127 & $82 n, 150 n, 188 n$ \\
\hline \multicolumn{2}{|l|}{ De bello judaico } & \multicolumn{2}{|c|}{ De specialibus legibus } \\
\hline $2.128-129$ & $83 n$ & $2.62-63$ & $28 n$ \\
\hline 2.131 & $37 n, 228$ & 2.148 & $212 n$ \\
\hline 2.132 & $83 n$ & & \\
\hline 2.166 & $28 n$ & \multicolumn{2}{|l|}{ De virtutibus } \\
\hline \multicolumn{4}{|l|}{ Vita } \\
\hline 268 & $36 n$ & \multicolumn{2}{|c|}{ De vita contemplativa } \\
\hline 279 & $29 n, 82 n$ & $\begin{array}{l}27 \\
30-33\end{array}$ & $\begin{array}{l}84 n \\
28 n\end{array}$ \\
\hline Mishnah & & 30 & $47 \mathrm{n}$ \\
\hline Berakhot & & $36-37$ & $47 n$ \\
\hline 1.2 & $84 n$ & $40-63$ & $27 \mathrm{n}$ \\
\hline 1.4 & $84 n$ & $66-90$ & $27 \mathrm{n}$ \\
\hline 5.4 & $278 n$ & $66-82$ & $27 n$ \\
\hline 6 & $238 n$ & $66-67$ & $229 n$ \\
\hline $6.5-8$ & $238 \mathrm{n}$ & 73 & $47 n, 60 n$ \\
\hline $7.1-5$ & $238 n$ & $\begin{array}{l}75-78 \\
80\end{array}$ & $\begin{array}{l}30 n, 189 n \\
212 n, 215 n\end{array}$ \\
\hline Megillah & & $83-87$ & $227 \mathrm{n}$ \\
\hline \multirow[t]{2}{*}{$4.3^{\circ}$} & \multirow[t]{2}{*}{$152 n$} & 84 & $212 n$ \\
\hline & & 89 & $84 n$ \\
\hline \multicolumn{4}{|l|}{ Sanhedrin } \\
\hline \multirow[t]{2}{*}{1.3} & \multirow[t]{2}{*}{$260 n$} & \multicolumn{2}{|c|}{ Legatio ad Gaium } \\
\hline & & 156 & $150 n, 188 n$ \\
\hline \multicolumn{4}{|l|}{ Ta'anit } \\
\hline 2.5 & $278 n$ & \multicolumn{2}{|c|}{$\begin{array}{l}\text { Quod omnis probus liber sit } \\
81-82 \quad 151 \mathrm{n}\end{array}$} \\
\hline \multicolumn{4}{|c|}{$01-025+5$} \\
\hline De opificio mundi & & Vita Mosis & \\
\hline 128 & $29 n$ & $2.215-216$ & $28 n$ \\
\hline
\end{tabular}

4. New Testament

$\begin{array}{llll}\text { Matthew } & & 7: 32 & 262 \mathrm{n} \\ 10: 10 & 273 \mathrm{n} & 8: 6 & 229 \mathrm{n} \\ 14: 19 & 229 \mathrm{n} & 10: 17-31 & 199 \\ 15: 36 & 229 \mathrm{n} & 10: 38 & 128,129 \\ 16: 18 & 39 \mathrm{n} & 10: 45 & 116 \mathrm{n} \\ 20: 28 & 116 \mathrm{n} & 11: 25 & 251 \mathrm{n} \\ 24: 15 & 179 & 13: 14 & 179 \\ 26: 26-29 & 122 \mathrm{n} & 14: 12 & 121 \mathrm{n} \\ 26: 27-29 & 126 & 14: 14 & 121 \mathrm{n} \\ & & 14: 16 & 121 \mathrm{n} \\ \text { Mark } & & 14: 22-26 & 119,129 \\ 1: 21 & 47,150 \mathrm{n} & 14: 22-25 & 111 \mathrm{n}, 121 \mathrm{n}, 127,129, \\ 1: 31 & 37 \mathrm{n}, 47 & & 129 \mathrm{n} \\ 5: 23 & 262 \mathrm{n} & 14: 22-24 & 123 \\ 6: 1-2 & 152 \mathrm{n} & 14: 22-23 & 234 \\ 6: 2 & 150 \mathrm{n}, 152 \mathrm{n} & 14: 22 & 123 \\ 6: 41 & 229 \mathrm{n} & 14: 23 & 233\end{array}$




\begin{tabular}{|c|c|c|c|}
\hline $14: 24$ & $106 n, 117 n, 119,129 n$ & $6: 51-58$ & $130,131,132$ \\
\hline $14: 25$ & 119,123 & $6: 51-56$ & 131 \\
\hline $14: 26$ & $126 \mathrm{n}, 129,212,234$ & $6: 51$ & $131 n, 134 n$ \\
\hline $14: 27$ & 164 & $6: 53$ & $134 n$ \\
\hline $14: 36$ & 128,129 & $6: 54$ & $131 n$ \\
\hline $14: 49$ & 164 & $6: 55$ & $131 \mathrm{n}$ \\
\hline $14: 61$ & 164 & $6: 56$ & $131 \mathrm{n}$ \\
\hline $15: 40$ & $23 n$ & $12: 2$ & $37 \mathrm{n}, 47$ \\
\hline $16: 1$ & $23 n, 45$ & $12: 3$ & $267 n$ \\
\hline \multirow[t]{2}{*}{$16: 8$} & $116 n$ & $12: 12-19$ & $47 \mathrm{n}$ \\
\hline & & $13: 1-20$ & $266 n$ \\
\hline Luke & & $13: 2-18: 1$ & $130 n$ \\
\hline $4: 16-20$ & 166 & $20: 19$ & $41 \mathrm{n}$ \\
\hline $4: 16-17$ & 152 & $20: 26$ & $41 n$ \\
\hline $4: 17-21$ & $152 n, 164 n$ & $21: 9$ & $60,271,272 n$ \\
\hline $6: 12-13$ & $42 n$ & $21: 13$ & $60,61 \mathrm{n}$ \\
\hline $7: 38$ & $267 n$ & & \\
\hline $7: 44-46$ & $267 n$ & \multicolumn{2}{|c|}{ Acts of the Apostles } \\
\hline $7: 44$ & $266 n$ & $1: 4$ & $60 n$ \\
\hline $7: 45$ & $257,257 \mathrm{n}$ & $1: 13$ & $51 \mathrm{n}, 55$ \\
\hline $9: 16$ & $229 n$ & $1: 14$ & $247 n$ \\
\hline $10: 7$ & $273 n$ & $2: 4$ & $247 n$ \\
\hline $10: 32$ & 264 & $2: 14$ & $209 n$ \\
\hline $10: 40$ & $47 n$ & $2: 17-18$ & 171 \\
\hline $16: 16$ & $152 n$ & $2: 41-47$ & 112 \\
\hline $16: 29$ & $152 n$ & $2: 42-46$ & 112 \\
\hline $17: 8$ & $47 \mathrm{n}$ & $2: 42$ & 112 \\
\hline $22: 7$ & $42 n$ & $2: 46$ & $51 \mathrm{n}, 112$ \\
\hline $22: 14-20$ & $123 n$ & $3: 6-10$ & $275 n$ \\
\hline $22: 14$ & 129 & $4: 24-31$ & $247 n$ \\
\hline $22: 15-19$ & 115 & $4: 31$ & $51 \mathrm{n}$ \\
\hline $22: 15-16$ & 129 & $5: 12-16$ & $275 n$ \\
\hline $22: 15$ & 123 & $5: 42$ & $51 \mathrm{n}$ \\
\hline $22: 16$ & 123 & $6: 1-6$ & $71 \mathrm{n}$ \\
\hline $22: 17-19$ & 234 & $6: 2$ & $47 n$ \\
\hline $22: 18$ & 123 & $6: 5-6$ & $260 n, 261 n$ \\
\hline $22: 19$ & $123,124,129$ & $6: 9$ & $28 n$ \\
\hline $22: 20$ & $62 n$ & $6: 11$ & $60 n$ \\
\hline $22: 26-27$ & $47 \mathrm{n}$ & $7: 52$ & $164 n$ \\
\hline $23: 54$ & $42 n$ & $7: 60$ & $251 n$ \\
\hline $24: 14$ & $185 n$ & $8: 3$ & $51 \mathrm{n}$ \\
\hline $24: 15$ & $185 n$ & $8: 7$ & $275 n$ \\
\hline $24: 25-26$ & $164 n$ & $8: 30$ & 148 \\
\hline $24: 27$ & $152 n$ & $9: 12$ & $262 n$ \\
\hline $24: 30$ & $229 n$ & $9: 17$ & $262 n$ \\
\hline $24: 33-43$ & $41 \mathrm{n}, 129$ & $9: 32-35$ & $275 n$ \\
\hline $24: 42$ & 60,271 & $9: 37$ & $51 \mathrm{n}$ \\
\hline \multirow[t]{2}{*}{$24: 44$} & $152 n$ & $9: 39$ & $51 n$ \\
\hline & & $9: 40$ & $251 n$ \\
\hline John & & $10: 9$ & $41,41 \mathrm{n}$ \\
\hline $1: 19$ & 264 & $10: 23$ & $41 \mathrm{n}$ \\
\hline $2: 5$ & $71 \mathrm{n}$ & $10: 24$ & $41 n$ \\
\hline $6: 9$ & 271 & $10: 41$ & $60 n$ \\
\hline $6: 11$ & $60 n, 229 n$ & $10: 48$ & $51 n$ \\
\hline
\end{tabular}




\begin{tabular}{|c|c|c|c|}
\hline $12: 12$ & $51 n$ & $5: 8$ & $116 n$ \\
\hline $13: 3$ & $260 n, 261 n$ & $5: 15$ & $117 \mathrm{n}$ \\
\hline $13: 6$ & $275 n$ & $5: 24$ & $166 n$ \\
\hline $13: 14-15$ & $28 n$ & $8: 31$ & $39 n$ \\
\hline $13: 14$ & 194 & $8: 32$ & $116 n$ \\
\hline $13: 15$ & $152,152 n$ & $11: 36$ & $282 n$ \\
\hline $14: 20$ & $41 \mathrm{n}$ & $12: 4$ & 206 \\
\hline $14: 23$ & $72 n$ & $12: 5$ & $105 n$ \\
\hline $15: 21$ & $152 n, 189 n$ & $12: 6-8$ & 206 \\
\hline $15: 22-35$ & 158 & $12: 8$ & 69 \\
\hline $15: 23$ & 159 & $14: 13-21$ & $61 \mathrm{n}$ \\
\hline $15: 30$ & 159 & $14: 15$ & $61 n, 116 n$ \\
\hline $15: 31$ & 157 & $14: 21$ & $61 \mathrm{n}$ \\
\hline $16: 15$ & $39 n, 51 n$ & $15: 5$ & $39 n$ \\
\hline $16: 16-18$ & $275 n$ & $15: 14$ & 206 \\
\hline $16: 31-34$ & $51 \mathrm{n}$ & $15: 30-31$ & $246 n$ \\
\hline $16: 33$ & $51 n$ & 16 & 50 \\
\hline $16: 40$ & $70 n$ & $16: 4$ & 69 \\
\hline $17: 5$ & $51 \mathrm{n}$ & $16: 5$ & $39 n, 50 n$ \\
\hline $17: 22$ & $209 n$ & $16: 10-11$ & $50 \mathrm{n}$ \\
\hline $18: 8$ & $51 \mathrm{n}$ & $16: 14-16$ & $50 \mathrm{n}$ \\
\hline 19:9 & $39 n, 50 n$ & $16: 16$ & $256 n$ \\
\hline 19:14 & $275 n$ & $16: 23$ & $50 \mathrm{n}$ \\
\hline 20 & 45 & $16: 25-27$ & $164 n$ \\
\hline $20: 7-12$ & $51 n, 55,275 n$ & & \\
\hline $20: 7-11$ & $32 n, 69$ & 1 Corinthians & \\
\hline \multirow[t]{2}{*}{$20: 7$} & $32 \mathrm{n}, 40,41,42,42 \mathrm{n}$ & $1: 10-12$ & $105 n$ \\
\hline & $46,112,129$ & $1: 14-16$ & $51 \mathrm{n}$ \\
\hline $20: 8-9$ & 51 & $1: 17-18$ & 192 \\
\hline \multirow[t]{2}{*}{$20: 11$} & $69,112,185$ & $2: 4$ & 192 \\
\hline & 185n, 189n, 190 & $6: 14-15$ & $117 \mathrm{n}$ \\
\hline 20:17 & $72,72 n, 207 n$ & $7: 10$ & 64 \\
\hline 20:20 & $51 \mathrm{n}$ & $8-10$ & 35 \\
\hline $20: 28$ & $72,207 n$ & 9 & 273 \\
\hline $20: 36$ & $251 n$ & $9: 14$ & 64 \\
\hline $21: 5$ & $251 \mathrm{n}$ & $10-14$ & $33,109 n$ \\
\hline $21: 8$ & $41 n$ & $10: 1$ & $58 n$ \\
\hline 21:9 & $208 n$ & $10: 14-22$ & 104 \\
\hline 21:16 & $51 \mathrm{n}$ & $10: 16-23$ & 31 \\
\hline 21:40 & $209 n$ & $10: 16-22$ & 127 \\
\hline $22: 30$ & $41 \mathrm{n}$ & $10: 16-21$ & $4 n$ \\
\hline $23: 22$ & $41 \mathrm{n}$ & $10: 16-17$ & $37 n, 39 n, 58 n, 115,123$ \\
\hline $24: 14$ & $152 \mathrm{n}$ & $10: 16$ & $33,63,100 \mathrm{n}, 112$ \\
\hline $24: 26$ & $185 n$ & & $124,230 \mathrm{n}, 231,232$ \\
\hline $25: 6$ & $41 \mathrm{n}$ & & $233,234,236 n$ \\
\hline $25: 23$ & $41 \mathrm{n}$ & $10: 17$ & $105 n, 109 n$ \\
\hline $27: 35-36$ & 112 & $10: 19-22$ & 35 \\
\hline $28: 23$ & $152 n$ & $10: 20-21$ & $104,104 \mathrm{n}$ \\
\hline \multirow[t]{2}{*}{$28: 30$} & $51 \mathrm{n}$ & $10: 20$ & 33 \\
\hline & & $10: 21$ & $105 n$ \\
\hline Romans & & $11-14$ & $7,39 n, 46 n$ \\
\hline $4: 25$ & $116 n$ & 11 & $115,123,136$ \\
\hline $5: 6$ & $116 n$ & $11: 5-15$ & $185 \mathrm{n}$ \\
\hline
\end{tabular}




\begin{tabular}{|c|c|c|c|}
\hline $11: 17-14: 40$ & $4 n, 31,31 n, 135 n$ & $14: 14-15$ & $63 n, 231 n$ \\
\hline $11: 17-34$ & $65 n, 104,127$ & $14: 14$ & $230 n$ \\
\hline $11: 17-33$ & 287 & $14: 15$ & $129 n, 216 n, 230 n$ \\
\hline $11: 17$ & $31,105 n$ & $14: 16$ & $63 \mathrm{n}, 100 \mathrm{n}$ \\
\hline $11: 18$ & $31,105 n$ & & $230 n, 278 n$ \\
\hline $11: 20-26$ & 119 & $14: 17$ & $246 n$ \\
\hline $11: 20-21$ & $37 n, 58 n$ & $14: 19$ & $63 n, 121 n, 186,192 n$ \\
\hline $11: 20$ & 31 & $14: 20$ & $39 n$ \\
\hline $11: 21$ & $31 n, 63 n, 105 n$ & $14: 23$ & $31,50 n, 54,63 n$ \\
\hline $11: 22$ & $104 n$ & $14: 25$ & $252 n$ \\
\hline $11: 23-26$ & 243 & $14: 26-28$ & $63 n$ \\
\hline $11: 23-25$ & $\begin{array}{l}106 \mathrm{n}, 114 \mathrm{n}, \\
119,129,233\end{array}$ & $14: 26$ & $\begin{array}{l}31,39 n, 63 n, 121 n \\
129 n, 166 n, 183 n\end{array}$ \\
\hline $11: 23$ & $39 n, 104 n, 114 n$ & & 186n, 190n, 192n, \\
\hline $11: 24-25$ & $8 \mathrm{n}$ & & $205,213 n, 216 n$ \\
\hline $11: 24$ & $100 \mathrm{n}, 106,117 \mathrm{n}, 119$ & $14: 27-33$ & $65 n, 184 n$ \\
\hline $11: 25$ & $\begin{array}{l}62 \mathrm{n}, 119,124,130 \\
166 \mathrm{n}, 234\end{array}$ & $\begin{array}{l}14: 29-31 \\
14: 29\end{array}$ & $\begin{array}{l}31 \\
193 n\end{array}$ \\
\hline $11: 26-28$ & $58 n$ & $14: 30$ & 57 \\
\hline $11: 26$ & $106 n, 119,222 n$ & $14: 31$ & $192 n$ \\
\hline $11: 27$ & $107 \mathrm{n}$ & $14: 33-36$ & $185 n, 208$ \\
\hline $11: 28$ & $107 \mathrm{n}$ & $14: 33-35$ & $185 n$ \\
\hline $11: 29$ & $105 n, 107 n$ & $14: 39$ & $39 n, 63 n$ \\
\hline $11: 30$ & $105 n, 117 n$ & $14: 40$ & $185 n$ \\
\hline $11: 31$ & $107 \mathrm{n}$ & $15: 3$ & $116 n, 164 n$ \\
\hline $11: 32$ & $107 \mathrm{n}$ & $15: 4$ & $165 n$ \\
\hline $11: 33$ & $31,39 n, 107 n$ & 16 & 45 \\
\hline $11: 34$ & $31,108 n$ & $16: 1-3$ & $269 n$ \\
\hline $12-14$ & $62,189 n$ & $16: 2$ & $40 n, 43,46 n, 110 n$ \\
\hline $12: 1$ & $39 n, 206$ & $16: 19$ & $39 n, 50 n, 69$ \\
\hline $12: 4-6$ & 62 & $16: 20$ & $256 n$ \\
\hline $12: 4$ & 206 & $16: 22$ & $280 n$ \\
\hline $12: 6-11$ & 63 & & \\
\hline $12: 8-10$ & $62 n$ & 2 Corinthians & \\
\hline $12: 8$ & 192 & $1: 1$ & $161 n$ \\
\hline $12: 9$ & $275 n$ & $1: 3$ & 231 \\
\hline $12: 12$ & $105 n$ & $3: 12-16$ & 164 \\
\hline $12: 13$ & $105 n$ & $5: 14$ & $116 n$ \\
\hline $12: 26$ & $116 n$ & $5: 15$ & $116 n$ \\
\hline $12: 27$ & $105 n$ & $8: 1-15$ & $269 n$ \\
\hline $12: 28-29$ & $70 \mathrm{n}$ & $9: 1-15$ & $269 n$ \\
\hline $12: 28$ & $70 n, 206,275 n$ & $13: 12$ & $256 n$ \\
\hline $12: 30$ & $275 n$ & & \\
\hline $13: 1-14: 1$ & $135 n$ & Galatians & \\
\hline $13: 1$ & 225 & $1: 2$ & $160 n$ \\
\hline 14 & $31 n, 37 n$ & $1: 4$ & $116 n$ \\
\hline $14: 1-4$ & $192 n$ & $2: 20$ & $116 n$ \\
\hline $14: 2$ & $63 n$ & $6: 6$ & $88 n, 273$ \\
\hline $14: 6$ & $39 n, 63 n, 121 n$ & & \\
\hline $14: 7-8$ & 225 & Ephesians & \\
\hline $14: 13-15$ & 31 & $1: 1$ & 161 \\
\hline $14: 13$ & $230 n$ & $1: 22-23$ & $39 n$ \\
\hline $14: 14-16$ & $231,246 n$ & $2: 19-22$ & $39 n$ \\
\hline
\end{tabular}




\begin{tabular}{|c|c|c|c|}
\hline $3: 4$ & 160 & $2: 8$ & $253 n$ \\
\hline $4: 11-12$ & $207 n$ & $2: 11-12$ & 208 \\
\hline $5: 2$ & $116 n$ & $3: 2$ & $71 n, 193 n, 207 n$ \\
\hline $5: 18-20$ & 224 & $3: 8$ & $71 \mathrm{n}$ \\
\hline $5: 19$ & $213 n, 214 n, 216 n$ & $3: 15$ & $51 \mathrm{n}$ \\
\hline $5: 20$ & 247 & $4: 11-16$ & $162 n$ \\
\hline $5: 25$ & $116 n$ & $4: 11$ & $162 n, 193 n$ \\
\hline $6: 19-20$ & $246 n$ & $4: 13$ & $\begin{array}{l}153 \mathrm{n}, 156 \mathrm{n}, 162 \mathrm{n} \\
163,164,165,166 \mathrm{n}\end{array}$ \\
\hline Philippians & & & $178,190 \mathrm{n}, 191,193 \mathrm{n}$ \\
\hline $1: 1$ & 71 & & $194,199,199 \mathrm{n}$ \\
\hline $2: 6-11$ & $222,222 n$ & $4: 14$ & $260 n, 262 n$ \\
\hline \multirow[t]{2}{*}{$2: 10$} & 252 & $4: 16$ & $162 n$ \\
\hline & & $5: 1-22$ & $193 n$ \\
\hline Colossians & & $5: 3$ & $39 n$ \\
\hline \multirow{2}{*}{$3: 16$} & 206n, 213n, 214n, & $5: 7$ & $207 \mathrm{n}$ \\
\hline & $216 n, 222 n$ & $5: 9-10$ & $266 n$ \\
\hline $4: 3-4$ & $246 n$ & $5: 16$ & $39 n$ \\
\hline $4: 7-8$ & $159 n$ & $5: 17-22$ & $72 \mathrm{n}$ \\
\hline $4: 15$ & $39 n, 51,70 n$ & $5: 17-18$ & $88 n, 273$ \\
\hline \multirow{2}{*}{$4: 16$} & $157,161,165$ & $5: 17$ & $193,193 n$ \\
\hline & & $5: 22$ & $260 n, 262 n$ \\
\hline 1 Thessalonians & & $6: 2$ & $193,193 n$ \\
\hline $2: 3$ & $191 n$ & $6: 21$ & $163 n$ \\
\hline $3: 2$ & $191 \mathrm{n}$ & & \\
\hline $4: 1$ & $191 \mathrm{n}$ & 2 Timothy & \\
\hline $4: 10$ & $191 \mathrm{n}$ & $2: 2$ & $193 n$ \\
\hline $4: 18$ & $191 \mathrm{n}$ & $2: 20$ & $52 n$ \\
\hline $5: 10$ & $116 n$ & $2: 24$ & $193 n$ \\
\hline $5: 11-27$ & 64 & $3: 16$ & $193 n$ \\
\hline $5: 11-25$ & 65 & $4: 2$ & $193 n$ \\
\hline $5: 11$ & $64 n, 191 n$ & $4: 22$ & $163 n$ \\
\hline $5: 12-25$ & $65 n$ & & \\
\hline $5: 12$ & 69 & Titus & \\
\hline $5: 14$ & $191 \mathrm{n}$ & $1: 5-7$ & $72,207 n$ \\
\hline $5: 20-22$ & $193 n$ & $1: 5$ & $72 n, 207$ \\
\hline $5: 20-21$ & $64,191 \mathrm{n}$ & $1: 7$ & $52 \mathrm{n}, 207$ \\
\hline $5: 21$ & $64 n$ & $1: 11$ & $193 n$ \\
\hline $5: 25$ & $64 n, 246 n$ & $2: 2-3: 8$ & $193 n$ \\
\hline $5: 26$ & $64 n, 255 n, 258 n$ & $2: 3$ & 208 \\
\hline \multirow[t]{3}{*}{$5: 27$} & $64,64 \mathrm{n}, 157,158$ & $2: 4$ & 208 \\
\hline & 159,165 & $2: 7$ & $193 n$ \\
\hline & & $2: 14$ & $116 n$ \\
\hline 2 Thessalonians & & $2: 15$ & $193 n$ \\
\hline $3: 1-2$ & $246 n$ & $3: 15$ & $163 n$ \\
\hline $3: 3$ & $39 n$ & & \\
\hline \multirow[t]{2}{*}{$3: 14$} & 165 & Philemon & \\
\hline & & $1-2$ & $160 \mathrm{n}$ \\
\hline 1 Timothy & & 2 & $39 n, 51 n, 69$ \\
\hline $1: 3$ & $163 n$ & & \\
\hline $1: 7$ & $282 n$ & Hebrews & \\
\hline $2: 1-2$ & $248 n$ & $5: 12$ & $206 n$ \\
\hline $2: 6$ & $116 n$ & $12: 2$ & $39 n$ \\
\hline
\end{tabular}




$\begin{array}{llll}\text { 13:18-19 } & 246 \mathrm{n} & \text { Revelation } & \\ 13: 22 & 194 \mathrm{n} & 1 & 45 \\ & & 1: 3-8 & 170 \\ \text { James } & & 1: 3 & 158,170,178, \\ 1: 27 & 39 \mathrm{n} & 1: 4 & 195 \mathrm{n}, 201 \mathrm{n} \\ 3: 1 & 206 \mathrm{n} & 1: 10 & 170 \\ 5: 13 & 213 & 1: 11 & 42 \mathrm{n}, 170 \\ & & 2 & 170 \\ 1 \text { Peter } & & 2: 1-3: 22 & 170 \\ 2: 11-3: 12 & 193 \mathrm{n} & 3 & 195 \\ 5: 1-5 & 72 \mathrm{n} & 5: 8 & 170 \\ 5: 1-4 & 207 \mathrm{n} & 5: 9-12 & 226 \\ 5: 14 & 256 \mathrm{n} & 5: 14 & 222 \mathrm{n} \\ & & 7: 11 & 252 \mathrm{n} \\ 2 \text { Peter } & & 10: 2 & 252 \mathrm{n} \\ 2: 13 & 51 \mathrm{n} & 11: 16 & 282 \mathrm{n} \\ 3: 14-16 & 157 & 15: 3-4 & 252 \mathrm{n} \\ 3: 16 & 165 & 15: 4 & 223 \\ & & 16: 2 & 252 \mathrm{n} \\ 1 \text { John } & & 19: 1 & 252 \mathrm{n} \\ 4: 1 & 193 \mathrm{n} & 19: 3 & 279 \mathrm{n} \\ & & 19: 4 & 279 \mathrm{n} \\ 2 \text { John } & & 22: 18 & 252 \mathrm{n}, 279 \mathrm{n} \\ 10 & 51 \mathrm{n} & 22: 20 & 158,170,195 \\ & & & 280 \mathrm{n}\end{array}$

Jude

12

$32 n, 104 n, 135 n, 143 n$

\section{Greek and Roman Literature}

Aelius Aristides Sacred Tales

1.22

1.30

Apuleius

De mundo

33

Metamorphoses

2.18-19

2.21

2.28

4.1

$4.8-22$

4.8

7.9

9.14

9.24

11.20
$86 n$

$85 n$

$252 n$

$70 \mathrm{n}$

$20 \mathrm{n}$

$86 \mathrm{n}$

$257 \mathrm{n}$

$22 \mathrm{n}$

$21 \mathrm{n}$

$257 \mathrm{n}$

$93 n$

$20 \mathrm{n}$

$85 n, 88$ n
Athenaeus

Deipnosophistai

4.129

$22 \mathrm{n}$

4.131

$22 \mathrm{n}$

4.149

$229 n$

4.150

$22 \mathrm{n}$

4.168

5.179

$266 n$

5.186

$222 \mathrm{n}$

8.349

$18 \mathrm{n}$

10.423-427 21n

11.486-487 19n

13.584

14.627-628 224n

$14.628 \quad 222 \mathrm{n}$

$15.666 \quad 257 \mathrm{n}$

$15.675 \quad 19 n, 228 n$

$15.688 \quad 267 \mathrm{n}$

15.701-702 222n, 228n 
Aulus Gellius

Noctes Atticae

$2.22 \quad 149 \mathrm{n}$

$3.19 \quad 149 \mathrm{n}$

$7.13 \quad 186 \mathrm{n}$

7.13.2-3 $44 \mathrm{n}$

$15.2 .3 \quad 44 \mathrm{n}$

$17.8 \quad 186$ n

$17.20 \quad 149 n$

$18.10 .5 \quad 186 n$

$19.9 \quad 225 \mathrm{n}$

$19.9 .4 \quad 183 n$

Cato

De agri cultura

56-58

$19 n$

Cicero

Actio in Verrem

3.25

$267 n$

Epistulae ad Familiares 16.27.2

$257 \mathrm{n}$

Dio Chrysostom 20.10

$148 n$

Diodorus Siculus 1.25.6

$133 n$

Diogenes Laertius

8.17

$85 n$

Epictetus

Discourses

2.17.12

$280 \mathrm{n}$

2.23 .5

$37 \mathrm{n}$

Euripides

Phoenissae

3

$86 n$

Homer

Iliad

9.219

$228 n$

Odyssey

9.231

$228 n$

Livy

1.18
Longus

Daphnis and Chloe

2.31.1-3 212n

$4.38 .3 \quad 212 \mathrm{n}$

Lucian

Asinus

3 19n, 20n

De morte Peregrini

114 4n, 34n, 148, 199n

Lover of Lies

$16 \quad 275 n$

On Dances

17

$86 n$

Symposium

$17 \quad 149 \mathrm{n}$

$21 \quad 157 \mathrm{n}$

$46 \quad 22 n$

Verae historiae

2.15

$149 n, 225 n$

Martial

3.12 .4

$267 n$

Nepos

Atticus

$13.3 \quad 149$ n, $179 n$

$14.1 \quad 149$ n, 179 n

Pausanias

Description of Greece

5.20.2-3 226n

Persius

5.182-184 37n, 47n

Petronius

Satyricon

23.1-2 211n

$28 \quad 267 \mathrm{n}$

$31.3266 n$

$55 \quad 149$ n

$70.7 \quad 211 \mathrm{n}$

$70.8 \quad 266 n, 267 n$

$71.4 \quad 149 n$

$73211 \mathrm{n}$

$75 \quad 179 n$

$109.6 \quad 211 \mathrm{n}$

110.6-112 183n 


\begin{tabular}{|c|c|c|c|}
\hline \multicolumn{2}{|l|}{ Philostratus } & 4.660 & $184 \mathrm{n}$ \\
\hline \multicolumn{2}{|c|}{ Vita Apollonii } & 4.672 & $37 n, 47 n$ \\
\hline 2.4 & $275 n$ & 7.706 & $275 n$ \\
\hline 3.38 & $275 n$ & $7.711-712$ & $148 n$ \\
\hline 4.4 & $275 n$ & 7.711 & $149 n, 150 n$ \\
\hline 4.20 & $275 n$ & 7.712 & $149 n$ \\
\hline 4.25 & $275 n$ & $8.733-734$ & $20 \mathrm{n}$ \\
\hline 4.44 & $275 n$ & 9.743 & $185 n$ \\
\hline \multirow[t]{2}{*}{6.10} & $85 n$ & & \\
\hline & & \multicolumn{2}{|c|}{ Septem sapientium convivium } \\
\hline \multicolumn{2}{|l|}{ Plato } & 150 & $22 \mathrm{n}$ \\
\hline \multicolumn{2}{|l|}{ Symposium } & 151 & $266 n$ \\
\hline \multirow[t]{2}{*}{$174-175$} & $266 n$ & & \\
\hline & & \multicolumn{2}{|c|}{ Pseudo-Aristotle } \\
\hline \multicolumn{2}{|c|}{ Pliny (the Younger) } & \multicolumn{2}{|c|}{ De mundo } \\
\hline \multicolumn{2}{|l|}{ Epistulae } & \multirow[t]{2}{*}{6} & \multirow[t]{2}{*}{$252 \mathrm{n}$} \\
\hline 1.3 & $53 n$ & & \\
\hline 1.15 .2 & $148 n$ & \multicolumn{2}{|l|}{ Suetonius } \\
\hline 9.17 & $179 n$ & \multicolumn{2}{|c|}{ De vita caesarum } \\
\hline 10.93 & $270 n$ & \multirow[t]{2}{*}{74} & \multirow[t]{4}{*}{$183 n$} \\
\hline 10.96 & $4 n, 46 n, 132 n$ & & \\
\hline 10.96 .7 & $34 n, 42,80 n$ & \multirow{2}{*}{$\begin{array}{l}\text { Virgil } \\
\quad \text { Aeneid }\end{array}$} & \\
\hline 10.96 .8 & $222 n$ & & \\
\hline 10.110 .1 & $36 n$ & 8.68 & $85 n$ \\
\hline \multicolumn{2}{|l|}{ Plutarch } & \multicolumn{2}{|l|}{ Xenophon } \\
\hline \multicolumn{2}{|c|}{ Quaestiones conviviales } & \multicolumn{2}{|l|}{ Symposium } \\
\hline $1.614-615$ & $223 n$ & 2.1 & $228 n$ \\
\hline 1.614 & $184 n$ & & \\
\hline 1.615 & $212 n$ & \multirow{2}{*}{\multicolumn{2}{|c|}{$\begin{array}{l}\text { Xenophon of Ephesus } \\
\text { Ephesian Tales }\end{array}$}} \\
\hline 1.616 & $185 n$ & & \\
\hline $1.620-622$ & $21 \mathrm{n}$ & 1.5 & $275 n$ \\
\hline 3.657 & $21 \mathrm{n}$ & & \\
\hline
\end{tabular}

6. Early Christian Literature

\begin{tabular}{llll}
$\begin{array}{c}\text { Acts of Andrew } \\
5\end{array}$ & \multicolumn{3}{c}{$\begin{array}{c}\text { Acts of Paul } \\
3.5-7\end{array}$} \\
20 & $275 \mathrm{n}$ & 3.5 & $52 \mathrm{n}, 71 \mathrm{n}$ \\
& $248 \mathrm{n}$ & 3.25 & $143 \mathrm{n}, 140 \mathrm{n}$ \\
$\begin{array}{c}\text { Acts of John } \\
19-25\end{array}$ & $275 \mathrm{n}$ & 9 & $67 \mathrm{n}, 141 \mathrm{n}, 190 \mathrm{n}$, \\
$30-37$ & $275 \mathrm{n}$ & 11.1 & $209 \mathrm{n}, 219 \mathrm{n}, 249 \mathrm{n}$ \\
46 & $71 \mathrm{n}, 141 \mathrm{n}, 189 \mathrm{n}$, & & $53 \mathrm{n}$ \\
& & & \\
85 & $198 \mathrm{n}, 248 \mathrm{n}, 26 \mathrm{n}$ & Acts of Peter & \\
$106-110$ & $240 \mathrm{n}$ & $1-2$ & $67 \mathrm{n}, 190 \mathrm{n}$ \\
$106-109$ & $67 \mathrm{n}, 71 \mathrm{n}, 141 \mathrm{n}$ & 2 & $71 \mathrm{n}, 140 \mathrm{n}, 249 \mathrm{n}$, \\
108 & $248 \mathrm{n}$ & & $250 \mathrm{n}$ \\
$109-110$ & $249 \mathrm{n}, 250 \mathrm{n}$ & 7 & $71 \mathrm{n}, 96 \mathrm{n}, 198 \mathrm{n}$ \\
109 & $110 \mathrm{n}$ & 8 & $53 \mathrm{n}$ \\
& $240 \mathrm{n}$ & 11 & $275 \mathrm{n}$ \\
& & 13 & $4 \mathrm{n}, 53 \mathrm{n}, 95 \mathrm{n}, 96 \mathrm{n}$,
\end{tabular}




\begin{tabular}{|c|c|c|c|}
\hline 16 & $36 n$ & \multicolumn{2}{|c|}{ Clement of Alexandria } \\
\hline $19-21$ & $53 n$ & \multicolumn{2}{|c|}{ Excerpta ex Theodoto } \\
\hline $20-22$ & $67 \mathrm{n}$ & 63.1 & $42 n$ \\
\hline $20-21$ & $275 n$ & 82.1 & $59 \mathrm{n}$ \\
\hline \multirow[t]{3}{*}{20} & $53 n, 71 n, 96 n$ & \multirow{2}{*}{\multicolumn{2}{|c|}{ Paedagogus }} \\
\hline & $166 n, 173 n, 189 n$ & & \\
\hline & $199 n, 262 n$ & 2.4 & $143 n$ \\
\hline 21 & $53 n, 275 n$ & $2.4 .3-5$ & $140 \mathrm{n}$ \\
\hline 22 & $140 \mathrm{n}$ & 2.4 .3 & $104 \mathrm{n}$ \\
\hline 29 & $71 n, 96 n, 140 n, 275 n$ & 2.4 .5 & $104 \mathrm{n}$ \\
\hline 30 & $96 n, 198 n$ & 2.19 .3 & $140 \mathrm{n}$ \\
\hline \multirow[t]{2}{*}{31} & $96 n, 275 n$ & $2.32 .1-33.1$ & $58 \mathrm{n}$ \\
\hline & & 2.32 .2 & $120 \mathrm{n}$ \\
\hline \multicolumn{2}{|c|}{ Acts of Thomas } & $2.40-41$ & $227 \mathrm{n}$ \\
\hline $27-29$ & 97 & 2.42 .1 & $227 \mathrm{n}$ \\
\hline 27 & $97 \mathrm{n}$ & 2.43 .3 & $227 \mathrm{n}$ \\
\hline \multirow[t]{2}{*}{29} & $59 \mathrm{n}, 60,71 \mathrm{n}, 97 \mathrm{n}$ & 2.44 .1 & $214 n$ \\
\hline & $262 n, 278 n$ & $2.44 .3-4$ & $214 n$ \\
\hline 67 & $249 n$ & 2.44 .4 & $223 n$ \\
\hline \multirow{2}{*}{135} & $133 n$ & 2.96 & $95 n$ \\
\hline & & 3.79 .3 & $56 n$ \\
\hline \multicolumn{2}{|c|}{ Athenagoras } & 3.80 .4 & $96 n, 223 n, 227 n$ \\
\hline \multicolumn{2}{|c|}{ Plea on Behalf of the Christians } & $3.81-88$ & $223 n$ \\
\hline 3 & $4 n, 34 n, 94 n$ & \multirow[t]{2}{*}{$3.81 .1-82.1$} & \multirow[t]{3}{*}{$258 n$} \\
\hline 31 & $4 n, 34 n, 94 n$ & & \\
\hline \multirow[t]{2}{*}{32} & $258 \mathrm{n}$ & Protrepticus & \\
\hline & & 12.92 & $226 n$ \\
\hline \multicolumn{4}{|c|}{ Augustine } \\
\hline \multicolumn{2}{|c|}{ Contra Faustum } & \multicolumn{2}{|c|}{ Quis dives salvetur } \\
\hline 20.20 & $101 \mathrm{n}$ & 23 & $95 n, 96 n, 202 n$ \\
\hline \multicolumn{2}{|c|}{ De haeresibus } & \multicolumn{2}{|l|}{ Stromateis } \\
\hline \multirow[t]{2}{*}{64} & \multirow[t]{2}{*}{$142 n$} & 1.19 .96 & $58 \mathrm{n}$ \\
\hline & & 1.19 .96 .1 & $142 \mathrm{n}$ \\
\hline Barnabas & & 3.108 .2 & $56 n$ \\
\hline 13.5 & $262 n$ & 4.12 & $221 \mathrm{n}$ \\
\hline 15.9 & $43 n, 44 n, 45 n, 48 n$ & 4.15 & $159 \mathrm{n}$ \\
\hline 19.10 & $90 \mathrm{n}$ & 4.123 .1 & $266 n$ \\
\hline & & 5.106 .2 & $42 n$ \\
\hline Canones & $u m$ & 6.113 & $4 n$ \\
\hline 16 & $181 \mathrm{n}$ & 6.113 .3 & $66 n, 139 n, 174 n$, \\
\hline 19 & $181 n$ & & $219 n, 248 n$ \\
\hline & & 7.29 .4 & $56 n$ \\
\hline Canon $M$ & & & \\
\hline $1-9$ & $166 n$ & 1 Clement & \\
\hline 4 & $155 n$ & 1.3 & $72 n$ \\
\hline $50-59$ & $164 n$ & 2.3 & $253 n$ \\
\hline 66 & $166 n$ & 20.12 & $282 n$ \\
\hline $71-78$ & $170 n$ & 21.6 & $72 n$ \\
\hline 72 & $166 n, 173$ & 34.7 & $249 n$ \\
\hline 78 & 172 & $44.1-5$ & $72 n$ \\
\hline $79-80$ & $164 n$ & 44.3 & $264 n$ \\
\hline $81-85$ & $221 n$ & 44.4 & $72 n$ \\
\hline & & 44.5 & $76 n$ \\
\hline
\end{tabular}




\begin{tabular}{|c|c|c|c|}
\hline $47.1-3$ & $158 n$ & 29.1 & $180 n$ \\
\hline 47.6 & $72 n$ & 29.1 .1 & $98 n$ \\
\hline 48.1 & $252 n$ & 38.2 & $180 \mathrm{n}$ \\
\hline $59.1-61.3$ & 248 & $39.4 .1-2$ & $180 n$ \\
\hline 64.2 & $281 n$ & 39.4.1 & $68 n, 98 n$ \\
\hline 65.1 & $158 \mathrm{n}$ & 55.8 .4 & $265 n$ \\
\hline & & 57.3 & $68 n, 98 n, 202 n$ \\
\hline 2 Clement & & 58.1 & $68 n, 98 n, 202 n$ \\
\hline $17.3-5$ & 207 & 63 & $4 n, 99,142 n$ \\
\hline 17.3 & $90 n, 196 n$ & 63.1 & $58 \mathrm{n}$ \\
\hline 19.1 & $169 n, 195 n$ & 63.9 & $120 n$ \\
\hline 20.5 & $282 n$ & 63.14 .4 & $75 n$ \\
\hline & & 63.15 .1 & $144 n$ \\
\hline Commodia & & 63.16 & $58 n$ \\
\hline Instructio & & $63.16 .1-2$ & $99 n, 144 n$ \\
\hline 26 & $181 \mathrm{n}$ & 63.16 .1 & $144 n$ \\
\hline & & 63.16 .2 & $107 n, 145 n$ \\
\hline Constitutior & stolicae & 63.17 .1 & $145 n$ \\
\hline 2.22 .14 & $252 n$ & $67.5 .1-2$ & $265 n$ \\
\hline 2.60 & $86 n$ & 67.5 .1 & $265 n$ \\
\hline $7.25-26$ & 239 & 69.15 .2 & $276 n$ \\
\hline 7.26 & $238 n$ & 70.2 & $268 n$ \\
\hline 7.36 .6 & $48 n$ & 75.10 & $76 n$ \\
\hline $8.6-10$ & $280 n$ & 76.3 & $75 n$ \\
\hline 8.6 .4 & $280 n$ & & \\
\hline 8.12 .5 & $281 n$ & Didache & \\
\hline & & 4.2 & $92 n$ \\
\hline Cyprian & & 4.3 & 32 \\
\hline De opere & mosynis & $9-10$ & $4 n, 46 n, 108,109 n$ \\
\hline 15 & $98 n, 272 n$ & & $\begin{array}{l}110,111,115,119, \\
135 \mathrm{n}, 237,287\end{array}$ \\
\hline De oratio & minica & 9 & $32,109 n, 123$ \\
\hline 4 & $251 n, 253 n$ & & $231,233,234$ \\
\hline 6 & $253 n$ & & $235 n, 236 n, 238$ \\
\hline 8 & $251 n$ & $9.1-4$ & $231 n, 237 n$ \\
\hline 18 & $98 n, 145 n, 202 n$ & $9.1-3$ & $234 n$ \\
\hline 23 & $259 n$ & 9.1 & $8 \mathrm{n}, 32,124,230 \mathrm{n}$ \\
\hline 24 & $259 n$ & $9.2-4$ & $230 n$ \\
\hline 31 & $281 n$ & 9.2 & $109 n$ \\
\hline 35 & $99 n$ & 9.4 & 109n, 238 \\
\hline & & 9.5 & $8 \mathrm{n}, 67 \mathrm{n}, 108 \mathrm{n}$ \\
\hline De unitat & siae & & $175 n, 198 n, 234 n$ \\
\hline 9 & $259 n$ & 10 & $32,109 n$ \\
\hline 13 & $259 n$ & $10.1-6$ & $237 n$ \\
\hline 26 & $274 n$ & 10.1 & $32,108 n, 234 n$ \\
\hline & & 10.2 & $282 n$ \\
\hline Epistulae & & 10.5 & 238 \\
\hline $1.1 .1-2$ & $274 n$ & 10.6 & $279,278 n, 280 n$ \\
\hline 1.1 & $75 n$ & 10.7 & $32,69 \mathrm{n}, 71 \mathrm{n}, 73$ \\
\hline 6.1 & $257 n$ & & $111 n, 239 n$ \\
\hline 8.3 .2 & $39 n$ & 11 & $197 n$ \\
\hline 9.2 & $263 n$ & $11.1-3$ & 32 \\
\hline 11.7 .3 & $251 n$ & $11.1-2$ & $32,197 \mathrm{n}$ \\
\hline 14.2 & $266 n$ & 11.3 & $71 n$ \\
\hline
\end{tabular}




$\begin{array}{ll}11.4 & 71 \mathrm{n}, 91 \mathrm{n} \\ 11.5 & 91 \mathrm{n} \\ 11.6 & 197 \mathrm{n} \\ 11.7-12 & 91 \mathrm{n} \\ 11.7-8 & 197 \mathrm{n} \\ 11.9 & 91 \mathrm{n} \\ 12.1-2 & 32 \\ 13.1-7 & 88 \mathrm{n} \\ 13.1 & 273 \\ 13.6 & 59 \mathrm{n} \\ 14 & 4 \mathrm{n}, 108,109 \mathrm{n}, 135 \\ 14.1 & 42 \mathrm{n}, 43 \mathrm{n}, 46 \mathrm{n}, 90, \\ & 91 \mathrm{n}, 112,108 \mathrm{n}, 110 \mathrm{n}, \\ & 113 \mathrm{n}, 140 \\ 15.1-2 & 69 \mathrm{n}, 73 \mathrm{n}, 89 \mathrm{n}, \\ & 207 \mathrm{n}, 264 \mathrm{n} \\ 15.1 & 32,71 \mathrm{n}, 73,73 \mathrm{n}, \\ & 197 \mathrm{n}, 264 \mathrm{n} \\ 15.2 & 73 \mathrm{n} \\ 15.3 & 32 \\ 16.2 & 90 \mathrm{n}, 92 \mathrm{n}\end{array}$

Epistula apostolorum

$18 \quad 42 \mathrm{n}$

Eusebius

Historia ecclesiastica

$2.23 \quad 176 \mathrm{n}$

$3.3 \quad 171 \mathrm{n}$

$3.16 \quad 176 \mathrm{n}$

$3.25 .3 \quad 168 \mathrm{n}$

$3.27 \quad 42 n, 43 n, 46 n, 49 n$

$3.31 \quad 168 \mathrm{n}, 208 \mathrm{n}$

3.38.4 195n

$4.23 \quad 169 n$

4.23.9 42n, 43n

$4.23 .10 \quad 269 \mathrm{n}$

4.23.11 162n, 196n

$4.27 \quad 208 \mathrm{n}$

$5.16 .17 \quad 208 \mathrm{n}$

$5.20 \quad 209 n$

$5.24 .27 \quad 74 \mathrm{n}$

$5.28 \quad 221 \mathrm{n}$

$6.8 .5 \quad 266 n$

$6.12 \quad 177 \mathrm{n}$

$6.19208 \mathrm{n}$

$6.23 .4 \quad 266 \mathrm{n}$

$6.43 .8 \quad 276 \mathrm{n}$

$6.43 .11 \quad 179 \mathrm{n}$

7.2.1 263n

$7.13 .1 \quad 56 \mathrm{n}$

$7.24 \quad 222 \mathrm{n}$

7.30.10-11 224n

Praeparatio evangelica

8.7.12-13 29n, 81n, 151n, 188n

Gospel of Judas

$\begin{array}{ll}33.22-34.11 & 134 \mathrm{n} \\ 33.22-34.10 & 137 \mathrm{n} \\ 56.20 & 137 \\ 57.17-24 & 137 \mathrm{n}\end{array}$

Gospel of Peter

$\begin{array}{ll}35 & 42 \mathrm{n}, 43 \mathrm{n} \\ 50 & 42 \mathrm{n}, 43 \mathrm{n}\end{array}$

Egeria

Itinerarium 280n

Epiphanius

Panarion

$30.16 \quad 142 \mathrm{n}$

$46.2 \quad 142 \mathrm{n}$

$80.2 \quad 87 \mathrm{n}$

\section{Gospel of Philip}

$\begin{array}{ll}55.5-24 & 138 \mathrm{n} \\ 59 & 257 \mathrm{n}, 259 \mathrm{n} \\ 63.21 & 138 \mathrm{n} \\ 75.14-25 & 138 \mathrm{n} \\ 75.14 & 138 \mathrm{n} \\ 75.18-19 & 138 \mathrm{n} \\ 77.2-8 & 138 \mathrm{n}\end{array}$


Gospel of Thomas 61

$23 n$

Hippolytus

Refutatio omnium haeresium

8.19

$10.25-26$

$208 \mathrm{n}$

$208 n$

Ignatius

Ephesians

1.3

2.1

2.2

$5.2-3$

5.2

6.2

9.2

13.1

20.2

Magnesians

4

6.1

7.1

7.2

9.1-2

9.1

Philadelphians

4

4.1

Polycarp

4.1

4.2

4.3

5.1

Romans

2.2

7.3

Smyrneans

6.2

7.1

8.1-2

8.1

8.2

\section{Trallians}

2.2-3

2.2

3.1

7.2
$197 \mathrm{n}$

$197 \mathrm{n}$

$72 \mathrm{n}$

$247 \mathrm{n}$

93n, 133n

$197 \mathrm{n}$

$185 \mathrm{n}, 196 \mathrm{n}$

$8 \mathrm{n}, 89 \mathrm{n}, 247 \mathrm{n}$

73n, 93n, 113n, 133n

$73 n$

$72 \mathrm{n}, 73 \mathrm{n}$

$73 \mathrm{n}$

$247 \mathrm{n}$

$45 \mathrm{n}, 88 \mathrm{n}$

$42 \mathrm{n}, 43 \mathrm{n}, 48 \mathrm{n}, 135 \mathrm{n}$

$131 \mathrm{n}$

$73 n, 134 n, 234 n$

270n

89 , 90 n

$270 \mathrm{n}$

185n, 190n, 197n

$216 n$

$131 n, 134 n$

270n

$104 \mathrm{n}, 131 \mathrm{n}, 134 \mathrm{n}$, 234n, 270n

$135 \mathrm{n}$

72n, 73n, 230n

$104 n, 143 n$

$73 \mathrm{n}$

$72 \mathrm{n}, 73 \mathrm{n}$

$72 \mathrm{n}, 73 \mathrm{n}$

$73 n, 135 n$
Irenaeus

Adversus haereses

1.6 .3

1.10

$61 \mathrm{n}$

1.13

1.13.2-4

1.13 .2

1.13 .3

1.13 .4

1.24 .5

1.25 .5

1.25 .6

1.26 .3

2.27.2

4.17 .5

4.18 .4

4.18 .5

4.33 .8

4.35 .4

5.1 .3

5.2.2-3

5.2 .2

5.2 .3

5.33.1

5.33.3-4

$201 \mathrm{n}$

$4 \mathrm{n}$

$67 \mathrm{n}, 190 \mathrm{n}$

74n, 139n, 236n

$208 \mathrm{n}$

$34 n, 138 n$

$61 \mathrm{n}$

$34 \mathrm{n}$

$74 \mathrm{n}$

$61 \mathrm{n}$

$173 n$

$120 \mathrm{n}, 126 \mathrm{n}$

$236 \mathrm{n}$

133n, 139n, 236n

$173 n, 201 n$

$174 \mathrm{n}$

$58 \mathrm{n}$

$235 n$

$133 n$

$139 n, 237 n$

$120 \mathrm{n}, 126 \mathrm{n}$

$235 \mathrm{n}$

Justin Martyr

First Apologia

13

$13.1-2$

13.2

26.7

65.1

65.3

66

66.1

$66.2-3$

66.2

66.4

67

67.3-6

67.3-5

67.3-4

67.3

67.4-5

67.4

67.5

$67.6-7$

67.6

67.7
$66 n$

$213 n$

$223 n$

$94 \mathrm{n}$

249 n

$235 n, 278 n$

125

$8 \mathrm{n}$

$125 \mathrm{n}, 136 \mathrm{n}$

120n, 136n, 236n

$25 \mathrm{n}, 35 \mathrm{n}$

$4 n, 7,34,46 n$,

158 n, 164n, 166n,

$198 \mathrm{n}$

$66 n$

189 n

$198 \mathrm{n}$

$43 n, 155 n, 162 n, 1$

$72 \mathrm{n}$

$74 \mathrm{n}$

39n, 179n, 200n,

$207 \mathrm{n}$

58n, 135n, 235n,

$248 \mathrm{n}$

$270 \mathrm{n}$

$94 \mathrm{n}$

$45 n, 278 n$ 


\begin{tabular}{lc}
\multicolumn{2}{l}{ Second Apologia } \\
12 & $34 \mathrm{n}$ \\
& \\
Dialogus cum & Tryphone Judaeo \\
10 & $35 \mathrm{n}$ \\
35.1 & $61 \mathrm{n}$ \\
41 & 125 \\
41.1 & $235 \mathrm{n}, 242 \mathrm{n}$ \\
41.3 & $136 \mathrm{n}$ \\
70 & 125 \\
70.4 & $120 \mathrm{n}, 136 \mathrm{n}$ \\
117.3 & $135 \mathrm{n}$
\end{tabular}

Lactantius

De mortibus persecutorum 48.9 $56 \mathrm{n}$

Martyrium Iustini et septem sodalium

$\begin{array}{ll}2 & 52 \mathrm{n} \\ 3 & 52 \mathrm{n}\end{array}$

Martyrium Perpetuae et Felicitatis $\begin{array}{ll}1.5 & 171 \mathrm{n} \\ 17 & 104 \mathrm{n}\end{array}$

Martyrium Pionii $3142 \mathrm{n}$

Martyrium Polycarpi 20 $171 \mathrm{n}$

Minucius Felix Octavius

$\begin{array}{ll}8.4 & 4 \mathrm{n}, 34 \mathrm{n} \\ 9 & 44 \mathrm{n} \\ 9.6 & 4 \mathrm{n}, 34 \mathrm{n} \\ 9.7 & 94 \mathrm{n} \\ 28.3 & 94 \mathrm{n} \\ 28.5 & 94 \mathrm{n} \\ 31 & 44 \mathrm{n} \\ 31.1 & 4 \mathrm{n}, 34 \mathrm{n}, 94 \mathrm{n} \\ 31.5 & 4 \mathrm{n}, 34 \mathrm{n}\end{array}$

Origen

Commentarii in Epistulam ad Romanos

$10.33 \quad 259 n$

\section{Contra Celsum}

$\begin{array}{ll}1.1 & 4 \mathrm{n}, 34 \mathrm{n} \\ 3.55 & 54 \mathrm{n} \\ 8.17 & 34 \mathrm{n} \\ 8.22 & 98 \mathrm{n}, 202 \mathrm{n} \\ 8.32 & 4 \mathrm{n}, 34 \mathrm{n}\end{array}$

$\begin{array}{ll}8.33 & 145 n \\ 8.67 & 223 n\end{array}$

De oratione

28.4

31.7

180 n, $253 n$

32

$56 \mathrm{n}$

$251 n$

Homiliae in Cantica

1

$259 n$

Homiliae in Exodum

7.5

$204 \mathrm{n}$

$8.4 \quad 276 \mathrm{n}$

$12.2 \quad 177 n, 205 n$

$13.3 \quad 204 n, 205 n$

Homiliae in Genesim

$4.2 \quad 266 \mathrm{n}$

10.15 56n, 175n, 204n, 205n

$10.398 n, 175 n, 202 n, 205 n$

$12.1 \quad 157 \mathrm{n}$

Homiliae in Isaiam

$4.3 \quad 204 \mathrm{n}$

$5.2 \quad 202 n$

$6.3 \quad 266 n$

Homiliae in Jeremiam

$\begin{array}{ll}14.4 .9 & 180 \mathrm{n} \\ 15.6 .1-3 & 204 \mathrm{n} \\ 20.9 & 248 \mathrm{n}\end{array}$

Homiliae in Josuam

$2.1 \quad 75 \mathrm{n}$

$4 \quad 176 n$

$4.198 n, 157 n, 202 n$

$17.3 \quad 274 \mathrm{n}$

$24.1 \quad 263 n, 276 n$

Homiliae in Judices

$3.2 \quad 204 \mathrm{n}$

Homiliae in Leviticum

$1.1 \quad 204 \mathrm{n}$

$1.4 \quad 204 n$

$2.1 \quad 204 n$

$7.1 \quad 177 \mathrm{n}$

Homiliae in Lucam

$12.6 \quad 248 \mathrm{n}$

$34.3 \quad 248 \mathrm{n}$

$36 \quad 204 \mathrm{n}$

$39.7 \quad 248 \mathrm{n}$ 
Homiliae in Numeros

5.1

$252 \mathrm{n}$

11.2 .2

11.9

13.1

14.1

15.1

20.1

$274 \mathrm{n}$

$248 \mathrm{n}, 252 \mathrm{n}$

$204 \mathrm{n}$

$204 \mathrm{n}$

$176 n, 180 n$

$204 n$

\section{Pastor Hermae \\ Mandates \\ 43.9}

$201 n$

Similitudes

5.3.7

$273 n$

9.16 .5

$207 \mathrm{n}$

9.26 .2

$271 n$

\section{Visions}

2.4 .3

2.8 .4

5

5.25 .7

Philaster of Brescia

De haeresibus

77

$142 n$

$\begin{array}{ll}\text { Polycarp } & \\ \text { Philippians } & \\ 12.3 & 249 \text { n } \\ 13.2 & 169 n\end{array}$

Pseudo-Athanasius

De virginitate

$\begin{array}{ll}12-13 & 239 \\ 13 & 238\end{array}$

13

$238 n$

Pseudo-Clement Epistula ad Jacobum 9.1-2

$60 \mathrm{n}$

\section{Homiliae}

$\begin{array}{ll}8.24 & 276 \mathrm{n} \\ 9.23 & 276 \mathrm{n} \\ 14.1 .1 & 60 \mathrm{n}\end{array}$

Recognitiones

10.71

Sidonius Apollinaris Epistulae

9.2
Tertullian

Ad nationes

1.2

1.7

1.13

1.13 .1

1.13 .4

Ad Scapulam

2.8-9

$249 n$

Ad uxorem

2.4

2.5

2.8

143n, 258n, 266n

$93 \mathrm{n}$

$143 n$

Adversus Marcionem

$\begin{array}{ll}1.14 & 66 \mathrm{n} \\ 1.23 & 66 \mathrm{n} \\ 4.9 & 249 \mathrm{n} \\ 4.40 & 66 \mathrm{n} \\ 4.40 .3 & 120 \mathrm{n}\end{array}$

Adversus Valentinianos

$1.1 \quad 35 \mathrm{n}$

Apologeticus or -ticum

$7 \quad 4 n, 34 n$

$7.2 \quad 94 \mathrm{n}$

$7.4 \quad 96 n$

$16.11 \quad 37 n, 44 n, 47 n, 86 n$

30.1-4 249n

$32.1 \quad 249 n$

$394 \mathrm{n}, 7,66,156 \mathrm{n}$,

$158 \mathrm{n}, 198$

39.2-3 142n

$39.3 \quad 156 n, 174 n, 201 n$

39.4-18 189 n

$39.439 n, 39 n, 143 n$,

39.5-6 270n, 271n

$39.5 \quad 74 \mathrm{n}$

$39.6 \quad 39 n, 248 n$

39.14-19 139n

$39.14 \quad 156 \mathrm{n}$

$39.15 \quad 35 n, 53 n$

39.16-18 32n

39.16-17 $142 \mathrm{n}$

$39.16 \quad 104 n, 142 \mathrm{n}$

39.17-18 58n, $156 \mathrm{n}$

$39.18156 n, 214 n, 219 n$,

$221 n, 224 n, 248 n$ 
De anima

$\begin{array}{ll}9 & 156 n, 219 n \\ 9.4 & 66 n, 174 n, 198 n, \\ & 209 n, 248 n\end{array}$

De baptismo

$17.4 \quad 209 n$

De carne Christi

$20.3219 n, 221 n$

De corona militis

$\begin{array}{ll}3 & 46 \mathrm{n} \\ 3.3 & 93 \mathrm{n}, 97,143 \mathrm{n} \\ 3.4 & 42 \mathrm{n}, 251 \mathrm{n} \\ 8.3 & 266 \mathrm{n}\end{array}$

De exhortatione castitatis

$7.3 \quad 74 \mathrm{n}$

De fuga in persecutione

$14.144 \mathrm{n}$

De idololatria

$\begin{array}{ll}7 & 94 \mathrm{n}, 143 \mathrm{n} \\ 7.1-3 & 96 \mathrm{n}, 202 \mathrm{n} \\ 14.6-7 & 44 \mathrm{n} \\ 14.7 & 42 \mathrm{n}\end{array}$

De ieiunio

$13.7 \quad 221 \mathrm{n}$

14.1-2 $44 \mathrm{n}$

$15.2 \quad 42 n$

De monogamia

$12.6 \quad 168 \mathrm{n}$

De oratione

$6 \quad 120 n$

$18 \quad 257$

$1993 n, 96 n, 97,143 n$

19.1-4 92n

19.1-2 93n

$19.1 \quad 202 n$

$23.2 \quad 251 \mathrm{n}$

$23.4 \quad 251 \mathrm{n}, 252 \mathrm{n}$

27.17 219n, 279n

De praescriptione haereticorum

$\begin{array}{ll}36 & 156 \mathrm{n} \\ 36.1-2 & 162 \mathrm{n}, 168 \mathrm{n} \\ 41.2-8 & 66 \mathrm{n} \\ 41.2 & 66 \mathrm{n}, 67 \mathrm{n} \\ 41.3 & 258 \mathrm{n}\end{array}$

41.5

41.6-8

41.8

75n, 209n, 276n

$264 n$

$75 n, 157 n, 178 n$, 179 n

De resurrectione carnis

$11.2 \quad 208$

De spectaculis

$13 \quad 143 n$

$25 \quad 282 \mathrm{n}$

$25.5 \quad 278 n$

De virginibus velandis

$9 \quad 209 n$

$9.275 n$

Theodoret of Cyrrhus

Treatise on Heresies

1.20

$177 \mathrm{n}$

Theophilus

Ad Autolycum

$3.4 \quad 4 n, 34 n$

Traditio apostolica

$\begin{array}{ll}2 & 248 \mathrm{n}, 265 \mathrm{n} \\ 3 & 278 \mathrm{n} \\ 3.6 & 282 \mathrm{n} \\ 4 & 68 \mathrm{n}, 75 \mathrm{n}, 107 \mathrm{n}, \\ & 127 \mathrm{n}, 145 \mathrm{n}, 244 \\ & 259 \mathrm{n}, 278 \mathrm{n}, 281\end{array}$

$4.3 \quad 281 \mathrm{n}$

4.4-13 242n

$5 \quad 272 \mathrm{n}$

$5.2 \quad 59$ n, 245n

$6 \quad 59 n, 272 n, 278 n$

6.2-4 245n

$7 \quad 265 n$

8 265n

$8.1266 n$

$9.1 \quad 266 n$

9.3-5 243n

$1168 n, 179 n$

$14276 \mathrm{n}$

$17 \quad 205 n$

18-19 68n

18997 , 203n, 204n

18.2-4 259n

$19 \quad 97 \mathrm{n}$

$19.1 \quad 263 n$

$19.2 \quad 276 n$

$20 \quad 178 \mathrm{n}$

20.3 263n, 276n 


$\begin{array}{llll}20.8 & 276 \mathrm{n} & 28.3 & 39 \mathrm{n} \\ 21 & 58 \mathrm{n}, 259 \mathrm{n} & 28.5 & 75 \mathrm{n} \\ 21.22 & 268 \mathrm{n} & 30 & 39 \mathrm{n} \\ 21.36 & 278 \mathrm{n} & 31 & 274 \mathrm{n} \\ 22 & 68,68 \mathrm{n}, 75 \mathrm{n}, 96 \mathrm{n}, & 35-38 & 68 \mathrm{n} \\ & 97 \mathrm{n}, 142 \mathrm{n}, 202 \mathrm{n} & 35-37 & 96 \mathrm{n}, 97 \mathrm{n}, 202 \mathrm{n}, 203 \mathrm{n} \\ 24 & 94 \mathrm{n} & 35 & 92 \mathrm{n}, 98 \mathrm{n}, 203 \mathrm{n} \\ 25-29 & 4 \mathrm{n}, 58 \mathrm{n}, 68 \mathrm{n} & 36 & 68,68 \mathrm{n}, 203 \mathrm{n} \\ 25-28 & 97 \mathrm{n}, 99 & 37 & 68,97 \mathrm{n}, 203 \mathrm{n} \\ 25 & 68,75 \mathrm{n}, 97 \mathrm{n}, 220 \mathrm{n}, & 39 & 68 \mathrm{n}, 92 \mathrm{n}, 98 \mathrm{n}, \\ & 225 \mathrm{n}, 279 & & 202 \mathrm{n}, 248 \mathrm{n} \\ 26 & 68,100,143 \mathrm{n}, 144 \mathrm{n} & 40 & 39 \mathrm{n} \\ 27 & 67,68,100 \mathrm{n} & 41 & 68 \mathrm{n}, 98 \mathrm{n}, 203 \mathrm{n} \\ 28 & 68,75 \mathrm{n}, 94 \mathrm{n}, 100 \mathrm{n}, & 41.2 & 251 \mathrm{n}\end{array}$

7. INSCRIPTIONS AND PAPYRI

$\begin{array}{llll}\text { CPJ 138-139 } & 28 \mathrm{n} & \text { PLond 2710 } & 24 \mathrm{n}, 37 \mathrm{n} \\ \text { IG 1368 } & \text { 24n, 69n, 184n, 277n } & & \\ \text { IGUR I 160 } & 26 \mathrm{n} & \text { POxy. 1786 } & 213 \mathrm{n}, 218 \\ \text { ILS 7212 } & 24 \mathrm{n}, 25 \mathrm{n} & \text { POxy. 4540 } & 24 \mathrm{n}\end{array}$




\section{SUBJECT INDEX}

Acclamations, 277, 281-282

agape, 80-81, 96, 101-102, 104, 109,

139n, 142-143, 286

Alleluia, 219, 279

almsgiving, 268

Amen, 235, 278

apostle, 69-73, 91, 140, 197, 207

associations, 1, 4, 17-18, 23-24, 27, 33-36, 38-39

\section{berakhot, 8, 238}

birkat ha-mazon, 12, 238

bishop, 32, 56, 68, 71-78, 100, 133-135, $205,207-208,243-245,263-264$

breaking of bread, 46, 67, 112, 141

catechumen, 67-68, 97, 175-176, 198, 202-205, 263, 276

cena, 32, 143n, 144, 156, 214, 221

cheese, 20, 59, 77, 245, 278

collections, 268-270

collegia, 18, 35, 71, 269

deacon, 56, 71, 73-75, 94, 197, 239, 252, 264-266, 272-273

deipnon, 7, 286

domus, 50-51

doxology, 204, 238, 241-242, 278, 282

drinking, 20-22, 33, 47, 213

elder, 72, 181, 193, 196, 207

Eucharist, 2-3, 7-8, 10-12, 14-15, 68, 73-76, 80-81, 92-101, 108-115, $125-145$

exorcism, 63, 75, 263, 275-276

foot washing, 266-267

gatherings of Christians, in the morning, $42 \mathrm{n}, 68,75,79-100$, $142-146,268$

in the evening, $49,87,92,138$, 143-144

healing, 62-63, 262, 267, 275-276

holy kiss, 64, 97, 255-260

homily, 27, 82, 183, 187, 191, 194, 199-200, 203-205
Hosanna, 279

hymn, 31-33, 38, 83, 85, 129, 206, 211, 223-227

Institution narrative, 114-115, 119-120, 125-128, 235-236, 239-240, 243

insula, 51, 53-55

interpretations, 62-63

interpretation words, 112-116, 119-120, 125-127, 136, 145

invitations, 24

Iobacchoi, 24-26, 184, 277

kline, 24

Last Supper, 10, 106-107, 114-128, 233-237

laying on of hands, 141, 260-263, 265-266

lector, 149, 178-180, 204

libation, 19, 21, 25-26, 211-213, 229

Lord's Supper, 48-49, 100-123, 127-131, 232-234

Meals

association, 1, 22

eucharistic, 14, 58-61, 140-141

festive, $47,58,212$

group, 1, 4, 22, 35, 58-61, 77, 127

Jewish, 27-30, 46-47

pagan, 33,35

meat, 19-20, 25-26, 35, 59-62, 77

milk, 19n, 58, 245, 272

music, 22, 30, 211-213, 226

musical instruments, 225-227

mystery cults, 23-26

oil, $26,59,77,244-245$

oil anointing, 266-268

order of the gathering, 65-68

ordination, $248,260-266$

Passover, 10, 115, 121-123, 190, 212

prayer

eucharistic, 68, 109-110, 127,

138-140, 230-245

non-eucharistic, 231, 239, 246-252

preaching, $7,31,62-64,67,183-204$ 
presbyter, $56,72-77,98,135,196,208$, 247, 266

prophet, 32, 69-73, 88, 90-91, 111, 193, 197, 201, 207

prophetess, 66, 76, 208

psalm, 63, 68, 75, 100, 141, 206, 213-216, 218-221, 279-280

Qumran, 27, 84, 153, 189, 229

reader, $148-149,155,176,178-181$

reading at symposia, $147-149$

reading in synagogue, 150-155

reading of

apocalypses, 170-171

gospels, 166-167, 172-173

Law, 151-153, 175-176

letters, 157-165, 168-169, 176

martyrdoms, 171-172

Prophets, 155-156, 165-166

Psalms, 176, 178

Scriptures, 156, 174-178

reclining, 20, 23-24, 129, 142, 266 refrigerium, $54,60,272 \mathrm{n}$

revelations, 31, 42, 63, 77, 183, 186, 209, 231

Sabbath, 28-29, 37, 42-43, 46-49, 77, $81,150-152,188-190$

salt, $28,59-60,77$

sermon, 25, 66-68, 77, 80, 82, 102, 169, 191, 194-204

singing, $7,22,63,66,81,84-88,129$, 211-227

stibadium, 54

Sunday, 40-49, 79-83, 87-88, 90-94

symposium, 18, 20-22, 29-30, 37-39, $62-65,228-231$

synagogue service, 10-12, 27-29, 46, 188

triclinium, 53

water, $21-22,25,77,99,135,138,140$

wine, 19-22, 58-59, 61-62, 77, 99-100, 109-111, 115-119, 228-230 